\title{
VOLCANOLOGY AND GEOCHEMISTRY OF ARCHEAN RHYOLITES AND RELATED VOLCANICLASTIC ROCKS ASSOCIATED WITH THE KIDD CREEK VOLCANOGENIC MASSIVE SULFIDE DEPOSIT, ABITIBI GREENSTONE BELT, SUPERIOR PROVINCE, CANADA
}

\author{
Glen James Prior, M.Sc.
}

二

Thesis submitted to the Faculty of Graduate Studies and Research in partial fulfillment of the requirements for the degree of Doctor of Philosophy

\author{
Department of Earth Sciences \\ Carleton University \\ Ottawa, Ontario, Canada
}

April, 1996

Copyright

1996, Glen James Prior 
The author has granted an irrevocable non-exclusive licence allowing the National Library of Canada to reproduce, loan, distribute or sell copies of his/her thesis by any means and in any form or format, making this thesis available to interested persons.
L'auteur a accordé une licence irrévocable et non exclusive permettant à la Bibliothèque nationale du Canada de reproduire, prêter, distribuer ou vendre des copies de sa thèse de quelque manière et sous quelque forme que ce soit pour mettre des exemplaires de cette thèse à la disposition des personnes intéressées.

L'auteur conserve la propriété du droit d'auteur qui protège sa thèse. Ni la thèse ni des extraits substantiels de celle-ci ne doivent être imprimés ou autrement reproduits sans son autorisation. 
Nom

Dissertation Abstracts International est organisé en catégories de sujets. Veuillez s.v.p. choisir le sujet qui décrit le mieux votre thèse et inscrivez le code numérique approprié dans l'espace réservé ci-dessous.

\section{Catégories par sujets}

\section{HUMANITES ET SCIENCES SOCIALES}

\section{COMINUNICATIONS ET LES ARTS}

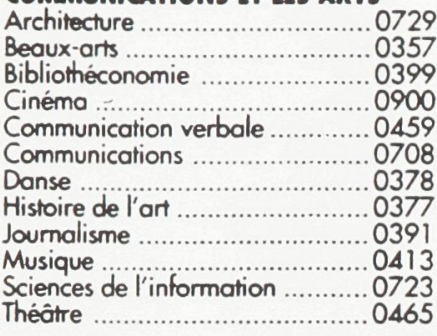

\section{EDUCATION}

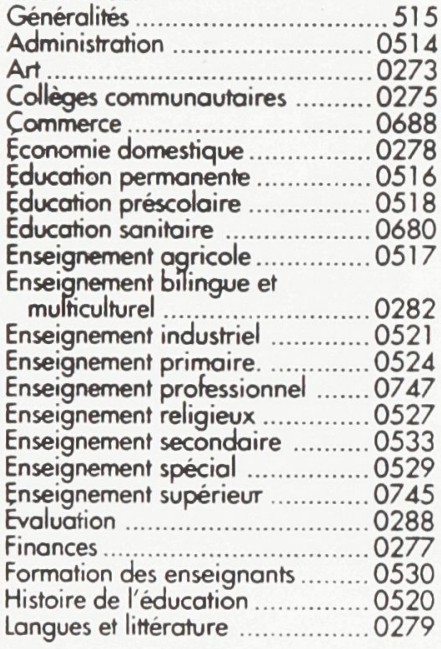

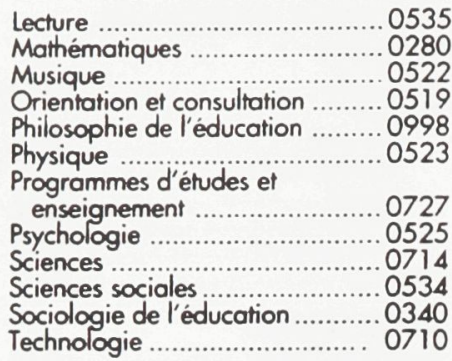

\section{LANGUE, LITTERATURE ET \\ LNGUISTIQUE}

Langues

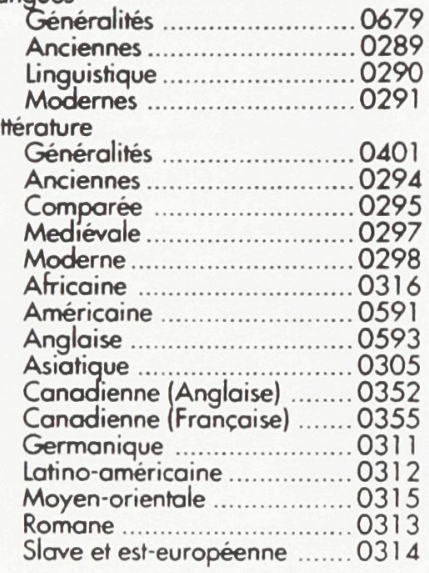

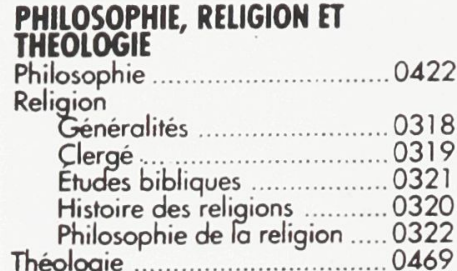

\section{SCIENCES SOCIALES}

Anthropologie

Archéologie ......................... 0324
Culturelle ........................ 0326
Physique ........................ 0327

Droit

Eroit ...........

Généralités ....................... 0501

Commerce-Affaires ................. 0505

Economie agricole ............... 0503

Economie du travail ............... 0510

Finances ............................ 0508

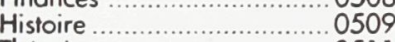

Theorie

Etudes américaines

Etudes canadiennes ....

Etudes féministes …….......... 0453

Folklore ................................... 0358

Géographie ............................... 0366

Gestion des affaires

Généralités

Administration

Banques

Comptabilité

Marketing

Histoire

Histoire génerale

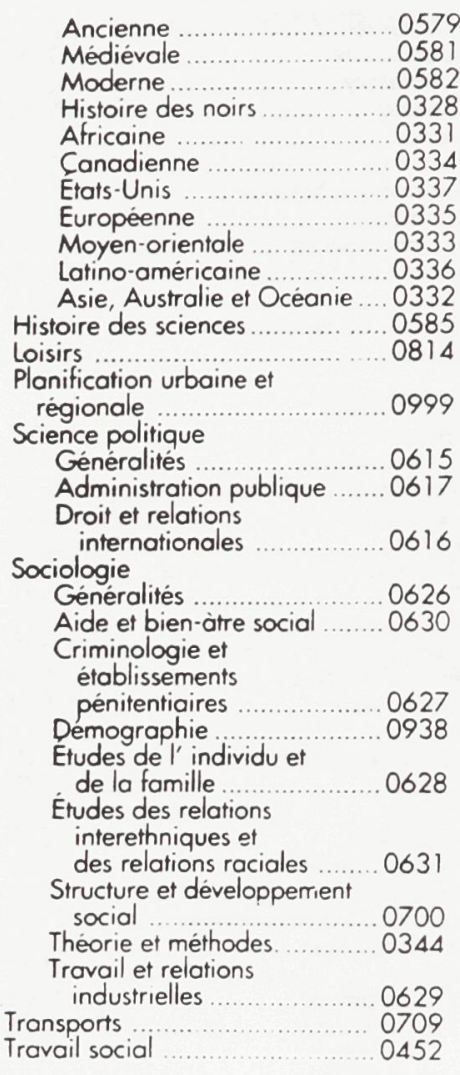

\section{SCIENCES ET INGENIERIE}

\section{SCIENCES BIOLOGIQUES}

Agriculture

\begin{tabular}{|c|c|}
\hline $\begin{array}{l}\text { Généralités .... } \\
\text { Agronomie. ... }\end{array}$ & 04 \\
\hline $\begin{array}{l}\text { Alimentation et technologie } \\
\text { alimentaire }\end{array}$ & \\
\hline Culture. & \\
\hline ge ef alimentation & \\
\hline oltation des péturages & \\
\hline $\begin{array}{l}\text { Pathologie animale .... } \\
\text { Pathologie végétale. }\end{array}$ & \\
\hline Physiologie vegétale. & \\
\hline culture et tau & \\
\hline $\mathrm{Te}$ & \\
\hline & \\
\hline ralités & \\
\hline omie & \\
\hline gie (Statistiques) & \\
\hline $\begin{array}{l}\text { logie moléculaire } \\
\text { tanique }\end{array}$ & \\
\hline ule & \\
\hline logie & \\
\hline mologie. & \\
\hline que & \\
\hline ologie & \\
\hline Microbiologie & \\
\hline urologie & \\
\hline éanographie. & \\
\hline Physiologie & \\
\hline tiation ............... & \\
\hline $\begin{array}{l}\text { ence veterınaire } \\
\text { ologie }\end{array}$ & \\
\hline & \\
\hline rralités & \\
\hline & \\
\hline
\end{tabular}

\section{SCIENCES DE LA TERRE}

Biogéochimie

Geochimie

Geodesie

0996

0370
0368

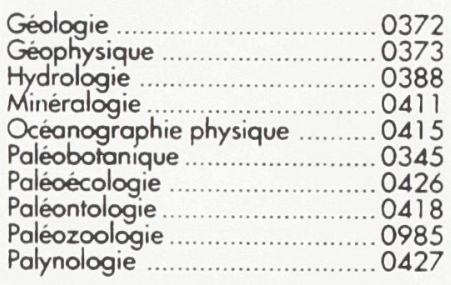

\section{SCIENCES DE LA SANTÉ ET DE} L'ENVIRONNEMENT

Économie domestique

Sciences de l'environnement ........0386 0768

Sciences de la sante

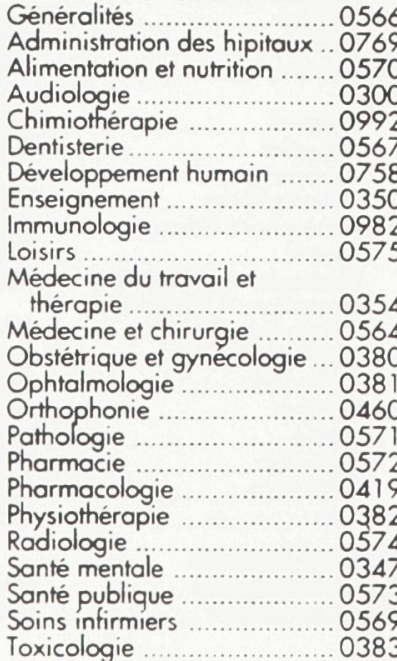

0383

\section{SCIENCES PHYSIQUES}

Sciences Pures

Chimie

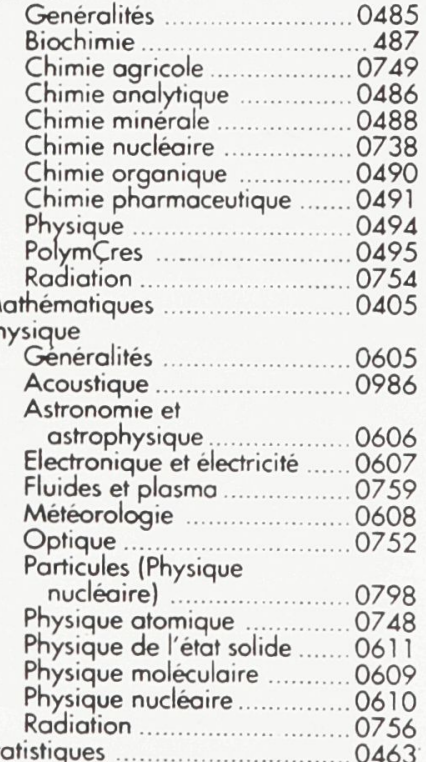

Sciences Appliqués Et

Technologie

Informatique

Ingénierie

Généralités

Agricole
Biomédicale

Choleur et ther

modynamique

Conditionnemen

(Emballage)

Genie aérospatial

Génie chimique

Genie civil

Génie électronique et

électrique

Génie industrie

Génie mécanique

Génie nucléaire

Ingénierie des systömes

Mecanique navale

Métallurgie

Science des materioux

Technique du pétrole

Technique miniere

Techniques sanitaires et municipales

oliqualique ......0545

0346

Meotechnologie

$$
\text { (Technologie) }
$$

0796

.

0794

\section{PSYCHOLOGIE}

\section{Genéralités}

Personnalité

Psychobiologie

Psychologie clinique 


\section{Carleton University \\ Ottawa, Canada K1S 5J7}

Thesis contains black and white and/or coloured graphs/tables/photographs which when microfilmed may lose their significance. The hardcopy of the thesis is available upon request from Carleton University Library. 


\section{ABSTRACT}

The Archean volcanogenic massive sulfide (VMS) ores of the Kidd Creek Mine occur within the Kidd Creek formation, a succession characterized by a predominance of rhyolitic volcanic and volcaniclastic rocks which represent a local felsic volcanic centre. The Kidd Creek formation is divisible into Lower, Middle, and Upper members with the known strata-bound massive sulfide lenses confined to the Middle member. The Lower member is dominated by coherent and autoclastic footwall (FW) rhyolite, the Middle member contains an abundance of bedded, polymict volcaniclastic rocks with subordinate argillite and massive sulfide, and the Upper member comprises coherent and autoclastic facies of quartz porphyritic (QP) rhyolite.

The QP rhyolite represents the last significant phase of felsic volcanism in the Kidd Creek Mine area. Facies analysis and morphological reconstruction using isopach maps indicate that the QP rhyolite erupted from two parallel fissures. Primarily passive fissure eruptions and endogenous dome growth resulted in the construction of two ridges that extend for at least $1.9 \mathrm{~km}$. Continued hydrothermal activity in the Kidd Creek area after deposition of the known massive sulfide orebodies is recorded by hanging wall alteration, primarily sericitization, silicification, and feldspar destruction, within QP rhyolite. A spatial correlation between the south orebody of the Kidd Creek Mine and the north QP rhyolite ridge suggests that ore-forming hydrothermal discharge and 
the subsequent eruption and alteration of the QP rhyolite may have been controlled by a common long-lived syn-volcanic structure.

The Kidd Creek rhyolites have relatively enriched, FIIlb incompatible element profiles; such rhyolites are favourable VMS exploration targets within the Superior Province (rare earth elements and high field strength elements remained relatively immobile in rhyolites outside the footwall stringer zone). Geochemical data demonstrate a close similarity between least-altered rhyolites of the Kidd Creek formation and the felsic igneous rocks of anomalous mid-ocean ridge spreading centres such as the rhyolites erupted from the central volcanoes Askja and Krafla in Iceland's eastern axial rift zone. A model is suggested in which the Kidd Creek rhyolites were derived by subsidence-induced partial melting of hydrated tholeiitic basalt within juvenile oceanic crust having a steep geothermal gradient (possibly related to an upwelling mantle plume).

Eleven rhyolite samples from the Kidd Creek Mine area yield a Sm-Nd isotopic regression age of $2733 \pm 260 \mathrm{Ma}$, within error of previously determined $\mathrm{U}-\mathrm{Pb}$ ages of zircons in Kidd Creek rhyolites which range from $2717 \pm 2$ to $2710.5 \pm 1.1 \mathrm{Ma}$. With the exception of two intensely chloritized and sericitized footwall samples, $\varepsilon_{\mathrm{Nd}}(2712 \mathrm{Ma})$ values range from +1.1 to +4.2 and show no systematic variation with height through the stratigraphic succession. These values bracket the depleted mantle curve and do not suggest contamination by older crust. The $\varepsilon_{\mathrm{Nd}}$ values are consistent with the eruption of 
the Kidd Creek rhyolites, and formation of the Kidd Creek orebodies, in an oceanic environment dominated by rocks of recent mantle derivation. 


\section{ACKNOWLEDGMENTS}

This study was supported by an NSERC-Falconbridge LimitedLaurentian University collaborative Research and Development Grant, the Geological Survey of Canada, and the Minerals Program of the joint federalprovincial Northern Ontario Development Agreement (NODA). The geological base for the Kidd Creek mine area on which this study rests is the culmination of high quality work by many company geologists in both the mine and exploration groups. Assistance at the mine site by the staff of the geology department including, but not limited to, Ron Cook, Phil Olson, Dave Luckett, Ron Lemery, Dave Richardson, Peter Jurenovskis, Peter Manojlovic, Dean Crick, Dean MacEachern, Paul Simunovic, Paul Roos, Mike Welch, and Marilyn Schonfeld is gratefully acknowledged. Bob Stewart supervised the collection of many of the samples used to form the Falconbridge analytical database. Capable field assistance was provided by Dave Richardson (1993) and John Everest (1994).

I wish to express sincere thanks to my thesis supervisors, David Watkinson (Carleton University) and Harold Gibson (Laurentian University). Brian Cousens (Carleton) performed the Sm-Nd isotopic analyses, and both Brian Cousens and Tucker Barrie (G.S.C.) contributed to my understanding of the Sm-Nd isotopic system. Mark Hannington (G.S.C.) coordinated research efforts at Kidd Creek, and Wouter Bleeker (formerly Falconbridge Limited, now G.S.C.) advanced the understanding of structural relationships in the mine area. SEM instruction was provided by Peter Jones (Carleton). I am grateful to Dr. Richard Moore of Falconbridge Limited for serving as the external examiner, and to David Prior for providing technical support. Robert Whitehead of Laurentian University reviewed an early version of Chapter 3 . Lastly, I wish to acknowledge financial support in the form of an NSERC scholarship. 


\section{ORIGINAL CONTRIBUTION}

This thesis is based on approximately 12 months of detailed underground mapping at the Kidd Creek Mine completed by the author during 1993, 1994, and 1995. Where data from geological level plans and drill hole logs prepared by the Kidd Creek Mine Geology Department, Falconbridge Limited, have been incorporated into this study an appropriate reference is given. Whole rock analyses for samples collected on this project were performed by X-Ray Assay Laboratories, Toronto, Ontario. Sm-Nd isotopic analyses were performed by Dr. Brian Cousens at Carleton University. The volcanological portion of the QP rhyolite study, which forms part of Chapter 2, represents a collaborative effort with Dr. Harold Gibson of Laurentian University. Chapters 1, 3, 4, 5, the appendices, and the lithogeochemical part of Chapter 2 are essentially the sole work of the author (with the exception of cited material and analytical geochemistry) although input by several colleagues is acknowledged (see Acknowledgments).

Chapters 2, 3, and 4 were written in a manner which will facilitate the publication of the research contained in each of these chapters as scientific articles. Much of the material presented in Chapter 2 has been accepted, with revisions, for publication by Economic Geology in the paper "Anatomy, lithogeochemistry and emplacement mechanisms for the QP rhyolite, Kidd Creek Mine, Timmins, Ontario", authored by Prior, G.J., Gibson, H.L., Watkinson, D.H., and Cook, R.E. 


\section{DEDICATION}

With love to Sandra and Sarah,

My family that first day,

And to Allie, Xate, and Fackie,

Who joined us along the way. 
Acceptance Sheet ii

Abstract iii

Acknowledgments vi vi

Original Contribution vii

Dedication viii

$\begin{array}{ll}\text { CHAPTER 1. INTRODUCTION TO THESIS } & 1\end{array}$

CHAPTER 2. VOLCANOLOGY AND GEOCHEMISTRY OF THE QP RHYOLITE

Introduction to Chapter 2

Geology of the Kidd Creek Mine Area 9

$\begin{array}{ll}\text { The QP Rhyolite } & 13\end{array}$

$\begin{array}{ll}\text { Coherent facies } & 13\end{array}$

$\begin{array}{ll}\text { Breccia facies } & 15\end{array}$

$\begin{array}{ll}\text { Geochemistry } & 18\end{array}$

$\begin{array}{ll}\text { Protolith composition } & 18\end{array}$

$\begin{array}{lr}\text { Element Mobility } & 18\end{array}$

$\begin{array}{ll}\text { Classification } & 20\end{array}$ 
Rhyolite discrimination in the Kidd Creek Mine area

Application of geochemical discrimination to the distribution of rhyolite in the Kidd Creek Mine area

Host rocks of the southwest orebody

Alteration

QP Rhyolite Morphology

Volcanic Reconstruction

29

\section{CHAPTER 3. RARE EARTH AND HIGH FIELD STRENGTH ELEMENT GEOCHEMISTRY OF THE KIDD CREEK RHYOLITES: EVIDENCE FOR ARCHEAN FELSIC VOLCANISM AND VMS ORE FORMATION IN AN ICELAND-STYLE RIFT ENVIRONMENT}

Introduction to Chapter 3

A Framework for Geochemical Comparison

Precursor composition for Kidd Creek rhyolites

Element mobility

Compilation of post-Triassic data

Comparison of the Kidd Creek Rhyolites to Post-Triassic

Felsic Rock Suites

REE-HFSE spider diagrams: the basis for comparison

Kidd Creek

Intraplate oceanic islands 
High-Al arc suites (adakites)

Rift zones

Mature mid-ocean ridges

Immature mid-ocean rifts

Back-arc marginal basins

Continental rifts

Discussion

Comparative geochemistry

Comparative volcanology

Petrogenesis

Comparison of the Kidd Creek Rhyolite With Other Superior

Province Felsic Volcanic Rocks Associated With VMS

Deposits

Formation and Preservation of the Kidd Creek VMS Deposit

Tectonomagmatic processes

Lifespan and volcanic accumulation rates

A model for the association of rhyolites and VMS

deposits in ancient bimodal successions

Tectonic preservation

\section{CHAPTER 4. SM-Nd ISOTOPIC STUDY OF RHYOLITES FROM THE LOWER AND UPPER MEMBERS OF THE KIDD CREEK FORMATION}

Introduction to Chapter 4

Temporal and tectonic setting 
Questions regarding the Sm-Nd isotope systematics of the Kidd Creek rhyolites

Sample Distribution and Analytical Techniques

Samples

Techniques

Sm-Nd Whole-Rock Isotope Systematics

$\mathrm{Sm}-\mathrm{Nd}$ regression ages

Initial $\varepsilon_{\mathrm{Nd}}$ Characteristics

123

Geochemistry of Phyllosilicate-Dominated Footwall Samples

Acid Leaching Results

Evolution of the Kidd Creek Formation in Light of Nd Isotopic Results

Nd Isotopic Shift in Altered Rhyolites

Syn-ore model

Post-ore model 


\section{APPENDICES}

Page

Appendix 1 Volcanology and geochemistry of the Lower and

Middle members of the Kidd Creek formation

Appendix 2 Chemical evolution of the mantle since the late Archean

$\begin{array}{lll}\text { Appendix } 3 & \text { Analytical Techniques } & 201\end{array}$

Appendix 4 Geochemical analyses of samples from the 1600 , $1800,2100,2300$, and 2400 Levels of the Kidd Creek Mine

Appendix 5 Chondrite Normalization Values

Appendix 6 Description of samples with $\mathrm{Nd}$ isotopic data shown in Figure 4.10.

Appendix 7 Photographs and microphotographs

Appendix $8 \quad$ Volcaniclastic rock terminology used in thesis

Appendix 9 Descriptions of rock samples from the 1600, 1800, 2100,2300 , and 2400 Levels of the Kidd Creek Mine

Appendix 10 Descriptions of felsic volcanic and volcaniclastic units between the 1600 and 2400 Levels of the Kidd Creek Mine 


\section{LIST OF TABLES}

Page

Table 2.1 Criteria used to select least-altered QP rhyolite samples

Table 2.2 Analyses of six least-altered QP rhyolite samples

Table 2.3 Example of constant sum effect on analytical values starting with $100 \mathrm{~g}$ of protolith

Table 2.4 Range factor (RF) values for the massive facies of the QP rhyolite

Table 2.5 Pearson correlation coefficients for QP rhyolite analyses (massive and breccia facies)

Table 3.1 Criteria used to select least-altered Kidd Creek FW rhyolite samples

Table 3.2 Representative analyses of least-altered FW rhyolite samples from the Kidd Creek mine area

Table 3.3 Summary of post-Triassic, felsic igneous rock comparison data

Table 4.1 Sample locations and descriptions

Table $4.2 \quad$ Sm-Nd isotopic results

Table 4.3 Major and trace element compositions of representative samples

Table A3.1 Summary of analytical reproducibility based on a comparison of values obtained by ICPMS and a second technique (XRF or NA)

Table A3.2 Comparison of two XRAL major-oxide determinations of SY-2 (glass bead XRF) with recommended SY-2 working values 
Table A3.3 Comparison of two XRAL Rb, $\mathrm{Sr}, \mathrm{Y}, \mathrm{Zr}, \mathrm{Nb}$, and $\mathrm{Ba}$ determinations of SY-2 (pressed pellet XRF analyses) with recommended SY-2 working values

Table A3.4 Comparison of six XRAL REE, Th, and $U$ 208 determinations of $\mathrm{SI}-1$ with SO-1 working values

Table A3.5 Summary of determinations by XRAL on geostandards 210 SY-1 and SO-1

Table A3.6 Repeatability statistics for duplicate pairs of analyses

Table A8.1 Classification of volcaniclastic rocks formed by 283 autoclastic of epiclastic processes 


\section{LIST OF FIGURES}

Page

Figure 1.1 Geology of the Abitibi Greenstone Belt, Superior

Province, showing the location of the Kidd Creek Mine

Figure 1.2 Regional geology

Figure 1.3 Geology of the Kidd Creek Mine area at the 2800 Level ( $850 \mathrm{~m}$ below surface)

Figure 2.1 Stratigraphic column of the Kidd Creek formation, Kidd Creek Mine area

Figure 2.2 Idealized stratigraphic sections through coherent facies (vent-proximal) and breccia (distal) facies of the QP rhyolite

Figure 2.3 Geological map of the west wall of 2101 Drive South. The contact between the upper, chilled margin of the "wedge" gabbro sill and the breccia facies of the QP rhyolite is marked by peperitic breccias where finegrained apophyses from the sill intruded, autobrecciated, and mixed with QP rhyolite fragmental material

Figure 2.4 Spider diagram for coherent QP rhyolite showing analyses normalized to the estimated QP rhyolite protolith composition ( $\mathrm{eP}$ QP $)$

Figure 2.5 Spider diagram for coherent QP rhyolite showing massive facies QP rhyolite analyses normalized to (i) a constant $Z r$ value, and (ii) the estimated protolith composition of the $\mathrm{QP}$ rhyolite $\left(\mathrm{eP} \mathrm{P}_{\mathrm{QP}}\right)$

Figure 2.6 $\mathrm{Nb} / \mathrm{Y}$ versus $\mathrm{Zr} / \mathrm{TiO} \mathrm{O}_{2}$ diagram showing massive facies QP rhyolite samples (after Floyd and Winchester, 1977) 
Figure 2.7 $\mathrm{Zr} / \mathrm{Y}$ versus $\mathrm{La}_{\mathrm{N}} / \mathrm{Yb}_{\mathrm{N}}$ diagram showing least-altered $\mathrm{QP}$ rhyolite samples

Figure 2.8 $\quad \mathrm{TiO}_{2}$ versus $\mathrm{Nb}$ discrimination diagram for the Kidd Creek rhyolites

Figure 2.9 $\quad \mathrm{Al}_{2} \mathrm{O}_{3} / \mathrm{TiO}_{2}$ versus $\mathrm{Nb} / \mathrm{Zr}$ discrimination diagram for the Kidd Creek rhyolites

Figure 2.10 $\quad \mathrm{Al}_{2} \mathrm{O}_{3} / \mathrm{TiO}_{2}$ contours for felsic volcanic and volcaniclastic rocks of the Kidd Creek Mine package in the mine area containing $>65 \% \mathrm{SiO}_{2}$ between 410 and 1020 metres below surface (1300 to 3400 foot levels). Data is projected vertically onto the 2800 level

Figure 2.11 $\mathrm{Al}_{2} \mathrm{O}_{3} / \mathrm{TiO}_{2}$ versus $\mathrm{Nb} / \mathrm{Zr}$ discrimination diagram for the Kidd Creek rhyolites showing samples of the rhyolitic rocks hosting the southwest orebody

Figure 2.12 $\mathrm{SiO}_{2}$ versus $\mathrm{Al}_{2} \mathrm{O}_{3}$ diagram for $\mathrm{QP}$ rhyolite samples

Figure 2.13 $\quad \mathrm{Fe}_{2} \mathrm{O}_{3}$ versus $\mathrm{H}_{2} \mathrm{O}^{+}$diagram for $\mathrm{QP}$ rhyolite samples

Figure 2.14 $\mathrm{MgO}$ versus $\mathrm{H}_{2} \mathrm{O}^{+}$diagram for QP rhyolite samples

Figure 2.15 $\mathrm{Na}_{2} \mathrm{O}$ versus $\mathrm{H}_{2} \mathrm{O}^{+}$diagram for $\mathrm{QP}$ rhyolite samples

Figure 2.16

Cu versus Zn diagram for QP rhyolite samples

Figure 2.17 Isopach of the QP rhyolite (coherent and breccia facies) between the 800 and 4700 foot levels ( 240 to 1430 metres below surface)

Figure 2.18 Paleotopographic reconstruction of the QP rhyolite (massive and breccia facies) between the 800 and 4700 foot levels

Figure 2.19 North-south section across the north and south QP Rhyolite ridges through the two highest domes

Figure 2.20 Isopach of QP rhyolite breccia between the 700 (8-1) and 3400 foot levels (210 to $1040 \mathrm{~m}$ below surface) 
Figure 2.21 Reconstructed view of the Kidd Creek deposit area subsequent to QP rhyolite volcanism and the onset of mafic volcanism but before intrusion of "wedge" gabbro sill

Figure 3.1 Spider diagram of least-altered FW rhyolite samples normalized to FW rhyolite 14259

Figure 3.2 Spider diagram of strongly altered FW rhyolite samples 92 from the stringer zone beneath the north orebody normalized to FW rhyolite sample 14259

Figure 3.3 Spider diagram of strongly altered FW rhyolite samples 93 from the stringer zone beneath the north orebody normalized to FW rhyolite sample 14259 and to a constant $\mathrm{Al}$ value

Figure 3.4 Chondrite normalized REE-HFSE spider diagram of 94 representative least altered Kidd Creek rhyolites

Figure 3.5 Chondrite normalized REE-HFSE spider diagram of 95 representative intraplate island samples

Figure 3.6 Chondrite normalized REE-HFSE spider diagram of 96 representative ensimatic arc samples

Figure 3.7 Chondrite normalized REE-HFSE diagram of representative ensialic arc samples

Figure 3.8 Chondrite normalized REE-HFSE diagram of representative adakite/high-AI TTD samples

Figure 3.9 Chondrite normalized REE-HFSE diagram of representative Icelandic samples

Figure 3.10 Chondrite normalized REE-HFSE diagram of representative mid-ocean ridge samples 
Figure 3.11 Chondrite normalized REE-HFSE diagram of representative immature mid-ocean rifts

Figure 3.12 Chondrite normalized REE-HFSE diagram of ensimatic back-arc samples

Figure 3.13 Chondrite normalized REE-HFSE diagram of ensialic back-arc samples

Figure 3.14 Chondrite normalized REE-HFSE diagram of representative continental rift samples

Figure 3.15 Histogram of $\mathrm{SiO}_{2}$ distribution in 542 volcanic rocks from Iceland and 975 igneous rocks from the Kidd Creek mine area

Figure 3.16 Th-Hf-Nb ternary diagram comparing mafic igneous rocks of the Kidd Creek mine area to subalkaline basalts from Iceland

Figure 3.17 Chondrite normalized REE-HFSE diagram of average $\mathrm{FI}, \mathrm{FII}$, Fllla, and Flllb felsic volcanic rocks

Figure 4.1 $\mathrm{Nd} / \mathrm{Sm}$ versus $\varepsilon_{\mathrm{Nd}}(2712 \mathrm{Ma})$ diagram showing Kidd Creek data of Maas et al., (1986)

Figure 4.2 Surface geology of the Kidd Creek Mine area showing sample sites

Figure 4.3 $\quad{ }^{147} \mathrm{Sm} /{ }^{144} \mathrm{Nd}$ versus ${ }^{143} \mathrm{Nd} /{ }^{144} \mathrm{Nd}$ diagram showing Kidd Creek rhyolitic whole rock data

Figure 4.4 $\mathrm{Zr}$ versus $\mathrm{TiO}_{2}$ diagram showing $\mathrm{FW}$ rhyolite, rhyolite breccia, chloritite, and sericitite

Figure 4.5 Ternary $\left(\mathrm{Na}_{2} \mathrm{O}+\mathrm{CaO}\right)-\mathrm{K}_{2} \mathrm{O}-\left(\mathrm{FeO}_{(\mathrm{t})}+\mathrm{MgO}\right)$ diagram for rhyolitic sample data from the Kidd Creek Mine area

Figure 4.6 $\mathrm{SiO}_{2}$ versus $\mathrm{Al}_{2} \mathrm{O}_{3}$ diagram for rhyolitic sample data from the Kidd Creek Mine area 
Figure 4.7 Chondrite normalized REE spider diagram showing chloritite, sericitite, and silicified rhyolite breccia

Figure 4.8 $\quad{ }^{147} \mathrm{Sm} /{ }^{144} \mathrm{Nd}$ versus ${ }^{143} \mathrm{Nd} /{ }^{144} \mathrm{Nd}$ diagram showing selected Kidd Creek whole rock samples

Figure 4.9 $\varepsilon_{\mathrm{Nd}}(2712 \mathrm{Ma})$ values for the Kidd Creek Mine package arranged in approximate stratigraphic order

Figure 4.10 Age versus $\varepsilon_{\mathrm{Nd}}(\mathrm{T})$ values for Kidd Creek rhyolitic samples (this study) and pre-2695 Ma igneous rocks from the southern Superior Province

Figure A1.1 North-south section through the north and south ridges 189 of coherent FW rhyolite viewed from the west at an angle of $12^{\circ}$ above a horizontal plane

Figure A1.2 $\mathrm{Zr}$ versus $\mathrm{TiO}_{2}$ diagram for Lower member rhyolites (FW rhyolites) and other rocks of the Kidd Creek Mine area

Figure A1.3 $\mathrm{Zr}$ versus $\mathrm{TiO}_{2}$ diagram for Middle member rhyolites (FW rhyolites) and Middle member polymict volcaniclastic rocks

Figure $\mathrm{A} 1.4 \quad \mathrm{Al}_{2} \mathrm{O}_{3}$ versus $\mathrm{P}_{2} \mathrm{O}_{5}$ diagram for mafic and ultramafic rocks of the Kidd Creek Mine area

Figure A1.5 Zr versus $\mathrm{P}_{2} \mathrm{O}_{5}$ diagram for Lower member rhyolites 194 ( $F W$ rhyolites) and other rocks of the Kidd Creek Mine area

Figure $\mathrm{A}$ 1.6 $\mathrm{Zr}$ versus $\mathrm{P}_{2} \mathrm{O}_{5}$ diagram for Middle member rhyolites 195 (FW rhyolites) and Middle member polymict volcaniclastic rocks

Figure A1.7 Zr versus Ni diagram for Middle member polymict volcaniclastic rocks, mafic rocks, and ultramafic rocks of the Kidd Creek Mine area

Figure A3.1 Comparison of La analyses obtained by ICPMS and neutron activation (NA) 
Figure A3.2 Chondrite normalized REE patterns for two Kidd Creek rhyolites (QP rhyolite sample 14261 and FW rhyolite sample 14256) comparing results of REE analyses by ICPMS and neutron activation (NA): filled circles = 14261 by ICPMS; open circle $=14261$ by NA; filled square $=14256$ by ICPMS; open square $=14256$ by NA)

Figure A3.3 Diagram showing average XRAL value / detection limit 216 versus average difference between XRAL determinations and working values for reference samples SY-2 (XRF data) and SO-1 (ICPMS data)

Figure A3.4 Diagram showing element abundances in geostandards (working values) versus average differences between XRAL determinations and working values for reference samples SY-2 (XRF data) and SO1 (ICPMS data)

Figure A3.5 Relationship between the median duplicate value to analytical detection limit ratio and repeatability 


\section{LIST OF MAPS}

$\begin{array}{llr}\text { Map 1 } & \begin{array}{l}\text { Location of Underground Map Areas and } \\ \text { Geological Legend }\end{array} & \text { in pocket } \\ \text { Map 2 } & \text { Geology of 1602 Drive North } & \text { in pocket } \\ \text { Map 3 } & \text { Geology of 1602 Drive South } & \text { in pocket } \\ \text { Map 4 } & \text { Geology of 1829 Crosscut } & \text { in pocket } \\ \text { Map 5 } & \text { Geology of 2129 Crosscut } & \text { in pocket } \\ \text { Map 6 } & \text { Geology of 2323 Crosscut } & \text { in pocket } \\ \text { Map 7 } & \text { Geology of 2421-K Pillar Slot } & \text { in pocket }\end{array}$




\section{Chapter 1}

\section{INTRODUCTION TO THESIS}

The Kidd Creek deposit is a world-class volcanogenic massive sulfide (VMS) deposit located in northeastern Kidd Township $27 \mathrm{~km}$ north of Timmins, Ontario, Canada. The Cu-Zn-Pb-Ag ores of the Kidd Creek Mine formed during the Archean and are located in the western part of the southern Abitibi greenstone belt (Abitibi Subprovince) in the Superior Structural Province of the Canadian Shield (Figure 1.1 and 1.2). Orebodies are hosted primarily within a felsic volcaniclastic sequence, underlain and overlain by rhyolites, within a bimodal volcanic succession (Figure 1.3).

The bulk of this thesis is devoted to studies of three major aspects of the geology and lithogeochemistry of the Kidd Creek deposit. These studies are herein presented in Chapters 2, 3 and 4.

Chapter 2 addresses the geological setting of the Kidd Creek deposit in general and the physical volcanology and geochemistry of the QP rhyolite, the last significant product of felsic volcanism at Kidd Creek, in more detail (Figure 1.3). It is proposed in Chapter 2 that the predominantly felsic volcanic and volcaniclastic succession which contains the Kidd Creek orebodies be 
informally named the Kidd Creek formation and that this formation may be subdivided into the Lower, Middle and Upper members. Applying this nomenclature the strata-bound massive sulfide orebodies of the Kidd Creek Mine lie within the Middle member of the Kidd Creek formation.

Quartz porphyritic QP rhyolite, which forms the Upper member of the Kidd Creek formation, was chosen in preference to FW (footwall) rhyolite of the Lower member for a detailed volcanological study because there are far more underground exposures and complete drill hole intersections through the QP rhyolite than the FW rhyolite. This reflects the fact that strata in the Kidd Creek Mine area, which dip steeply to the east, are overturned so the shafts and most diamond drill stations are located in the stratigraphic hanging wall (structural footwall). No underground workings and relatively few diamond drill holes penetrate to the stratigraphic base of the FW rhyolite. By studying rhyolite morphology and depositional processes a better understanding of the geological environment in which the Kidd Creek orebodies formed can be obtained. In addition to volcanological aspects, the QP rhyolite is interesting as it provides an example of extensive hydrothermal alteration within the stratigraphic hanging wall of a world-class VMS deposit. Hydrothermal alteration processes related to VMS formation are commonly recognized in the Superior Province within footwall rocks but alteration effects in hanging wall rocks are not as well documented. 
In Chapter 3 a comparative lithogeochemical technique is developed to identify the tectonic environment in which the Kidd Creek rhyolites were erupted and the Kidd Creek VMS ores formed. The method relies on the identification of distinctive geochemical characteristics of post-Triassic felsic igneous rocks from different tectonic settings and the comparison of these features to the Kidd Creek rhyolites. Hydrothermal metasomatic effects on the original igneous geochemical (juvenile) compositions of the Kidd Creek rhyolites are minimized by selecting least-altered Kidd Creek rhyolites for comparative purposes and by basing the comparisons on the relatively immobile rare earth elements (REE) and high field strength elements (HFSE). The underlying premise of this research is that variability among rhyolite compositions is primarily a function of factors controlled by tectonic setting (i.e., available parental material and thermal regime) rather than factors related to individual magma chambers (i.e., differentiation processes). The study has exploration implications as the Kidd Creek rhyolites are geochemically similar to other "favourable" rhyolites in the Superior Province associated with VMS deposits (Lesher et al., 1986; Barrie et al., 1993). 
Chapter 4 examines the Sm-Nd isotopic characteristics of the Kidd Creek rhyolites in order to address the following questions:

(i) What is the source of the Kidd Creek rhyolites?

(ii) Does the $\mathrm{Nd}$ isotopic composition of felsic magmas in the Kidd Creek area vary with stratigraphic position?

(iii) Does strong hydrothermal alteration accompanied by LREE depletion, indicative of high water/rock ratios, affect $\mathrm{Nd}$ isotopic ratios? 

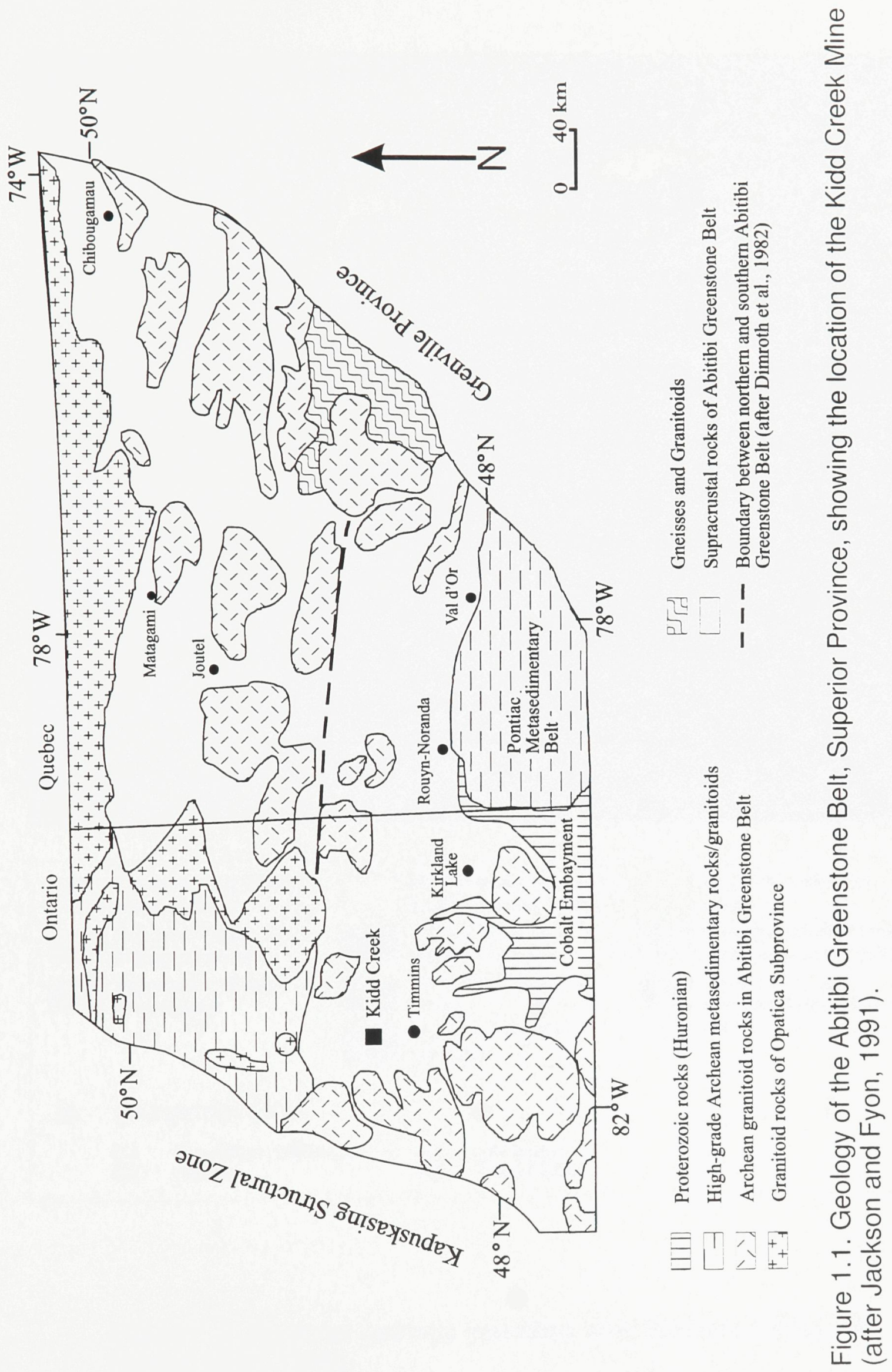


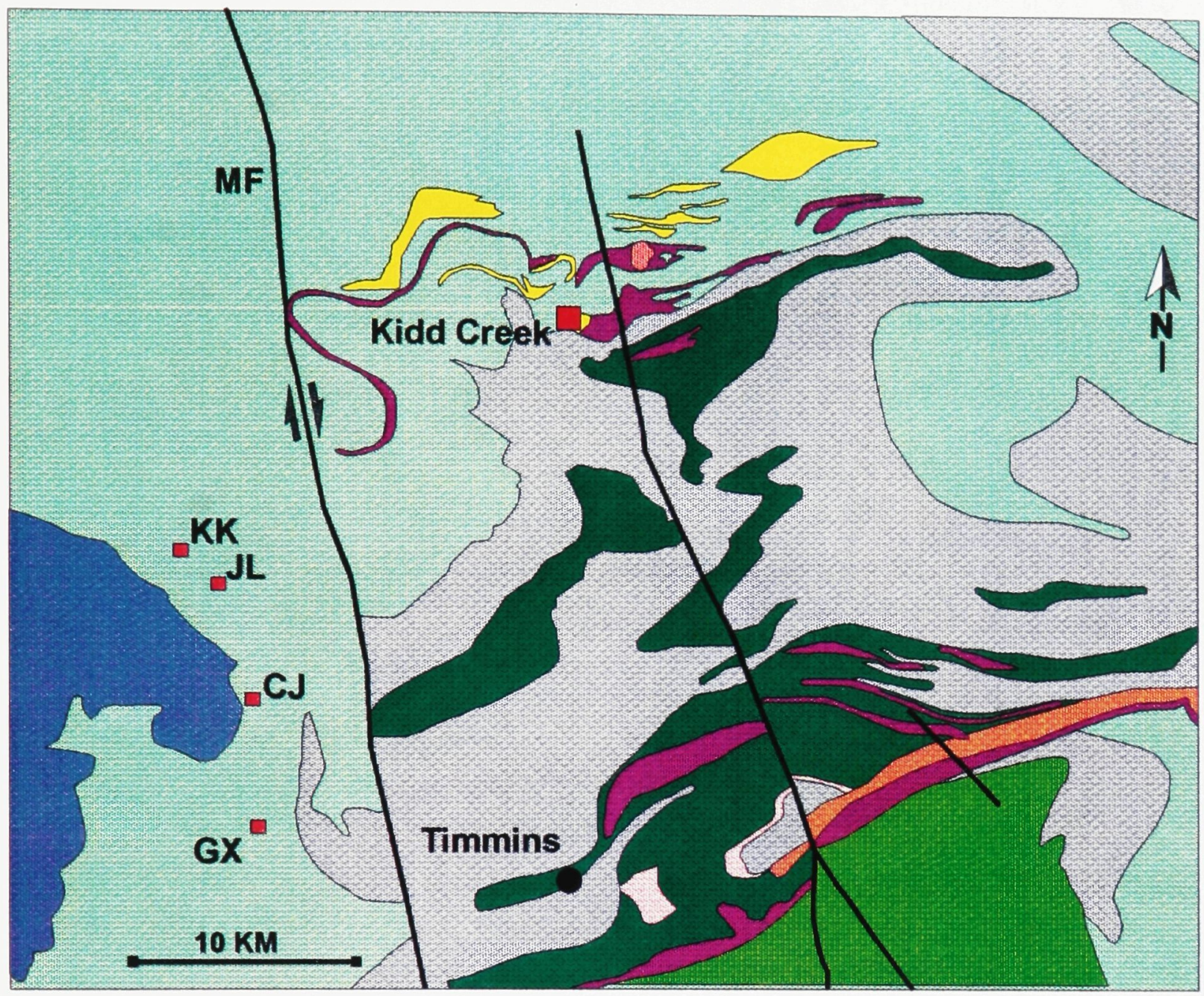

\begin{tabular}{|l|l|l|l|}
\hline $\begin{array}{l}\text { Timiskaming Group; } \\
\text { clastic rocks }\end{array}$ & $\square$ & $\begin{array}{l}\text { Krist framental; felsic } \\
\text { volcaniclastic rocks }\end{array}$ & $\begin{array}{l}\text { Rhyolitic volcanic } \\
\text { rocks }\end{array}$ \\
\hline $\begin{array}{l}\text { Prosser Porphyry; } \\
\text { intrusive stocks }\end{array}$ & $\begin{array}{l}\text { Tisdale Group; } \\
\text { mafic volcanics }\end{array}$ & $\begin{array}{l}\text { Undifferentiated, mainly } \\
\text { mafic volcanic rocks }\end{array}$ \\
\hline $\begin{array}{l}\text { Porcupine Group; } \\
\text { greywacke }\end{array}$ & $\begin{array}{l}\text { Ultramafic volcanic } \\
\text { rocks }\end{array}$ & $\begin{array}{l}\text { Deloro Group; } \\
\text { intermediate volcanic } \\
\text { rocks }\end{array}$ \\
\hline $\begin{array}{l}\text { Kamiskotia gabbro } \\
\text { complex }\end{array}$ & \\
$\begin{array}{l}\text { SULFIDE DEPOSITS: } \\
\text { CJ Canadian Jamieson }\end{array}$ & JL Jameland \\
GX Genex & KK Kam-Kotia & \\
\hline
\end{tabular}

Figure 1.2. Regional geology (modified after Bleeker, 1995a, and Huston et al., 1995). 


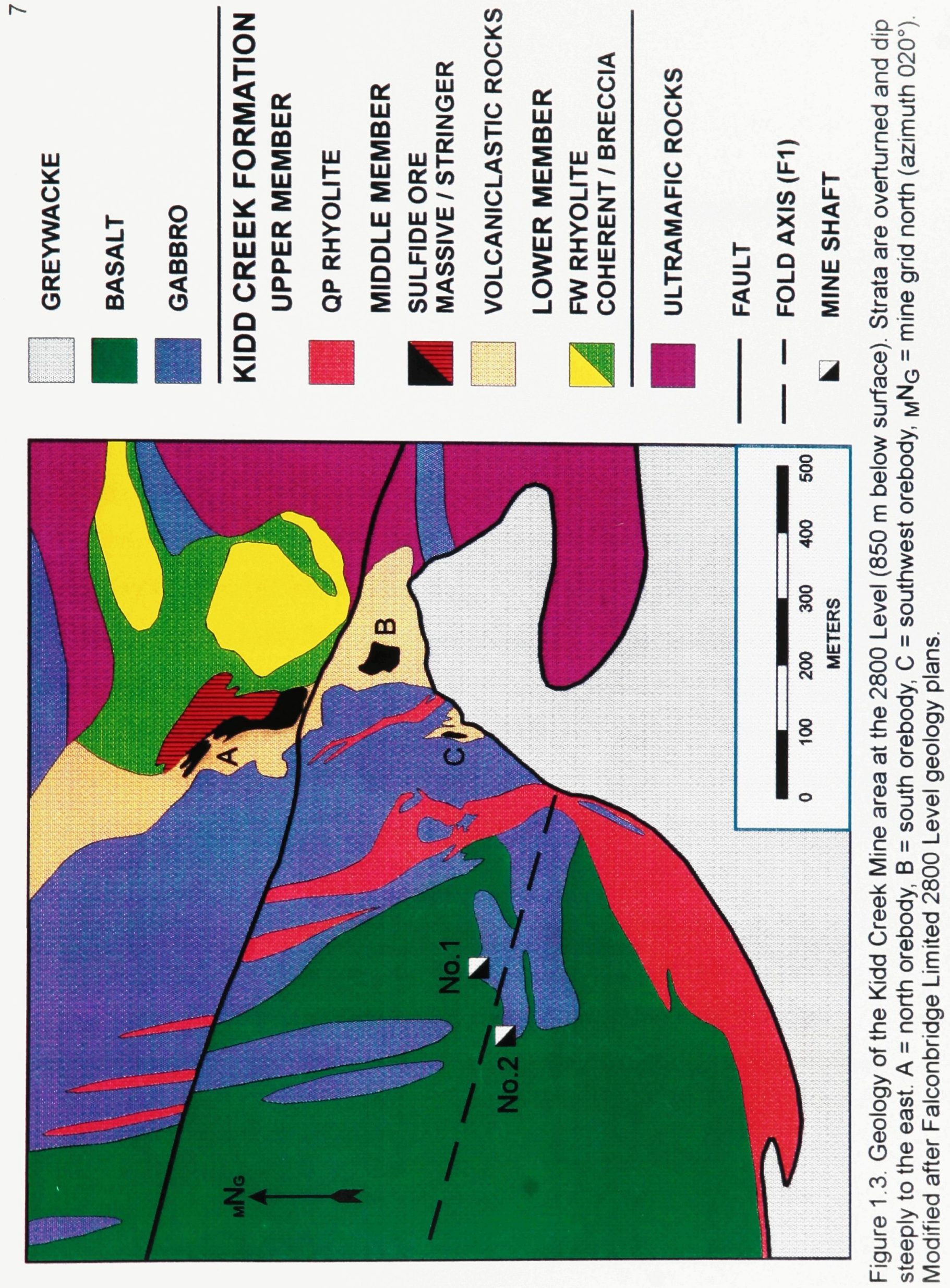


Chapter 2

\section{VOLCANOLOGY AND GEOCHEMISTRY OF THE QP RHYOLITE}

\section{Introduction To Chapter 2}

The quartz- and quartz-feldspar-porphyritic rhyolite that directly overlies the succession of bedded volcaniclastic deposits and massive sulfide lenses at the Kidd Creek Mine (Figure 1.3) is referred to, in mine terminology, as QP rhyolite. The QP rhyolite represents the last significant phase of rhyolitic volcanism at Kidd Creek and it has been interpreted as either a rhyolitic flow or pyroclastic deposit (Bleeker, 1994) (Figure 2.1). Field and petrographic evidence presented herein are consistent with its emplacement as a rhyolitic dome complex, the product of largely passive fissure eruptions. The objectives of this chapter are to describe the QP rhyolite, reconstruct its morphology and mechanisms of emplacement, document primary and alteration lithogeochemical characteristics, and illustrate its significance with respect to ore-forming processes at the Kidd Creek Mine. In addition, an informal stratigraphic nomenclature for the predominantly felsic volcanic and volcaniclastic sucession which hosts the Kidd Creek deposit is proposed. 


\section{Geology of the Kidd Creek Mine Area}

The Kidd Creek Mine extracts $\mathrm{Cu}-\mathrm{Zn}-\mathrm{Pb}-\mathrm{Ag}$ ore from a volcanogenic massive sulfide (VMS) deposit of Archean age located in the Kidd-Munro assemblage within the western part of the southern Abitibi Greenstone Belt (Abitibi Subprovince) in the Superior Province of the Canadian Shield (Figures

1.1 and 1.2). The Kidd Munro assemblage is an east-west striking, steeply dipping succession of intercalated Archean ultramafic, mafic and felsic volcanic rocks and intrusions which range in age from about 2720 to $2710 \mathrm{Ma}$ (Jackson and Fyon, 1992; Bleeker, 1995b, and references therein). Volcanic rocks in the Kidd Creek Mine area have been assigned to the Kidd Volcanic Complex (KVC) by Bleeker (1995b). Cumulative production and reserve figures for the Kidd Creek Mine total approximately 130 million metric tonnes at $2.4 \%$ $\mathrm{Cu}, 6.5 \% \mathrm{Zn}, 0.2 \% \mathrm{~Pb}$ and $89 \mathrm{~g} /$ tonne $\mathrm{Ag}$ (Olson et al., 1994), approximately $30 \%$ of total VMS production and reserves within the Abitibi Greenstone Belt (Barrie et al., 1993). The mine exploits massive sulfide ores rich in sphalerite +/- galena, massive sulfide ores rich in chalcopyrite +/- bornite, sphalerite-rich sulfide breccia ores, and chalcopyrite-rich stringer sulfide ores. Host rocks to the orebodies are primarily rhyolitic to polymict volcaniclastic rocks of the Kidd Creek formation, a locally thickened felsic volcanic center in a geochemically bimodal (ultramafic-mafic and felsic) succession.

The Kidd Volcanic Complex (KVC) is a poorly exposed suite composed primarily of greenschist facies, subaqueous, strongly bimodal volcanic rocks. Volume contributions to the KVC are approximately $60 \%$ basaltic to andesitic 
(icelandic) volcanic rocks (lavas, breccias, volcaniclastic sediments, and sills), $20 \%$ felsic volcanic rocks (rhyolite flows and felsic volcaniclastic rocks), $10 \%$ ultramafic rocks (komatiite and basaltic komatiite successions possibly containing subvolcanic sills and dikes), and less than $5 \%$ each of intermediate volcanic rocks, sedimentary rocks, granitoids, and late dikes (including lamprophyre dikes and dikes of the Matachewan swarm) (Bleeker, 1995b). The KVC extends for a minimum distance of $10 \mathrm{~km}$ to the east, north, and west of the Kidd Creek Mine. Immediately south of the mine rocks of the KVC are in thrust fault and/or unconformable contact with significantly younger (less than approximately $2699 \mathrm{Ma}$ ) greywacke turbidites of the Porcupine Group (Bleeker and Parish, 1995; Bleeker and Parrish, 1996). These greywackes are interpreted by Bleeker (1995b) to represent a post-volcanic flysch sequence deposited in response to crustal thickening and emergence.

The Kidd Volcanic Complex, as defined by Bleeker (1995b), includes all of the rocks which predate the Porcupine Group within a radius of at least 10 $\mathrm{km}$ from the Kidd Creek Mine. It is herein proposed, after consultation with the mine staff, that the 350 to 450 m thick, dominantly felsic volcanic and volcaniclastic succession which hosts the Kidd Creek deposit be informally named the Kidd Creek formation and that this formation be subdivided into the Lower, Middle and Upper members (Figure 2.1). The Kidd Creek formation rests on a thick sequence of ultramafic rocks which are composed in part of komatiitic flows with locally preserved spinifex texture and contain intercalations of rhyolite (Walker et al., 1975; Brisbin et al., 1990). The Lower member, located in the footwall to the massive sulfide orebodies, is dominated 
by massive, flow-banded and autobrecciated rhyolite domes and cryptodomes (FW rhyolite) and contains chalcopyrite stringer mineralization. The Lower member is conformably overlain by the Middle member which contains the massive sulfide orebodies and is characterized by bedded volcaniclastic rocks. Rock types within the Middle member include polymict boulder and pebble conglomerates, commonly containing sulfide clasts, volcaniclastic sandstones and mudstones, graphitic argillites, rhyolite, autoclastic rhyolite breccia, rhyolite hyaloclastite, and massive sulfides. The volcaniclastic rocks are commonly, though not always, dominated by variably altered rhyolitic clasts. Other common clast types include altered mafic volcanic clasts, argillite clasts, sulfide clasts and quartz crystal clasts. The Upper member consists of quartz porphyritic, coherent and autoclastic QP rhyolite, locally up to $130 \mathrm{~m}$ thick, which represents the last significant period of felsic volcanism at Kidd Creek (Figures 1.3 and 2.1). A thick (>1500 m) succession of pillowed basalt flows, pillow breccias, heterolithologic breccias, and interflow graphitic, cherty sediments conformably overlies the QP rhyolite (Bleeker, 1995b). The volcanic succession is intruded by fine-grained gabbro including two thick sills which separate the QP rhyolite from underlying volcaniclastic rocks of the Middle member and from the overlying basaltic succession. Major folds have ENE-trending axes and strata in the mine area become younger to the west (Bleeker and Parrish, 1996).

Rhyolites and felsic volcaniclastic rocks in both the footwall and hanging wall to the orebodies have undergone extensive silicification and sericitization, whereas zones of intense chloritization occur exclusively in the footwall. 
Ultramafic rocks in the mine area commonly contain assemblages of serpentine, talc, magnesite and chlorite (J. Everest, written communication, 1995). The basaltic sequence overlying the felsic rocks and the fine-grained gabbro generally display little or no evidence of exposure to the Kidd Creek oreforming event (Koopman et al., 1996; Huston and Taylor, 1996). All rocks in the Kidd Creek Mine area have undergone regional metamorphism at greenschistfacies conditions and most display penetrative deformation.

Bleeker and Parrish (1995) reported U-Pb zircon ages of $2714 \pm 1.5 \mathrm{Ma}$ for FW rhyolite of the Lower member and $2710.5 \pm 1.1 \mathrm{Ma}$ for QP rhyolite of the Upper member indicating that the entire 300 to 500 m thick Kidd Creek formation spans a 1.4 to 6.1 m.y. time interval. Previous U-Pb data on zircons from the footwall felsic sequence at Kidd Creek returned ages of $2717 \pm 4 \mathrm{Ma}$ and $2717 \pm 2 \mathrm{Ma}$ (Nunes and Pyke, 1982; Barrie and Davis, 1990). Sm-Nd isotopic data indicate derivation of the Kidd Creek rhyolites from a mantle or mantle-derived source consistent with results for igneous rocks of similar age throughout the southern Superior Province (Maas et al., 1986; Chapter 4).

The structural setting of the Kidd Creek Mine area is strongly controlled by two major $F_{1}$ folds, the axes of which are located north and south of the minesite (the southern $F_{1}$ fold axis is shown in Figure 1.3). The more northerly of these folds plunges $70^{\circ}$ toward $020^{\circ}$ (Bleeker, 1995b). Regionally, supracrustal rocks of the Kidd Volcanic Complex (KVC) have east-west trends but within the panel of strata between the two major $F_{1}$ fold hinges, a strike length of about $600 \mathrm{~m}$, rocks have a northerly strike and dip steeply $\left(70^{\circ}\right.$ to $\left.80^{\circ}\right)$ 
to the east (Figure 2). Second order $F_{1}$ folds are the dominant structures throughout the mine and are best developed within volcaniclastic rocks and massive sulfide (Bleeker, 1994 ). However, second order $F_{1}$ folds are either not as well developed in, or they are not as apparent in the more coherent units such as the QP rhyolite and the thick mafic sills that dilate volcanic strata. Heterogeneous development of the dominant $S_{1}$ cleavage (axial planar to $F_{1}$ folds) and strong stretching lineation which plunges parallel to the $F_{1}$ folds, has resulted in variable modification of the shape of primary textures and structures (Bleeker, 1994). Primary textures and structures are, however, well preserved when viewed perpendicular to the pronounced stretching lineation, even in highly sheared exposures. Consequently the best exposures for mapping were the backs of underground workings rather than the walls and samples selected for thin section or polished slab examination were routinely cut to provide surfaces that are perpendicular to the stretching lineation.

\section{The QP Rhyolite}

QP rhyolite, the Upper member of the Kidd Creek formation, is subdivided into coherent and breccia facies. These facies have a distinct, predictable organization that defines the anatomy of the QP rhyolite.

\section{Coherent Facies}

The coherent facies is characterized by massive and flow-banded, 
aphanitic, quartz and quartz-feldspar porphyritic rhyolite. Subhedral to anhedral, locally glomeroporphyritic and embayed, quartz phenocrysts typically comprise $8-12 \%$ of the rock (Figure A7.15). The quartz phenocrysts $(<4 \mathrm{~mm}$ in diameter) occur within a recrystallized groundmass of quartz, sericite, and minor chlorite and carbonate. The groundmass contains as much as $35 \%$, round, $<2 \mathrm{~mm}$, composite quartz grains with sector extinction typical of recrystallized spherulites (Figures A7.16 and A7.17). Subhedral to euhedral albite phenocrysts, typically $<5 \mathrm{~mm}$ in size and locally glomeroporphyritic, are commonly partly to totally altered to sericite and carbonate assemblages (Figure A7.15). Albite phenocrysts, which locally form up to $5 \%$ of the QP rhyolite, are more readily recognizable in parts of the QP rhyolite on the south limb of the large, $F_{1}$ syncline (Figure 1.3). In the author's opinion this reflects better preservation (i.e., less alteration) of albite in parts of the south limb of the QP rhyolite, south of the $F_{1}$ fold axial plane, than in the north limb. There are no variations in major or trace element compositions or in quartz phenocryst abundances between the north and south limbs of the QP rhyolite which would support their being the products of separate magmas.

Broken phenocrysts were not observed and glomeroporphyritic textures occur locally. These features, as well as recrystallized quartz spherulites within the groundmass and lack of bedding, are compatible, along with the morphological features to be described, for the interpretation that the coherent rhyolite is a flow and not a pyroclastic deposit.

Coherent rhyolite exposed along the 2100 Access Drive occurs, in part, 
as large lobes that range from several metres to $>10 \mathrm{~m}$ across and are characterized by faintly flow-banded margins that locally contain $2-5 \%$ elongate quartz amgydules ( $<5 \mathrm{~mm}$ in length; Figure 2.2). Toward the bottom, and less commonly toward the top, massive rhyolite lobes are surrounded by flowbanded, quartz (feldspar) porphyritic rhyolite. Flow banding typically parallels lobe margins and is locally flow folded. Flow-banded rhyolite at the base of the QP rhyolite contains dispersed, angular blocks of massive, white, quartz porphyritic rhyolite and lies in sharp contact with underlying rhyolite breccia; flow banding there is not contorted but parallels the contact with underlying breccia (Map 4).

Exposures of QP rhyolite dominated by massive and flow-banded rock are interpreted to represent a cross section through a subaqueous rhyolite flow or dome. The small volume of breccia with respect to massive and flowbanded rhyolite, and the occurrence of breccia primarily at the base of the flow, are interpreted to represent a vent-proximal flow facies (Figure 2.2).

\section{Breccia Facies}

Assuming that massive and flow-banded coherent rhyolite represents rhyolitic lava either as a dome or flow, then the breccia facies, as exposed along the 2101 and 1600 South Drives and the 2100, 1800 and 1700 Access Drives, may be divided on the basis of their distribution, into flank breccia and basal, flow foot breccia. Flank breccia consists of white to grey, pebble- to block-sized fragments of coherent quartz (feldspar) porphyritic rhyolite in a 
quartz crystal-bearing hyaloclastite matrix (Figures 2.3, A7.18, A7.19).

White, quartz porphyritic massive rhyolite blocks, up to $30 \mathrm{~cm}$ in size, define crude, unsorted, non-graded, framework to matrix supported beds within the breccia. The breccias are locally sericitized. On the 2100 South Drive, flank breccia is conformably underlain by a $1.5 \mathrm{~m}$ thick unit of finely laminated to plane-bedded, siliceous and sphalerite-impregnated, volcaniclastic sandstone.

Flow foot breccia consists of $50 \mathrm{~cm}$ to $2 \mathrm{~m}$ thick beds of breccia and hyaloclastite containing angular to subangular, white silicified blocks of massive QP rhyolite $(1 \mathrm{~cm}$ to $40 \mathrm{~cm}$ in size), flow-banded QP rhyolite blocks, rare fragments of sericitized QP rhyolite, and tan, mafic, pebble-sized fragments (Figure A7.1 and Map 4). The breccias are matrix to framework supported and occasionally display normal grading. On the 1700, 1800 and 2100 levels, beds in the flow foot breccia are discordant with the flow-banded base of the QP flow which truncates the breccia units (Figure A7.1). The breccias are interpreted to be imbricated and their angular discordance with the flow base suggests an "upward" (towards the present day surface) and "north to south" flow direction. The matrices to flank and flow foot breccias consist primarily of QP rhyolite hyaloclastite and pebble-size aphyric to porphyritic rhyolite fragments. In addition, QP rhyolite flank and flow bottom breccias often contain up to $1 \%$ altered mafic fragments similar to the chilled mafic rocks of sill margins, apophyses and dikes.

Two large mafic sills dilate strata and separate the QP rhyolite from the 
underlying volcaniclastic rocks of the Middle member and overlying basaltic flows (Figures 1.3 and 2.1). Where the sills intruded QP rhyolite breccia, the contact is not sharp and regular but is characterized by aphanitic, finger-like dikes and apophyses of mafic sills that intruded and autobrecciated into flow bottom and flank breccia as illustrated in Figures 2.3, A7.1 and A7.18. Breccia within decimeters of the dikes is a mixture of QP rhyolite and chilled, aphanitic mafic ("andesitic" in mine terminology) fragments. These "mixed breccias", containing both QP rhyolite and aphanitic mafic fragments, are interpreted as peperite breccia, the product of passive fragmentation of the sill margins during their emplacement into unconsolidated, wet, QP rhyolite breccia.

Exposures of QP rhyolite dominated by breccia and hyaloclastite are interpreted to represent a cross section through the flank (distal or marginal facies) of a subaqueous rhyolite flow or dome. (Figure 2.3). As illustrated in Map 4, flow foot breccia also occurs in proximal, near-vent facies but the proportion of breccia is volumetrically insignificant with respect to massive and flow-banded rhyolite.

Both the proximal and distal facies of the flow are commonly sericitized and silicified, and locally contain pyrite and sphalerite (1700 level and 2101 Drive South) indicating that hydrothermal activity continued after emplacement of the QP rhyolite flow. Gabbro sills and overlying basalt flows show limited evidence of hydrothermal alteration which is consistent with their emplacement during waning hydrothermal activity (Huston et al., 1995). 


\section{Geochemistry}

All whole-rock chemical analyses were performed by X-Ray Assay Laboratories, Toronto, Ontario; a summary of their analytical techniques is presented in Appendix 3.

\section{Protolith Composition}

Because of extensive alteration it is unlikely that a true protolith composition for the QP rhyolite remains; however an estimation of the protolith composition may be obtained using the analytical values of least-altered samples. Six QP rhyolite samples which satisfy the geochemical criteria listed in Table 2.1 have been selected as representative of least-altered compositions (Table 2.2). The average of these six analyses provides a reasonable estimation of the protolith composition. Samples of the fragmental facies of the QP rhyolite were excluded because of possible contamination from other rock types.

\section{Element Mobility}

The content of any given element " $X$ " within a rock sample may vary from that of the protolith due to (i) gains or losses of element $X$ from the rock or (ii) gains or losses of one or more elements other than $X$ from the rock due to the constant sum (closure) effect. The effect of constant sums (100 wt.\%) on 
chemical analyses is illustrated in Table 2.3 using an example of silicification in which $30 \mathrm{~g}$ of $\mathrm{SiO}_{2}$ is added to the estimated QP rhyolite protolith composition. The results demonstrate that after recalculation to $100 \mathrm{~g}$ (100 wt.\%): (i) all oxides other than $\mathrm{SiO}_{2}$ have undergone apparent depletion (dilution) as a result of the mass gain accompanying silicification; (ii) the apparent addition of $\mathrm{SiO}_{2}$ obtained by subtracting its value in the final analyses from the protolith content $(83.03 \mathrm{~g}-77.93 \mathrm{~g}=5.1 \mathrm{~g})$ is much less than the actual $\mathrm{SiO}_{2}$ addition ( $30 \mathrm{~g}$ ); (iii) inter-element ratios for elements not added or subtracted remain constant between the analyses of protolith and altered rock (e.g., $\mathrm{Al}_{2} \mathrm{O}_{3} / \mathrm{Zr}$ protolith $=\mathrm{Al}_{2} \mathrm{O}_{3} / \mathrm{Zr}$ altered $=487$ ).

A number of graphical representations have been developed for identifying elements which have remained relatively immobile within suites of altered rocks sharing common protoliths (e.g. Gresens, 1967, Grant, 1986, Babcock, 1973, MacLean, 1990; Huston, 1993). Figure2.4 presents a spider diagram for 36 coherent facies QP rhyolite samples normalized to the estimated protolith composition of the $\mathrm{QP}$ rhyolite $(\mathrm{eP} \mathrm{QP})$. The "spider" lines for which this type of diagram is named (lines connecting data points for individual samples) have been removed for clarity. For any sample which has not undergone significant mass change, elements which have remained immobile will have a value near 1.0 (i.e., immobile element abundances unchanged from the protolith composition). Provided element variations due to metasomatic gains and losses outweigh the effects of mass change, those elements whose values tend to cluster near 1.0 are those which have been the least mobile during metasomatism. In order to minimize the effects of mass change 
a second spider diagram of the same samples is presented in Figure 2.5 which has been doubly normalized to the $\mathrm{Zr}$ value of the average least-altered $\mathrm{QP}$ rhyolite. Based upon this representation it can be determined that $\mathrm{Al}, \mathrm{Y}, \mathrm{Zr}$, $\mathrm{Nb}$ and $\mathrm{Ce}$ were the least mobile elements; $\mathrm{Si}, \mathrm{Ti}, \mathrm{Hf}$, Ta and Th have been moderately mobile, and the remaining elements shown in Figure 2.5 have been considerably mobile. This discussion of mobility is based on relative rather than absolute additions and depletions - a distinction most notable for $\mathrm{SiO}_{2}$ which dominates most silicate rocks. For example, a $30 \%$ change in $\mathrm{SiO}_{2}$ from the estimated QP rhyolite protolith composition results in a gain or loss of $23.4 \mathrm{~g} / 100 \mathrm{~g}$ of rock $(77.9 \mathrm{wt} . \%$ (protolith) $\times 0.50)$ whereas a $30 \%$ change in $\mathrm{MgO}$ produces a gain or loss of only $0.20 \mathrm{~g} / 100 \mathrm{~g}$ of rock $(0.65 \mathrm{wt}$ \% (protolith) $\mathrm{x}$ $0.30)$.

\section{Classification}

In order to minimize the effects of alteration, classification schemes which use the less mobile elements have been employed. On the $\mathrm{Nb} / \mathrm{Y}$ versus $\mathrm{Zr} / \mathrm{TiO}_{2}$ classification diagram of Winchester and Floyd (1977) all QP rhyolite samples fall in the subalkaline part of the diagram, and nearly all are classified as rhyolite (Figure 2.6). All least-altered QP rhyolite samples have in excess of $74 \% \mathrm{SiO}_{2}$ indicting that the protolith may have been a high-Si rhyolite consistent with the abundance of quartz phenocrysts (caution is warranted as the QP rhyolite has undergone extensive silicification). Barrie et al., (1993) suggested $73 \% \mathrm{SiO}_{2}$ as the lower limit for high-Si rhyolite. Classification of the QP rhyolite as either calc-alkaline or tholeitic is somewhat problematic. The commonly 
used ternary plots of Irvine and Baragar (1971; AFM plot) and Jensen (1976, Jensen cation plot) have limited discrimination ability for rhyolitic compositions especially when $\mathrm{Na}, \mathrm{K}, \mathrm{Fe}$ and $\mathrm{Mg}$ metasomatism has occurred, as is the case for the QP rhyolite. For altered felsic volcanic rocks of the Abitibi Greenstone Belt in the Noranda area, Quebec, Ujike and Goodwin (1987) and Barrett et al. (1993) proposed the use of the chondrite-normalized La/Yb ratio as a means of discrimination, whereas MacLean and Barrett (1993) used a $\mathrm{Zr}$ versus $Y$ diagram for the same purpose. Using $L a_{N} / Y b_{N}$ the least-altered $Q P$ rhyolite is classified as calc-alkaline whereas $\mathrm{Zr} / \mathrm{Y}$ ratios place it in the tholeiitic field (Figure 2.7). Associated mafic volcanic and intrusive rocks in the Kidd Creek mine area have tholeiitic characteristics and QP rhyolite is geochemically very similar to rhyolite erupted in the tholeiitic terranes of Iceland (Chapter 3). Therefore, the QP rhyolite is best characterized as having a tholeiitic association. QP rhyolite samples have REE patterns which are intermediate between end member FIIIb and FIIla felsic volcanic rocks (Lesher et al., 1986) but their pronounced negative Eu anomalies and elevated Th and $\mathrm{U}$ contents favour their inclusion in the Flllb group. The REE characteristics of the Kidd Creek rhyolites are discussed in detail in Chapter 3.

\section{Rhyolite Discrimination in the Kidd Creek Mine Area}

The north and south orebodies at the Kidd Creek Mine are contained within felsic volcaniclastic rocks of the Middle member which appear to be derived predominantly from FW rhyolite of the Lower member. The QP and FW rhyolites are geochemically very similar (Chapter 3 ) but discrimination is 
possible using selected elements which have remained relatively immobile. In Figure 2.8, a $\mathrm{TiO}_{2}$ versus $\mathrm{Nb}$ diagram is presented for samples of QP rhyolite (coherent and breccia facies) and FW rhyolite (coherent and monomict breccia facies). The QP rhyolite may be distinguished from the FW rhyolite by its generally higher $\mathrm{TiO}_{2}$ and lower Nb contents; a line drawn at a $\mathrm{Nb} / \mathrm{TiO}_{2}$ ratio of 0.0175 serves to separate the two rock types. Both the QP and FW rhyolite data tend to occur in elongate fields with long axes trending toward the origin. This pattern is typical for immobile-element binary diagrams constructed for a suite of rock samples having a common protolith in which significant mass changes have occurred (MacLean, 1990). Three QP breccia samples fall in the FW rhyolite field which may reflect the incorporation of FW rhyolitic and/or mafic clasts. In Figure 2.9, an $\mathrm{Al}_{2} \mathrm{O}_{3} / \mathrm{TiO}_{2}$ versus $\mathrm{Nb} / \mathrm{Zr}$ discrimination diagram is presented. Good separation is attained using a $\mathrm{Nb} / \mathrm{Zr}$ ratio of 0.085 with the QP rhyolites having the lower values. The $\mathrm{Al}_{2} \mathrm{O}_{3} / \mathrm{TiO}_{2}$ ratio is a less precise discriminator; all Lower member rhyolite samples have ratios of greater than 85 and most QP rhyolite samples have ratios of less than 85. However, four of 48 QP rhyolite samples have ratios between 85 and 110 .

\section{Application of Geochemical Discrimination to the Distribution of Rhyolite in the Kidd Creek Mine Area}

A large geochemical database ( $>1000$ chemical analyses) exists for samples of exploration drill core from the Kidd Creek Mine area (Falconbridge Limited data). Locations of samples within a volume of rock between 400 and $1050 \mathrm{~m}$ below surface (between the 1300 and 3400 foot mine levels) are 
shown in Figure 2.10. The $\mathrm{Al}_{2} \mathrm{O}_{3} / \mathrm{TiO}_{2}$ ratios of 217 felsic volcanic and volcaniclastic rocks containing $>65 w t . \% \mathrm{SiO}_{2}$ have been contoured. As shown in Figure 2.9, $\mathrm{Al}_{2} \mathrm{O}_{3} / \mathrm{TiO}_{2}$ ratios of $<80$ correspond to $\mathrm{QP}$ rhyolite whereas ratios of $>90$ indicate Lower member rhyolite affinities. Comparison of Figure 2.10, with the geological plan for 2800 Level (Figure 1.3) demonstrates the accuracy of the $\mathrm{Al}_{2} \mathrm{O}_{3} / \mathrm{TiO}_{2}$ ratio as a tool for discriminating stratigraphy in the immediate vicinity of the mine (the small area with $\mathrm{Al}_{2} \mathrm{O}_{3} / \mathrm{TiO}_{2}$ ratios of $>90$ south of the No.1 shaft represents a thin felsic tuffaceous unit overlying the QP rhyolite).

\section{Host Rocks of the Southwest Orebody}

The southwest orebody $(345,961$ metric tonnes of ore with an average grade of $9.45 \% \mathrm{Zn}, 0.84 \% \mathrm{~Pb}, 0.03 \% \mathrm{Cu}$ and $340 \mathrm{~g} / \mathrm{t} \mathrm{Ag}$; R. Cook, personal communication, 1995) is a small massive sulfide lens located in a structurally complicated area just north of the major fault which separates the Kidd Creek Mine package from a package of younger greywackes to the south (Bleeker, at al. 1996 ). The deposit is hosted by felsic volcanic rocks which appear to lie along strike from QP rhyolite and stratigraphically above the volcaniclastic sequence of the Middle member which hosts the north and south orebodies (Figure 1.3). If the southwest orebody is indeed hosted by QP rhyolite then it would demonstrate that ore formation continued after the eruption of the QP rhyolite which would greatly enhance the attractiveness of the QP rhyolite as an exploration target. Eight analyses of samples from the felsic volcanic rocks hosting the southwest orebody are shown on an $\mathrm{Al}_{2} \mathrm{O}_{3} / \mathrm{TiO}_{2}$ versus $\mathrm{Nb} / \mathrm{Zr}$ discrimination diagram in Figure 2.11. Seven of the eight values fall clearly 
within the Lower member rhyolite field indicating that the southwest orebody lies within the same stratigraphic sequence as the north and south orebodies and not within the QP rhyolite. This is consistent with the generally quartz-phenocryst poor nature of the southwest orebody felsic volcanic rocks.

\section{Alteration}

The spider diagrams presented in Figures 2.4 and 2.5 demonstrate that although considerable element mobility and mass change have occurred within the QP rhyolite, several elements including Al have remained relatively immobile. A diagram of $\mathrm{SiO}_{2}$ versus $\mathrm{Al}_{2} \mathrm{O}_{3}$ demonstrates that mass change effects, which control the apparent additions and depletions of Al, are largely controlled by gains and losses of Si with the data lying along a trend passing through the point $100 \mathrm{wt} . \% \mathrm{SiO}_{2}$ and $0 \mathrm{wt} . \% \mathrm{Al}_{2} \mathrm{O}_{3}$ which represents infinite $\mathrm{Si}$ addition (Figure 2.12). The two samples which lie off the trend have undergone strong alteration (these samples contain up to $30.50 \mathrm{wt} . \% \mathrm{CaO}$ and $24.00 \mathrm{wt} . \%$ $\mathrm{CO}_{2}$ ). $\mathrm{Al}_{2} \mathrm{O}_{3}$ varies from $5.45-15.70$ wt. \% due almost entirely to mass change. This range of values may be expressed as a range factor (RF) defined simply as the maximum analytical value divided by the minimum analytical value for any given element in a suite of rocks having a common protolith:

$$
\operatorname{RF}\left(\mathrm{Al}_{2} \mathrm{O}_{3}\right)=\mathrm{Al}_{2} \mathrm{O}_{3}(\max ) / \mathrm{Al}_{2} \mathrm{O}_{3}(\min )=15.70 \mathrm{wt} . \% / 5.45 \mathrm{wt} . \%=2.9
$$

Range factor values for several elements of interest are listed in Table 2.4 for samples of coherent QP rhyolite. The relatively immobile elements $\mathrm{Al}$, 
$\mathrm{Zr}, \mathrm{Nb}, \mathrm{Hf}, \mathrm{Ta}$, Th and the REE have range factor values of generally less than 4 which primarily reflect dilution (mass gain) and concentration (mass loss) rather than mobility of $\mathrm{Al}$, high field strength elements (HFSE) and REE. In contrast, several elements which are commonly mobilized during VMS hydrothermal alteration including $\mathrm{Fe}, \mathrm{Mn}, \mathrm{Mg}, \mathrm{Ca}, \mathrm{Na}_{2}, \mathrm{~K}_{2}, \mathrm{H}_{2} \mathrm{O}^{+}, \mathrm{S}, \mathrm{Cu}, \mathrm{Zn}, \mathrm{Rb}$, $\mathrm{Sr}$ and $\mathrm{Ba}$ have range factors that vary from 8.3 to 1146 . Note the small range factor value for $\mathrm{SiO}_{2}(2.4)$ despite the large range of $\mathrm{SiO}_{2}$ values (49.1 wt.\%). High range factor values of $\mathrm{CaO}(191)$ and $\mathrm{CO}_{2}(2400)$ reflect, in part, the postore development of calcite along late fractures. These results indicate that within the QP rhyolite mass-change effects are relatively insignificant compared to metasomatic additions and depletions and need not be considered in a general study of alteration.

Alteration within the QP rhyolite is investigated using binary diagrams presented in Figures 2.13 to 2.16 for 48 samples from both the coherent and breccia facies of the QP rhyolite. The $\mathrm{Fe}_{2} \mathrm{O}_{3}$ versus $\mathrm{H}_{2} \mathrm{O}^{+}$and $\mathrm{MgO}$ versus $\mathrm{H}_{2} \mathrm{O}^{+}$ plots show that 21 of the 48 samples are enriched in $\mathrm{Fe}, 18$ of the 48 samples are enriched in $\mathrm{Mg}$ and that 17 of the 48 samples are enriched in $\mathrm{H}_{2} \mathrm{O}^{+}$relative to the fields containing the least altered QP rhyolite analyses. Strong correlations between $\mathrm{Fe}_{2} \mathrm{O}_{3}, \mathrm{MgO}$ and $\mathrm{H}_{2} \mathrm{O}^{+}$, a lack of $\mathrm{Fe}_{2} \mathrm{O}_{3}-\mathrm{S}$ correlation and generally low $\mathrm{S}$ values (only four samples contain greater than $0.25 \mathrm{wt}$.\% S) indicate that the added $\mathrm{Fe}$ and $\mathrm{Mg}$ is being accommodated in chlorite (Table 2.5). The four QP rhyolite samples enriched in S (0.77 - 2.04 wt. \% S) are all from the breccia facies suggesting that sulfide deposition was greatest within the relatively permeable fragmental zones. Three of the S enriched QP breccia 
samples fall off the correlation trend between $\mathrm{Fe}_{2} \mathrm{O}_{3}$ and $\mathrm{H}_{2} \mathrm{O}^{+}$in Figure 2.13 consistent with the presence of Fe sulfide. Twenty-two of the $48 \mathrm{QP}$ rhyolite samples contain $<1.0 \mathrm{wt} . \% \mathrm{Na}_{2} \mathrm{O}$ and 31 of the samples contain $<2.0$ wt. \% $\mathrm{Na}_{2} \mathrm{O}$. The negative correlation between $\mathrm{Na}_{2} \mathrm{O}$ and $\mathrm{H}_{2} \mathrm{O}^{+}$reflects the development of a hydrous phylosilicate alteration assemblage (sericite and chlorite) at the expense of plagioclase. The $\mathrm{SiO}_{2}$ versus $\mathrm{Al}_{2} \mathrm{O}_{3}$ plot presented in Figure 2.12 reveals both silicification and silica depletion relative to the estimated protolith composition. Silica depletion commonly accompanies the development of phylosilicate alteration assemblages (MacLean and Barrett, 1993). On a Cu versus $\mathrm{Zn}$ plot, 16 of the 48 samples (33\%) display anomalous $\mathrm{Cu}(>40 \mathrm{ppm})$ and/or $\mathrm{Zn}$ (>150 ppm Zn) concentrations with values up to 541 ppm Cu and 1940 ppm Zn. Seven of the eight samples containing the highest $\mathrm{Zn}$ values are from the breccia facies suggesting that $\mathrm{Zn}$ deposition was greatest within the permeable breccia zones. The occurrence of extensive hydrothermal alteration within the QP rhyolite, documented above, indicates that the Kidd Creek hydrothermal system was still operating subsequent to eruption of QP rhyolite.

\section{QP Rhyolite Morphology}

The morphology of the QP Rhyolite is illustrated by the isopach and relief maps shown in Figures 2.17 and 2.18. Isopachs are based on continuous sections through the QP rhyolite, excluding mafic sills, in underground workings and drill core between the 800 to 4700 foot levels of the Kidd Creek 
Mine. The QP rhyolite is viewed from the WNW, parallel to the $F_{1}$ fold axial plane and, as illustrated in these figures, has been unfolded about this plane. Isopachs south of the axial plane represent minimum thicknesses as the base of the QP rhyolite is in fault contact with a regionally extensive greywacke package to the south. The relief map in Figure 2.18 is constructed from the isopach map assuming a horizontal base for the QP flow. A horizontal base for the flow is a reasonable assumption considering that the footwall mixed fragmental unit, a succession of debris and mass flow deposits, would have been localized within and filled topographic irregularities. As further support, bedding within underlying, plane-bedded volcaniclastic sandstone parallels the flow base.

The isopach and relief maps clearly illustrate that the QP rhyolite consists of two separate ridges, a north ridge exposed in mine workings east of the mine shafts and a south ridge located south of the mine shafts. These two ridges are separated by the $F_{1}$ fold axis which occupies the intervening "valley". Paleotopographic domes situated along the ridges attain heights (thicknesses) of up to $130 \mathrm{~m}$. Within the area encompassed by Figures 2.17 and 2.18, the north and south ridges of the QP rhyolite flow have a combined volume of approximately $0.1 \mathrm{~km}^{3}$ The ridges show a pronounced elongation that is subparallel to the $F_{1}$ fold axis. This "vertical" elongation is interpreted to represent a primary trend that reflects the orientation of an underlying synvolcanic fissure. The location of the $F_{1}$ fold axis in the area between the two ridges, where the flow is thin, may reflect a primary zone of weakness that was exploited during folding. Thus, the plunge of the ridge axes and not the $F_{1}$ fold 
axis may represent the trend of primary synvolcanic faults. A north-south profile across the north and south ridges, through the two highest QP rhyolite domes (Figure 2.19) depicts a paleotopography consistent with steep-sided domes with aspect ratios of 3 to 5 flanked by breccias (aspect ratio=horizontal extent/dome height: Walker, 1973). Aspect ratios of less than 10 clearly distinguish the QP rhyolite from pyroclastic flow or fall deposits.

The QP breccia isopach in Figure 2.20, constructed using data available from the mine workings only, illustrates that the breccia is thickest on the flanks of the "domes" and thins immediately below the domes. This distribution of breccia clearly supports an origin through shedding from the top and sides of the rhyolitic ridge during emplacement and growth of the dome. Shown on Figure 2.20 are two flow direction vectors based on the angular discordance between beds within the basal flow foot breccia, which dip away from the domes, and overlying flow-banded rhyolite. Note that the flow vectors are consistent with the isopach map as they indicate a flow direction that extends away from the dome.

Post-volcanic deformation may have elongated the QP rhyolite by up to $100 \%$ in the down-plunge dimension and shortened it by as much as $50 \%$ perpendicular to plunge (Bleeker, et al., 1996). Structural elongation and shortening has not, however, significantly modified the ridge and dome morphology of the QP rhyolite flow depicted in Figures 2.17 to 2.19. The north and south QP rhyolite ridges are remarkably similar, in mineralogy, textures, structures, morphology and scale to the undeformed Upper and Lower QP 
flows of the Millenbach Rhyolite, host to the Millenbach massive sulfide deposits, at Noranda, Quebec (Gibson, 1990; Gibson and Watkinson, 1990).

\section{Volcanic Reconstruction}

The QP rhyolite erupted from two, parallel fissures, $800 \mathrm{~m}$ apart, constructing two, elongate ridges where domes mark vent sites that had high lava extrusion rates and /or sustained eruptions. At the time of their eruption the ridges would have directly overlain their feeding fissures. The fissure below the south ridge is concealed (or removed) by the younger, fault-bounded greywacke. The feeding fissure beneath the north ridge should occur within the area of the mine workings, but QP rhyolite dikes have not been identified. This may reflect drainage and/or collapse of the fissure during waning QP rhyolite volcanism.

The QP rhyolite ridges are interpreted to have formed largely by endogenous growth, where each internal lobe represents a new pulse of magma that was emplaced into the flow. Endogenous growth of the flow/dome occurred along the ridge but was concentrated at two vent areas on the north ridge and one vent area on the south ridge within the area shown in Figure 2.17. Both flank- and flow foot breccias are interpreted to have been derived through slumping, mass wasting, of the rhyolite flow during endogenous dome growth. Flow foot breccia is essentially a flank breccia that has been overridden by coherent rhyolite during dome growth. Fragments of sericitized and 
silicified rhyolite in flank and flow foot breccias are interpreted to have been derived from altered rhyolite that surrounded paleo-hotsprings on the dome surface. In this scenario the QP rhyolite is interpreted to have been emplaced during hydrothermal activity; an example of coincident and contemporaneous volcanism and alteration. The absence of basalt in the footwall rhyolite succession suggests that occasional, rounded to subangular, basaltic fragments (pebble-size to block-size) found within the breccias may have been derived from contemporaneous mafic volcanism or possibly through explosive eruptions during the initiation of QP rhyolitic eruptions; however, they may also be derived from an external source.

The feeding fissure for the north ridge marks a primary structure, possibly a synvolcanic fault that parallels the known ore bodies. Prior to the eruption of the QP rhyolite this fissure may have been the principal conduit that focused hydrothermal discharge responsible for the formation of the south and southwest orebodies. An ancillary, parallel structure may have been the principal conduit for ascending hydrothermal fluids which formed the north orebody. It is probable that the synvolcanic structure which controlled the eruption of the south QP rhyolite ridge may have also provided a conduit for ascending hydrothermal fluid. This suggests that there is a possibility for additional sulfide lenses to occur, at depth, below the younger greywacke where underlying volcanic strata may be preserved (Figure 2.21).

Mafic sills and overlying basalt flows show limited evidence of hydrothermal alteration (Huston, et al., 1995) which indicates that they were 
emplaced during waning hydrothermal activity. Perhaps the emplacement of this thick, basaltic succession and co-magmatic sills may, in part, have been responsible for "shutting-down" the Kidd Creek hydrothermal system. 


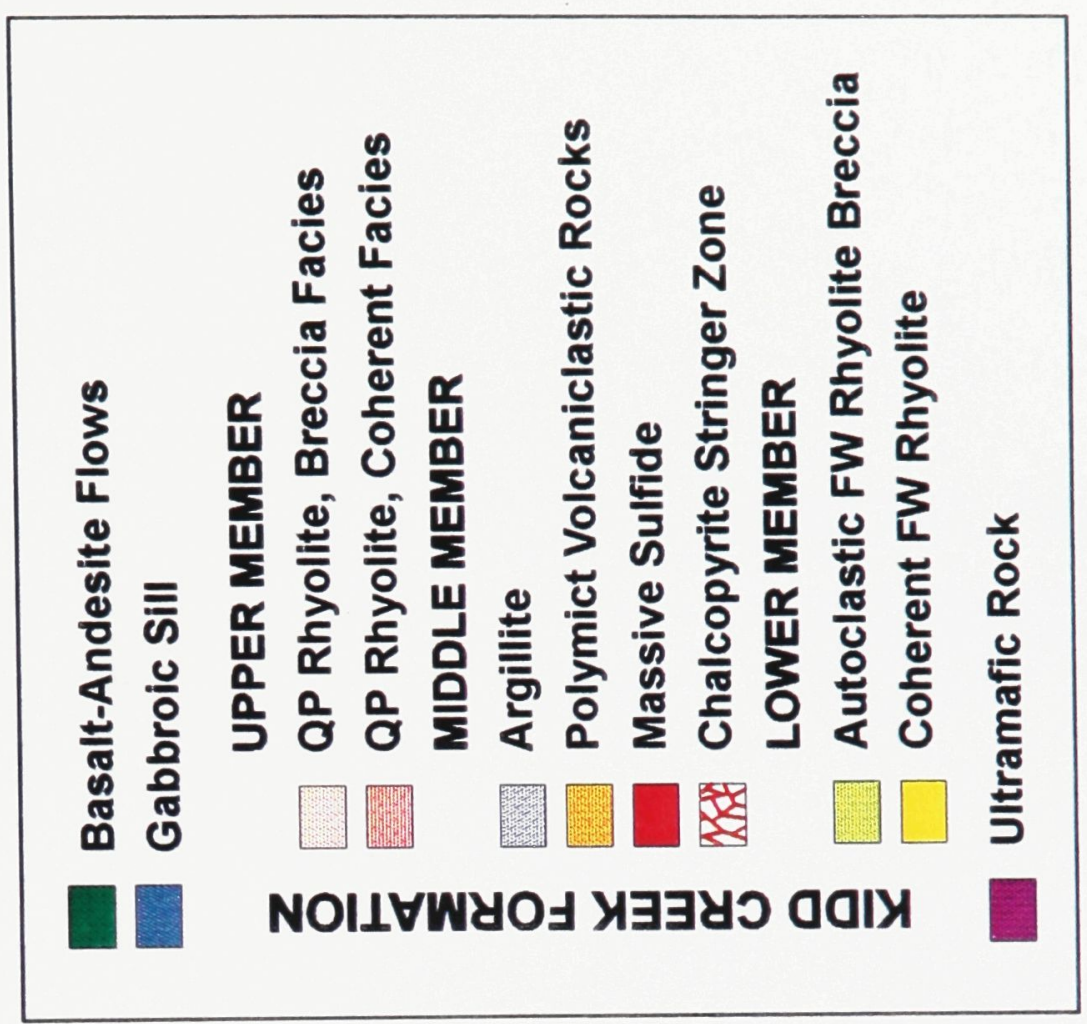

है

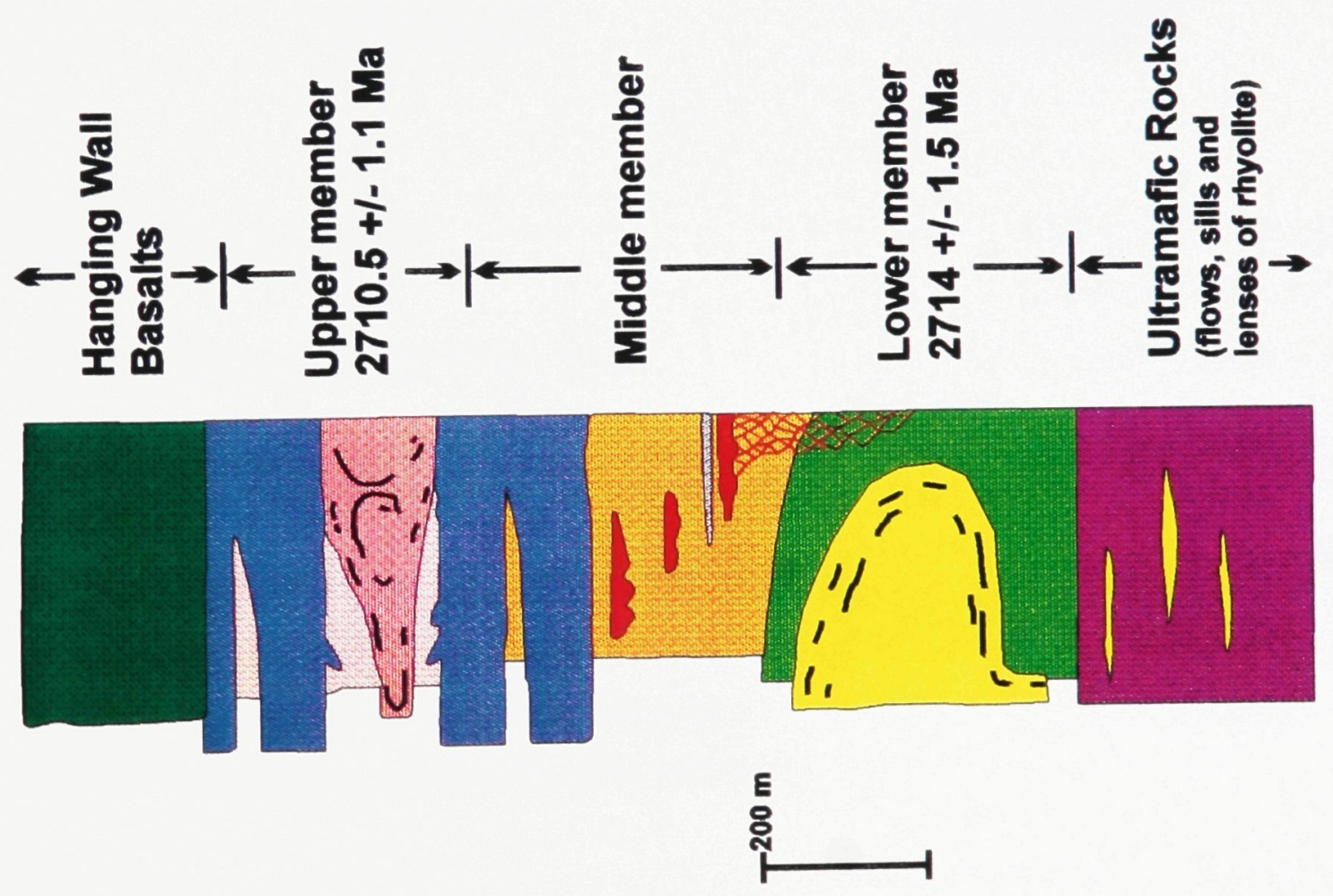

믐

送

임

寡

응

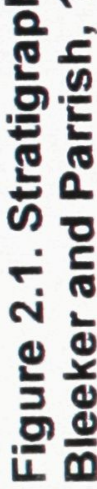




\section{COHERENT FACIES}

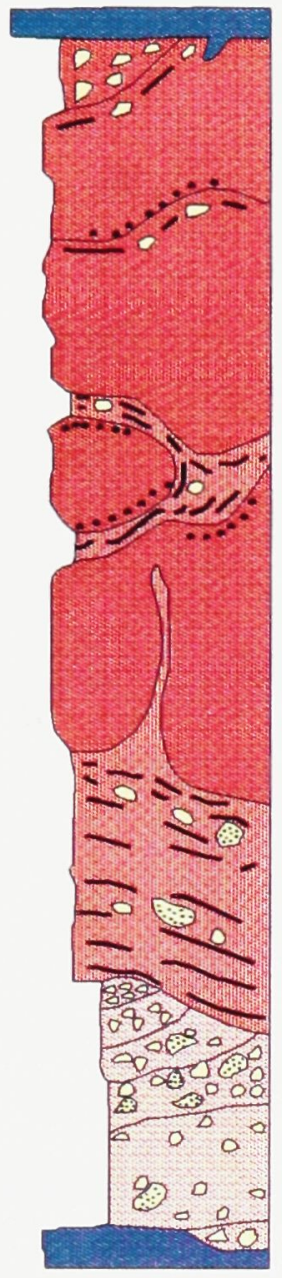

\section{BRECCIA FACIES}

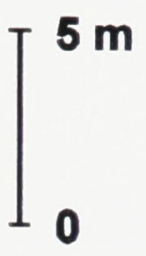

Gabbro Sill

$\triangle$ Rhyolite Blocks (silicified/sericitized)

Massive QP Rhyolite

..... Quartz Amygdules

Flow-Banded QP Rhyolite

- Flow Banding

Flank And Flow-Foot Breccia And Hyaloclastite

Bedding

Volcaniclastic Sandstone (Redeposited Hyaloclastite)

Figure 2.2. Idealized stratigraphic sections through coherent facies (vent-proximal) and breccia (distal) facies of the QP rhyolite. Drawing by H. Gibson. 
NORTH

SOUTH

\section{WEST WALL, 2101 DRIVE SOUTH}
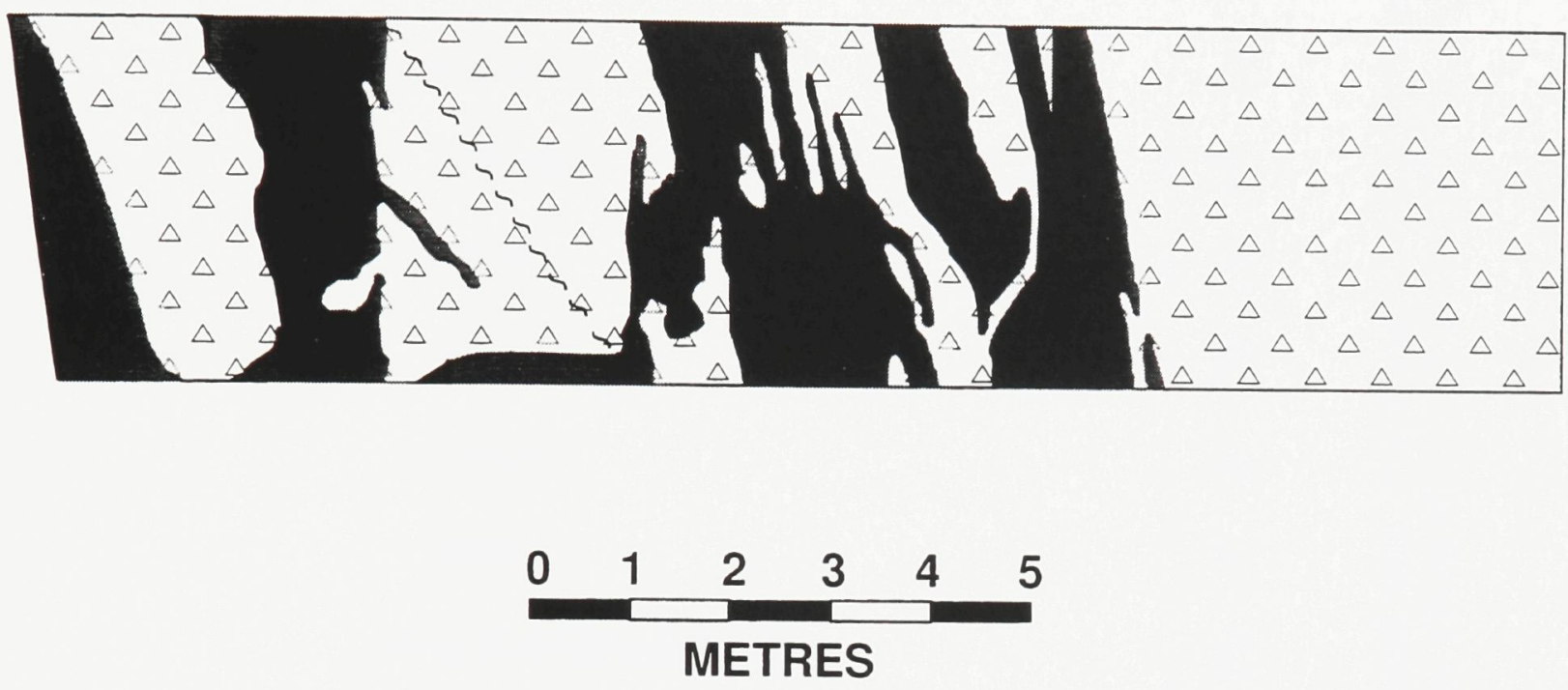

Gabbro Sill

$\Delta$ QP Rhyolite Breccia Facies

Figure 2.3. Geological map of west wall of 2101 Drive South. The contact between the upper, chilled margin of the "wedge" gabbro sill and the breccia facies of the QP rhyolite is marked by peperitic breccias where fine-grained apophyses from the sill intruded, autobrecciated, and mixed with QP rhyolite fragmental material. Mapped by H. Gibson. 


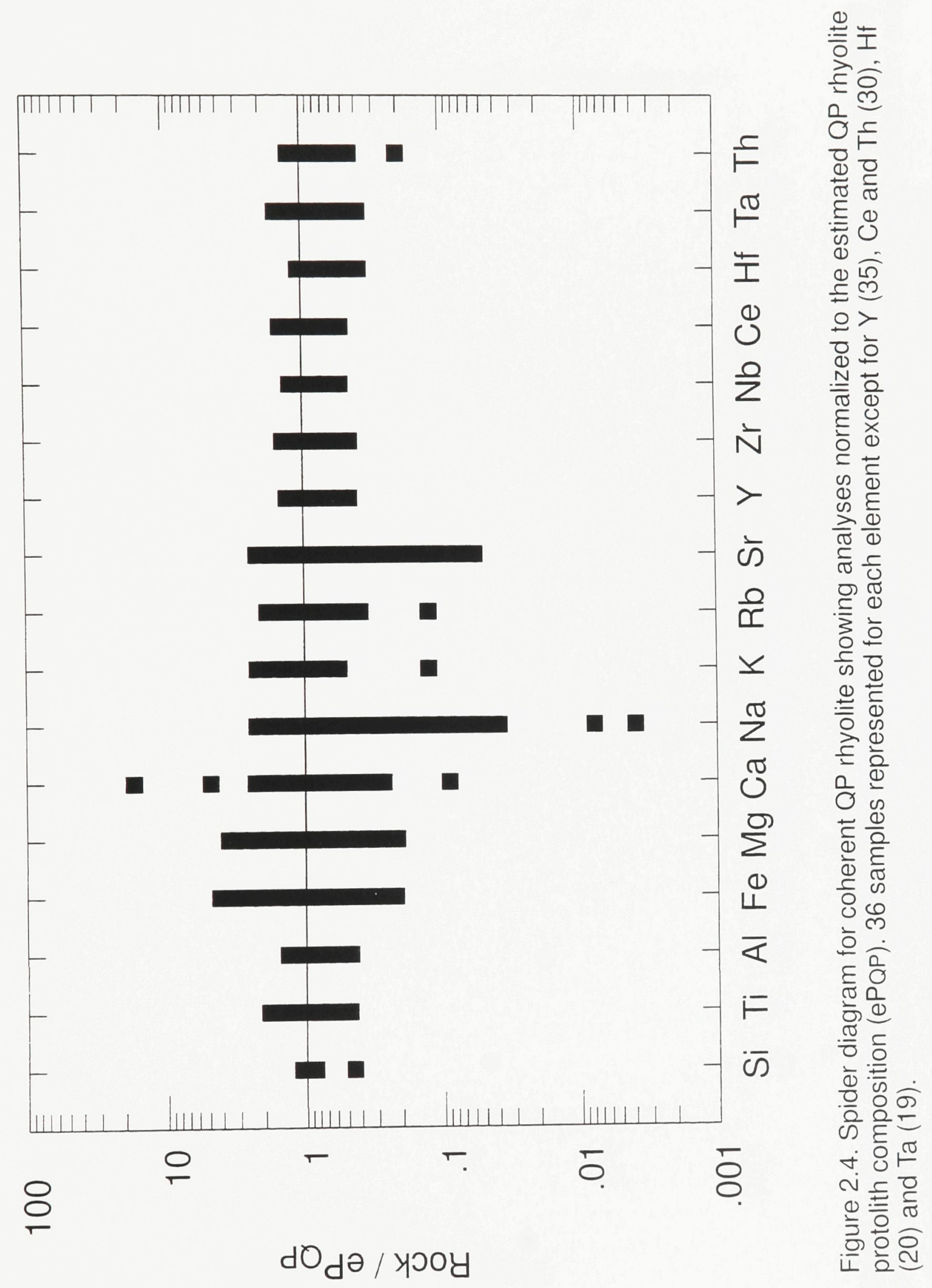




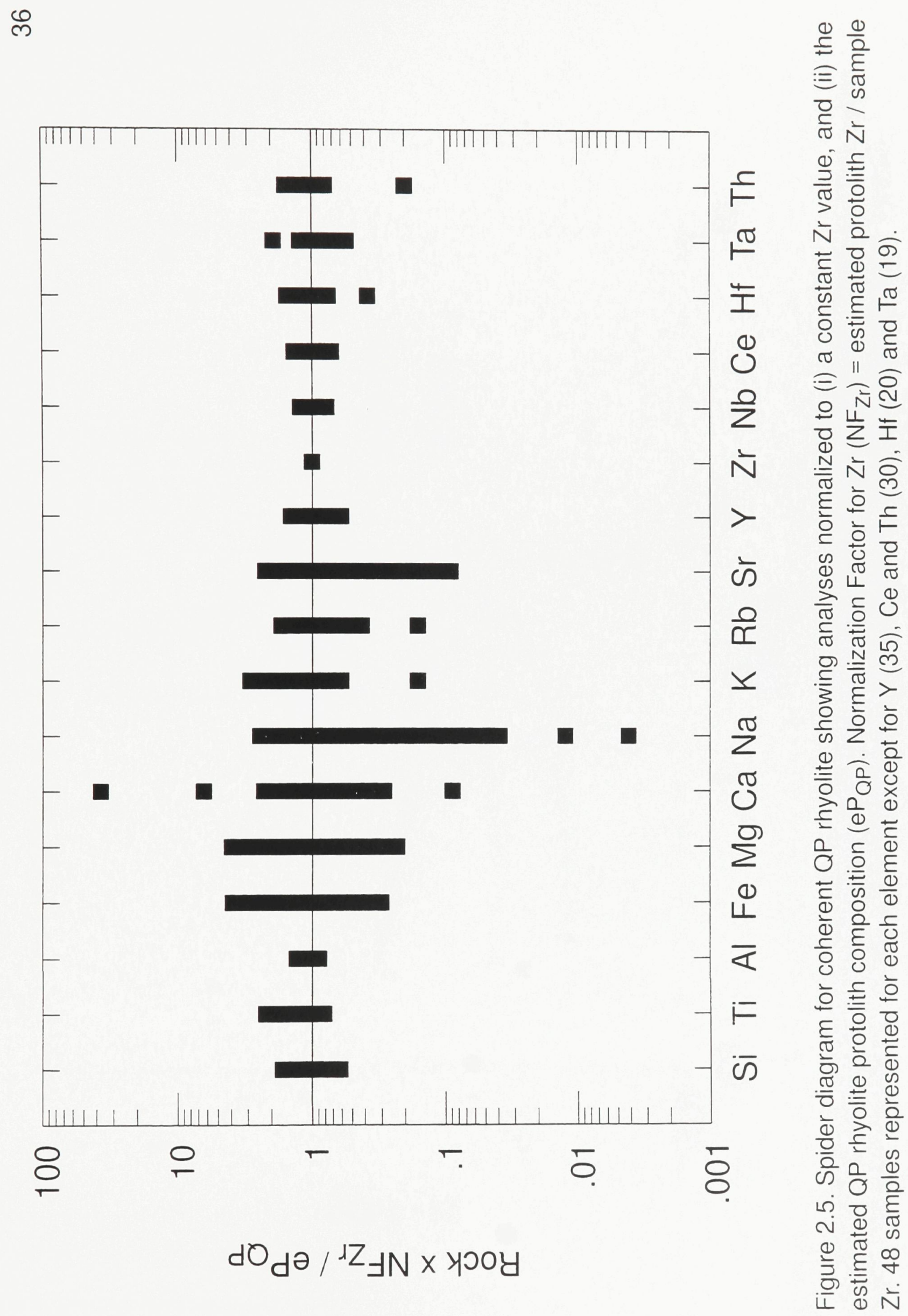


ก

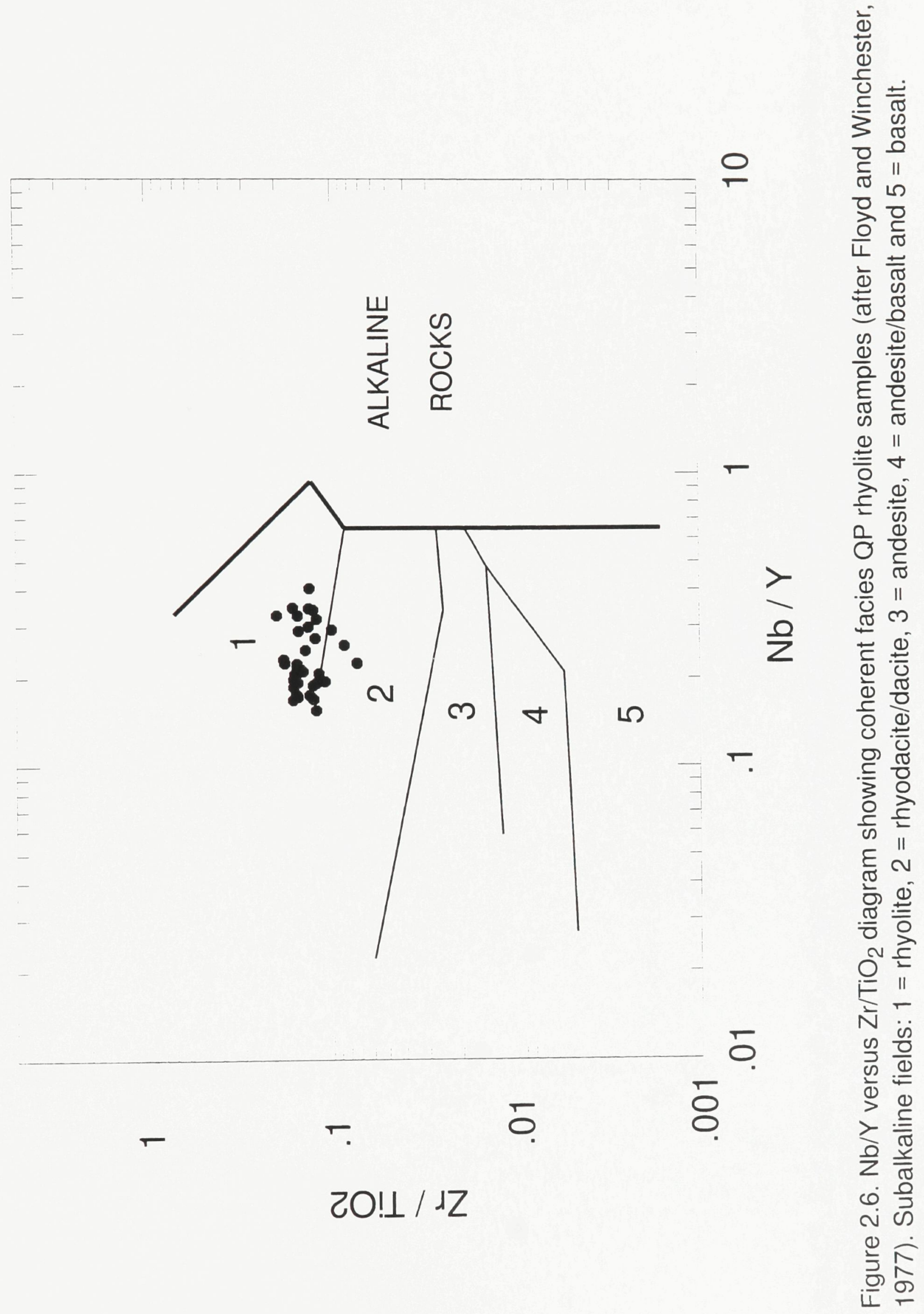




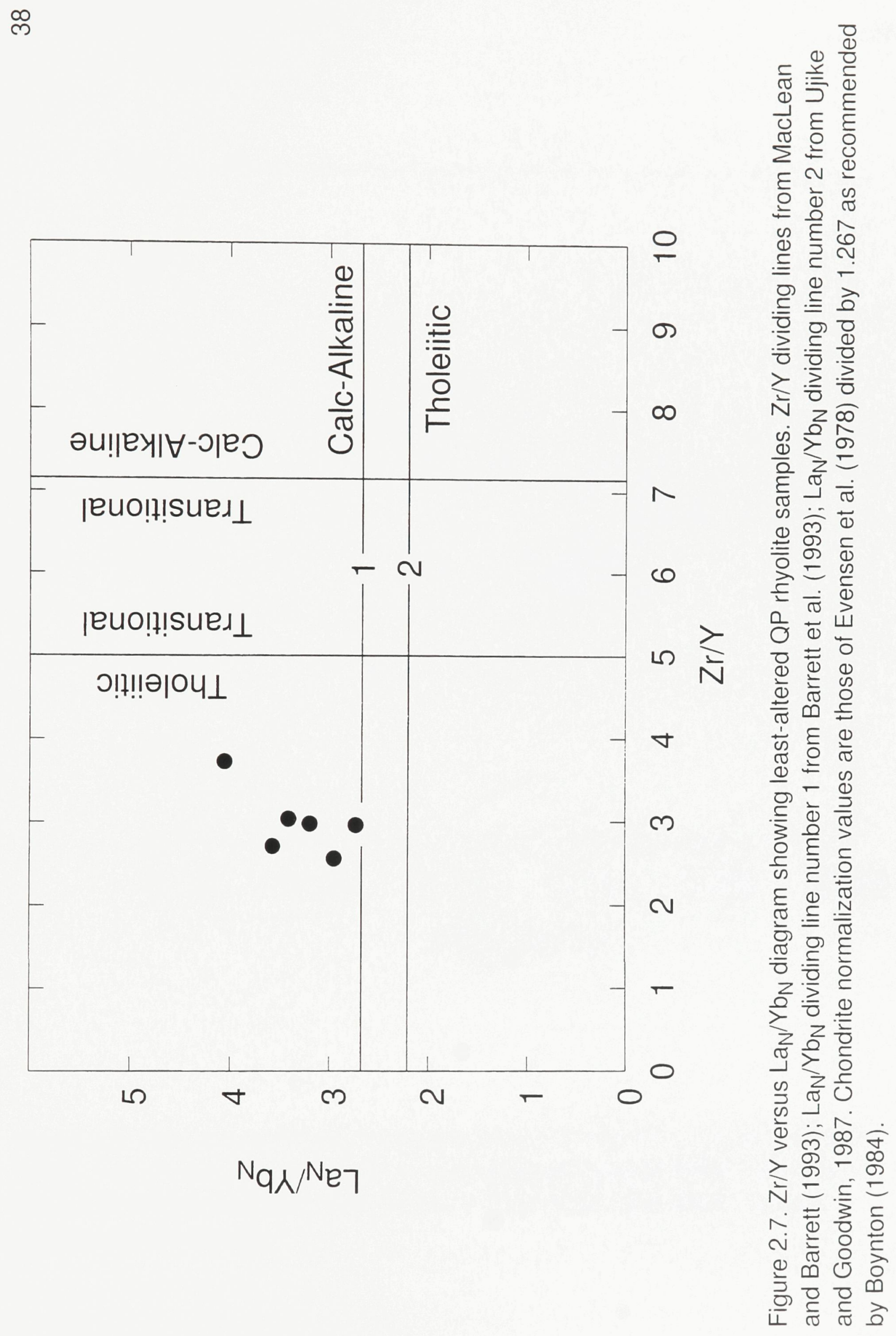




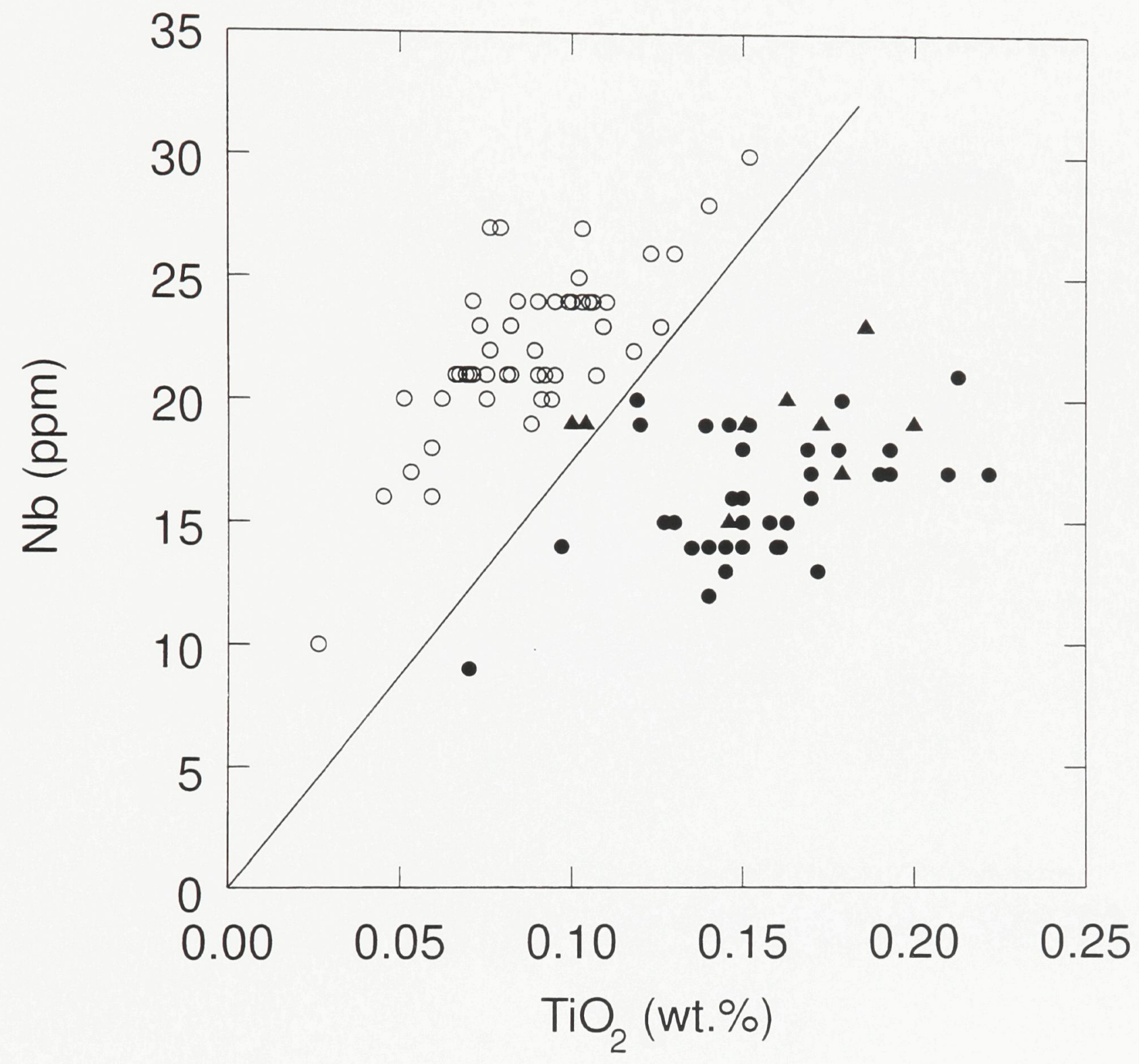

Figure 2.8. $\mathrm{TiO}_{2}$ versus $\mathrm{Nb}$ discrimination diagram for the Kidd Creek rhyolites. Filled circles = coherent facies QP rhyolite samples; filled triangles $=$ breccia facies QP rhyolite samples; open circles = coherent and autoclastic breccia samples of FW rhyolite. 


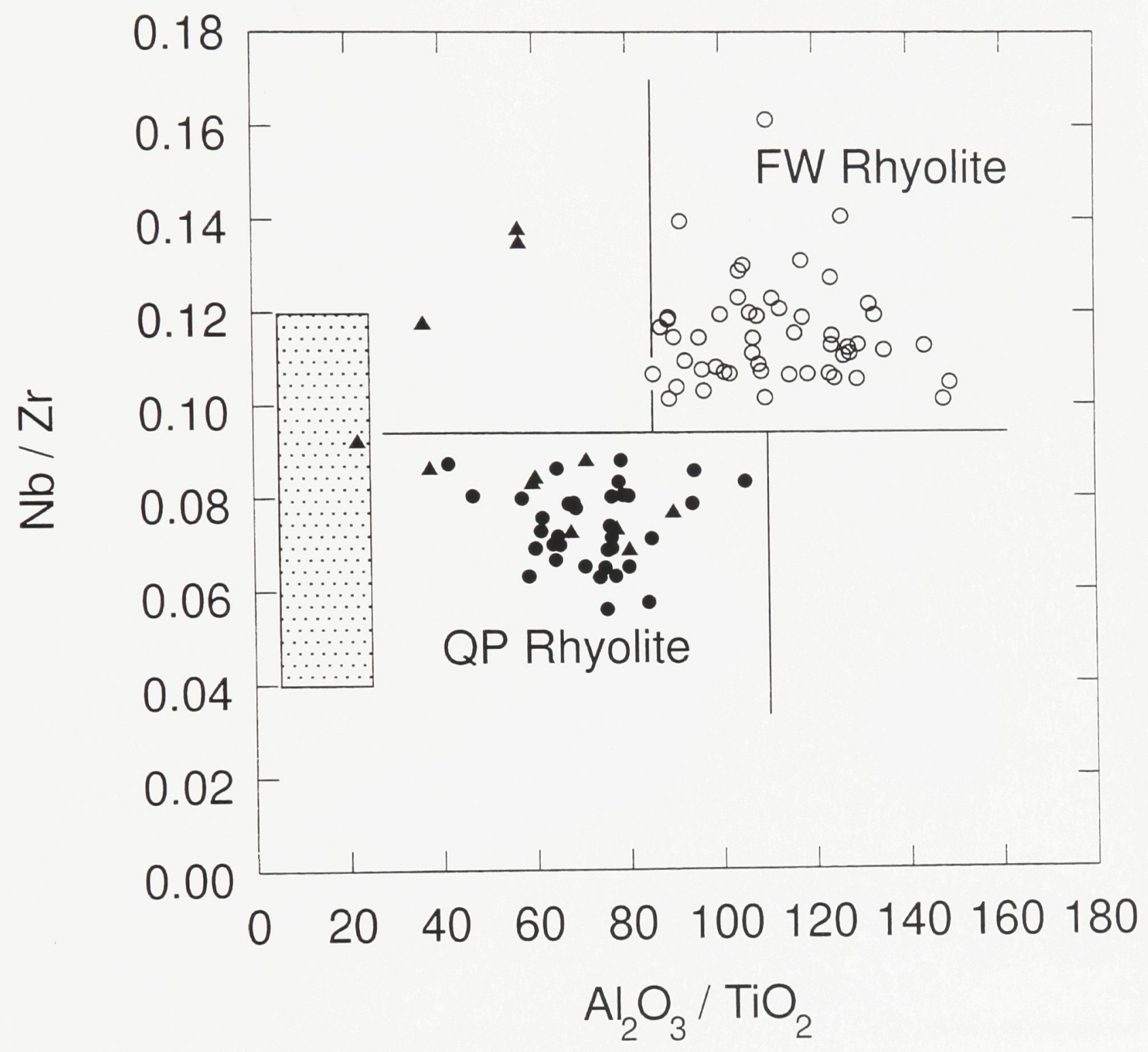

Figure 2.9. $\mathrm{Al}_{2} \mathrm{O}_{3} / \mathrm{TiO}_{2}$ versus $\mathrm{Nb} / \mathrm{Zr}$ discrimination diagram for the Kidd Creek rhyolites. Filled circles = coherent facies QP rhyolite samples; filled triangles = breccia facies QP rhyolite samples; open circles = coherent and autoclastic breccia samples of FW rhyolite; stippled area = field of mafic igneous rocks. 


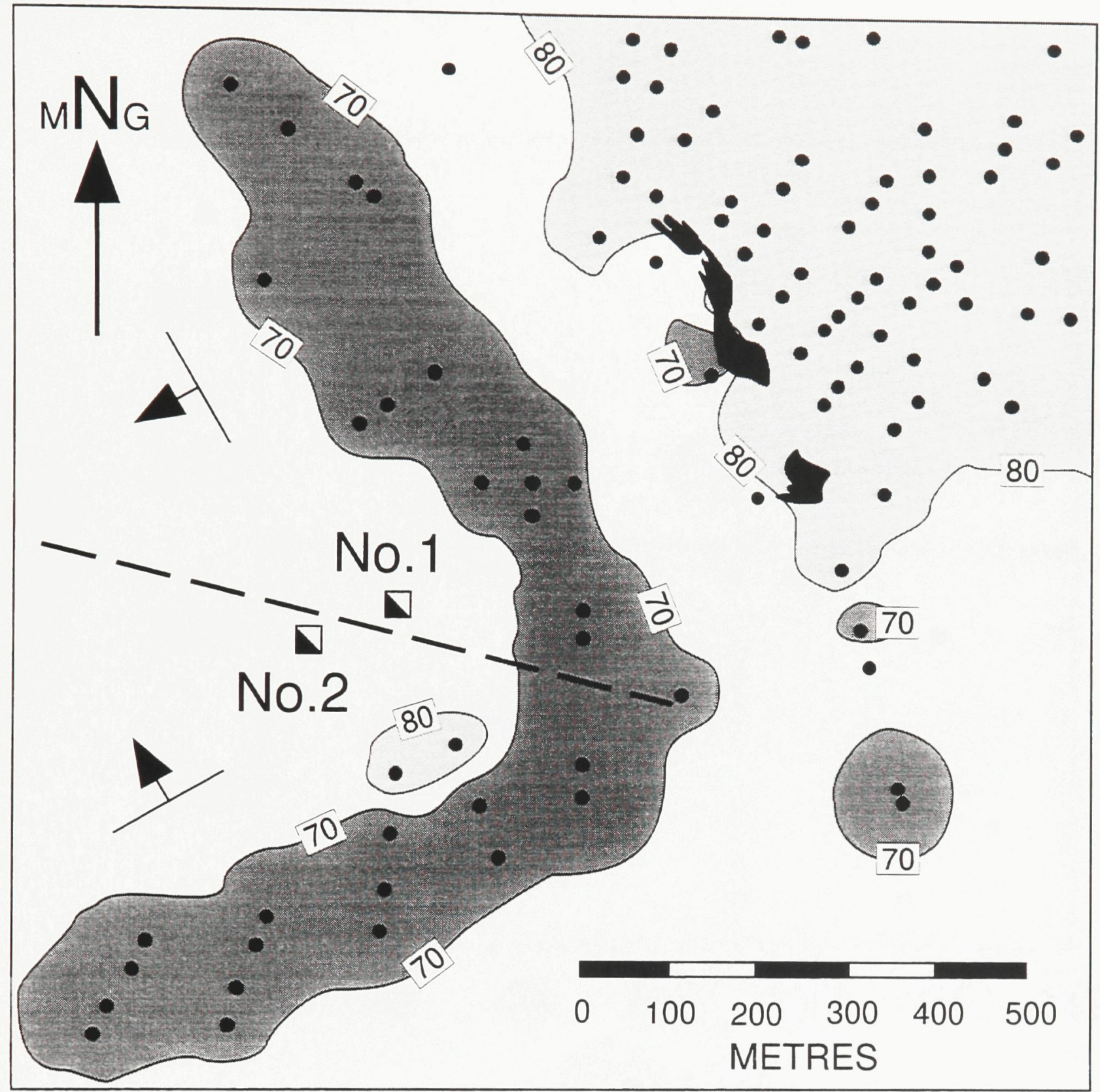

Figure 2.10. $\mathrm{Al}_{2} \mathrm{O}_{3} / \mathrm{TiO}_{2}$ contours for felsic $\left(>65 \% \mathrm{SiO}_{2}\right)$ volcanic and volcaniclastic rocks in the Kidd Creek Mine area between 410 and 1020 metres below surface (1300 to 3400 foot levels). Data is projected vertically onto the 2800 level. Dark grey $=\mathrm{Al}_{2} \mathrm{O}_{3} / \mathrm{TiO}_{2}$ ratios of $\angle 80$ (QP rhyolite), white = ratios of 80 to 90 , light grey =ratios of $>90$, black $=$ north and south orebodies, heavy dashed lines $=F_{1}$ fold axes, arrows indicate top directions, ${ }_{M} N_{G}=$ mine grid north (azimuth $020^{\circ}$ ), and dots = felsic volcanic rock sample locations (approximately $50 \%$ of the 217 sample locations have been omitted for clarity). Areas with no felsic volcanic samples were assigned a background $\mathrm{Al}_{2} \mathrm{O}_{3} / \mathrm{TiO}_{2}$ ratio of 85 . Geochemical and geological data from Falconbridge Limited. 


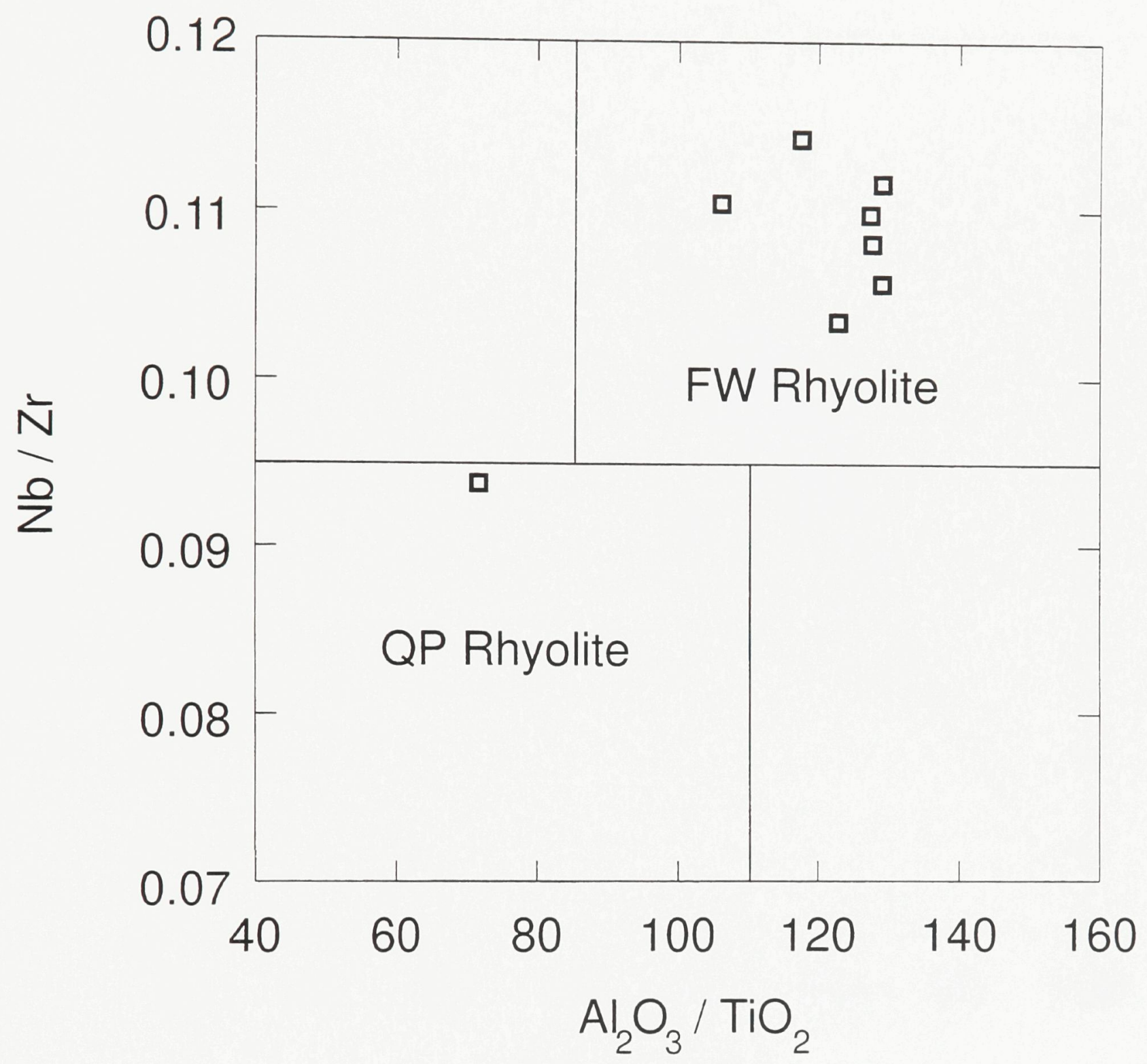

Figure 2.11. $\mathrm{Al}_{2} \mathrm{O}_{3} / \mathrm{TiO}_{2}$ versus $\mathrm{Nb} / \mathrm{Zr}$ discrimination diagram for the Kidd Creek rhyolites showing samples of the rhyolitic rocks hosting the southwest orebody. 


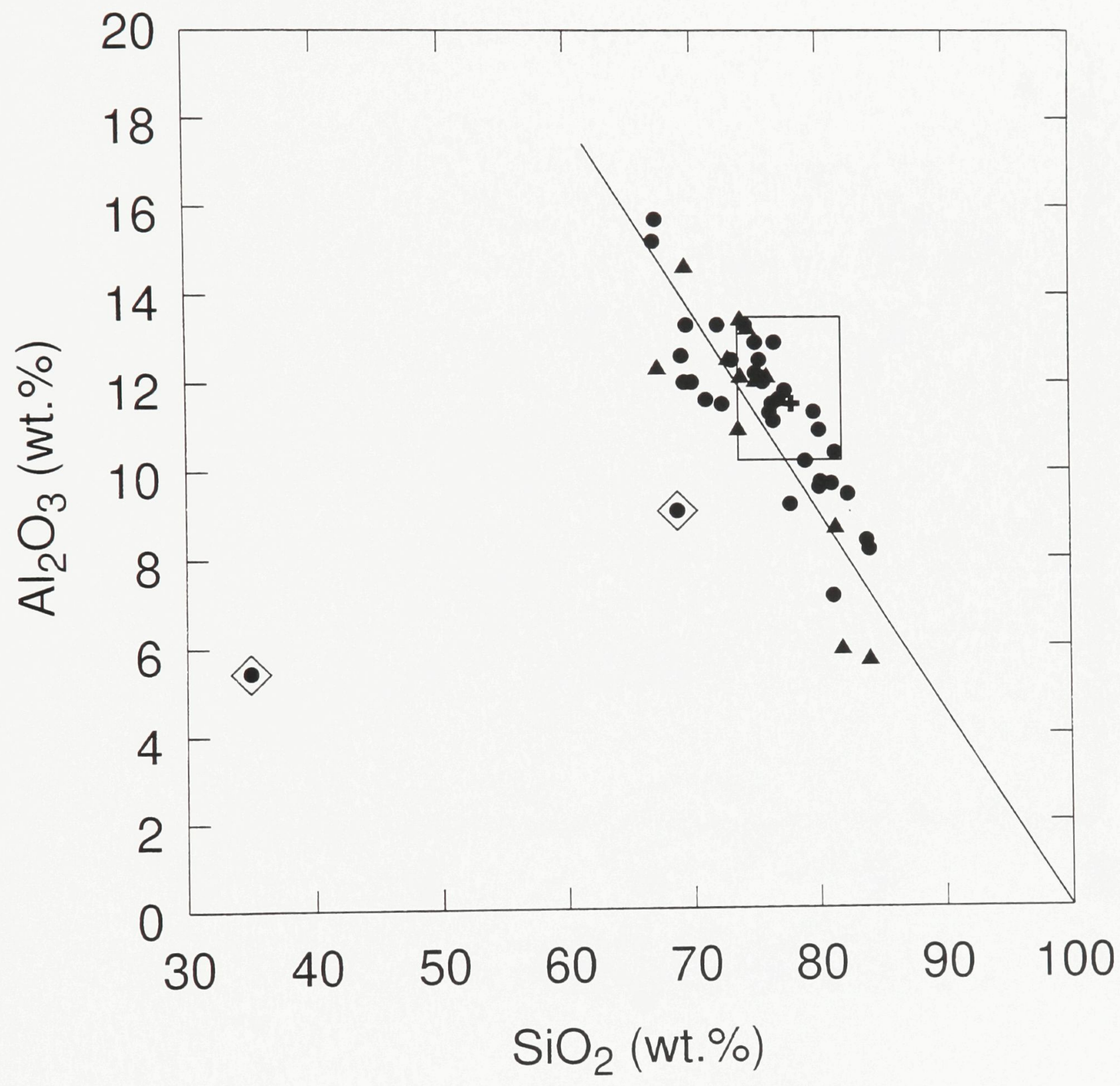

Figure 2.12. $\mathrm{SiO}_{2}$ versus $\mathrm{Al}_{2} \mathrm{O}_{3}$ diagram. Filled circles = coherent facies QP rhyolite samples; filled triangles = breccia facies QP rhyolite samples; cross = estimated protolith composition; open box = field of least-altered QP rhyolite samples. Symbols enclosed by diamonds are from samples with strong calcite alteration (up to 31 wt. $\% \mathrm{CaO}$ and 24 wt. $\% \mathrm{CO}_{2}$ ). 


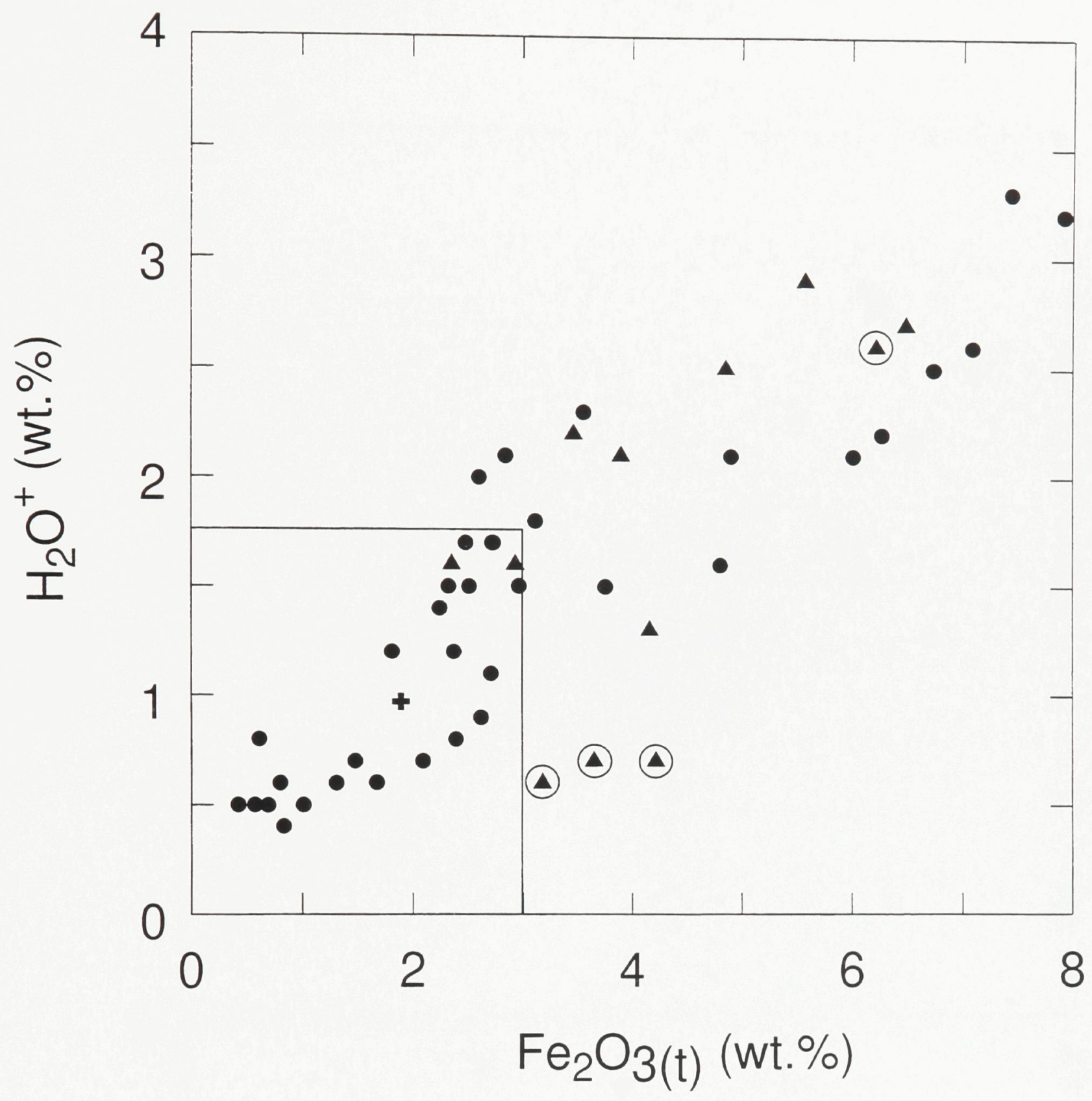

Figure 2.13. $\mathrm{Fe}_{2} \mathrm{O}_{3(\mathrm{t})}$ versus $\mathrm{H}_{2} \mathrm{O}^{+}$diagram (data in wt.\%). $\mathrm{Fe}_{2} \mathrm{O}_{3(\mathrm{t})}=$ total $\mathrm{Fe}$; filled circles = coherent facies $\mathrm{QP}$ rhyolite samples; filled triangles $=$ breccia facies QP rhyolite samples; cross = estimated protolith composition; open box = field of least-altered QP rhyolite samples. Symbols enclosed by circles are from samples enriched in S ( $0.77-2.04$ wt. $\%$ S; remaining samples contain $<0.25$ wt.\% S). 


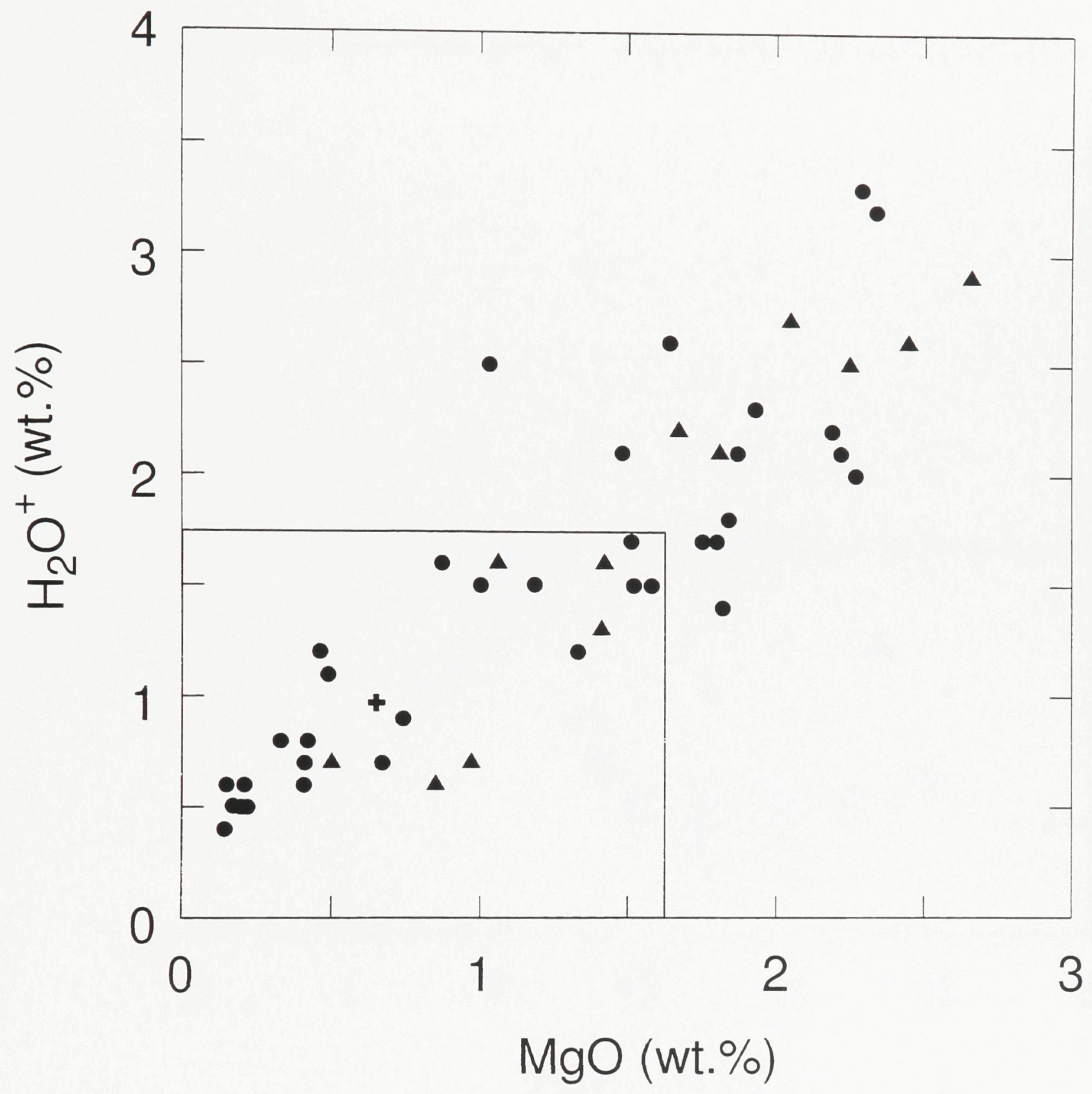

Figure 2.14. $\mathrm{MgO}$ versus $\mathrm{H}_{2} \mathrm{O}^{+}$diagram (data in wt.\%). Filled circles = coherent facies QP rhyolite samples; filled triangles = breccia facies $Q P$ rhyolite samples; cross = estimated protolith composition; open box = field of least-altered QP rhyolite samples. 


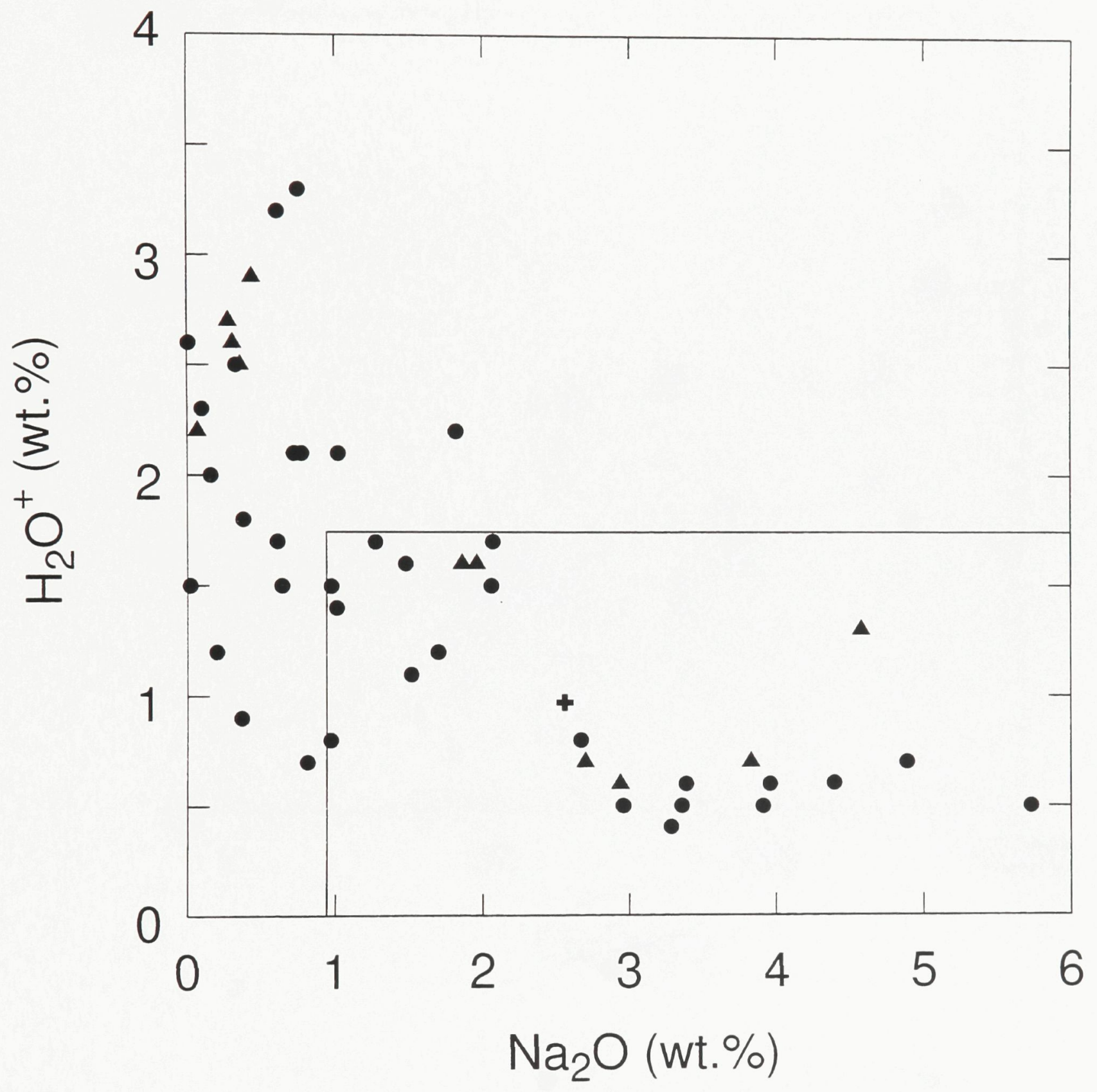

Figure 2.15. $\mathrm{Na}_{2} \mathrm{O}$ versus $\mathrm{H}_{2} \mathrm{O}^{+}$diagram (data in wt.\%). Filled circles = coherent facies QP rhyolite samples; filled triangles = breccia facies QP rhyolite samples; cross = estimated protolith composition; open box = field of least-altered QP rhyolite samples. 


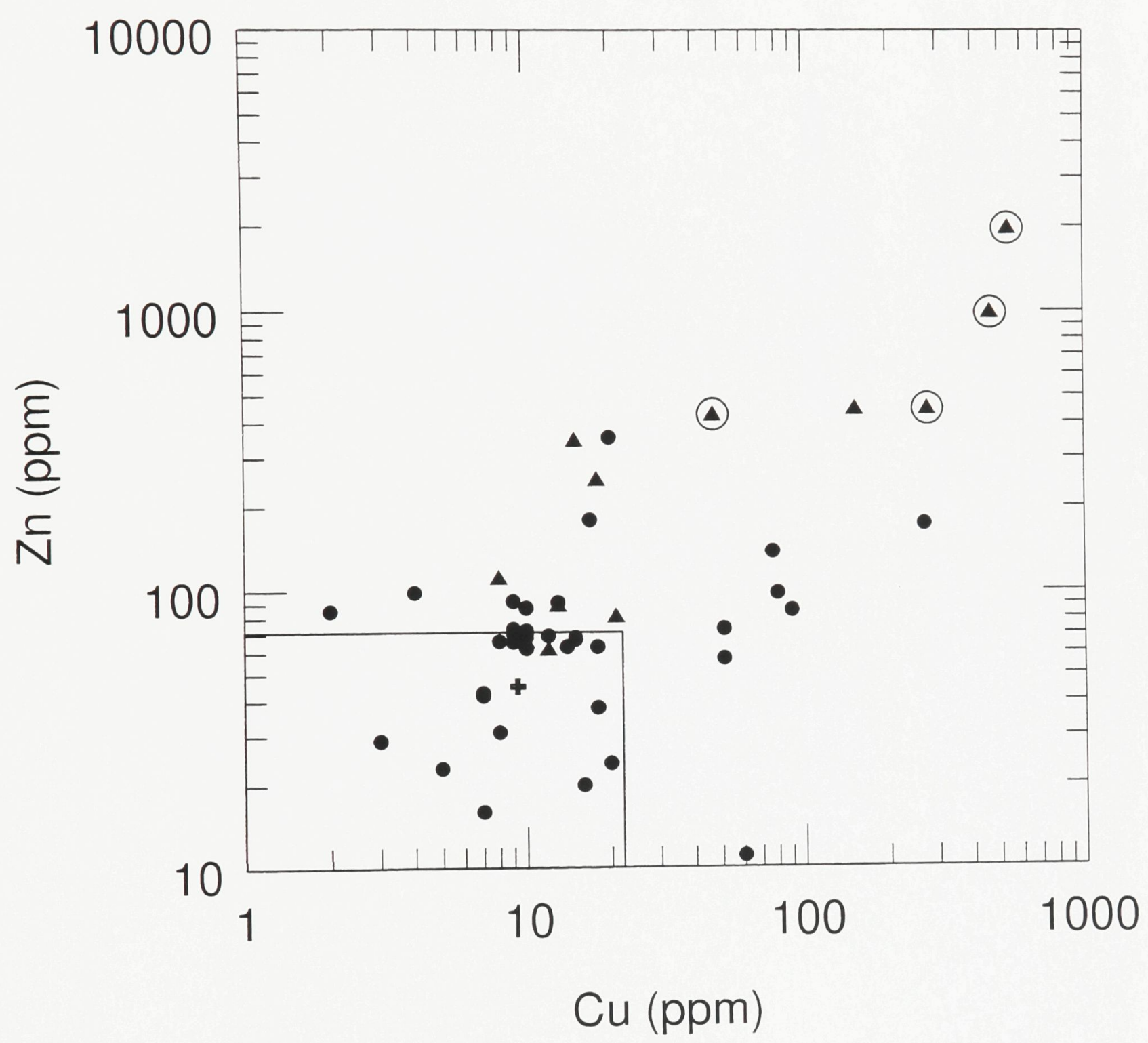

Figure 2.16. Cu versus $\mathrm{Zn}$ diagram (data in $\mathrm{ppm}$ ). Filled circles = coherent facies $\mathrm{QP}$ rhyolite samples; filled triangles = breccia facies $\mathrm{QP}$ rhyolite samples; cross = estimated protolith composition; open box = field of least-altered QP rhyolite samples. Symbols enclosed by circles are from samples enriched in S 0.77 2.04 wt. $\%$ S; remaining samples contain $<0.25$ wt. $\%$ S). 
$\stackrel{\infty}{q}$

(H) $า \exists \wedge \exists า \exists N I N$

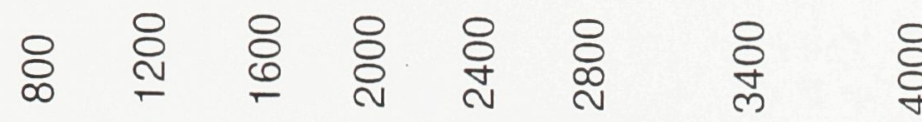

I
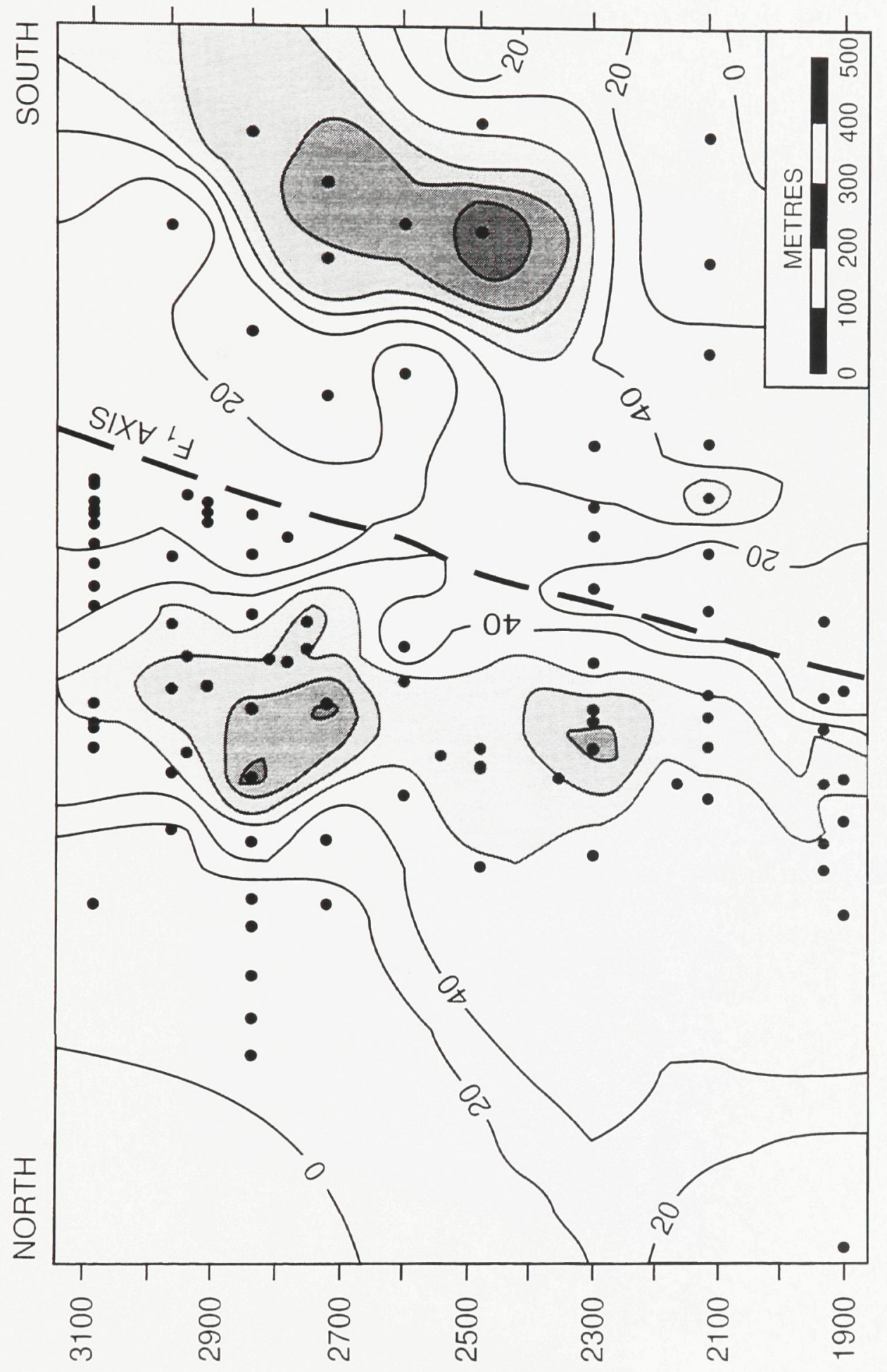

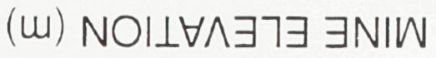

요는

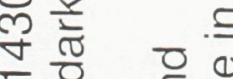

은 $-\frac{\overline{0}}{\frac{5}{0}}$ क

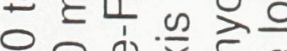

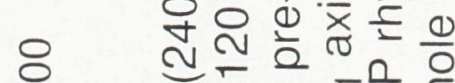

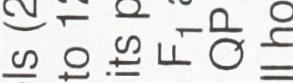

눙워 이워 후원은 은

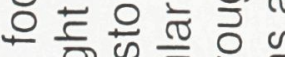
8. 드음

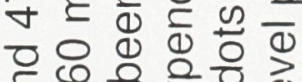

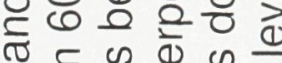
$\circ \stackrel{0}{0} \stackrel{2}{0} \approx$ $\infty \stackrel{\infty}{\infty} \frac{\Phi}{3}$

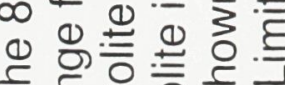

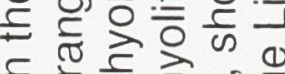

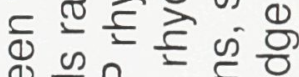

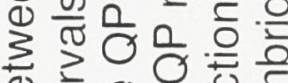

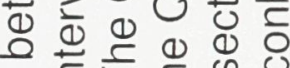

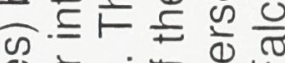

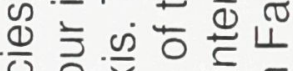
它 읻

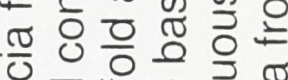
엉으일 过以告

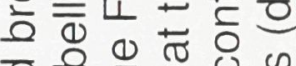
은 을 స 5 Q) ป

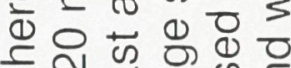
유요 이 플 ब $\bar{\pi}$

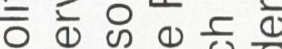

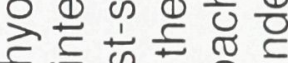
든

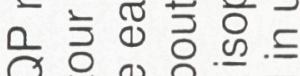

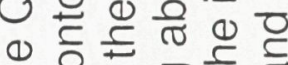
엉유 눙ㅎㅇ 뒁 巳

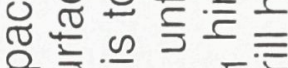
응 ज施以 ㄱ. 궁 스응

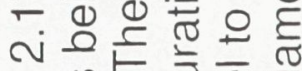

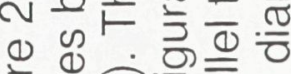

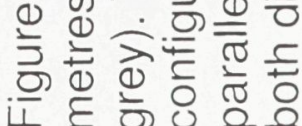




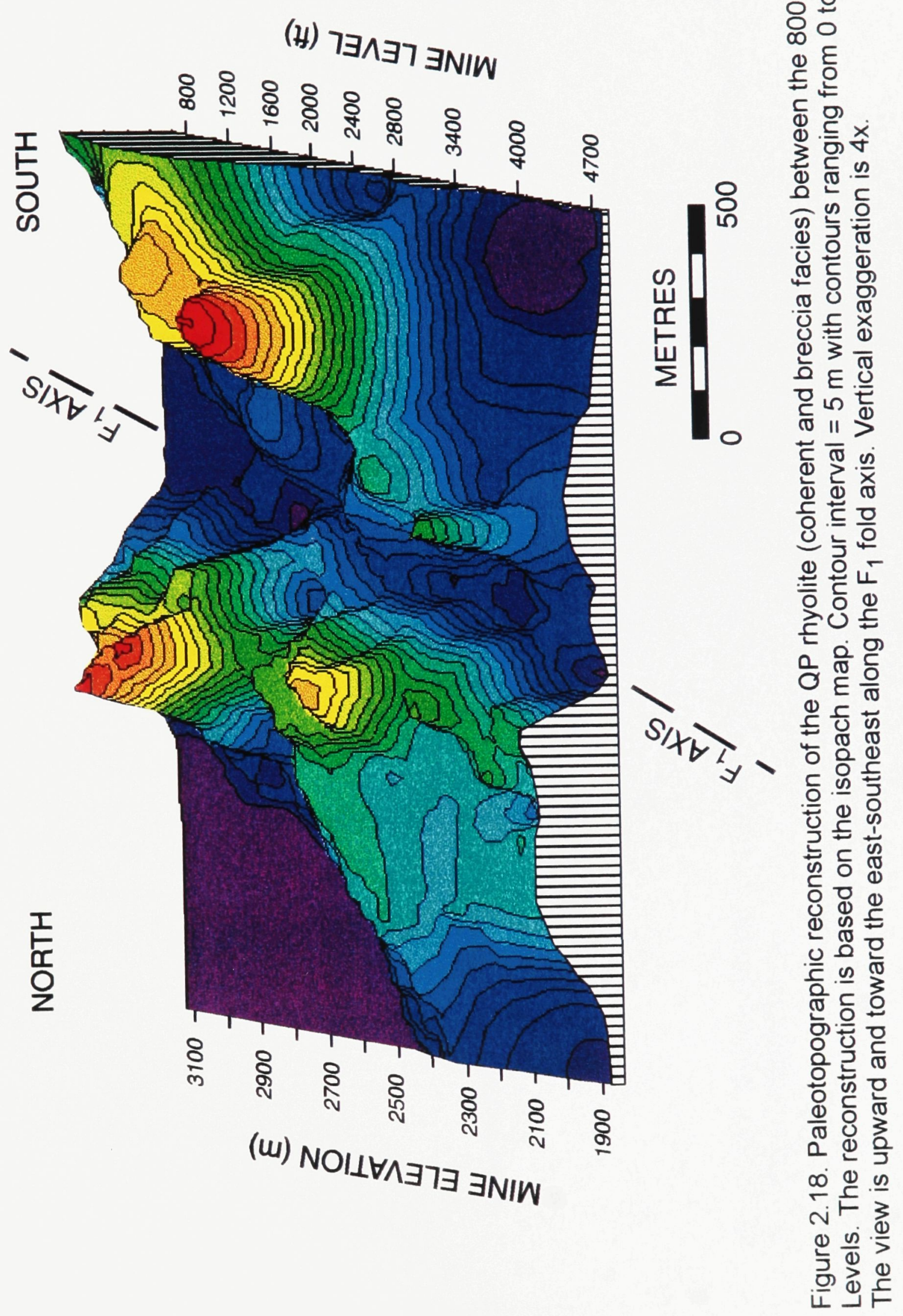


요

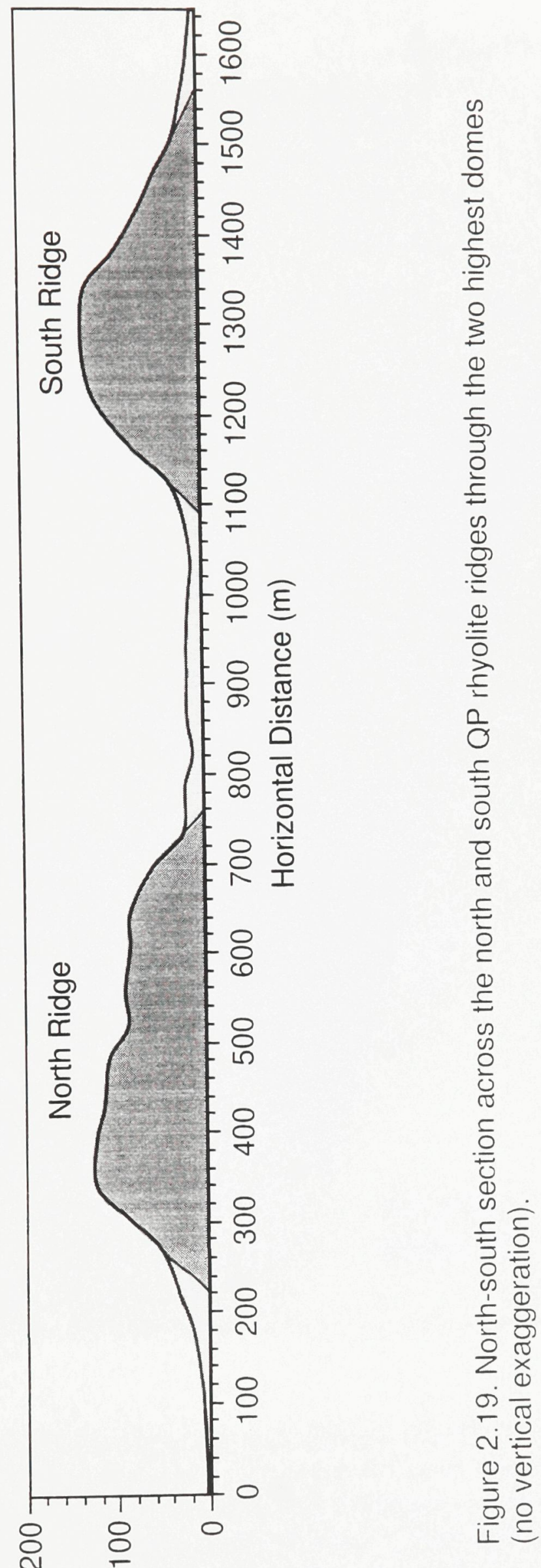

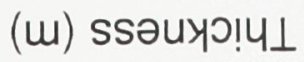




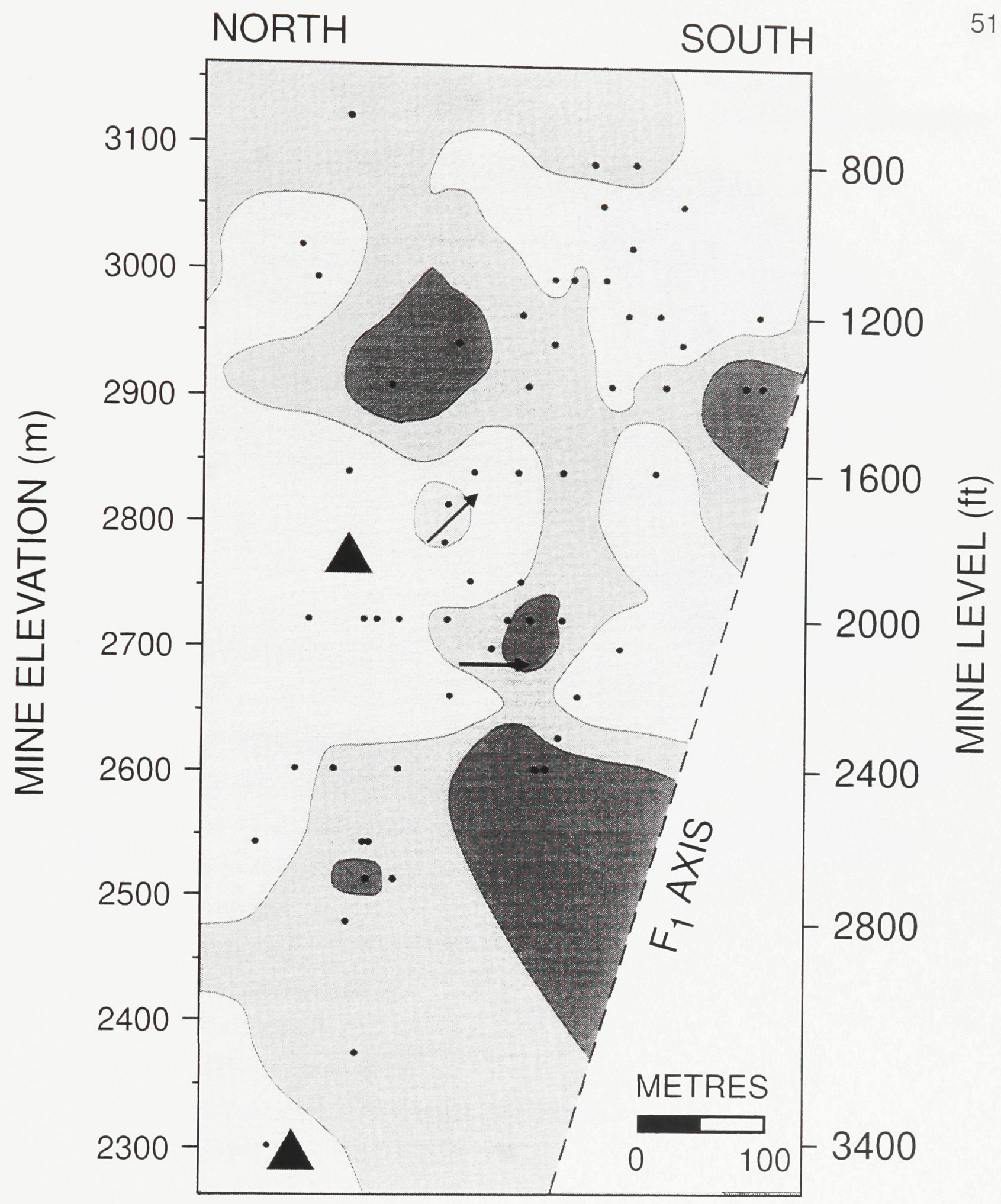

Figure 2.20. Isopach of QP rhyolite breccia between the 700 (8-1) and 3400 Levels ( 210 to $1040 \mathrm{~m}$ below surface). Light grey $=0-4 \mathrm{~m}$ thickness, medium grey $=4-8 \mathrm{~m}$ thickness, dark grey $=>8 \mathrm{~m}$ thickness, triangles $=$ areas of maximum thickness (domes) in the QP rhyolite isopach, dots = data points (underground workings). Arrows indicate inferred flow direction in coherent rhyolite above basal breccia. Thickness data from Falconbridge Limited geological plans. 


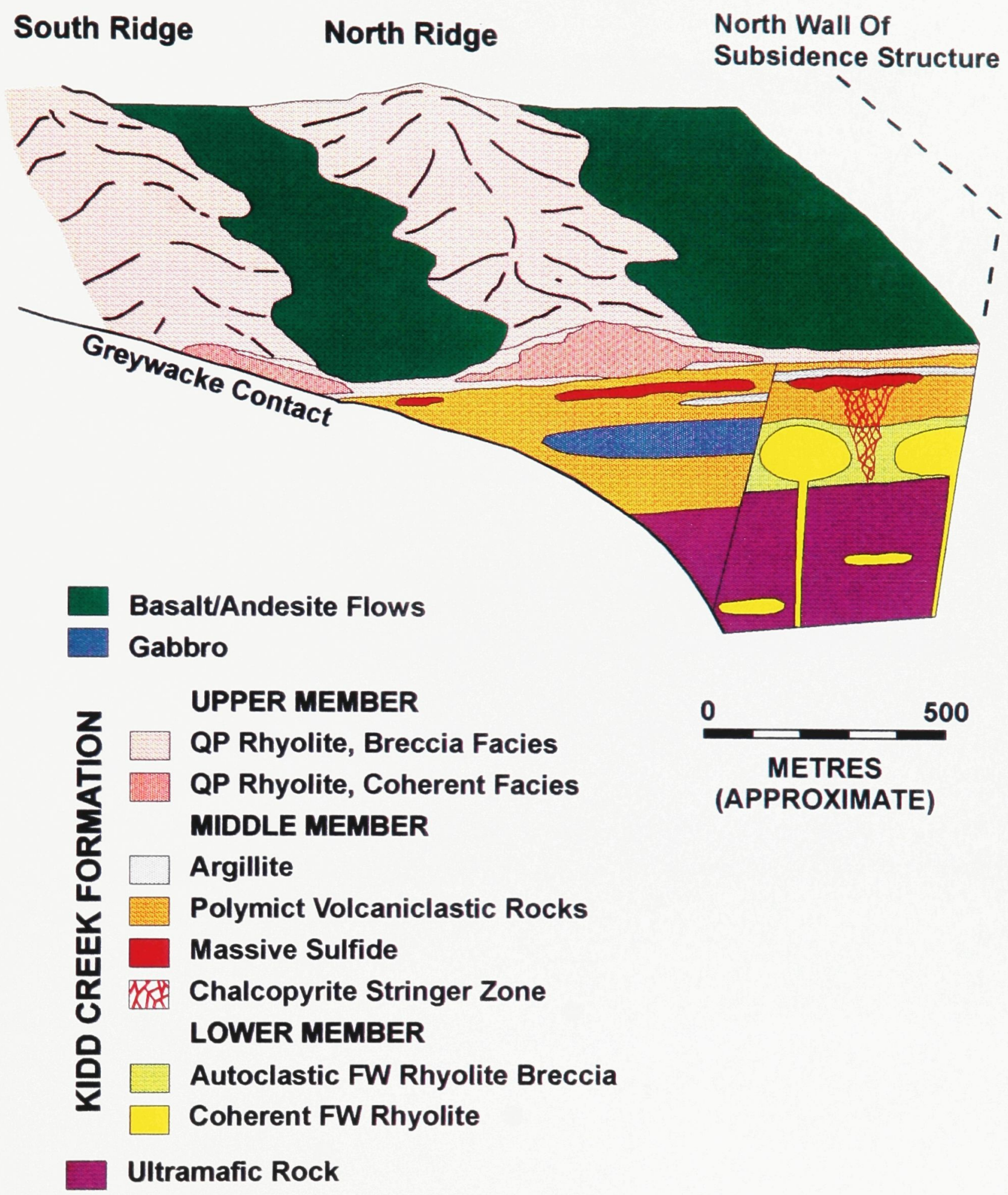

Figure 2.21. Reconstructed view of the Kidd Creek deposit area subsequent to QP rhyolite volcanism and the onset of mafic volcanism but before intrusion of "wedge" gabbro sill between Middle and Upper members. 


\begin{tabular}{cc}
\hline \hline Criteria & Least-Altered QP Rhyolite Samples \\
\hline $\mathrm{Na}_{2} \mathrm{O}$ & $>0.95 \mathrm{wt} . \%$ \\
Loss on Ignition (L.O.I.) & $<2.6 \mathrm{wt} . \%$ \\
$\mathrm{CO}_{2}$ & $<1.3 \mathrm{wt} . \%$ \\
$\mathrm{H}_{2} \mathrm{O}$ & $<1.8 \mathrm{wt} . \%$ \\
$\mathrm{Cu}$ & $<20 \mathrm{ppm}$ \\
$\mathrm{Zn}$ & $<70 \mathrm{ppm}$ \\
Alumina Saturation Index & $<1.7$ \\
Ishikawa Index & $<0.6$ \\
Goodfellow Index & $<0.35$ \\
\hline \hline
\end{tabular}

Table 2.1. Criteria used to select least-altered QP rhyolite samples.

Alumina Index: $\mathrm{Al} /(2 \mathrm{Ca}+\mathrm{Na}+\mathrm{K})$, elements expressed as molecular proportions (Shand, 1951).

Ishikawa Index: $\left(\mathrm{K}_{2} \mathrm{O}+\mathrm{MgO}\right) /\left(\mathrm{K}_{2} \mathrm{O}+\mathrm{Na}_{2} \mathrm{O}+\mathrm{CaO}+\mathrm{MgO}\right)$, oxides expressed as wt.\% (Ishikawa et al., 1976).

Goodfellow Index: $(\mathrm{MgO}+\mathrm{FeO}) /\left(\mathrm{MgO}+\mathrm{FeO}+\mathrm{CaO}+\mathrm{Na}_{2} \mathrm{O}+\mathrm{K}_{2} \mathrm{O}\right)$, oxides expressed as wt.\%, $\mathrm{FeO}=$ total $\mathrm{Fe}$ as FeO (Goodfellow, 1975; Riverin and Hodgson, 1980). 


\begin{tabular}{|c|c|c|c|c|c|c|c|c|}
\hline & & $\begin{array}{c}1073- \\
667 F \\
\end{array}$ & $\begin{array}{c}1073- \\
757 \mathrm{~F} \\
\end{array}$ & $\begin{array}{c}1073- \\
823 F \\
\end{array}$ & $\begin{array}{c}1073- \\
877 \mathrm{~F}\end{array}$ & 14262 & 14266 & $\overline{\mathrm{eP}_{\mathrm{QP}}}$ \\
\hline \multicolumn{2}{|c|}{$\mathrm{DDH}$} & 1073 & 1073 & 1073 & 1073 & 2589 & 1073 & \\
\hline \multicolumn{2}{|c|}{ Footage } & 667 & 757 & 823 & 877 & 539 & 949 & \\
\hline $\mathrm{SiO}_{2}$ & wt. \% & 75.7 & 81.3 & 80.1 & 74.3 & 79.7 & 76.5 & 77.9 \\
\hline $\mathrm{TiO}_{2}$ & wt. \% & 0.150 & 0.135 & 0.139 & 0.178 & 0.120 & 0.147 & 0.145 \\
\hline $\mathrm{Al}_{2} \mathrm{O}_{3}$ & wt. \% & 12.00 & 10.40 & 10.90 & 13.30 & 11.30 & 11.10 & 11.50 \\
\hline $\mathrm{Fe}_{2} \mathrm{O}_{3}$ & wt. \% & 0.70 & 0.39 & 0.35 & 1.19 & 0.46 & 1.06 & 0.69 \\
\hline $\mathrm{FeO}$ & wt. \% & 1.60 & 0.40 & 0.30 & 1.60 & 1.10 & 1.50 & 1.08 \\
\hline $\mathrm{MnO}$ & wt. \% & 0.03 & 0.04 & 0.02 & 0.03 & $<0.01$ & 0.11 & 0.04 \\
\hline $\mathrm{MgO}$ & wt. \% & 1.51 & 0.14 & 0.17 & 1.18 & 0.41 & 0.49 & 0.65 \\
\hline $\mathrm{CaO}$ & wt. \% & 1.85 & 1.03 & 1.14 & 2.38 & 0.48 & 3.44 & 1.72 \\
\hline $\mathrm{Na}_{2} \mathrm{O}$ & wt. \% & 1.27 & 3.29 & 3.91 & 0.97 & 4.39 & 1.52 & 2.56 \\
\hline $\mathrm{K}_{2} \mathrm{O}$ & wt. \% & 2.39 & 1.99 & 1.47 & 3.02 & 1.12 & 1.89 & 1.98 \\
\hline $\mathrm{P}_{2} \mathrm{O}_{5}$ & wt. \% & 0.02 & 0.02 & 0.02 & 0.02 & $<0.01$ & 0.02 & 0.02 \\
\hline LOI & wt. \% & 2.55 & 1.20 & 1.05 & 1.70 & 0.55 & 2.05 & 1.52 \\
\hline Sum & wt. \% & 99.90 & 100.40 & 99.60 & 100.00 & 99.80 & 100.00 & 99.95 \\
\hline $\mathrm{CO}_{2}$ & wt. \% & 0.72 & 0.26 & 0.74 & 0.14 & 0.01 & 1.23 & 0.52 \\
\hline $\mathrm{H}_{2} \mathrm{O}^{+}$ & wt. \% & 1.7 & 0.4 & 0.5 & 1.5 & 0.6 & 1.1 & 1.0 \\
\hline C & wt. \% & 0.39 & 0.21 & 0.31 & 0.06 & 0.01 & 0.45 & 0.24 \\
\hline$S$ & wt. \% & $<0.01$ & $<0.01$ & $<0.01$ & $<0.01$ & 0.08 & $<0.01$ & $<0.01$ \\
\hline $\mathrm{Li}$ & ppm & 13 & 3 & 4 & 13 & 6 & 9 & 8 \\
\hline $\mathrm{Be}$ & ppm & 2 & 2 & 1 & 2 & 2 & 2 & 2 \\
\hline$F$ & ppm & 358.0 & $<20$ & 123.0 & 505.0 & $<20$ & 481.0 & 240.5 \\
\hline Sc & ppm & 3.0 & 2.2 & 2.5 & 3.4 & 2.4 & 3.3 & 2.8 \\
\hline $\mathrm{Cr}$ & ppm & 14.0 & 13.0 & 4.0 & 4.0 & 14.0 & 19.0 & 11.3 \\
\hline $\mathrm{Ni}$ & ppm & 8.0 & 3.0 & 2.0 & 2.0 & $<1$ & 2.0 & 2.0 \\
\hline $\mathrm{Cu}$ & ppm & 8.9 & 4.5 & 2.5 & 10.4 & 19.7 & 9.8 & 9.3 \\
\hline $\mathrm{Zn}$ & ppm & 66.4 & 22.9 & 29.0 & 67.8 & 23.7 & 62.1 & 45.3 \\
\hline $\mathrm{Ga}$ & ppm & 28 & 27 & 29 & 32 & 28 & 27 & 29 \\
\hline $\mathrm{Br}$ & ppm & n.a. & n.a. & n.a. & n.a. & 1.5 & 1.2 & 0.5 \\
\hline $\mathrm{Rb}$ & ppm & 115 & 55 & 45 & 139 & 47 & 118 & 87 \\
\hline $\mathrm{Sr}$ & ppm & 69.4 & 49.0 & 50.2 & 97.0 & 62.4 & 190.0 & 86.3 \\
\hline$Y$ & ppm & 81 & 75 & 58 & 93 & 82 & 91 & 80 \\
\hline $\mathrm{Zr}$ & ppm & 246 & 222 & 216 & 277 & 222 & 233 & 236 \\
\hline $\mathrm{Nb}$ & ppm & 16 & 14 & 19 & 18 & 19 & 16 & 17 \\
\hline Mo & ppm & $<1$ & $<1$ & $<1$ & $<1$ & $<1$ & $<1$ & $<1$ \\
\hline $\mathrm{Ag}$ & ppm & 0.4 & $<0.1$ & 0.2 & 0.3 & $<0.1$ & 0.3 & 0.3 \\
\hline $\mathrm{Sn}$ & ppm & 11 & $<5$ & $<5$ & 12 & 11 & 5 & 8.0 \\
\hline Cs & ppm & n.a. & n.a. & n.a. & n.a. & 1.5 & 2.1 & 0.6 \\
\hline $\mathrm{Ba}$ & ppm & 257 & 522 & 338 & 401 & 360 & 381 & 377 \\
\hline
\end{tabular}

Table 2.2. See following page for caption. 


\begin{tabular}{|c|c|c|c|c|c|c|c|c|}
\hline & & $\begin{array}{r}1073- \\
667 \mathrm{~F} \\
\end{array}$ & $\begin{array}{l}1073- \\
757 \mathrm{~F} \\
\end{array}$ & $\begin{array}{c}1073- \\
823 F\end{array}$ & $\begin{array}{l}1073- \\
877 \mathrm{~F} \\
\end{array}$ & 14262 & 14266 & $\overline{e P_{Q P}}$ \\
\hline $\mathrm{La}$ & ppm & 41.0 & 35.3 & 34.9 & 46.5 & 41.9 & 39.0 & 39.8 \\
\hline $\mathrm{Ce}$ & $\mathrm{ppm}$ & 92.4 & 79.3 & 79.2 & 107.0 & 94.0 & 87.3 & 89.9 \\
\hline $\mathrm{Pr}$ & ppm & 9.8 & 8.4 & 8.5 & 11.5 & 10.1 & 9.2 & 9.6 \\
\hline $\mathrm{Nd}$ & ppm & 41.6 & 36.3 & 35.7 & 50.1 & 44.1 & 39.9 & 41.3 \\
\hline Sm & ppm & 9.60 & 8.70 & 8.30 & 12.20 & 10.40 & 9.60 & 9.8 \\
\hline Eu & $\mathrm{ppm}$ & 1.50 & 1.26 & 1.27 & 1.64 & 1.50 & 1.47 & 1.4 \\
\hline $\mathrm{Gd}$ & ppm & 10.4 & 9.4 & 9.0 & 12.8 & 10.9 & 10.5 & 10.5 \\
\hline $\mathrm{Tb}$ & ppm & 2.1 & 1.9 & 1.7 & 2.5 & 2.1 & 2.0 & 2.1 \\
\hline Dy & ppm & 11.0 & 10.6 & 8.6 & 13.0 & 11.1 & 10.8 & 10.9 \\
\hline $\mathrm{Ho}$ & $\mathrm{ppm}$ & 2.96 & 2.94 & 2.18 & 3.52 & 2.91 & 3.04 & 2.9 \\
\hline $\mathrm{Er}$ & ppm & 7.0 & 7.0 & 4.9 & 8.3 & 6.7 & 7.2 & 6.9 \\
\hline $\mathrm{Tm}$ & $\mathrm{ppm}$ & 1.4 & 1.5 & 1.0 & 1.6 & 1.3 & 1.5 & 1.4 \\
\hline $\mathrm{Yb}$ & ppm & 8.1 & 8.7 & 5.8 & 9.8 & 7.9 & 8.9 & 8.2 \\
\hline Lu & ppm & 1.4 & 1.5 & 1.0 & 1.7 & 1.3 & 1.5 & 1.4 \\
\hline $\mathrm{Hf}$ & ppm & 8.5 & 7.5 & 7.9 & 9.7 & 8.4 & 8.3 & 8.4 \\
\hline Ta & ppm & 1.4 & 0.6 & 1.0 & 1.3 & 1.4 & 1.1 & 1.1 \\
\hline $\mathrm{Au}$ & ppb & n.a. & n.a. & n.a. & n.a. & $<2$ & $<2$ & $<2$ \\
\hline $\mathrm{Pb}$ & ppm & $<2$ & $<2$ & $<2$ & $<2$ & $<2$ & $<2$ & $<2$ \\
\hline Th & ppm & 8.5 & 6.3 & 6.7 & 9.2 & 6.7 & 7.3 & 7.5 \\
\hline$U$ & ppm & 2.2 & 1.5 & 1.6 & 2.1 & 1.6 & 1.7 & 1.8 \\
\hline \multicolumn{2}{|c|}{$\begin{array}{l}\text { Goodfellow } \\
\text { Index }\end{array}$} & 0.40 & 0.12 & 0.11 & 0.38 & 0.24 & 0.30 & 0.26 \\
\hline \multicolumn{2}{|c|}{$\begin{array}{l}\text { Ishikawa } \\
\text { Index }\end{array}$} & 0.56 & 0.33 & 0.25 & 0.56 & 0.24 & 0.32 & 0.38 \\
\hline \multicolumn{2}{|c|}{$\begin{array}{l}\text { Alumina } \\
\text { Index }\end{array}$} & 1.66 & 1.30 & 1.28 & 1.59 & 1.48 & 1.11 & 1.40 \\
\hline \multirow{2}{*}{\multicolumn{2}{|c|}{$\frac{L a_{N} / Y b_{N}}{F_{1} / F_{H^{*}}}$}} & 3.41 & 2.74 & 4.06 & 3.20 & 3.58 & 2.95 & 3.32 \\
\hline & & 0.46 & 0.42 & 0.45 & 0.40 & 0.43 & 0.45 & 0.43 \\
\hline
\end{tabular}

Table 2.2. Analyses of six least-altered QP rhyolite samples. Estimated protolith composition for the $\mathrm{QP}$ rhyolite $\left(\mathrm{eP}_{\mathrm{QP}}\right.$ ) represents the average of the least-altered samples except for cases having some values below analytical detection for which median values are shown. Alteration indexes defined in Table 2.1; $\mathrm{DDH}=$ diamond drill hole; $\mathrm{n} . \mathrm{a}$. = not analyzed; $\mathrm{N}=$ chondrite normalized; $\mathrm{Eu}_{\mathrm{Eu}} \mathrm{Eu}^{*}=\mathrm{Eu}_{\mathrm{N}} /\left(0.5\left(\mathrm{Sm}_{\mathrm{N}}\right)+0.5\left(\mathrm{Gd}_{\mathrm{N}}\right)\right)$. Chondrite normalization values are those of Evensen et al. (1978) divided by 1.267 as recommended by Boynton (1984). 


\begin{tabular}{|c|c|c|c|c|c|c|c|}
\hline & $\overline{e P_{Q P}}$ & & Add & $\mathrm{AC}_{130}$ & & $\overline{A C_{100}}$ & \\
\hline $\mathrm{SiO}_{2}$ & 77.93 & $g$ & $30.00 \mathrm{~g}$ & 107.93 & 9 & 83.03 & g \\
\hline $\mathrm{TiO}_{2}$ & 0.145 & $g$ & & 0.145 & $\mathrm{~g}$ & 0.111 & $\mathrm{~g}$ \\
\hline $\mathrm{Al}_{2} \mathrm{O}_{3}$ & 11.50 & $g$ & & 11.50 & $\mathrm{~g}$ & 8.85 & $\mathrm{~g}$ \\
\hline $\mathrm{Fe}_{2} \mathrm{O}_{3(\mathrm{t})}$ & 1.89 & $g$ & & 1.89 & $\mathrm{~g}$ & 1.46 & $\mathrm{~g}$ \\
\hline $\mathrm{MnO}$ & 0.05 & $g$ & & 0.05 & $\mathrm{~g}$ & 0.04 & $\mathrm{~g}$ \\
\hline $\mathrm{MgO}$ & 0.65 & $g$ & & 0.65 & $\mathrm{~g}$ & 0.50 & $\mathrm{~g}$ \\
\hline $\mathrm{CaO}$ & 1.72 & $\mathrm{~g}$ & & 1.72 & $\mathrm{~g}$ & 1.32 & g \\
\hline $\mathrm{Na}_{2} \mathrm{O}$ & 2.56 & $\mathrm{~g}$ & & 2.56 & $\mathrm{~g}$ & 1.97 & g \\
\hline $\mathrm{K}_{2} \mathrm{O}$ & 1.98 & $g$ & & 1.98 & $\mathrm{~g}$ & 1.52 & g \\
\hline $\mathrm{P}_{2} \mathrm{O}_{5}$ & 0.02 & $g$ & & 0.02 & $\mathrm{~g}$ & 0.02 & g \\
\hline LOI & 1.52 & $\mathrm{~g}$ & & 1.52 & $\mathrm{~g}$ & 1.17 & $\mathrm{~g}$ \\
\hline $\mathrm{Zr}$ & 0.0236 & $\mathrm{~g}$ & & 0.0236 & $\mathrm{~g}$ & 0.0182 & g \\
\hline $\mathrm{Nb}$ & 0.0017 & $\mathrm{~g}$ & & 0.0017 & $\mathrm{~g}$ & 0.0013 & $\mathrm{~g}$ \\
\hline Sum & 100 & $g$ & & 130 & $\mathrm{~g}$ & 100 & $\mathrm{~g}$ \\
\hline $\mathrm{Al}_{2} \mathrm{O}_{3} / \mathrm{Zr}$ & 487 & & & 487 & & 487 & \\
\hline $\mathrm{Al}_{2} \mathrm{O}_{3} / \mathrm{Nb}$ & 6765 & & & 6765 & & 6765 & \\
\hline
\end{tabular}

Table 2.3. Example of constant sum effect on analytical values starting with 100 $\mathrm{g}$ of protolith. $\mathrm{Fe}_{2} \mathrm{O}_{3(\mathrm{t})}=$ total $\mathrm{Fe} ; \mathrm{eP}_{\mathrm{QP}}=$ estimated protolith composition of the $\mathrm{QP}$ rhyolite; $\mathrm{AC}_{130}=$ altered composition $(130 \mathrm{~g}) ; \mathrm{AC}_{100}=$ altered composition recalculated to $100 \mathrm{~g} \mathrm{(100} \mathrm{wt. \% ).}$ 


\begin{tabular}{|c|c|c|c|c|c|c|}
\hline & & Number & Minimum & Maximum & Range & $\overline{\mathrm{RF}}$ \\
\hline $\mathrm{SiO}_{2}$ & wt. \% & 36 & 35.0 & 84.1 & 49.1 & $\overline{2.4}$ \\
\hline $\mathrm{TiO}_{2}$ & wt. \% & 36 & 0.070 & 0.270 & 0.200 & 3.9 \\
\hline $\mathrm{Al}_{2} \mathrm{O}_{3}$ & wt. \% & 36 & 5.45 & 15.70 & 10.25 & 2.9 \\
\hline $\mathrm{Fe}_{2} \mathrm{O}_{3(\mathrm{t})}$ & wt. \% & 36 & 0.42 & 7.92 & 7.50 & 18.9 \\
\hline $\mathrm{MnO}$ & wt. \% & 35 & 0.01 & 0.51 & 0.50 & 51.0 \\
\hline $\mathrm{MgO}$ & wt. \% & 36 & 0.14 & 2.34 & 2.20 & 16.7 \\
\hline $\mathrm{CaO}$ & wt. \% & 36 & 0.16 & 30.50 & 30.34 & 190.6 \\
\hline $\mathrm{Na}_{2} \mathrm{O}$ & wt. \% & 36 & 0.01 & 5.73 & 5.73 & 1146.0 \\
\hline $\mathrm{K}_{2} \mathrm{O}$ & wt. $\%$ & 36 & 0.25 & 4.36 & 4.11 & 17.4 \\
\hline $\mathrm{CO}_{2}$ & wt. \% & 36 & 0.01 & 24.00 & 23.99 & 2400.0 \\
\hline $\mathrm{H}_{2} \mathrm{O}^{+}$ & wt. $\%$ & 36 & 0.4 & 3.3 & 2.9 & 8.3 \\
\hline $\mathrm{C}$ & wt. \% & 26 & 0.01 & 6.62 & 6.61 & 662.0 \\
\hline $\mathrm{S}$ & wt. \% & 26 & 0.009 & 0.222 & 0.213 & 24.7 \\
\hline $\mathrm{Cr}$ & ppm & 27 & 2 & 180 & 178 & 90.0 \\
\hline $\mathrm{Cu}$ & ppm & 36 & 2 & 268 & 266 & 148.9 \\
\hline $\mathrm{Zn}$ & ppm & 36 & 11 & 355 & 344 & 31.1 \\
\hline $\mathrm{Ga}$ & ppm & 32 & 9 & 32 & 23 & 3.6 \\
\hline $\mathrm{Rb}$ & ppm & 36 & 11 & 163 & 152 & 14.8 \\
\hline $\mathrm{Sr}$ & ppm & 36 & 5 & 190 & 185 & 38.0 \\
\hline$Y$ & ppm & 35 & 37 & 106 & 69 & 2.9 \\
\hline $\mathrm{Zr}$ & ppm & 36 & 108 & 334 & 226 & 3.1 \\
\hline $\mathrm{Nb}$ & ppm & 36 & 9 & 21 & 12 & 2.3 \\
\hline $\mathrm{Ba}$ & ppm & 32 & 58 & 1830 & 1772 & 31.6 \\
\hline $\mathrm{Ce}$ & ppm & 30 & 47.3 & 130.0 & 82.7 & 2.7 \\
\hline $\mathrm{Yb}$ & ppm & 30 & 3.0 & 10.7 & 7.7 & 3.6 \\
\hline $\mathrm{Hf}$ & ppm & 20 & 3.2 & 8.9 & 5.7 & 2.8 \\
\hline Ta & ppm & 19 & 0.5 & 2.0 & 1.5 & 4.0 \\
\hline Th & ppm & 30 & 1.5 & 9.2 & 7.7 & 6.1 \\
\hline U & ppm & 30 & 0.4 & 2.6 & 2.2 & 6.5 \\
\hline
\end{tabular}

Table 2.4. Range factor (RF) values for the coherent facies of the QP rhyolite. 


\begin{tabular}{|c|c|c|c|}
\hline \multicolumn{2}{|c|}{ Elements } & Correlation & $\mathrm{N}$ \\
\hline $\mathrm{Fe}_{2} \mathrm{O}_{3(t)}$ & $-\mathrm{H}_{2} \mathrm{O}$ & 0.80 & 46 \\
\hline $\mathrm{MgO}$ & $-\mathrm{H}_{2} \mathrm{O}$ & 0.88 & 46 \\
\hline $\mathrm{Na}_{2} \mathrm{O}$ & $-\mathrm{H}_{2} \mathrm{O}$ & -0.70 & 45 \\
\hline $\mathrm{K}_{2} \mathrm{O}$ & $-\mathrm{H}_{2} \mathrm{O}$ & 0.35 & 46 \\
\hline $\mathrm{Fe}_{2} \mathrm{O}_{3(\mathrm{t})}$ & $-S$ & 0.38 & 36 \\
\hline $\mathrm{CaO}$ & $-\mathrm{CO}_{2}$ & 0.84 & 44 \\
\hline
\end{tabular}

Table 2.5. Pearson correlation coefficients for QP rhyolite analyses (massive and breccia facies). $\mathrm{CO}_{2}$-rich samples (>7 wt.\%) ommitted. $\mathrm{N}=$ number of samples. All data normalized to $\mathrm{Zr}$ to eliminate apparent correlations due to mass change (constant sum) effects: $\mathrm{N}_{\mathrm{A}}=\mathrm{S}_{\mathrm{A}} \times \mathrm{eP}_{\mathrm{Zr}} / \mathrm{S}_{\mathrm{Zr}}$ where $\mathrm{N}_{\mathrm{A}}=$ normalized value for element ' $A$ ', $S_{A}=$ sample value of element ' $A$; $e P_{Z r}=$ estimated protolith $\mathrm{Zr}$ content and $\mathrm{S}_{\mathrm{Zr}}=$ sample $\mathrm{Zr}$ content. 


\section{Chapter 3}

\section{RARE EARTH AND HIGH FIELD STRENGTH ELEMENT GEOCHEMISTRY OF THE KIDD CREEK RHYOLITES: EVIDENCE FOR ARCHEAN FELSIC VOLCANISM AND VMS ORE FORMATION IN AN ICELAND-STYLE RIFT ENVIRONMENT}

\section{Introduction to Chapter 3}

The Archean volcanogenic massive sulfide $(\mathrm{Cu}-\mathrm{Zn}-\mathrm{Pb}-\mathrm{Ag})$ ores of the Kidd Creek Mine are located in the western part of the southern Abitibi greenstone belt, Superior Structural Province, Canada (Figures 1.1 and 1.2). The deposits are hosted primarily within a felsic volcaniclastic sequence, underlain and overlain by rhyolites, within a bimodal volcanic succession (Figures 1.3 and 2.21). The spatial and temporal coexistence of rhyolites, especially those occurring within bimodal mafic-felsic volcanic sequences, and volcanogenic massive sulfide (VMS) deposits is a common, although not universal, association within the Superior Province (e.g., Franklin and Thorpe, 1982; Hutchinson, 1982). Furthermore, VMS deposits within the Superior Province are most likely to occur in proximity to rhyolites with elevated, unfractionated REE profiles and negative Eu anomalies (FIII rhyolites) which may be used as an exploration tool (Thurston, 1981; Lesher et al., 1986; Barrie et al., 1993). This relationship has been ascribed to the presence of 
subvolcanic intrusions which yield rhyolitic magma and drive the VMS-forming hydrothermal convection systems (Campbell et al., 1981; Campbell et al., 1982; Lesher et al., 1986), and to high heat-flow environments coupled with favorable volcanological/tectonic settings (Barrie et al., 1993; Barrie, 1995). Previous researchers have suggested extensional mid-ocean ridge environments, such as the axial rift zones of Iceland and the Galapagos spreading centre, and extensional back-arc basin settings as modern analogues for the tectonic environment in which FIII rhyolites are erupted (Hart, 1984; Barrie and Davis, 1990; Barrie et al., 1993; Jackson et al., 1994).

In this chapter I explore two related hypotheses: (i) the incompatible trace element composition of the Kidd Creek rhyolites reflects a particular tectonic environment, and (ii) processes operative in that tectonic setting are favorable for the formation and preservation of VMS ores including the giant Kidd Creek deposit. Differences in chemical composition of basalts and, to a lesser extent, that of granitic rocks as a function of tectonic setting are well documented for modern environments (Pearce and Cann, 1973; Floyd and Winchester, 1978; Wood, 1980; Pearce et al., 1984). Discrimination of the tectonic environment in which the Kidd Creek rhyolites erupted is based upon incompatible element comparisons with post-Triassic felsic volcanic rocks and plagiogranites from known tectonic environments. Non-igneous (metasomatic) chemical variability is minimized by (i) using Kidd Creek data for least-altered samples, and (ii) by basing comparisons on the rare earth elements (REE) 
and high field strength elements (HFSE). These elements remained relatively immobile during the Kidd Creek hydrothermal event outside the footwall stringer zone.

\section{A Framework for Geochemical Comparison}

\section{Precursor composition for Kidd Creek rhyolites}

All rhyolites in the Kidd Creek mine area have undergone some degree of hydrothermal alteration. In order to compare magmatic (pre-alteration) compositions I selected data for least altered, coherent rhyolites and based comparisons on relatively immobile elements. Six FW rhyolite samples (Lower member) and 6 QP rhyolite samples (Upper member) were selected as being representative of relatively unaltered Kidd Creek formation rhyolites - selection criteria and analyses of selected FW rhyolites are shown in Tables 3.1 and 3.2. Selection criteria and analyses of the 6 least altered QP rhyolite samples are presented in Tables 2.1 and 2.2. Analytical techniques are described in Appendix 3. 


\section{Element mobility}

Within igneous rocks sharing the same protolith (magmatic) composition, constant interelement ratios are maintained between immobile elements during metasomatism, irrespective of overall mass change, whereas interelement ratios do not remain consistent between element pairs in which one or both elements been mobilized. (Gresens, 1967; Grant, 1986; MacLean, 1990). A spider diagram (Figure 3.1) illustrates compositional data for the six least-altered FW rhyolites, normalized to the composition of least-altered FW rhyolite sample 14259. The elements shown, listed in increasing atomic number, are commonly used in petrogenetic studies except for $\mathrm{Al}$ and $\mathrm{Ga}$ (e.g., Wood, 1980; Sun, 1980; Thompson, 1982; Sun and McDonough, 1989). Constant interelement ratios, which have values near 1.0 for these samples indicating no significant mass changes, are evident for $\mathrm{Al}, \mathrm{Ti}, \mathrm{Ga}, \mathrm{Y}, \mathrm{Zr}, \mathrm{Nb}, \mathrm{Hf}$, $\mathrm{Ta}, \mathrm{Th}, \mathrm{U}$ and the REE. In contrast $\mathrm{K}, \mathrm{Sc}, \mathrm{Rb}, \mathrm{Sr}$, and $\mathrm{Ba}$ data indicate their considerable mobility. Similar results are obtained using the least-altered QP rhyolite samples (Table 2.5 ).

In order to test for the immobility of $\mathrm{Al}, \mathrm{Ti}, \mathrm{Ga}, \mathrm{Y}, \mathrm{Zr}, \mathrm{Nb}, \mathrm{Hf}, \mathrm{Ta}, \mathrm{Th}, \mathrm{U}$ and the REE during intense alteration, data from strongly altered samples of the footwall stringer zones beneath the north and central orebodies were plotted on a least-altered FW rhyolite normalized spider diagram (Figure 3.2). The 
altered samples are two chloritites $\left(<26 \% \mathrm{SiO}_{2},>21 \% \mathrm{Al}_{2} \mathrm{O}_{3},>9 \% \mathrm{MgO}\right.$ and $\left.>10 \% \mathrm{H}_{2} \mathrm{O}\right)$, one sericitite $\left(58.2 \% \mathrm{SiO}_{2}, 23.9 \% \mathrm{Al}_{2} \mathrm{O}_{3}, 5.9 \% \mathrm{~K}_{2} \mathrm{O}\right)$, and five silicified autoclastic rhyolite breccia ("cherty breccia") samples (84-89\% $\mathrm{SiO}_{2}$, $0.04-0.37 \% \mathrm{Na}_{2} \mathrm{O}$ ). The patterns show considerable scatter that is in part due to the mass change (closure) effects caused by silicification and chloritization (MacLean and Barrett, 1993). In order to overcome the problem of mass change effects the data have been doubly normalized to Al; the results are shown in Figure 3.3 (all element concentrations have been multiplied by a mass change factor (M.C.F.) which yields a constant Al value in the reconstructed composition (MacLean, 1990); M.C.F. = Al $I_{L A} / A I_{S}$ where $S$ is any sample and LA is least-altered sample 14259). Relatively constant interelement ratios exist for all samples between $\mathrm{Al}, \mathrm{Ti}, \mathrm{Zr}, \mathrm{Nb}, \mathrm{Th}$ and $\mathrm{U}$, and in 7 of the 10 samples between these elements and the heavy rare earth elements Dy and $\mathrm{Yb}(\mathrm{Hf}$ and Ta were not analyzed). However, the patterns of La, $\mathrm{Nd}$ and Eu indicate considerable loss of the LREE in the strongly altered stringer zone samples consistent with the findings of Campbell et al. (1984)

\section{Compilation of post-Triassic data}

The certainty with which tectonic environments may be identified in the geologic record is, in general, inversely related to age. As a consequence most of the analyses in the comparative database are from Cenozoic rocks but 
some Jurassic and Cretaceous examples have been included. VMS deposits form at or below the seafloor so, where possible, samples for the post-Triassic comparative database were selected which originated in or near marine environments. In modern oceanic environments, felsic volcanism occurs at intraplate islands, ensimatic arcs, ensialic arcs and rift zones including nonspreading rifts, immature spreading centres and mature spreading centres (as used in this Chapter spreading refers to areas in which new oceanic crust is being created). The post-Triassic database consists of 41 published analyses of rocks considered to be representative of felsic igneous products in oceanic tectonic settings including samples of rhyolite, high-Si dacite, rhyodacite, dacite, pantellerite, comendite, plagiogranite and quartz diorite (Table 3.3). Volcanic rocks (flows, domes, pyroclastic rocks and high-level dikes) were chosen preferentially over plutonic rocks, and analyses with rhyolitic rather than dacitic compositions were selected where available to match the high-Si values of the Kidd Creek rhyolites.

The most striking difference between rhyolites of the Kidd Creek formation and the post-Triassic data is the difference in ages $(2710-2715 \mathrm{Ma}$ versus $<200 \mathrm{Ma}$ ). Over time, the formation of continental crust has depleted the upper mantle in incompatible elements relative to the estimated composition of the primitive mantle (Hofmann, 1988). The mantle has also been modified by recycling of material in subducting oceanic plates and in cold plumes 
(Campbell and Griffiths, 1993). The degree of change in mantle composition from the late Archean to present day continues to be a matter of controversy but most evidence suggests that sweeping changes in mantle composition during the past 2.7 billion years are unlikely (Taylor and McLennan, 1985; McCulloch and Bennet, 1994; Drummond and Defant, 1990; Condie, 1989). This contribution follows the implicit assumption of Condie (1989) that whatever changes have occurred are probably small relative to the magnitude of chemical variation imposed on magmas by tectonic environment (Appendix 2).

Comparison of the Kidd Creek Rhyolites To Post-Triassic Felsic Rock Suites

\section{REE-HFSE spider diagrams: the basis for comparison}

In order to make reasonable comparisons of primary petrochemical features where altered rocks are involved the effects of metasomatism must be minimized. The high field strength elements $Y, \mathrm{Zr}, \mathrm{Hf}, \mathrm{Nb}$, Ta, Th and $U$ (HFSE; Rollinson, 1993) and the rare earth elements (REE) were relatively immobile in rhyolites which escaped intense hydrothermal alteration at Kidd Creek

whereas several other elements commonly used in petrogenetic studies have experienced considerable mobility. Geochemical comparison of these elements is facilitated by using a chondrite-normalized REE-HFSE spider 
diagram as shown in Figure 3.4 for the 12 least altered Kidd Creek rhyolite compositions (chondrite normalization values are listed in Appendix 5). The left part of the diagrams consists of the familiar REE spider diagram while the high field strength elements $\mathrm{Y}, \mathrm{Zr}, \mathrm{Hf}, \mathrm{Nb}, \mathrm{Ta}$, Th and $\mathrm{U}$ are listed in the right side of the diagram in order of increasing concentration in continental crust relative to primitive mantle - a measure of element incompatibility (Hofmann, 1988). Thus the most incompatible elements, $\mathrm{La}, \mathrm{Ce}$, Th and $\mathrm{U}$, are located at the ends of the diagram and the least incompatible elements, the HREE and $Y$, are located near the centre. For many felsic volcanic suites, including rhyolites of the Kidd Creek formation, this arrangement of elements results in broad, concaveupward patterns disrupted by negative Eu anomalies.

\section{Kidd Creek}

All least-altered rhyolite samples from the Kidd Creek formation have nearly identical REE-HFSE profiles and were considered as a single group of rocks for this study; geochemical discrimination between FW rhyolite (Lower member) and QP rhyolite (Upper member) is discussed in Chapter 2 (Figures 2.8 to 2.10 ). The REE part of the spider diagram is characterized by relatively shallow slopes $\left(\mathrm{La}_{N} / \mathrm{Yb}_{N}=2.7-4.1\right)$ and moderate, negative Eu anomalies $\left(E u / E u^{*}=0.32-0.50\right)$. The overall slope is due to a moderately steep LREE profile with the HREE pattern being essentially flat. On the extended part of the 
diagram the Kidd Creek rhyolites display a gradual overall increase from $Y$ to Ta, a steep slope between $\mathrm{Ta}$ and Th and a very slight decline from Th to $\mathrm{U}$. Overall the traces for the REE and HFSE define a broad, concave upward pattern with a moderate trough at Eu and a Th-U plateau. The unusual sawtooth pattern for the HREE data between Dy and Tm is believed to be an analytical artifact (REE analyses by ICPMS).

\section{Intraplate oceanic islands}

Intraplate oceanic islands consist of seamounts that are commonly regarded as the surface manifestations of mantle plumes or hotspots (Wilson, 1973; Wilson, 1989; McBirney, 1993). Rhyolite (including peralkaline rhyolite, comendite and pantellerite) is recorded in only a few of these islands and comparisons with Kidd Creek rhyolite are made using representative analyses from Gran Canaria (peralkaline rhyolite), Ascension (comendite) and Pinzon (tholeiitic rhyolite; Table 3.3). Rhyolites from the intraplate islands are characterized by strong enrichment in $\mathrm{Nb}, \mathrm{Ta}, \mathrm{Zr}$ and $\mathrm{Hf}$ resulting in a noticeable hump between $Y$ and Th in the REE-HFSE profiles (Figure 3.5). Their REE profiles are relatively steep with variable Eu anomalies. 


\section{Ensimatic arcs}

Comparative data for ensimatic island arcs consist of analyses of dacite and rhyolite erupted in arc and fore arc environments from four areas: (i) Fiji and the Tonga fore arc, (ii) Izu-Bonin arc and fore arc, (iii) Adak Island in the central Aleutians, and (iv) the Virgin Islands (Table 3.3). Felsic volcanic rocks from ensimatic arcs such as those of the western Pacific are characterized by relatively flat REE patterns, general absence of Eu anomalies, subdued Th contents and strongly depleted $\mathrm{Nb}$ and $\mathrm{Ta}$ values resulting in a distinct $\mathrm{Nb}-\mathrm{Ta}$ trough on the REE-HFSE diagram (Figure 3.6).

\section{Ensialic arcs}

Ensialic arcs are represented in the database by analyses from (i) volcanic islands in the Aegean (Milos, Santorini), (ii) the Taupo volcanic zone, New Zealand, (iii) the Padang area, Sumatra, and (iv) the Valley of Ten Thousand Smokes, Alaska. Felsic volcanic rocks from ensialic arcs are characterized by LREE enrichment, moderately steep LREE trends, moderate to strong negative Eu anomalies, relatively flat HREE patterns and strong Th enrichments producing a steep slope between $Y$ and Th on the REE-HFSE diagram (Figure 3.7). 


\section{High-Al arc suites (adakites)}

Adakites, which occur in both ensialic and ensimatic Cenozoic arcs, include andesite, dacite and sodic rhyolite, with dacite most common, and their intrusive equivalents tonalite and trondhjemite (Defant and Drummond, 1990). Adakites appear to be equivalent to the high-Al trondhjemite-tonalite-dacite (TTD) suite of rocks which occur in terranes from the Archean to the Phanerozoic (Defant and Drummond, 1990; Drummond and Defant, 1990; Kay et al., 1993). These rocks are believed to form by direct melting of young, hot subducted oceanic crust (eclogite with or without amphibolite) leaving garnet and amphibole in the residue, making them genetically distinct from rocks derived by melting in the mantle wedge above the slab (Drummond and Defant, 1990, 1993; Defant and Drummond, 1990). This distinctiveness is readily apparent on a REE-HFSE spider diagram, shown in Figure 3.8, showing representative data for felsic volcanic samples from adakite/high-Al TTD suites (Table 3.3). The patterns are characterized by extremely steep REE profiles and the absence of negative Eu anomalies which clearly distinguishes them from mantle derived felsic igneous rocks. 


\section{Rift zones}

Rift zones, a consequence of crustal extension, may be subdivided on the basis of (i) location (continental, back-arc, mid-ocean) and (ii) maturity. Rifts are initiated as non-spreading extensional zones in both oceanic and continental settings in which crust is thinned by block faulting and attenuation as a result of extensional tectonism, commonly accompanied by high heat flow, but true spreading - the formation of new oceanic crust - has not yet occurred. If extension is relaxed the rift may fail to open and an aborted (failed) rift is preserved in the geologic record. With continued extension continental rifts, back-arc rifts (marginal basins) and immature mid-ocean rifts may develop into mature mid-ocean ridges.

\section{Mature mid-ocean ridges}

Most felsic volcanism and plutonism along mid-ocean ridges (mature spreading centres) seems to occur along anomalous ridge segments characterized by the eruption of enriched MORB (E-MORB) or transitional (TMORB) basalt. Iceland is both the most prolific known source of felsic magmatism in a mid-ocean ridge environment and the best documented (Saemundsson, 1978; O'Nions and Gronvold, 1973; MacDonald et al., 1987; Sigurdsson, 1977; Walker, 1966; Wood, 1978). Icelandic data used include 
analyses for two rhyolites from the neovolcanic central volcanoes of the eastern axial rift zone (Askja and Krafla) and two rhyolites from Tertiary felsic volcanic complexes near Iceland's east coast (Thingmuli and Reydarfjordur). Data are also used for rhyodacite dredged from the Galapagos spreading centre, a plagiogranite from the mid-Atlantic ridge at $45^{\circ} \mathrm{N}$ and a quartz monzonite from the Argo Fracture Zone in the Indian Ocean (Table 3.3). The latter sample is somewhat atypical in that it is associated with LREE depleted (N-MORB) tholeiites (Engel and Fisher, 1975; Hedge et al., 1979).

The four Icelandic rhyolites are moderately enriched in LREE and the more incompatible HFSE resulting in shallow concave upward REE-HFSE patterns (Figure 3.9). Rhyolites from the neovolcanic, axial rift zone volcanoes Kerlingarfjoll and Namafjall, not shown on Figure 3.10, have similar REE patterns (O'Nions and Gronvold., 1973). The REE-HFSE trace of the Askja rhyolite is an almost perfect match for Kidd Creek rhyolites. The rhyolite data from Krafla, Thingmuli and Reydarfjordur are also quite similar to those of the Kidd Creek rhyolites but are displaced to somewhat higher values. The Galapagos spreading centre, Mid-Atlantic ridge, and Argo Fracture Zone data, shown in Figure 3.10, are also quite similar to Kidd Creek data except for slightly flatter REE slopes and the very pronounced negative Eu anomaly of the quartz monzonite from the Argo Fracture Zone. 


\section{Immature mid-ocean rifts}

Immature mid-ocean rifts with associated felsic volcanism include (i) the non-spreading lateral rift (flank) zones of Iceland (Saemundsson, 1978), and

(ii) the Terceira Rift zone of the Azores Archipelago, a recently formed spreading axis at the western end of the African-Eurasia plate boundary which is undergoing slow oblique extension (Mungall and Martin, 1995; White et al., 1979). Comparative analyses are presented for a pre-postglacial $(>10,000$ year old) peralkaline rhyolite and a postglacial subalkaline rhyolite from the Torfajokull volcanic complex in Iceland's South Eastern Zone (MacDonald et al., 1990; McGarvie et al., 1990) and a comendite from the island of Terceira in the Azores (Table 3.3). These samples have high overall REE and HFSE contents with particularly strong enrichments of $\mathrm{Zr}, \mathrm{Hf}, \mathrm{Nb}, \mathrm{Ta}$, Th, $\mathrm{U}$ and the LREE. Data for the two peralkaline samples, Azores T-13 and Torfajokull ORU5, show a Nb-Ta hump similar to intraplate oceanic islands (Figure 3.11).

\section{Back-arc marginal basins}

Felsic volcanic rocks from ensimatic marginal basins are represented in the database by analyses for a representative rhyolite from the Sumisu Rift, a back-arc basin behind the Izu-Bonin arc in the western Pacific, and a fresh 
dacite glass and an altered dacite from the PACMANUS hydrothermal VMS deposit site in the eastern Manus back-arc basin south of New Ireland (Gill et al., 1992; Binns and Scott, 1993; Table 3.3). The Sumisu Rift rhyolite displays the $\mathrm{Nb}-\mathrm{Ta}$ trough, lack of Eu anomaly, low overall REE-HREE contents and subdued Th and $U$ values characteristic of ensimatic island arcs (Figure 3.12). However, compared to Izu arc, the Sumisu Rift rhyolites have the higher overall contents of REE and HFSE and display LREE enrichment (elevated La $/ Y \mathrm{Yb}_{N}$ ratios). Both PACMANUS dacite samples display fairly flat REE patterns, lack Eu anomalies, and have low Th-U contents typical of ensimatic island arc felsic volcanic rocks (Figure 3.12). In addition the fresh dacite has a pronounced $\mathrm{Nb}$ trough ( $\mathrm{Nb}$ was not analyzed in the altered sample and Ta was below the detection limit of $1 \mathrm{ppm})$. The elevated Ta value in the fresh dacite probably reflects Ta contamination from grinding in a tungsten carbide mill (R. A. Binns, CSIRO, Australia, written communication, 1995). Note the similarity between the REE-HFSE patterns of the fresh and altered PACMANUS dacites indicating relative immobility of the REE and HFSE in the PACMANUS hydrothermal system.

Comparative data for felsic igneous rocks formed in ensialic marginal basins are from (i) a preore and postore dacite from the Miocene succession hosting the Kuroko VMS ores of the Hokuroku District, Japan (aborted ensialic arc rift), (ii) Quaternary rhyodacite from Deception Island, Bransfield Strait 
(back-arc spreading centre), and (iii) Late Jurassic plagiogranite from the Rocas Verdes ophiolite complex of southern Chile (aborted back-arc spreading centre; Table 3.3). The REE and HFSE patterns of the Deception Island rhyodacite and the Rocas Verdes plagiogranite are similar to those of the Kidd Creek rhyolites except for their shallower LREE slopes and distinctive Zr peaks relative to $\mathrm{Nb}$ (Figure 3.13). The Hokuroku dacite is similar to Kidd Creek rhyolite except for higher $U / T h$ and $U / Y$ ratios and generally lower overall REE-HFSE contents.

\section{Continental rifts}

Data are available from five areas in which subalkaline rhyolites have been erupted in association with continental rifting; (i) the Afar area, Ethiopia, (ii) the Salton Trough, California, (iii) the Red Sea coast, Saudi Arabia, (iv) the central Queensland coast, Australia, and (v) the Lord Howe Rise, Tasman Sea (Table 3.3). The Afar area is near the non-spreading Ethiopian Rift, the Salton Trough is in the incipient stages of spreading and the Red Sea is young spreading centre (Walter et al., 1987; Herzig and Jacobs, 1994; Pallister, 1987). The rhyolites from the Queensland coast and the Lord Howe Rise are of Cretaceous age and are believed to have erupted in small continental rift basins which formed prior to the breakup of eastern Australia and the opening of the Tasman Sea (Bloomer et al., 1994; Ewart et al., 1992). 
Composition profiles for the Afar, Salton Trough and Saudi Arabia rhyolites are very similar and may be distinguished from the Queensland and Lord Howe Rise rhyolites; the latter have relatively low HREE and Y contents (Figure 3.14). All of the continental rift rhyolites shown on Figure 3.14 have REE and HFSE contents comparable to Kidd Creek rhyolite with the exceptions of Th and $U$ enrichments and lower HREE and $Y$ values in the Queensland-Lord Howe Rise rhyolites. The strong Th-U enrichment of the continental crust may explain the distinctive enrichment of Th and $U$ in the continental rift rhyolites reflecting assimilation or partial melting of continental crust.

\section{Discussion}

\section{Comparative geochemistry}

There is good correlation among data for rhyolites of the Kidd Creek formation and (i) subalkaline rhyolites from mid-ocean ridges exemplified by Iceland, and (ii) subalkaline rhyolites associated with zones of continental rifting (Afar area, Red Sea and Salton Sea). The closest match is with rhyolite pumice from the 1875 eruption of Askja in Iceland's eastern axial rift zone. Relative to the Icelandic examples Kidd Creek rhyolites are somewhat 
depleted in $\mathrm{Nb}$ and Ta whereas the continental rift rocks tend to have $\mathrm{Nb}-\mathrm{Ta}$ values similar to those of Kidd Creek but Th and $U$ enrichments typical of continental crust (Taylor and McLennan, 1985). Several lines of evidence are not compatible with a continental component in Kidd Creek rhyolites including (i) lack of continental clastic sedimentary rocks in the Kidd Creek area, (ii) general lack of inherited zircons in preorogenic ( $>2700 \mathrm{Ma}$ ) volcanic rocks in the Abitibi Greenstone Belt (Corfu, 1993), (iii) lack of inherited zircons in Kidd Creek rhyolite (Bleeker and Parrish, 1996; Barrie and Davis, 1990), and (iv) Pb and $\mathrm{Sm}-\mathrm{Nd}$ isotopic results for Kidd Creek igneous rocks consistent with a mantle or mantle-derived source (Barrie et al., 1996; Chapter 4). In addition, the Kidd Creek ores have low $\mathrm{Pb} /(\mathrm{Cu}+\mathrm{Zn}+\mathrm{Pb})$, typical of mid-ocean ridge deposits, whereas VMS deposits associated with continental crust, such as the Kuroko deposits and the modern seafloor deposits of the Okinawa trough, have high $\mathrm{Pb} /(\mathrm{Cu}+\mathrm{Zn}+\mathrm{Pb})$ (Fouquet et al., 1993). Thus the closest geochemical match for Kidd Creek rhyolite is subalkaline rhyolite erupted from central volcanoes within Iceland's axial rift zones. Similarity between Kidd Creek and the axial rift zones of Iceland's is not limited to rhyolite geochemistry.

Within Iceland's neovolcanic zones subalkaline volcanism is concentrated along fissure swarms within extensional axial rift zones which represent extensions of the mid-Atlantic ridge (Saemundsson, 1978; Marsh et al., 1991; MacDonald et al., 1990). Central volcanoes formed within the axial rift 
zones are compositionally bimodal being constructed primarily of basalt and rhyolite with a paucity of intermediate compositions (Carmicheal, 1964; McGarvie et al., 1990; Sigurdsson, 1977; MacDonald et al., 1987). A strong basalt-rhyolite bimodality also exists in the Kidd Creek area. A histogram (Figure 3.15) comparing the $\mathrm{SiO}_{2}$ distribution of 542 volcanic rock analyses from Iceland (Sigurdsson, 1977) and 975 igneous rocks intersected in exploration drill holes in the Kidd Creek area (data from Falconbridge Ltd.) illustrates a pronounced gap in intermediate compositions. Note that ultramafic compositions are not shown and that the Kidd Creek data are biased by an overabundance of rhyolitic analyses as exploration drilling targeted felsic volcanic rocks. Icelandites, andesitic rocks with elevated $\mathrm{Fe}, \mathrm{Ti}$ and $\mathrm{P}$ contents, occur in restricted amounts in both settings (Oskarsson et al., 1985; Wood, 1978; Barrie et al., 1996).

The subalkaline basalts of Iceland and the subvolcanic mafic sills at Kidd Creek both have E-MORB compositions as illustrated on the Th- $\mathrm{HF}-\mathrm{Nb}$ tectonomagmatic discrimination diagram in Figure 3.16. Mg-rich extrusive rocks, a product of high mantle temperatures (high degrees of partial melting), are a product of both the Kidd Creek and Iceland magmatic systems. Within Iceland, which is located above a mantle plume, picrites containing up to $20.6 \% \mathrm{MgO}$ have been erupted in the eastern and western axial rift zones (Hemond et al., 1993). Within the ultramafic rocks beneath the Kidd Creek Mine 
package, which include spinifex textured komatiite flows, less altered samples $(<5 \%$ loss on ignition) contain up to $23.1 \% \mathrm{MgO}$ (J. Everest, written communication, 1995).

\section{Comparative volcanology}

The Kidd Creek mine area represents a local centre of volcanism consisting mainly of rhyolitic lava and felsic volcaniclastic rocks, possibly within the upper part of a central volcanic complex, overlain by extensive basaltic flows, intruded by subvolcanic mafic sills, and underlain by ultramafic rocks. Reconstruction of rhyolite morphology at Kidd Creek indicates emplacement of the QP rhyolite along fissures spaced approximately $800 \mathrm{~m}$ apart (Figure 2.17 to 2.19). At the Torfajokull central volcano, Iceland, five postglacial silicic lava units have erupted from parallel volcanic fissures spaced approximately 1 to 3 km apart (MacDonald et al., 1990). There is a paucity of distally derived, nonvolcanogenic sedimentary rocks at Kidd Creek, as well as in Iceland, which is consistent with (i) an environment located far from continental margins, and/or

(ii) the construction of a large, volcanic edifice. The Kidd Creek VMS deposits have been interpreted to occur within a graben or half-graben (Bleeker and Parrish, 1996). The existence of coarse, polymict breccias, stratigraphic offsets, and the alignment of rhyolite ridges and elongate sulfide orebodies within the Kidd Creek succession are consistent with the development of 
grabens or half-grabens during synvolcanic faulting along a rift zone, and with caldera development resulting from collapse within the upper part of a shieldlike volcanic edifice. Over time Icelandic central volcanoes are displaced to the margins of the axial rift zone, become extinct and are eventually buried under younger flood basalts fed mainly by fissure eruptions (Walker, 1966;

Saemundsson, 1978; Piper, 1971). These flood basalts may be similar to the thick succession of basaltic flows and breccias which overlie the QP rhyolite (Figures 1.3 and 2.21).

Fingers and lenses of rhyolite peperite, which indicate injection of a lowviscosity, high-temperature felsic magma, occur within footwall rocks of the Kidd Creek deposit (H. Gibson, personal communication, 1995). Barrie (1995) estimates temperatures of approximately $840^{\circ} \mathrm{C}$ to $920^{\circ} \mathrm{C}$ for rhyolites in the Kidd Creek area based on zircon geothermometry. Temperature estimates for rhyolite from the 1875 eruption of Askja in Iceland's eastern axial rift zone are in the range of $990^{\circ} \mathrm{C}$ to $1010^{\circ} \mathrm{C}$ suggestive of superheating by underlying basaltic magma (Sigurdsson and Sparks, 1981). High-temperature geothermal fields occur within the central volcanoes of Iceland; drilling beneath the Krafla caldera has revealed temperatures in excess of $340^{\circ}$ at $2 \mathrm{~km}$ depth (Bjornsson et al., 1977; Saemundsson, 1978). Tertiary central volcanoes exposed in eastern Iceland reveal extensively propylitised cores representing 
large hydrothermal reservoirs, each with a volume of the order of $100 \mathrm{~km}^{3}$, and there is a close coincidence between the distribution of felsic rocks and the areas of intense hydrothermal alteration (Walker, 1966).

\section{Petrogenesis}

Strong geochemical and volcanological similarities suggest that the petrogenetic history of the Kidd Creek rhyolites may be similar to that of rhyolites erupted from central volcanoes in the axial rift zones of Iceland. Several studies have concluded that Iceland rhyolites form by partial melting of juvenile crust with the rock type undergoing anatexis being either hydrated basalt, plagiogranite or felsic differentiates formed during the crystallization of mafic igneous bodies (O'Nions and Gronvold, 1973; Sigurdsson, 1977; Oskarsson et al., 1982; Marsh et al., 1991; Sigmarsson et al., 1991;

Sigmarsson et al., 1992). Burial by subsequent eruptions and accompanying isostatic readjustments result in the rapid downward migration of crust with subsidence rates of up to several $\mathrm{km} / \mathrm{m} . \mathrm{y}$. This subsidence coupled with high geothermal gradients (up to $160^{\circ} \mathrm{C} / \mathrm{km}$ ) in the axial rift zones provide favorable conditions for partial melting (Marsh et al., 1991; Meyer et al., 1985; and references therein). High magma production rates and $\mathrm{Mg}$-rich picritic lavas are manifestations of an ascending plume (hotspot) beneath Iceland (Hemond 
et al., 1993; Bjornsson, 1985). The komatiite-bearing ultramafic succession, which forms the footwall to the Kidd Creek Mine package, and high eruption temperatures for the rhyolites (Barrie, 1995) suggest that steep geothermal gradients, possibly related to a mantle plume, existed beneath Kidd Creek. Experimental study by Spulber and Rutherford (1983) has shown that 10\% partial melting of an oceanic tholeiite from Kilauea, Hawaii, under relatively reducing conditions, can produce a rhyolitic melt $\left(73.1 \% \mathrm{SiO}_{2}, 4.32 \% \mathrm{Na}_{2} \mathrm{O}\right.$, $2.39 \% \mathrm{~K}_{2} \mathrm{O}$ ) similar to naturally occurring Icelandic rhyolites.

If the Iceland analogy is correct and the Kidd Creek rhyolites did indeed form by partial melting it may provide an explanation for the remarkable similarity between rhyolites at the base (FW rhyolites) and top (QP rhyolites) of the Kidd Creek formation which, according to $\mathrm{U}-\mathrm{Pb}$ zircon dates, erupted at least 1.4 million years apart (Bleeker and Parrish, 1995). It is unlikely that a siliceous magma with nearly homogeneous composition was maintained for this time span or that fractional crystallization in two separate chambers produced such similar differentiates. However, if the rhyolites formed by near eutectic partial melting of a common parent under similar pressuretemperature conditions then compositionally similar rhyolitic products would be expected. 
Information on the petrogenesis of the Kidd Creek rhyolites can also be obtained by evaluating their REE and HFSE contents which reflect source composition, source restite mineralogy, rhyolitic liquid composition, and magma temperature. Flat HREE profiles are incompatible with garnet or amphibole in the residue while negative Eu anomalies indicate retention of plagioclase (Hanson, 1978). The high overall REE and HFSE contents of the Kidd Creek rhyolites, compared to most subalkaline rhyolites, are compatible with (i) derivation from an incompatible element enriched source (e.g., EMORB), and (ii) high magmatic temperatures (Montel, 1993; Watson and Harrison, 1983; Barrie, 1995). All of these characteristics are consistent with the formation of the Kidd Creek rhyolites by partial melting in an anomalous mid-ocean ridge environment with high heat flow. Magmatic temperatures of 840 to $920^{\circ} \mathrm{C}$ (Barrie, 1995) suggest that after they were formed the Kidd Creek rhyolite magmas continued to thermally interact with mafic-ultramafic magmas, possibly in a compositionally zoned magma chamber (Hildreth, 1979, 1981). High rhyolite magmatic temperatures are not consistent with a fractional crystallization model in which rhyolitic magma is only produced after much of the original basaltic magma has cooled and crystallized. 


\section{Comparison of the Kidd Creek Rhyolite With Other Superior Province Felsic Volcanic Rocks Associated With VMS Deposits}

REE and HFSE abundances in post-Triassic felsic volcanic rocks and plagiogranites vary considerably between tectonic environments whereas within a tectonic environment most felsic igneous rocks display limited variability. Therefore, within post-Triassic felsic volcanic rocks geochemical variability of these elements is, to a large extent, controlled by tectonomagmatic processes. It is reasonable to hypothesize that much of the REE and HFSE variability observed in Archean successions may also be a product of tectonomagmatic processes.

Lesher et al. (1986), building on the work of Condie $(1976 ; 1981)$ and Campbell et al. (1982), proposed the subdivision of Archean metavolcanic rocks into four groups based on trace element geochemistry (FI, FII, FIIla and FIllb). Average analyses for each of these groups, determined from data presented by Lesher et al. (1986), are shown in REE-HFSE diagrams in Figure 3.17. Comparison of the Archean group FI - Flllb data to the REE-HFSE profiles of the post-Triassic data (Figures 3.5 to 3.14 ) indicate that group FI is similar to adakites, groups FII and FIIla are similar to felsic volcanic rocks erupted in ensialic island arcs (e.g. Aegean island arc and New Zeaiand rhyolites) and ensialic back-arc basins (e.g. Hokuroku District high-Si dacites), and group 
FIIIb is similar to the rhyolites and plagiogranites of mid-ocean ridges (e.g., rhyolites of Iceland's axial rift zones). Similar observations were made by Barrie et al. (1993). Thus the variability in REE and HFSE contents observed within felsic volcanic rocks of the Superior Province may be accounted for by differences in tectonic settings (tectonomagmatic variability). This does not necessarily imply that the tectonic processes operative during the late Archean were identical to those of the present day. One of the most striking features noted during the comparison of data from Superior Province felsic volcanic rocks to the post-Triassic data is the absence of a Superior Province geochemical analogue for ensimatic island arc felsic volcanic rocks (compare Figure 3.6 to Figure 3.17). This is particularly significant in light of many current models for the evolution of the Superior Province by accretion of oceanic terranes including island arcs (e.g. Jackson and Cruden, 1995; Jackson et al., 1994; Stern et al., 1994; Kimura et al., 1993; Hoffman, 1991).

Kidd Creek rhyolites have REE and HFSE abundances intermediate between FII, FIIla and FIIlb felsic volcanic rocks but large negative Eu anomalies and small $Z_{N} / Y_{N}$ ratios, due to relative HREE and $Y$ enrichment, favor their inclusion in the Flllb group (Figure 3.17). 


\section{Formation and Preservation of the Kidd Creek VMS Deposit}

\section{Tectonomagmatic processes}

Geochemical and volcanological similarities make it reasonable to speculate that many of the processes occurring in the central volcanoes of Iceland's axial rift zones also occurred at Kidd Creek. The most important of these, with respect to VMS formation, are high heat flow and subsidence. High heat flow drives the hydrothermal circulation system and may also result in production of rhyolitic magma by partial melting. Subsidence, either as a result of caldera collapse or graben development in an extensional environment, provides cross-strata permeability which focuses hydrothermal discharge. A second benefit of subsidence is that discharge is likely to occur within clastic/volcaniclastic debris covering the floor of the subsidence structure resulting in subseafloor sulfide mineralization by open space filling, hydraulic jacking or replacement, thereby improving the efficiency of sulfide deposition (i.e. less metal dispersed into seawater by "black smokers"). The TAG VMS deposit on the Mid-Atlantic Ridge, estimated to contain about 4 million tonnes of massive sulfides, is believed to be formed primarily by hydrothermal replacement within breccias (Humphris et al., 1995). A subseafloor replacement model has also been applied to the Horne deposit, the largest of the known VMS deposits in the Noranda camp (54.3 million tonnes of ore 
extracted; Kerr and Gibson, 1993). Evidence of high heat flow during the formation of the Kidd Creek volcanic centre is recorded by komatiites, which have liquidus temperatures of about $1600^{\circ} \mathrm{C}$ (Campbell et al., 1989; Jochum et al., 1991), and zircon saturation temperatures of 840 to $920^{\circ} \mathrm{C}$ in Kidd Creek rhyolites (Barrie, 1995). The existence of a subsidence structure in the Kidd Creek mine area is suggested by a pronounced local thickening of felsic volcaniclastic rocks, and by the presence of heterolithologic, poorly sorted, sulfide clast-bearing breccias.

\section{Lifespan and volcanic accumulation rate}

U-Pb dating of zircons by Bleeker and Parrish (1995) indicates that felsic volcanism at Kidd Creek occurred over a time interval of $1.4 \mathrm{Ma}$ to $6.1 \mathrm{Ma}$ which is somewhat anomalous for the emplacement of only $300-500 \mathrm{~m}$ of volcanic and volcaniclastic strata (average accumulation rate between 60 and $300 \mathrm{~m}$ per m.y.). Felsic volcanic complexes of Iceland have typical life spans of 0.5 1.0 million years and average accumulation rates of basaltic lava in Iceland have been estimated at 690 to 730 m per m.y. (Piper, 1971; McDougall et al., 1976, 1977). At Noranda, Quebec, the 7 to $9 \mathrm{~km}$ thick Noranda volcanic complex, interpreted to be a large shield volcano, may have been formed in as little as 3.5 m.y. for an average accumulation rate of between 2000 and 2600 m per m.y. (Mortensen, 1987; Gibson and Watkinson, 1990). Low accumulation 
rates of lava and volcaniclastic material at Kidd Creek would have allowed hydrothermal convection to remain focused over long periods of time.

\section{A model for the association of rhyolites and VMS deposits in ancient}

\section{bimodal successions}

A disproportionate number of ancient VMS deposits, including the Kidd Creek deposit, are underlain by rhyolitic volcanic rocks. More than $70 \%$ of VMS deposits on land are associated with felsic volcanic centres (Franklin et al., 1981 ) and $56 \%$ (284 of 508 deposits studied) are immediately underlain by rhyolitic rocks (Rona, 1988, and references therein). Only 86 of the 508 deposits studied $(17 \%)$ are underlain by basalt ; the dominant volcanic product in most modern oceanic settings and in greenstone belts (Rona, 1988; Franklin and Thorpe, 1982; Goodwin, 1977). In contrast to ancient VMS deposits, modern seafloor sulfide deposits are commonly basalt or sediment hosted with no indication of contemporaneous rhyolites or dacites (Rona, 1988; Rona and Scott, 1993). This data suggests that felsic magmatic activity is favorable, but not essential, for the formation off VMS deposits.

One possible explanation for the rhyolite association lies in the physical differences between rhyolitic and mafic-ultramafic magmas; rhyolites being cooler, more viscous, and less dense. The model proposed below is based 
loosely on (i) an Iceland axial rift central volcano with a summit caldera, and (ii) the geology of the Kidd Creek mine area. Rhyolite magma in contact with basaltic (-ultramafic) magma will ascend through the magmatic plumbing network because of its lower density; its viscosity lowered through superheating by the surrounding, hotter magma (the process by which the rhyolitic magma forms is immaterial to the model). Eventually the rhyolitic magma will collect in the upper part of the magma system, perhaps forming a compositionally zoned subvolcanic magma chamber (Hildreth, 1979, 1981), and felsic volcanism will commence. The low density cap of siliceous magma forms a physical barrier to the upward movement of more mafic magmas (Thurston et al., 1985) and subsequent eruptions of mafic (-ultramafic) magma will seek alternate routes to the surface. If the original conduit system fed the central part of a volcanic edifice, such as the caldera of a central volcano, prerhyolite basalt (-komatiites) would erupt near the summit whereas post-rhyolite magmas may work their way laterally along fissures and erupt on the flanks of the volcano or on the surrounding plain. Lateral magma flow along fissures away from central volcanoes has been documented in Iceland (Sigurdsson and Sparks, 1978; Sigurdsson and Sparks, 1981). This change in magma conduits, initiated by the introduction of rhyolitic magma, results in a period of relative volcanic quiescence in the summit area. However, hydrothermal convection, which is centred beneath the central volcano due to high magma productivity in this area, will continue to rise along subsidence faults and vent 
in the caldera. Magma chamber recharge, accompanied by flank eruptions, provides sustained thermal energy to drive a long-lived hydrothermal convection system. The coupling of volcanic quiescence and long-lived hydrothermal venting in the summit caldera provide a fertile environment for the formation of VMS deposits. Eventually the summit of the central volcano is surmounted by basaltic lavas from distal fissure eruptions which seal off the hydrothermal system.

\section{Tectonic preservation}

From the perspective of land-based exploration the incorporation of seafloor VMS ores into a landmass is as important as their formation. Exploration of the present day seafloor leaves no doubt as to the capacity of basalt-dominated mid-ocean ridge systems to form VMS deposits in the absence of felsic volcanism (Rona, 1988; Rona and Scott, 1993) while deposits associated with rhyolites or dacites tend to occur in arc or back-arc settings (Binns and Scott, 1993; Fouquet et al., 1993; Halbach et al., 1993). Ancient VMS deposits preserved on land are generally associated with felsic volcanic rocks (Rona, 1988; Franklin and Thorpe, 1982; Hutchinson, 1982) suggesting that most normal mid-ocean ridge, basalt-hosted VMS deposits are consumed by subduction. Deposits formed in normal oceanic crust may be preserved by obduction but ophiolites are rare in the Archean (Helmstaedt et 
al., 1986; Burke and Kidd, 1980), and several studies suggest that most ophiolites formed in supra-subduction zone environments and not at normal ridges (e.g., Alabaster et al., 1982; Coish and Rogers, 1987; Elthon, 1991; Taylor et al., 1992). One environment where the high VMS productivity of midocean ridges is likely to be retained in ancient terrains is at anomalous ridge segments underlain by mantle plumes where high magma production rates form thick oceanic plateaux such as at Iceland. In contrast to normal oceanic crust these are buoyant bathymetric highs which are likely to be scraped off and accreted at destructive plate margins rather than subducted (Burke et al., 1976; Hoffman, 1991; Storey et al., 1991). An example of plateau accretion is provided by the komatiite-tholeiitic basalt sequence of Gorgona Island, Columbia, believed to have formed over the Galapagos hotspot in the Cretaceous and accreted to the Pacific continental margin of South America in the early Eocene (Storey et al., 1991). 


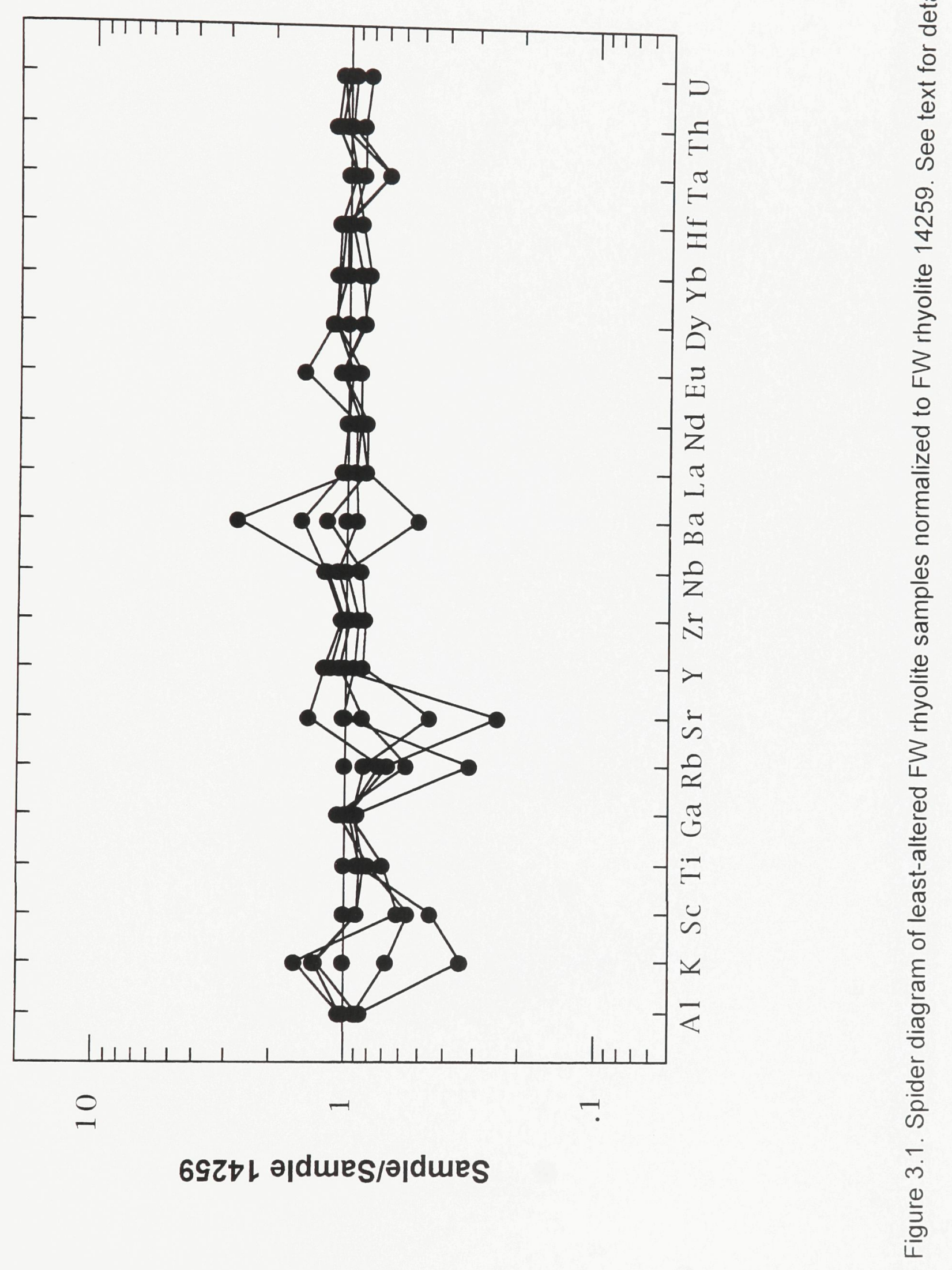




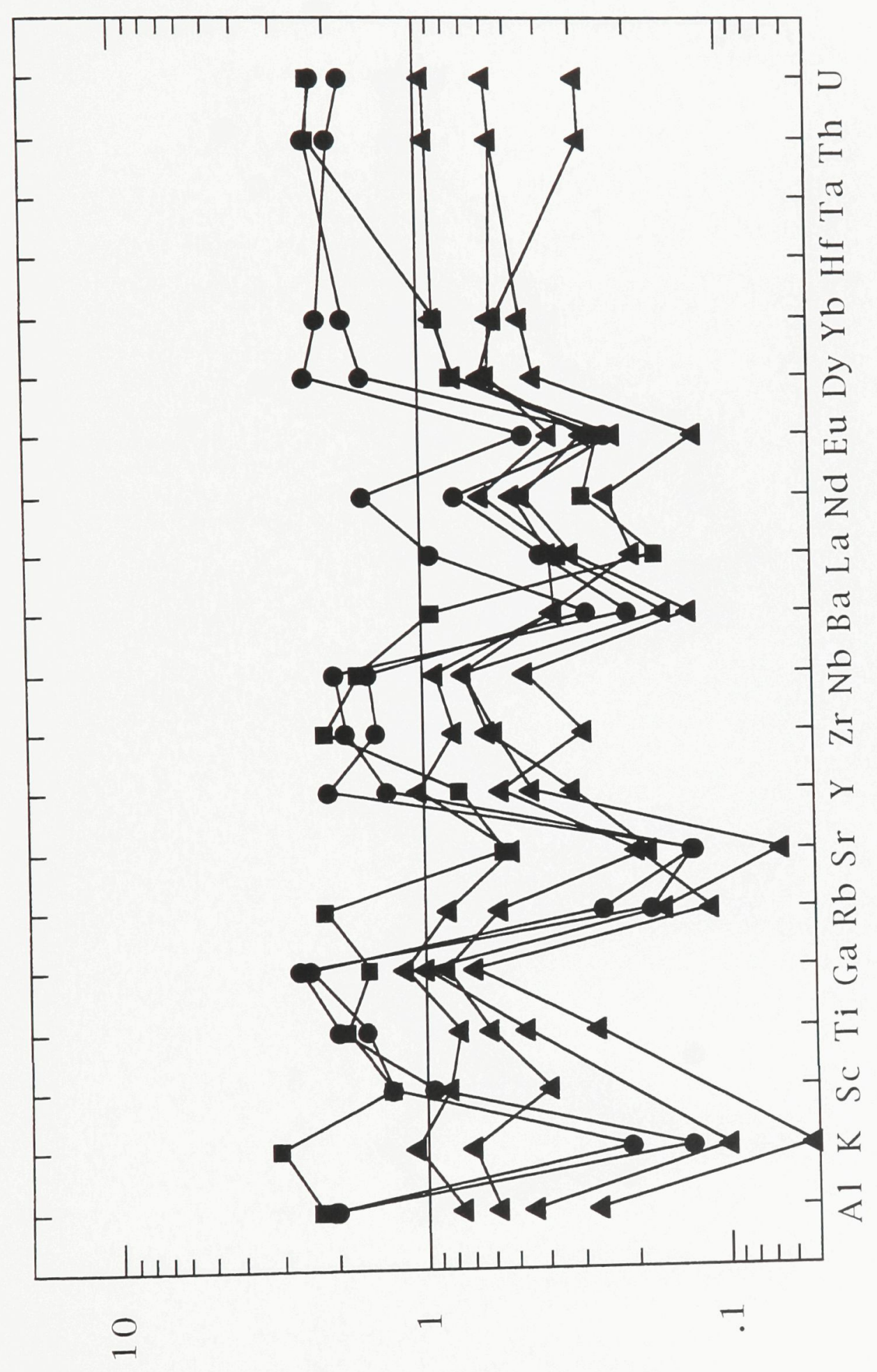

6SZ†

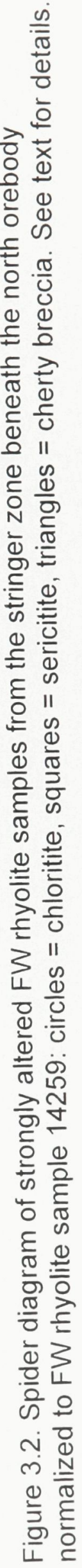


๓

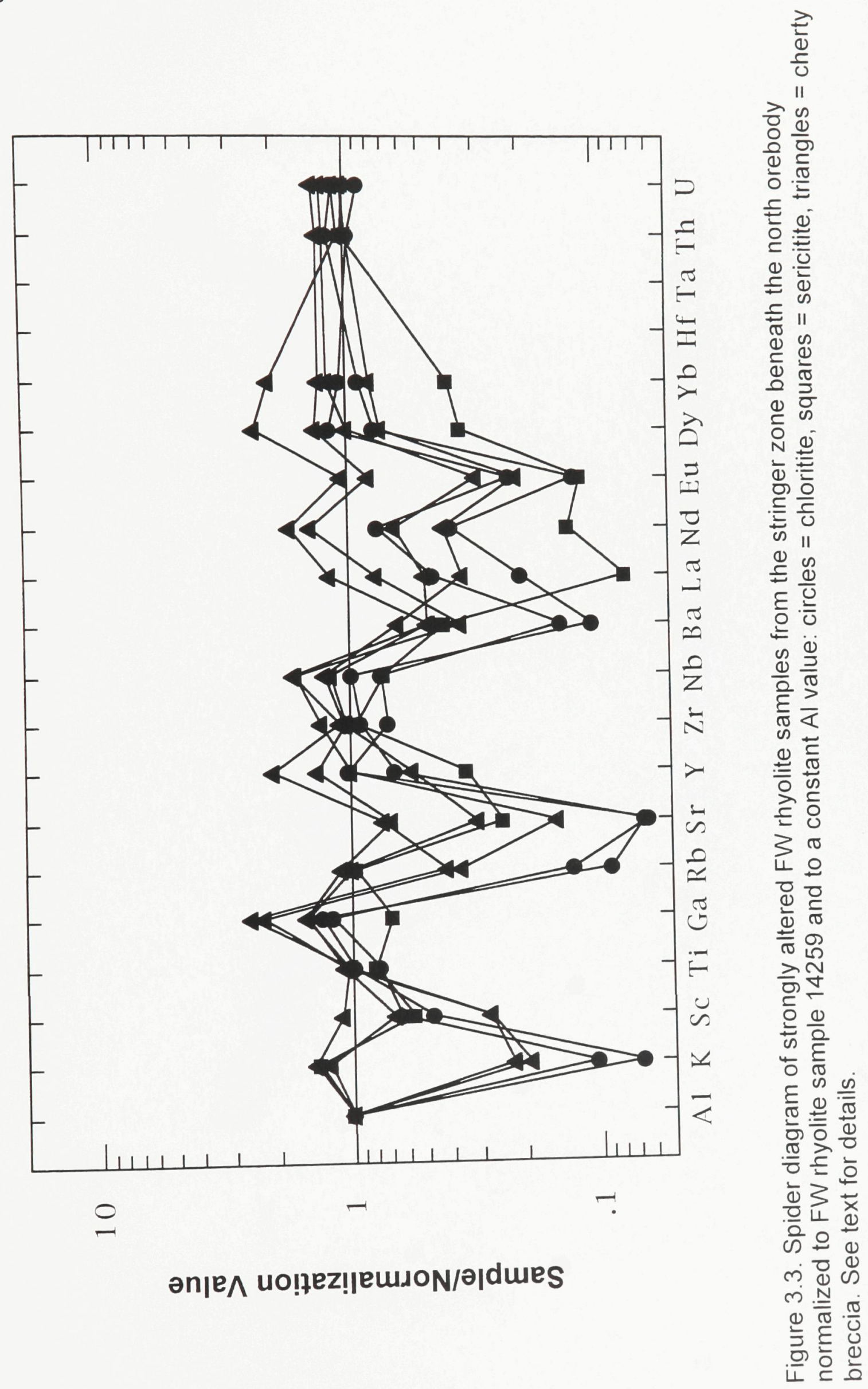


ઠ

0

$\frac{0}{11}$

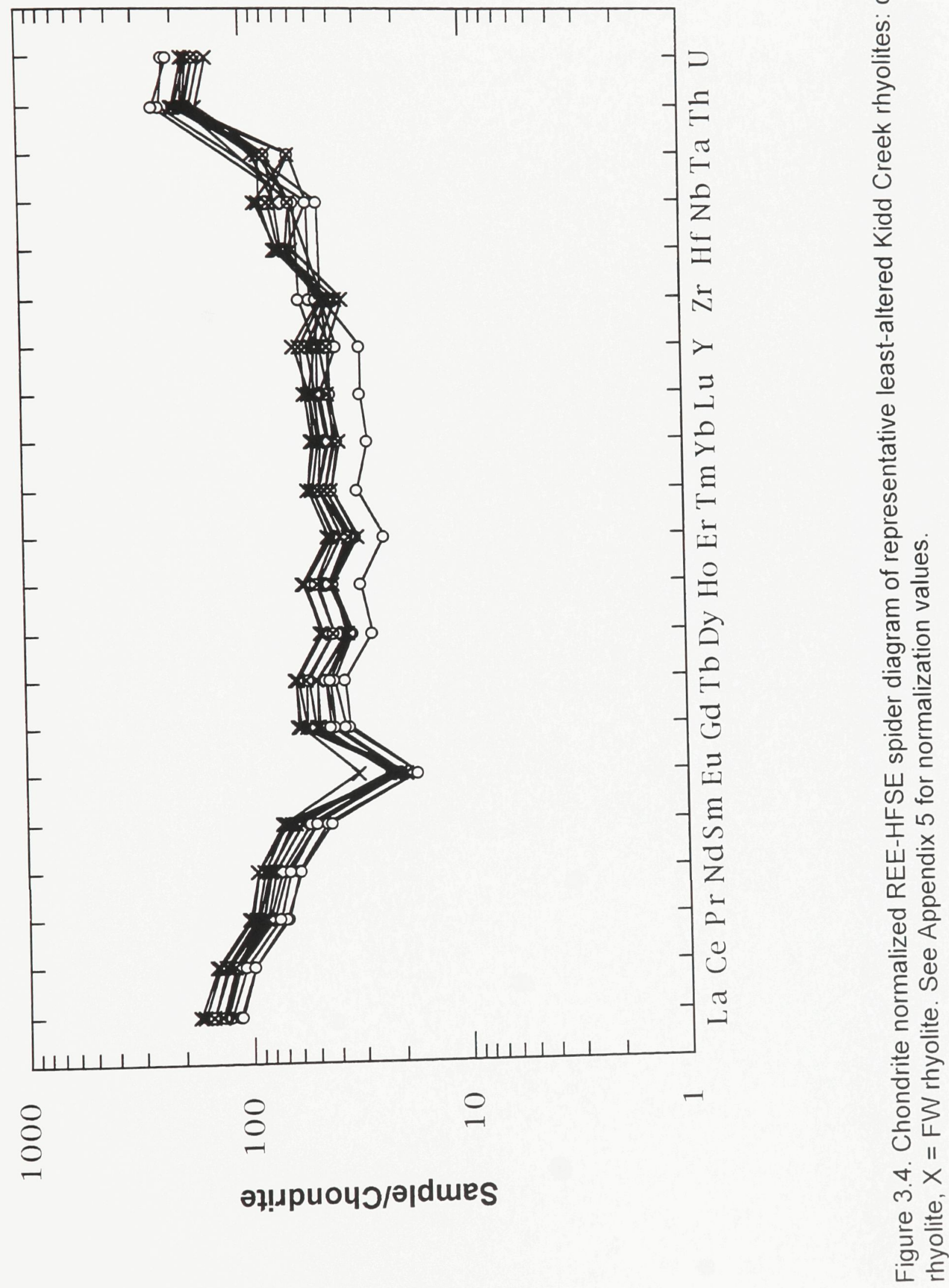


นึ

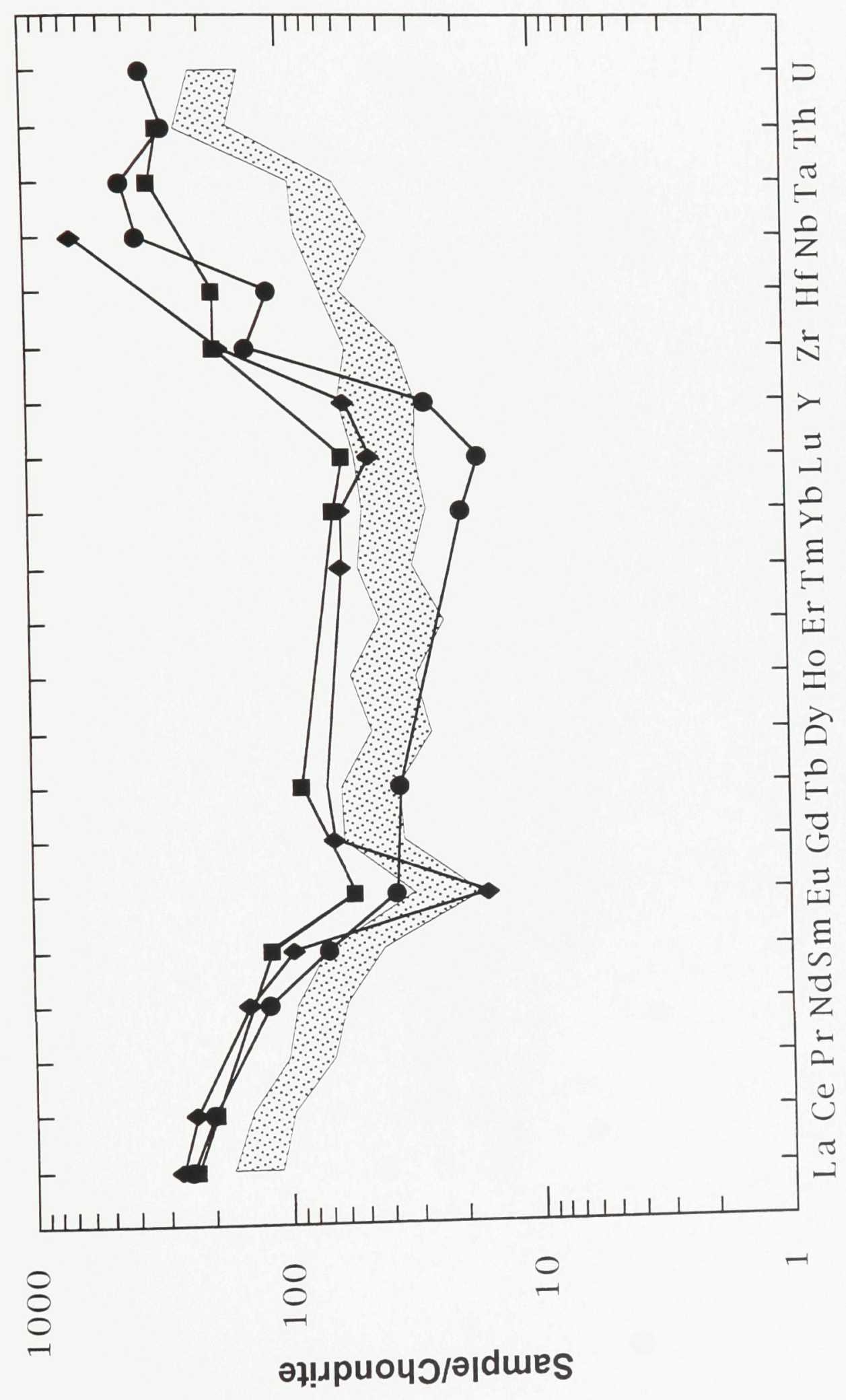

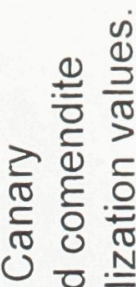

을

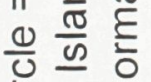

는 흥

is क

잉

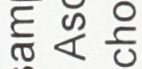

के

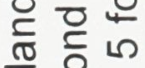

똘

屯. 흥

त क

정

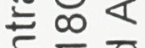

ब $\frac{\bar{\sigma}}{\mathrm{T}}$

$\geq$ o

원

흥

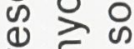

흥

ब용

능 $\frac{\mathrm{C}}{\mathrm{\sigma}}$

트음

훙

.

늠 $\frac{0}{\sigma}$

d)

응 (1)

का

崩

饪 严兽

嵌

뜬

ㅇํㅇ

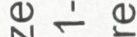

Nㅗㅇ

है

흥흐

ᄃ

논

흥

응

U 亲

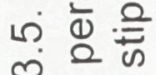

\%

응

운 뜬 
ต

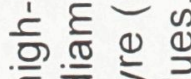
㐘 음 文

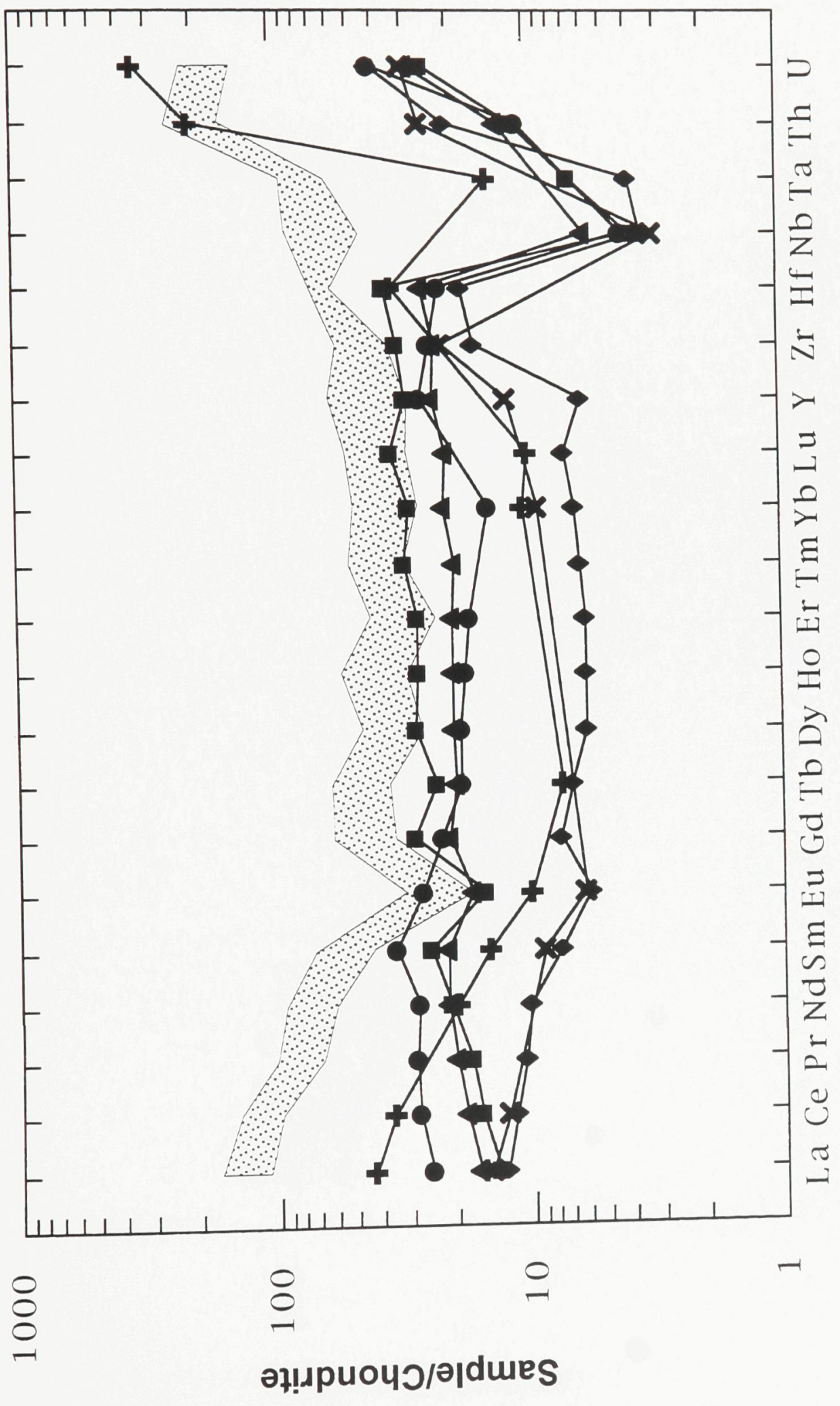

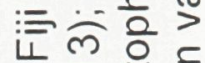

"1 흔으

뜽으 홍

는 온 응 is $\frac{2}{T} \frac{E}{0}$

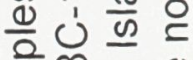
है $\infty$ 츤 U 0 > 흥 "11 원 으은 은은 क定立 (1) 응 $\geq 0$

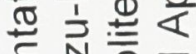
으응무 "

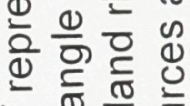
넝은 으 हิ 후웡 뜬

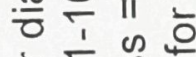
ब중 응인 क ⿱宀 山्य तै

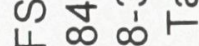
岌 $\underset{N}{\infty}$ 山े 山 종 d ช 0 男 츄 전 है웧 웅 (1) 옹 등ㄷㄴ은 은 는 ○ 0 눙이으 o 的的 (1) -

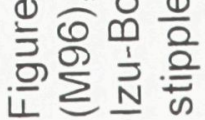


ò

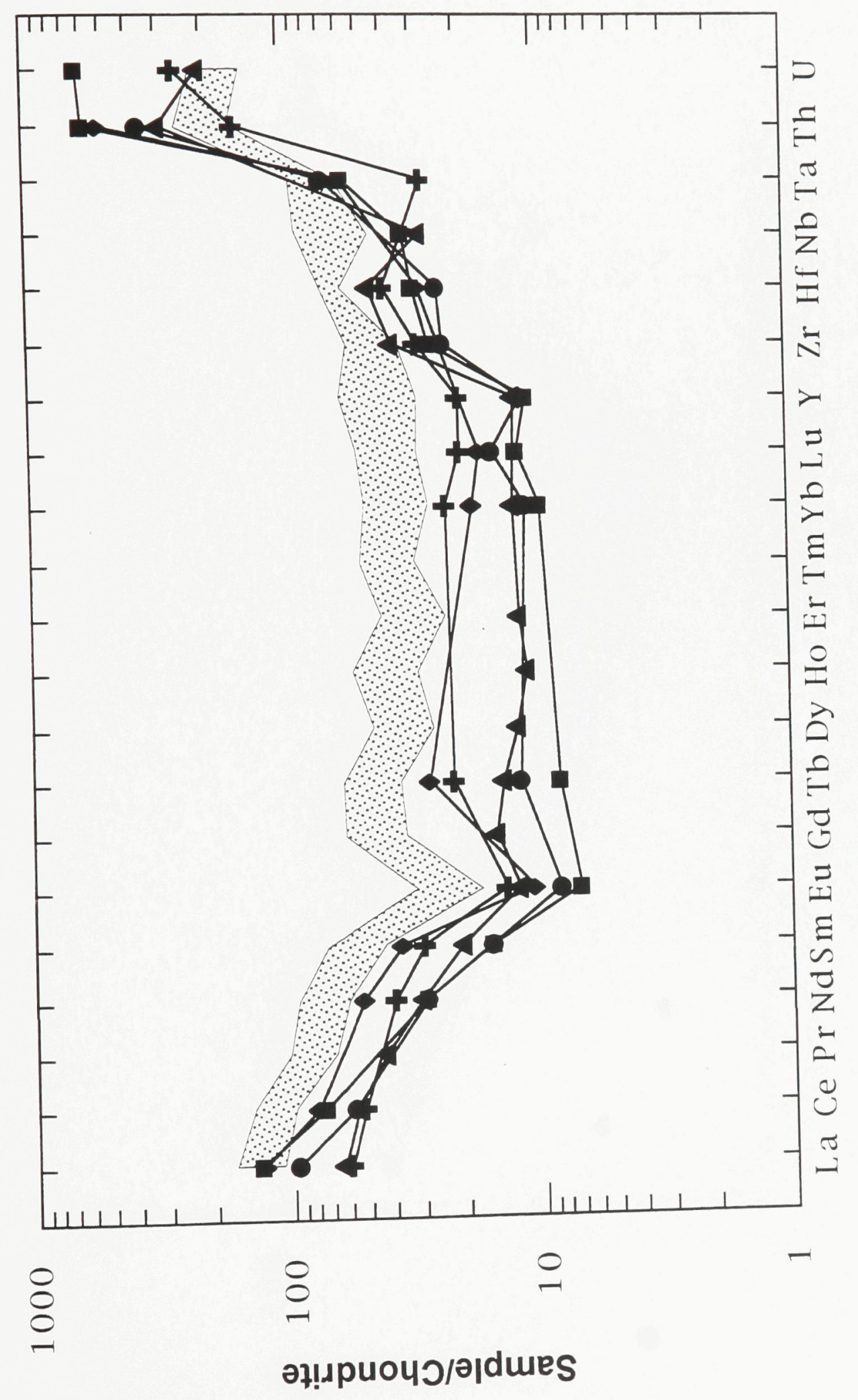

雨

$\Phi$ 工

安

(1) 응

흥흐원

空全这

क

을 के

"1.

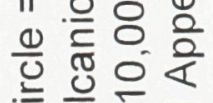

는 응은

is $>\frac{0}{\sigma}$

응은 훵

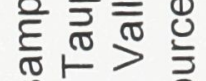

क II II

능 용

은 은

需

क

बकेष

(1)으

这 $\frac{0}{0} \frac{0}{\frac{0}{\sigma}}$

둥

कण है

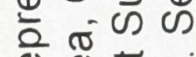

ब क क क

प

ह

뜽

कृषे

क

山ั엉

出 $\frac{0}{0} \frac{0}{\sigma}$ 응

交

山े흐

뜰 중 흥

क ळ口

N II II

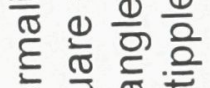

흥 해유

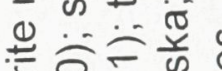

曹守要

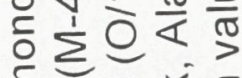

Uิ \&

‥

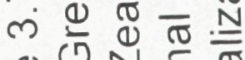

凹UN穴

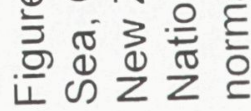


$\infty$

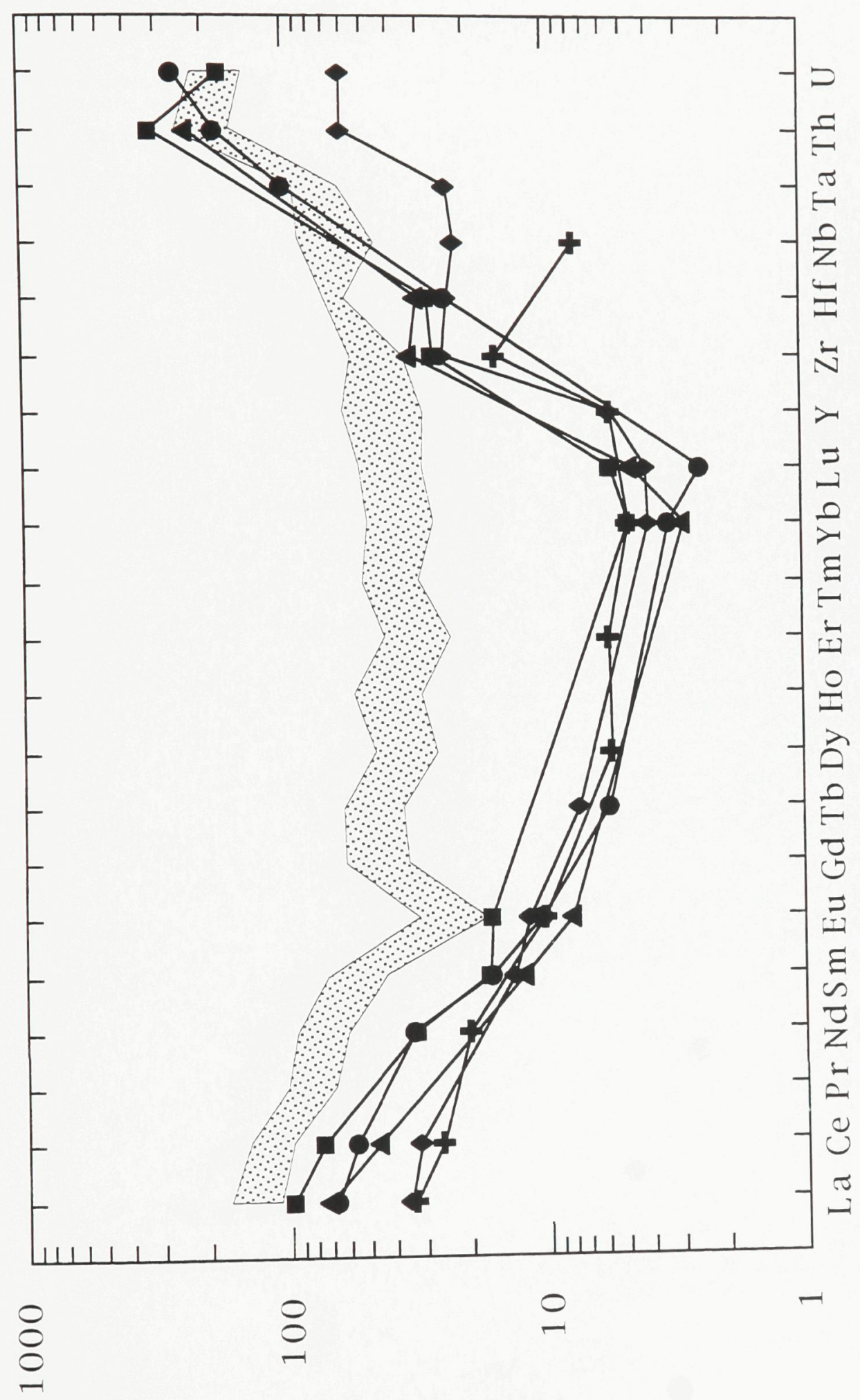

әң!.puочว/әdues

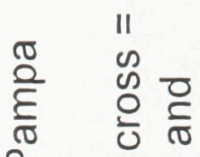

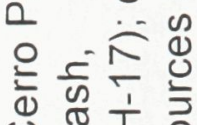

बंग $\begin{aligned} & 1 \\ & 0\end{aligned}$

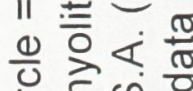

은 लि

is

क

을 잉

党 응

心) 등

오웛

ष" कि

는

을

Q

产云这

त

๙

$\stackrel{0}{2} \frac{0}{0}$

元U 舟

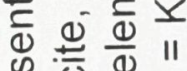

ळ

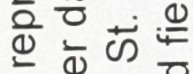

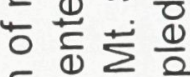

हญ

흘 क क

要 元

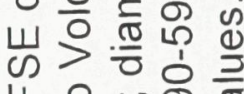

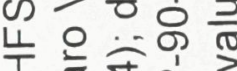

西 0

山心

$\square-\sigma \stackrel{N}{\sim}$

웡

Nㅜㅇㅝ

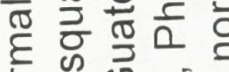

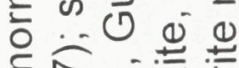

0 뜬 $\frac{0}{\bar{\sigma}} \frac{0}{0}$

징

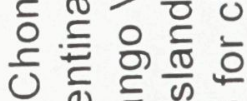

西

门ं

Q

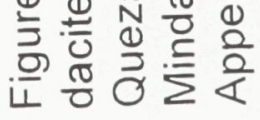


8

产

बิ흘

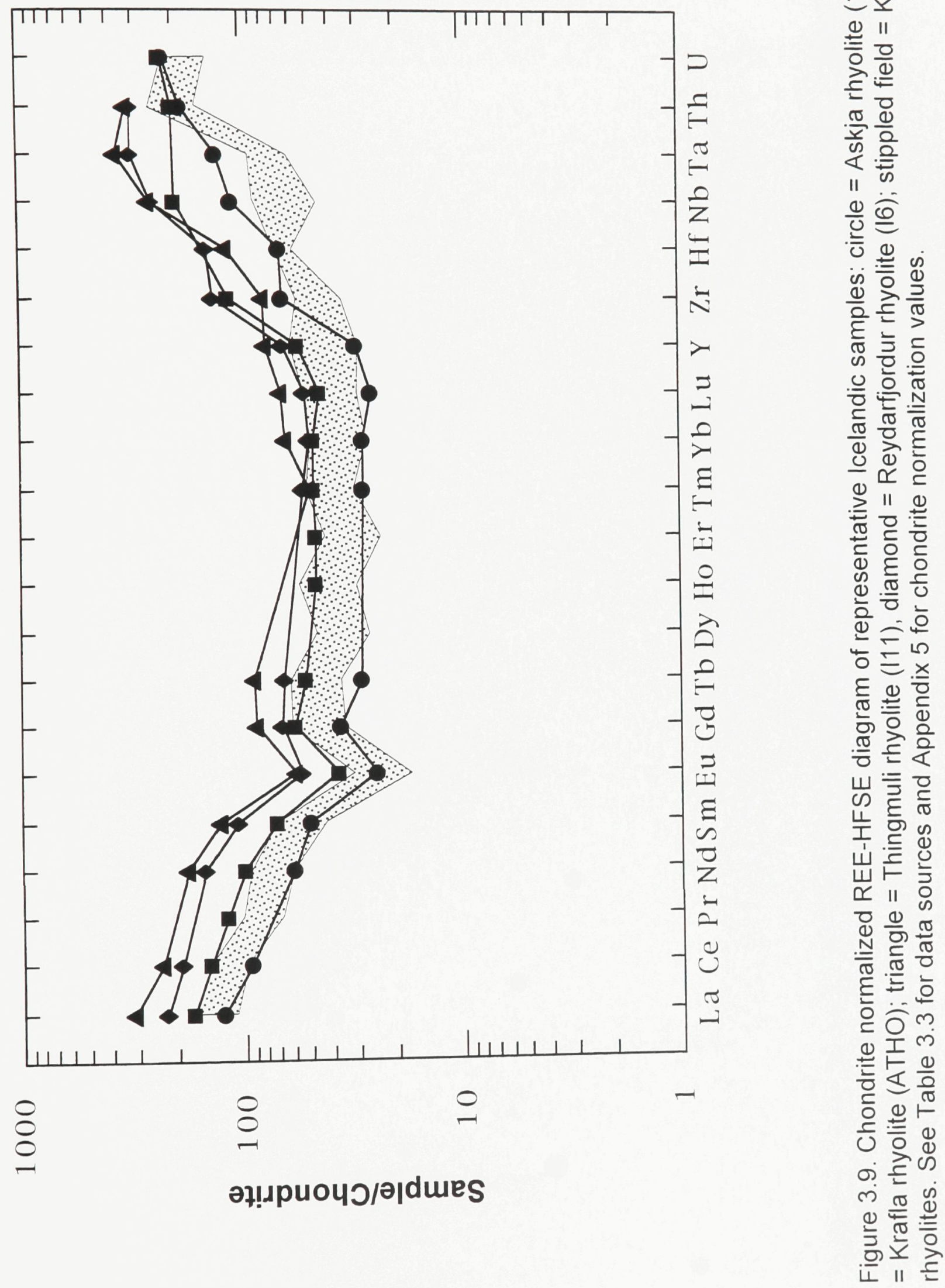


움

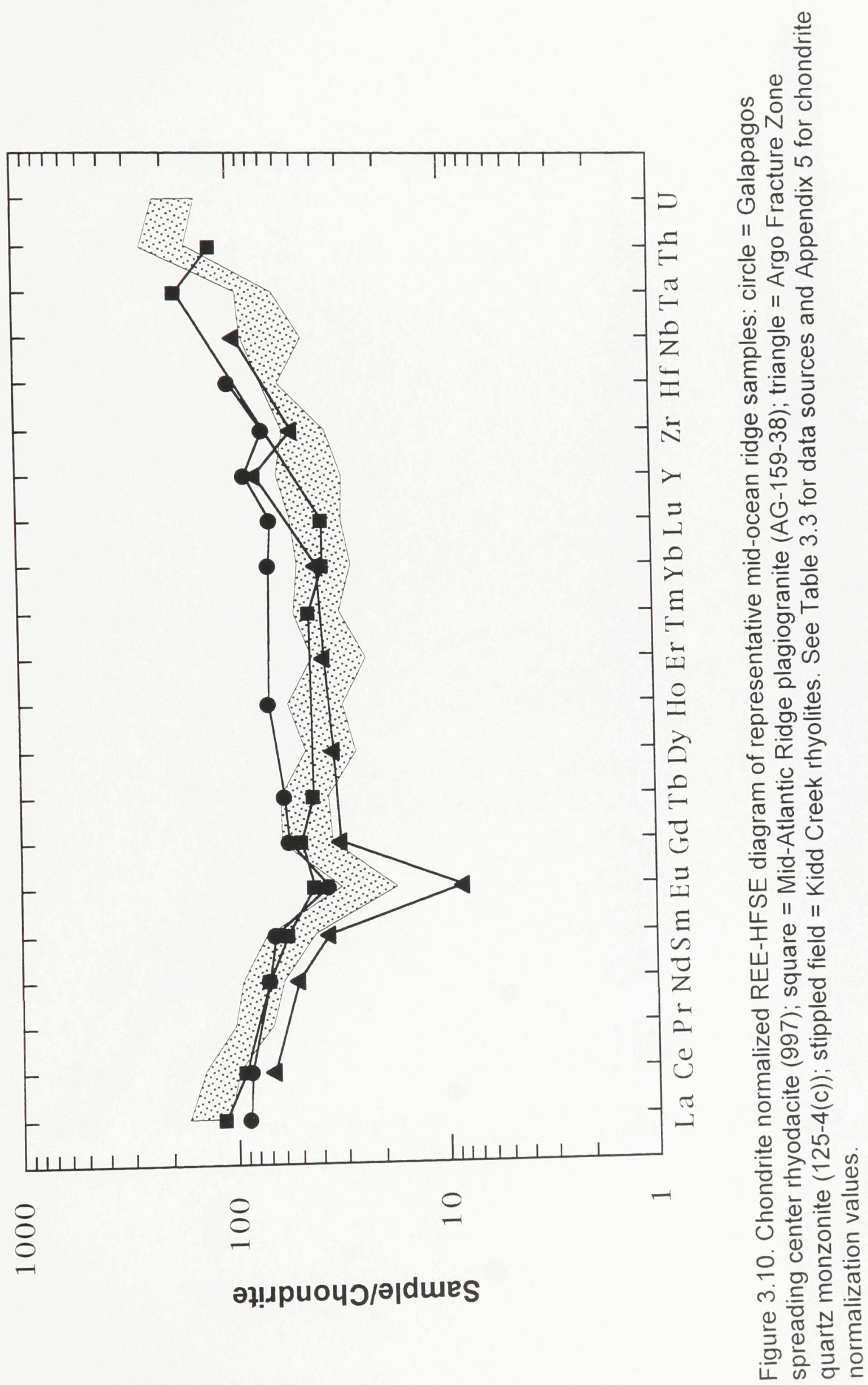


믐

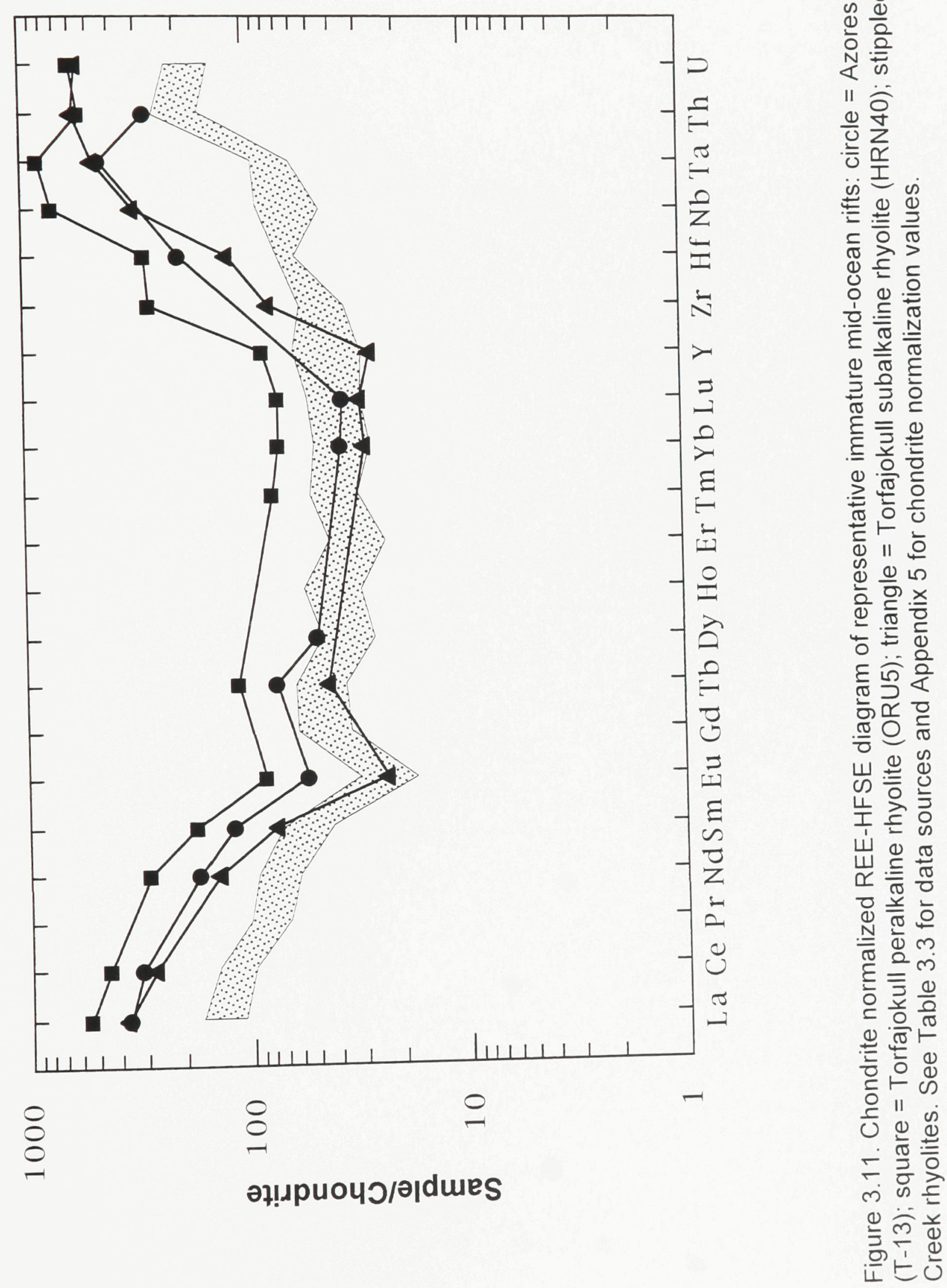


ㅇ

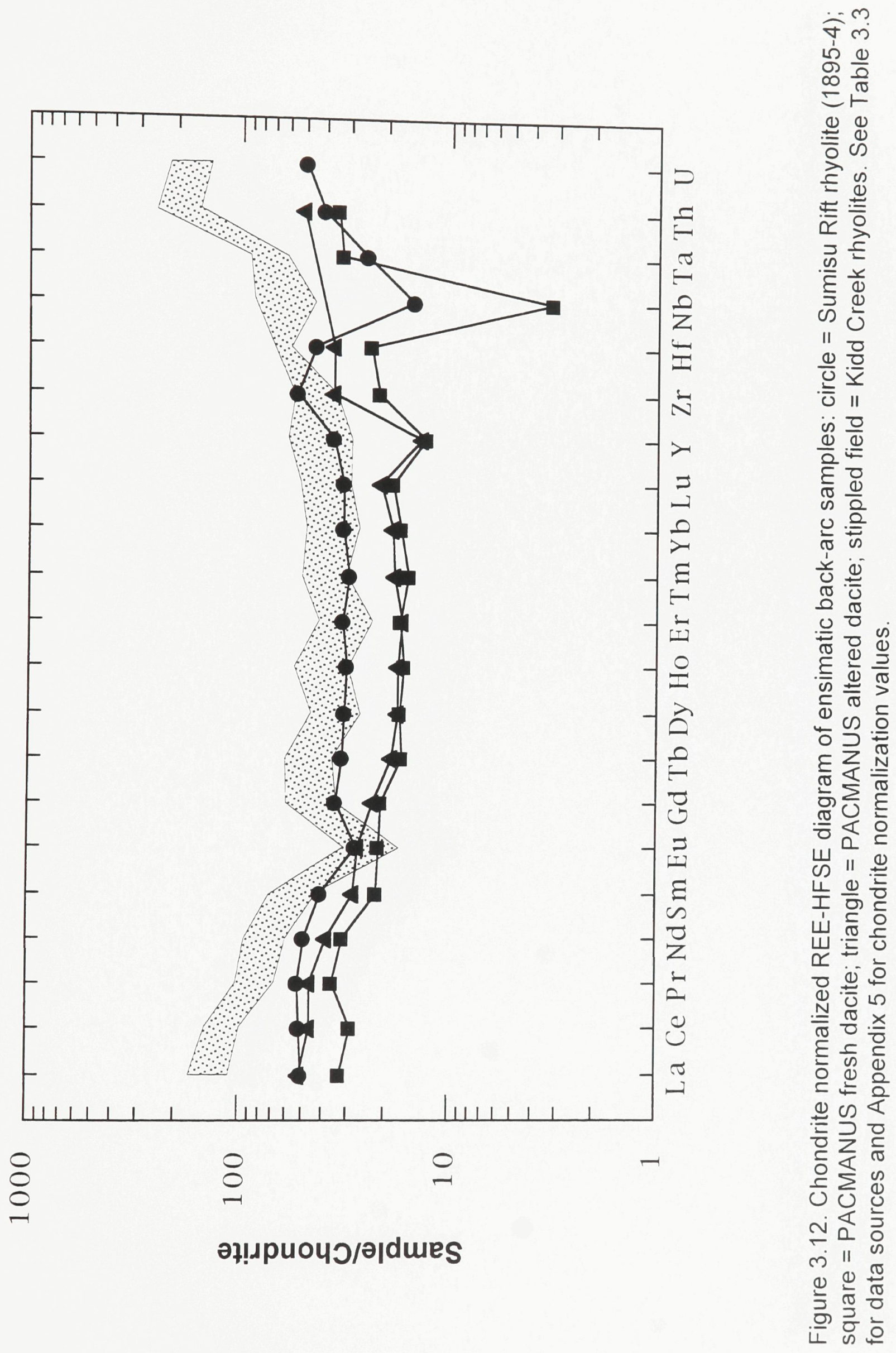


$\stackrel{8}{9}$

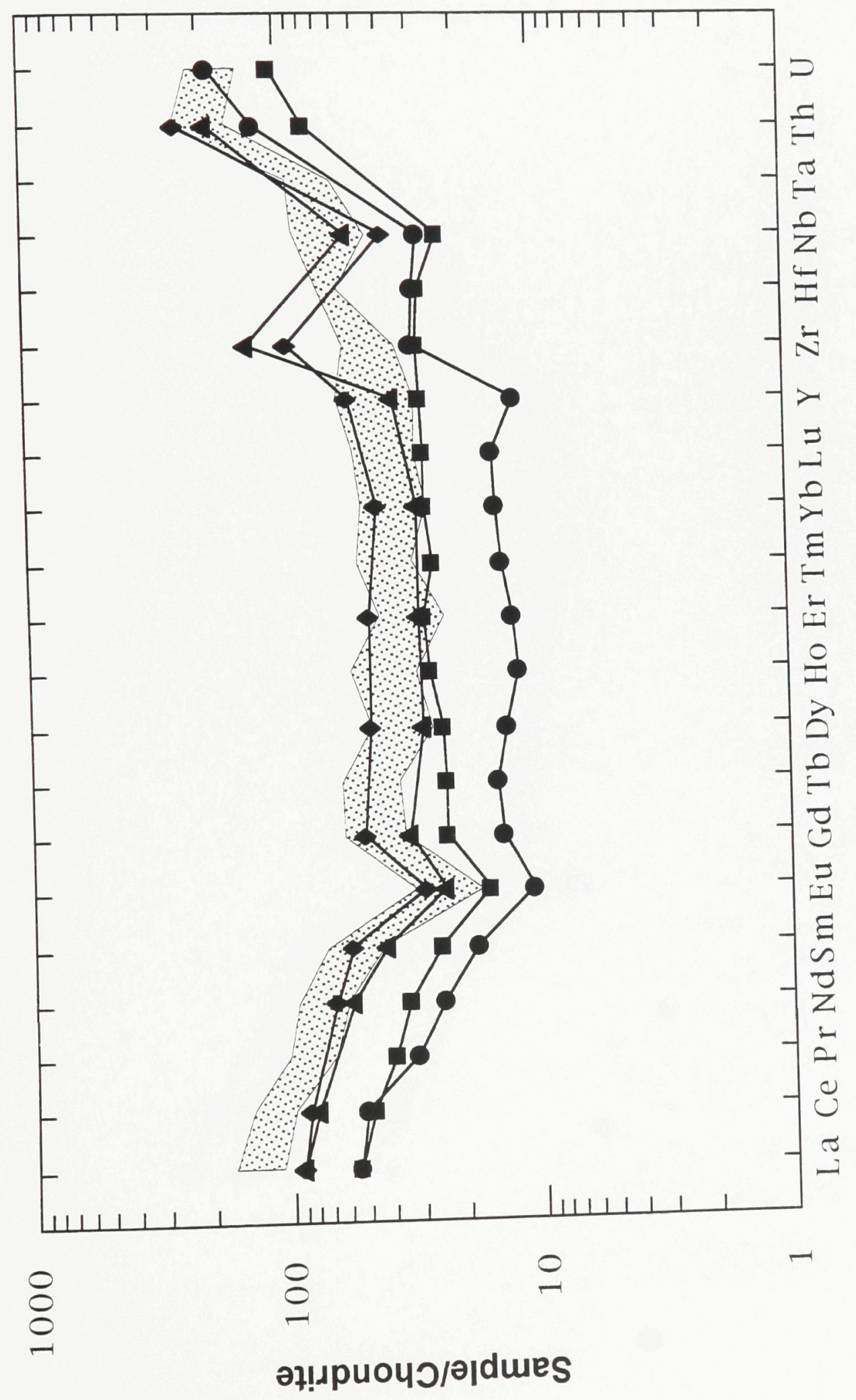

$\frac{\check{z}}{\underline{z}}$

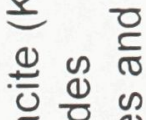
त 잉 홍 क्षे Э용 우모 중 1) II 힝ำ

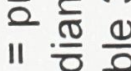
은 웡 is 을 당 का 응

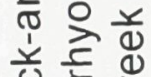
¿ 은 흥음 믐

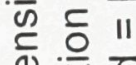
눙 훙원 E 밍 후에을 要 山玄灾 岌等

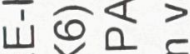

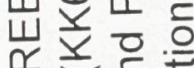

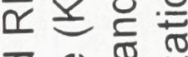

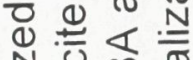
Nㅡㅇ है ख 홍 金造 능우 융응

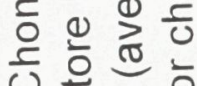
क क mं 을 का 11 त 0 흥 는 응 은흥 흘 운 
음

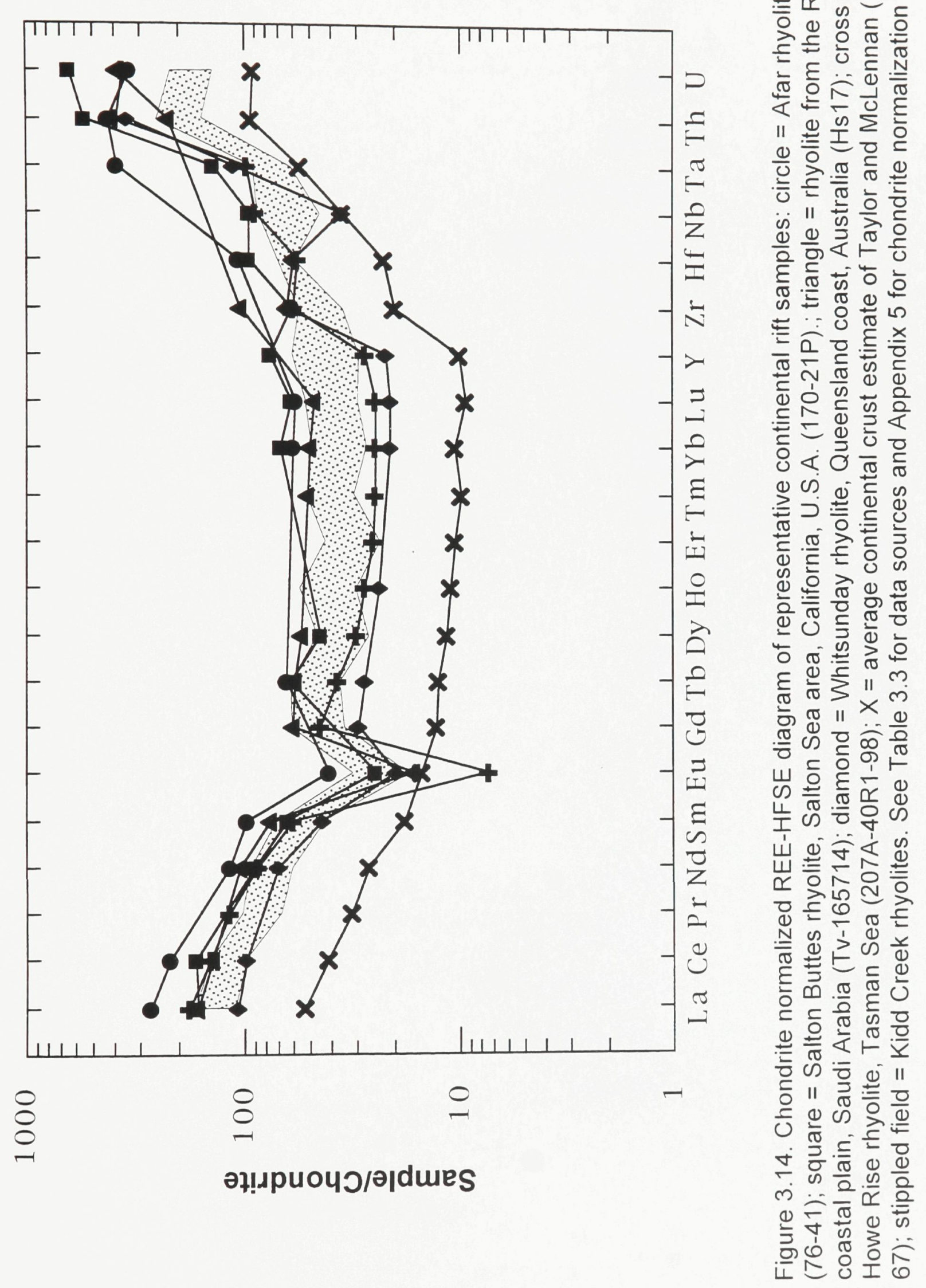


$\stackrel{\leftrightarrow}{\circ}$

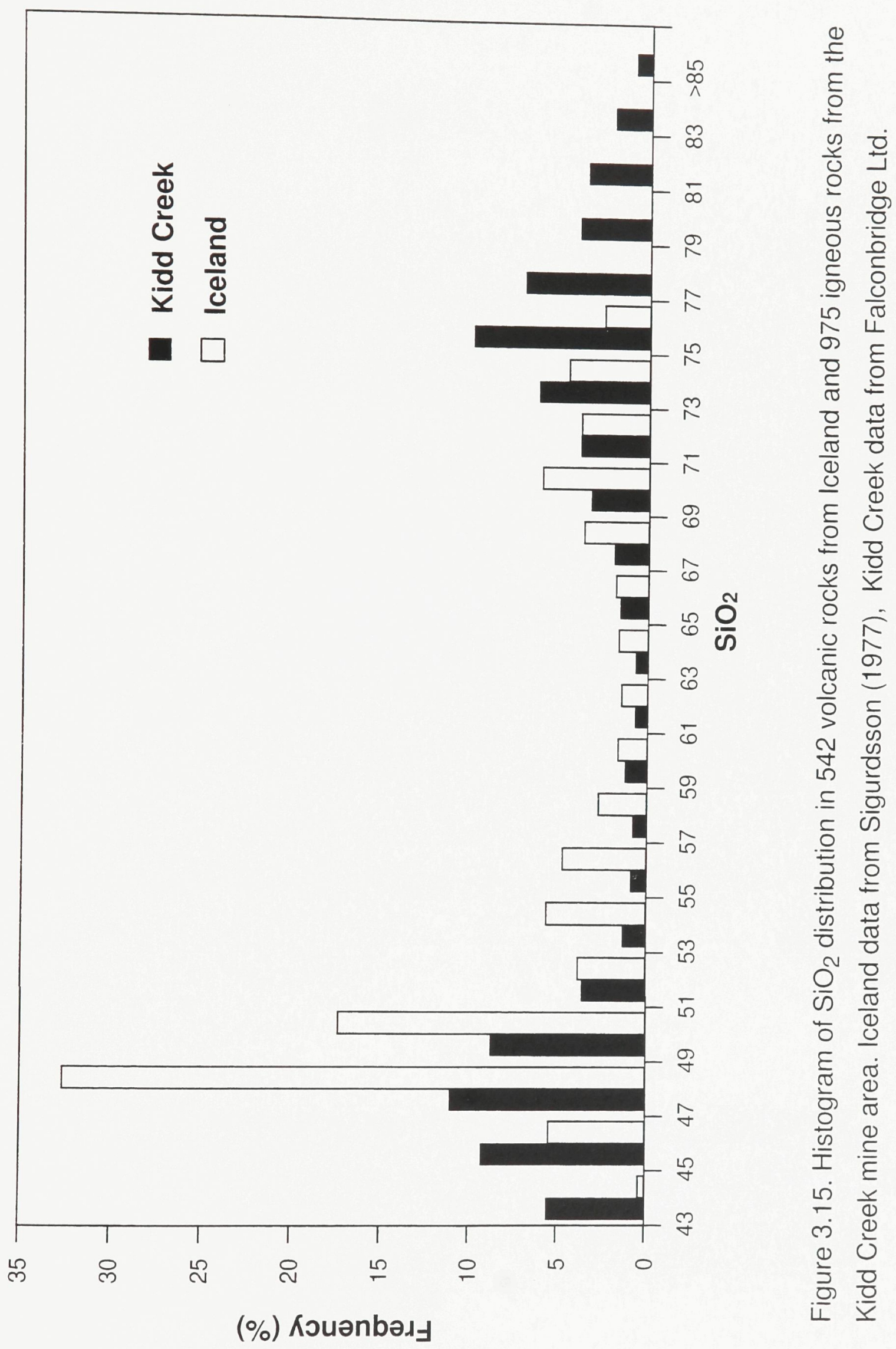




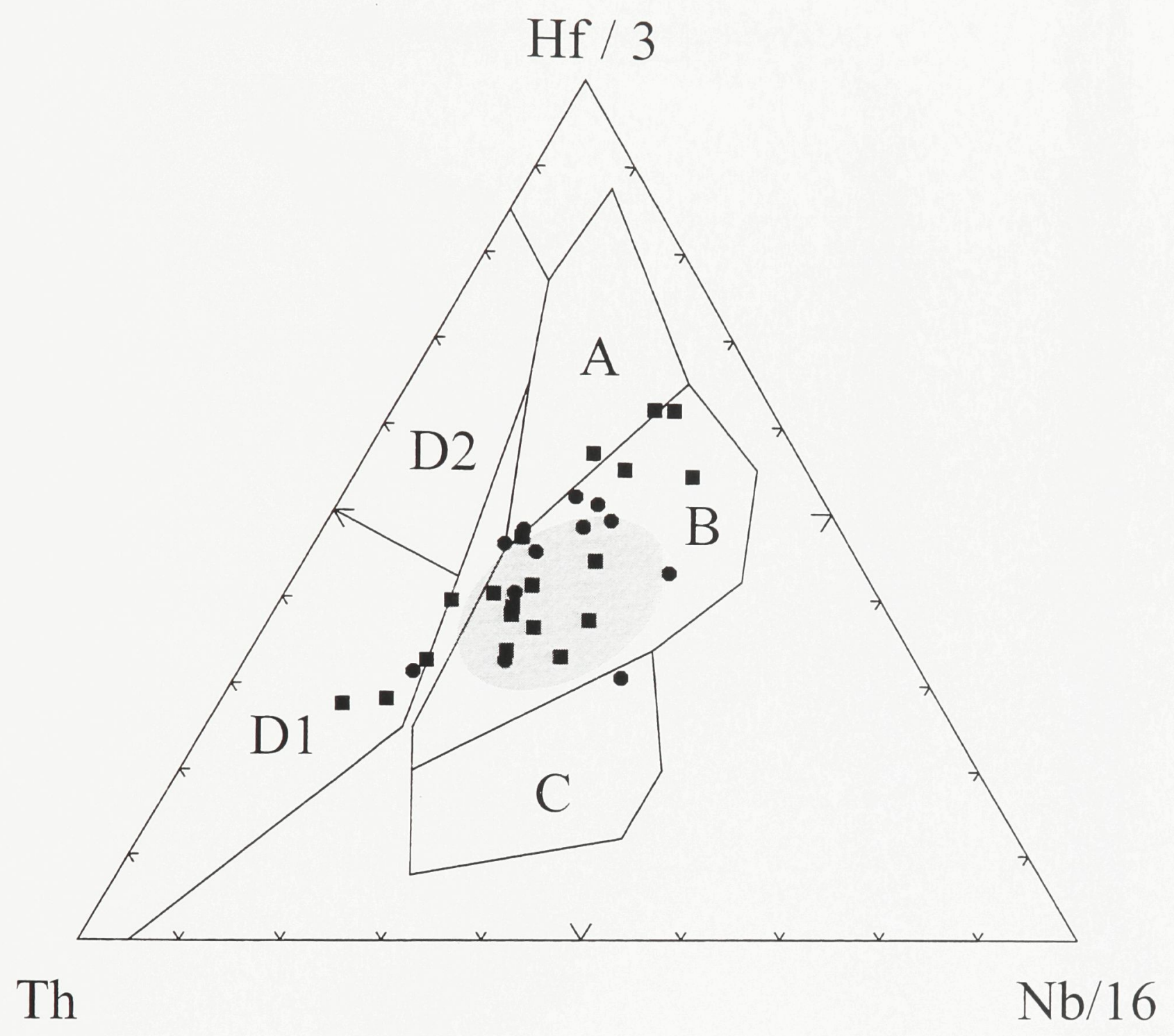

Figure 3.16. Th- Hf-Nb ternary diagram comparing mafic igneous rocks of the Kidd Creek mine area to subalkaline basalts from Iceland: circles $=$ Kidd Creek basalts, squares $=$ Kidd Creek subvolcanic mafic rocks; shaded area $=$ field of 33 Icelandic basalts from MacDonald et al. (1987), O'Nions and Gronvold (1973), and Wood (1978). Diagram after Wood (1980): A = N-type MORB; B = E-type MORB; $C$ = alkaline within plate basalts; $D 1$ = calc-alkaline destructive plate margin basalts; $\mathrm{D} 2$ = primitive arc tholeiites. 
$\stackrel{\circ}{\circ}$

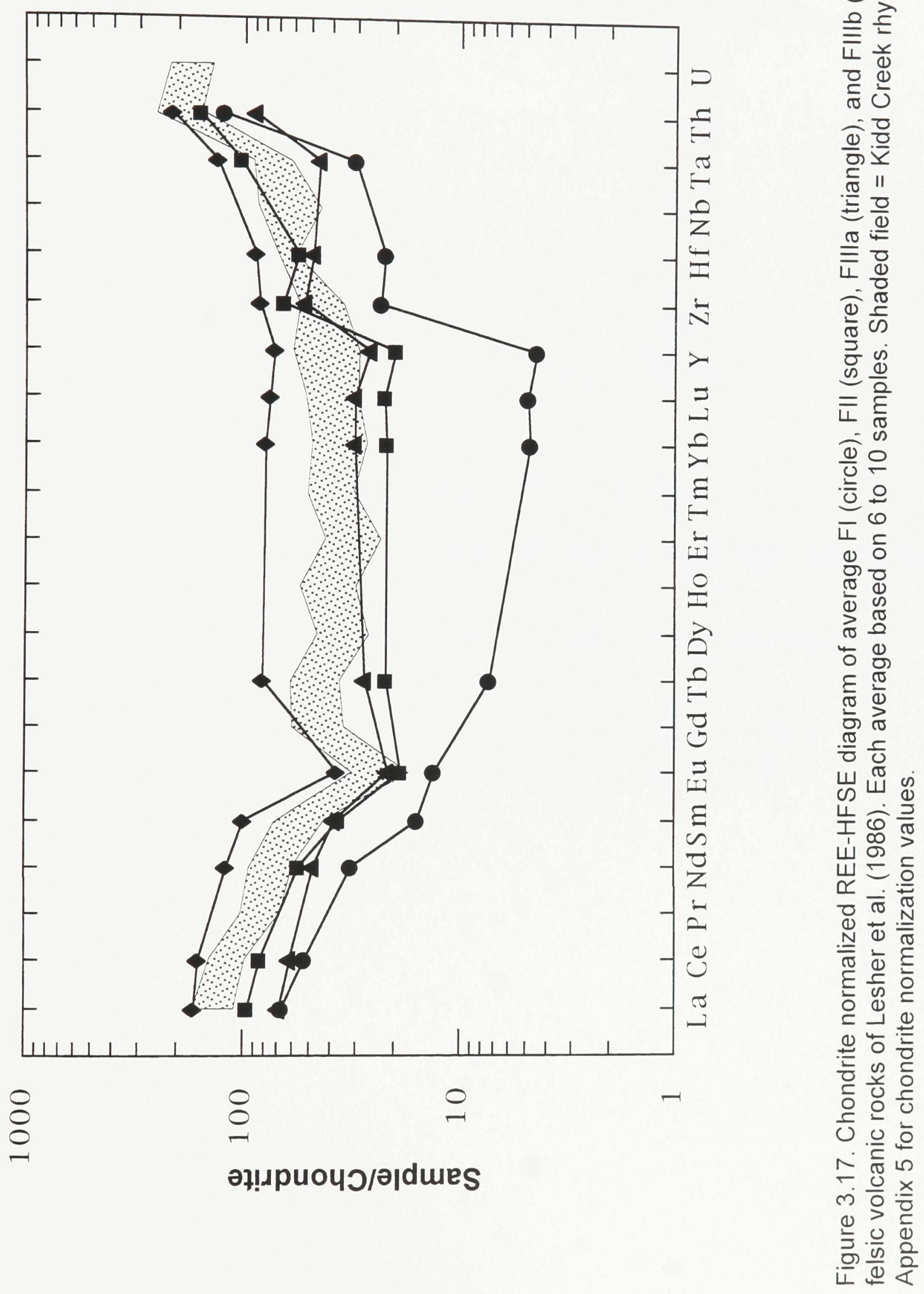




\begin{tabular}{cc}
\hline \hline Criteria & Least-Altered FW Rhyolites \\
\hline $\mathrm{Na}_{2} \mathrm{O}$ & $>2 \mathrm{wt} \%$ \\
Loss on Ignition (L.O.I.) & $<2.2 \mathrm{wt} \%$ \\
$\mathrm{CO}_{2}$ & $<1.8 \mathrm{wt} \%$ \\
$\mathrm{H}_{2} \mathrm{O}$ & $<1.1 \mathrm{wt} \%$ \\
$\mathrm{Cu}$ & $<11 \mathrm{ppm}$ \\
$\mathrm{Zn}$ & $<70 \mathrm{ppm}$ \\
Alumina Saturation Index & $<1.7$ \\
Ishikawa Index & $<0.6$ \\
Goodfellow Index & $<0.45$ \\
\hline \hline
\end{tabular}

Table 3.1. Criteria used to select least-altered FW rhyolites.

Alumina Index: $\mathrm{Al} /(2 \mathrm{Ca}+\mathrm{Na}+\mathrm{K})$, elements expressed as molecular proportions (Shand, 1951).

Ishikawa Index: $\left(\mathrm{K}_{2} \mathrm{O}+\mathrm{MgO}\right) /\left(\mathrm{K}_{2} \mathrm{O}+\mathrm{Na}_{2} \mathrm{O}+\mathrm{CaO}+\mathrm{MgO}\right)$, oxides expressed as wt.\% (Ishikawa et al., 1976).

Goodfellow Index: $(\mathrm{MgO}+\mathrm{FeO}) /\left(\mathrm{MgO}+\mathrm{FeO}+\mathrm{CaO}+\mathrm{Na}_{2} \mathrm{O}+\mathrm{K}_{2} \mathrm{O}\right)$, oxides expressed as wt.\% (Goodfellow, 1975; Riverin and Hodgson, 1980). 


\begin{tabular}{|c|c|c|c|c|c|c|c|}
\hline & & 14255 & 14256 & 14259 & 14263 & 14264 & 14265 \\
\hline $\mathrm{DDH}$ & & 3229 & 2622 & 2796 & 10 & 628 & 1100 \\
\hline Footage & & 1453 & 433 & 704 & 1738 & 832 & 465 \\
\hline $\mathrm{SiO}_{2}$ & wt. $\%$ & 79.1 & 80.2 & 79.6 & 81.2 & 80.9 & 82.8 \\
\hline $\mathrm{TiO}_{2}$ & wt. \% & 0.08 & 0.07 & 0.10 & 0.09 & 0.08 & 0.08 \\
\hline $\mathrm{Al}_{2} \mathrm{O}_{3}$ & wt. $\%$ & 11.10 & 11.10 & 10.70 & 9.10 & 9.65 & 9.57 \\
\hline $\mathrm{Fe}_{2} \mathrm{O}_{3}$ & wt. $\%$ & 0.99 & 0.09 & 0.83 & 0.34 & 0.52 & 0.04 \\
\hline $\mathrm{FeO}$ & wt. $\%$ & 0.30 & 0.20 & 1.40 & 0.90 & 1.00 & 0.20 \\
\hline $\mathrm{MnO}$ & wt. $\%$ & $<0.01$ & $<0.01$ & 0.02 & 0.07 & 0.08 & $<0.01$ \\
\hline $\mathrm{MgO}$ & wt. $\%$ & 0.92 & 0.32 & 0.36 & 0.05 & 0.10 & $<0.01$ \\
\hline $\mathrm{CaO}$ & wt. \% & 0.77 & 0.58 & 0.96 & 1.32 & 1.24 & 0.23 \\
\hline $\mathrm{Na}_{2} \mathrm{O}$ & wt. \% & 2.35 & 3.60 & 2.86 & 4.31 & 3.03 & 3.49 \\
\hline $\mathrm{K}_{2} \mathrm{O}$ & wt. $\%$ & 2.51 & 3.00 & 1.92 & 0.65 & 1.29 & 2.48 \\
\hline $\mathrm{P}_{2} \mathrm{O}_{5}$ & wt. $\%$ & $<0.01$ & $<0.01$ & $<0.01$ & $<0.01$ & $<0.01$ & $<0.01$ \\
\hline LOI & wt. \% & 1.80 & 0.75 & 1.10 & 1.90 & 2.10 & 0.60 \\
\hline Sum & wt. $\%$ & 100.0 & 99.9 & 100.0 & 100.0 & 100.1 & 99.5 \\
\hline $\mathrm{CO}_{2}$ & wt. \% & 0.53 & $<0.01$ & 0.38 & 1.57 & 1.70 & 0.16 \\
\hline $\mathrm{H}_{2} \mathrm{O}^{+}$ & wt. \% & 1.0 & 0.6 & 0.9 & 0.5 & 0.6 & 0.2 \\
\hline C & wt. \% & 0.21 & 0.22 & 0.28 & 0.64 & 0.60 & 0.12 \\
\hline$S$ & wt. \% & $<0.01$ & $<0.01$ & 0.03 & 0.04 & 0.05 & 0.02 \\
\hline $\mathrm{Li}$ & ppm & 7 & 15 & 7 & $<1$ & $<1$ & $<1$ \\
\hline $\mathrm{Be}$ & $\mathrm{ppm}$ & 2 & 2 & 1 & 1 & $<0.5$ & 2 \\
\hline $\mathrm{F}$ & ppm & $<20$ & $<20$ & $<20$ & $<20$ & $<20$ & $<20$ \\
\hline Sc & ppm & 1.6 & 1.1 & 1.8 & 0.8 & 1.0 & 1.6 \\
\hline $\mathrm{Cr}$ & ppm & 4 & 14 & 15 & 23 & 16 & 15 \\
\hline $\mathrm{Ni}$ & ppm & 8 & 1 & 3 & 2 & 2 & $<1$ \\
\hline $\mathrm{Cu}$ & ppm & 2.8 & 7.5 & 5.8 & 4.3 & 10.7 & 1.6 \\
\hline $\mathrm{Zn}$ & ppm & 21.6 & 16.4 & 67.8 & 37.1 & 56.3 & 42.8 \\
\hline Ga & ppm & 28 & 28 & 29 & 26 & 31 & 27 \\
\hline $\mathrm{Br}$ & ppm & 2.5 & 1.7 & 1.7 & 2.7 & 1.4 & 2.1 \\
\hline $\mathrm{Rb}$ & ppm & 43.0 & 46.0 & 63.0 & 20.0 & 36.0 & 53.0 \\
\hline $\mathrm{Sr}$ & ppm & 9.9 & 56.4 & 40.5 & 41.4 & 34.6 & 18.6 \\
\hline$Y$ & ppm & 110.0 & 117.0 & 96.0 & 89.0 & 102.0 & 82.0 \\
\hline $\mathrm{Zr}$ & ppm & 218.0 & 222.0 & 212.0 & 190.0 & 202.0 & 178.0 \\
\hline $\mathrm{Nb}$ & $\mathrm{ppm}$ & 26.0 & 27.0 & 22.0 & 22.0 & 24.0 & 19.0 \\
\hline Mo & ppm & $<1$ & $<1$ & $<1$ & $<1$ & $<1$ & 2 \\
\hline $\mathrm{Ag}$ & ppm & 0.4 & 0.4 & $<0.1$ & 0.3 & 0.4 & 0.6 \\
\hline $\mathrm{Sn}$ & ppm & 5 & 11 & $<5$ & $<5$ & 8 & 12 \\
\hline
\end{tabular}

Table 3.2. See following page for caption. 


\begin{tabular}{|c|c|c|c|c|c|c|c|}
\hline & & 14255 & 14256 & 14259 & 14263 & 14264 & 14265 \\
\hline $\mathrm{Cs}$ & $\mathrm{ppm}$ & 1.6 & 1.2 & 1.8 & 0.7 & 1.2 & 0.8 \\
\hline $\mathrm{Ba}$ & ppm & 1150 & 640 & 425 & 218 & 383 & 502 \\
\hline La & ppm & 46.7 & 53.0 & 51.0 & 42.9 & 47.0 & 42.9 \\
\hline $\mathrm{Ce}$ & ppm & 103.0 & 115.0 & 113.0 & 95.9 & 106.0 & 97.6 \\
\hline $\operatorname{Pr}$ & ppm & 11.0 & 12.5 & 12.3 & 10.4 & 11.7 & 11.0 \\
\hline $\mathrm{Nd}$ & $\mathrm{ppm}$ & 49.4 & 56.1 & 56.1 & 46.8 & 52.3 & 50.0 \\
\hline Sm & ppm & 12.60 & 13.80 & 13.40 & 11.30 & 13.50 & 12.20 \\
\hline Eu & $\mathrm{ppm}$ & 1.41 & 1.52 & 1.58 & 1.69 & 2.32 & 1.69 \\
\hline $\mathrm{Gd}$ & $\mathrm{ppm}$ & 14.0 & 15.4 & 14.0 & 12.3 & 14.9 & 12.6 \\
\hline $\mathrm{Tb}$ & $\mathrm{ppm}$ & 2.8 & 2.9 & 2.6 & 2.3 & 2.9 & 2.3 \\
\hline Dy & $\mathrm{ppm}$ & 14.7 & 14.6 & 13.0 & 11.1 & 14.9 & 11.3 \\
\hline $\mathrm{Ho}$ & $\mathrm{ppm}$ & 4.00 & 3.91 & 3.39 & 2.92 & 3.90 & 2.88 \\
\hline Er & ppm & 8.9 & 8.9 & 7.8 & 7.1 & 8.5 & 6.5 \\
\hline $\mathrm{Tm}$ & ppm & 1.7 & 1.7 & 1.5 & 1.4 & 1.6 & 1.3 \\
\hline$Y b$ & ppm & 10.3 & 10.1 & 9.4 & 8.3 & 9.6 & 7.8 \\
\hline Lu & ppm & 1.7 & 1.6 & 1.6 & 1.4 & 1.5 & 1.4 \\
\hline $\mathrm{Hf}$ & $\mathrm{ppm}$ & 9.5 & 9.1 & 8.8 & 8.7 & 8.9 & 7.9 \\
\hline $\mathrm{Ta}$ & ppm & 1.5 & 1.1 & 1.6 & 1.4 & 1.1 & 1.5 \\
\hline $\mathrm{Au}$ & $\mathrm{ppb}$ & $<2$ & $<2$ & $<2$ & $<2$ & $<2$ & $<2$ \\
\hline $\mathrm{Pb}$ & ppm & $<2$ & $<2$ & $<2$ & $<2$ & $<2$ & $<2$ \\
\hline Th & ppm & 7.5 & 7.3 & 6.7 & 5.8 & 6.6 & 6.8 \\
\hline U & $\mathrm{ppm}$ & 1.8 & 1.7 & 1.7 & 1.4 & 1.6 & 1.8 \\
\hline \multicolumn{2}{|c|}{ Goodfellow Index } & 0.27 & 0.08 & 0.30 & 0.17 & 0.22 & $\overline{0.04}$ \\
\hline \multicolumn{2}{|c|}{ Ishikawa Index } & 0.52 & 0.44 & 0.37 & 0.11 & 0.25 & 0.40 \\
\hline \multicolumn{2}{|c|}{ Alumina Index } & 1.63 & 1.30 & 1.47 & 1.05 & 1.30 & 1.32 \\
\hline \multicolumn{2}{|c|}{$\mathrm{La}_{\mathrm{N}} / \mathrm{Yb}_{\mathrm{N}}$} & 3.06 & 3.54 & 3.66 & 3.48 & 3.30 & 3.71 \\
\hline \multicolumn{2}{|c|}{$\mathrm{Eu} / \mathrm{Eu}^{*}$} & 0.32 & 0.32 & 0.35 & 0.44 & 0.50 & 0.41 \\
\hline
\end{tabular}

Table 3.2. Representative analyses of least-altered FW rhyolite samples from the Kidd Creek mine area. Alteration indexes defined in caption for Table 3.1; $\mathrm{DDH}=$ diamond drill hole; "N" denotes chondrite normalized value; $E u / E u^{*}=2\left(E u_{N}\right) /\left(\mathrm{Sm}_{N}+\mathrm{Gd}_{N}\right)$; see Appendix 5 for chondrite normalization values. 


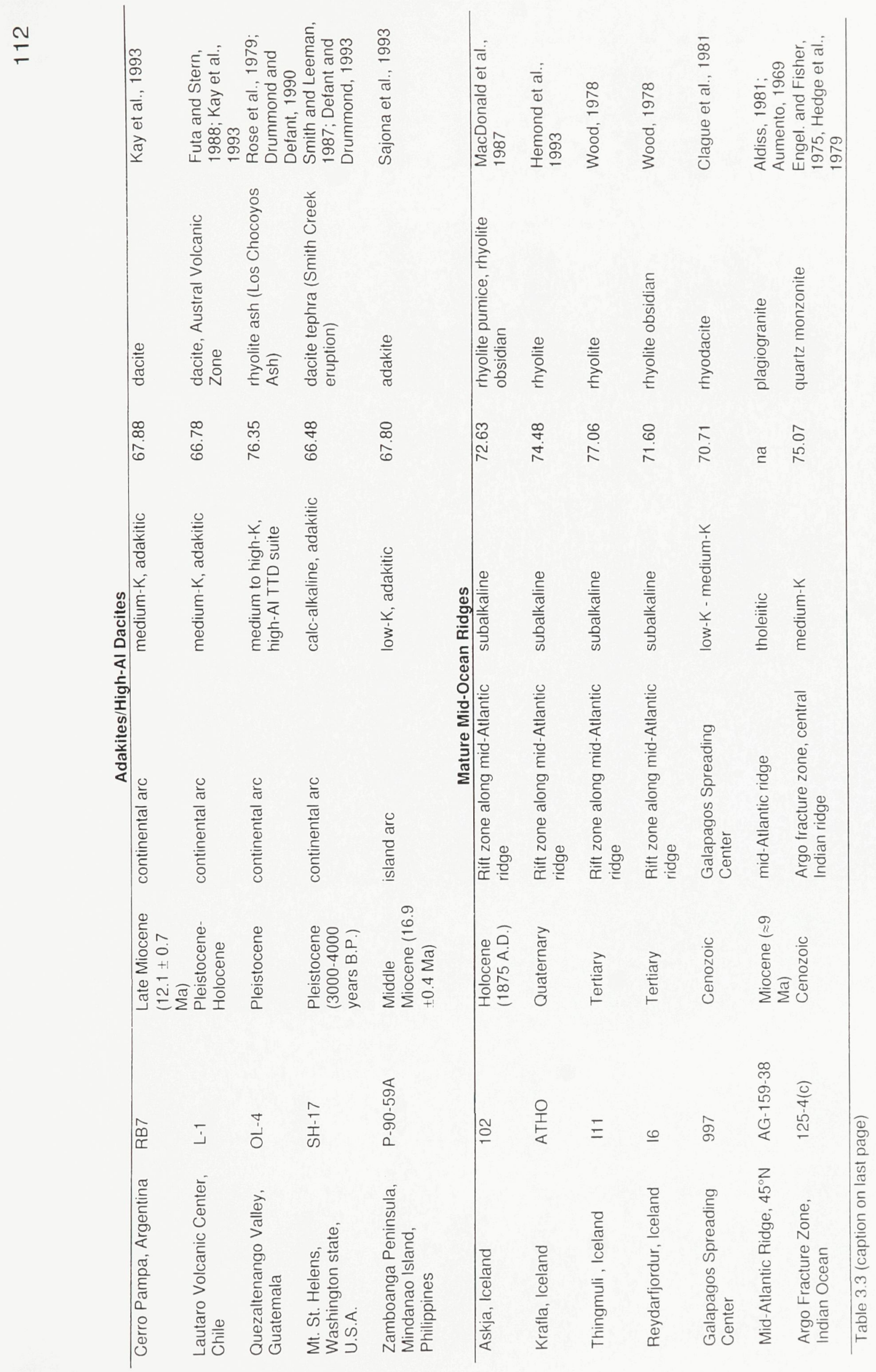




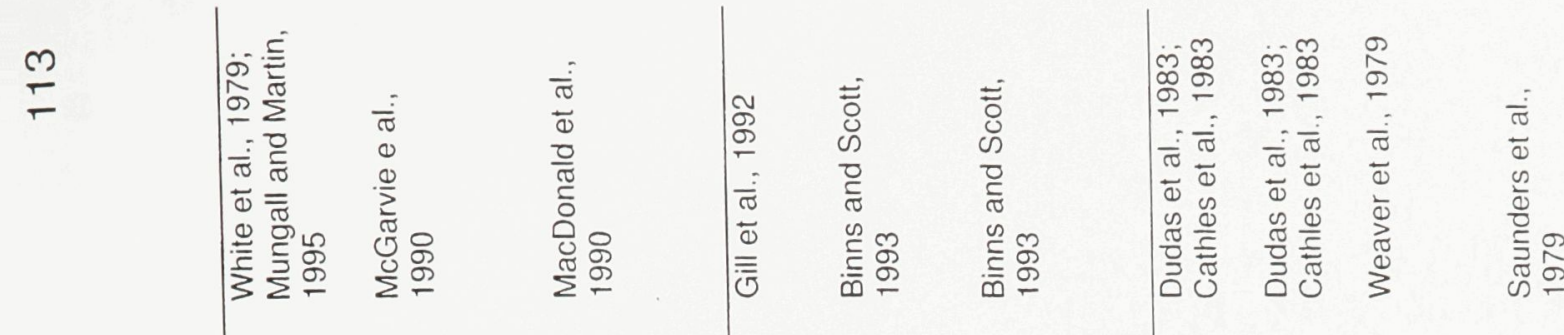

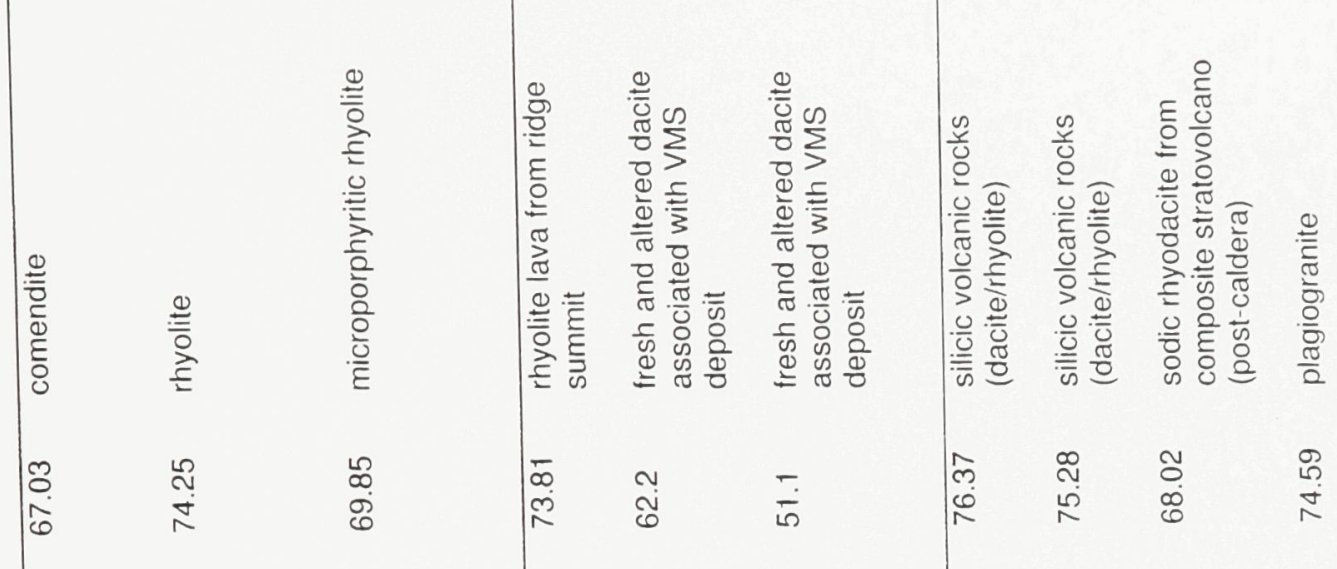<smiles></smiles>

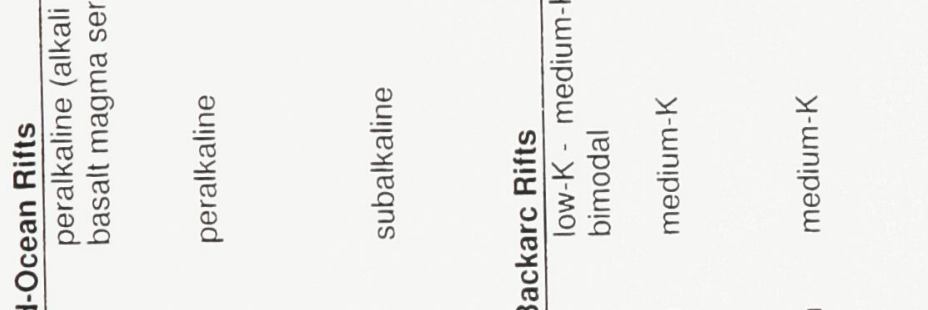

항 产器

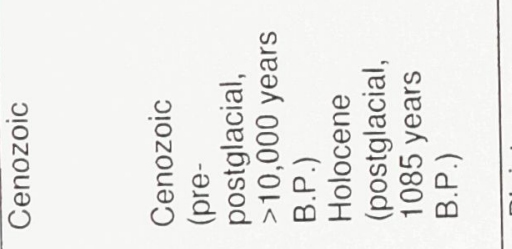

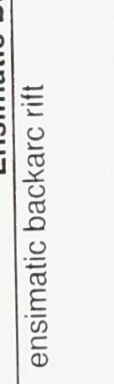

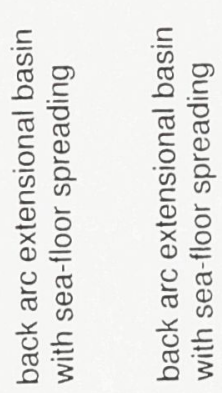

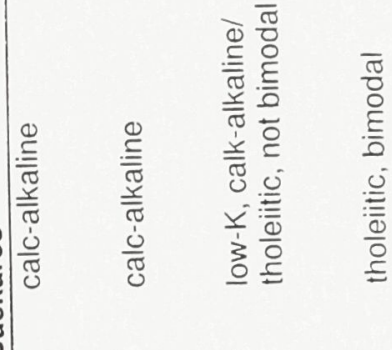

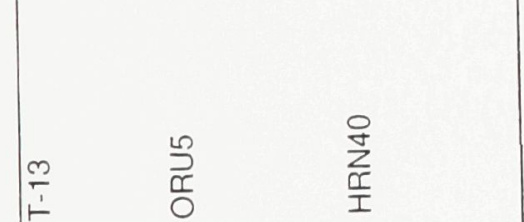

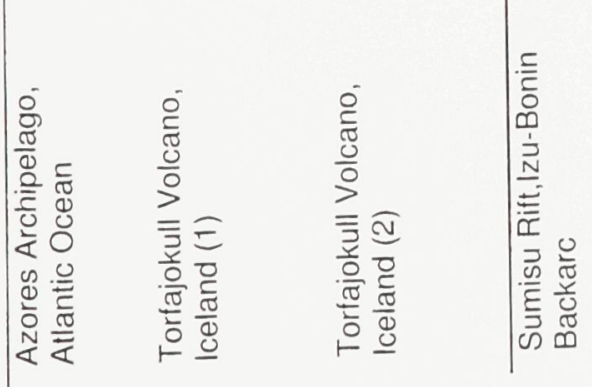

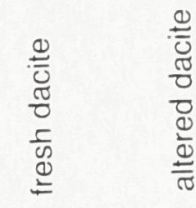

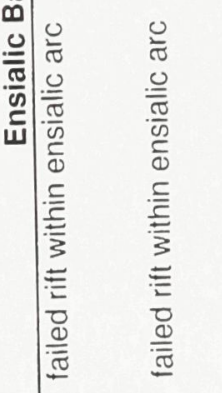

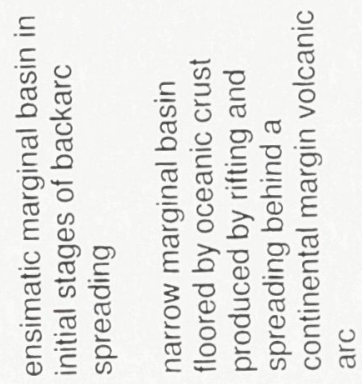

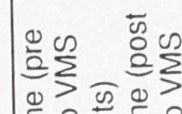
$\begin{array}{lll}0 & 0 \\ 0 & 0 \\ 0 & 0 \\ 0 & 0 \\ 0 & 0 \\ 0 & 0\end{array}$

$\frac{0}{5}$
$\frac{0}{0}$
$\frac{0}{3}$
$\frac{0}{5}$
$\frac{0}{5}$ 


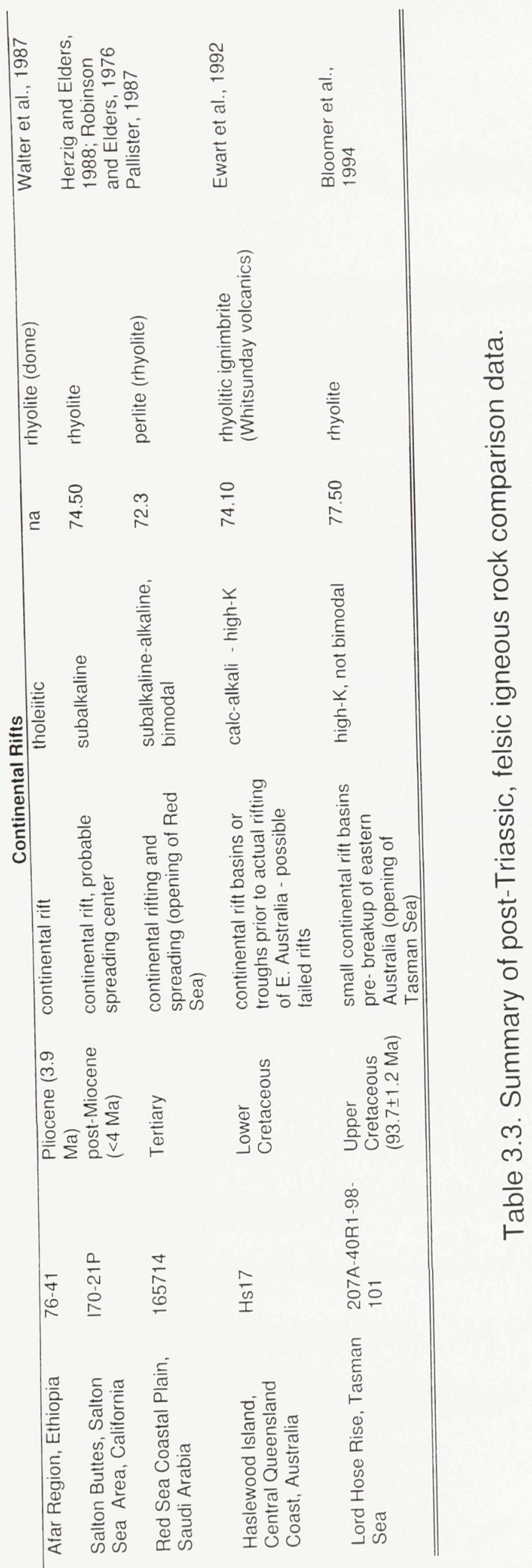




\title{
Chapter 4
}

\section{Sm-Nd ISOTOPIC STUDY OF RHYOLITES FROM THE LOWER AND UPPER MEMBERS OF THE KIDD CREEK FORMATION}

\author{
Introduction To Chapter 4
}

\section{Temporal and Tectonic Setting}

Bleeker and Parrish (1995) reported U-Pb zircon ages of $2714.1 \pm 1.5$ Ma for rhyolite near the base of the Kidd Creek formation (FW rhyolite) and $2710.5 \pm 1.1 \mathrm{Ma}$ for rhyolite near the top of the Kidd Creek formation (QP rhyolite) for an average age of felsic volcanism at Kidd Creek of approximately $2712 \mathrm{Ma}$. Previous U-Pb data on zircons from the footwall felsic sequence at Kidd Creek returned ages of $2717 \pm 4 \mathrm{Ma}$ and $2717 \pm 2 \mathrm{Ma}$ (Nunes and Pyke, 1982; Barrie and Davis, 1990). Maas et al. (1986) determined a Sm-Nd isochron of $2674 \pm 40$ Ma based on samples of altered rhyolitic rocks from the Kidd Creek footwall succession. Other dating techniques have produced younger dates which are not within error of the $\mathrm{U}-\mathrm{Pb}$ zircon ages; these may 
reflect post-depositional metamorphic/metasomatic events (Barrie et al., 1996).

Many recent investigators of the evolution of the Superior Province favor models in which the southern Superior Province, including the Abitibi greenstone belt, is formed of oceanic terranes which were accreted along what is presently the southern edge of a continental mass, part of which is preserved in the northern Superior Province (Percival et al., 1994; Williams et al., 1992). Within the western part of the southern Abitibi Greenstone Belt, preorogenic magmatism spans the time interval from 2750 to 2700 Ma with most magmatic activity, including the Kidd Creek volcanism, occurring between 2720 and $2700 \mathrm{Ma}$ (Corfu, 1993; Jackson and Fyon, 1991, Bleeker and Parrish, 1995). Most pre-tectonic rocks in the Abitibi Greenstone Belt have mantle-like $\mathrm{Nd}$ isotopic signatures and no evidence of zircon inheritance indicating little or no assimilation of older continental crust (Vervoort et al., 1994; Corfu, 1993).

\section{Questions regarding the Sm-Nd isotope systematics of the Kidd Creek rhyolites}

(i) What is the source of the Kidd Creek rhyolites? Rhyolites of the Kidd Creek formation (FW and QP rhyolites) may be related to mantle-derived mafic 
magmas through fractional crystallization or partial melting, or they may have been formed by partial melting of older crustal material (e.g. felsic granulites or continentally-derived greywackes). In the first case they will have mantle-like $\mathrm{Nd}$ isotopic values whereas in the second case their $\mathrm{Nd}$-isotopic ratios should reflect involvement of older crust.

(ii) Does the Nd isotopic composition of felsic magmas in the Kidd Creek area vary with stratigraphic position? Nd isotopic and geological stratigraphy for the Flin Flon and Snow Lake areas of Manitoba indicate that VMS deposits formed during or shortly after periods of isotopically primitive, mantle-derived felsic magmatism suggesting a relationship between VMS mineralization and the input of mantle-derived heat or fluids (Stern et al., 1992). Maas et al. (1986) presented $\mathrm{Nd}$ isotopic data for felsic volcanic rocks from the footwall of the Kidd Creek deposit but there are no previous $\mathrm{Nd}$ isotopic determinations on the hanging wall QP rhyolite.

(iii) Does strong hydrothermal alteration effect $\mathrm{Nd}$ isotopic ratios? The LREE have been depleted within the footwall stringer zone beneath the north and central orebodies of the Kidd Creek mine indicating water/rock ratios of approximately $10^{5}$ or greater (Campbell et al., 1984; Piepgras and Wasserburg, 1985; Michard and Albarede, 1986). At such high water/rock ratios the potential 
exists for the $\mathrm{Nd}$ isotopic composition of wallrocks to be significantly influenced by the hydrothermal fluids, and Kidd Creek rhyolite data reported by Maas et al. (1986) show a decrease in average $\varepsilon_{\mathrm{Nd}}$ values with increasing LREE depletion (Figure 4.1).

\section{Sample Distribution And Analytical Techniques}

$\mathrm{Sm}-\mathrm{Nd}$ isotopic analyses were determined in this study for 13 rhyolitic samples from the Kidd Creek Mine area (see Table 4.1 for sample descriptions, Table 4.2 for Sm-Nd isotopic analyses and Table 4.3 for major and trace element geochemistry).

\section{Samples}

Rhyolite samples from the Kidd Creek formation include 9 samples from the underground workings between the 1800 and 4700 levels (550 to $1430 \mathrm{~m}$ below surface) and 2 samples from the "east outcrop" located on the east rim of the open pit (Figure 4.2). These samples include coherent QP rhyolite from the Upper member, and samples of coherent rhyolite, rhyolite blocks (east outcrop samples), and autoclastic rhyolite breccia from the Lower 
member (FW rhyolite). Most of the samples have been subjected to only weak to moderate silicification, sericitization and/or chloritization. However, four strongly altered samples from the stringer zone beneath the north and central orebodies were also analyzed - two strongly silicified, autoclastic rhyolite breccias ("cherty breccias"), one chloritite and one sericitite. The chloritite and sericitite occur in seams up to $1 \mathrm{~m}$ wide cutting the silicified rhyolitic host rocks. In addition to the Kidd Creek Mine samples, Sm-Nd isotopic analyses were determined for two weakly to moderately altered rhyolites collected near the Chance Cu-Zn deposit in north-central Kidd Township approximately $2 \mathrm{~km}$ northwest of the Kidd Creek Mine (AJ00691 and AJ09313; sample locations shown by Barrie et al. ,1996). Nd concentrations in the 11 rhyolitic samples range from 14.36 to $83.61 \mathrm{ppm}$ with a median of $41.17 \mathrm{ppm}$ and $\mathrm{Sm}$ contents vary from 4.36 to $21.43 \mathrm{ppm}$ with a median of $9.83 \mathrm{ppm}$. The variations in $\mathrm{Nd}$ and Sm contents reflect (i) magmatic variability, (ii) LREE mobility, and/or (iii) apparent enrichment or depletion effects resulting from mass loss or mass gain, respectively. LREE-rich accessory minerals within the rhyolites, identified by S.E.M., include monazite, allanite, titanite, synchysite and bastnaesite. 


\section{Techniques}

Samples were ground in an agate mill at XRAL Laboratories, Toronto, Canada, prior to Sm-Nd isotopic analyses performed by Dr. Brian Cousens at Carleton University, Ottawa, Canada. Analyses were obtained for both wholerock samples and for residues remaining after acid leaching experiments. For whole-rock analyses approximately 100 milligrams of rock powder were spiked with a mixed ${ }^{148} \mathrm{Nd}^{149} \mathrm{Sm}$ spike, dissolved in $50 \% \mathrm{HF}-12 \mathrm{~N} \mathrm{HNO}_{3}$, then attacked with $8 \mathrm{~N} \mathrm{HNO}_{3}$ and finally $6 \mathrm{~N} \mathrm{HCl}$. The sample was then taken to dryness and the residue was taken up in $2.5 \mathrm{~N} \mathrm{HCl}$ and passed through a chromatographic column containing Dowex AG50-X8 cation resin to separate the rare earth elements from major elements and Sr. The rare earth element residues were dissolved in $0.26 \mathrm{~N} \mathrm{HCl}$ and loaded into a $10 \mathrm{ml}$ glass chromatographic column containing a $2 \mathrm{~cm}$ high bed of Teflon powder coated with HDEHP [di (2ethylhexyl) orthophosphoric acid (Richard et al., 1976)]. Nd was eluted using $0.26 \mathrm{~N} \mathrm{HCl}$, followed by $\mathrm{Sm}$ in $0.5 \mathrm{~N} \mathrm{HCl}$. Total procedural blanks for $\mathrm{Nd}$ were < 75 picograms. Concentrations are precise to $\pm 1 \%$. A second split of rhyolite powder was subjected to a two-stage acid leaching process prior to dissolution. Powders were leached in $8 \mathrm{~N} \mathrm{HNO}_{3}$ at room temperature for 3 hours, rinsed with $\mathrm{H}_{2} \mathrm{O}$, then leached for 3 hours in hot $\left(120-150^{\circ} \mathrm{C}\right) 2 \mathrm{~N} \mathrm{HCl}$, 
and rinsed again with $\mathrm{H}_{2} \mathrm{O}$. The residues were spiked and processed in the same way as the unleached whole-rock powders.

Samples were loaded with $0.25 \mathrm{~N} \mathrm{HCl}$ on one side of a Re double filament and run at temperatures of $1780-1820^{\circ} \mathrm{C}$ on a Finnigan MAT 261 mass spectrometer operating in static mode. Isotope ratios were normalized to ${ }^{146} \mathrm{Nd} /{ }^{144} \mathrm{Nd}=0.72190 .{ }^{147} \mathrm{Sm} / /^{144} \mathrm{Nd}$ ratios are reproducible to $\pm 1.0 \%(2 \sigma)$ and ${ }^{143} \mathrm{Nd} /{ }^{144} \mathrm{Nd}$ ratios are reproducible to $\pm 0.000020(2 \sigma)$. These analytical errors correspond to approximately $\pm 0.5 \varepsilon_{\mathrm{Nd}}$ units. Analyses of the USGS standard $\mathrm{BCR}-1$ yield $\mathrm{Nd}=29.02 \mathrm{ppm}, \mathrm{Sm}=6.68 \mathrm{ppm}$ and ${ }^{143} \mathrm{Nd} / /^{144} \mathrm{Nd}=0.512668 \pm$ $0.000020(n=4)$. The average of twenty-three determinations of the La Jolla standard (Sept. 1992 - Sept. 1994) is ${ }^{143} \mathrm{Nd} / /^{144} \mathrm{Nd}=0.511874 \pm 0.000019(2 \sigma)$. Analytical techniques for major and trace element whole-rocks analyses, performed by XRAL Laboratories, Toronto, Canada, are described in Appendix 3. LREE-rich minerals in the rhyolites were identified using a JEOL 6400 scanning electron microscope interfaced to a LINK Systems eXL LZ4 x-ray analyzer. 


\section{Sm-Nd Whole-Rock Isotope Systematics}

\section{Sm-Nd Regression Ages}

$\mathrm{Nd}$ isotopic results for the 13 Kidd Creek whole-rock rhyolite samples are shown on a ${ }^{147} \mathrm{Sm} /{ }^{144} \mathrm{Nd}$ versus ${ }^{143} \mathrm{Nd} /{ }^{144} \mathrm{Nd}$ diagram in Figure 4.3. Two intensely chloritized and sericitized samples from the footwall of the central orebody, considered in detail in a subsequent section, plot well below the average trend and are not included in regression age calculations. A wholerock regression age obtained using the 11 remaining rhyolite samples yields an age of $2733 \pm 260 \mathrm{Ma}$ (2 sigma errors), an initial ${ }^{143} \mathrm{Nd} /{ }^{144} \mathrm{Nd}$ ratio of 0.509221 and an M.S.W.D. value of 6.72 (regression lines and M.S.W.D. values calculated by the computer program Isoplot (version 2.82) using Yorkfit model 1 (Ludwig, 1995; York, 1969). The high M.S.W.D. value reflects the fact that three of the samples, 18-14046, 18-14051R and EO-92-9B, are not within error of the regression line. Recalculation without these three samples generates a whole-rock isochron of $2747 \pm 95 \mathrm{Ma}$, an initial ${ }^{143} \mathrm{Nd} /{ }^{144} \mathrm{Nd}$ ratio of 0.509206 and an M.S.W.D. value of 1.57 . The similarity in ages and the initial ${ }^{143} \mathrm{Nd} /{ }^{144} \mathrm{Nd}$ ratios indicates that the outlying samples do not significantly lever the regression line when included in the calculation. However, there is no a priori reason for omitting samples $18-14046,18-14051 \mathrm{R}$ and EO-92-9B from the 
calculations. The $\mathrm{Sm}-\mathrm{Nd}$ isotopic age estimates obtained from the rhyolite samples are within error of the U-Pb zircon ages of $2714.1 \pm 1.5 \mathrm{Ma}$ for the footwall (FW) rhyolites and $2710.5 \pm 1.1$ Ma for the hanging wall $(Q P)$ rhyolites of Bleeker and Parrish (1995) and are similar to Sm-Nd age estimates for less altered basaltic, gabbroic and komatiitic samples reported by Barrie et al. (1996).

A previous Sm-Nd isotopic study of Kidd Creek rocks by Maas et al. (1986) reported analyses for 4 samples of weakly altered felsic volcanic rocks, 10 samples of strongly altered felsic volcanic rocks from the footwall stringer zone and 2 analyses of massive, stratiform Cu-rich ore. Using the altered felsic volcanic rock and massive sulfide data, Maas et al. (1986) determined a Sm$\mathrm{Nd}$ isochron of $2674 \pm 40 \mathrm{Ma}$. The weakly altered felsic volcanic rock data have a restricted range of intermediate $147 \mathrm{Sm} /{ }^{144} \mathrm{Nd}$ ratios relative to the range of the isochron and do not significantly affect the age (Maas et al., 1986).

\section{Initial $\varepsilon_{N d}$ Characteristics}

Initial $\varepsilon_{\mathrm{Nd}}$ values, calculated for an age of $2712 \mathrm{Ma}$ (the average rhyolite U-Pb zircon age of Bleeker and Parrish, 1995), are presented in Table 4.2. Excluding the footwall chloritite and sericitite samples $\varepsilon_{\mathrm{Nd}}$ values for the 
rhyolite samples of this study range from +1.4 to +4.2 . These values are similar to those obtained by Barrie et al. (1996) for less altered basalt and gabbro samples from the Kidd Creek hanging wall and for komatiite samples from the Kidd Creek footwall. The $\varepsilon_{\mathrm{Nd}}$ values for the rhyolitic footwall samples of Maas et al. (1986), recalculated for $\mathrm{T}=2712 \mathrm{Ma}$ and a present day chondritic ${ }^{143} \mathrm{Nd} / /^{144} \mathrm{Nd}$ ratio of 0.7219 for consistency with data presented in this study, range from +0.2 to +2.3 .

\section{Geochemistry of Phyllosilicate-Dominated Footwall Samples}

Two samples of intensely altered rocks from the footwall of the central orebody on 4700 Level, a chloritite (sample 14267) and a sericitite (sample 14287), have anomalous $\varepsilon_{\mathrm{Nd}}(\mathrm{T})$ values of -3.6 and -5.1 respectively (Table 4.2). These samples are from irregular, discontinuous, Fe-chlorite-dominated lenses up to 1 meter wide associated with chalcopyrite stringers located stratigraphically below the economic chalcopyrite stringer zone. The chloritite and sericitite are identified as being the alteration products of rhyolitic protoliths as (i) they occur as alteration zones within rhyolitic assemblages, and (ii) they have ratios between relatively immobile incompatible $(\mathrm{Zr})$ and compatible ( $\mathrm{Ti}$ ) elements nearly identical to those of less altered FW rhyolites despite 
extensive metasomatism accompanied by mass loss (MacLean, 1990; Figure 4.4). In a $\left(\mathrm{Na}_{2} \mathrm{O}+\mathrm{CaO}\right)-\mathrm{K}_{2} \mathrm{O}-(\mathrm{FeO}+\mathrm{MgO})$ diagram these samples plot along the $\mathrm{K}_{2} \mathrm{O}-(\mathrm{FeO}-\mathrm{MgO})$ join indicating total loss of (normative) plagioclase - the sericitite plots mid-way along the $\mathrm{K}_{2} \mathrm{O}-(\mathrm{FeO}+\mathrm{MgO})$ side whereas the chlorite plots at the $(\mathrm{FeO}+\mathrm{MgO})$ apex (Figure 4.5). The Fe/Mg cation ratio in the chloritite sample is 1.8. In a $\mathrm{SiO}_{2}$ versus $\mathrm{Al}_{2} \mathrm{O}_{3}$ diagram the chloritite plots within a field defined by 29 analyses of chlorites from Abitibi VMS deposits which, combined with the data outlined above, indicates that the rock is composed almost entirely of Fe-chlorite (Figure 4.6). In the same diagram the sericitite plots near a field defined by 14 analyses of sericites from Abitibi VMS deposits along a tieline between sericite compositions and least-altered FW rhyolites. Other geochemical features of note are high water contents (3.3 wt.\% - sericitite, 10.6 wt. \% - chloritite), high Cu (783 ppm - sericitite, 429 ppm - chloritite), elevated Zn in the chloritite (499 ppm), and anomalous $\mathrm{F}$ and $\mathrm{Sn}$ values in the sericitite (1430 ppm F, 71 ppm Sn). A chondrite-normalized REE plot demonstrates that the chloritite and sericitite samples have undergone extensive LREE depletion relative to less altered FW rhyolites (Figure 4.7). However, LREE depletion may also occur without anomalous $\mathrm{Nd}$ isotopic values as demonstrated by the samples of rhyolite breccia (14242 and 14281) which have also undergone strong LREE depletion but which maintain $\varepsilon_{\mathrm{Nd}}$ values similar to less altered rhyolites $\left(\varepsilon_{\mathrm{Nd}}\right.$ of +3.2 and +2.6 respectively). 
A relationship between increasing intensity of alteration, indicated by LREE depletion, and decreasing average $\varepsilon_{\mathrm{Nd}}$ values is suggested by the data of Maas et al. (1986) for rhyolitic samples from the Kidd Creek footwall (Figure 4.1). A highly altered rhyolite with an anomalously low $\varepsilon_{\mathrm{Nd}}$ value (-1.9 compared to average $\varepsilon_{\mathrm{Nd}}$ values of +3.2 ) and strong LREE depletion has also been reported from VMS footwall rocks in the Matagami district of Quebec (porphyritic metarhyolite of the Watson Lake Group; Vervoort et al., 1994).

\section{Acid Leaching Results}

Nine of the less altered rhyolite samples were subjected to an acid leach procedure to remove the more labile components (described in analytical techniques section) and the residues were analyzed for their $\mathrm{Sm}-\mathrm{Nd}$ isotopic composition. In each case the residue had a lower $\mathrm{Nd}$ and $\mathrm{Sm}$ content than the whole-rock sample implying that a significant proportion of the LREE reside in labile components (Table 4.2). In 4 cases the residues have $\mathrm{Sm}-\mathrm{Nd}$ isotopic values which plot well below the $2733 \mathrm{Ma}$ regression line and have ${ }^{147} \mathrm{Sm} /{ }^{144} \mathrm{Nd}$ ratios which are significantly higher than the corresponding whole-

rock samples indicating LREE depletion in the residues (Figure 4.8). Two point 
regression ages calculated for these whole-rock - residue pairs returned values of $2182 \pm 59 \mathrm{Ma}, 1980 \pm 89 \mathrm{Ma}$ and $896 \pm 110 \mathrm{Ma}$ for samples $\mathrm{KC}-102 \mathrm{~A}$, AJ00691, 18-14046 and AJ09313 respectively whereas a zero age (-41 Ma \pm $280 \mathrm{Ma}$ ) was obtained using the whole-rock and residue analyses of sample AJ09313. These ages clearly do not correspond to late Archean magmatic or tectonic events and indicate that the $\mathrm{Nd}$ isotopic systems in these samples have not remained closed. It is interesting to note that (i) the residue data shown in Figure 4.8 are all displaced from the 2733 Ma regression line by approximately the same amount, and (ii) the sericitite and chloritite whole-rock analyses exhibit a similar displacement (Figure 4.3). Further work is required to determine the significance of these relationships.

\section{Evolution of the Kidd Creek Formation in Light of Nd Isotopic Results}

A plot of $\varepsilon_{\mathrm{Nd}}$ versus rock type, with data arranged in approximate stratigraphic sequence, is shown In Figure 4.9 for the Kidd Creek formation (data from this study and Maas et al., 1986). With the exception of the chloritite and sericitite samples, $\varepsilon_{\mathrm{Nd}}$ values range between 0.0 and +4.2 with most values between +1.0 and +3.0 ; there is no discernible relationship between $\varepsilon_{\mathrm{Nd}}$ values and stratigraphic position. These values are similar to data for 
komatiites in the stratigraphic footwall to the Kidd Creek formation and less altered basalts and gabbros in the hanging wall to the Kidd Creek formation (Barrie et al., 1996) and indicate that the $\mathrm{Nd}$ isotopic composition of magmas in the Kidd Creek area did not change significantly over time. These results contrast with data for the Flin Flon and Snow Lake areas of Manitoba where considerable stratigraphic $\mathrm{Nd}$ isotopic variability exists and VMS deposits are associated with episodes of "mantle-derived felsic magmatism" (Stern et al., 1992, p. 82).

In the southern Superior Province at $2695 \pm 10$ Ma there was a shift in magma compositions from predominantly isotopically primitive, incompatible element depleted tholeiitic-komatiitic melts to predominantly incompatible element enriched alkalic melts (Barrie and Shirey, 1989). Figure 4.10 displays $\varepsilon_{\mathrm{Nd}}(\mathrm{T})$ data for several pre-2695 Ma suites of southern Superior Province igneous rocks and mineral separates, described in the appendix 6 , along with the Kidd Creek rhyolite data (this study), the depleted mantle trend of Stern et al. (1994) and a continental crustal trend based upon samples of Australian shale (Allegre and Rousseau, 1984). Note the similarity of the Kidd Creek rhyolite $\varepsilon_{\mathrm{Nd}}(T)$ values (excluding the chloritite and sericitite samples) to other analyses from the southern Superior Province and that all data (excluding highly altered samples) are close to the depleted mantle curve. These results 
are compatible with (i) the derivation of the Kidd Creek volcanic succession from the mantle or by melting of young (relative to the Kidd Creek rocks), mantle-derived crust with no input of continental material, and (ii) the suggestion that central volcanoes within the axial rift zones of Iceland provide an appropriate modern analogue for the Kidd Creek volcanic succession (Chapter 3 and references therein).

\section{Nd Isotopic Shift in Altered Rhyolites}

Three lines of evidence indicate that the $\mathrm{Nd}$ isotopic systems in some Kidd Creek rhyolite samples do not reflect magmatic values: (i) anomalously low ${ }^{143} \mathrm{Nd} /{ }^{144} \mathrm{Nd}$ ratios in chalcopyrite-stringer associated chloritite and sericitite samples from the footwall of the central orebody $\left(\varepsilon_{\mathrm{Nd}}(2712 \mathrm{Ma})=-3.6\right.$ and 5.1), (ii) anomalously low ${ }^{143} \mathrm{Nd} /{ }^{144} \mathrm{Nd}$ ratios in acid leach residues of samples $\mathrm{KC}-102 \mathrm{~A}, 18-14046, \mathrm{AJ}-00691$ and $\mathrm{AJ} 09313\left(\varepsilon_{\mathrm{Nd}}(2712 \mathrm{Ma})=-3.3\right.$ to -6.0$)$, and (iii) the trend of decreasing $\varepsilon_{\mathrm{Nd}}(2712 \mathrm{Ma})$ values with increasing LREE depletion noted in the Maas et al. (1986) data. The data suggest that the negative $\varepsilon_{\mathrm{Nd}}(T)$ signatures are related to hydrothermal alteration within the rhyolites and that the timing of the isotopic shifts is either syn-ore or post-ore. 


\section{Syn-ore model}

Preferential leaching of ${ }^{143} \mathrm{Nd}$ relative to ${ }^{144} \mathrm{Nd}$ during hydrothermal alteration is not a viable hypothesis because their relative mass differences are too small to allow physical separation of the isotopes (Rollinson, 1993; Poitrasson et al., 1995). Therefore, if the isotopic shifts occurred during ore formation they must reflect high water/rock ratios and a negative $\varepsilon_{\mathrm{Nd}}(T)$ signature in the hydrothermal fluids. This signature may have reflected the $\mathrm{Nd}$ isotopic composition of overlying seawater, or wallrocks within the flow path of the hydrothermal fluids.

Water Rock Ratios: The Nd content of hydrothermal fluids that formed the Kidd Creek deposit would have been derived from seawater modified by interaction with wallrocks. Measured Nd concentrations in modern seafloor hydrothermal vents range from $20 \times 10^{-6} \mathrm{ppm}$ to $2100 \times 10^{-6} \mathrm{ppm}$ compared to present day seawater values of approximately $2.5 \times 10^{-6}$ and possible Archean seawater values of about $30 \times 10^{-6} \mathrm{ppm} \quad$ (Piepgras and Wasserburg, 1980; Michard et al., 1983; Piepgras and Wasserburg, 1985; Michard and Albarede, 1986; Hinkley and Tatsumoto, 1987; Campbell et al., 1988; Jacobsen and Pimentel-Klose, 1988). Therefore, the observed isotopic shift in the chloritite and sericitite would have required minimum water/rock ratios of approximately 
$10^{3}$ to $10^{5}$ or greater (Faure, 1986; Valsami-Jones and Cann, 1994). LREE depletion within chloritite, sericitite and siliceous rhyolite breccia in the footwall of the north and central orebodies indicate water/rock ratios of approximately $10^{5}$ or greater (Figure 4.7; Piepgras and Wasserburg, 1985; Michard and Albarede, 1986). Nd isotopic exchange during hydrothermal alteration in various geological settings has been documented by German et al. (1995), Schade et al. (1989), Tourpin et al. (1991), Valbracht (1992), Valsami-Jones and Cann (1994), Cliff and Rickard (1992), and Poitrasson et al. (1995).

Seawater Nd signature: In order for seawater to have been the source of the isotopic shifts noted in some samples, the $\varepsilon_{\mathrm{Nd}}(T)$ value of seawater above the Kidd Creek rhyolites would have had to have been -5 or less. The $\varepsilon_{N d}(T)$ values of Archean banded iron formations, which are probably representative of $\mathrm{Nd}$ isotopic compositions in Archean seawater, commonly vary from -1 to +4 but values of less than -5 have been reported (Jacobsen and Pimentel-Klose, 1988a; Jacobsen and Pimentel-Klose, 1988b; Shimizu et al., 1990; Miller and O'Nions, 1985). These values suggest that seawater with negative $\varepsilon_{\mathrm{Nd}}(\mathrm{T})$ values would have been restricted to environments near continental margins. However, such an environment is incompatible with the oceanic character of the pre-tectonic southern Superior Province making this model for the $\varepsilon_{\mathrm{Nd}}$ shifts unlikely. 
Wallrock Nd signature: The $\mathrm{Nd}$ isotopic composition of seawater drawn downward into deep, high temperature convection systems is generally overwhelmed by Nd derived by leaching of LREE from the wallrocks (Piepgras and Wasserburg, 1985; Michard and Albarede, 1986; Hinkley and Tatsumoto, 1987; Valsami-Jones and Cann, 1994). Therefore, the presence of continentally derived material within the succession below Kidd Creek such as turbidite or pyroclastic air fall deposits could explain the $\varepsilon_{\mathrm{Nd}}$ shift in highly altered rocks but no such rock type is known to occur beneath the Kidd Creek deposit. For this model to apply the source of the negative $\varepsilon_{\mathrm{Nd}}$ signature is either buried well beneath the Kidd Creek formation or has been removed from the Kidd Creek area by tectonic means (e.g. accretion of volcanic edifice coupled with subduction of greywacke-bearing substrate - see arc-trench propagation model advocated by Hoffman (1991) for greenstone belt accretion).

\section{Post-ore model}

The model favored by the author is that the negative $\varepsilon_{N d}$ value reflect a disturbance in the isotopic system by metamorphic and/or metasomatic activity which post-dates deposition of the Kidd Creek ores. Resetting of the Sm-Nd 
isotopic system followed by preferential leaching of $\mathrm{Sm}$ relative to $\mathrm{Nd}$ may account for the observed isotopic shifts in the chloritite and sericitite samples. That these shifts occur in intensely altered rocks could reflect preferential migration of late fluids through the permeable, phyllosilicate-rich zones and/or the relative stability with respect to post-ore events of REE-bearing hydrothermal alteration assemblages formed during the Kidd Creek mineralization event. Acid leaching experiments on less altered rhyolites indicate that a significant proportion of the LREE reside in labile minerals (Table 4.2). Post-ore mobility of LREE at Kidd Creek is demonstrated by the occurrence of hydrothermal monazite from the Kidd Creek mine with a U-Pb age of $2659 \pm 3 \mathrm{Ma}$ (Schandl and Gorton, 1991; Davis et al., 1994). 


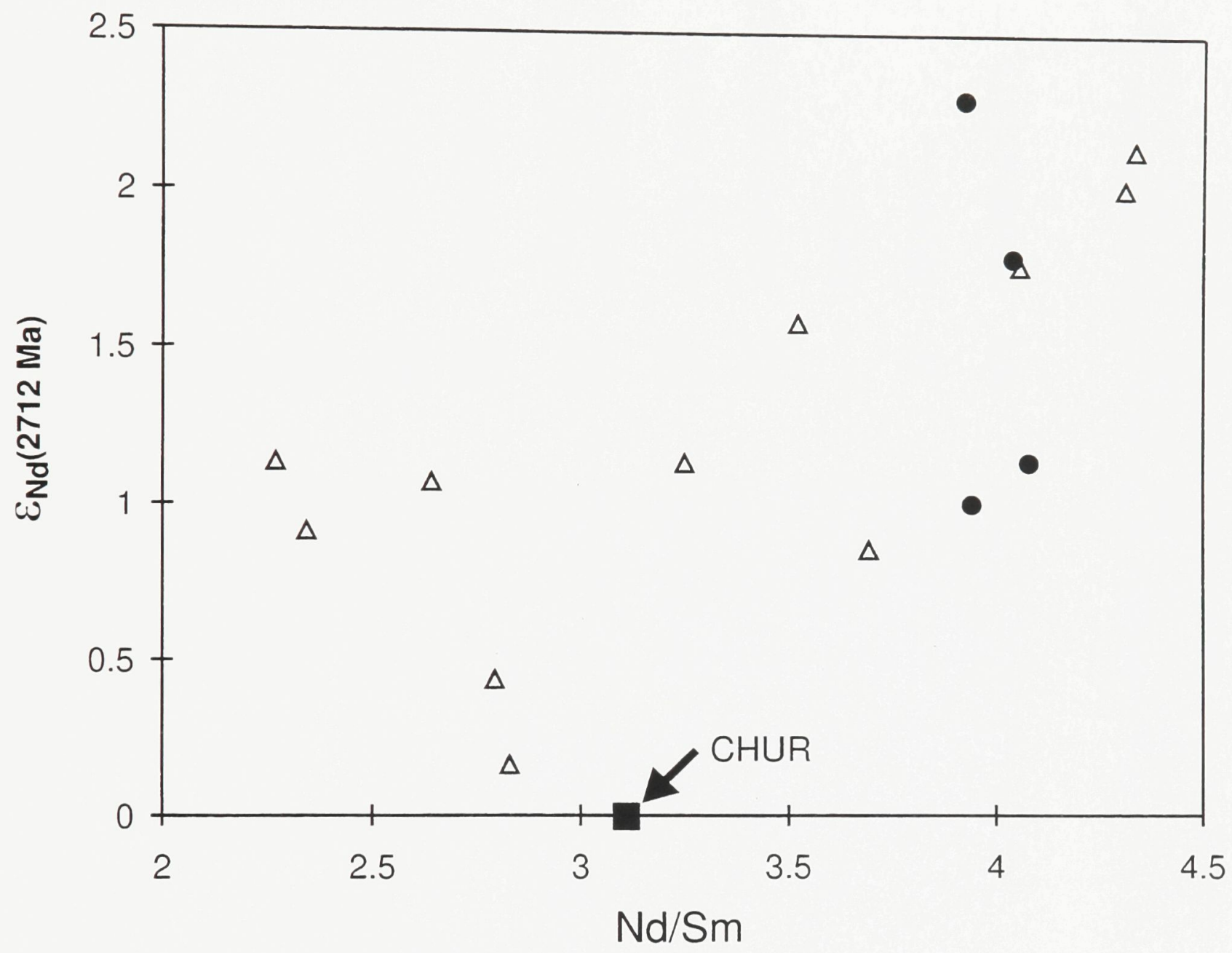

Figure 4.1. $\mathrm{Nd} / \mathrm{Sm}$ versus $\varepsilon_{\mathrm{Nd}}(2712 \mathrm{Ma})$ diagram showing Kidd Creek data of Maas et al. (1986). Filled circles = weakly altered felsic volcanic rocks, open triangles = altered felsic volcanic rocks, CHUR = chondritic uniform reservoir . 
$\stackrel{\varrho}{\varrho}$

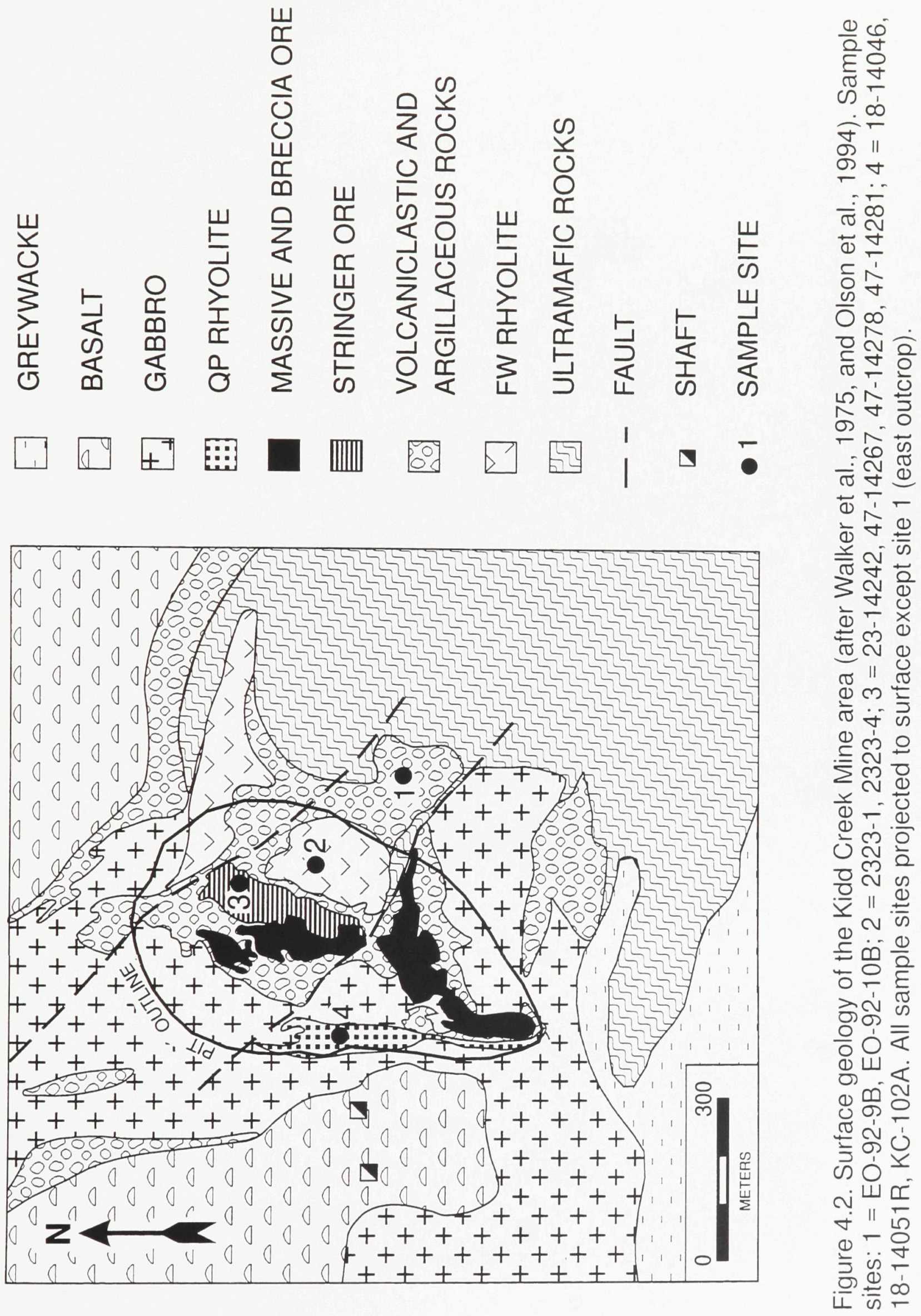




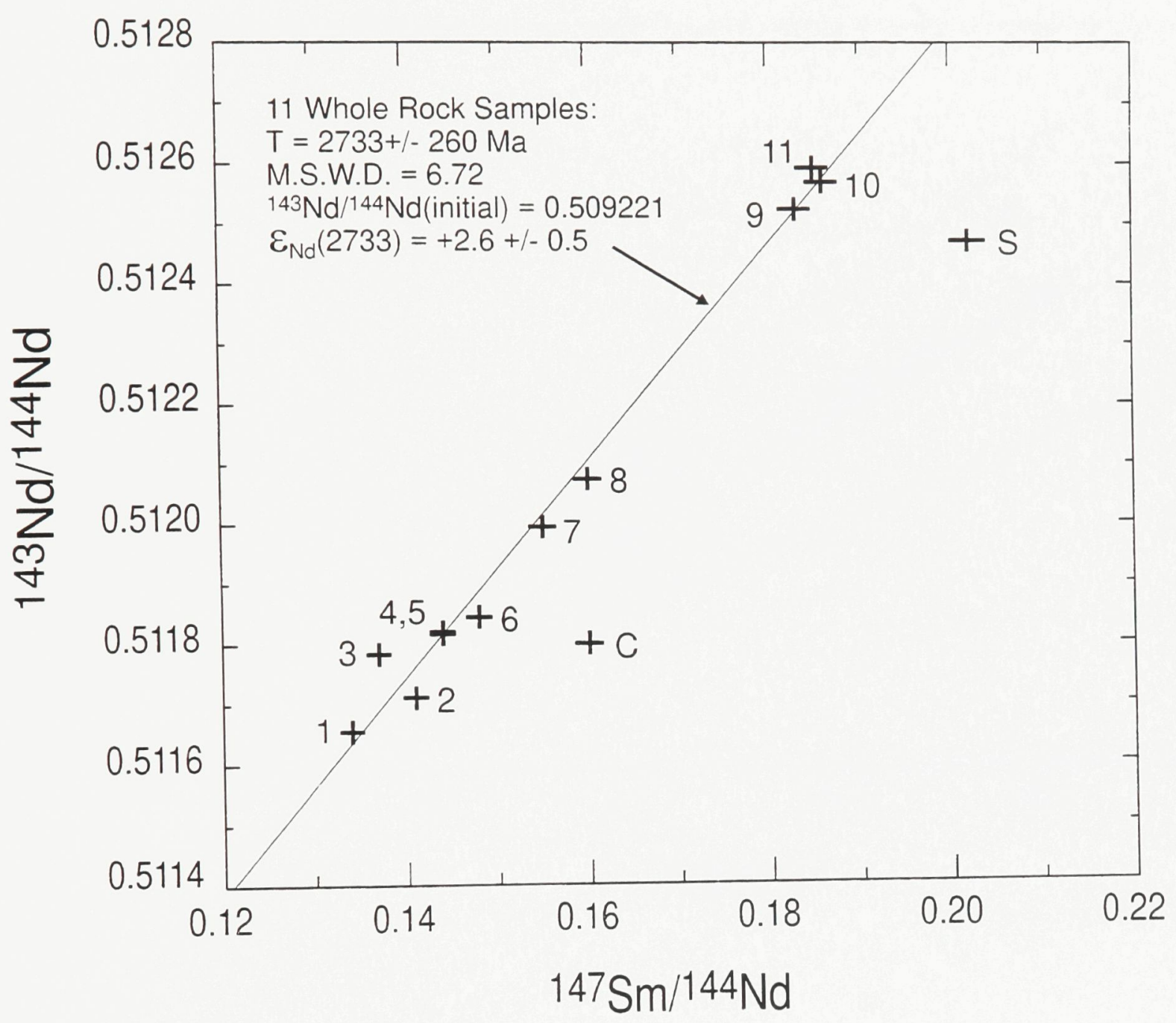

Figure 4.3. ${ }^{147} \mathrm{Sm} /{ }^{144} \mathrm{Nd}$ versus $143 \mathrm{Nd} /{ }^{144} \mathrm{Nd}$ diagram showing Kidd Creek rhyolitic whole rock data (crosses): $1=\mathrm{KC}-102 \mathrm{~A}, 2=18-14046,3=$ 18-14051R, $4=2323-4,5=\mathrm{EO}-92-10 \mathrm{~B}, 6=\mathrm{EO}-92-9 \mathrm{~B}, 7=\mathrm{AJ} 09313,8=$ 2323-1, $9=47-14281,10=23-14242,11=$ AJ00691, $C=47-14267, \mathrm{~S}=$ 47-14278. Size of cross represents analytical error (2s). Regression line calculated excluding chloritite (C) and sericitite (S) samples. 


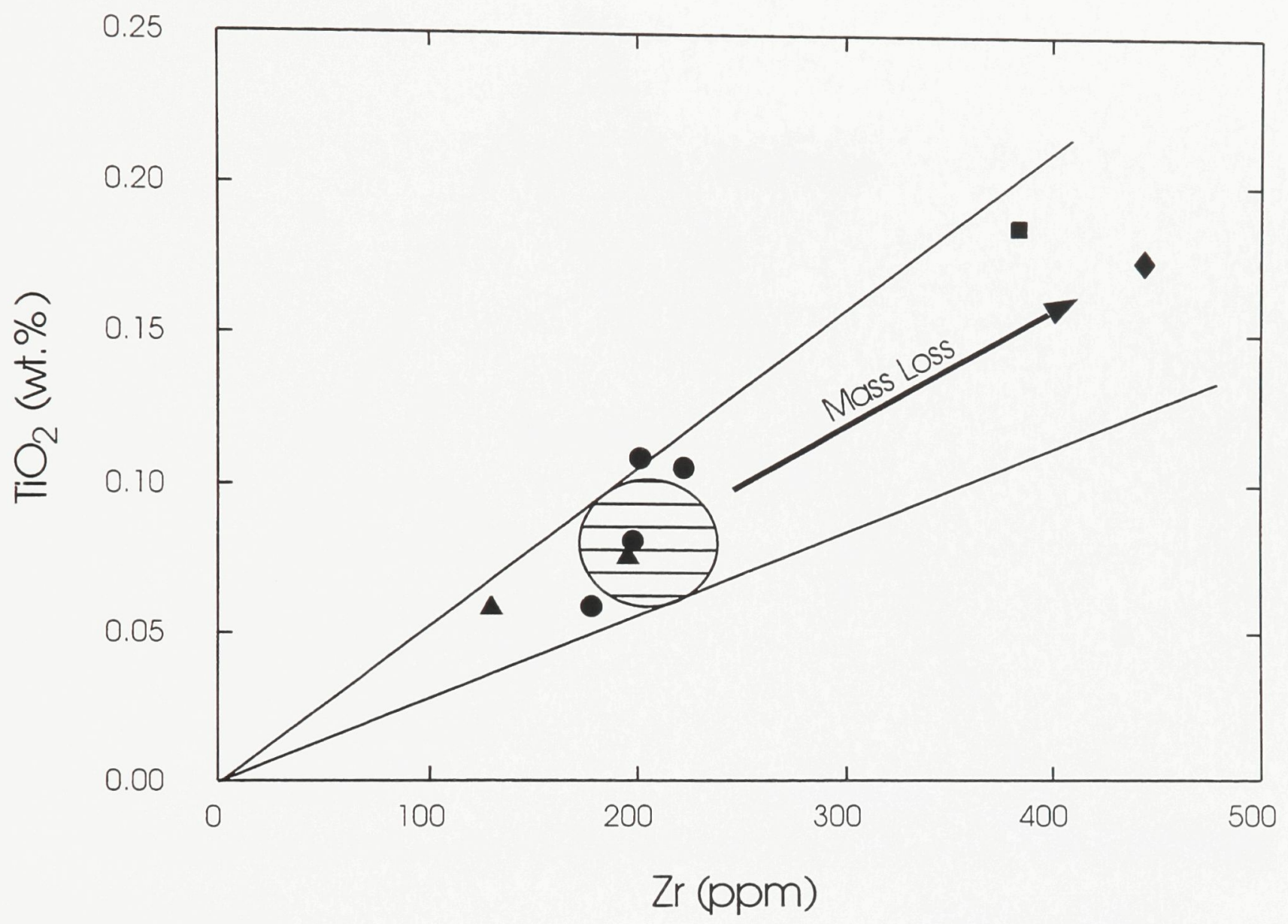

Figure 4.4. $\mathrm{Zr}$ versus $\mathrm{TiO}_{2}$ diagram. Filled circles $=\mathrm{FW}$ rhyolite, triangles $=$ rhyolite breccia, square $=$ chloritite , diamond $=$ sericitite, large ruled circle $=$ field of 6 least-altered FW rhyolite samples (Chapter 3). 


\section{$\mathrm{K}_{2} \mathrm{O}$}

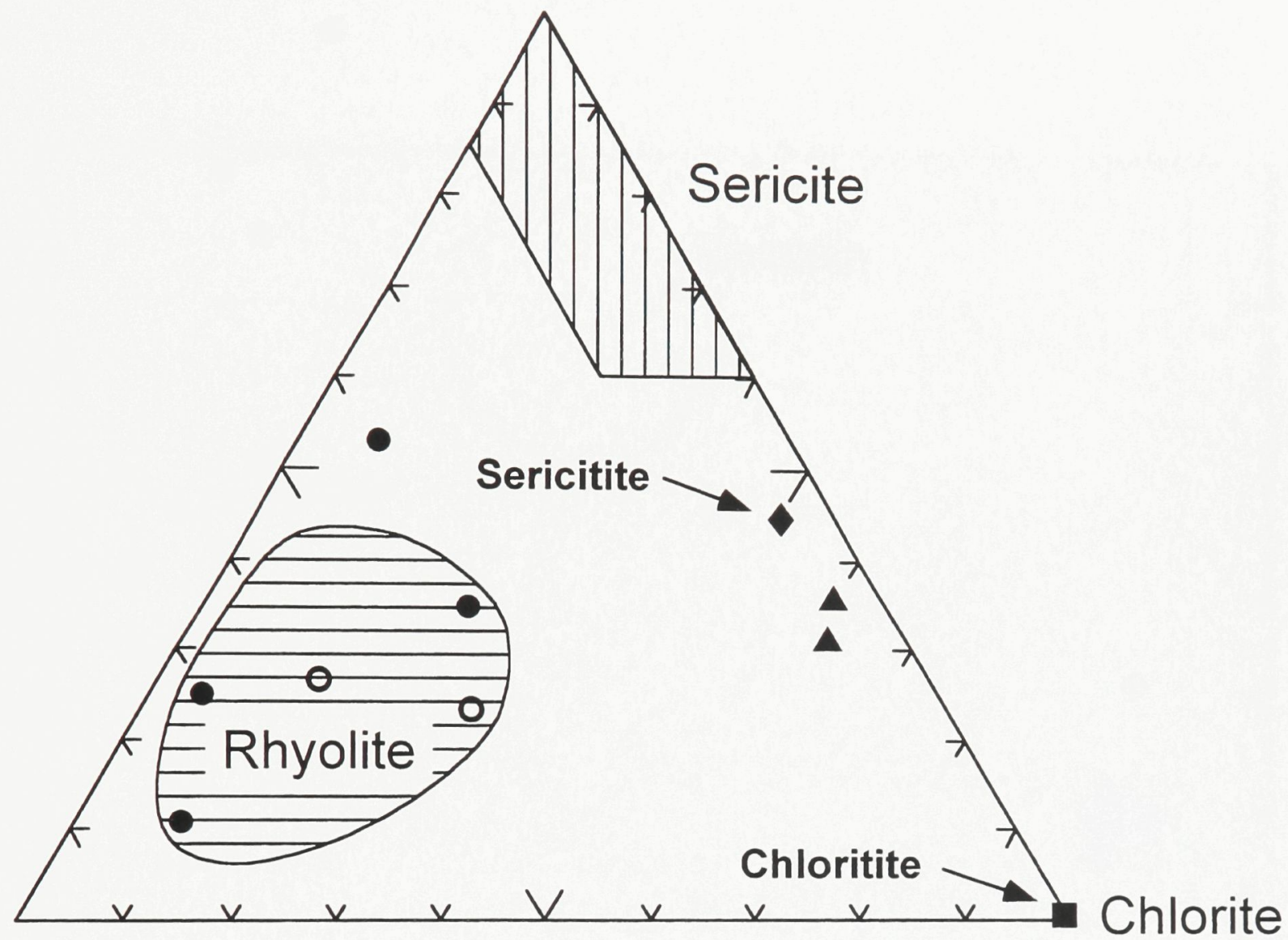

$\mathrm{Na}_{2} \mathrm{O}+\mathrm{CaO}$

$\mathrm{FeO}_{(\mathrm{t})}+\mathrm{MgO}$

Figure 4.5. Ternary $\left(\mathrm{Na}_{2} \mathrm{O}+\mathrm{CaO}\right)-\mathrm{K}_{2} \mathrm{O}-\left(\mathrm{FeO}_{(\mathrm{t})}+\mathrm{MgO}\right)$ diagram for rhyolitic sample data from the Kidd Creek Mine area. Filled circles $=$ FW rhyolite, open circles $=Q P$ rhyolite, triangles $=$ rhyolite breccia, square $=$ chloritite, diamond $=$ sericitite .

Horizontal ruling $=$ field of least-altered FW rhyolites (Chapter 3 ), vertical ruling = field of 13 out of 14 sericites from Abitibi VMS deposits. Twenty-nine chlorites from Abitibi VMS deposits plot within $1 \%$ of the $\mathrm{FeO}_{(\mathrm{t})}+\mathrm{MgO}$ apex. Chlorite and sericite data: Horne Mine - MacLean and Hoy (1991); Ansil Mine - Barrett et al. (1991); Delbridge Mine - Barrett et al. (1993); Kidd Creek Mine - Slack and Coad (1989). 


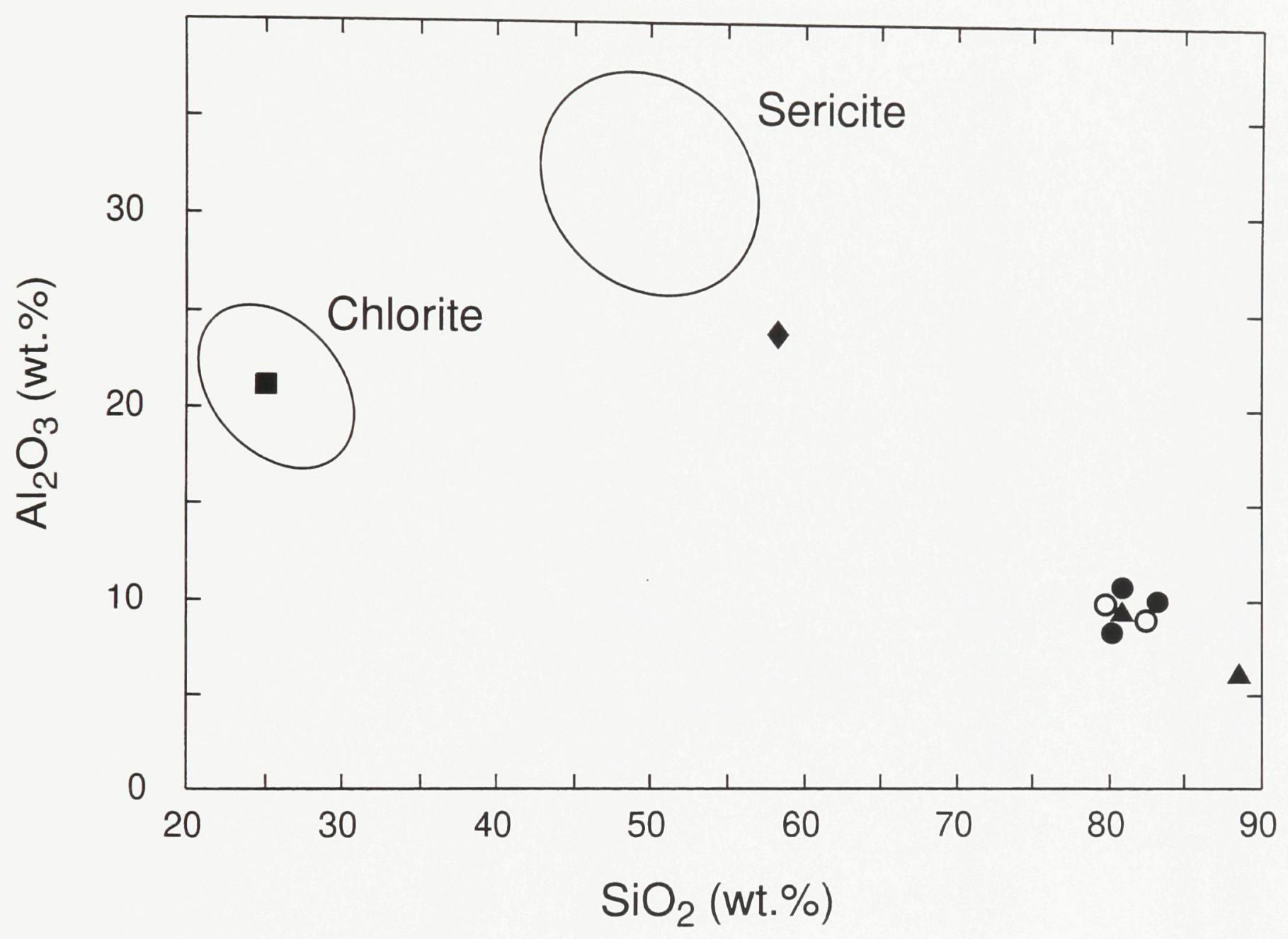

Figure 4.6. $\mathrm{SiO}_{2}$ versus $\mathrm{Al}_{2} \mathrm{O}_{3}$ diagram for rhyolitic sample data from the Kidd Creek Mine area. Sericite ellipse $=$ field of 13 out of 14 sericite samples from Abitibi VMS deposits, chlorite ellipse $=$ field of 29 chlorite samples from Abitibi VMS deposits. Sample symbols and sources of chlorite and sericite data as in Figure 4.5. 
옴

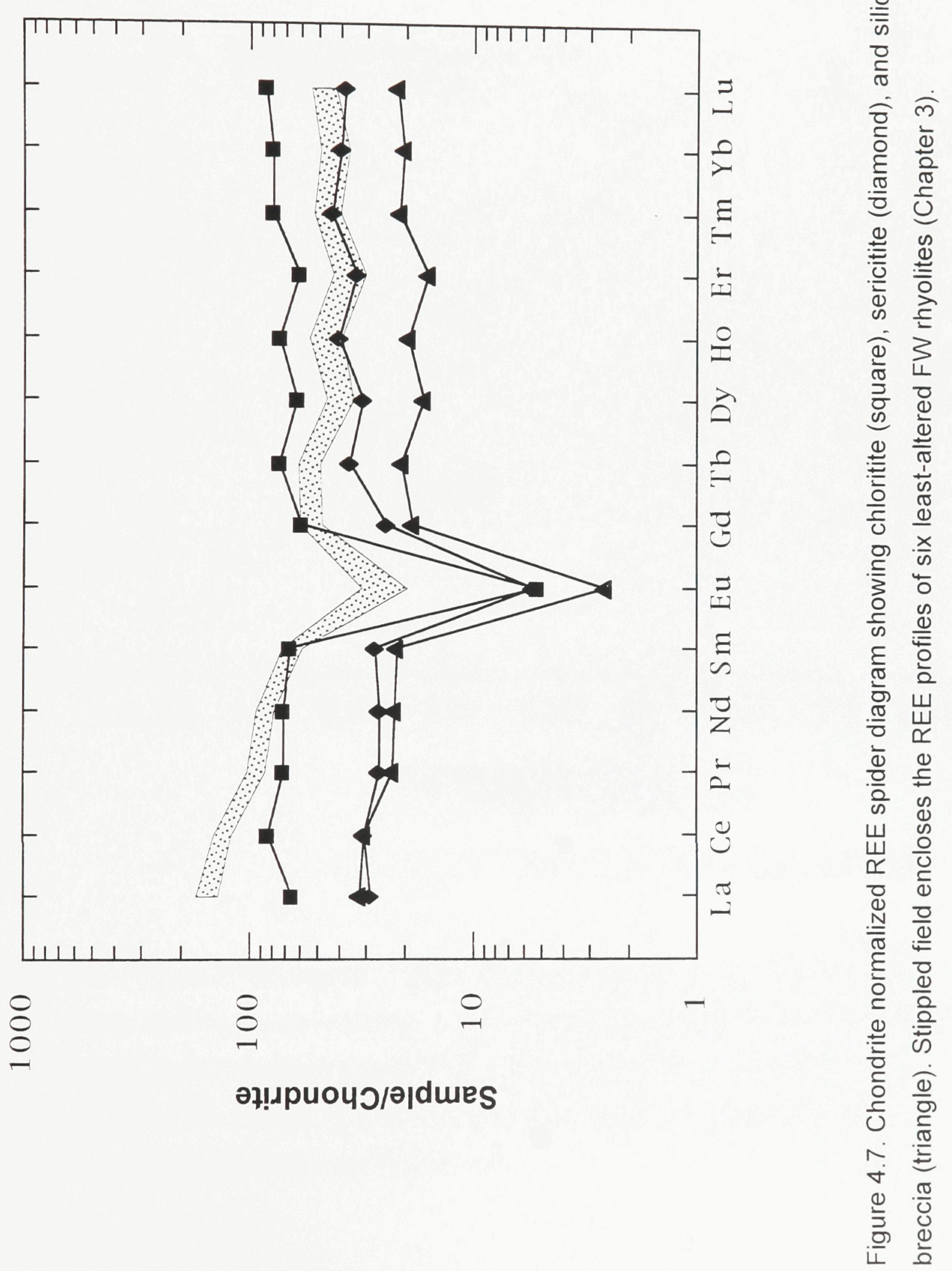




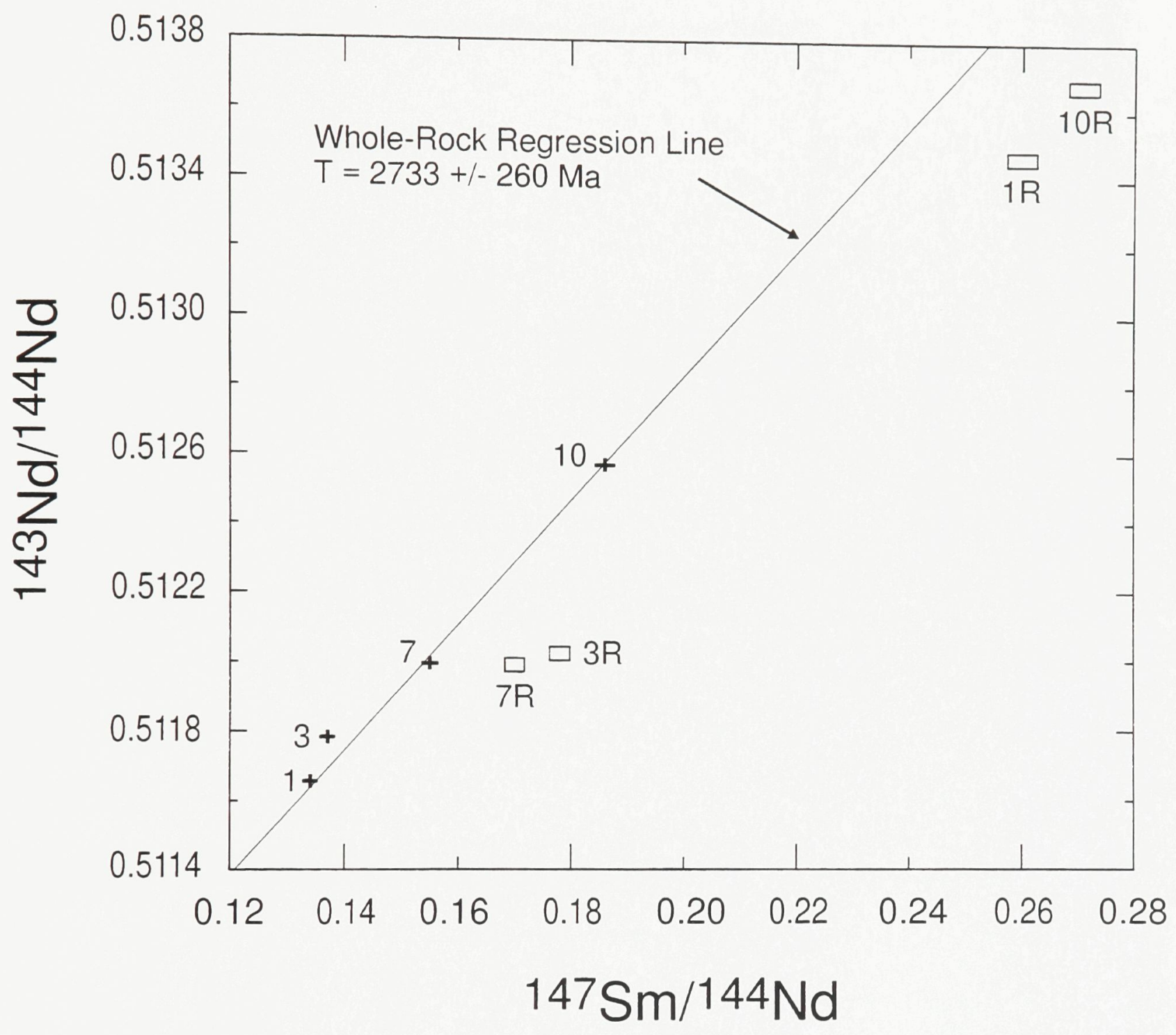

Figure 4.8. ${ }^{147} \mathrm{Sm} / 144 \mathrm{Nd}$ versus $143 \mathrm{Nd} / 144 \mathrm{Nd}$ diagram showing selected Kidd Creek whole rock samples (crosses: $1=\mathrm{KC}-102 \mathrm{~A}, 3=18-14051 \mathrm{R}, 7=\mathrm{AJ} 09313$, $10=23-14242$, and residues (boxes: $1 R=K C-102 A, 3 R=18-14051 R, 7 R=$ AJ09313, 10R = 23-14242). Size of symbol represents analytical error (2 s). Whole rock regression line from Figure 4.3. 


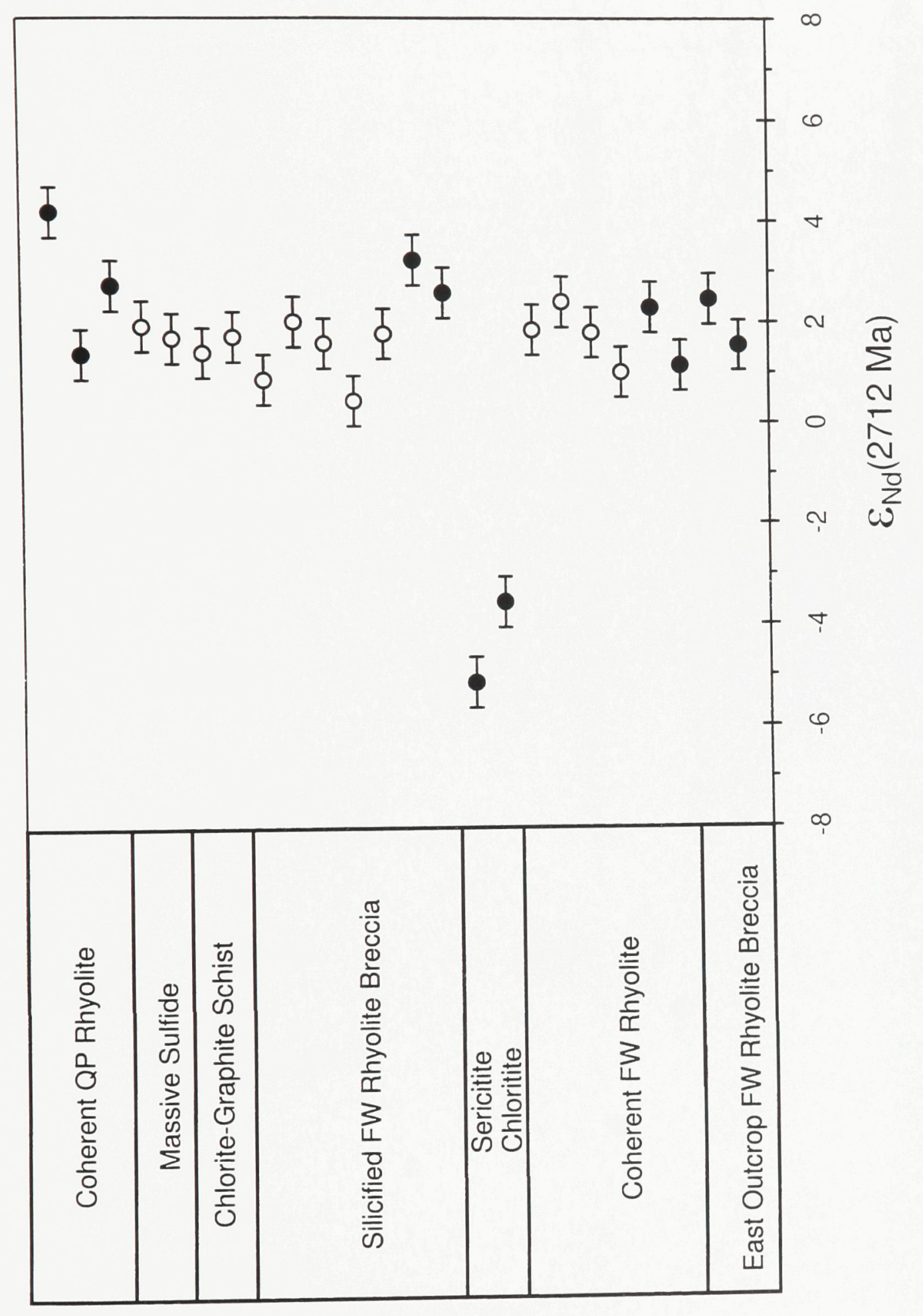

임

言. 응

ब家

훙휴

을 중

응

인

흠워

क

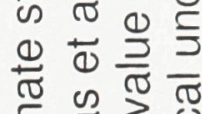

है

일을 을

응논

ब

吕它

ब。․․

E $=\pi$ क

힌요

떠유

응 훙

त $\mathbb{2}$.

ह $\sum \frac{0}{\sqrt{0}}$

응월

ब

才范

응

응

$0 \frac{0}{0}=$

든 는

흘

क ज़

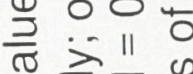

훌은 흥

त

$\sum$ 요유

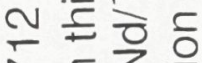

등

등워

닢ㅇㅇ

흉 ㅎㅇㅇ

\%

(1) क

竞 $\frac{0}{0}$ है 


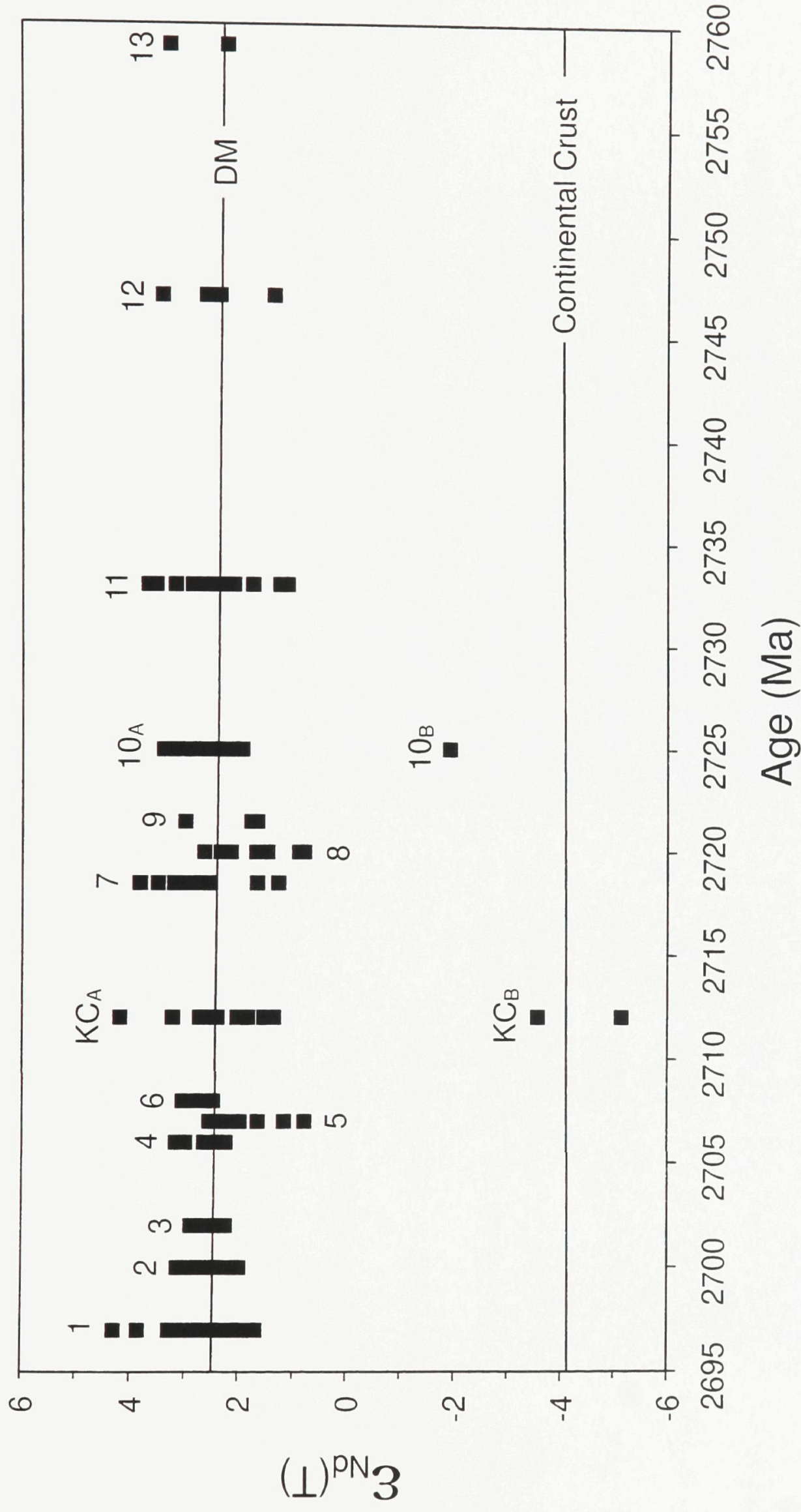

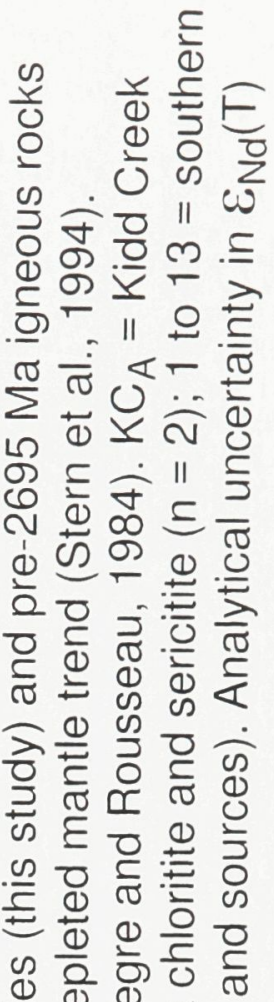

잉잉 है 츤 क य $\omega \sum \infty 0$ 을 을 은

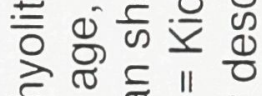
돈

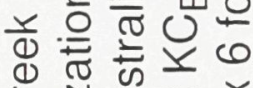
UํN을 응 焉 $\frac{5}{0}$ 전 흐 $\|$ D 90 कト ते

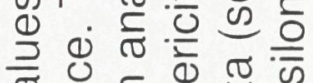
穴 잉ㅁㄷㅇ

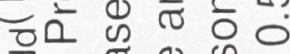
认ᄒ

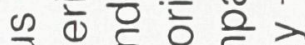
ज次 ब $>$ 듀

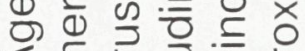

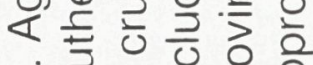
응 점 $\forall 0 \frac{1}{0} \omega$ (1) $ᄃ ㅇ ㅛ$

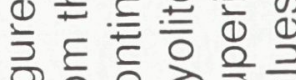

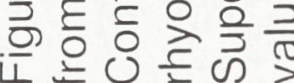




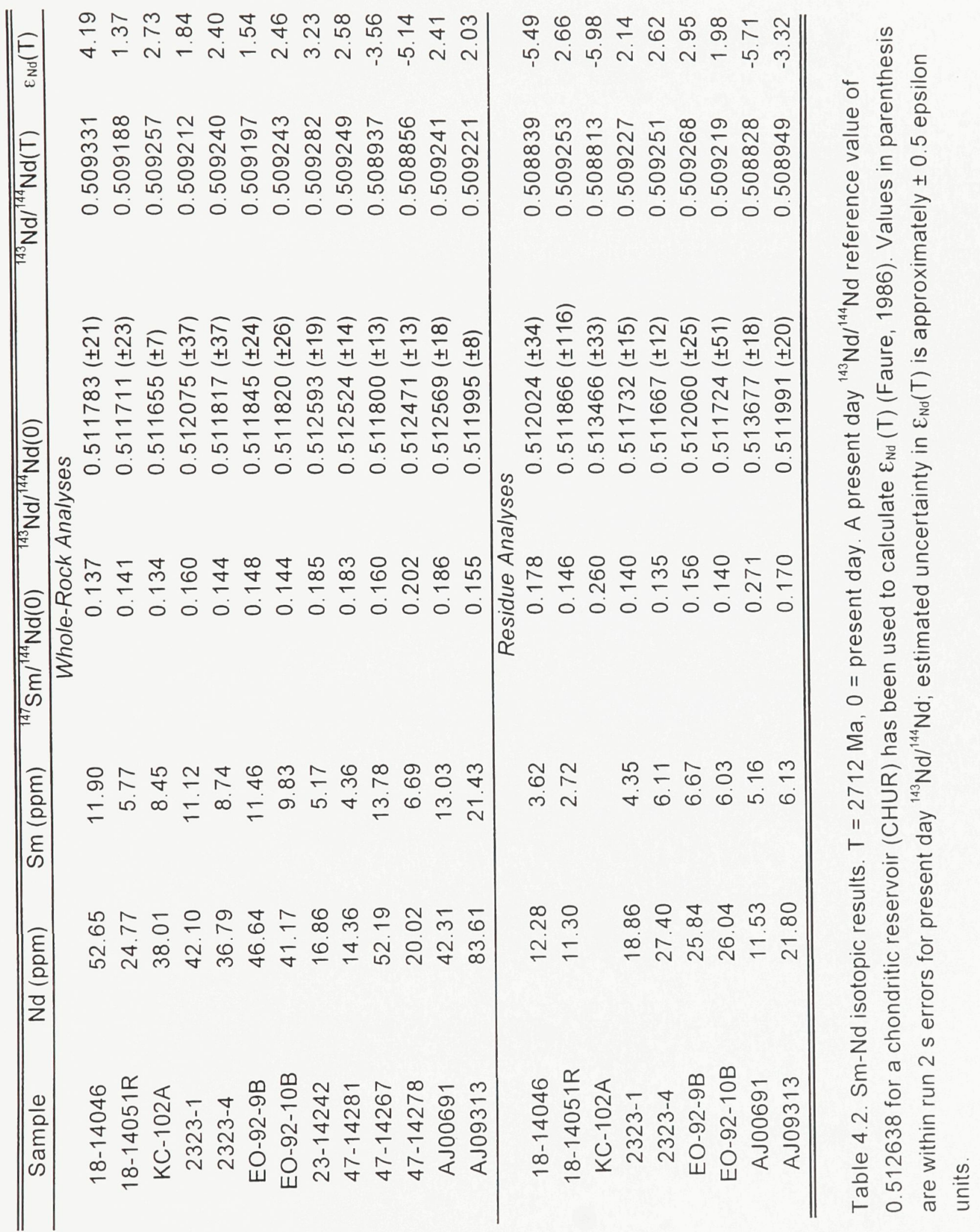


$\stackrel{O}{\sim}$

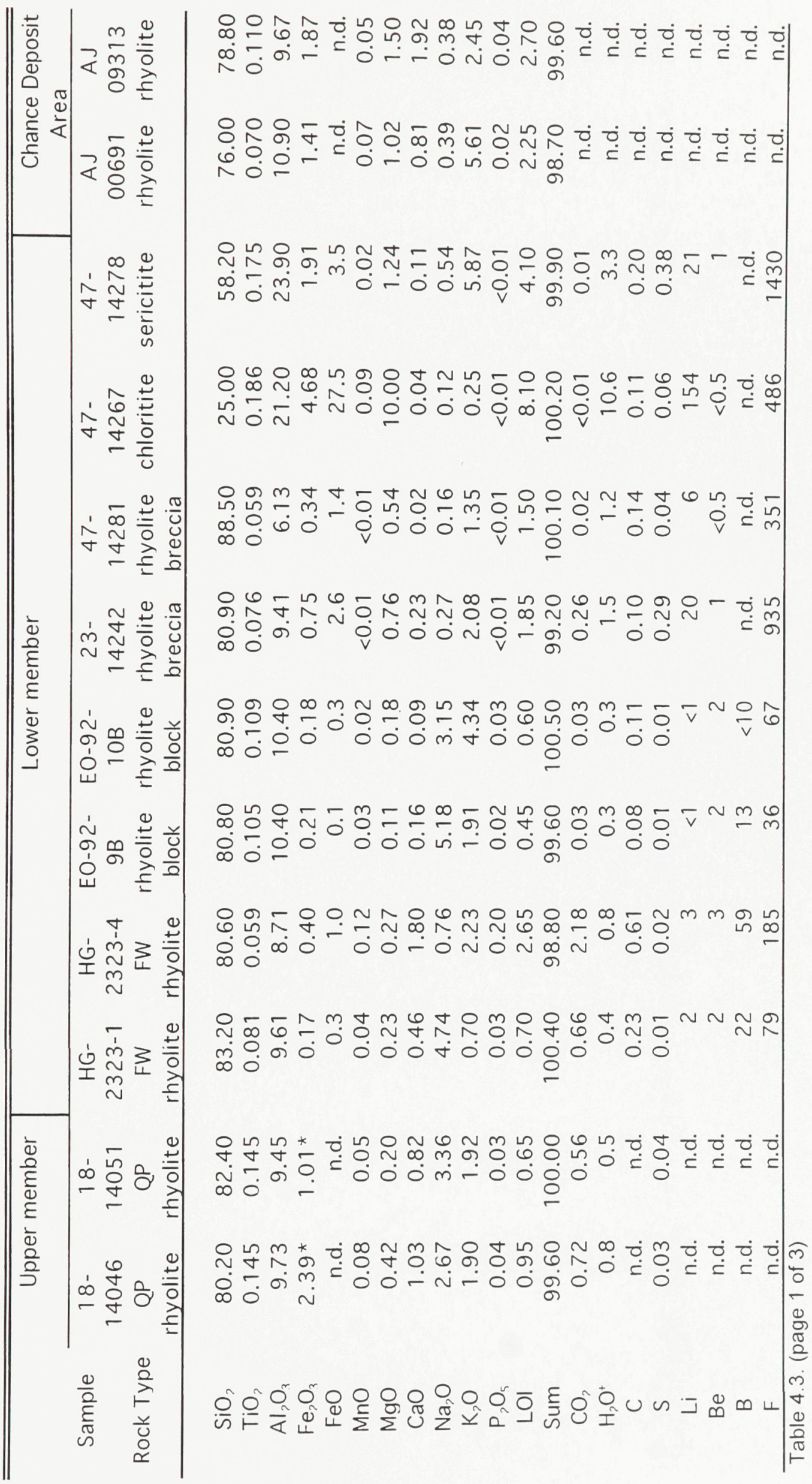




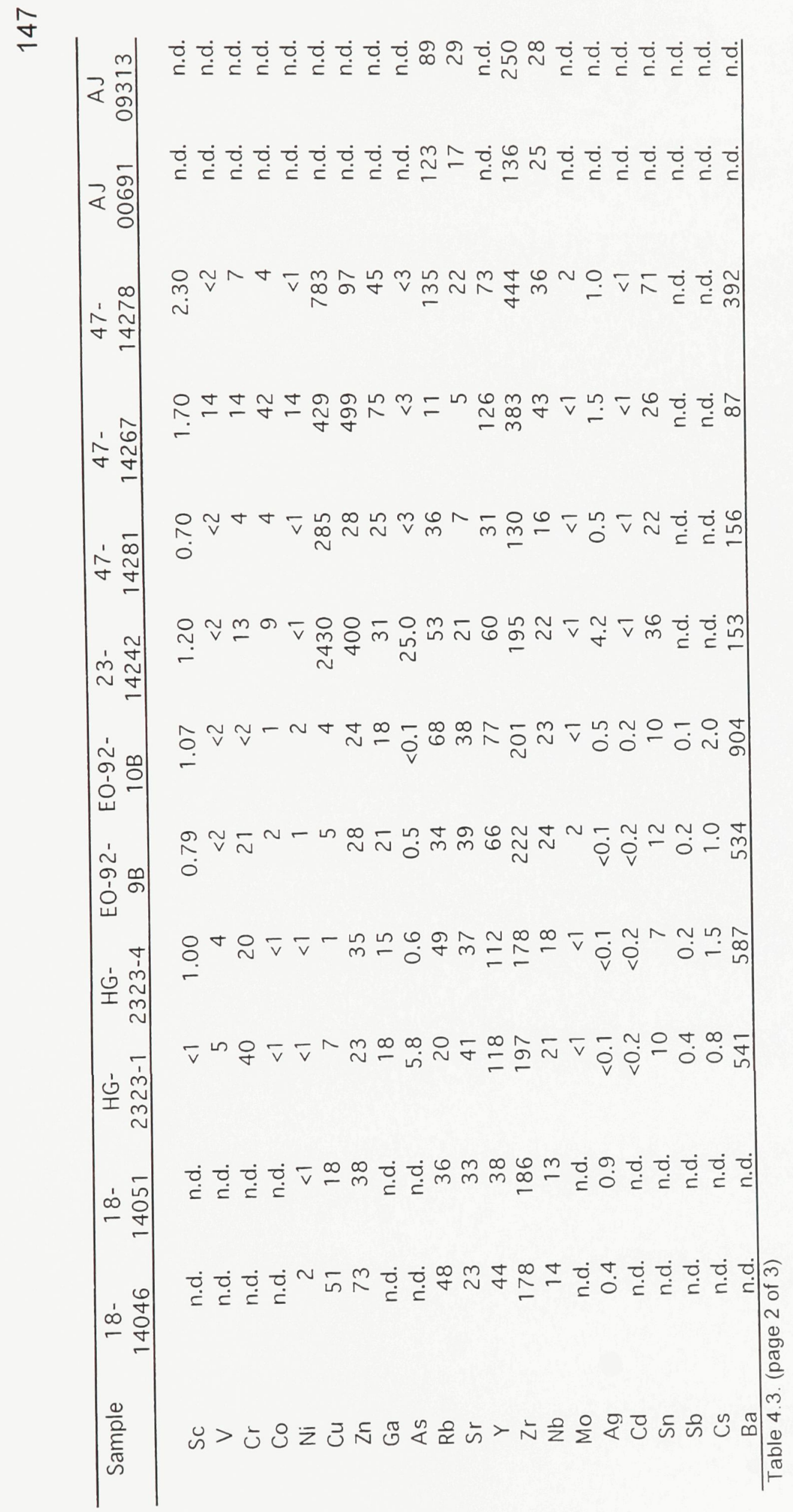




\section{Chapter 5}

\section{SUMMARY AND CONCLUSIONS}

It is proposed that the $350-450 \mathrm{~m}$ thick, predominantly felsic volcanic and volcaniclastic succession containing the Kidd Creek VMS deposit be informally named the Kidd Creek formation. The Kidd Creek formation is further subdivided on an informal basis into the Lower, Middle, and Upper members. The Lower member, in the stratigraphic footwall of the massive sulfide-bearing succession, is characterized by coherent rhyolite (FW rhyolite) and autoclastic rhyolite breccia. The Middle member, which hosts all of the known strata-bound orebodies, is composed primarily of a bedded sequence of volcaniclastic rocks (boulder conglomerate, pebble conglomerate, sandstone, mudstone) along with subordinate amounts of coherent and autoclastic rhyolite, argillite, and massive sulfide. The Upper member, located stratigraphically above the massive sulfide-bearing succession, consists of coherent and autoclastic facies of quartz-porphyritic rhyolite (QP rhyolite).

The QP rhyolite erupted from two, parallel fissures that are now subparallel to the $F_{1}$ fold axial plane. Two rhyolite domes were constructed above the north fissure to form the north ridge whereas one elongate dome was constructed above the south fissure to form the south ridge. These rhyolitic ridges extend for a least $1.9 \mathrm{~km}$. The plunge of the ridge axes represents the intersection of primary synvolcanic faults with the paleoseafloor. 
The synvolcanic fissure beneath the north ridge is interpreted to have acted as a conduit for ascending hydrothermal fluids before QP rhyolite volcanism and is interpreted to have exerted a strong influence on the location of hydrothermal discharge and the deposition of the south orebody. It is also probable that the synvolcanic fissure which controlled eruption of the south QP rhyolite ridge also acted as conduit for ascending hydrothermal fluids. This suggests exploration targets (i) at depth where the greywacke contact may have migrated southward thereby preserving strata beneath the south QP rhyolite ridge, and (ii) along the greywacke contact where fault slices of offset strata may be preserved (assuming that the greywacke contact does not represent an erosional unconformity).

Rhyolites of the Kidd Creek formation have tholeiitic affinities. REE patterns are intermediate between end member FIIla and FIIIb felsic volcanic rocks but pronounced negative Eu anomalies and high Th and $U$ contents favour their inclusion in the Flllb group.

The QP rhyolite retains a record of hanging wall alteration, primarily in the form of sericitization, silicification and feldspar destruction, which may be detected visually and chemically. Therefore, the Kidd Creek hydrothermal system was operative before, during and after QP volcanism; however, no VMS ores are known to occur within or above the QP rhyolite. 
The QP rhyolite represents the end of significant felsic volcanism in the Kidd Creek Mine area. Both the coherent and breccia facies of the QP rhyolite may be discriminated geochemically from felsic volcanic and volcaniclastic rocks in the Lower and Middle members of the Kidd Creek formation. This is particularly important as the QP rhyolite may mark the end of hydrothermal activity at the mine and exploration in and outside of the mine area should be focused on strata below the QP rhyolite or time-stratigraphic equivalent units.

The REE and the high field strength elements $\mathrm{Y}, \mathrm{Hf}, \mathrm{Zr}, \mathrm{Nb}, \mathrm{Ta}$, Th and $\mathrm{U}$ were relatively immobile during hydrothermal alteration and subsequent metamorphism of coherent rhyolite within the Lower member (FW rhyolite) and Upper member (QP rhyolite) of the Kidd Creek formation. The preservation of constant interelement ratios, the test of element immobility in rocks sharing common protolith compositions, is readily apparent on spider diagrams normalized to appropriate least-altered analyses.

Least-altered rhyolites of the Kidd Creek formation were compared to postTriassic oceanic rhyolites and plagiogranites of known tectonic environments on spider diagrams using incompatible elements that were relatively immobile during hydrothermal alteration (REE and HFSE). The Kidd Creek rhyolites are dissimilar to the post-Triassic felsic volcanic rocks and plagiogranites from intraplate islands, ensimatic island arcs, ensialic island arcs, ensimatic backarc rifts, immature mid-ocean rifts and immature continental rifts. They are similar to rhyolites from mature continental rifts undergoing sea-floor spreading such as the Red Sea. However, the lack of thick terrigenous clastic 
assemblages, and $\mathrm{U}-\mathrm{Pb}$ and $\mathrm{Sm}-\mathrm{Nd}$ isotopic data are not consistent with a continental rift environment for Kidd Creek area (Bleeker and Parrish, 1996; Barrie et al., 1996; Chapter 4). Kidd Creek rhyolites have strong REE and HFSE geochemical similarities to rhyolites and plagiogranites from anomalous midoceanic ridge spreading-Centre environments including the axial rift zones of Iceland, the Galapagos spreading Centre and the mid-Atlantic ridge at $45^{\circ} \mathrm{N}$. The closest match is with rhyolites erupted from Askja and Krafla in Iceland's eastern axial rift zone. As at Kidd Creek, most post-Triassic spreading Centre environments that contain rhyolites and/or plagiogranites are compositionally bimodal and are characterized by incompatible element enriched basaltic rocks.

The similarity of Kidd Creek and Iceland's axial rift zones is not limited to rhyolite geochemistry. Kidd Creek basaltic rocks and the tholeiitic basalts of Iceland have similar incompatible element enriched geochemical signatures and both environments are also characterized by Mg-rich volcanic rocks indicative of high-temperature environments: spinifex-textured komatiite at Kidd Creek and picrite in Iceland. Within Iceland's axial rift zones the eruption of both rhyolites and basalts is strongly controlled by parallel fissure swarms with rhyolitic volcanism restricted to areas of high volcanic output which form central volcanoes. Kidd Creek represents a felsic volcanic Centre and the distribution of felsic volcanic ridges at Kidd Creek is consistent with eruption from parallel fissures. 
By analogy to the central volcanoes of Iceland's axial rift zones, the Kidd Creek rhyolites and felsic volcaniclastic rocks, which host the Kidd Creek VMS deposit, are interpreted to have formed in or on oceanic crust characterized by a steep geothermal gradient and rapid subsidence, possibly above a rising mantle plume. This interpretation is supported by the presence of a komatiitebearing ultramafic succession below the Kidd Creek formation and high rhyolite eruption temperatures (Barrie, 1995). This high-temperature environment, coupled with high cross stratal permeability due to faulting inherent in rift and caldera environments, provided ideal conditions to generate, sustain and focus the high-temperature hydrothermal system required to form the giant Kidd Creek deposit. In this model the komatiites, the rhyolites and the $\mathrm{Cu}-\mathrm{Zn}-\mathrm{Pb}-\mathrm{Ag}$ ores are all manifestations of thermal and structural regimes within the crust.

The temporal and spatial association of rhyolites and VMS ores at Kidd Creek and many other VMS deposits in bimodal successions suggests that the formation of these orebodies may be related to the introduction of silicic melt into a mafic-ultramafic magmatic system. One possible explanation is that low-density, high-viscosity siliceous magma "clogs" the upper magma conduits creating a transient period of volcanic quiescence favorable for longlived hydrothermal discharge.

$\mathrm{Sm}-\mathrm{Nd}$ isotopic data are presented for 13 rhyolite samples (coherent and breccia facies) from the Kidd Creek Mine area. Excluding samples containing intense phyllosilicate alteration (chloritite and sericitite) a whole- 
rock regression age of $2733 \pm 260$ Ma has been obtained based on 11 samples. This age is within error of the U-Pb zircon ages of $2714.1 \pm 1.5 \mathrm{Ma}$ for FW (footwall) rhyolite and 2710.5 $\pm 1.1 \mathrm{Ma}$ for QP (hanging wall) rhyolite obtained by Bleeker and Parrish (1995).

The $\varepsilon_{\text {Nd }}$ values for the Kidd Creek rhyolites, excluding chloritite and sericitite samples, range from +1.4 to +4.2 with an average of $+2.43(n=11)$ when evaluated at $2712 \mathrm{Ma}$ (the average of rhyolite $\mathrm{U}-\mathrm{Pb}$ zircon ages determined by Bleeker and Parrish, 1995). A plot of Nd isotopic data for the Kidd Creek Mine formation against relative stratigraphic position shows no systematic variation in $\varepsilon_{\mathrm{Nd}}$ with stratigraphic height. When $\varepsilon_{\mathrm{Nd}}$ is plotted against age the Kidd Creek data, excluding the chloritite and sericitite analyses, form a cluster which straddles the depleted mantle curve with no evidence of contamination by older crust. The Kidd Creek $\varepsilon_{\mathrm{Nd}}$ values are similar to those obtained for Archean igneous rocks and mineral separates collected elsewhere in the southern Superior Province and are consistent with the formation of the Kidd Creek VMS deposit in an ensimatic environment, possibly at a mid-ocean rift, well removed from continental margins.

Two intensely altered, LREE depleted samples with rhyolitic protoliths, an Fe-rich chloritite and a sericitite associated with chalcopyrite stringers beneath the central orebody, return anomalously low $\varepsilon_{\mathrm{Nd}}(2712 \mathrm{Ma})$ values $(-3.6$ and -5.1$)$. These results may record syn-ore isotopic exchange between hydrothermal fluids and wallrocks at high water/rock ratios. However, it is more likely that the negative $\varepsilon_{\mathrm{Nd}}$ shifts reflect disturbance of the $\mathrm{Sm}-\mathrm{Nd}$ isotopic 
system during metamorphism and/or metasomatism postdating volcanism and the formation of the VMS ores. This interpretation is supported by the occurrence at Kidd Creek of hydrothermal monazite with a U-Pb age of $2659 \pm$ $3 \mathrm{Ma}$ (Schandl and Gorton, 1991), and by acid leaching experiments which indicate that a significant proportion of the LREE reside in labile minerals. 


\section{REFERENCES}

Alabaster, T., Pearce, J.A., and Malpas, J., 1982, The volcanic stratigraphy and petrogenesis of the Oman Ophiolite Complex: Contributions to Mineralogy and Petrology, v. 81, p. 168-183.

Aldiss, D.T., 1981, Plagiogranites from the ocean crust and ophiolites: Nature v. 289 , p. $577-578$.

Allegre, C.J., and Rousseau, D., 1984, The growth of the continent through geological time studied by Nd isotope analysis of shales: Earth and Planetary Science Letters, v. 67, p. 19-34.

Anders, E., and Grevesse, N., 1989, Abundances of the elements: Meteoritic and solar: Geochimica et Cosmochimica Acta, v. 53, p. 197-214.

Ashwal, L.D., Wooden, J.L., Phinney, W.C., and Morrison, D.A., 1985, Sm-Nd and $\mathrm{Rb}-\mathrm{Sr}$ isotope systematics of an Archean anorthosite and related rocks from the Superior Province of the Canadian Shield: Earth and Planetary Science Letters, v. 74, p. 338-346.

Aumento, F., 1969, Diorites from the Mid-Atlantic Ridge at $45^{\circ} \mathrm{N}$ : Science, v. 165 , p. $1112-1113$.

Babcock, R.S., 1973, Computational models of metasomatic processes: Lithos, v.6, p.279-290.

Baitis, H.M., and Lindstrom, M.M., 1980, Geology, petrography, and petrology of Pinzon Island, Galapagos Archipelago: Contributions to Mineralogy and Petrology, v. 72, p. 367-386.

Barrett, T.J., Cattalani, S., and MacLean, W.H., 1993, Volcanic lithogeochemistry and alteration at the Delbridge massive sulfide deposit, Noranda, Quebec: Journal of Geochemical Exploration, v. 48, p. 135-173.

Barrett, T.J., MacLean, W.H., Cattalani, S., Hoy, L., and Riverin, G., 1991, Massive sulfide deposits of the Noranda area, Quebec. III. The Ansil mine: Canadian Journal of Earth Science., v. 28, p. 1699-1730.

Barrie, C.T., 1995, Zircon thermometry of high-temperature rhyolites near volcanic-associated massive sulfide deposits, Abitibi Subprovince, Canada: Geology, v. 23, p. 169-172. 
Barrie, C.T., and Davis, D.W., 1990, Timing of magmatism and deformation in the Kamiskotia - Kidd Creek area, western Abitibi Subprovince, Canada: Precambrian Research, v. 46, p. 217-240.

Barrie, C.T., and Shirey, S.B., 1989, Geochemistry and Nd-Sr isotope systematics of the Kamiskotia area, western Abitibi Subprovince, Canada: Implications for mantle processes during the formation of the southern Superior Craton, in Ashwal, L.D., ed., Workshop on the Archean Mantle: Lunar and Planetary Institute Technical Report 89-05, p. 30-32.

Barrie, C.T., and Shirey, S.B., 1991, Nd- and Sr-isotope systematics for the Kamiskotia-Montcalm area: implications for the formation of late Archean crust in the western Abitibi Subprovince, Canada: Canadian Journal of Earth Science, v. 28, p. 58-76.

Barrie, C.T., Cousens, B.L., Hannington, M.D., Bleeker, W., and Gibson, H.L., 1996, Lead isotope systematics of the Kidd Creek mine stratigraphy and ore, Abitibi Subprovince, Canada: Submitted to special issue of Economic Geology on the Kidd Creek Mine.

Barrie, C.T., Ludden, J.N. and Green, T.H., 1993, Geochemistry of volcanic rocks associated with $\mathrm{Cu}-\mathrm{Zn}$ and $\mathrm{Ni}-\mathrm{Cu}$ deposits in the Abitibi Subprovince: Econ. Geol., v.88, p.1341-1358.

Bates, R.L., and Jackson, J.A., 1987, Glossary of geology: American Geological Institure, Alexandria, Virginia, $788 \mathrm{p}$.

Binns, R.A., and Scott, S.D., 1993, Actively forming polymetallic sulfide deposits associated with felsic volcanic rocks in the eastern Manus back-arc basin, Papua New Guinea: Economic Geology, v. 88, p. 2226-2236.

Bjornsson, A., 1985, Dynamics of crustal rifting in NE Iceland: Journal of geophysical Research, v. 90, p. 10151-10162.

Bjornsson, A., Saemundsson, K., Einarsson, P., Tryggvason, E., and Gronvold, K., 1977, Current rifting episode in north Iceland: Nature, v. 266, p. 318323.

Bleeker, W., 1994, The giant Kidd Creek massive sulphide deposit: A new perspective: Falconbridge Limited Internal report, 88p.

Bleeker, W., 1995a, Surface geology of the Porcupine camp, in, Heather, K.B., Percival, J.A., Moser, D., and Bleeker, W. (eds.), Tectonics and metallogeny of Archean crust in the Abitibi-Kapuskasing-Wawa region: Geological Survey of Canada, Open File 3141, p. 13-33. 
Bleeker, W., 1995b, The giant Kidd Creek massive sulphide deposit, in, Heather, K.B., Percival, J.A., Moser, D., and Bleeker, W. (eds.), Tectonics and metallogeny of Archean crust in the Abitibi-Kapuskasing-Wawa region: Geological Survey of Canada, Open File 3141, p. 107-127.

Bleeker, W., and Parrish, R., 1995, New U-Pb zircon ages for Kidd Creek: Implications for formation of giant VMS and the tectonic history of the Abitibi Belt, in Owsiacki, L., Walters, M., Brown, H. and Shannon, R. (eds.), Northern Ontario Development Agreement (Minerals), Summary Report 1994-1995: Natural Resources Canada and Ontario Ministry of Northern Development and Mines, p.67.

Bleeker, W., and Parrish, R., 1996, Regional geologic setting, structure, stratigraphy, and geochronology of the Kidd Creek Volcanic Complex: Submitted to Economic Geology Special Issue - The Kidd Creek volcanogenic massive sulfide deposit, Abitibi Subprovince, Canada.

Bleeker, W., and Parrish, R., submitted, Stratigraphy and U-Pb geochronology of Kidd Creek; implications for the formation of a giant VMS deposit and the tectonic history of the Abitibi greenstone belt: Canadian Journal of Earth Sciences.

Bloomer, S.H., Ewart, A., Hergt, J.M., and Bryan, W.B., 1994, Geochemistry and origin of igneous rocks from the outer Tonga Forearc (Site 841), in Hawkins, J., Parson, L., Allan, J., et al., eds., Proceedings of the Ocean Drilling Program: Scientific Results, Vol. 135, p. 625-646.

Boynton, W.V., 1984, Geochemistry of the rare earth elements: meteorite studies, in Henderson, P., ed., Rare earth element geochemistry: Amsterdam, Elsevier, p. 63-114.

Briggs, R.M., Gifford, M.G., Moyle, A.R., Taylor, S.R., Norman, M.D., Houghton, B.F., and Wilson, C.J.N., 1993, Geochemical zoning and eruptive mixing in ignimbrites from Mangakino volcano, Taupo Volcanic Zone, New Zealand: Journal of Volcanology and Geothermal Research, v. 56, p. 175-203.

Burke, K., Dewey, J.F., and Kidd, W.S.F., 1976, Dominance of horizontal movements, arc and microcontinental collisions during the later permobile regime, in Windley, B.F., ed., The early history of the Earth: London, John Wiley, p. 113-129.

Burke, K.C., and Kidd, W.S.F., 1980, Volcanism on Earth through time, in Strangeway, D., ed., The continental crust of the Earth and its mineral deposits: Geological Association of Canada Special Publication 20, p 503-522. 
Campbell, A.C., Palmer, M.R., Klinkhammer, G.P., Bowers, T.S., Edmond, J.M. Lawrence, J.R., Casey, J.F., Thompson, G., Humphris, S., Rona, P., and Karson, J.A., 1988, Chemistry of hot springs on the Mid-Atlantic Ridge: Nature, v. 335, p. 514-518.

Campbell, I.H., and Griffiths, R.W., 1993, The evolution of the mantle's chemical structure: Lithos, v. 30, p. 389-399.

Campbell, I.H., Coad, P., Franklin, J.M., Gorton, M.P., Scott, S.D., Sowa, J., and Thurston, P.C., 1982, Rare earth elements in volcanic rocks associated with $\mathrm{Cu}-\mathrm{Zn}$ massive sulphide mineralization: a preliminary report: Canadian Journal of Earth Science, v. 19, p. 619-623.

Campbell, I.H., Franklin, J.M., Gorton, M.P., Hart, T.R., and Scott, S.D., 1981, The role of subvolcanic sills in the generation of massive sulfide deposits: Economic Geology, v. 76, p. 2248-2253.

Campbell, I.H., Griffiths, R.W., and Hill, R.I., 1989, Melting in an Archaean mantle plume: heads it's basalts, tails it's komatiites: Nature, v. 339, p. 697-699.

Campbell, I.H., Lesher, C.M., Coad, P., Franklin, J.M., Gorton, M.P., and Thurston, P.C., 1984. Rare-earth element mobility in alteration pipes below massive Cu-Zn sulfide deposits: Chemical Geology, v. 45, p. 181202.

Carmicheal, I.S.E., 1964, The petrology of Thingmuli, a Tertiary volcano in eastern Iceland: Journal of Petrology, v. 5, p. 435-460.

Cathles, L.M., Guber, A.L., Lenagh, T.C., and Dudas, F.O., 1983, Kuroko-type massive sulfide deposits of Japan: Products of an aborted island-arc rift, in Ohmoto, $\mathrm{H}$, and Skinner, B.J., eds., The Kuroko and related volcanogenic massive sulfide deposits: Economic Geology, Monograph 5 , p. 96-114.

Cattell, A., Krogh, T.E., and Arndt, N.T., 1984, Conflicting Sm-Nd whole rock and $\mathrm{U}-\mathrm{Pb}$ zircon ages for Archean lavas from Newton Township, Abitibi Belt, Ontario: Earth and Planetary Science Letters, v. 70, p. 280-290.

Clague, D.A., Frey, F.A., Thompson, G., and Rindge, S., 1981, Minor and trace element geochemistry of volcanic rocks dredged from the Galapagos spreading center: Role of crystal fractionation and mantle heterogeneity: Journal of Geophysical Research, v. 86, p. 9469-9482.

Cliff, R.A., and Rickard, D., 1992, Isotope systematics of the Kiruna magnetite ores, Sweden: Part 2. Evidence for a secondary event 400 m.y. after ore formation: Economic Geology, v. 87, p. 1121-1129. 
Coad, P.R., 1985, Rhyolite geology at Kidd Creek - a progress report: Canadian Institute of Metallurgy and Mining Transactions, v. 78, p. 70-83.

Coish, R.A., and Rogers, N.W., 1987, Geochemistry of the Boil Mountain ophiolitic complex, northwest Maine, and tectonic implications: Contributions to Mineralogy and Petrology, v. 97, p. 51-65.

Condie, K.C., 1976, Trace-element geochemistry of Archean greenstone belts: Earth-Science Reviews, v. 12, p. 393-417.

Condie, K.C., 1981, Archean greenstone belts: Amsterdam, Elsevier, 434 p.

Condie, K.C., 1989a, Geochemical changes in basalts and andesites across the Archean-Proterozoic boundary: Identification and significance: Lithos, v. 23 , p. $1-18$.

Condie, K.C., 1989b, Plate tectonics and crustal evolution: Pergamon Press, Oxford, $476 \mathrm{p}$.

Corfu, F., 1993, The evolution of the southern Abitibi Greenstone Belt in light of precise U-Pb geochronology: Economic Geology, v. 88, p. 1323-1340.

Davis, D.W., Schandl, E.S., and Wasteneys, H.A., 1994, U-Pb dating of minerals in alteration halos of Superior Province massive sulfide deposits: syngenesis versus metamorphism: Contributions to Mineralogy and Petrology, v. 115, p. 427-437.

Defant, M.J., and Drummond, M.S., 1990, Derivation of some modern arc magmas by melting of young subducted lithosphere: Nature, v. 347, p. 662-665.

Defant, M.J., and Drummond, M.S., 1993, Mount St. Helens: Potential example of the partial melting of the subducted lithosphere in a volcanic arc: Geology, v. 21, p. 547-550.

Dimroth, E., Imreh, L., Rocheleau, M., and Goulet, N., 1982, Evolution of the south-central part of the Archean Abitibi belt, Quebec, Part I., Stratigraphy and paleogeographic model: Can. J. Earth Sci., v.19, p.1729-1758.

Donnelly, T.W., Beets, D., Carr, M.J., Jackson, T., Klaver, G., Lewis, J., Maury, R., Schellenkens, H., Smith, A.L., Wadge, G., and Westercamp, D., 1990, History and tectonic setting of Caribbean magmatism, in Dengo, G., and Case, eds., The Carribean region: Boulder, Colorado, Geological Society of America, The Geology of North America, Vol. H., p, 339-374. 
Drummond M.S., and Defant, M.J., 1990, A model for trondhjemite-tonalitedacite genesis and crustal growth via slab melting: Archean to modern comparisons: Journal of Geophysical Research, v. 95, p. 21503-21521.

Dudas, F.O., Campbell, I.H., and Gorton, M.P., 1983, Geochemistry of igneous rocks in the Hokuroku District, northern Japan, in Ohmoto, $\mathrm{H}$, and Skinner, B.J., eds., The Kuroko and related volcanogenic massive sulfide deposits: Economic Geology, Monograph 5, p. 115-133.

Dupre, B., Chauvel, C., and Arndt, N.T., 1984, Pb and Nd isotopic study of two Archean komatiitic flows from Alexo, Ontario: Geochimica et Cosmochimica Acta, v. 48, p. 1965-1972.

Elthon, D., 1991, Geochemical evidence for formation of the Bay of Islands ophiolite above a subduction zone: Nature, v. 354, p. 140-143.

Engel, C.G., and Fisher, R.L., 1975, Granitic to ultramafic rock complexes of the Indian Ocean ridge system, western Indian Ocean: Geological Society of America Bulletin, v. 86, p. 1553-1578.

Evensen, N.M., Hamilton, P.J., and O'Nions, R.K., 1978, Rare-earth abundances in chondritic meteorites: Geochimica et Cosmochimica Acta, v. 42, p. 1199-1212.

Ewart , A., Schon, R.W., and Chappell, B.W., 1992, The Cretaceous volcanicplutonic province of the central Queensland (Australia) coast - a rift related 'calc-alkaline' province: Transactions of the Royal Society of Edinburgh, Earth Sciences, v. 83, p. 327-345.

Faure, G., 1986, Principles of isotope geology (second edition): New York, John Wiley and Sons, $589 \mathrm{p}$.

Floyd, P.A., and Winchester, J.A., 1975, Magma type and tectonic setting discrimination using immobile elements: Earth and Planetary Science Letters, v. 27 , p. 211-218.

Floyd, P.A., and Winchester, J.A., 1978, Identification and discrimination of altered and metamorphosed volcanic rocks using immobile elements: Chemical Geology, v. 21, p. 291-306.

Fouquet, Y., von Stackelberg, U., Charlou, J.L., Erzinger, J., Herzig, P.M., Muhe, R., and Wiedicke, M., 1993, Metallogenesis in back-arc environments: the Lau basin: Economic Geology, v. 88, p. 2154-2181. 
Franklin, J.M., and Thorpe, R.I., 1982, Comparative metallogeny of the Superior, Slave and Churchill Provinces, in Hutchinson, R.W., Spence, C.D., and Franklin, J.M., eds., Precambrian Sulphide Deposits: Geological Association of Canada Special Paper 25, p. 3-90

Franklin, J.M., Lydon, J.W., and Sangster, D.F., 1981, Volcanic-associated massive sulphide deposits: Economic Geology, 75th Anniversary Volume, p. 485-627.

Freundt A., and Schmincke, H., 1995, Petrogenesis of rhyolite-trachyte-basalt composite ignimbrite P1, Gran Canaria, Canary Islands: Journal of Geophysical Research, v. 100, p. 455-474.

Futa, K., and Stern, C.R., 1988, Sr and Nd isotopic and trace element compositions of Quaternary volcanic centers of the southern Andes: Earth and Planetary Science letters. v. 88, p. 253-262.

Fytikas, M., Innocenti, F., Kolios, N., Manetti, P., Mazzuoli, R., Poli, G., Rita, F., and Villari, L., 1986, Volcanology and petrology of volcanic products from the Island of Milos and neighbouring islets: Journal of Volcanology and Geothermal Research, v. 28, p. 297-317.

German, C.R., Barreiro, B.A., Higgs, N.C., Nelsen, T.A., Ludford, E.M., and Palmer, M.R., 1995, Seawater-metasomatism in hydrothermal sediments (Escanaba Trough, northeast Pacific): Chemical Geology, v. 199 , p. 175-190.

Gibson, H.L., 1990, The Mine Sequence of the Central Noranda volcanic complex: Geology, alteration, massive sulphide deposits and volcanological reconstruction: Unpubl. PhD. thesis, Carleton University, Ottawa, Canada, 715p.

Gibson, H.L., and Kerr, D.J., 1993, Giant volcanic-associated massive sulfide deposits: with emphasis on Archean deposits, in, Whiting, B.H., Hodgson, C.J., and Mason, R., eds., Giant ore deposits: Society of Economic Geologists, Special Publication No. 2, p. 319-348.

Gibson, H.L., and Watkinson, D.H., 1990, Volcanogenic massive sulphide deposits of the Noranda Cauldron and Shield Volcano, in Rive, M., Verpaelst, P., Gagnon, Y., Lulin, J.-M., Riverin, G., and Simard, A., eds., The northwestern Quebec polymetallic belt: The Canadian Institute of Mining and Metallurgy, Special Volume 43, p. 119-132.

Gill, J.B., and Stork, A.L., 1979, Miocene low-K dacites and trondhjemites of Fiji, in Barker, F., ed., Trondhjemites, dacites and related rocks: Amsterdam, Elsevier, p. 629-649. 
Gill, J.B., Seales, C., Thompson, P., Hochstaedter, A.G., and Dunlap, C., 1992, Petrology and geochemistry of Pliocene-Pleistocene volcanic rocks from the Izu Arc, Leg 126, in Taylor, B., Fujioka, K., et al., eds., Proceeding of the Ocean Drilling Program: Scientific Results, Vol. 126, p. 383-401.

Goodfellow, W.D., 1975. Major and minor element halos in volcanic rocks at Brunswick No. 12 sulphide deposit, N.B., Canada, in Elliot, I.L., and Fletcher, W.K., eds., Geochemical exploration 1974: Amsterdam, Elsevier, p. 279-295.

Goodwin, A.M., 1977, Archean volcanism in the Superior Province, Canadian Shield, in Baragar, W.R.A., Coleman, L.C., and Hall, J.M., eds., Volcanic regimes in Canada: Geological Association of Canada Special Paper 16 , p. 205-241.

Govindaraju, K., 1994, 1994 compilation of working values and sample description for 383 geostandards: Geostandards Newsletter, v. 18, p. 1 158.

Grant, J.A., 1986, The isocon diagram - a simple solution to Gresens' equation for metasomatic alteration: Economic Geology, v. 81, p. 1976-1982.

Gresens, R.L., 1967, Composition-volume relationships of metasomatism: Chemical Geology, v. 2, p. 47-65.

Halbach, P., Pracejus, B., and Marten, A., 1993, Geology and mineralogy of massive sulfide ores from the central Okinawa trough, Japan: Economic Geology, v. 88, p. 2210-2225.

Hanson, G.B., 1978, The application of trace elements to the petrogenesis of igneous rocks of granitic composition: Earth and Planetary Science Letters, v. 38, p. 26-43.

Harris, C., 1983, The petrology of lavas and associated plutonic inclusions of Ascension Island: Journal of Petrology, v. 24, p. 424-470.

Hart, T.R., 1984, The geochemistry and petrogenesis of a metavolcanic and intrusive sequence in the Kamiskotia area; Timmins, Ontario: Unpub. M.Sc. thesis, Univ. Toronto, 146 p.

Hedge, C.E., Futa, K., Engel, C.G., and Fisher, R.L., 1979, Rare earth abundances and Rb-Sr systematics of basalts, gabbro, anorthosite and minor granitic rocks from the Indian Ocean Ridge system: Contributions to Mineralogy and Petrology, v. 68, p. 373-376. 
Helmstaedt, H., Padgham, W.A., and Brophy, J.A., 1986, Multiple dikes in Lower Cam Group, Yellowknife greenstone belt: evidence for Archean sea-floor spreading?: Geology, v. 14, p. 562-566.

Hemond, C., Arndt, N.T., Lichtenstein, U., Hofmann, A.W., Oskarsson, N., and Steinthorsson, S., 1993, The heterogeneous Iceland plume, Nd-Sr-O isotopes and trace element constraints: Journal of Geophysical Research, v. 98, p. 15833-15850.

Herzig, C.T., and Elders, W.A., 1988, Nature and significance of igneous rocks cored in the State 2-14 research borehole: Salton Sea Scientific Drilling Project, California: Journal of Geophysical Research, v. 93, p. 1306913080.

Herzig, C.Y., and Jacobs, D.C., 1994, Cenozoic volcanism and two-stage extension in the Salton trough, southern California and northern Baja California: Geology, v. 22, p. 991-994.

Hildreth, W., 1979, The Bishop Tuff: evidence for the origin of compositional zonation in silicic magma chambers: in, Chapin, C.E., and Elston, W.E., eds., Ash-flow tuffs: Geological Society of America, Special Paper 180, p. 43-75.

Hildreth, W., 1981. Gradients in silicic magma chambers: implications for lithospheric magmatism: Journal of Geophysical Research, v. 86, p. 10153-10192.

Hildreth, W., 1983, The compositionally zoned eruption of 1912 in the Valley of Ten Thousand Smokes, Katmai National Park, Alaska: Journal of Volcanology and Geothermal Research, v. 18, p. 1-56.

Hinkley, T.K., and Tatsumoto, M., 1987, Metals and isotopes in Juan de Fuca Ridge hydrothermal fluids and their associated solid materials: Journal of Geophysical Research., v. 92, p. 11400-11410.

Hoffman, P.F., 1991, On accretion of granite-greenstone terranes, in Robert, F., Sheahan, P.A., and Green. S.B., eds., Greenstone Gold and Crustal Evolution, NUNA Conference Volume: St. John's, Newfoundland, Geological Association of Canada, p. 32-45.

Hofmann, A.W., 1988, Chemical differentiation of the Earth: the relationship between mantle, continental crust, and oceanic crust: Earth and Planetary Science Letters, v. 90, p. 297-314. 
Huijsmans, J.P.P., Barton, M., and Salters, V.J.M., 1988, Geochemistry and evolution of the calc-alkaline volcanic complex of Santorini, Aegean Sea, Greece: Journal of Volcanology and Geothermal Research, v. 34, p. 283306.

Humphris, S.E., Herzig, P.M., Miller, D.J., Alt, J.C., Becker, K., Brown, D., Brugmann, G., Chiba, H., Fouquet, Y., Gemmell, J.B., Guerin, G., Hannington, M.D., Holm, N.G., Honnorez, J.J., Iturrino, G.J., Knott, R., Ludwig, R., Nakamura, K., Petersen, S., Reysenbach, A-L., Rona, P.A., Smith, S., Sturz, A.A., Tivey, M.K., and Zhao, X., 1995, The internal structure of an active sea-floor massive sulphide deposit, Nature, v. 377 , p. 713-716.

Huston, D.L., 1993, The effect of alteration and metamorphism on wall rocks to the Balcooma and Dry River South volcanic-hosted massive sulfide deposits, Queensland, Australia: J. Geochem. Explor., v.48, p.277-307.

Huston, D.L., and Taylor, B., 1996, Oxygen and hydrogen isotope studies of the Kidd Creek Mine: Submitted to Economic Geology Special Issue - The Kidd Creek volcanogenic massive sulfide deposit, Abitibi Subprovince, Canada.

Huston, D.L., Taylor, B.E., Bleeker, W., Stewart, B., Cook, R., and Koopman, E., 1995, Isotope mapping around the Kidd Creek Deposit, Ontario: Application to exploration and comparison with other geochemical indicators: Exploration and Mining Geology, v.4, p. 175-187.

Hutchinson, R.W., 1982, Syn-depositional hydrothermal processes and Precambrian sulphide deposits, in Hutchinson, R.W., Spence, C.D., and Franklin, J.M., eds., Precambrian Sulphide Deposits: Geological Association of Canada Special Paper 25, p. 761-791.

Irvine, T.N., and Baragar, W.R.A., 1971. A guide to the chemical classification of the common volcanic rocks: Can. J. Earth Sci., v.8, p.523-548.

Ishikawa, Y., Sawaguchi, T., Iwaya, S., and Horiuchi, M., 1976, Delineation of prospecting targets for Kuroko deposits based on modes of volcanism of underlying dacite and alteration haloes [in Japanese with English abs.]: Mining Geology, v. 26, p. 105-117.

Jackson, S.L., and Cruden, A.R., 1995, Formation of the Abitibi greenstone belt by arc-trench migration: Geology, v. 23, p. 471-474.

Jackson, S.L., and Fyon, J.A., 1991, The western Abitibi Subprovince in Ontario, in Thurston, P.C., Williams, H.R., Sutcliffe, R.H., and Stott, G.M., eds., Geology of Ontario: Ontario Geological Survey, Special Volume 4, Part 1, p. $405-482$. 
Jackson, S.L., Fyon, J.A., and Corfu, F., 1994, Review of Archean supracrustal assemblages of the southern Abitibi greenstone belt in Ontario,

Canada: products of microplate interaction within a large-scale platetectonic setting: Precambrian Research, v. 65, p. 183-205.

Jacobsen, S.B., and Pimentel-Klose, M.R., 1988a, A Nd isotopic study of the Hamersley and Michipicoten banded iron formations: the source of REE and $\mathrm{Fe}$ in Archean oceans: Earth and Planetary Science Letters, v. 87, p. $29-44$.

Jacobsen, S.B., and Pimentel-Klose, M.R., 1988b, Nd isotopic variations in Precambrian banded iron formations: Geophysical Research Letters, v. 15 , p. 393-396.

Jensen, L.S., 1976, A new cation plot for classifying subalkalic volcanic rocks: Ontario Div. Mines, Misc. Paper 66, 22p.

Jochum, K.P., Arndt, N.T., and Hofmann, A.W., 1991, Nb-Th-La in komatiites and basalts: constraints on komatiite petrogenesis and mantle evolution: Earth and Planetary Science Letters, v. 107, p. 272-289.

Kay, S.M., Ramos, V.A., and Marquez, M., 1993, Evidence in Cerro Pampa volcanic rocks for slab-melting prior to ridge-trench collision in southern South America: Journal of Geology, v. 101, p. 703-714.

Kerr, D.J., and Gibson, H.L., 1993, A comparison of the Horne volcanogenic massive sulfide deposit and intracauldron deposits of the Mine sequence, Noranda, Quebec: Economic Geology, v. 88, p. 1419-1442.

Kimura, G., Ludden, J.N., Desrochers, J-P., and Hori, R., 1993, A model of ocean-crust accretion for the Superior province, Canada: Lithos, v. 30, p. 337-355.

Koopman, L., Hannington, M.D., and Santaguida, F., 1996, Petrology and geochemistry of hydrothermal alteration in the Kidd Creek Mine: Submitted to Economic Geology Special Issue - The Kidd Creek volcanogenic massive sulfide deposit, Abitibi Subprovince, Canada.

Leo, G.W., Hedge, C.E., and Marvin, R.F., 1980, Geochemistry, strontium isotope data, and potassium-argon ages of the andesite-rhyolite association in the Padang area, west Sumatra: Journal of Volcanology and Geothermal research, v. 7, p. 139-156.

Lesher, C.M., Goodwin, A.M., Campbell, I.H., and Gorton, M.P., 1986, Traceelement geochemistry of ore-associated and barren, felsic metavolcanic rocks in the Superior Province, Canada: Canadian Journal of Earth Science, v. 23, p. 222-237. 
Ludwig, K.R., 1995, Isoplot: A plotting and regression program for radiogenicisotope data, version 2.82: August 15, 1995 revision of U.S. Geological Survey Open-File Report 91-445, 45 p.

Maas, R., McCulloch, M.T., Campbell, I.H., and Coad, P.R., 1986, Sm-Nd and $\mathrm{Rb}-\mathrm{Sr}$ dating of an Archean massive sulfide deposit: Kidd Creek, Ontario: Geology, v. 14, p. 585-588

MacDonald, R., McGarvie, D.W., Pinkerton, H., Smith, R.L., and Palacz, Z.A., 1990, Petrogenetic evolution of the Torfajokull Volcanic Complex, Iceland I. Relationship between the magma types: Journal of Petrology, v. 31, p. 429-459.

MacDonald, R., Sparks, R.S.J., Sigurdsson, H., Mattey, D.P., McGarvie, D.W., and Smith, R.L., 1987, The 1875 eruption of Askja volcano, Iceland, combined fractional crystallization and selective contamination in the generation of rhyolitic magma: Mineralogical Magazine, v. 51, p. 183-202.

Machado, N. and Brooks, C., 1986, Determination of initial ${ }^{87} \mathrm{Sr} /{ }^{86} \mathrm{Sr}$ and ${ }^{143} \mathrm{Nd} /{ }^{144} \mathrm{Nd}$ in primary minerals from mafic and ultramafic rocks: Experimental procedure and implications for the isotopic characteristics of the Archean mantle under the Abitibi greenstone belt, Canada: Geochimica et Cosmochimica Acta, v. 50, p. 2335-2348.

MacLean, W.H., 1990, Mass changes in altered rock series: Mineral. Deposita, v. 25, p. $44-49$.

MacLean, W.H., and Barrett, T.J., 1993, Lithogeochemical techniques using immobile elements: Journal of Geochemical Exploration, v. 48, p. 109133.

MacLean, W.H., and Hoy, L.D., 1991, Geochemistry of hydrothermally altered rocks at the Horne Mine, Noranda, Quebec: Economic Geology, v. 86, p. 506-528.

Marsh, B.D., Gunnarsson, B., Congdon, R., and Carmody, R., 1991, Hawaiian basalt and Icelandic rhyolite: indicators of differentiation and partial melting: Geologische Rundschau, v. 80/2, p. 481-510.

Martin, H., 1986, Effect of steeper Archaean geothermal gradient on geochemistry of subduction-zone magmas: Geology, v. 14, p. 753-756.

Martin, H., 1993, The mechanisms of petrogenesis of the Archaean continental crust - Comparison with modern processes: Lithos, v. 30, p. 373-388. 
McBirney, A.R., 1993, Differentiated rocks of the Galapagos hotspot, in Prichard, H.M., Alabaster, T., Harris, N.B.W., and Neary, C.R., eds., Magamatic processes and plate tectonics: Geological Society Special Publication No. 76, p. 61-69.

McCulloch, M.T. and Bennet, V.C., 1994, Progressive growth of the Earth's continental crust and depleted mantle: Geochemical constraints: Geochimica et Cosmochimica Acta, v. 58, p. 4717-4738.

McDougall, I., Saemundsson, K., Johannesson, H., Watkins, N.D., and Kristjansson, L., 1977, Extension of the geomagnetic polarity time scale to 6.5 m.y.: K-Ar dating, geological and paleomagnetic study of a 3,500$\mathrm{m}$ lava succession in western Iceland: Geological Society of America Bulletin, v. 88, p. 1-15.

McDougall, I., Watkins, N.D., Walker, G.P.L., and Kristjansson, L., 1976, Potassium-argon and paleomagnetic analysis of Icelandic lava flows: limits on the age of anomaly 5: Journal of Geophysical Research, v. 81, p. $1505-1512$.

McGarvie, D.W., MacDonald, R., Pinkerton, H., and Smith, R.L., 1990, Petrogenetic evolution of the Torfajokull Volcanic Complex, Iceland II. The role of magma mixing: Journal of Petrology, v. 31, p. 461-481.

McPhie, J., Doyle, M., and Allen, R., 1993, Volcanic textures: a guide to the interpretation of textures in volcanic rocks: CODES Key Centre, University of Tasmania, Hobart, Tasmania, 196 p.

Meyer, P.S., Sigurdsson, H., and Schilling, J.-G., 1985, Petrological and geochemical variations along Iceland's neovoicanic zones: Journal of Geophysical Research, v. 90, p. 10043-10072.

Michard, A., Albarede, F., Michard, G., Minster, J.F., and Charlou, J.L., 1983, Rare-earth elements and uranium in high-temperature solutions from East Pacific Rise hydrothermal vent field $\left(13^{\circ} \mathrm{N}\right)$ : Nature, v. 303, p. 795797.

Michard, A., and Albarede, F., 1986, The REE content of some hydrothermal fluids: Chemical Geology, v. 55, p. 51-60.

Miller, R.G., and O'Nions, R.K., 1985, Source of Precambrian chemical and clastic sediments: Nature, v. 314, p. 325-330.

Montel, J-M., 1993, A model for monazite/melt equilibrium and application to the generation of granitic magmas: Chemical Geology, v. 110, p. 127-146. 
Morrison, D.A., Davis, D.W., Wooden, J.L., Bogard, D.D., Maczuga, D.E., Phinney, W.C., and Ashwal, L.D., 1985, Age of the Mulcahy Lake intrusion, northwest Ontario, and implications for the evolution of greenstone-granite terrains: Earth and Planetary Science Letters, v. 73 , p. 306-316.

Mortensen, J.K., 1987, Preliminary U-Pb zircon ages for volcanic and plutonic rocks of the Noranda-Lac Abitibi area, Abitibi Subprovince, Quebec, in Current Research, Part A: Geological Survey of Canada, Paper 87-1A, p. 581-590.

Mungall, J.E., and Martin, R.F., 1995, Petrogenesis of basalt-comendite and basalt-pantellerite suites, Terceira, Azores, and some implications for the origin of ocean-island rhyolites: Contributions to Mineralogy and Petrology, v. 119, 43-55.

Murton B.J., Peate, D.W., Arculus, R.J., Pearce, J.A., van der Laan, S., 1992, Trace-element geochemistry of volcanic rocks from Site 786: The IzuBonin Forearc, in Fryer, P., Pearce, J.A., Stokking, L.B., et al., eds., Proceedings of the Ocean Drilling Program: Scientific Results, Vol. 125, p. 211-235.

Nunes, P.D., and Pyke, D.R., 1982, Time-stratigraphic correlation of the Kidd Creek orebody with volcanic rocks south of Timmins, Ontario, as inferred from zircon U-PB ages: Economic Geology, v. 76, p. 944-951.

O'Nions, R.K., and Gronvold, K., 1973, Petrogenetic relationships of acid and basic rocks in Iceland: Sr-isotopes and rare-earth elements in late and postglacial volcanics: Earth and Planetary Science Letters, v. 19, p. 397409.

Olson, P.E., Crick, D., Brisbin, D.I., and Cook, R.E., 1994, Kidd Creek Mine, in Field Trip 4 Guidebook (Northeast Ontario): The Fourth Annual CIM Geological Society Field Conference, Sudbury, 1994, 6 p.

Oskarsson, N., Sigvaldason, G.E., and Steinthorsson, S., 1982, A dynamic model of rift zone petrogenesis and the regional petrology of Iceland: Journal of Petrology, v. 23, p. 28-74.

Oskarsson, N., Steinthorsson, S., and Sigvaldason, G.E., 1985, Iceland geochemical anomaly: origin, volcanotectonics, chemical fractionation and isotope evolution of the crust: Journal of Geophysical Research, v. 90 , p. 10011-10025

Pallister, J.S., 1987, Magmatic history of Red Sea rifting: Perspective from the central Saudi Arabian coastal plain: Geological Society of America Bulletin, v. 98, p. 400-417. 
Pearce, J.A., and Cann, J.R., 1973, Tectonic setting of basic volcanic rocks determined using trace element analyses: Earth and Planetary Science Letters, v. 19, p. 290-300.

Pearce, J.A., and Norry, M.J., 1979, Petrogenetic implications of $\mathrm{Ti}, \mathrm{Zr}, \mathrm{Y}$, and $\mathrm{Nb}$ variations in volcanic rocks: Contributions to Mineralogy and Petrology, $v$. 69 , p. $33-47$.

Pearce, J.A., Harris, N.B.W., and Tindle, A.G., 1984, Trace element discrimination diagrams for the tectonic interpretation of granitic rocks: Journal of Petrology, v. 25, p. 956-983.

Percival, J.A., Stern, R.A., Skulski, T., Card, K.D., Mortensen, J.K., and Begin, N.J., 1994, Minto block, Superior province: Missing link in deciphering assembly of the craton at $2.7 \mathrm{Ga}$ : Geology, v. 22, p. 839-842.

Piepgras, D.J., and Wasserburg, G.J., 1980, Neodymium isotopic variations in seawater: Earth and Planetary Science Letters, v. 50, p. 128-138.

Piepgras, D.J., and Wasserburg, G.J., 1985, Strontium and neodymium isotopes in hot springs on the East Pacific Rise and Guaymas Basin: Earth and Planetary Science Letters, v. 72, p. 341-356.

Piper, J.D.A., 1971, Ground magnetic studies of crustal growth in Iceland: Earth and Planetary Science Letters, v. 12, p. 199-207.

Poitrasson, F., Pin, C., and Duthou, J., 1995, Hydrothermal remobilization of rare earth elements and its effect on $\mathrm{Nd}$ isotopes in rhyolite and granite: Earth and Planetary Science Letters, v. 130. p. 1-11.

Richard, P., Shimizu, N., and Allegre, C.J., $1976,{ }^{143} \mathrm{Nd} /{ }^{146} \mathrm{Nd}$, a natural tracer: an application to oceanic basalts: Earth and Planetary Science Letters, $v$. 31 , p. 269-278.

Riverin G., and Hodgson, C.J., 1980, Wall-rock alteration at the Millenbach CuZn mine, Noranda, Quebec: Economic Geology, v. 75, p. 424-444.

Robinson, P.T., and Elders, W.A., 1976, Quaternary volcanism in the Salton Sea geothermal field, Imperial Valley, California: Geological Society of America Bulletin, v.87, p. 347-360.

Rollinson, H.R., 1993, Using geochemical data: Harlow, England, Longman Scientific and Technical, $352 \mathrm{p}$. 
Romick, J.D., Kay, S.M., and Kay, R.W., 1992, The influence of amphibole fractionation on the evolution of calc-alkaline andesite and dacite tephra from the central Aleutians, Alaska: Contributions to Mineralogy and Petrology, v. 112, p. 101-118.

Rona, P.A., 1988, Hydrothermal mineralization at ocean ridges: Canadian Mineralogist, v. 26, p. 431-466.

Rona, P.A., and Scott, S.D., 1993, A Special Issue on sea-floor hydrothermal mineralization: new perspectives (preface): Economic Geology, v. 88, p. 1935-1975.

Rose, W.I., Grant, N.K., and Easter, J., 1979, Geochemistry of the Los Chocoyos Ash, Quezaltenango Valley, Guatemala: Geological Society of America, Special Paper 180, p. 87-99.

Saemundsson, K., 1978, Fissure swarms and central volcanoes of the neovolcanic zones of Iceland: Geol. Jour. Spec. Issue, v. 10, p. 415-432.

Sajona, F.G., Maury, R.C., Bellon, H., Cotten, J., Defant, M.J., and Pubellier, M., 1993, Initiation of subduction and the generation of slab melts in western and eastern Mindanao, Philippines: Geology, v. 21, p. $1007-$ 1010.

Saunders, A.D., Tarney, J., Stern, C.R., and Dalziel, I.W.D., 1979, Geochemistry of Mesozoic marginal basin floor igneous rocks from southern Chile: Geological Society of America Bulletin, Part I, v. 90, p. 237-258.

Schade, J., Cornell, D.H., and Theart, H.F., 1989, Rare earth element and isotopic evidence for the genesis of the Prieska massive sulfide deposit, South Africa: Economic Geology, v. 84, p. 49-63.

Schandl, E.S., and Gorton, M.P., 1991, Postore mobilization of rare earth elements at Kidd Creek and other Archean massive sulfide deposits: Economic Geology, v. 86, p. 1546-1553.

Schmid, R., 1981, Descriptive nomenclature and classification of pyroclastic deposits and fragments: Recommendations of the IUGS Subcommission on the systematics of igneous rocks: Geology, v. 9, p. 41-43.

Shand, S.J., 1951, Eruptive rocks: John Wiley and Sons, New York.

Shaw, D.M., Dicken, A.P., Li, H., McNutt, R.H., Schwarcz, H.P., and Truscott, M.G., 1994, Crustal geochemistry in the Wawa-Foleyet region, Ontario: Canadian Journal of Earth Science., v. 31, p. 1104-1121. 
Shimizu, H., Umemoto, N., Masuda, A., and Appel, P.W.U., 1990, Sources of iron-formations in the Archean Isua and Malene supracrustals, West Greenland: Evidence from La-Ce and Sm-Nd isotopic data and REE abundances: Geochimica et Cosmochimica Acta, v. 54, p. 1147-1154.

Shirey, S.B., 1991, The Rb-Sr, Sm-Nd and Re-Os isotopic systems: A summary and comparison of their applications to the cosmochronology and geochronology of igneous rocks, in Heaman, L., and Ludden, J.N., eds., Applications of radiogenic isotope systems to problems in geology: Mineralogical Association of Canada, Short Course Handbook, v. 19, p. 103-166.

Shirey, S.B., and Hanson, G.N., 1986, Mantle heterogeneity and crustal recycling in Archean granite-greenstone belts: Evidence from $\mathrm{Nd}$ isotopes and trace elements in the Rainy Lake area, Superior Province, Ontario, Canada: Geochimica et Cosmochimica Acta, v. 50, 2631-2651

Sigmarsson, O., Condomines, M., and Fourcade, S., 1992, A detailed Th, Sr and $\mathrm{O}$ isotope study of Hekla: differentiation processes in an Icelandic volcano: Contributions to Mineralogy and Petrology, v. 112, p. 20-34.

Sigmarsson, O., Hemond, M., Condomines, M., Fourcade, S., and Oskarsson, N., 1991, Origin of silicic magma in Iceland revealed by Th isotopes: Geology, v. 19, p. 621-624.

Sigurdsson, H., 1977, Generation of Icelandic rhyolites by melting of plagiogranites in the oceanic layer: Nature, v. 269, p. 25-28.

Sigurdsson, H., and Sparks, R.S.J., 1978, Lateral magma flow within rifted Icelandic crust: Nature, v. 274, p. 126-130.

Sigurdsson, H., and Sparks, R.S.J., 1981, Petrology of rhyolitic and mixed magma ejecta from the 1875 eruption of Askja, Iceland: Journal of Petrology, v. 22, p. 41-84.

Slack, J.F., and Coad, P.R., 1989, Multiple hydrothermal and metamorphic events in the Kidd Creek volcanogenic massive sulphide deposit, Timmins, Ontario: evidence from tourmalines and chlorites: Canadian Journal of Earth Science., v. 26, 694-715.

Smith, D.R., and Leeman, W.P., 1987, Petrogenesis of Mount St. Helens dacitic magmas: Journal of Geophysical Research, v. 92, p. 10313-10334.

Spulber, S.D., and Rutherford, M.J., 1983, The origin of rhyolite and plagiogranite in oceanic crust: an experimental study: Journal of Petrology, v. 24, p. 1-25. 
Stern, R.A., Percival, J.A., and Mortensen, J.K., 1994, Geochemical evolution of the Minto block: a 2.7 Ga continental magmatic arc built on the Superior proto-craton: Precambrian Research, v. 65, p. 155-153.

Stern, R.A., Syme, E.C., Bailes, A.H., Galley, A.G., Thomas, D.J., and Lucas, S.B., 1992, Nd-isotopic stratigraphy of Early Proterozoic Amisk Group metavolcanic rocks from the Flin Flon belt, Manitoba and Saskatchewan, in Radiogenic age and isotopic studies: Report 6; Geological Survey of Canada, Paper 92-2, p. 73-84.

Storey, M., Mahoney, J.J., Kroenke, L.W., and Saunders, A.D., 1991, Are oceanic plateaus sites of komatiite formation?: Geology, v. 19, p. 376-379.

Sun, S.-S., 1980, Lead isotopic study of young volcanic rocks from mid-ocean ridges, ocean islands and island arcs: Phil. Trans. R. Soc. Lond., v. A297, p. 409-445.

Sun, S.-S., and McDonough, W.F., 1989, Chemical and isotopic systematics of oceanic basalts: implications for mantle composition and processes, in Saunders, A.D., and Norry, M.J., eds., Magmatism in the ocean basins: Geological Society Special Publication No. 42, p. 313-345.

Sun, S.-S., and Nesbitt, R.W., 1977, Chemical heterogeneity of the Archaean mantle, composition of the earth and mantle evolution: Earth and Planetary Science Letters, v. 35, p. 429-448.

Taylor, R.N., Murton, B.J., and Nesbitt, R.W., 1992, Chemical transects across intra-oceanic arcs: implications for the tectonic setting of ophiolites, in Parson, L.M., Murton, B.J., and Browning, P., eds., Ophiolites and their modern oceanic analogues: Geological Society Special Publication No. 60 , p. $117-132$

Taylor, S.R., and McLennan, S.M., 1985, The continental crust: its composition and evolution: Oxford, Blackwell Scientific, $312 p$.

Thompson, R.N., 1982, Magmatism of the British Tertiary Volcanic Province: Scottish Journal of Geology, v. 18, p. 1-108.

Thurston, P.C., 1981, Economic evaluation of Archaean felsic volcanic rocks using REE geochemistry, in Glover, J.E., and Groves, D.I., eds., Archean Geology: Second International Symposium, Perth, 1980: Geological Society of Australia, Special Publication No. 7, p. 439-450. 
Thurston, P.C., Ayres, L.D., Edwards, G.R., Gelinas, L., Ludden, J.N., and Verpaelst, P., 1985, Archean bimodal volcanism, in, Ayres, L.D., Thurston, P.C., Card, K.D., and Weber, W., eds., Evolution of Archean supracrustal sequences: Geological Association of Canada Special Paper 28, 1985.

Tourpin, S., Gruau, G., Blais, S., and Fourcade, S., 1991, Resetting of REE, and $\mathrm{Nd}$ and $\mathrm{Sr}$ isotopes during carbonatization of a komatiite flow from Finland: Chemical Geology, v. 90, p. 15-29.

Ujike, O. and Goodwin, A.M., 1987, Geochemistry and origin of Archean felsic metavolcanic rocks, central Noranda area, Quebec, Canada: Can. J. Earth Sci., v.24, p.2551-2567.

Valbracht, P.J., 1992, $\varepsilon_{\mathrm{Nd}}(\mathrm{T})$ variation in an Early Proterozoic actinolite skarn, Sweden, reflecting felsic volcanite-seawater interaction: Geologie en Mijnbouw, v. 71, p. 65-70.

Valsami-Jones, E., and Cann, J.R., 1994, Controls on the Sr and $\mathrm{Nd}$ isotopic compositions of hydrothermally altered rocks from the Pindos Ophiolite Greece: Earth and Planetary Science Letters, v. 125, p. 39-54.

Vervoort, J.D., White, W.M., and Thorpe, R.I., 1994, Nd and Pb isotope ratios of the Abitibi greenstone belt: new evidence for very early differentiation of the Earth: Earth and Planetary Science Letters, v. 128, p. 215-229.

Walker, G.P.L., 1966, Acid volcanic rocks in Iceland: Bull. Volcanol., v. 29, p. $375-406$.

Walker, G.P.L., 1973, Lengths of lava flows: Phil. Trans. R. Soc. Lond., A, v.274, p. $107-118$.

Walker, R.J., Shirey, S.B., and Stecher, O., 1988, Comparative Re-Os, Sm-Nd and $\mathrm{Rb}$-Sr isotope and trace element systematics for Archean komatiite flows from Munro Township, Abitibi Belt, Ontario: Earth and Planetary Science Letters, v. 87, p. 1-12.

Walker, R.R. and Mannard, G.W., 1974, Geology of the Kidd Creek Mine - A progress report: CIM Bulletin, v. 67, no. 752, p. 41-57.

Walker, R.R., Matulich, A., Amos, A.C., Watkins, J.J., and Mannard, G.W., 1975, The geology of the Kidd Creek mine: Economic Geology, v. 70, p. 80-89

Walter, R.C., Hart, W.K., and Westgate, J.A., 1987, Petrogenesis of a basaltrhyolite tephra from the west-central Afar, Ethiopia: Contributions to Mineralogy and Petrology, v. 95, p. 462-480. 
Watson, E.B., and Harrison, T.M., 1983, Zircon saturation revisited: temperature and composition effects in a variety of crustal magma types: Earth and Planetary Science Letters, v. 64, p. 295-304.

Weaver, S.D., Saunders, A.D., Pankhurst, R.J., and Tarney, J., 1979, A geochemical study of magmatism associated with the initial stages of back-arc spreading: Contributions to Mineralogy and Petrology, v. 68, p. 151-169.

White, W.M., Tapia, M.D.M., and Schilling, J., 1979, The petrology and geochemistry of the Azores Islands: Contributions to Mineralogy and Petrology, v. 69, p. 201-213.

Williams, H.R., Stott, G.M., and Thurston, P.C., 1992, Tectonic Evolution of Ontario: Summary and Synthesis, Part 1: Revolution in the Superior Province: in Thurston, P.C., Williams, H.R., Sutcliffe, R.H., and Stott, G.M., eds., Geology of Ontario: Ontario Geological Survey, Special Volume 4, Part 2, p. 1256-1294.

Wilson, J.T., 1973, Mantle plumes and plate motion: Tectonophysics, v. 19, p. 149-164.

Wilson, M., 1989, Igneous petrogenesis: London, Chapman and Hall, 456 p.

Winchester, J.A., and Floyd, P.A., 1977. Geochemical discrimination of different magma series and their differentiation products using immobile elements: Chem. Geol., v.20, p.325-343.

Wood, D.A., 1978, Major and trace element variations in the Tertiary lavas of eastern Iceland and their significance with respect to the Iceland geochemical anomaly: Journal of Petrology, v. 19, p. 393-436.

Wood, D.A., 1980, The application of a Th-Hf-Ta diagram to problems of tectonomagamtic classification and to establishing the nature of crustal contamination of basaltic lavas of the British Tertiary Volcanic Province: Earth and Planetary Science Letters, v. 50, p. 11-30.

Wood, D.A., Joron, J.-L., and Treuil, M., 1979, A re-appraisal of the use of trace elements to classify and discriminate between magma series erupted in different tectonic settings: Earth and Planetary Science Letters, v. 45, p. 326-336.

Wright, J.V., Smith, A.L., and Self, S., 1980, A working terminology of pyroclastic deposits: Journal of Volcanology and Geothermal Research, v. 8, p. 315336. 
York, D., 1969, Least-squares fitting of a straight line with correlated errors: Earth and Planetary Science Letters, v. 5, p. 320-324.

Zindler, A., 1982, $\mathrm{Nd}$ and $\mathrm{Sr}$ isotopic studies of komatiites and related rocks, in Arndt, N.T., and Nesbit, E.G., eds., Komatiites: George Allen and Unwin, New York, p. 399-420. 


\section{Appendix 1}

\section{VOLCANOLOGY AND GEOCHEMISTRY OF THE LOWER AND MIDDLE MEMBERS OF THE KIDD CREEK FORMATION}

Geological mapping at the Kidd Creek Mine, and discussion with mine geological staff, has led to the subdivision of the Kidd Creek formation into the Lower, Middle and Upper members (some of this mapping is presented in Chapter 2 and in Maps 2 to 7). The volcanology and geochemistry of the Upper member, the QP rhyolite, are discussed at length in Chapter 2.

\section{Lower Member of the Kidd Creek Formation}

The term "FW rhyolite" is used by the author to refer to rhyolite within the Lower and Middle members of the Kidd Creek formation which may be distinguished chemically and petrographically from Upper member rhyolite (QP rhyolite; Chapter 2; Figures 1.3 and 2.21). The Lower member of the Kidd Creek formation is composed almost entirely of vent-proximal facies of FW rhyolite. Vent-proximal facies include massive and flow-banded coherent rhyolite, in situ to locally transported autoclastic rhyolite breccia, and rhyolite hyaloclastite (see Appendix 8 for a description of volcaniclastic rock terminology used in this thesis, and Appendix 10 for rock type descriptions). In situ FW rhyolite breccia is approximately equivalent to the "crackle-breccia" of 
Coad (1985). The breccia and hyaloclastite of the Lower member are monomict and geochemically identical to the coherent rhyolite facies except for variability introduced by hydrothermal metasomatism. Both the monomict nature the Lower member volcaniclastic rocks and the geochemical homogeneity of the fragmental rocks with coherent rhyolite are incompatible with the mixing of clast types likely to occur during significant transport. Additional evidence for an autoclastic origin for the breccia and hyaloclastite include: (i) in situ autoclastic breccia is devoid of matrix (the darker areas between fragments are the result of phyllosilicate crystallization during alteration), (ii) coherent rhyolite grades with increasing multidirectional fracturing into autoclastic breccia (2323 Pillar Access Drive and 4700 Drill Drive; Figure A7.3 to A7.6; Map 6), and (iii) jig-saw fit texture is common within the autoclastic breccia and hyaloclastite (Figures A7.4 and A7.9); jig-saw fit texture implies that if the interfragmental material was removed the fragments would fit back together leaving little or no space between fragments). The rounded appearance of some fragments within autoclastic breccia (brecciaconglomerate) is ascribed to (i) alteration processes with more intense sericitization and chloritization alteration occurring near fracture intersections, and (ii) local resedimentation of some breccia (Figure A7.9). Silicified areas of autoclastic breccia are generally mapped as "cherty breccia" or "curdy rhyolite" by mine staff. Much of the chalcopyrite-rich stringer zone beneath the north and central orebodies occurs within silicified, autoclastic, rhyolite breccia of the Lower member (Figure A7.5). Other minerals accompanying the chalcopyrite are pyrrhotite, chlorite, sericite, tourmaline, and albite. Autoclastic breccia marginal to chalcopyrite stringer zones commonly contains sphalerite as 
fracture-controlled to pervasive "stain" (very fine-grained, disseminated sphalerite; Figure A7.3, A7.4, and A7.9; Map 6). Sphalerite mineralization terminates abruptly at the contact between autoclastic breccia and coherent rhyolite (sphalerite-free). This relationship is thought to reflect a primary permeability contrast between coherent rhyolite and in situ rhyolite breccia during the mineralization event.

\section{Distribution of Coherent Rhyolite Within the Lower Member}

FW rhyolite in the Lower member of the Kidd Creek formation was mapped in the footwall of the north and central orebodies on 1600,2300, and 4700 levels of the Kidd Creek MIne (Maps 2 and 6). This work indicates that rocks mapped as rhyolite by mine geologists correspond to the massive and flow-banded coherent facies of the FW rhyolite and exclude the autoclastic facies, much of which is mapped as "cherty breccia". Figure A1.1 shows the distribution of coherent rhyolite in the footwall of the north and central orebodies from the 800 foot level ( 3085 m elevation) to the 6000 foot level (1512 m elevation), a vertical distance of $1573 \mathrm{~m}$. The data for this diagram were taken from company level plans. The view in Figure A1.1 is toward the east from $12^{\circ}$ above a horizontal plane. Behind the view (to the east and stratigraphically lower) ultramafic rocks are dominant while in front of the view (to the west and stratigraphically higher) the main rock types are autoclastic rhyolite, polymict pebble and boulder conglomerates, argillite and massive sulfides of the north and central orebodies. 
Also shown on Figure A1.1 is the distribution of structurally related "fingers" of ultramafic rock which jut toward the west into the felsic volcanic and volcaniclastic pile. Regarding these ultramafic fingers, Bleeker (1995, p. 116) stated "... the apparent apophyses coincide with tight to isoclinal F1 hinges and are thus structural rather than primary features". In the upper levels of the mine the southern ultramafic finger lies along the east-west shear zone. The northern ultramafic finger is situated at or near an abrupt change in strike of volcanic strata related to either tight folding, faulting, or both. Volcanic strata are west-facing in the immediate mine area and north-facing to the north and east of the mine.

Figure A1.1 demonstrates that coherent FW rhyolite of the Lower member of the Kidd Creek formation forms two distinct, parallel "ridges" approximately $200 \mathrm{~m}$ apart which plunge steeply to the north. Only the southern ridge is exposed in underground workings. The attitude of these FW rhyolite ridges is parallel to that of the QP rhyolite ridges of the Upper member (Chapter 2). Figure A1.1 shows that the two FW rhyolite ridges are continuous between the 800 foot level and 6000 foot levels and maps of the open pit show that these two ridges extend to surface (Walker and Mannard, 1974; Walker et al., 1975) for a total known length of $1.8 \mathrm{~km}$. The area between the coherent rhyolite ridges consists primarily of rhyolite autoclastic breccia ("cherty breccia") which hosts chalcopyrite-rich stringer ore beneath the north and central orebodies. These ridges are interpreted to occur directly over fissures which fed the rhyolitic volcanism. Parallelism between the FW rhyolite ridges and the 
ultramafic trend suggests that the structures which control the location of the ultramafic fingers, which lie marginal to the rhyolite ridges, are parallel to the FW rhyolite feeding fissures. Parallelism between the FW rhyolite ridges of the Lower member, the structures controlling the ultramafic fingers, and the QP rhyolite ridges of the Upper member indicates that these trends represent a series of parallel, long-lived synvolcanic structures.

The two ridges shown in Figure A1.1 are interpreted to represent two linear bodies of coalescing rhyolite cryptodomes formed above their feeding fissures and below a covering of in situ autoclastic breccia. This interpretation is consistent with their morphology, the lack of internal flow contacts and interflow units, and the occurrence of complete lateral gradations between (i) unfractured coherent rhyolite, (ii) coherent rhyolite with polygonal fractures, and (iii) in-situ autoclastic rhyolite breccia.

\section{Middle Member of the Kidd Creek Formation}

The Middle member of the Kidd Creek formation is characterized by a suite of transported volcaniclastic rocks composed largely of resedimented autoclastic rhyolite fragments. Resedimentation is interpreted to have been a response to gravitational instability and transport possibly down a fault scarp or volcanic edifice. Volcaniclastic rock types of the Middle member include polymict boulder conglomerate, polymict pebble conglomerate, monomict rhyolite pebble conglomerate, sandstone and mudstone. Non-volcaniclastic 
lithologic units within the Middle member are graphitic argillite and massive sulfide consisting of one or more of pyrite, sphalerite, galena, chalcopyrite, and pyrrhotite. Textures indicate that a large proportion of the massive sulfide ores formed by subseafloor replacement of volcaniclastic rocks. Evidence of replacement includes (i) the screens of rhyolite pebbles within massive sulfide ore mapped in 2129 Crosscut (Map 5), and (ii) the sulfide replacement front mapped at the top of the north orebody in 2421K Pillar Slot (Map 7). The common occurrence of pyrite and sphalerite ( \pm galena) clasts in polymict conglomerate within the Middle member demonstrates that early massive sulfide lenses underwent destruction and transport (locally the proportion of sphalerite-rich clasts within volcaniclastic conglomerate is high enough to be of ore grade). The rare occurrence of chalcopyrite clasts within volcaniclastic conglomerate indicates that either (i) destructive processes (e.g., erosion) rarely penetrated deeply enough to uncover stringer zone mineralization, or (ii) the stringer zone during the initial stages of deposit formation was pyrite- and sphalerite-rich rather than chalcopyrite-rich. The second interpretation is consistent with the replacement of massive pyrite-sphalerite by chalcopyrite (e.g. 2129 Crosscut), pyrite-sphalerite mineralization marginal to chalcopyrite stringers in the Lower member (Figures A7.2 to A7.4 and A7.9), and the occurrence of sphalerite-stained, pyrite-veined rhyolitic clasts within the volcaniclastic, polymict conglomerates (Figure A7.13). Hydrothermally altered, tan mafic clasts are also common in volcaniclastic breccias where they generally form less than $5 \%$ of the clast population but locally form up to $30 \%$ of the clasts. Argillite clasts are an important clast type stratigraphically above the graphitic argillite unit in the immediate hanging wall of the north orebody. 
Locally, volcaniclastic rocks may have an argillaceous matrix.

The Middle member of the Kidd Creek formation also includes coherent rhyolite, autoclastic rhyolite breccia, and rhyolite hyaloclastite which are interlayered with volcaniclastic rocks (e.g. 1602 Drive South, 2129 Crosscut). Unlike the Lower member, where these rocks dominate, coherent and autoclastic rhyolites generally form less than $50 \%$ of stratigraphic successions within the Middle member. The recognition of coherent and autoclastic rhyolite within rocks of the Middle member is a new contribution to the geologic understanding of the Kidd Creek formation. Many of these rocks were formerly mapped as rhyolite tuffs (coherent rhyolite and rhyolite hyaloclastite) and "curdy rhyolite" (autoclastic rhyolite breccia-conglomerate).

\section{Physical evidence of Middle member coherent and autoclastic rhyolite}

(i) Coherent rhyolites, which are weakly quartz porphyritic, have randomly dispersed, generally intact quartz phenocrysts up to $2 \mathrm{~mm}$ across in an aphanitic groundmass (Figure A7.20). Less altered samples also contain a small percentage of intact, randomly distributed feldspars up to $2 \mathrm{~mm}$ across. Within these rocks there is no evidence of layering based on grain size, broken phenocrysts are not abundant, and no lithic clasts or bubble-wall shards were observed. 
(ii) Coherent rhyolites are locally flow banded on a microscopic scale (Figure A7-24).

(iii) Some coherent rhyolite samples contain quartz spherulites up to $0.3 \mathrm{~mm}$ in diameter. Coherent rhyolites commonly contain spherical aggregates of quartz crystals (spherules) which are interpreted to be sector recrystallized spherulites (Figures A7.21 to A7.23).

(iii) Samples with definite spherulites contain a microscopic anastomosing fracture pattern caused by fractures wrapping around spherulites (i.e., fractures occupy the spaces between spherulites). A similar anastomosing fracture pattern is common in coherent rhyolites which contain spherules but lack clearly identifiable spherulites.

(iv) Autoclastic rhyolite breccia and rhyolite hyaloclastite are monomict (Figures A7.4, A7.9, and A7.25). For example, a polished slab of "curdy" rhyolite from 1602 Drive South is clearly a monomict rhyolite breccia-conglomerate (Figure A7.9).

(v) In situ rhyolite breccias display jig-saw fit texture (i.e. fragments may be visually put back together by removing matrix; Figure A7.4 and A7.9). Jig-saw fit texture is also locally present in rhyolite hyaloclastite. 
(vi) All known rhyolites in the Kidd Creek Mine area are essentially nonvesicular. Therefore, local formation of tuff by magmatic eruption is unlikely; as noted above, bubble-wall glass shards are absent.

\section{Geochemical evidence of Middle member coherent and autoclastic rhyolite}

Figure $\mathrm{A} 1.2$ shows a plot of $\mathrm{Zr}$ versus $\mathrm{TiO}_{2}$ for (i) ultramafic rock samples from stratigraphically below the Kidd Creek formation, (ii) Lower member rhyolites $\left(\mathrm{RH}_{\mathrm{LM}}\right.$ : coherent rhyolites and autoclastic breccias from underground and the east outcrop), (iii) argillites of the Middle member, (iv) mafic volcanic fragments within volcaniclastic conglomerate of the Middle member, (v) finegrained gabbros and basalts of the wedge gabbro sill (between the Middle and Upper members), and (vi) mafic volcanic rocks, primarily basalts, from above the Kidd Creek formation. A similar diagram is presented in Figure A1.3 for rhyolites (coherent and autoclastic) and resedimented volcaniclastic rocks of the Middle member. Basaltic rocks in the Kidd Creek Mine area are divided into two groups, $\mathrm{Al}$-rich and $\mathrm{P}$-rich, as identified on the $\mathrm{Al}_{2} \mathrm{O}_{3}$ versus $\mathrm{P}_{2} \mathrm{O}_{5}$ diagram in Figure A1.4. The P-rich basaltic rocks, which also tend to be enriched in $\mathrm{Ti}, \mathrm{Fe}$, $\mathrm{Zr}, \mathrm{Nb}$, and LREE, grade into "icelandic" andesites with increasing silica content. Note in Figure A1.3 that the resedimented volcaniclastic rock samples tend to plot above the $\mathrm{RH}_{\mathrm{LM}}$ field consistent with the introduction of mafic volcanic clasts \pm argillite clasts ( \pm argillite matrix) during the resedimentation process. However, rocks from the Middle member identified as coherent or autoclastic rhyolite plot within the $\mathrm{RH}_{L M}$ field. The lack of a geochemical mixing component is inconsistent with an interpretation of these rocks as fine-grained, 
distal, resedimented volcaniclastic material. Similar conclusions may be drawn from the $\mathrm{Zr}$ versus $\mathrm{P}_{2} \mathrm{O}_{5}$ plots presented in Figures $\mathrm{A} 1.5$ and $\mathrm{A} 1.6$. The strong linear trends of the rhyolite samples in Figures A1.2, A1.3, A1.5, and A1.6 reflects residual gains and losses of relatively immobile $\mathrm{Zr}, \mathrm{TiO}_{2}$ and $\mathrm{P}_{2} \mathrm{O}_{5}$ due to mass changes (the average least-altered, coherent, footwall rhyolite contains 204 ppm Zr). At infinite mass gain (infinite depletion of $\mathrm{Zr}, \mathrm{TiO}_{2}$ and $\mathrm{P}_{2} \mathrm{O}_{5}$ ) the mass change trends would intersect the origins of the diagrams).

\section{Evidence From Polymict Volcaniclastic Conglomerates On The Timing of Basin Subsidence}

The accumulation of a thick volcaniclastic succession and the pronounced elongation of the orebodies has led researchers to suggest that the Kidd Creek deposit formed in a basin, possibly a rift-related graben, created by subsidence along one or more synvolcanic structures (e.g., Gibson and Kerr, 1993; Bleeker, 1995). The presence of parallel, strongly elongate rhyolite ridges in both the Lower and Upper Kidd Creek formations is compatible with a rift model as is the chemistry of the rhyolites (Chapters 2, 3, and 4). The Kidd Creek formation was deposited on an ultramafic footwall - an extrusive origin for at least part of the ultramafic succession is demonstrated by the presence of spinifex-textured komatiite flows (J. Everest, written communication, 1995). If subsidence occurred prior to the onset of Kidd Creek formation felsic volcanism or if the subsidence exceeded the accumulation rate 
of the Kidd Creek formation then ultramafic rocks would have been exposed on the basin walls (fault scarps). Therefore, early or rapid basin subsidence should be reflected by an ultramafic component within the polymict conglomerates.

No ultramafic clasts were identified by the author during underground mapping and subsequent sample examination. Similarly a study of polished slabs of volcaniclastic conglomerates from the Middle member, which included geochemical analysis of individual clasts, did not reveal ultramafic clasts (S. Petersen, written communication, 1993). However, this evidence does not exclude the possibility that ultramafic clasts were present in the original volcaniclastic conglomerates but have subsequently been rendered unrecognizable due to hydrothermal alteration and mechanical deformation.

In Figures A1.3 and A1.6 the Middle member volcaniclastic rocks appear to be displaced from the $\mathrm{RH}_{\mathrm{LU}}$ field toward the $M V_{P}$ and/or $M V_{A I}$ fields rather than toward the UM field but the data are not conclusive. However, a Zr versus Ni diagram (Figure A1.7) demonstrates that the very low Ni values in the Middle member volcaniclastic rocks are clearly inconsistent with input of ultramafic or $\mathrm{MV}_{\mathrm{Al}}$ clasts but are consistent with input of $\mathrm{Ni}$-poor $\mathrm{MV}_{\mathrm{P}}$ clasts. This is compatible with the fact that chemically analyzed mafic clasts from Middle member volcaniclastic conglomerates fall within the $M V_{P}$ fields on Figures A1.2, A1.4, and A1.7. The lack of an ultramafic component within the polymict conglomerates suggests (i) it is unlikely that significant subsidence occurred before a substantial veneer of rhyolitic and $\mathrm{P}$-rich basaltic $\left(\mathrm{MV}_{\mathrm{P}}\right)$ rocks had been 
extruded above the ultramafic succession, and/or (ii) the rate of subsidence did not exceed the input of Kidd Creek formation volcanic material into the basin. This raises the interesting possibility that subsidence was linked to the onset of rhyolitic and basaltic volcanism such as might occur from the development of a collapse caldera. 
NORTH

ELEVATION (M)

LEVEL (FT)

SOUTH
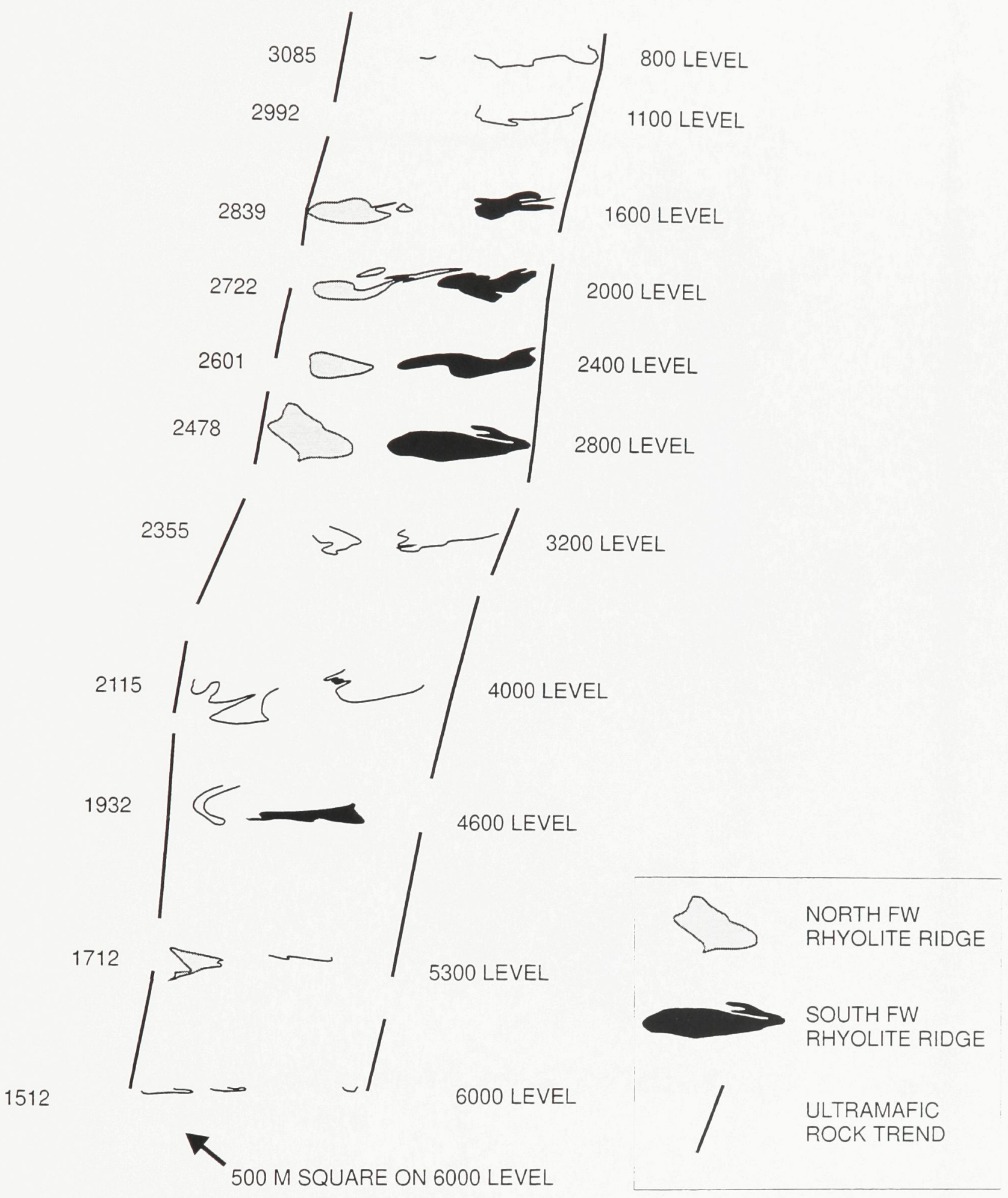

Figure A1.1. North-south section through the north and south ridges of coherent FW rhyolite viewed from the west at an angle of $12^{\circ}$ above a horizontal plane. Areas of rhyolite shown with solid fill have reasonably well defined footwall contacts based on diamond drill hole data. Areas of rhyolite shown as lines lack sufficient diamond drill hole information to define footwall contacts. 
욤

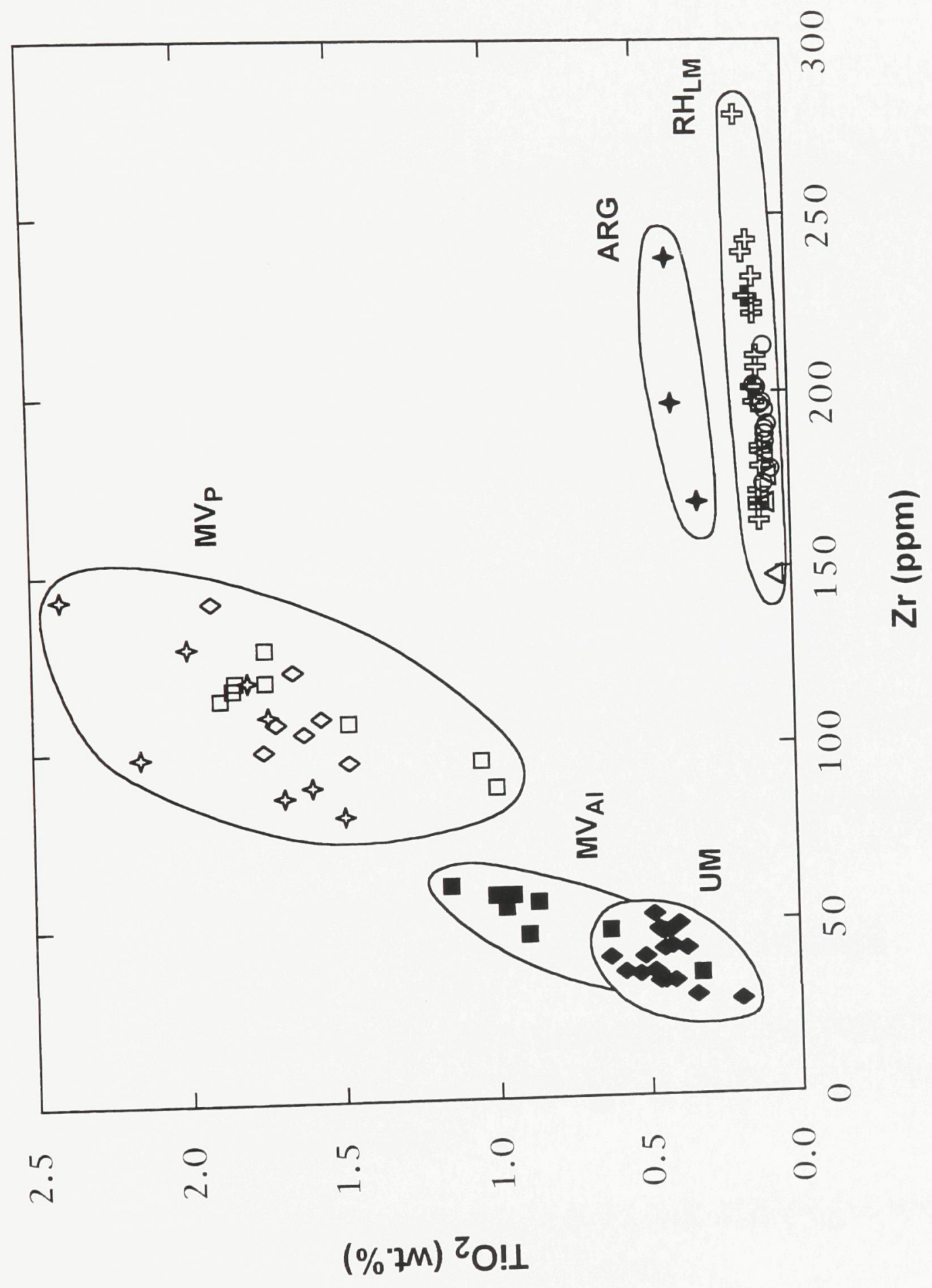




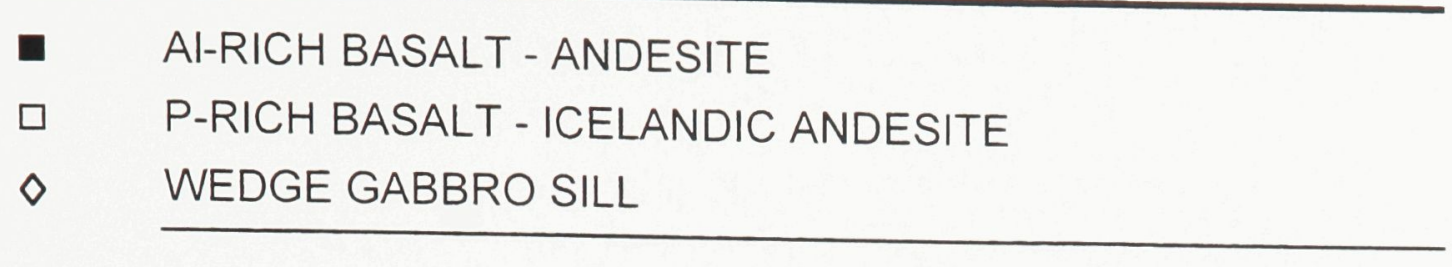

\section{KIDD CREEK FORMATION}

\section{MIDDLE MEMBER}

$\diamond \quad$ MAFIC CLAST IN VOLCANICLASTIC CONGLOMERATE

$\downarrow \quad$ GRAPHITIC ARGILLITE

Y VOLCANICLASTIC MUDSTONE

$+\quad$ VOLCANICLASTIC SANDSTONE

$\times \quad$ Volcaniclastic pebBle conglomerate

- MIDDLE MEMBER AUtOCLASTIC RHYOLITE

- MIDDLE MEMBER COHERENT RHYOLITE

\section{LOWER MEMBER}

ÆEAST OUTCROP AUTOCLASTIC RHYOLITE*

$\triangle \quad$ UNDERGROUND AUTOCLASTIC RHYOLITE

O UNDERGROUND COHERENT RHYOLITE

\section{- ULTRAMAFIC ROCK}

$M_{\text {AI }}$ AI-RICH MAFIC VOLCANIC ROCKS

$M_{P} \quad P-R I C H M A F I C$ VOLCANIC AND INTRUSIVE ROCKS

ARG GRAPHITIC ARGILLITE

$\mathrm{RH}_{\text {LA }}$ LEAST-ALTERED LOWER MEMBER (FW) COHERENT RHYOLITE $\mathrm{RH}_{\text {LU }}$ LOWER MEMBER COHERENT AND AUTOCLASTIC RHYOLITE UM ULTRAMAFIC ROCK

* INCLUDES SAMPLES OF AUTOCLASTIC BRECCIA AND INDIVIDUAL RHYOLITE BLOCKS SAMPLES CONTAINING $>5 \% \mathrm{CO}_{2}$ OR $>4 \%$ S OMITTED ARGILLITE ANALYSES FROM FALCONBRIDGE DATA (COLLECTED BY W. BLEEKER)

Figure A1.2 (Part B - Legend) 


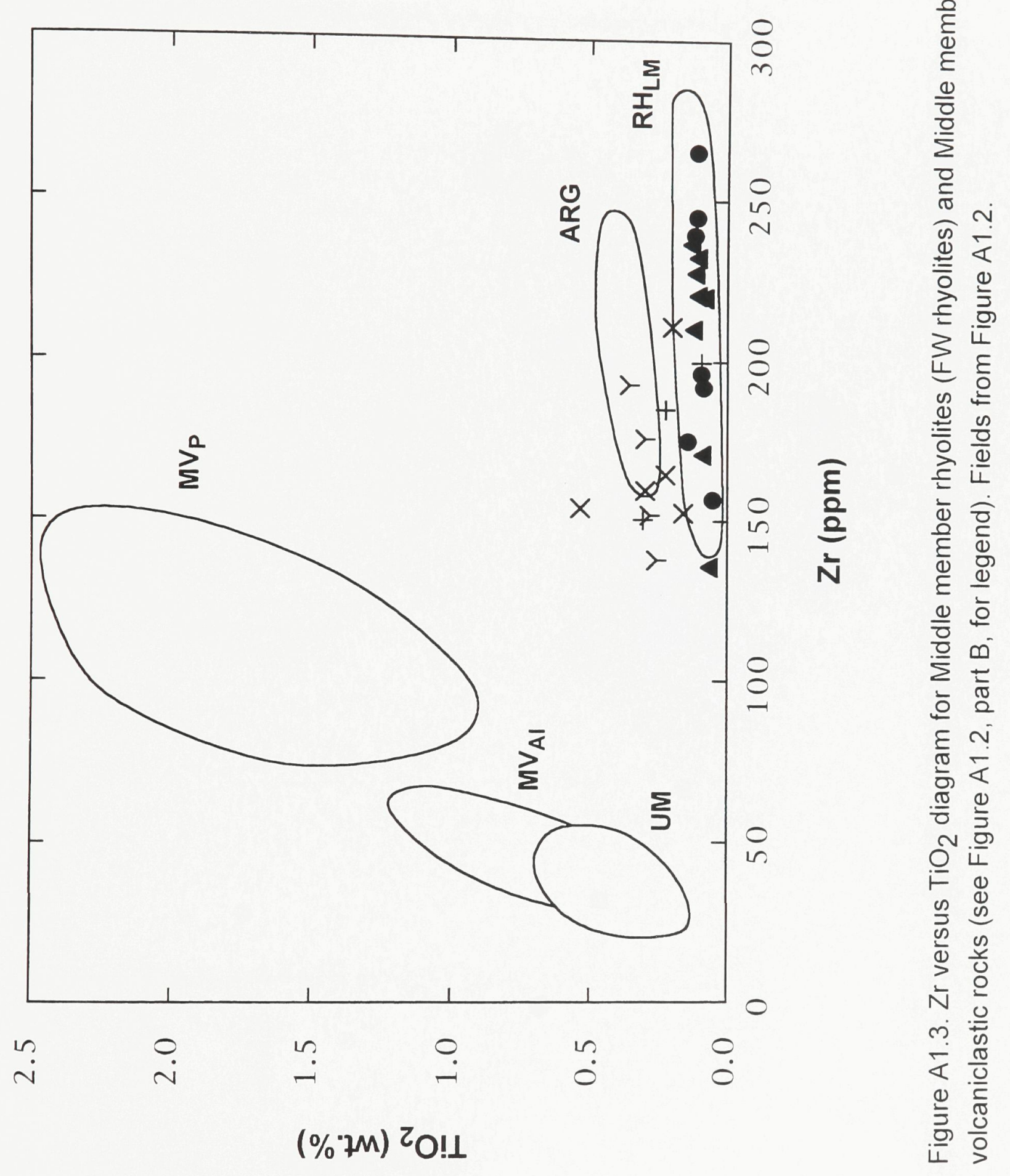


$\stackrel{m}{\sigma}$

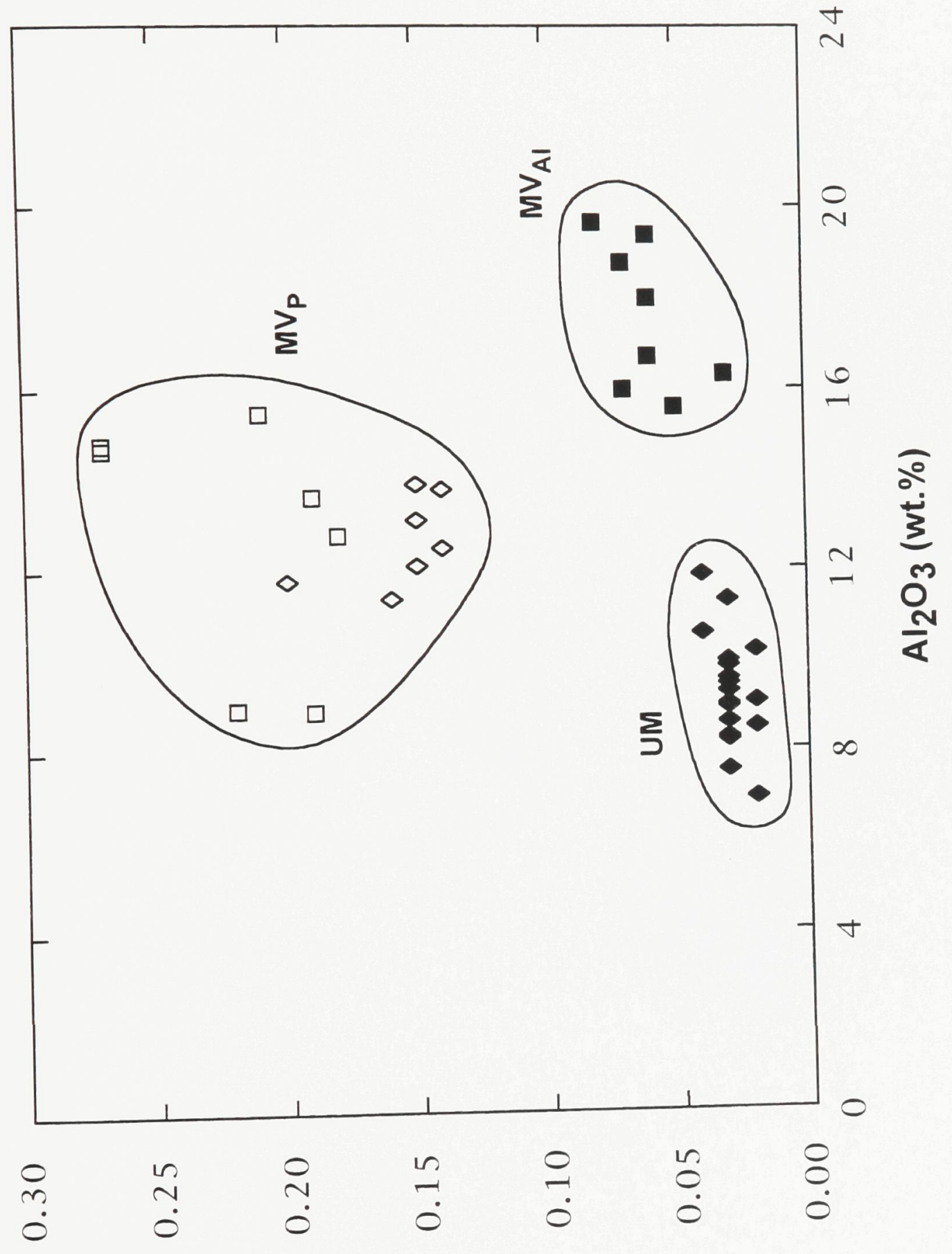

$$
(\%+7 M){ }^{s} o^{2}
$$


声

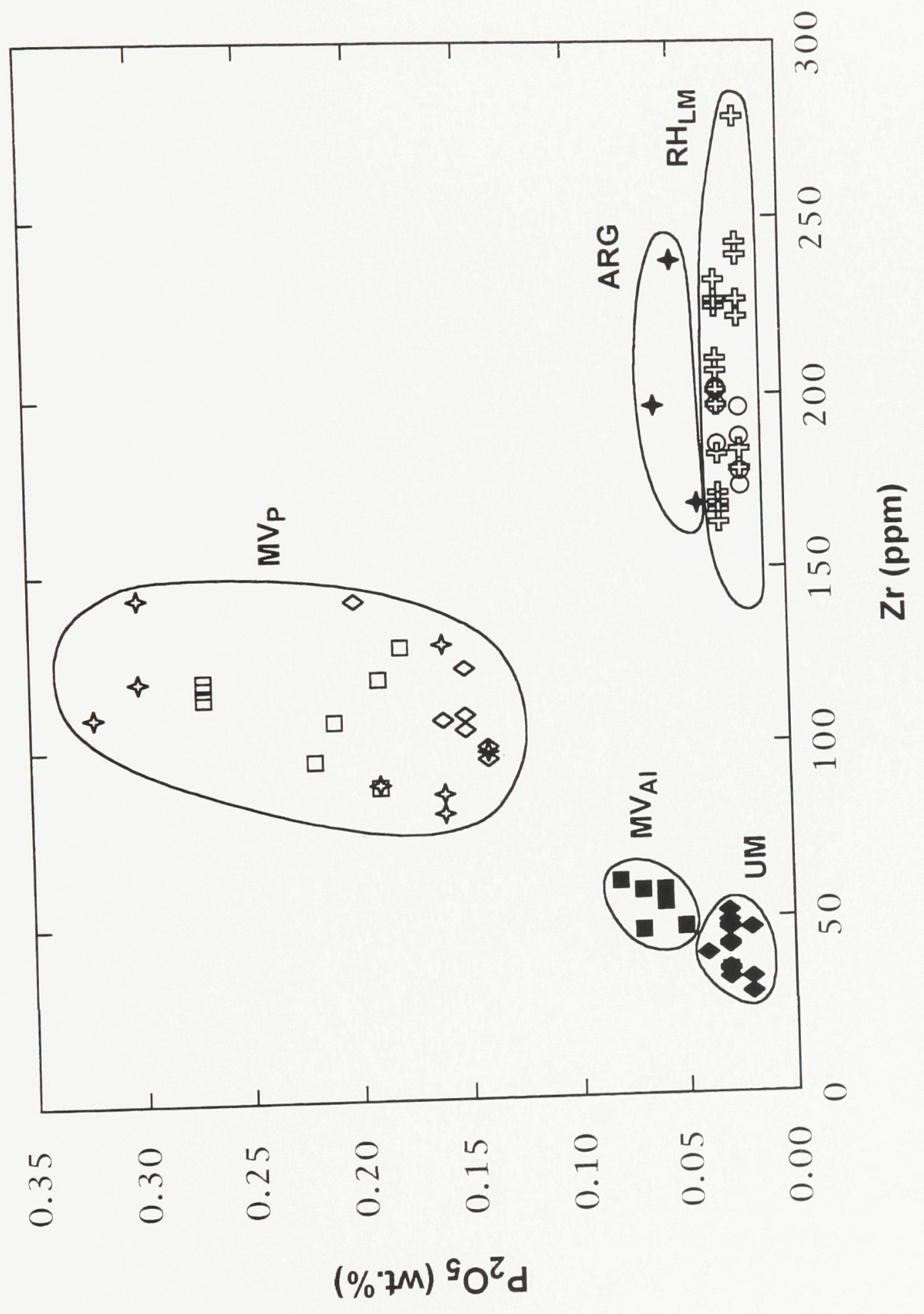

$\frac{\pi}{\frac{1}{\sigma}}$

$\stackrel{\varrho}{\Sigma}$

ఖ 
$\stackrel{\mathscr{Q}}{\circ}$
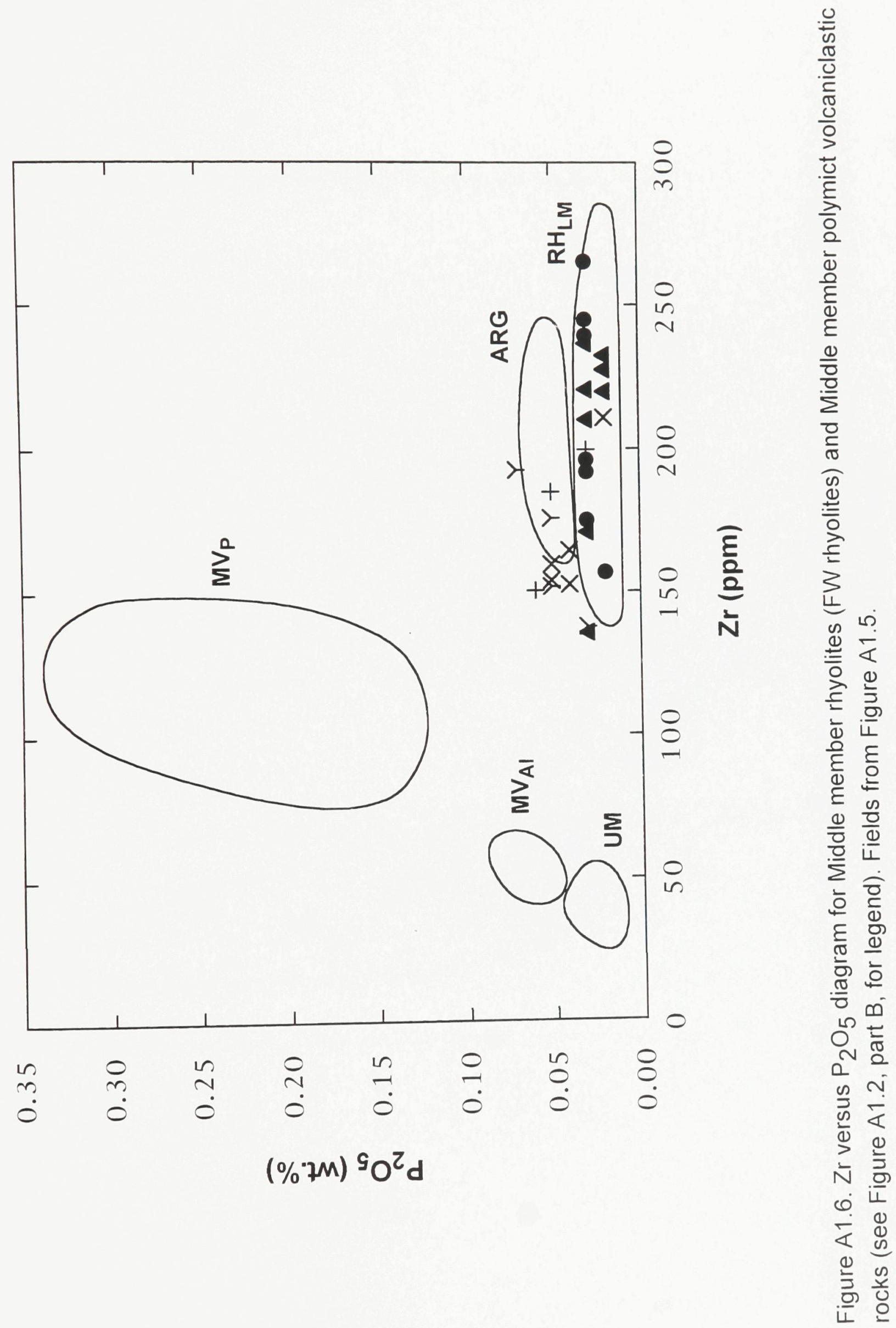


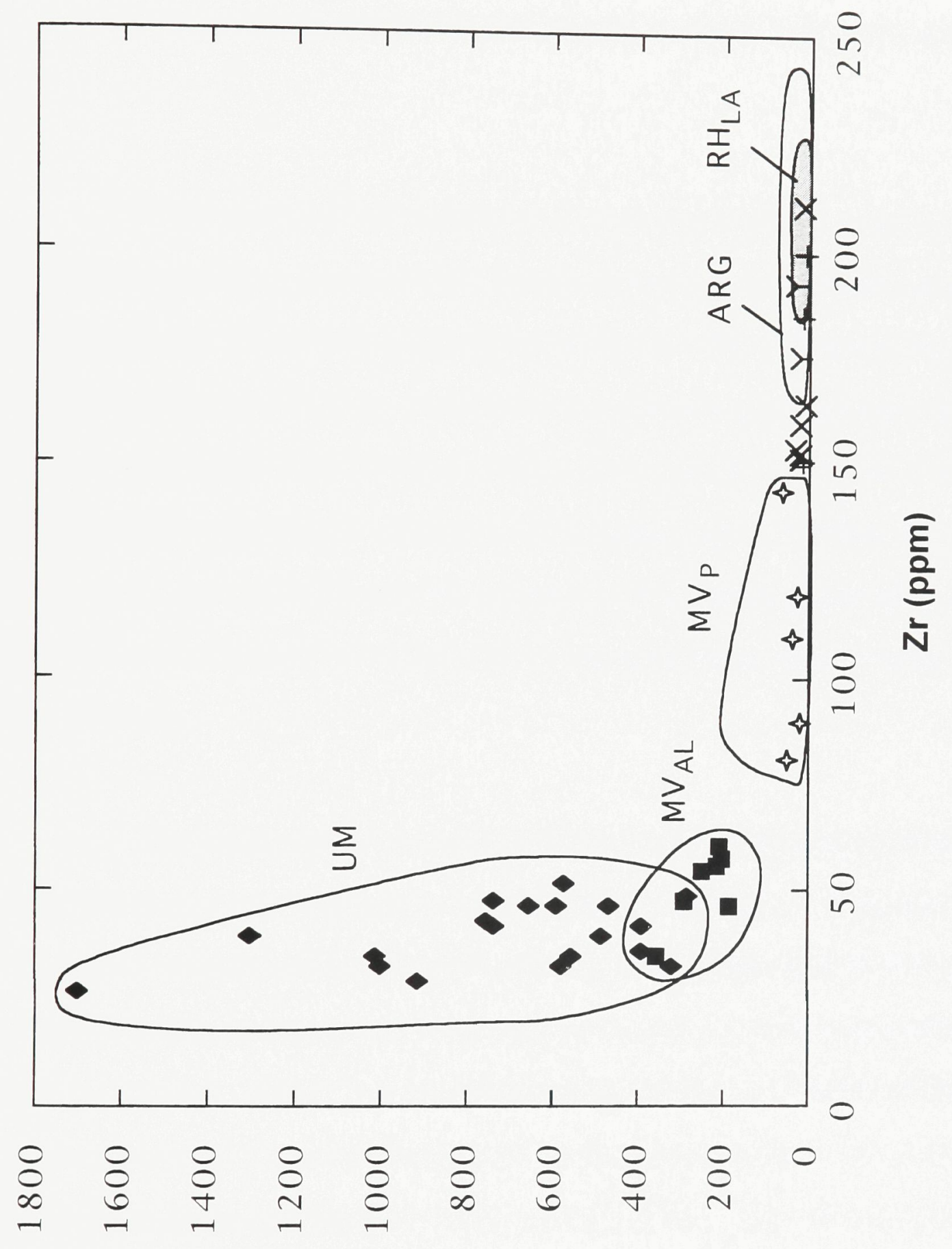

(udd) !N $\stackrel{\frac{0}{f}}{\frac{1}{ \pm}}$

원

이응

는

है त्]

독웅

들

는

인

은

हี

is 흔

흥

원

응

के

중 문

월

ช్

응

गे $\frac{0}{\pi}$

ह

총

워

¿

흔

(1)

ह

Q

흥 을

$\sum \sim \bar{\pi}$

후웡

ह 0

즌

흐의 홓

나음

응

$\overline{0}$

赵

क

$>0 \overline{\bar{\omega}}$

$\bar{N} \cdot$

승

$\overline{4}$

๒ั)

G응 


\section{Appendix 2}

\section{CHEMICAL EVOLUTION OF THE MANTLE SINCE THE LATE ARCHEAN}

The formation of continental crust has enriched the crust and depleted the upper mantle in incompatible elements relative to the estimated composition of the primitive mantle (Hofmann, 1988). The mantle has also been modified by recycling of material in subducting oceanic plates and in cold plumes (Campbell and Griffiths, 1993). In this thesis comparisons are made between the composition of Kidd Creek rhyolite (ca. $2712 \mathrm{Ma}$ ) and postTriassic (< about $200 \mathrm{Ma}$ ) felsic igneous rocks; this requires discussion as to the extent of chemical evolution within the upper and lower mantle since the late Archean.

1. The existence of a significant volume of emergent continental crust near the end of the Archean is established by significant increases in LREE, Th, and $U$ contents and the La/Yb ratios of Proterozoic and Phanerozoic finegrained clastic sedimentary rocks relative to their Archean equivalents (Taylor and McLennan, 1985). Two intermediate estimates for the percentage of the present mass of the continental crust formed by the end of the Archean are 5060\% (McCulloch and Bennet, 1994) and 70-90\% (Taylor and McLennan, 1985). Large estimates suggest small changes in upper mantle composition during the Proterozoic and Phanerozoic related to crustal extraction. In the model of McCulloch and Bennet (1994), an increase in the proportion of mantle involved 
in the extraction process (upper or depleted mantle) relative to primitive (undepleted) mantle buffers the trace element composition of the upper mantle such that by approximately $2700 \mathrm{Ma}$ its trace-element composition was the same as at present except for an increase in the $U$ and Th contents.

2. Comparisons of Archean and post-Archean tonalite reveal very similar trace element compositions except for strikingly lower contents of $\mathrm{Ti}, \mathrm{Y}$ and HREE in the Archean samples (Condie, 1989b). The depletion of $Y$ and the high $\mathrm{La} / \mathrm{YbN}$ ratios of Archean relative to post-Archean trondhjemite, tonalite and granodiorite (TTG) are attributed to differences in magma generation processes at Archean and post-Archean destructive plate boundaries and not from a change in mantle composition (Martin 1986, 1993). In the Archean subducted oceanic crust was generally young and warm and the subducting slab reached melting conditions before dehydration occurred leaving a garnetand hornblende-bearing residue which retained $Y$ and the HREE. In contrast, subducting plates in post-Archean time tend to be old and cool so dehydration occurs before melting conditions are encountered. This fluid migrates into the overlying mantle wedge where it induces partial melting leaving a residue in which olivine and pyroxene are the dominant residual phases thereby avoiding strong source retention of HREE and $Y$ (Martin, 1986, 1993). Drummond and Defant (1990) have demonstrated that in modern arc terranes where young $(<20-30 \mathrm{Ma})$, hot oceanic plates are subducted high-Al trondhjemite-tonalitedacite (TTD) suites with REE patterns almost identical to those of the Archean are still produced. 
3. Sun and Nesbitt (1977) showed that Ti, Zr, Yb and Y each have the same degree of enrichment relative to primitive mantle (enrichment factor of 8.0) indicating no fractionation of these elements over time. They also concluded, based on a comparison of incompatible element ratios between Archean basalt and modern MORB that the mantle source of "normal" MORB is, relative to the source of $2.7 \mathrm{Ga}$ basalt, "... severely depleted in highly incompatible elements such as $\mathrm{Cs}, \mathrm{Ba}, \mathrm{Rb}, \mathrm{U}, \mathrm{Th}, \mathrm{K}$, La and $\mathrm{Nb}$, but has comparable abundances of less incompatible elements such as $\mathrm{Ti}, \mathrm{Zr}, \mathrm{Y}, \mathrm{Yb}$ " (Sun and Nesbitt, 1977 p.429). However, Sun and Nesbitt (1977) made no allowance for the possibility that Archean basalt may not have formed at normal mid-ocean ridge spreading centres and do not consider that tectonic setting may strongly influence the trace element characteristics of basaltic rocks (Pearce and Cann, 1973; Floyd and Winchester, 1975; Pearce and Norry, 1979; Wood et al., 1979; Wood, 1980). Condie (1989a), based on a trace-element classification scheme, found that one of the most striking of features of Archean and Proterozoic greenstone belts is the rarity of basalt with N-MORB geochemical characteristics. Average incompatible element contents in greenstone-belt basalt tend to increase with time, except for $\mathrm{Nb}$ and $\mathrm{Ta}$, and $\mathrm{La} / \mathrm{Sm}$ ratios also increase from the Archean to post-Archean basalt (Condie, 1989a), opposite to the temporal trend advocated by Sun and Nesbitt (1977). The observed variations in average basalt compositions probably represent changes in the proportions of basalt from different tectonic environments (Condie, 1989a). 
4. Evidence for temporal change in lower mantle composition since the late Archean is even more elusive than for the upper mantle. In a study of 207 basalt samples from several Archean greenstone belts Condie (1989a) found no samples with the chemical characteristics of within-plate basalt which could represent plume-derived magma from the lower mantle. Komatiite is another rock type that may form from plumes emanating from the lower mantle (Campbell et al., 1989; Campbell and Griffiths, 1993). Based on relative enrichments of highly incompatible elements in komatiite and picrite with decreasing age from the late Archean to the Phanerozoic, Campbell and Griffiths (1993) suggested that the composition of plume sources changed from MORB-type to OIB- (ocean island basalt) type at the Archean-Proterozoic boundary and that OIB-type plumes were absent during the Archean (cf. Condie, 1989a). They credit this change to the onset, somewhat earlier, of subduction as the principal mechanism of downward mass transfer. However, the Cretaceous komatiite of Gorgona Island, Columbia, is more strongly depleted in highly incompatible elements than many typical examples of late Archean komatiite (Campbell and Griffiths, 1993; Jochum, et al., 1991).

The evidence presented above suggests that sweeping changes in mantle composition during the past 2.7 billion years are unlikely. This thesis adheres to the implicit assumption of Condie (1989a) that whatever changes have occurred are probably small relative to the magnitude of chemical variation imposed on magmas by petrogenetic processes in different tectonic environments. 


\title{
Appendix 3
}

\begin{abstract}
ANALYTICAL TECHNIQUES
(analytical details presented below provided by XRAL Laboratories)
\end{abstract}

\begin{abstract}
All analyses were performed by XRAL Laboratories, Toronto, Ontario. Samples were crushed in a steel jaw crusher followed by vibratory milling in agate using a pot ring and puck method. Silica cleaner was milled in pot between samples to eliminate the possibility of cross contamination.
\end{abstract}

The major elements (reported as oxides) were determined by $\mathrm{X}$-ray fluorescence spectrometry (XRF). A 2 grams sample was roasted at $950^{\circ} \mathrm{C}$ for 1 hour, then fused with 7.7 grams of lithium tetraborate, and the melt was cast into a $40 \mathrm{~mm}$ button. The button was analyzed on a Philips PW1600 simultaneous $\mathrm{X}$-ray fluorescence spectrometer calibrated using more than $\mathbf{4 0}$ reference materials. Loss on ignition (L.O.I.) was determined by the difference in sample weights before and after the roasting procedure. Samples with sums of less than $98 \mathrm{wt}$ \% of greater than $101 \mathrm{wt} . \%$ were automatically repeated. Instrument precision on most elements is better than $0.5 \mathrm{wt} . \%$. Detection limits for all of the major oxides and for L.O.I. were 0.01 wt.\%.

Ferrous iron analyses were performed on a 0.5 gram sample digested with sulfuric, hydrochloric, and hydrofluoric acids using an oxidation technique 
based on the quantitative oxidation of ferrous salts in acid solution to the ferric oxidation state by titration with a standardized potassium dichromate solution. A slight excess of potassium dichromate caused the redox indicator sodium diphenylamino-sulfonate to change to a violet colour.

Carbon dioxide content was measured by titration. $2 \mathrm{~N} \mathrm{HClO}_{4}$ was added to the sample to release $\mathrm{CO}_{2}$ which was then measured by titration using a coulometer. Total $\mathrm{C}$ and $\mathrm{S}$ were determined by combustion using a Leco procedure and $\mathrm{F}$ was analyzed by specific ion electrode using automated Lachat instrumentation.

$\mathrm{H}_{2} \mathrm{O}^{+}$is the weight of crystallized or combined water in the sample. Moisture was removed from a 1.0 gram sample by drying at $110^{\circ} \mathrm{C}$ for 3 hours. The sample was then mixed with $\mathrm{PbO}$ and heated in a pyrex test tube in such a manner that any water vapour was condensed on a piece of preweighed paper in the upper, cooled part of test tube (cooled by ice in a polyethylene jacket). The weight gained by the paper was the amount of $\mathrm{H}_{2} \mathrm{O}^{+}$in the sample.

$\mathrm{Rb}, \mathrm{Y}, \mathrm{Zr}, \mathrm{Nb}, \mathrm{Ba}, \mathrm{Sn}, \mathrm{Ga}$ and $\mathrm{Ni}$ values were determined by $\mathrm{X}$-ray fluorescence spectrometry (XRF) using $40 \mathrm{~mm}$ diameter pressed pellets prepared from at least 5 grams of milled rock powder. Elements are analyzed in an inert nitrogen atmosphere employing a rhodium tube in a Phillips PW1400 wavelength dispersive $X$-ray spectrometer. The presence of percentage levels of any elements except the usual major rock forming constituents (e.g. sulfides) would have had an adverse effect on calibration. 
$\mathrm{Li}, \mathrm{Be}, \mathrm{Sc}, \mathrm{V}, \mathrm{Cr}, \mathrm{Co}, \mathrm{Ni}, \mathrm{Cu}, \mathrm{Zn}, \mathrm{As}, \mathrm{Sr}, \mathrm{Mo}, \mathrm{Ag}, \mathrm{Cd}, \mathrm{W}, \mathrm{Pb}$ and $\mathrm{Bi}$ analyses were obtained for 0.5 gram samples by ICP spectroscopy following a multi-acid $\left(\mathrm{HF}-\mathrm{HClO}_{4}\right)$ digestion on a hot plate (some refractory minerals may remain incompletely attacked). In house standards and previously analyzed standards were run to monitor proper digestion procedures while synthetic standards were used to calibrate the instrument.

For REE, Th and $U$ concentrations $0.1 \mathrm{~g}$ of sample was mixed with $0.5 \mathrm{~g}$ of $\mathrm{Na}_{2} \mathrm{O}_{2}$ and fused at $700^{\circ} \mathrm{C}$, the fusion melt dissolved in $7 \% \mathrm{HNO}_{3}$ and analyses performed on a VG Plasma Quad inductively coupled plasma mass spectrometer. $\mathrm{Au}, \mathrm{Se}, \mathrm{Br}, \mathrm{Sb}, \mathrm{Cs}, \mathrm{Hf}$ and Ta were determined by neutron activation (NA) analyses on irradiated $0.5 \mathrm{~g}$ samples after approximately 7 days of decay.

In addition to the analyses described above, comparative chemical determination for $Y, T h, U$, and the rare earth elements (REE) were obtained for 12 samples using different methods - REE, Th and $U$ by neutron activation and $Y$ by ICPMS (Table 3.1). Differences between analyses by two techniques for a given sample are generally less than $10 \%$ except for $U$ in which the average difference is $16 \%$. A binary plot showing the differences in values obtained by ICPMS and NA for La (average difference $=7.7 \%$, maximum difference $=19 \%$ ) is shown in Figure 3.1. In Figure 3.2 a REE spider diagram is shown for two Kidd Creek rhyolite samples with data by both ICPMS and NA analyses. Note the close agreement between values obtained by the two techniques (neither 
technique returns $\mathrm{Pm}$ values and $\mathrm{Gd}, \mathrm{Dy}, \mathrm{Ho}, \mathrm{Er}$ and $\mathrm{Tm}$ are not reported by NA). The unusual sawtooth pattern for the ICPMS data between Dy and Tm is believed to be an analytical artifact.

Tables A3.2 to A3.4 show major oxide and trace element values determined by XRAL Laboratories during 1995 and 1996 for geological reference standards (geostandards) SY-2 and SO-1. SY-2 is a syenite from the Bancroft area of eastern Ontario, and SO-1 is a clay soil collected near Hull, Quebec (Govindaraju, 1994). The results are summarized in Table 3.5 and Figures A3.3 and A3.4. The two major oxide determinations of SY-2 by XRF analyses of glass beads all fall within $7 \%$ of the recommended values values and all but $\mathrm{TiO}_{2}$ and $\mathrm{P}_{2} \mathrm{O}_{5}$ fall within about $1 \%$ of the recommended values (Table A3.2; difference $=X R A L$ value $/$ recommended value). For the two analyses of $\mathrm{Rb}, \mathrm{Sr}, \mathrm{Y}, \mathrm{Zr}, \mathrm{Nb}$, and $\mathrm{Ba}$ (XRF on pressed pellets) the poorest results were a $19 \%$ difference between the recommended value and one determination of $\mathrm{Ba}$, and a $17 \%$ difference between the recommended $\mathrm{Nb}$ value and one determination of $\mathrm{Nb}$ (Table A3.3). All of the remaining determinations were within $10 \%$ of the recommended values for SY-2. Six ICPMS analyses of geostandard SO-1 were performed for the rare earth elements (REE), $U$, and Th (Table A3.4). Differences between the working values and the XRAL results for $\mathrm{Sm}, \mathrm{Gd}$, Dy, Ho, Er, and Tm (middle to heavy REE) are commonly between $15 \%$ and $35 \%$. It is in the middle to heavy part of Kidd Creek rhyolite REE spider diagrams that a pronounced sawtooth pattern occurs when XRAL ICPMS data is plotted (Figure A3.2). Determinations by 
XRAL for the remaining REE, along with Th and $U$, were generally within $10 \%$ of the working values for SO-1.

A negative correlation exists for the XRF data between the accuracy of the XRAL results for the geostandards (relative to the recommended values) and the amount by which each element exceeds the detection limit of the analytical method (Table 3.5; Figure 3.3). XRAL defines detection limit "... as the level at which the chemist can expect $+/-100 \%$ variation in the data" (L. Bloom, written communication, 1996). A negative correlation also occurs for the XRF data between the element concentrations in the geostandards (working values) and the reproducibility of the recommended geostandard values (Figure A3.4).

For each batch of samples a number of duplicate analyses were performed during the same analytical session using the same techniques. Comparisons between the original and duplicate analytical values, which provide a measure of precision (repeatability), are presented in Table A3.6. Repeatability is strongly influenced by the amount by which the content of an element in a sample exceeds the detection limit of the analytical method (Figure A3.5). 


\begin{tabular}{ccccc}
\hline \hline Element & $\begin{array}{c}\text { Average ICPMS } \\
\text { Value }(\mathrm{ppm})\end{array}$ & $\begin{array}{c}\text { Second } \\
\text { Method }\end{array}$ & $\begin{array}{c}\text { Average } \\
\text { Difference* }\end{array}$ & $\begin{array}{c}\text { Maximum } \\
\text { Difference** }\end{array}$ \\
\hline $\mathrm{Y}$ & 82 & XRF & $10 \%$ & $17 \%$ \\
$\mathrm{La}$ & 44.0 & $\mathrm{NA}$ & $7.7 \%$ & $19 \%$ \\
$\mathrm{Ce}$ & 98.7 & $\mathrm{NA}$ & $0.6 \%$ & $13 \%$ \\
$\mathrm{Nd}$ & 47.6 & $\mathrm{NA}$ & $6.4 \%$ & $16 \%$ \\
$\mathrm{Sm}$ & 11.7 & $\mathrm{NA}$ & $-2.7 \%$ & $-8.9 \%$ \\
$\mathrm{Eu}$ & 1.62 & $\mathrm{NA}$ & $-9.0 \%$ & $-28.6 \%$ \\
$\mathrm{~Tb}$ & 2.38 & $\mathrm{NA}$ & $-10.0 \%$ & $-23.1 \%$ \\
$\mathrm{Yb}$ & 8.63 & $\mathrm{NA}$ & $0.2 \%$ & $7.4 \%$ \\
$\mathrm{Lu}$ & 1.42 & $\mathrm{NA}$ & $-7.4 \%$ & $-10.8 \%$ \\
$\mathrm{Th}$ & 6.7 & $\mathrm{NA}$ & $0.4 \%$ & $6.9 \%$ \\
$\mathrm{U}$ & 1.6 & $\mathrm{NA}$ & $16.2 \%$ & $47 \%$ \\
\hline
\end{tabular}

Table A3.1. Comparison of analytical values for 12 samples obtained by ICPMS and a second technique (XRF or NA).

* relative to ICPMS data, e.g. average [( $\left.\left.\mathrm{Ce}_{\mathrm{NA}}-\mathrm{C} \mathrm{e}_{\mathrm{ICPMS}}\right) / \mathrm{C} \mathrm{e}_{\mathrm{ICPMS}}\right]$

** relative to ICPMS data, e.g. maximum [( $\left.\left.\mathrm{Ce}_{N A}-\mathrm{C} e_{I C P M S}\right) / C e_{I C P M S}\right]$ 
음

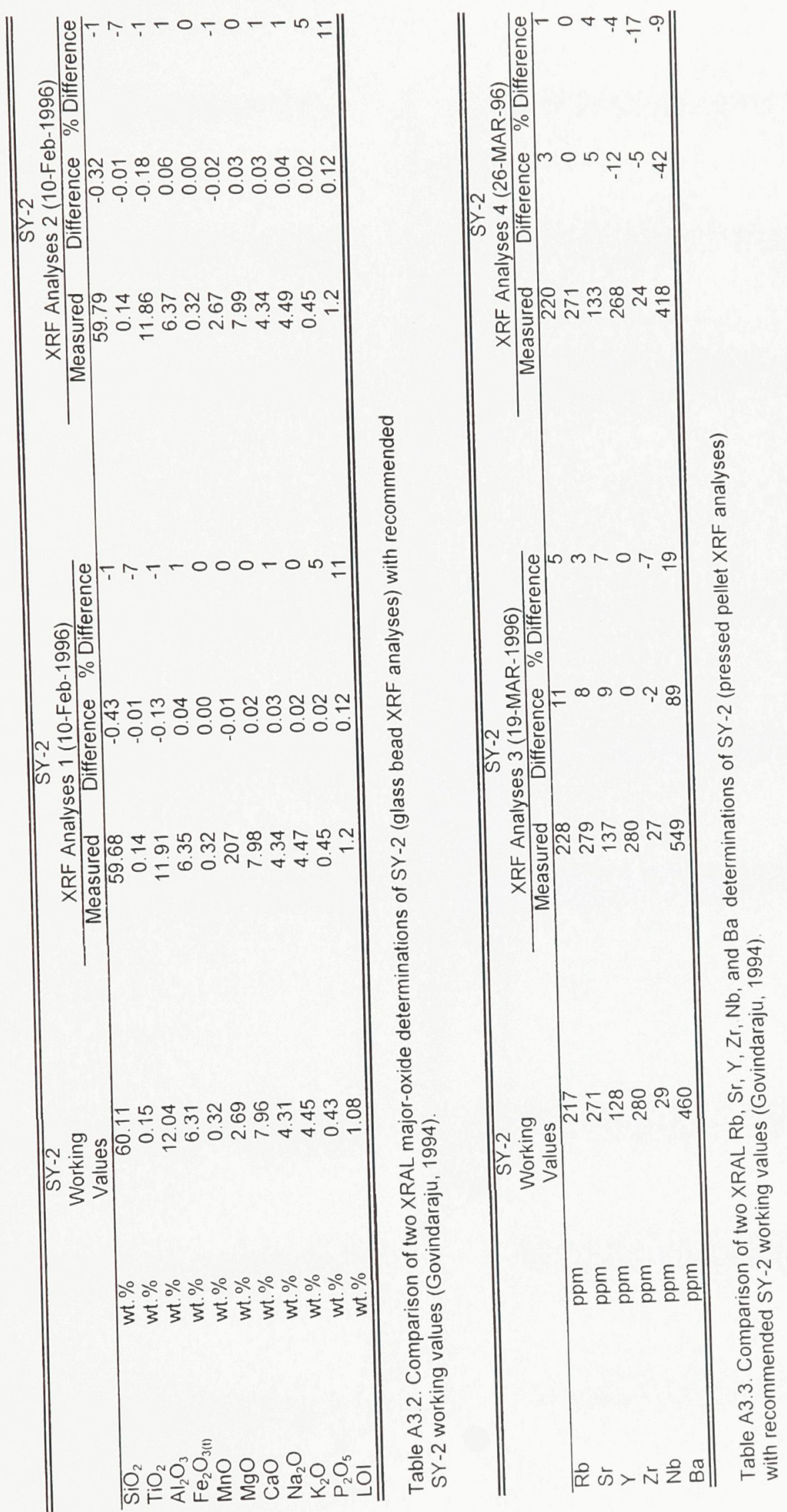



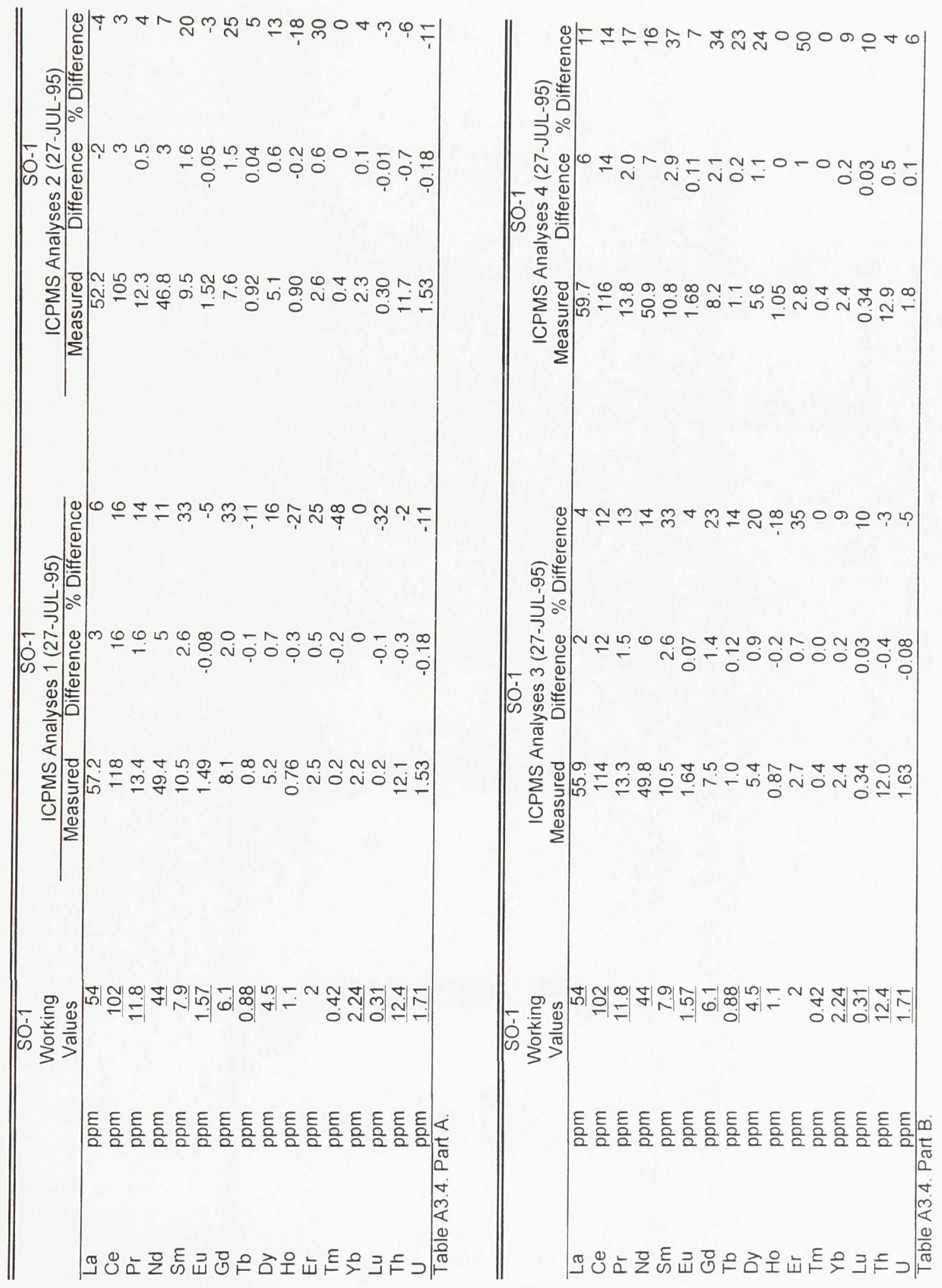


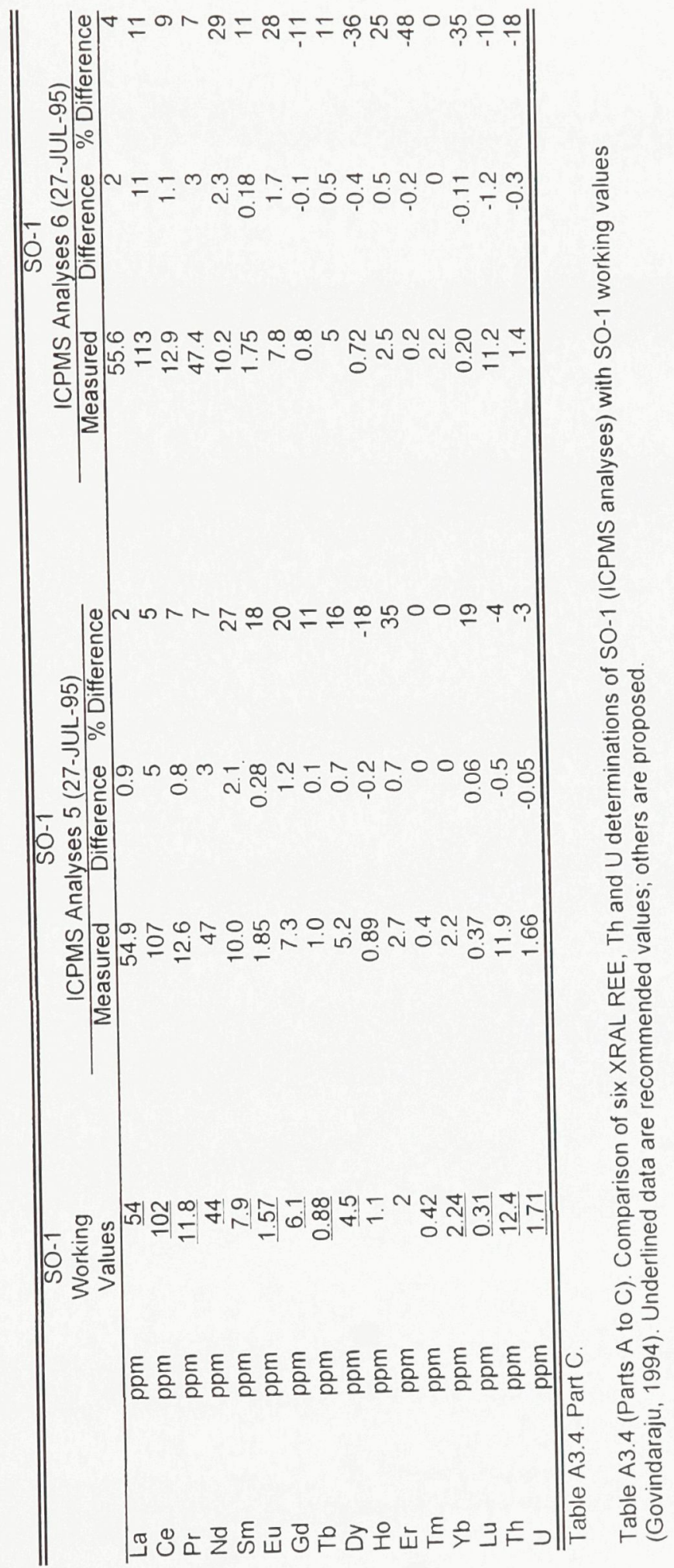




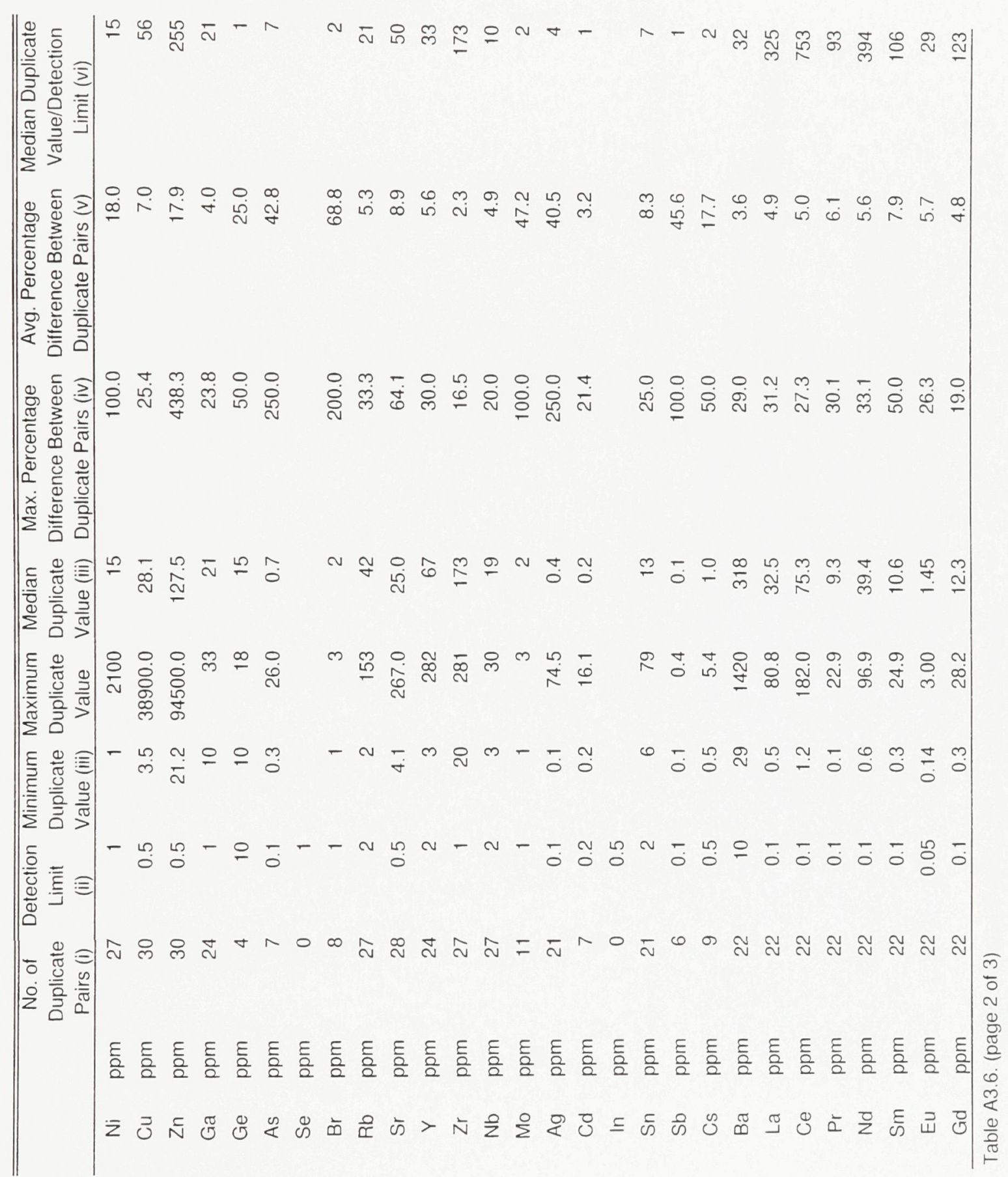




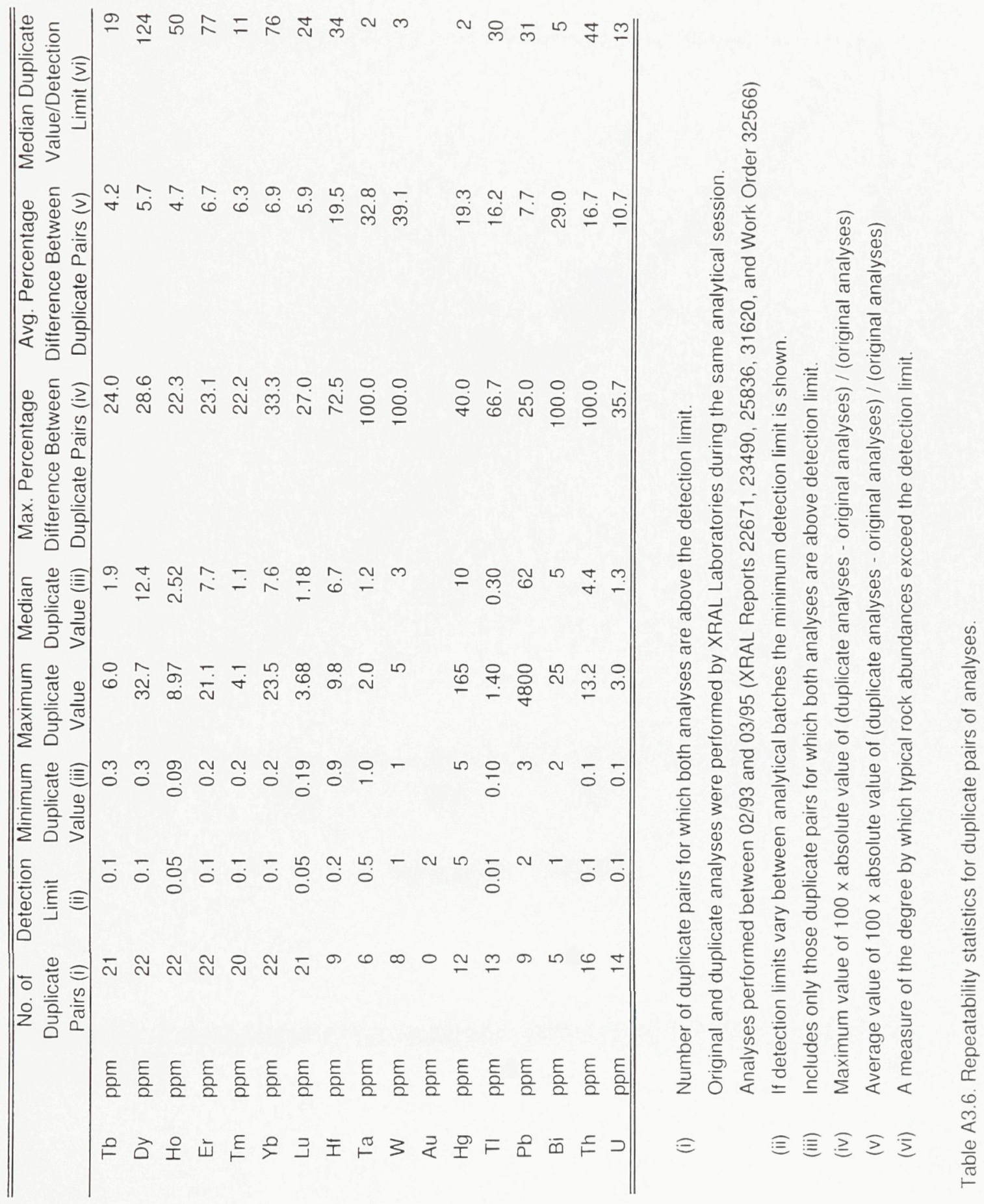




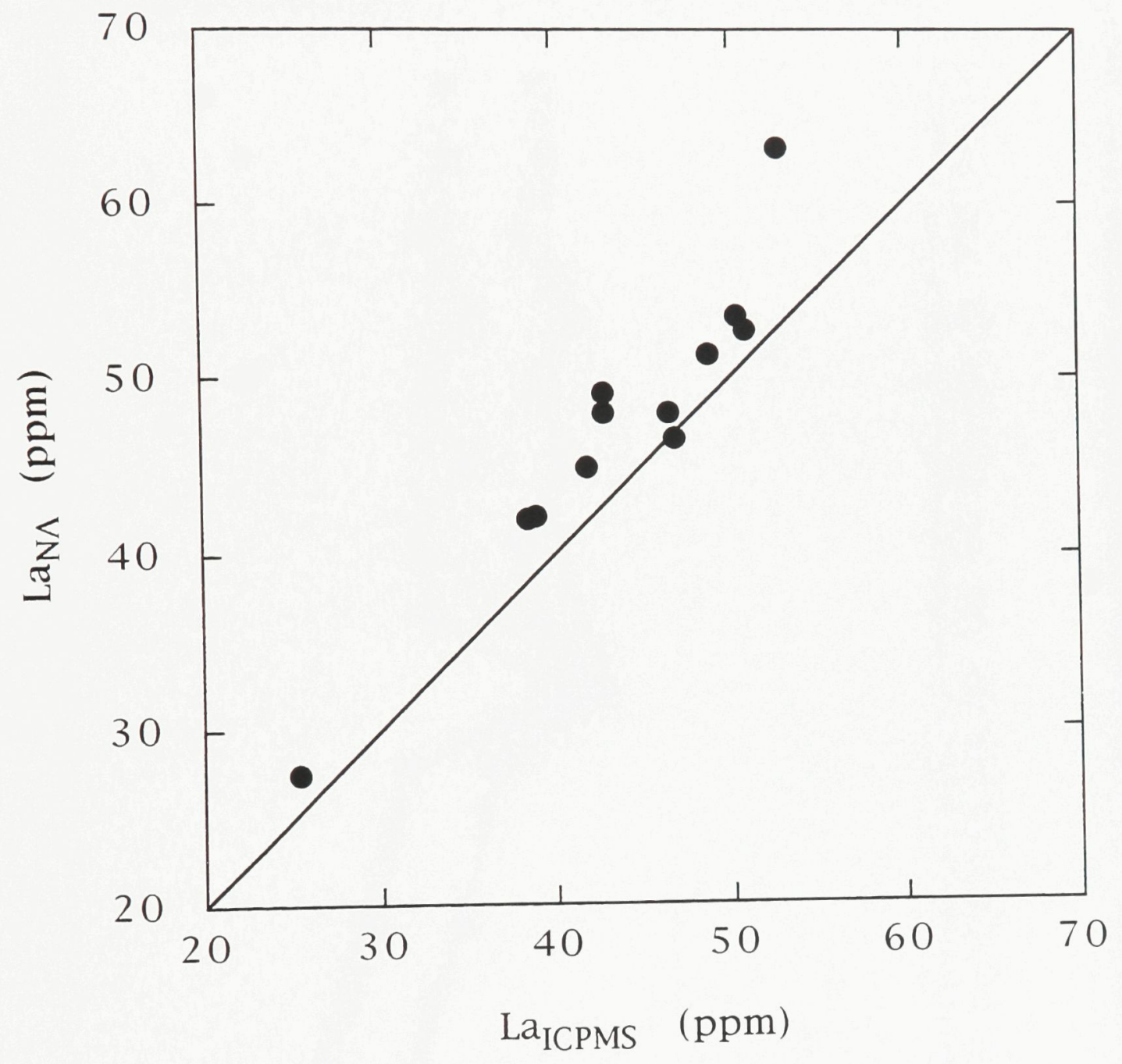

Figure A3.1. Comparison of La analyses obtained by ICPMS and neutron activation (NA). 
$\frac{1}{2}$

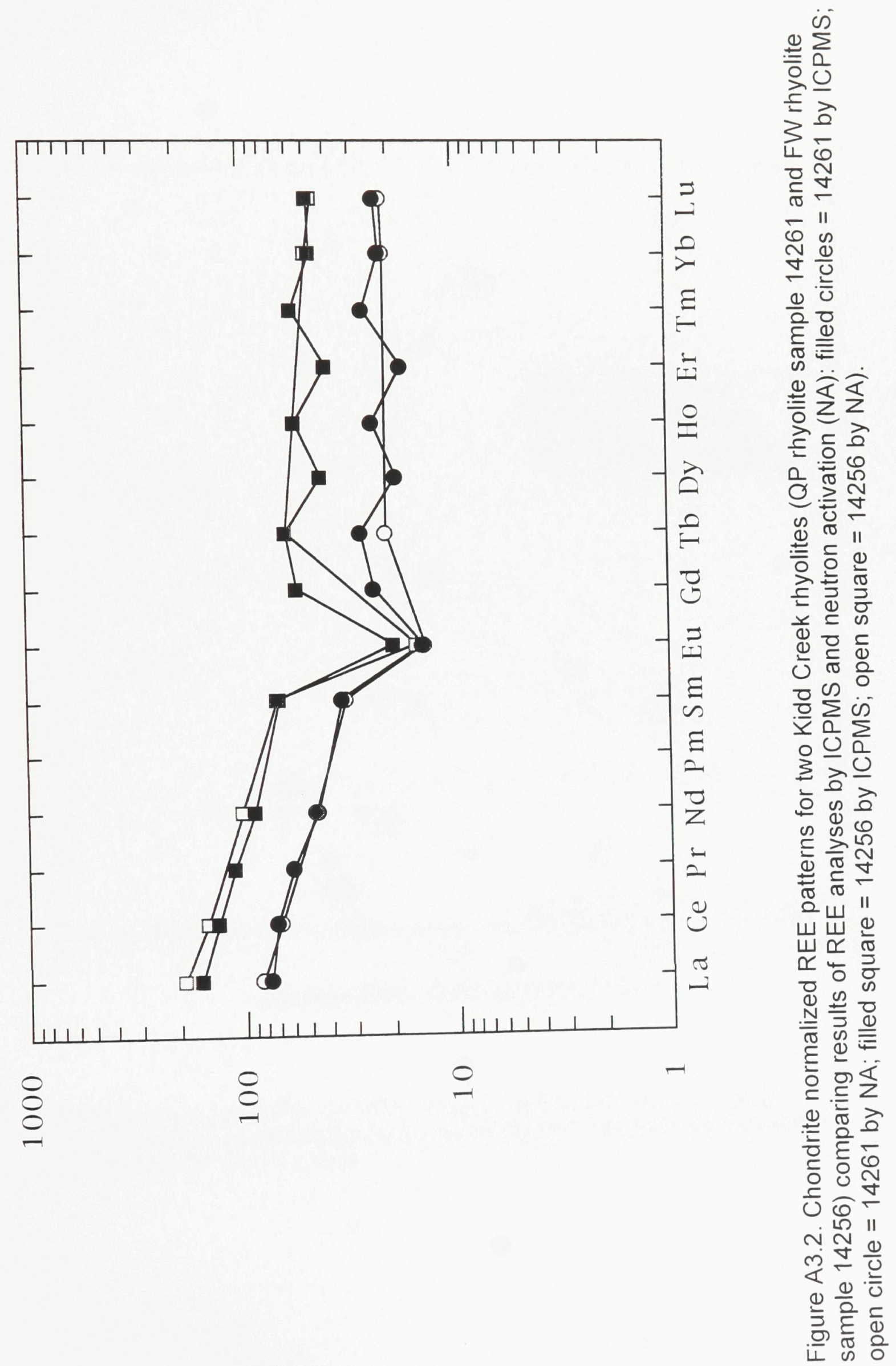




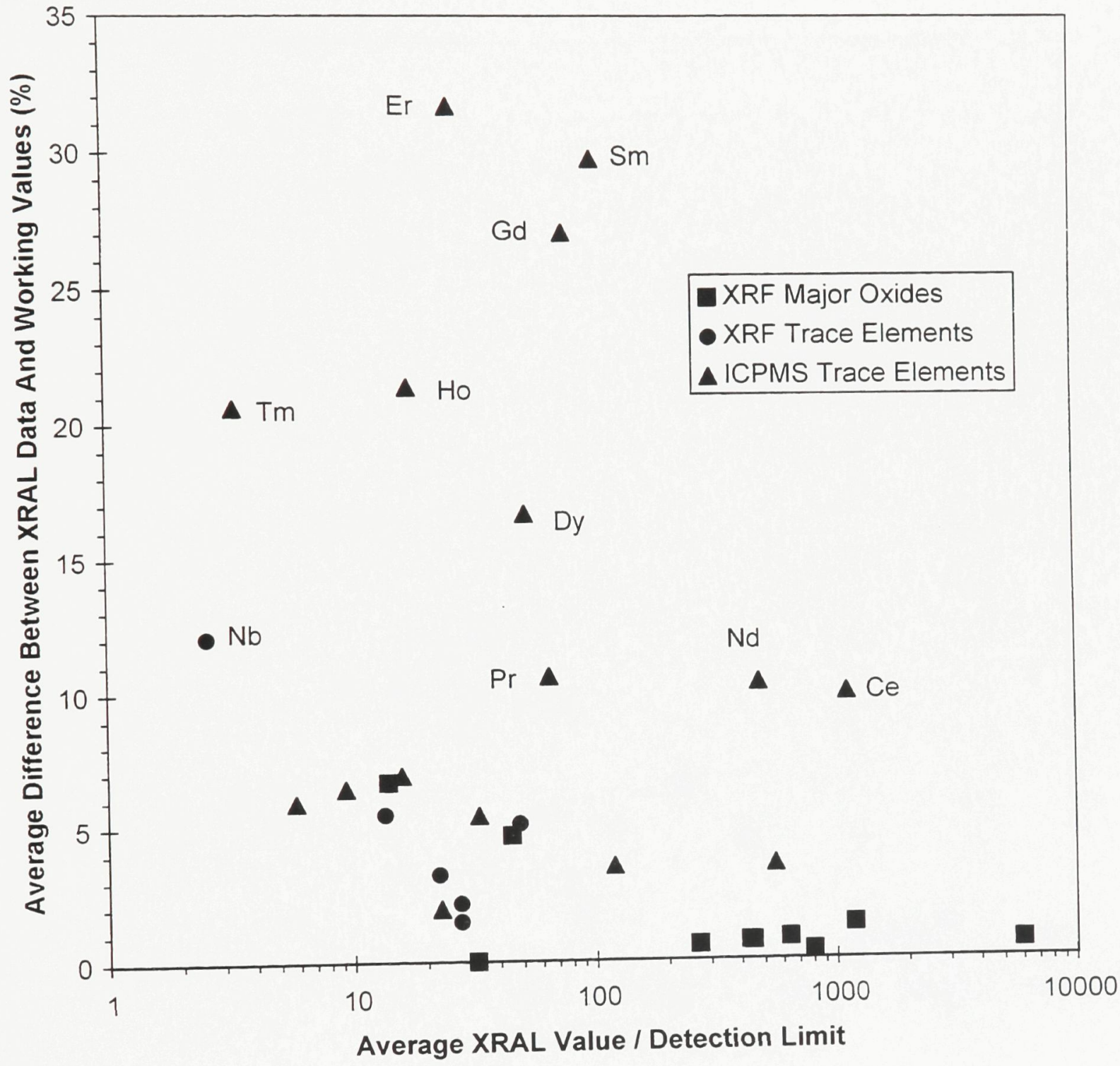

Figure A3.3. Diagram showing average XRAL value / detection limit versus average difference between XRAL determinations and working values for reference samples SY-2 (XRF data) and and SO-1 (ICPMS data) 


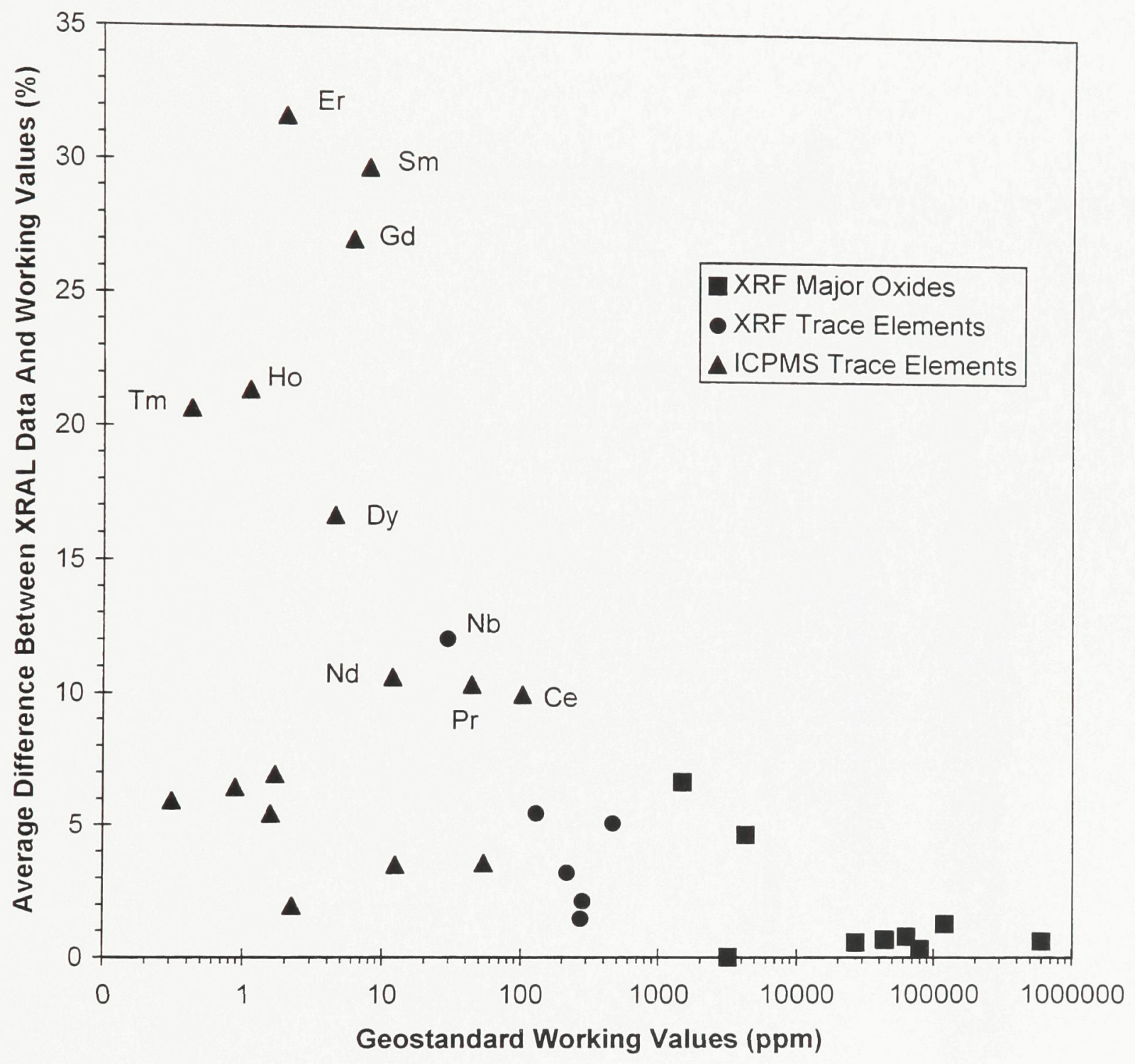

Figure A3.4. Diagram showing element abundances in geostandards (working values) versus average differences between XRAL determinations and working values for reference samples SY-2 (XRF data) and and SO-1 (ICPMS data). 


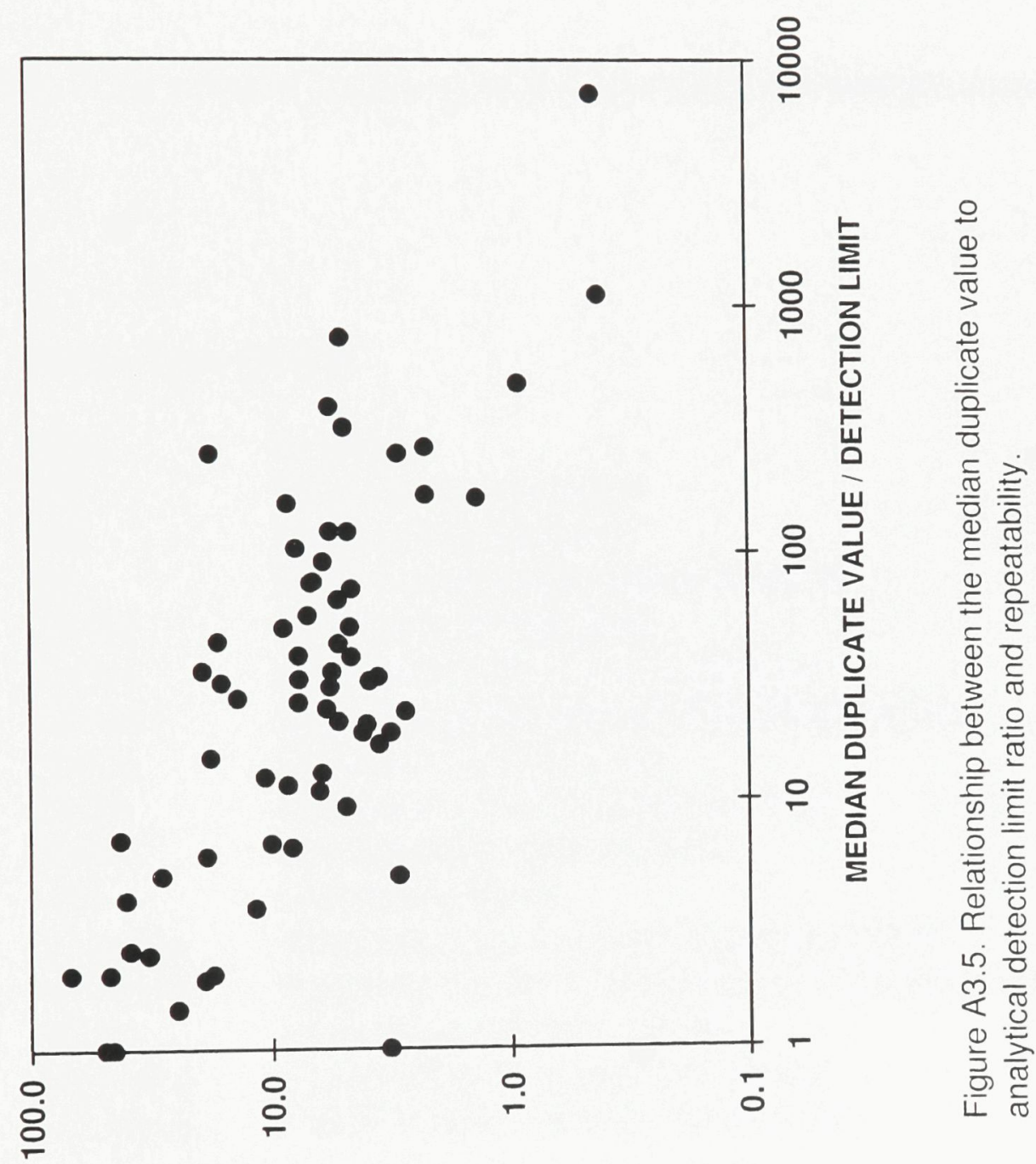

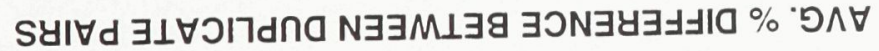




\section{Appendix 4}

\section{GEOCHEMICAL ANALYSES OF SAMPLES FROM THE 1600, 1800, 2100, 2300, AND 2400 LEVELS OF THE KIDD CREEK MINE}

(see Maps 2 to 7 for sample locations and Appendix 9 for sample descriptions)

\section{Rock Type Codes:}

$\begin{array}{ll}\text { ARG } & \text { Argillite } \\ \text { FV } & \text { Felsic Volcanic Rock } \\ \text { ME } & \text { Mafic Extrusive Rock } \\ \text { MI } & \text { Mafic Subvolcanic Intrusive Rock } \\ \text { QPco } & \text { Coherent QP Rhyolite } \\ \text { QPbx } & \text { Autoclastic QP Rhyolite Breccia } \\ \text { QPcrbx } & \text { Coarse Autoclastic QP Rhyolite Breccia } \\ \text { RHco } & \text { Coherent FW Rhyolite } \\ \text { RHbx } & \text { Autoclastic FW Rhyolite Breccia } \\ \text { RHhy } & \text { FW Rhyolite Hyaloclastite } \\ \text { UM } & \text { Ultramafic Rock } \\ \text { VCbdcg } & \text { Volcaniclastic Boulder Conglomerate } \\ \text { VCpbcg } & \text { Polymict Volcaniclastic Pebble Conglomerate } \\ \text { VCsa } & \text { Volcaniclastic Sandstone } \\ \text { VCsamu } & \text { Volcaniclastic Sandy Mudstone } \\ \text { VCmusa } & \text { Volcaniclastic Muddy Sandstone }\end{array}$




\begin{tabular}{|c|c|c|c|c|c|c|c|c|c|c|c|}
\hline $\begin{array}{l}\text { Sample } \\
\text { Rock Type } \\
\text { Member }\end{array}$ & & $\begin{array}{cc}16-14061 & 1 \\
\text { RHco } & \\
\text { Middle } & \end{array}$ & $\begin{array}{c}16-140621 \\
\text { UM } \\
\text { Middle }\end{array}$ & $\begin{array}{c}6-140631 \\
\text { UM } \\
\text { Middle }\end{array}$ & $\begin{array}{l}16-14064 \\
\text { VCpbcg } \\
\text { Middle }\end{array}$ & $\begin{array}{c}16-140661 \\
\text { VCsamu } \\
\text { Middle }\end{array}$ & $\begin{array}{l}16-14069 \\
\text { VCsamu F } \\
\text { Middle }\end{array}$ & $\begin{array}{c}16-14074 \\
\text { RHbx-RHhy } \\
\text { Middle }\end{array}$ & $\begin{array}{c}16-14079 \\
\text { VCsa } \\
\text { Middle }\end{array}$ & $\begin{array}{cc}16-14080 & 1 \\
\text { RHbx } \\
\text { Middle }\end{array}$ & $\begin{array}{l}16-14081 \\
\text { VCbdcg } \\
\text { Middle }\end{array}$ \\
\hline $\mathrm{SiO}_{2}$ & wt.\% & 77.0 & 30.8 & 31.6 & 40.6 & 85.2 & 73.6 & 73.8 & 66.6 & 71.8 & 45.0 \\
\hline $\mathrm{TiO}_{2}$ & wt. \% & 0.12 & 0.09 & 0.09 & 0.18 & 0.25 & 0.29 & 0.07 & 0.09 & 0.11 & 0.19 \\
\hline $\mathrm{Al}_{2} \mathrm{O}_{3}$ & wt.\% & 12.10 & 1.96 & 1.79 & 5.44 & 8.75 & 11.10 & 10.90 & 9.73 & 11.70 & 8.62 \\
\hline $\mathrm{Fe}_{2} \mathrm{O}_{3 i}$ & wt.\% & 2.45 & 6.20 & 7.52 & 14.50 & 0.86 & 4.38 & 1.80 & 7.22 & 3.83 & 15.00 \\
\hline $\mathrm{MnO}$ & wt. \% & 0.03 & 0.12 & 0.15 & 0.12 & 0.02 & 0.03 & 0.06 & 0.07 & 0.06 & 0.04 \\
\hline $\mathrm{MgO}$ & wt.\% & 2.24 & 29.50 & 32.80 & 4.58 & 0.25 & 3.22 & 1.08 & 8.88 & 3.89 & 4.18 \\
\hline $\mathrm{CaO}$ & $w t . \%$ & 0.23 & 1.45 & 0.84 & 3.03 & $<0.01$ & 0.25 & 4.10 & 0.72 & 1.11 & 0.12 \\
\hline $\mathrm{Na}_{2} \mathrm{O}$ & wt.\% & 0.20 & 0.09 & 0.07 & 1.34 & 0.27 & 0.28 & 0.18 & 0.08 & 0.21 & 1.14 \\
\hline $\mathrm{K}_{2} \mathrm{O}$ & wt. \% & 3.35 & $<0.01$ & $<0.01$ & 0.31 & 2.49 & 2.15 & 3.17 & 0.27 & 2.44 & 1.00 \\
\hline $\mathrm{P}_{2} \mathrm{O}_{5}$ & wt. \% & 0.03 & $<0.01$ & $<0.01$ & 0.03 & 0.03 & 0.05 & 0.02 & 0.03 & 0.02 & 0.04 \\
\hline $\mathrm{Cr}_{2} \mathrm{O}_{3}$ & $w t . \%$ & $<0.01$ & 0.32 & 0.18 & 0.09 & $<0.01$ & $<0.01$ & $<0.01$ & $<0.01$ & $<0.01$ & $<0.01$ \\
\hline LOI & wt. \% & 2.20 & 29.90 & 24.80 & 9.05 & 1.75 & 3.15 & 3.25 & 5.00 & 3.55 & 9.45 \\
\hline Sum & $w t . \%$ & 99.9 & 100.4 & 99.8 & 79.3 & 99.9 & 98.5 & 98.4 & 98.7 & 98.7 & 84.8 \\
\hline $\mathrm{H}_{2} \mathrm{O}^{+}$ & $w t . \%$ & 2.0 & 1.5 & 2.4 & 2.4 & 1.0 & 2.5 & 1.3 & 4.4 & 2.5 & 3.1 \\
\hline $\mathrm{CO}_{2}$ & wt. \% & 0.29 & 28.40 & 22.00 & 4.79 & 0.05 & 0.37 & 3.38 & 1.12 & 1.73 & 0.16 \\
\hline $\mathrm{FeO}$ & wt.\% & 1.6 & 1.8 & 1.5 & nd & nd & nd & nd & nd & 2.4 & nd \\
\hline C & ppm & nd & 7.95 & 6.02 & nd & nd & nd & nd & nd & nd & nd \\
\hline S & $\mathrm{ppm}$ & 0.05 & 0.02 & $<0.01$ & 12.10 & 0.62 & 1.00 & 0.67 & 0.47 & 0.38 & 11.40 \\
\hline $\mathrm{Li}$ & $\mathrm{ppm}$ & nd & 6 & 7 & nd & nd & nd & nd & nd & nd & nd \\
\hline $\mathrm{Be}$ & $\mathrm{ppm}$ & nd & $<0.5$ & $<0.5$ & nd & nd & nd & nd & nd & nd & nd \\
\hline B & $\mathrm{ppm}$ & nd & nd & nd & nd & nd & nd & nd & nd & nd & nd \\
\hline $\mathrm{F}$ & ppm & nd & $<20$ & 131 & nd & nd & nd & nd & nd & nd & nd \\
\hline $\mathrm{Cl}$ & $\mathrm{ppm}$ & nd & nd & nd & nd & nd & nd & nd & nd & nd & nd \\
\hline $\mathrm{Sc}$ & $\mathrm{ppm}$ & nd & 6.8 & 6.7 & nd & nd & nd & nd & nd & nd & nd \\
\hline V & $\mathrm{ppm}$ & nd & 22 & 23 & nd & nd & nd & nd & nd & nd & nd \\
\hline $\mathrm{Cr}$ & $\mathrm{ppm}$ & nd & 711 & 484 & nd & nd & nd & nd & nd & nd & nd \\
\hline Co & $\mathrm{ppm}$ & nd & 79 & 74 & nd & nd & nd & nd & nd & nd & nd \\
\hline $\mathrm{Ni}$ & $\mathrm{ppm}$ & $<1$ & 1650 & 2100 & 11 & 10 & 16 & $<1$ & 5 & $<1$ & 13 \\
\hline $\mathrm{Cu}$ & $\mathrm{ppm}$ & 20 & 13 & 7 & 1650 & 981 & 1080 & 25 & 143 & 32 & 3370 \\
\hline $\mathrm{Zn}$ & $\mathrm{ppm}$ & 165 & 105 & 53 & 93600 & 1600 & 2030 & 190 & 630 & 153 & 73600 \\
\hline Ga & $\mathrm{ppm}$ & nd & 16 & 16 & nd & nd & nd & nd & nd & nd & nd \\
\hline As & $\mathrm{ppm}$ & nd & $<3$ & $<3$ & nd & nd & nd & nd & nd & nd & nd \\
\hline$R b$ & $\mathrm{ppm}$ & 113 & 7 & 3 & 11 & 64 & 68 & 96 & 10 & 77 & 33 \\
\hline $\mathrm{Sr}$ & $\mathrm{ppm}$ & 12 & 20 & 8 & 18 & 15 & 22 & 33 & 6 & 19 & 13 \\
\hline Y & $\mathrm{ppm}$ & 200 & $<2$ & 4 & 121 & 84 & 91 & 111 & 66 & 117 & 94 \\
\hline $\mathrm{Zr}$ & $\mathrm{ppm}$ & 240 & 19 & 19 & 104 & 138 & 176 & 220 & 200 & 228 & 175 \\
\hline $\mathrm{Nb}$ & $\mathrm{ppm}$ & 30 & 6 & 5 & 19 & 17 & 19 & 26 & 23 & 25 & 17 \\
\hline Mo & $\mathrm{ppm}$ & nd & $<1$ & $<1$ & nd & nd & nd & nd & nd & nd & nd \\
\hline $\mathrm{Ag}$ & $\mathrm{ppm}$ & 0.5 & 0.4 & 0.3 & 75.2 & 2.5 & 12.4 & 0.9 & 6.1 & 1.5 & 102.0 \\
\hline $\mathrm{Cd}$ & $\mathrm{ppm}$ & nd & $<1$ & $<1$ & nd & nd & nd & nd & nd & nd & nd \\
\hline Sn & $\mathrm{ppm}$ & nd & $<5$ & 8 & nd & nd & nd & nd & nd & nd & nd \\
\hline $\mathrm{Sb}$ & $\mathrm{ppm}$ & nd & nd & nd & nd & nd & nd & nd & nd & nd & nd \\
\hline Cs & $\mathrm{ppm}$ & nd & nd & nd & nd & nd & nd & nd & nd & nd & nd \\
\hline $\mathrm{Ba}$ & ppm & nd & 93 & 64 & nd & nd & nd & nd & nd & nd & nd \\
\hline La & $\mathrm{ppm}$ & 56.4 & 0.5 & 0.8 & nd & nd & nd & nd & nd & 56.3 & nd \\
\hline $\mathrm{Ce}$ & ppm & 120 & 1.3 & 1.8 & nd & nd & nd & nd & nd & 121 & nd \\
\hline Pr & ppm & 14.6 & 0.1 & 0.2 & nd & nd & nd & nd & nd & 15 & nd \\
\hline $\mathrm{Nd}$ & $\mathrm{ppm}$ & 63.6 & 0.7 & 1.1 & nd & nd & nd & nd & nd & 61.4 & nd \\
\hline $\mathrm{Sm}$ & $\mathrm{ppm}$ & 17.2 & 0.2 & 0.4 & nd & nd & nd & nd & nd & 14.8 & nd \\
\hline Eu & $\mathrm{ppm}$ & 1.89 & 0.16 & 0.09 & nd & nd & nd & nd & nd & 1.46 & nd \\
\hline Gd & $\mathrm{ppm}$ & 15.3 & 0.3 & 0.4 & nd & nd & nd & nd & nd & 12.1 & nd \\
\hline Tb & ppm & 3.7 & $<0.1$ & $<0.1$ & nd & nd & nd & nd & nd & 2.5 & nd \\
\hline Dy & ppm & 28.8 & 0.4 & 0.5 & nd & nd & nd & nd & nd & 17.5 & nd \\
\hline $\mathrm{HO}$ & $\mathrm{ppm}$ & 8.1 & 0.1 & 0.14 & nd & nd & nd & nd & nd & 4.74 & nd \\
\hline Er & ppm & 18.3 & 0.2 & 0.3 & nd & nd & nd & nd & nd & 10.3 & nd \\
\hline Tm & $\mathrm{ppm}$ & 4 & $<0.1$ & $<0.1$ & nd & nd & nd & nd & nd & 2.2 & nd \\
\hline $\mathrm{Yb}$ & ppm & 22.2 & 0.3 & 0.4 & nd & nd & nd & nd & nd & 12.4 & nd \\
\hline Lu & $\mathrm{ppm}$ & 3.05 & $<0.05$ & $<0.05$ & nd & nd & nd & nd & nd & 1.66 & nd \\
\hline $\mathrm{Hf}$ & ppm & 10.0 & nd & nd & nd & nd & nd & nd & nd & 11.0 & 4 \\
\hline Ta & ppm & 2.1 & nd & nd & nd & nd & nd & nd & nd & 2.0 & d \\
\hline W & ppm & nd & $<10$ & $<10$ & nd & nd & nd & nd & nd & nd & nd \\
\hline $\mathrm{Au}$ & $\mathrm{ppb}$ & nd & nd & nd & nd & nd & nd & nd & nd & nd & nd \\
\hline $\mathrm{Pb}$ & $\mathrm{ppm}$ & $<2$ & 3 & 4 & 4810 & 32 & 110 & 2 & 215 & 63 & 2480 \\
\hline Th & ppm & 8.3 & $<0.1$ & 0.1 & 3.1 & 4.5 & 5.7 & 7.7 & 7.0 & 8.1 & 5.5 \\
\hline U & $\mathrm{ppm}$ & 2.0 & $<0.1$ & $<0.1$ & 0.3 & 0.9 & 1.8 & 1.9 & 1.6 & 1.9 & 1.2 \\
\hline
\end{tabular}




\begin{tabular}{|c|c|c|c|c|c|c|c|c|c|c|c|}
\hline $\begin{array}{c}\text { Sample } \\
\text { Rock Type } \\
\text { Member }\end{array}$ & & $\begin{array}{cc}16-14082 & 1 \\
\text { RHhy } & \\
\text { Middle } & \end{array}$ & $\begin{array}{cc}\text { 16-14083 } & 1 \\
\text { MI } & \\
\text { Middle } & \\
\end{array}$ & $\begin{array}{c}16-140841 \\
\text { VCpbcg } \\
\text { Middle }\end{array}$ & $\begin{array}{c}16-14085 \\
\text { HRhy } \\
\text { Middle }\end{array}$ & $\begin{array}{l}16-14086 \\
\text { VCbdcg } \\
\text { Middle }\end{array}$ & $\begin{array}{c}16-14087 \\
\text { VCsamu } \\
\text { Middle }\end{array}$ & $\begin{array}{c}16-14088 \\
\text { VCsa } \\
\text { Middle }\end{array}$ & $\begin{array}{c}16-14089 \\
\text { RHhy } \\
\text { Middle }\end{array}$ & $\begin{array}{l}16-14090 \\
\text { VCsamu } \\
\text { Middle }\end{array}$ & $\begin{array}{c}16-14091 \\
\text { VCpbcg-ARG } \\
\text { Middle }\end{array}$ \\
\hline $\mathrm{SiO}_{2}$ & wt. \% & 75.4 & 40.7 & 59.3 & 75.3 & 48.1 & 69.5 & 56.2 & 69.6 & 59.8 & 65.5 \\
\hline $\mathrm{TiO}_{2}$ & wt. $\%$ & 0.10 & 0.84 & 0.22 & 0.08 & 0.19 & 0.28 & 0.31 & 0.12 & 0.35 & 0.53 \\
\hline $\mathrm{Al}_{2} \mathrm{O}_{3}$ & wt. \% & 11.60 & 12.50 & 9.24 & 8.45 & 7.69 & 9.33 & 8.91 & 12.40 & 13.40 & 11.50 \\
\hline $\mathrm{Fe}_{2} \mathrm{O}_{3}$ & $w t . \%$ & 4.02 & 14.90 & 16.30 & 8.10 & 16.40 & 11.70 & 15.60 & 8.84 & 11.90 & 9.79 \\
\hline $\mathrm{MnO}$ & $w t . \%$ & 0.04 & 0.34 & 0.09 & 0.05 & 0.08 & 0.08 & 0.24 & 0.07 & 0.09 & 0.07 \\
\hline $\mathrm{MgO}$ & $w t . \%$ & 3.06 & 6.94 & 4.70 & 3.59 & 3.08 & 3.55 & 5.30 & 3.02 & 5.82 & 6.72 \\
\hline $\mathrm{CaO}$ & $w t . \%$ & 0.24 & 7.81 & 0.15 & 0.01 & 0.16 & 0.11 & 0.07 & 0.10 & 0.54 & $<0.01$ \\
\hline $\mathrm{Na}_{2} \mathrm{O}$ & wt. \% & 0.24 & 0.21 & 0.45 & 0.08 & 1.08 & 0.17 & 0.45 & 0.23 & 0.24 & 0.13 \\
\hline $\mathrm{K}_{2} \mathrm{O}$ & wt. \% & 2.44 & 1.72 & 0.10 & 0.80 & 0.34 & 0.61 & 0.04 & 2.08 & 1.53 & 0.99 \\
\hline $\mathrm{P}_{2} \mathrm{O}_{5}$ & wt. $\%$ & 0.03 & 0.17 & 0.04 & 0.03 & 0.04 & 0.05 & 0.06 & 0.03 & 0.07 & 0.05 \\
\hline $\mathrm{Cr}_{2} \mathrm{O}_{3}$ & wt. \% & $<0.01$ & $<0.01$ & $<0.01$ & $<0.01$ & $<0.01$ & $<0.01$ & $<0.01$ & $<0.01$ & $<0.01$ & $<0.01$ \\
\hline LOI & wt. $\%$ & 2.60 & 11.80 & 5.35 & 2.75 & 7.20 & 3.15 & 5.40 & 2.95 & 4.45 & 4.30 \\
\hline Sum & $w t . \%$ & 99.8 & 97.9 & 95.9 & 99.2 & 84.4 & 98.5 & 92.6 & 99.4 & 98.2 & 99.6 \\
\hline $\mathrm{H}_{2} \mathrm{O}^{+}$ & wt. $\%$ & 2.4 & 3.9 & 4.6 & 3.1 & 3.8 & 3.8 & 4.7 & 3.5 & 4.6 & 4.5 \\
\hline $\mathrm{CO}_{2}$ & wt. \% & 0.41 & 11.30 & 0.17 & $<0.01$ & 0.13 & 0.09 & 0.02 & 0.03 & 0.67 & 0.03 \\
\hline $\mathrm{FeO}$ & wt. \% & nd & nd & nd & nd & nd & nd & nd & 7.1 & nd & nd \\
\hline C & ppm & nd & nd & nd & nd & nd & nd & nd & nd & nd & nd \\
\hline$S$ & ppm & 0.06 & 0.15 & 3.35 & 0.18 & 8.58 & 0.45 & 3.48 & 0.04 & 0.26 & 0.03 \\
\hline $\mathrm{Li}$ & $\mathrm{ppm}$ & nd & nd & nd & nd & nd & nd & nd & nd & nd & nd \\
\hline $\mathrm{Be}$ & $\mathrm{ppm}$ & nd & nd & nd & nd & nd & nd & nd & nd & nd & nd \\
\hline$B$ & ppm & nd & nd & nd & nd & nd & nd & nd & nd & nd & nd \\
\hline $\mathrm{F}$ & $\mathrm{ppm}$ & nd & nd & nd & nd & nd & nd & nd & nd & nd & nd \\
\hline $\mathrm{Cl}$ & ppm & nd & nd & nd & nd & nd & nd & nd & nd & nd & nd \\
\hline Sc & ppm & nd & nd & nd & nd & nd & nd & nd & nd & nd & nd \\
\hline V & ppm & nd & nd & nd & nd & nd & nd & nd & nd & nd & nd \\
\hline $\mathrm{Cr}$ & ppm & nd & nd & nd & nd & nd & nd & nd & nd & nd & nd \\
\hline Co & ppm & nd & nd & nd & nd & nd & nd & nd & nd & nd & nd \\
\hline $\mathrm{Ni}$ & $\mathrm{ppm}$ & 1 & 92 & 6 & 1 & 12 & 17 & 13 & $<1$ & 28 & 27 \\
\hline $\mathrm{Cu}$ & $\mathrm{ppm}$ & 41 & 79 & 451 & 632 & 1100 & 1240 & 10600 & 33 & 563 & 34 \\
\hline $\mathrm{Zn}$ & ppm & 472 & 345 & 22900 & 415 & 75900 & 3250 & 25300 & 428 & 3580 & 224 \\
\hline $\mathrm{Ga}$ & ppm & nd & nd & nd & nd & nd & nd & nd & nd & nd & nd \\
\hline As & ppm & nd & nd & nd & nd & nd & nd & nd & nd & nd & nd \\
\hline$R b$ & ppm & 70 & 47 & 9 & 26 & 18 & 21 & 4 & 59 & 44 & 25 \\
\hline $\mathrm{Sr}$ & ppm & 15 & 43 & 2 & 5 & 3 & 5 & 2 & 15 & 14 & 3 \\
\hline$Y$ & $\mathrm{ppm}$ & 56 & 20 & 102 & 61 & 90 & 81 & 76 & 54 & 77 & 130 \\
\hline $\mathrm{Zr}$ & $\mathrm{ppm}$ & 221 & 101 & 165 & 171 & 148 & 152 & 151 & 237 & 193 & 154 \\
\hline $\mathrm{Nb}$ & $\mathrm{ppm}$ & 27 & 9 & 23 & 19 & 18 & 17 & 17 & 25 & 22 & 23 \\
\hline Mo & $\mathrm{ppm}$ & nd & nd & nd & nd & nd & nd & nd & nd & nd & nd \\
\hline $\mathrm{Ag}$ & $\mathrm{ppm}$ & 1.5 & 1.0 & 40.2 & 35.1 & 51.9 & 71.3 & 30.1 & 1.1 & 8.3 & 0.5 \\
\hline $\mathrm{Cd}$ & ppm & nd & nd & nd & nd & nd & nd & nd & nd & nd & nd \\
\hline Sn & $\mathrm{ppm}$ & nd & nd & nd & nd & nd & nd & nd & nd & nd & nd \\
\hline $\mathrm{Sb}$ & $\mathrm{ppm}$ & nd & nd & nd & nd & nd & nd & nd & nd & nd & nd \\
\hline Cs & $\mathrm{ppm}$ & nd & nd & nd & nd & nd & nd & nd & nd & nd & nd \\
\hline $\mathrm{Ba}$ & $\mathrm{ppm}$ & nd & nd & nd & nd & nd & nd & nd & nd & nd & nd \\
\hline La & ppm & nd & nd & nd & nd & nd & nd & nd & 21.7 & nd & no \\
\hline $\mathrm{Ce}$ & $\mathrm{ppm}$ & nd & nd & nd & nd & nd & nd & nd & 51.2 & nd & no \\
\hline Pr & $\mathrm{ppm}$ & nd & nd & nd & nd & nd & nd & nd & 6.6 & nd & nd \\
\hline $\mathrm{Nd}$ & $\mathrm{ppm}$ & nd & nd & nd & nd & nd & nd & nd & 27.8 & nd & nd \\
\hline Sm & $\mathrm{ppm}$ & nd & nd & nd & nd & nd & nd & nd & 7.7 & nd & nd \\
\hline Eu & ppm & nd & nd & nd & nd & nd & nd & nd & 0.7 & nd & nd \\
\hline Gd & $\mathrm{ppm}$ & nd & nd & nd & nd & nd & nd & nd & 6.6 & nd & nd \\
\hline $\mathrm{Tb}$ & ppm & nd & nd & nd & nd & nd & nd & nd & 1.6 & nd & nd \\
\hline Dy & $\mathrm{ppm}$ & nd & nd & nd & nd & nd & nd & nd & 11.7 & nd & nd \\
\hline Ho & $\mathrm{ppm}$ & nd & nd & nd & nd & nd & nd & nd & 3.25 & nd & nd \\
\hline Er & $\mathrm{ppm}$ & nd & nd & nd & nd & nd & nd & nd & 7.5 & nd & nd \\
\hline $\mathrm{Tm}$ & $\mathrm{ppm}$ & nd & nd & nd & nd & nd & nd & nd & 1.8 & nd & nd \\
\hline$Y b$ & ppm & nd & nd & nd & nd & nd & nd & nd & 10.4 & nd & nd \\
\hline Lu & ppm & nd & nd & nd & nd & nd & nd & nd & 1.47 & nd & nd \\
\hline $\mathrm{Hf}$ & $\mathrm{ppm}$ & nd & nd & nd & nd & nd & nd & nd & 11.0 & nd & nd \\
\hline $\mathrm{Ta}$ & $\mathrm{ppm}$ & nd & nd & nd & nd & nd & nd & nd & 2.0 & nd & nd \\
\hline$w$ & $\mathrm{ppm}$ & nd & nd & nd & nd & nd & nd & nd & nd & nd & nd \\
\hline $\mathrm{Au}$ & $\mathrm{ppb}$ & nd & nd & nd & nd & nd & nd & nd & nd & nd & nd \\
\hline $\mathrm{Pb}$ & ppm & 41 & 21 & 1590 & 390 & 4770 & 1120 & 13 & 37 & 75 & 7 \\
\hline Th & ppm & 6.9 & 0.6 & 5.3 & 6.0 & 4.8 & 4.6 & 5.1 & 8.9 & 6.4 & 4.4 \\
\hline$U$ & ppm & 1.5 & $<0.1$ & 0.8 & 1.4 & 1.0 & 1.1 & 0.8 & 1.8 & 1.0 & 1.0 \\
\hline
\end{tabular}




\begin{tabular}{|c|c|c|c|c|c|c|c|c|c|c|c|}
\hline $\begin{array}{c}\text { Sample } \\
\text { Rock Type } \\
\text { Member }\end{array}$ & & $\begin{array}{c}16-14092 \\
\text { VCpbcg-ARG } \\
\text { Middle }\end{array}$ & $\begin{array}{c}16-140941 \\
\text { VCsa } \\
\text { Middle }\end{array}$ & $\begin{array}{c}\text { 16-14099 } \\
\text { RHhy } \\
\text { Middle } \\
\end{array}$ & $\begin{array}{c}16-14107 \\
\text { ME-in-VCbdcg } \\
\text { Middle }\end{array}$ & $\begin{array}{l}16-14131 \\
\text { RHco } \\
\text { Middle }\end{array}$ & $\begin{array}{c}16-141321 \\
\text { RHco } \\
\text { Middle }\end{array}$ & $\begin{array}{l}16-14133 \\
\text { RHco } \\
\text { Middle } \\
\end{array}$ & $\begin{array}{c}16-14138 \\
\text { VCmusa } \\
\text { Middle }\end{array}$ & $\begin{array}{c}18-14046 \\
\text { QPco } \\
\text { Upper }\end{array}$ & $\begin{array}{c}18-14048 \\
\text { QPco } \\
\text { Upper }\end{array}$ \\
\hline $\mathrm{SiO}_{2}$ & $w t . \%$ & 75.0 & 76.8 & 77.6 & 54.3 & 84.4 & 80.6 & 81.3 & 58.4 & 80.2 & 68.8 \\
\hline $\mathrm{TiO}_{2}$ & wt. $\%$ & 0.12 & 0.22 & 0.09 & 2.40 & 0.08 & 0.10 & 0.07 & 0.53 & 0.15 & 0.10 \\
\hline $\mathrm{Al}_{2} \mathrm{O}_{3}$ & $w t . \%$ & 11.00 & 10.80 & 11.90 & 20.00 & 9.24 & 9.90 & 9.45 & 13.60 & 9.73 & 9.09 \\
\hline $\mathrm{Fe}_{2} \mathrm{O}_{3} \mathrm{t}$ & $w t . \%$ & 4.17 & 2.25 & 2.49 & 6.86 & 0.44 & 2.74 & 1.52 & 17.30 & 2.39 & 1.81 \\
\hline $\mathrm{MnO}$ & wt. $\%$ & 0.07 & 0.06 & 0.03 & 0.04 & 0.02 & 0.03 & 0.06 & 0.07 & 0.08 & 0.20 \\
\hline $\mathrm{MgO}$ & wt. \% & 3.49 & 2.16 & 2.20 & 6.07 & 0.28 & 0.18 & 0.26 & 1.16 & 0.42 & 1.33 \\
\hline $\mathrm{CaO}$ & wt. $\%$ & $<0.01$ & 1.38 & 0.21 & 0.39 & 0.33 & 0.33 & 2.15 & $<0.01$ & 1.03 & 8.58 \\
\hline $\mathrm{Na}_{2} \mathrm{O}$ & wt. $\%$ & 0.16 & 0.44 & 0.17 & 0.33 & 0.25 & 1.58 & 1.27 & 0.40 & 2.67 & 0.20 \\
\hline $\mathrm{K}_{2} \mathrm{O}$ & $w t . \%$ & 2.37 & 2.75 & 3.25 & 4.00 & 2.56 & 2.16 & 2.12 & 2.49 & 1.90 & 2.26 \\
\hline $\mathrm{P}_{2} \mathrm{O}_{5}$ & wt. \% & 0.03 & 0.05 & 0.02 & 0.30 & 0.02 & 0.03 & 0.02 & 0.05 & 0.04 & 0.03 \\
\hline $\mathrm{Cr}_{2} \mathrm{O}_{3}$ & wt. \% & $<0.01$ & $<0.01$ & $<0.01$ & 0.03 & $<0.01$ & $<0.01$ & $<0.01$ & $<0.01$ & $<0.01$ & $<0.01$ \\
\hline LOI & wt. \% & 2.60 & 2.45 & 2.30 & 4.50 & 1.55 & 2.30 & 2.30 & 5.25 & 0.95 & 7.35 \\
\hline Sum & wt. \% & 99.0 & 99.4 & 100.3 & 99.2 & 99.2 & 99.9 & 100.5 & 99.3 & 99.6 & 99.7 \\
\hline $\mathrm{H}_{2} \mathrm{O}^{-}$ & wt. \% & 2.6 & 1.7 & 2.1 & 4.6 & 1.0 & 0.9 & 0.9 & $<0.01$ & 0.8 & 1.2 \\
\hline $\mathrm{CO}_{2}$ & wt. \% & 0.04 & 1.68 & 0.18 & 0.03 & 0.50 & 0.41 & 1.83 & $<0.01$ & 0.72 & 7.31 \\
\hline $\mathrm{FeO}$ & wt.\% & nd & nd & nd & 5.3 & nd & nd & nd & nd & nd & nd \\
\hline C & ppm & nd & nd & nd & nd & nd & nd & nd & nd & nd & nd \\
\hline$S$ & $\mathrm{ppm}$ & 0.02 & 0.20 & 0.04 & 0.09 & 0.05 & 1.81 & 0.51 & nd & 0.03 & 0.01 \\
\hline $\mathrm{Li}$ & ppm & nd & nd & nd & nd & nd & nd & nd & nd & nd & nd \\
\hline $\mathrm{Be}$ & ppm & nd & nd & nd & nd & nd & nd & nd & 1 & nd & nd \\
\hline B & ppm & nd & nd & nd & nd & nd & nd & nd & nd & nd & nd \\
\hline $\mathrm{F}$ & $\mathrm{ppm}$ & nd & nd & nd & nd & nd & nd & nd & nd & nd & nd \\
\hline $\mathrm{Cl}$ & ppm & nd & nd & nd & nd & nd & nd & nd & nd & nd & nd \\
\hline Sc & $\mathrm{ppm}$ & nd & nd & nd & nd & nd & nd & nd & 8.4 & nd & nd \\
\hline V & ppm & nd & nd & nd & nd & nd & nd & nd & 71 & nd & nd \\
\hline $\mathrm{Cr}$ & ppm & nd & nd & nd & nd & nd & nd & nd & 53 & nd & nd \\
\hline Co & $\mathrm{ppm}$ & nd & nd & nd & nd & nd & nd & nd & 18 & nd & nd \\
\hline $\mathrm{Ni}$ & ppm & 10 & 10 & $<1$ & 58 & 1 & $<1$ & 1 & 40 & 2 & 1 \\
\hline $\mathrm{Cu}$ & ppm & 22 & 170 & 19 & 68 & 12 & 19 & 15 & 1010 & 51 & 15 \\
\hline $\mathrm{Zn}$ & ppm & 96 & 358 & 141 & 745 & 49 & 95 & 61 & 3810 & 73 & 68 \\
\hline $\mathrm{Ga}$ & ppm & nd & nd & nd & nd & nd & nd & nd & 23 & nd & nd \\
\hline As & ppm & nd & nd & nd & nd & nd & nd & nd & 7.0 & nd & nd \\
\hline$R b$ & $\mathrm{ppm}$ & 70 & 97 & 110 & 129 & 51 & 39 & 38 & 50 & 48 & 76 \\
\hline $\mathrm{Sr}$ & ppm & 6 & 25 & 11 & 26 & 13 & 16 & 22 & 28 & 23 & 30 \\
\hline$Y$ & ppm & 74 & 186 & 83 & 20 & 73 & 94 & 80 & 197 & 44 & 62 \\
\hline $\mathrm{Zr}$ & ppm & 210 & 185 & 233 & 144 & 174 & 201 & 188 & 193 & 178 & 178 \\
\hline $\mathrm{Nb}$ & ppm & 23 & 21 & 28 & 21 & 21 & 24 & 21 & 28 & 14 & 14 \\
\hline Mo & $\mathrm{ppm}$ & nd & nd & nd & nd & nd & nd & nd & 2 & nd & no \\
\hline $\mathrm{Ag}$ & ppm & 0.6 & 2.1 & 0.4 & 5.1 & $<0.1$ & 0.7 & 0.2 & 13.6 & 0.4 & 0.4 \\
\hline $\mathrm{Cd}$ & $\mathrm{ppm}$ & nd & nd & nd & nd & nd & nd & nd & 13.0 & nd & nd \\
\hline Sn & $\mathrm{ppm}$ & nd & nd & nd & nd & nd & nd & nd & 875 & nd & nd \\
\hline $\mathrm{Sb}$ & ppm & nd & nd & nd & nd & nd & nd & nd & 8.0 & nd & nd \\
\hline Cs & ppm & nd & nd & nd & nd & nd & nd & nd & nd & nd & nd \\
\hline $\mathrm{Ba}$ & ppm & nd & nd & nd & nd & nd & nd & nd & 213 & nd & nd \\
\hline La & ppm & nd & nd & nd & 4.2 & 41.9 & 52.2 & 44.8 & nd & 43.2 & 31.6 \\
\hline $\mathrm{Ce}$ & ppm & nd & nd & nd & 9 & 96.7 & 119 & 98.2 & nd & 92.1 & 70.7 \\
\hline$P_{r}$ & $\mathrm{ppm}$ & nd & nd & nd & 1.1 & 12.3 & 14.9 & 12.4 & nd & 11 & 8.6 \\
\hline Nd & $\mathrm{ppm}$ & nd & nd & nd & 5.3 & 52.2 & 62.3 & 52.5 & nd & 44.6 & 34.9 \\
\hline $\mathrm{Sm}$ & $\mathrm{ppm}$ & nd & nd & nd & 1.8 & 13.7 & 17.1 & 14.8 & nd & 11.3 & 9.1 \\
\hline $\mathrm{Eu}$ & $\mathrm{ppm}$ & nd & nd & nd & 0.31 & 2.37 & 4.79 & 6.31 & nd & 1.39 & 1.09 \\
\hline $\mathrm{Gd}$ & $\mathrm{ppm}$ & nd & nd & nd & 1.8 & 13.2 & 17 & 14.9 & nd & 10.4 & 9 \\
\hline $\mathrm{Tb}$ & $\mathrm{ppm}$ & nd & nd & nd & 0.5 & 2.2 & 3 & 2.5 & nd & 1.8 & 1.6 \\
\hline Dy & $\mathrm{ppm}$ & nd & nd & nd & 3.4 & 13.5 & 18.6 & 14.9 & nd & 9.9 & 10.3 \\
\hline $\mathrm{Ho}$ & ppm & nd & nd & nd & 0.93 & 2.73 & 3.86 & 2.96 & nd & 1.84 & 2.26 \\
\hline Er & $\mathrm{ppm}$ & nd & nd & nd & 2.1 & 8.1 & 11.5 & 8.9 & nd & 5.1 & 6.8 \\
\hline $\mathrm{Tm}$ & $\mathrm{ppm}$ & nd & nd & nd & 0.5 & 1.2 & 1.7 & 1.3 & nd & 0.7 & 1 \\
\hline $\mathrm{Yb}$ & $\mathrm{ppm}$ & nd & nd & nd & 3 & 7.8 & 10.9 & 8.7 & nd & 4.2 & 6.8 \\
\hline $\mathrm{Lu}$ & $\mathrm{ppm}$ & nd & nd & nd & 0.43 & 1.14 & 1.63 & 1.33 & nd & 0.6 & 1.02 \\
\hline $\mathrm{Hf}$ & $\mathrm{ppm}$ & nd & nd & nd & 4.3 & nd & nd & nd & nd & nd & nd \\
\hline $\mathrm{Ta}$ & ppm & nd & nd & nd & $<0.5$ & nd & nd & nd & nd & nd & nd \\
\hline W & $\mathrm{ppm}$ & nd & nd & nd & nd & nd & nd & nd & $<10$ & nd & nd \\
\hline $\mathrm{Au}$ & $p p b$ & nd & nd & nd & nd & nd & nd & nd & nd & nd & nd \\
\hline $\mathrm{Pb}$ & ppm & $<2$ & 41 & $<2$ & 425 & $<2$ & $<2$ & $<2$ & 399 & $<2$ & $<2$ \\
\hline Th & ppm & 6.6 & 5.7 & 7.8 & 0.6 & 6.3 & 6.8 & 6.0 & nd & 5.6 & 5.1 \\
\hline$U$ & $\mathrm{ppm}$ & 1.6 & 1.5 & 1.3 & 0.2 & 1.6 & 1.9 & 1.5 & nd & 1.7 & 1.5 \\
\hline
\end{tabular}




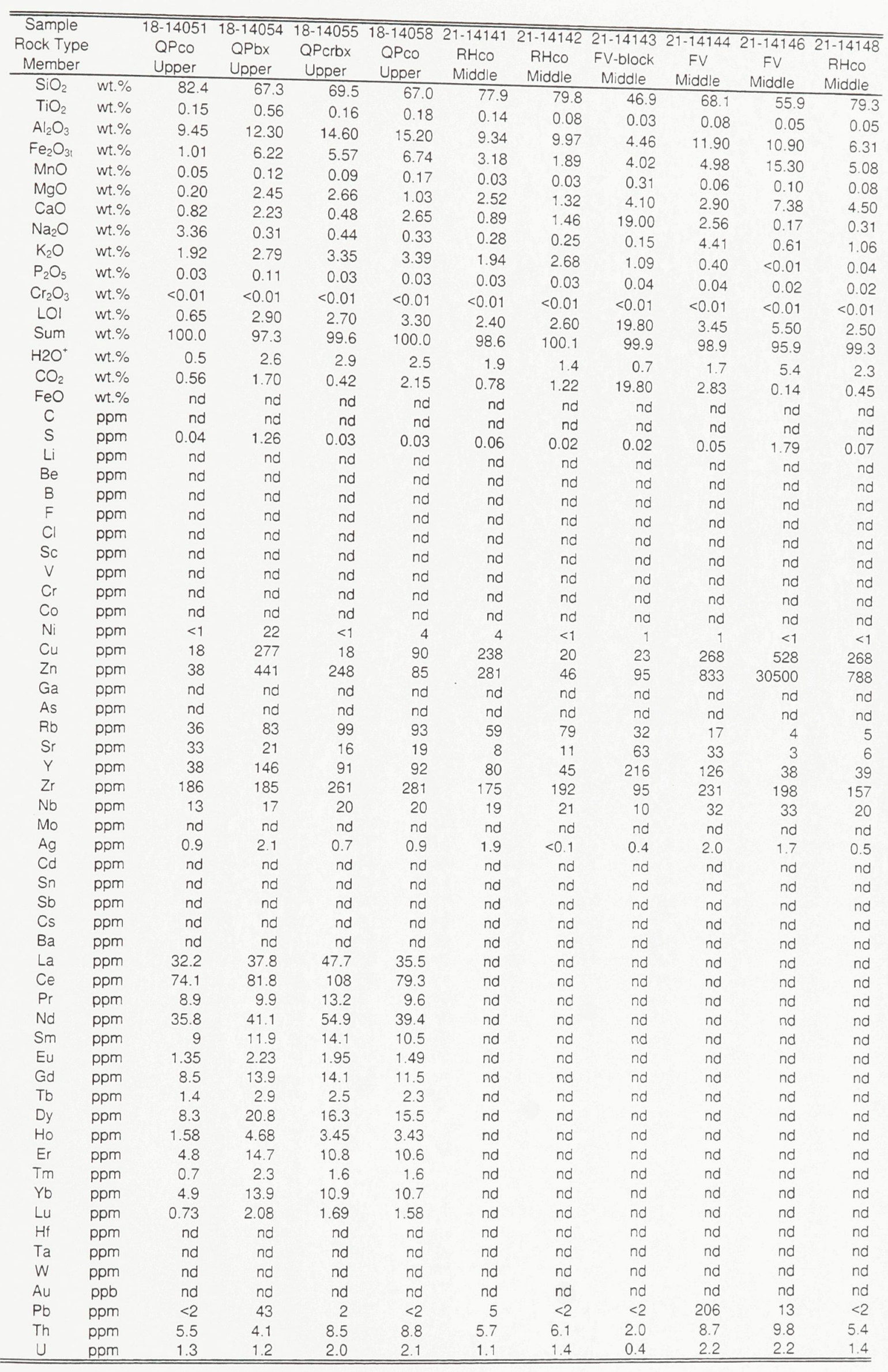




\begin{tabular}{|c|c|c|c|c|c|c|c|c|c|c|c|}
\hline $\begin{array}{c}\text { Sample } \\
\text { Rock Type } \\
\text { Member }\end{array}$ & & $\begin{array}{c}\text { 21-14149SR } \\
\text { RHco } \\
\text { Middle } \\
\end{array}$ & $\begin{array}{l}21-14150 \\
\text { VCpbcg } \\
\text { Middle } \\
\end{array}$ & $\begin{array}{l}21-14151 \\
\text { VCpbcg } \\
\text { Middle }\end{array}$ & $\begin{array}{c}21-14153 \\
\text { RHco } \\
\text { Middle } \\
\end{array}$ & $\begin{array}{c}\text { 21-14155 } \\
\text { RHbx } \\
\text { Middle }\end{array}$ & $\begin{array}{c}21-14235 \\
\text { RHco } \\
\text { Middle } \\
\end{array}$ & $\begin{array}{c}21-14236 \\
\text { RHco } \\
\text { Middle }\end{array}$ & $\begin{array}{c}\text { 23-14237 } \\
\text { RHbx } \\
\text { Lower }\end{array}$ & $\begin{array}{c}23-14238 \\
\text { VCpbcg } \\
\text { Lower }\end{array}$ & $\begin{array}{c}\text { 23-14239 } \\
\text { VCpbcg } \\
\text { Lower } \\
\end{array}$ \\
\hline $\mathrm{SiO}_{2}$ & wt. \% & 73.7 & 72.0 & 76.5 & 78.9 & 81.0 & 72.6 & 70.3 & 74.7 & 71.3 & 56.0 \\
\hline $\mathrm{TiO}_{2}$ & $w t . \%$ & 0.07 & 0.30 & 0.16 & 0.09 & 0.06 & 0.10 & 0.11 & 0.05 & 0.20 & 0.24 \\
\hline $\mathrm{Al}_{2} \mathrm{O}_{3}$ & $w t . \%$ & 8.58 & 8.94 & 7.58 & 8.64 & 5.94 & 12.90 & 14.20 & 6.57 & 11.60 & 19.30 \\
\hline $\mathrm{Fe}_{2} \mathrm{O}_{3}$ & $w t . \%$ & 4.12 & 6.16 & 4.43 & 2.90 & 3.81 & 2.22 & 2.06 & 4.75 & 5.15 & 11.30 \\
\hline $\mathrm{MnO}$ & $w t . \%$ & 0.01 & 0.04 & 0.04 & 0.03 & 0.04 & 0.05 & 0.05 & $<0.01$ & 0.04 & 0.02 \\
\hline $\mathrm{MgO}$ & $w t . \%$ & 8.69 & 7.86 & 6.47 & 4.46 & 4.87 & 1.54 & 1.17 & 0.41 & 2.41 & 2.47 \\
\hline $\mathrm{CaO}$ & wt.\% & $<0.01$ & 0.07 & 0.43 & 0.36 & 0.43 & 2.63 & 2.40 & 0.07 & 0.37 & 0.14 \\
\hline $\mathrm{Na}_{2} \mathrm{O}$ & wt. \% & 0.14 & 0.16 & 0.16 & 0.26 & 0.13 & 0.30 & 0.40 & 1.99 & 0.82 & 0.82 \\
\hline $\mathrm{K}_{2} \mathrm{O}$ & wt. \% & 0.38 & 0.23 & 0.37 & 1.25 & 0.30 & 3.45 & 4.02 & 1.24 & 2.15 & 3.95 \\
\hline $\mathrm{P}_{2} \mathrm{O}_{5}$ & wt. $\%$ & $<0.01$ & 0.05 & 0.04 & 0.03 & 0.03 & 0.03 & 0.03 & $<0.01$ & 0.02 & 0.03 \\
\hline $\mathrm{Cr}_{2} \mathrm{O}_{3}$ & wt. $\%$ & $<0.01$ & $<0.01$ & $<0.01$ & $<0.01$ & $<0.01$ & $<0.01$ & $<0.01$ & $<0.01$ & $<0.01$ & $<0.01$ \\
\hline LOI & wt. \% & 4.10 & 3.90 & 3.60 & 2.85 & 2.80 & 3.85 & 3.65 & 3.70 & 3.25 & 5.75 \\
\hline Sum & wt. $\%$ & 99.8 & 99.7 & 99.8 & 99.8 & 99.4 & 99.7 & 98.4 & 93.5 & 97.3 & 100.0 \\
\hline $\mathrm{H}_{20} \mathrm{O}^{+}$ & wt. $\%$ & $<0.01$ & 3.8 & 3.0 & 2.2 & 2.3 & 1.7 & 1.6 & 1.4 & 2.5 & 3.2 \\
\hline $\mathrm{CO}_{2}$ & wt. $\%$ & $<0.01$ & 0.05 & 0.62 & 0.52 & 0.61 & 2.40 & 2.47 & 0.10 & 0.45 & 0.02 \\
\hline $\mathrm{FeO}$ & $w t . \%$ & 2.9 & nd & 3.3 & nd & nd & 1.4 & 0.9 & nd & nd & nd \\
\hline$c$ & $\mathrm{ppm}$ & nd & nd & nd & nd & nd & 0.68 & 0.71 & nd & nd & nd \\
\hline$S$ & $\mathrm{ppm}$ & nd & 0.09 & 0.01 & 0.02 & 0.02 & 0.12 & 0.49 & 4.28 & 1.15 & 4.05 \\
\hline $\mathrm{Li}$ & $\mathrm{ppm}$ & nd & nd & nd & nd & nd & 14 & 9 & 10 & 39 & 45 \\
\hline $\mathrm{Be}$ & ppm & 1 & nd & nd & nd & nd & 2 & 3 & $<0.5$ & 2 & 1 \\
\hline B & $\mathrm{ppm}$ & nd & nd & nd & nd & nd & 39 & 44 & nd & nd & nd \\
\hline$F$ & $\mathrm{ppm}$ & nd & nd & nd & nd & nd & 1800 & 1920 & nd & nd & nd \\
\hline $\mathrm{Cl}$ & $\mathrm{ppm}$ & nd & nd & nd & nd & nd & 55 & 31 & nd & nd & nd \\
\hline Sc & $\mathrm{ppm}$ & 11.0 & nd & nd & nd & nd & 2.0 & 2.0 & $<0.5$ & 3.5 & 2.9 \\
\hline V & $\mathrm{ppm}$ & 15 & nd & nd & nd & nd & 4 & 4 & $<2$ & 19 & 17 \\
\hline $\mathrm{Cr}$ & $\mathrm{ppm}$ & $<1$ & nd & nd & nd & nd & $<2$ & $<2$ & 14 & 18 & 12 \\
\hline Co & $\mathrm{ppm}$ & 4 & nd & nd & nd & nd & $<1$ & 2 & 17 & 6 & 13 \\
\hline $\mathrm{Ni}$ & $\mathrm{ppm}$ & 18 & 15 & 17 & 7 & 20 & $<1$ & 1 & 1 & 12 & 14 \\
\hline $\mathrm{Cu}$ & $\mathrm{ppm}$ & 67 & 207 & 11 & 7 & 16 & 18 & 29 & 477 & 483 & 794 \\
\hline $\mathrm{Zn}$ & $\mathrm{ppm}$ & 1630 & 470 & 90 & 66 & 53 & 47 & 135 & 66100 & 15800 & 10500 \\
\hline $\mathrm{Ga}$ & $\mathrm{ppm}$ & 47 & nd & nd & nd & nd & 25 & 26 & $<3$ & 27 & 42 \\
\hline As & $\mathrm{ppm}$ & $<3$ & nd & nd & nd & nd & 1.8 & 15.0 & 3.0 & $<3$ & 21.0 \\
\hline $\mathrm{Rb}$ & $\mathrm{ppm}$ & 14 & 10 & 13 & 30 & 13 & 101 & 121 & 37 & 58 & 108 \\
\hline $\mathrm{Sr}$ & $\mathrm{ppm}$ & 4 & 3 & 5 & 10 & 5 & 19 & 13 & 10 & 21 & 24 \\
\hline$Y$ & ppm & 81 & 92 & 78 & 82 & 64 & 103 & 87 & $<2$ & 92 & 43 \\
\hline $\mathrm{Zr}$ & $\mathrm{ppm}$ & 216 & 160 & 153 & 196 & 136 & 245 & 266 & 148 & 211 & 340 \\
\hline $\mathrm{Nb}$ & $\mathrm{ppm}$ & 20 & 24 & 24 & 28 & 15 & 26 & 26 & 17 & 24 & 38 \\
\hline Mo & $\mathrm{ppm}$ & $<1$ & nd & nd & nd & nd & $<1$ & $<1$ & $<1$ & 2 & 3 \\
\hline $\mathrm{Ag}$ & $\mathrm{ppm}$ & 0.5 & 0.9 & 0.6 & 0.6 & 0.3 & 0.1 & 0.4 & 7.2 & 17.4 & 8.0 \\
\hline $\mathrm{Cd}$ & $\mathrm{ppm}$ & 6.0 & nd & nd & nd & nd & $<0.2$ & 0.8 & 237.0 & 64.0 & 43.0 \\
\hline Sn & $\mathrm{ppm}$ & 5 & nd & nd & nd & nd & 14 & 13 & 182 & 348 & 205 \\
\hline Sb & $\mathrm{ppm}$ & $<5$ & nd & nd & nd & nd & 0.3 & 0.3 & nd & nd & nd \\
\hline Cs & $\mathrm{ppm}$ & nd & nd & nd & nd & nd & 1.5 & 2.1 & nd & nd & nd \\
\hline $\mathrm{Ba}$ & $\mathrm{ppm}$ & 95 & nd & nd & nd & nd & 400 & 397 & 139 & 234 & 361 \\
\hline La & $\mathrm{ppm}$ & 2.5 & nd & 40.3 & nd & nd & 58.5 & 46.6 & nd & nd & nd \\
\hline $\mathrm{Ce}$ & $\mathrm{ppm}$ & 6 & nd & 106 & nd & nd & 133 & 112 & nd & nd & nd \\
\hline Pr & ppm & 0.9 & nd & 15.1 & nd & nd & nd & nd & nd & nd & nd \\
\hline $\mathrm{Nd}$ & ppm & 5.1 & nd & 68.8 & nd & nd & nd & nd & nd & nd & nd \\
\hline $\mathrm{Sm}$ & $\mathrm{ppm}$ & 3.6 & nd & 19.7 & nd & nd & nd & nd & nd & nd & nd \\
\hline Eu & $\mathrm{ppm}$ & 0.6 & nd & 0.89 & nd & nd & nd & nd & nd & nd & nd \\
\hline $\mathrm{Gd}$ & $\mathrm{ppm}$ & 4.7 & nd & 13.9 & nd & nd & nd & nd & nd & nd & nd \\
\hline $\mathrm{Tb}$ & $\mathrm{ppm}$ & 1.5 & nd & 2.6 & nd & nd & nd & nd & nd & nd & nd \\
\hline Dy & $\mathrm{ppm}$ & 12.1 & nd & 15.4 & nd & nd & nd & nd & nd & nd & nd \\
\hline Ho & $\mathrm{ppm}$ & 3.38 & nd & 3.81 & nd & nd & nd & nd & nd & nd & nd \\
\hline $\mathrm{Er}$ & $\mathrm{ppm}$ & 7.6 & nd & 7.7 & nd & nd & nd & nd & nd & nd & nd \\
\hline $\mathrm{Tm}$ & $\mathrm{ppm}$ & 1.7 & nd & 1.7 & nd & nd & nd & nd & nd & nd & nd \\
\hline$Y_{b}$ & $\mathrm{ppm}$ & 9.6 & nd & 9 & nd & nd & nd & nd & nd & nd & nd \\
\hline Lu & $\mathrm{ppm}$ & 1.38 & nd & 1.21 & nd & nd & nd & nd & nd & nd & nd \\
\hline $\mathrm{H}^{f}$ & $\mathrm{ppm}$ & 9.7 & nd & 6.5 & nd & nd & 11.0 & 14.0 & nd & nd & nd \\
\hline $\mathrm{Ta}$ & $\mathrm{ppm}$ & 2.3 & nd & 1.3 & nd & nd & 3.0 & 3.1 & nd & nd & nd \\
\hline W & $\mathrm{ppm}$ & $<10$ & nd & nd & nd & nd & 5 & 4 & $<10$ & $<10$ & $<10$ \\
\hline $\mathrm{Au}$ & $\mathrm{ppb}$ & nd & nd & nd & nd & nd & 4 & 4 & nd & nd & nd \\
\hline $\mathrm{Pb}$ & ppm & 6 & $<2$ & $<2$ & $<2$ & $<2$ & $<2$ & $<2$ & 5360 & 962 & 1220 \\
\hline Th & $\mathrm{ppm}$ & 6.8 & 4.8 & 4.9 & 7.0 & 4.4 & 9.8 & 12.0 & nd & nd & nd \\
\hline U & $\mathrm{ppm}$ & 2.0 & 1.2 & 1.0 & 1.8 & 0.9 & 2.7 & 2.6 & nd & nd & nd \\
\hline
\end{tabular}




\begin{tabular}{|c|c|c|c|c|c|c|c|c|c|c|c|}
\hline $\begin{array}{l}\text { Sample } \\
\text { Rock Type } \\
\text { Member }\end{array}$ & & $\begin{array}{l}23-1424023 \\
\text { RHbx } \\
\text { Lower }\end{array}$ & $\begin{array}{l}\text { 23-14241 } \\
\text { RHco } \\
\text { Lower }\end{array}$ & $\begin{array}{l}23-142422 \\
\text { RHco } \\
\text { Lower }\end{array}$ & $\begin{array}{l}-142432 \\
\text { RHco } \\
\text { Lower }\end{array}$ & $\begin{array}{l}23-142442 \\
\text { RHco } \\
\text { Lower }\end{array}$ & $\begin{array}{l}\text { 23-14245 } \\
\text { RHbx } \\
\text { Lower }\end{array}$ & $\begin{array}{l}\text { 23-14246 H } \\
\text { RHbx } \\
\text { Lower }\end{array}$ & $\begin{array}{l}\text { HG-2323-1 } \\
\text { RHco } \\
\text { Lower }\end{array}$ & $\begin{array}{l}\text { HG-2323-2 H } \\
\text { RHco } \\
\text { Lower }\end{array}$ & $\begin{array}{l}\text { HG-2323-3 } \\
\text { RHco } \\
\text { Lower } \\
\end{array}$ \\
\hline $\mathrm{SiO}_{2}$ & wt. \% & 82.9 & 81.8 & 80.9 & 84.6 & 83.5 & 79.5 & 86.0 & 83.2 & 83.9 & 82.4 \\
\hline $\mathrm{TiO}_{2}$ & wt. \% & 0.07 & 0.07 & 0.08 & 0.06 & 0.07 & 0.08 & 0.08 & 0.08 & 0.07 & 0.11 \\
\hline $\mathrm{Al}_{2} \mathrm{O}_{3}$ & wt. \% & 8.78 & 10.20 & 9.41 & 9.24 & 9.07 & 8.69 & 8.09 & 9.61 & 9.20 & 9.42 \\
\hline $\mathrm{Fe}_{2} \mathrm{O}_{3 \mathrm{t}}$ & wt. \% & 0.79 & 0.81 & 3.64 & 0.45 & 0.83 & 6.50 & 1.32 & 0.50 & 0.44 & 0.60 \\
\hline $\mathrm{MnO}$ & wt. \% & $<0.01$ & 0.02 & $<0.01$ & 0.02 & 0.04 & 0.04 & $<0.01$ & 0.04 & 0.04 & 0.06 \\
\hline $\mathrm{MgO}$ & wt.\% & 0.08 & 0.33 & 0.76 & 0.17 & 0.13 & 0.98 & 0.17 & 0.23 & 0.22 & 0.26 \\
\hline $\mathrm{CaO}$ & wt.\% & 0.08 & 0.85 & 0.23 & 0.51 & 1.32 & 0.14 & 0.14 & 0.46 & 0.41 & 0.62 \\
\hline $\mathrm{Na}_{2} \mathrm{O}$ & wt.\% & 1.99 & 2.95 & 0.27 & 3.04 & 1.98 & 0.47 & 0.37 & 4.74 & 4.69 & 5.12 \\
\hline $\mathrm{K}_{2} \mathrm{O}$ & wt. \% & 1.67 & 1.56 & 2.08 & 1.30 & 1.69 & 1.43 & 2.07 & 0.70 & 0.62 & 0.60 \\
\hline $\mathrm{P}_{2} \mathrm{O}_{5}$ & wt. \% & $<0.01$ & $<0.01$ & $<0.01$ & $<0.01$ & $<0.01$ & $<0.01$ & $<0.01$ & 0.03 & 0.03 & 0.03 \\
\hline $\mathrm{Cr}_{2} \mathrm{O}_{3}$ & wt.\% & $<0.01$ & $<0.01$ & $<0.01$ & $<0.01$ & $<0.01$ & $<0.01$ & $<0.01$ & $<0.01$ & $<0.01$ & $<0.01$ \\
\hline LOI & wt.\% & 2.15 & 1.20 & 1.85 & 0.80 & 1.75 & 2.30 & 1.85 & 0.70 & 0.60 & 0.70 \\
\hline Sum & wt.\% & 98.5 & 99.8 & 99.2 & 100.2 & 100.4 & 100.1 & 100.1 & 100.4 & 100.3 & 100.0 \\
\hline $\mathrm{H}_{2} \mathrm{O}^{+}$ & $w t . \%$ & 1.0 & 0.6 & 1.5 & 0.4 & 0.5 & 1.8 & 0.8 & 0.4 & 0.3 & 0.2 \\
\hline $\mathrm{CO}_{2}$ & $w t . \%$ & 0.02 & 1.08 & 0.26 & 0.71 & 1.31 & 0.21 & 0.16 & 0.66 & 0.58 & 0.86 \\
\hline $\mathrm{FeO}$ & $w t . \%$ & 0.7 & nd & 2.6 & nd & nd & nd & 0.2 & 0.3 & 0.2 & 0.3 \\
\hline$C$ & ppm & 0.04 & nd & 0.10 & nd & nd & nd & 0.13 & 0.23 & 0.20 & 0.26 \\
\hline$S$ & $\mathrm{ppm}$ & 1.82 & 0.29 & 0.29 & 0.02 & $<0.01$ & 0.71 & 0.63 & 0.01 & 0.01 & 0.01 \\
\hline Li & $\mathrm{ppm}$ & 3 & $<1$ & 20 & $<1$ & $<1$ & 24 & 7 & 2 & 2 & 2 \\
\hline $\mathrm{Be}$ & $\mathrm{ppm}$ & $<0.5$ & 2 & 1 & 1 & 2 & $<0.5$ & $<0.5$ & 2 & 2 & 2 \\
\hline B & $\mathrm{ppm}$ & nd & nd & nd & nd & nd & nd & nd & 22 & 21 & 18 \\
\hline$F$ & $\mathrm{ppm}$ & 876 & nd & 935 & nd & nd & nd & 825 & 79 & 77 & 69 \\
\hline $\mathrm{Cl}$ & $\mathrm{ppm}$ & nd & nd & nd & nd & nd & nd & nd & 39 & 30 & 42 \\
\hline Sc & $\mathrm{ppm}$ & $<0.5$ & 0.7 & 1.2 & 0.7 & 1.0 & 0.5 & 1.5 & $<1$ & $<1$ & $<1$ \\
\hline V & ppm & $<2$ & $<2$ & $<2$ & $<2$ & $<2$ & 2 & $<2$ & 5 & $<2$ & 3 \\
\hline $\mathrm{Cr}$ & $\mathrm{ppm}$ & 8 & 2 & 13 & 14 & 4 & 16 & 15 & 40 & 32 & 48 \\
\hline Co & $\mathrm{ppm}$ & 22 & $<1$ & 9 & $<1$ & $<1$ & 6 & 14 & $<1$ & $<1$ & $<1$ \\
\hline $\mathrm{Ni}$ & $\mathrm{ppm}$ & 2 & $<1$ & $<1$ & $<1$ & $<1$ & $<1$ & 3 & $<1$ & $<1$ & $<1$ \\
\hline $\mathrm{Cu}$ & $\mathrm{ppm}$ & 191 & 38 & 2430 & 3 & 5 & 167 & 170 & 7 & 10 & 6 \\
\hline $\mathrm{Zn}$ & ppm & 27100 & 156 & 400 & 52 & 41 & 169 & 47 & 23 & 25 & 25 \\
\hline Ga & $\mathrm{ppm}$ & 18 & 28 & 31 & 29 & 28 & 32 & 34 & 18 & 16 & 18 \\
\hline As & $\mathrm{ppm}$ & 340.0 & $<3$ & 25.0 & $<3$ & $<3$ & $<3$ & $<3$ & 5.8 & 7.9 & 19.0 \\
\hline$R b$ & $\mathrm{ppm}$ & 42 & 33 & 53 & 36 & 47 & 34 & 53 & 20 & 16 & 22 \\
\hline $\mathrm{Sr}$ & $\mathrm{ppm}$ & 23 & 25 & 21 & 24 & 38 & 18 & 21 & 41 & 36 & 38 \\
\hline$Y$ & $\mathrm{ppm}$ & 17 & 71 & 60 & 107 & 125 & 39 & 100 & 118 & 95 & 101 \\
\hline $\mathrm{Zr}$ & ppm & 176 & 213 & 195 & 191 & 189 & 182 & 168 & 197 & 186 & 202 \\
\hline $\mathrm{Nb}$ & $\mathrm{ppm}$ & 21 & 24 & 22 & 20 & 21 & 21 & 20 & 21 & 21 & 24 \\
\hline Mo & $\mathrm{ppm}$ & $<1$ & $<1$ & $<1$ & $<1$ & $<1$ & $<1$ & 36 & $<1$ & $<1$ & $<1$ \\
\hline $\mathrm{Ag}$ & $\mathrm{ppm}$ & 9.3 & 0.6 & 4.2 & 0.2 & 0.3 & 0.3 & 0.6 & $<0.1$ & $<0.1$ & $<0.1$ \\
\hline $\mathrm{Cd}$ & $\mathrm{ppm}$ & 165.0 & $<1$ & $<1$ & $<1$ & $<1$ & $<1$ & $<1$ & $<0.2$ & $<0.2$ & $<0.2$ \\
\hline Sn & $\mathrm{ppm}$ & 124 & 12 & 36 & & 10 & 49 & 23 & 10 & 8 & 14 \\
\hline $\mathrm{Sb}$ & $\mathrm{ppm}$ & nd & nd & nd & nd & nd & nd & nd & 0.4 & 0.4 & 0.3 \\
\hline Cs & $\mathrm{ppm}$ & nd & nd & nd & nd & nd & nd & nd & 0.8 & 0.7 & 0.5 \\
\hline $\mathrm{Ba}$ & $\mathrm{ppm}$ & 129 & 421 & 153 & 436 & 435 & 125 & 155 & 541 & 500 & 378 \\
\hline La & $\mathrm{ppm}$ & 6.1 & nd & 9.6 & nd & nd & nd & 19 & 43.2 & 41.1 & 50.8 \\
\hline $\mathrm{Ce}$ & $\mathrm{ppm}$ & 16.9 & nd & 25 & nd & nd & nd & 52.6 & 101 & 95 & 114 \\
\hline $\mathrm{Pr}$ & $\mathrm{ppm}$ & 1.8 & nd & 3 & nd & nd & nd & 6.2 & nd & nd & nd \\
\hline Nd & $\mathrm{ppm}$ & 7.7 & nd & 14.7 & nd & nd & nd & 27.8 & nd & nd & nd \\
\hline $\mathrm{Sm}$ & $\mathrm{ppm}$ & 1.4 & nd & 4.8 & nd & nd & nd & 6.4 & nd & nd & nd \\
\hline Eu & $\mathrm{ppm}$ & 0.14 & nd & 0.32 & nd & nd & nd & 0.36 & nd & nd & nd \\
\hline Gd & $\mathrm{ppm}$ & 1.3 & nd & 5.9 & nd & nd & nd & 7.3 & nd & nd & nd \\
\hline $\mathrm{Tb}$ & ppm & 0.3 & nd & 1.5 & nd & nd & nd & 1.6 & nd & nd & nd \\
\hline Dy & ppm & 2.6 & nd & 8.3 & nd & nd & nd & 9.9 & nd & nd & nd \\
\hline Ho & $\mathrm{ppm}$ & 0.95 & nd & 2.42 & nd & nd & nd & 3.1 & nd & nd & nd \\
\hline Er & $\mathrm{ppm}$ & 2.9 & nd & 6.2 & nd & nd & nd & 7.6 & nd & nd & nd \\
\hline $\mathrm{Tm}$ & $\mathrm{ppm}$ & 0.7 & nd & 1.3 & nd & nd & nd & 1.5 & nd & nd & nd \\
\hline$Y b$ & $\mathrm{ppm}$ & 4.8 & nd & 8 & nd & nd & nd & 8.4 & nd & nd & nd \\
\hline Lu & $\mathrm{ppm}$ & 0.87 & nd & 1.38 & nd & nd & nd & 1.39 & nd & nd & nd \\
\hline $\mathrm{Hf}$ & $\mathrm{ppm}$ & nd & nd & nd & nd & nd & nd & nd & 8.3 & 7.0 & 7.6 \\
\hline Ta & $\mathrm{ppm}$ & nd & nd & nd & nd & nd & nd & nd & 1.7 & 0.5 & 0.9 \\
\hline$W$ & $\mathrm{ppm}$ & $<10$ & $<10$ & $<10$ & $<10$ & $<10$ & $<10$ & $<10$ & 2 & 1 & 2 \\
\hline $\mathrm{Au}$ & $\mathrm{ppb}$ & nd & nd & nd & nd & nd & nd & nd & $<2$ & $<2$ & $<2$ \\
\hline $\mathrm{Pb}$ & $\mathrm{ppm}$ & 18 & $<2$ & $<2$ & $<2$ & $<2$ & 3 & 5 & $<2$ & $<2$ & $<2$ \\
\hline Th & $\mathrm{ppm}$ & 6.7 & nd & 6.9 & nd & nd & nd & 6.2 & 6.9 & 6.3 & 6.9 \\
\hline$U$ & $\mathrm{ppm}$ & 1.7 & nd & 1.6 & nd & nd & nd & 1.6 & 2.0 & 2.2 & 2.2 \\
\hline
\end{tabular}




\begin{tabular}{|c|c|c|c|c|c|c|}
\hline $\begin{array}{l}\text { Sample } \\
\text { Rock Type } \\
\text { Member }\end{array}$ & & $\begin{array}{l}\text { HG-2323-3 H } \\
\text { RHco } \\
\text { Lower }\end{array}$ & $\begin{array}{l}\text { HG-2323-4 } \\
\text { RHco } \\
\text { Lower } \\
\end{array}$ & $\begin{array}{l}24-14228 \\
\text { VCsa-ARG F } \\
\text { Middle } \\
\end{array}$ & $\begin{array}{l}24-14230 \\
R \\
\text { RHhy-VCpbcg } \\
\text { Middle }\end{array}$ & $\begin{array}{c}\text { RC-2420-4 } \\
\text { ARG } \\
\text { Middle } \\
\end{array}$ \\
\hline $\mathrm{SiO}_{2}$ & wt. \% & 82.4 & 80.6 & 60.0 & 80.2 & 64.3 \\
\hline $\mathrm{TiO}_{2}$ & $w t . \%$ & 0.11 & 0.06 & 0.32 & 0.08 & 0.22 \\
\hline $\mathrm{Al}_{2} \mathrm{O}_{3}$ & $w t . \%$ & 9.42 & 8.71 & 15.60 & 11.50 & 8.34 \\
\hline $\mathrm{Fe}_{2} \mathrm{O}_{3}$ & wt.\% & 0.60 & 1.51 & 6.79 & 1.84 & 7.77 \\
\hline $\mathrm{MnO}$ & wt. $\%$ & 0.06 & 0.12 & 0.02 & $<0.01$ & $<0.01$ \\
\hline $\mathrm{MgO}$ & wt. $\%$ & 0.26 & 0.27 & 2.25 & 1.24 & 0.60 \\
\hline $\mathrm{CaO}$ & wt. \% & 0.62 & 1.80 & 0.24 & 0.21 & 0.23 \\
\hline $\mathrm{Na}_{2} \mathrm{O}$ & $w t . \%$ & 5.12 & 0.76 & 1.85 & 0.73 & 1.13 \\
\hline $\mathrm{K}_{2} \mathrm{O}$ & wt.\% & 0.60 & 2.23 & 2.65 & 2.11 & 1.76 \\
\hline $\mathrm{P}_{2} \mathrm{O}_{5}$ & wt.\% & 0.03 & 0.02 & 0.04 & $<0.01$ & 0.04 \\
\hline $\mathrm{Cr}_{2} \mathrm{O}_{3}$ & wt.\% & $<0.01$ & $<0.01$ & $<0.01$ & $<0.01$ & 0.04 \\
\hline LOI & wt. $\%$ & 0.70 & 2.65 & 4.65 & 2.15 & 15.10 \\
\hline Sum & $w t . \%$ & 100.0 & 98.8 & 94.4 & 100.1 & 99.5 \\
\hline $\mathrm{H}^{2} \mathrm{O}^{+}$ & wt. \% & 0.2 & 0.8 & nd & nd & $<0.01$ \\
\hline $\mathrm{CO}_{2}$ & wt.\% & 0.86 & 2.18 & nd & nd & $<0.01$ \\
\hline $\mathrm{FeO}$ & wt.\% & 0.3 & 1.0 & 4.0 & 1.2 & 0.3 \\
\hline C & $\mathrm{ppm}$ & 0.26 & 0.61 & 0.14 & 0.07 & 9.82 \\
\hline$S$ & $\mathrm{ppm}$ & 0.01 & 0.02 & 3.32 & 0.24 & 6.20 \\
\hline $\mathrm{Li}$ & $\mathrm{ppm}$ & 2 & 3 & nd & nd & nd \\
\hline $\mathrm{Be}$ & $\mathrm{ppm}$ & 2 & 3 & 2 & 1 & 1 \\
\hline$B$ & $\mathrm{ppm}$ & 18 & 59 & nd & nd & nd \\
\hline$F$ & $\mathrm{ppm}$ & 69 & 185 & nd & nd & nd \\
\hline $\mathrm{Cl}$ & $\mathrm{ppm}$ & 42 & 56 & nd & nd & nd \\
\hline Sc & $\mathrm{ppm}$ & $<1$ & 1.0 & 6.9 & 2.0 & 5.8 \\
\hline V & $\mathrm{ppm}$ & 3 & 4 & 36 & $<2$ & 40 \\
\hline $\mathrm{Cr}$ & $\mathrm{ppm}$ & 48 & 20 & 32 & 5 & 163 \\
\hline Co & $\mathrm{ppm}$ & $<1$ & $<1$ & 33 & $<1$ & 47 \\
\hline $\mathrm{Ni}$ & $\mathrm{ppm}$ & $<1$ & $<1$ & 48 & 1 & 179 \\
\hline $\mathrm{Cu}$ & $\mathrm{ppm}$ & 6 & 1 & 600 & 47 & 145 \\
\hline $\mathrm{Zn}$ & $\mathrm{ppm}$ & 25 & 35 & $>10000$ & 390 & $>10000$ \\
\hline Ga & ppm & 18 & 15 & $<3$ & 20 & 19 \\
\hline As & $\mathrm{ppm}$ & 19.0 & 0.6 & 47.0 & 5.0 & 64.0 \\
\hline Rb & $\mathrm{ppm}$ & 22 & 49 & 69 & 67 & 50 \\
\hline $\mathrm{Sr}$ & $\mathrm{ppm}$ & 38 & 37 & 51 & 49 & 26 \\
\hline Y & $\mathrm{ppm}$ & 101 & 112 & 157 & 73 & 28 \\
\hline $\mathrm{Zr}$ & $\mathrm{ppm}$ & 202 & 178 & 266 & 227 & 126 \\
\hline $\mathrm{Nb}$ & ppm & 24 & 18 & 26 & 24 & 16 \\
\hline Mo & $\mathrm{ppm}$ & $<1$ & $<1$ & 14 & 2 & 10 \\
\hline $\mathrm{Ag}$ & $\mathrm{ppm}$ & $<0.1$ & $<0.1$ & 35.2 & 1.0 & $>1000$ \\
\hline $\mathrm{Cd}$ & $\mathrm{ppm}$ & $<0.2$ & $<0.2$ & 301.0 & 2.0 & 122.0 \\
\hline Sn & $\mathrm{ppm}$ & 14 & 7 & 539 & 36 & 142 \\
\hline $\mathrm{Sb}$ & $\mathrm{ppm}$ & 0.3 & 0.2 & 25.0 & $<5$ & 36.0 \\
\hline Cs & $\mathrm{ppm}$ & 0.5 & 1.5 & nd & nd & nd \\
\hline $\mathrm{Ba}$ & $\mathrm{ppm}$ & 378 & 587 & 222 & 160 & 144 \\
\hline La & ppm & 50.8 & 46.6 & nd & nd & 29.6 \\
\hline $\mathrm{Ce}$ & ppm & 114 & 105 & nd & nd & 58.9 \\
\hline Pr & $\mathrm{ppm}$ & nd & nd & nd & nd & 7.3 \\
\hline $\mathrm{Nd}$ & $\mathrm{ppm}$ & nd & nd & nd & nd & 30.3 \\
\hline $\mathrm{Sm}$ & $\mathrm{ppm}$ & nd & nd & nd & nd & 7.4 \\
\hline Eu & $\mathrm{ppm}$ & nd & nd & nd & nd & 1.53 \\
\hline $\mathrm{Gd}$ & $\mathrm{ppm}$ & nd & nd & nd & nd & 6.4 \\
\hline $\mathrm{Tb}$ & $\mathrm{ppm}$ & nd & nd & nd & nd & 1.3 \\
\hline Dy & $\mathrm{ppm}$ & nd & nd & nd & nd & 9.1 \\
\hline Ho & $\mathrm{ppm}$ & nd & nd & nd & nd & 2.44 \\
\hline Er & $\mathrm{ppm}$ & nd & nd & nd & nd & 5.2 \\
\hline $\mathrm{Tm}$ & $\mathrm{ppm}$ & nd & nd & nd & nd & 1.1 \\
\hline $\mathrm{Yb}$ & $\mathrm{ppm}$ & nd & nd & nd & nd & 6.3 \\
\hline Lu & $\mathrm{ppm}$ & nd & nd & nd & nd & 0.89 \\
\hline $\mathrm{Hf}$ & $\mathrm{ppm}$ & 7.6 & 8.3 & 9.7 & nd & 4.4 \\
\hline Ta & $\mathrm{ppm}$ & 0.9 & 2.0 & 2.1 & nd & 0.9 \\
\hline W & ppm & 2 & 3 & $<10$ & $<10$ & $<10$ \\
\hline $\mathrm{Au}$ & $p p b$ & $<2$ & $<2$ & nd & nd & nd \\
\hline $\mathrm{Pb}$ & $\mathrm{ppm}$ & $<2$ & $<2$ & 1050 & 34 & 3660 \\
\hline Th & $\mathrm{ppm}$ & 6.9 & 6.8 & 9.6 & nd & 3.6 \\
\hline U & $\mathrm{ppm}$ & 2.2 & 2.0 & 2.7 & nd & 1.0 \\
\hline
\end{tabular}




\section{Appendix 5}

\section{CHONDRITE NORMALIZATION VALUES}

Rare earth element (REE) values are normalized to average $\mathrm{Cl}(\mathrm{Cl} 1)$ chondrite values of Evensen et al. (1978) multiplied by 1.267 as recommended by Boynton (1984), while the HFSE are normalized to the average $\mathrm{Cl}$ chondrite values of Anders and Grevesse (1989) also multiplied by a factor of 1.267. All values in ppm.

\begin{tabular}{|cl|cl|cl|}
\hline $\mathrm{La}$ & 0.310 & $\mathrm{~Tb}$ & 0.0474 & $\mathrm{Y}$ & 1.98 \\
\hline $\mathrm{Ce}$ & 0.808 & $\mathrm{Dy}$ & 0.322 & $\mathrm{Zr}$ & 4.99 \\
\hline $\mathrm{Pr}$ & 0.122 & $\mathrm{Ho}$ & 0.0718 & $\mathrm{Hf}$ & 0.132 \\
\hline $\mathrm{Nd}$ & 0.600 & $\mathrm{Er}$ & 0.210 & $\mathrm{Nb}$ & 0.312 \\
\hline $\mathrm{Sm}$ & 0.195 & $\mathrm{Tm}$ & 0.0324 & $\mathrm{Ta}$ & 0.0180 \\
\hline $\mathrm{Eu}$ & 0.0735 & $\mathrm{Yb}$ & 0.209 & $\mathrm{Th}$ & 0.0372 \\
\hline $\mathrm{Gd}$ & 0.259 & $\mathrm{Lu}$ & 0.0322 & $\mathrm{U}$ & 0.010 \\
\hline
\end{tabular}




\section{Appendix 6}

\section{DESCRIPTION OF SAMPLE SUITES WITH ND ISOTOPIC DATA SHOWN IN} FIGURE 4.10

The comparison sample suites with $\mathrm{Nd}$ isotopic data shown in Figure 4.10, listed in order of increasing age, are: 1. komatiitic and tholeiitic lavas, Newton Township, Swayze Belt, Ontario (Cattell et al., 1984), 2. Noranda district volcanic and intrusive rocks, Quebec (Vervoort et al., 1994), 3. clinopyroxene separates from igneous rocks of the Abitibi greenstone belt (Machado et al., 1986), 4. intrusive/volcanic rocks and mineral separates from the Kamiskotia area, Ontario (Barrie and Shirey, 1991), 5. tonalite-granodiorite gneiss, Wawa gneiss terrane, Ontario (Shaw et al., 1994), 6. komatiite flows of the Alexo area, Ontario (Dupre et al., 1984), 7. komatiites from Pyke Hill, Munro Township, Ontario (Walker et al., 1988), 8. gabbros and pyroxenites from the MunroWarden Sill and gabbro-textured and spinifex-textured lavas from Fred's Flow, Munro Township., Ontario (Zindler, 1982; age from Walker et al., 1988), 9. lower mafic volcanic rocks of the Kamiskotia area, Ontario (Barrie and Shirey, 1991), $10_{\mathrm{A}}$. VMS footwall rhyolites and Bell River granophyres, Quebec (Vervoort et al. 1994), $10_{B}$. highly altered Matagami district VMS footwall rhyolite, 11. gabbros (whole-rock and mineral separates) and basalts, Mulcahy Lake area, Wabigoon Subprovince (Morrison et al., 1985), 12. anorthosite, gabbro and metabasalt from the Bad Vermilion Lake anorthosite complex, Rainy Lake area, Ontario (Ashwal et al., 1985) and 13. tholeiitic basalts, Keewatin Group, 
Rainy Lake area, Ontario (Shirey and Hanson, 1986). All $\varepsilon_{\mathrm{Nd}}$ values presented are calculated relative to a present day chondritic ${ }^{143} \mathrm{Nd} /{ }^{144} \mathrm{Nd}$ ratio of 0.7219 . 
Appendix 7

PHOTOGRAPHS AND MICROPHOTOGRAPHS 
Figure A7.1 (following page)

A. Photograph by H. Gibson of back of 2100 Access Drive, rock bolt plate is 13 $\mathrm{cm}$ across. Bedded QP rhyolite breccia near stratigraphic base of QP rhyolite succession (flow foot breccia), Upper member, Kidd Creek formation. Depositional units within the breccia are characterized by differences in fragment size and density. Most of the blocks are white (silicified), greenish colouration in some blocks is due to sericitization.

B. Photograph by H. Gibson, 2101 Drive South. Irregular dikes, apophyses and fragments of altered basalt or andesite (tan) within flank breccia facies of QP rhyolite (Upper member, Kidd Creek formation). 


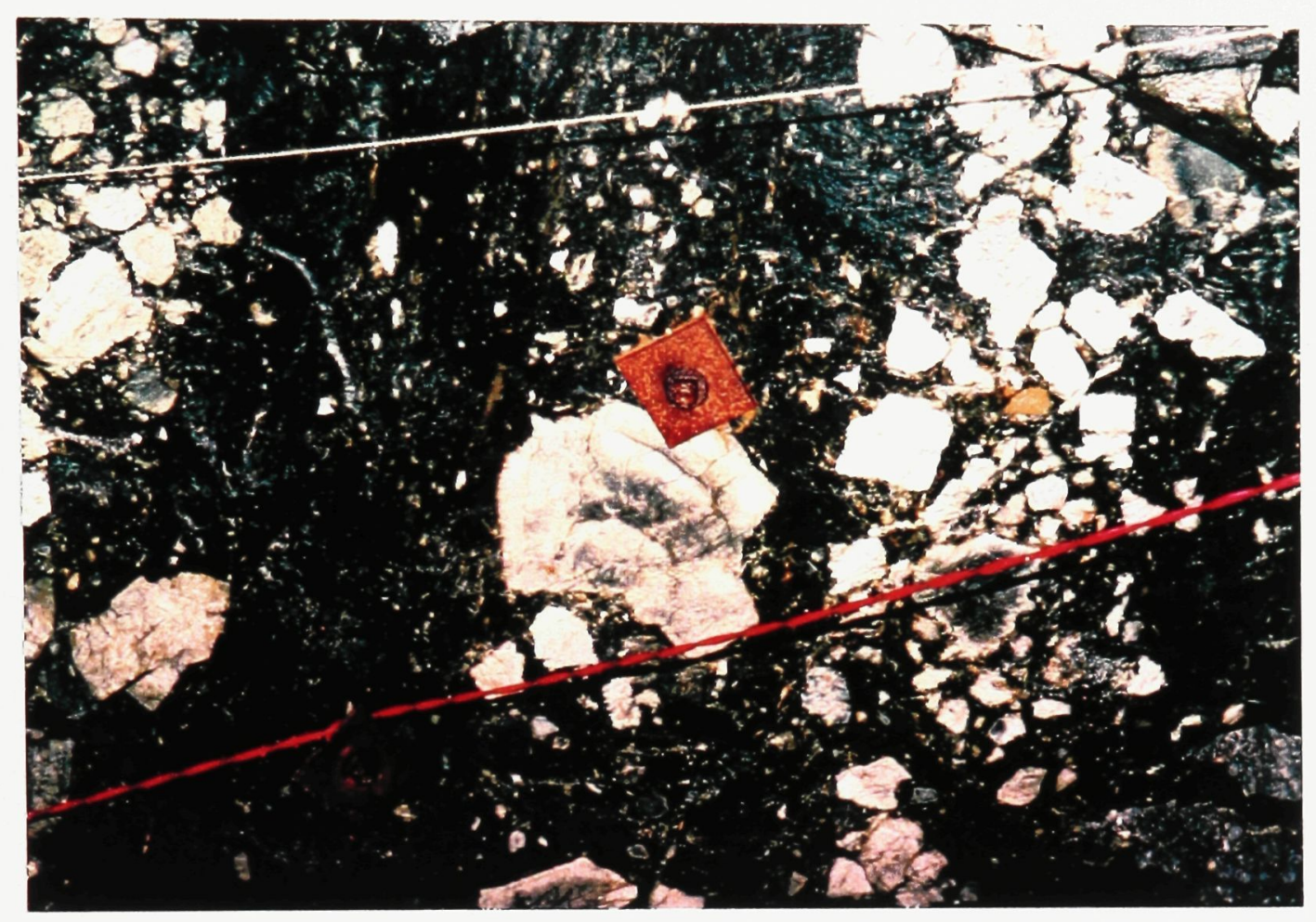

A

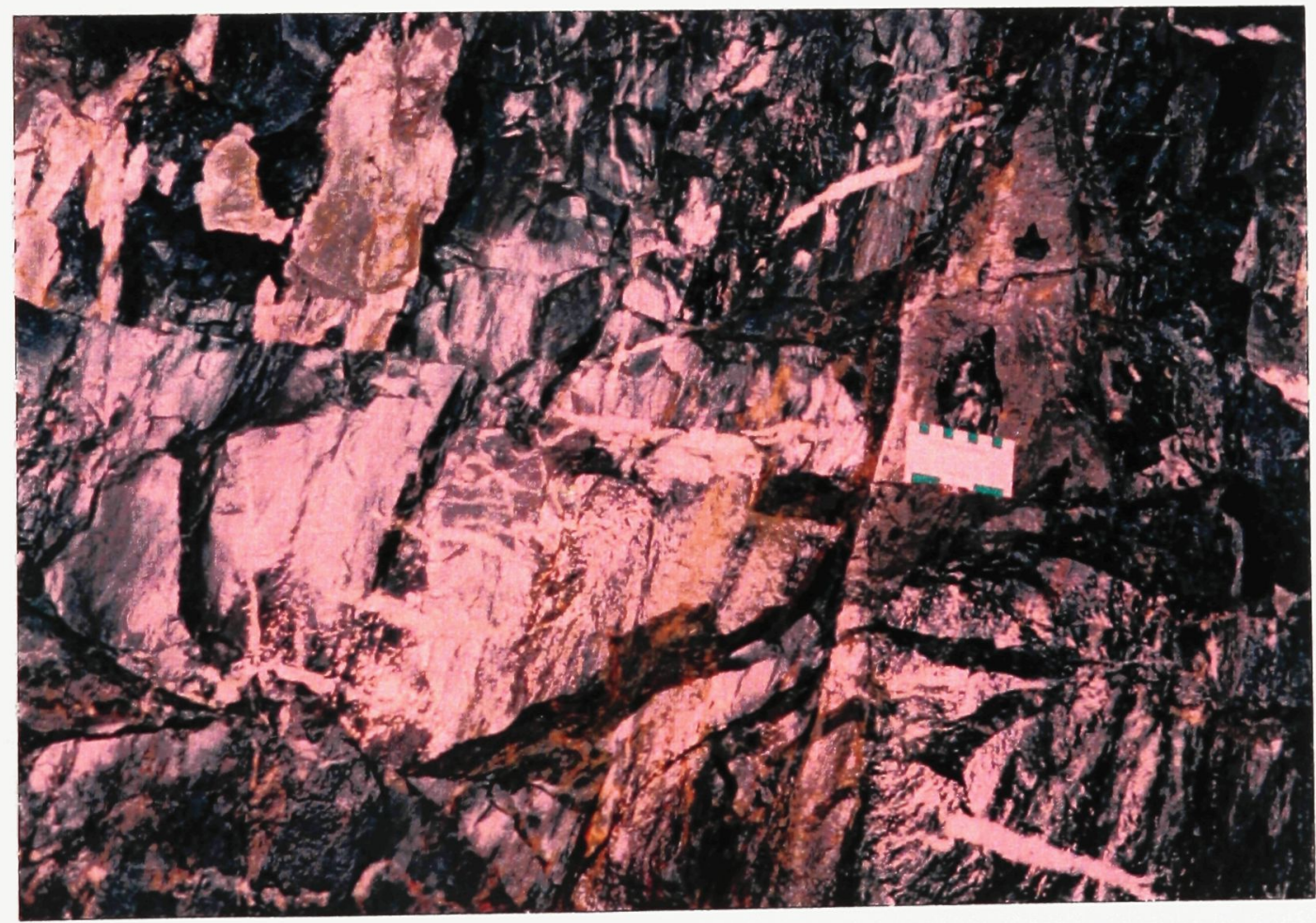


Figure A7.2 (following page)

A. Photograph of back of 23 NE Vent Raise Access (2323 Pillar Access area), $12 \mathrm{~m}$ south of survey point 7913 . Flow banded coherent rhyolite.

B. Photograph of back of 2323 Pillar Access Drive, $8 \mathrm{~m}$ southwest of survey point 7907 . Pyrite stringers along polygonal fractures in coherent rhyolite. 

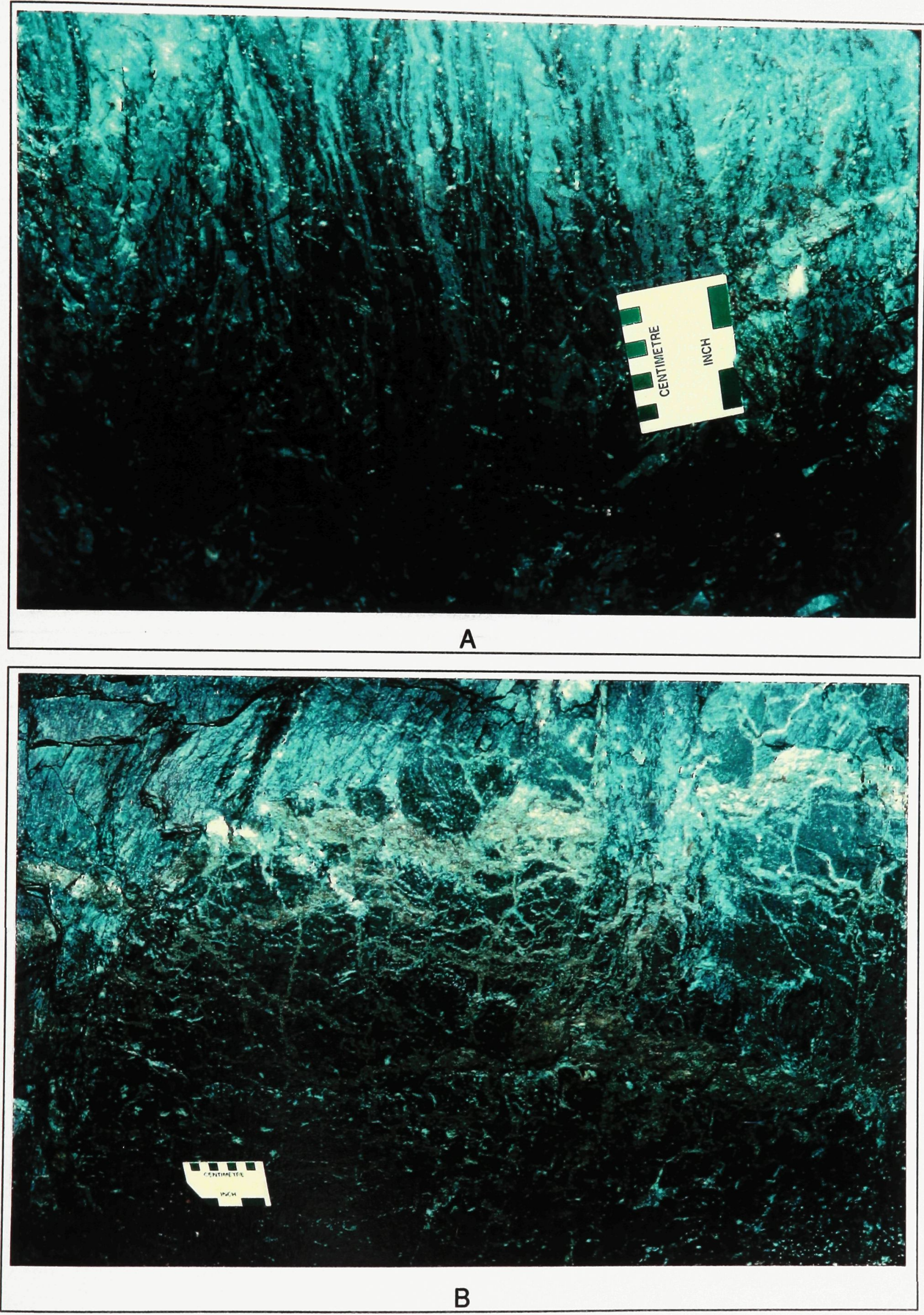
Figure A7.3 (following page)

A. Photograph of back of 2323 Pillar Access Drive, directly southeast of survey point 7907 , field of view is approximately $1 \mathrm{~m}$. Strong polygonal fracturing in coherent rhyolite.

B. Photograph of southeast wall of 2323 Pillar Access Drive, $27 \mathrm{~m}$ southwest of survey point 7907 . Autoclastic rhyolite breccia impregnated by sphalerite along fractures. Note elongation and steep plunge of fragments. 

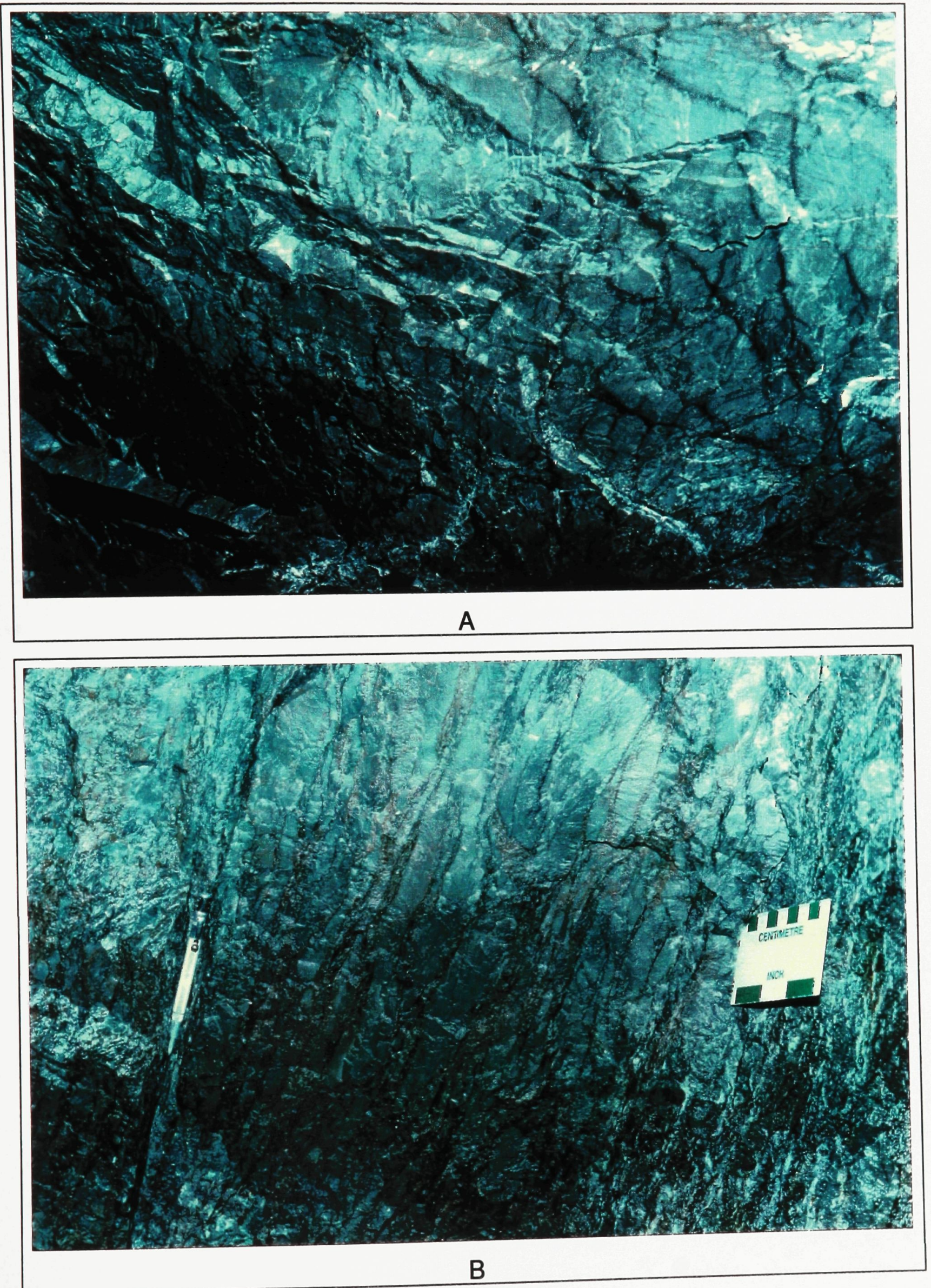
Figure A7.4 (following page)

\begin{abstract}
A. Photograph of back of 60735 Crosscut, $1 \mathrm{~m}$ southwest of survey point 8131 , metal screen has a $10 \mathrm{~cm}$ mesh. Silicified, in situ rhyolite breccia (Lower member of Kidd Creek formation). Note reddish brown sphalerite stain in lower part of photograph.
\end{abstract}

B. Photograph of back of 60735 Crosscut, $1 \mathrm{~m}$ southwest of survey point 8131 , metal screen has a $10 \mathrm{~cm}$ mesh. Silicified, in situ rhyolite breccia (Lower member of Kidd Creek formation). Note reddish brown sphalerite stain throughout photograph. 


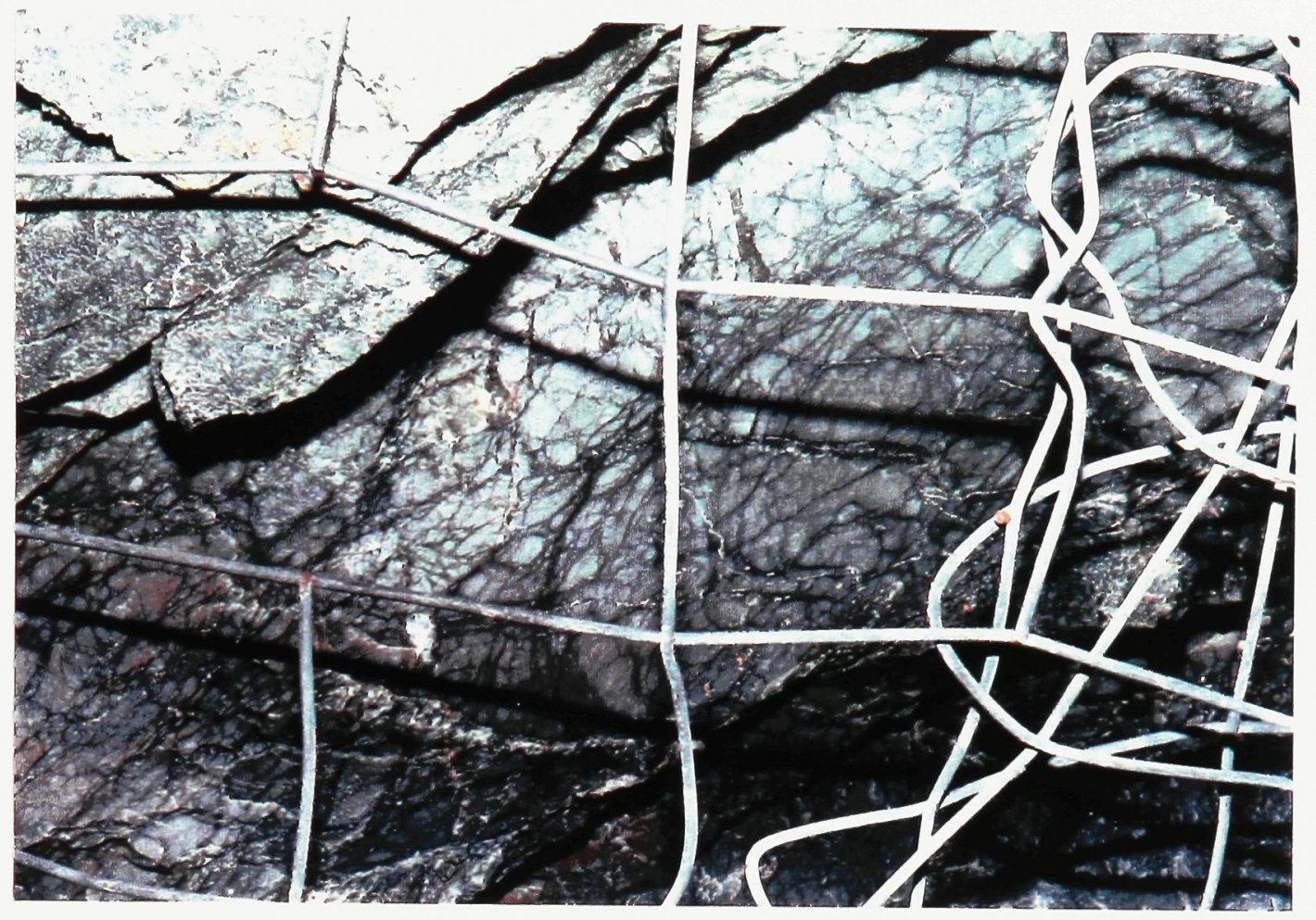

A

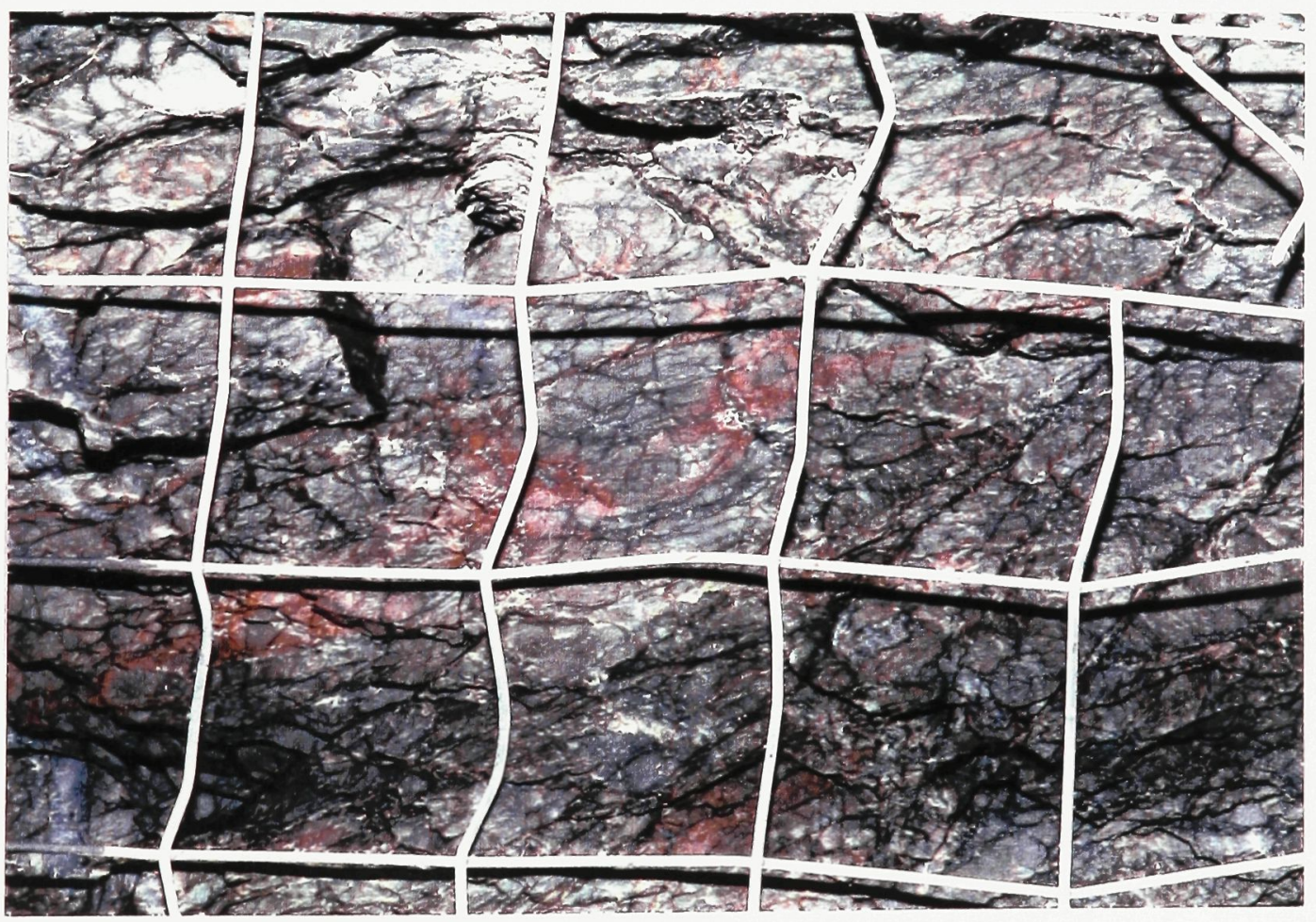


Figure A7.5 (following page)

A. Photograph of back of 2304 Fringe Drive, $30 \mathrm{~m}$ north of survey point 7913 , rock bolt plate is $13 \mathrm{~cm}$ across. Silicified, in situ rhyolite breccia cut by chalcopyrite stringers (Lower member of Kidd Creek formation). Dark areas within rhyolite breccia are zones of chlorite \pm sericite alteration.

B. Photograph of back of 2304 Fringe Drive, $24 \mathrm{~m}$ north of survey point 7913 , rock bolt plate is $13 \mathrm{~cm}$ across. Silicified, in situ rhyolite breccia cut by chalcopyrite stringers and partly replaced by chalcopyrite (Lower member of Kidd Creek formation). Chloritization, sericitization, and chalcopyrite mineralization are concentrated along fractures in breccia. 


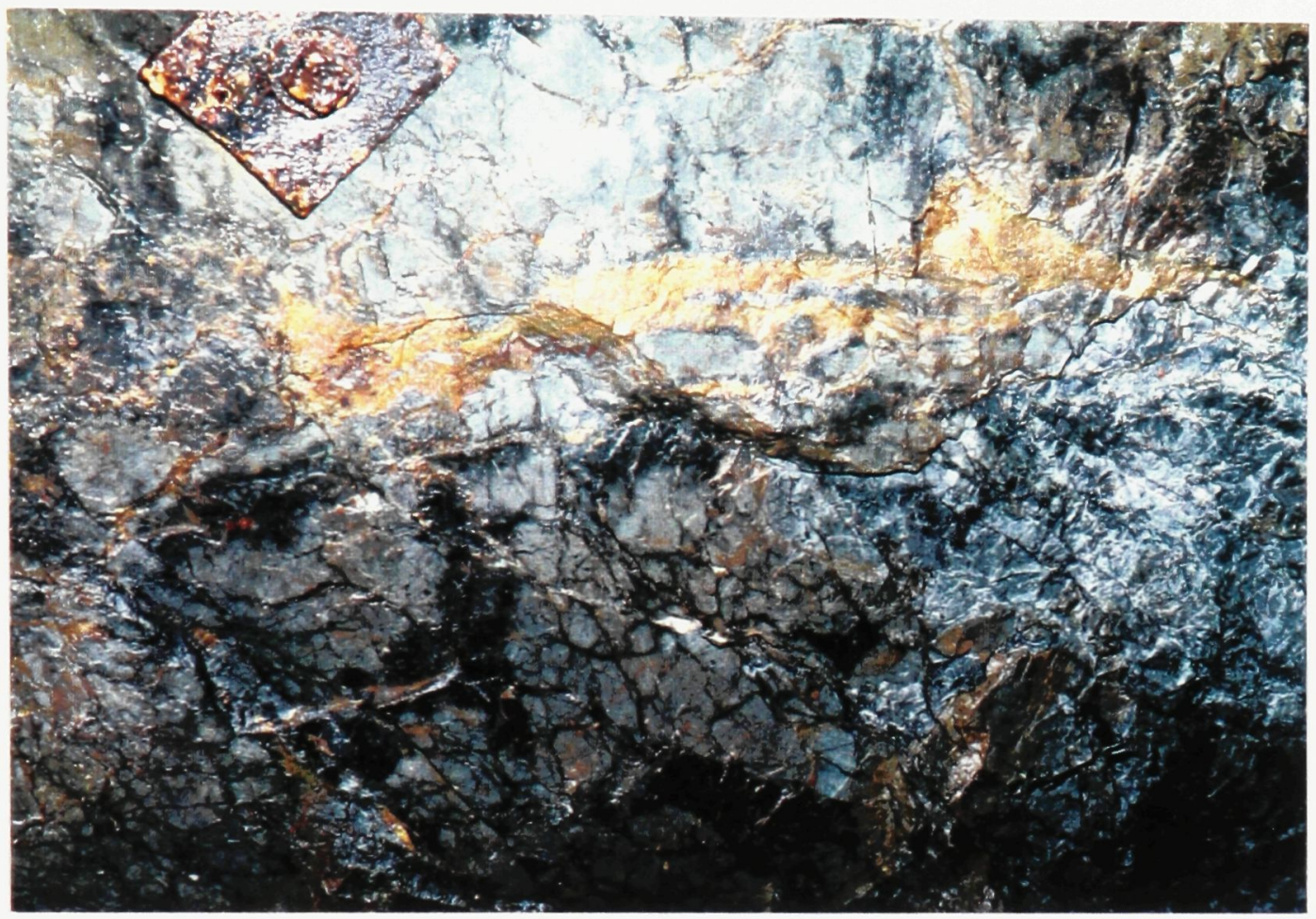

A

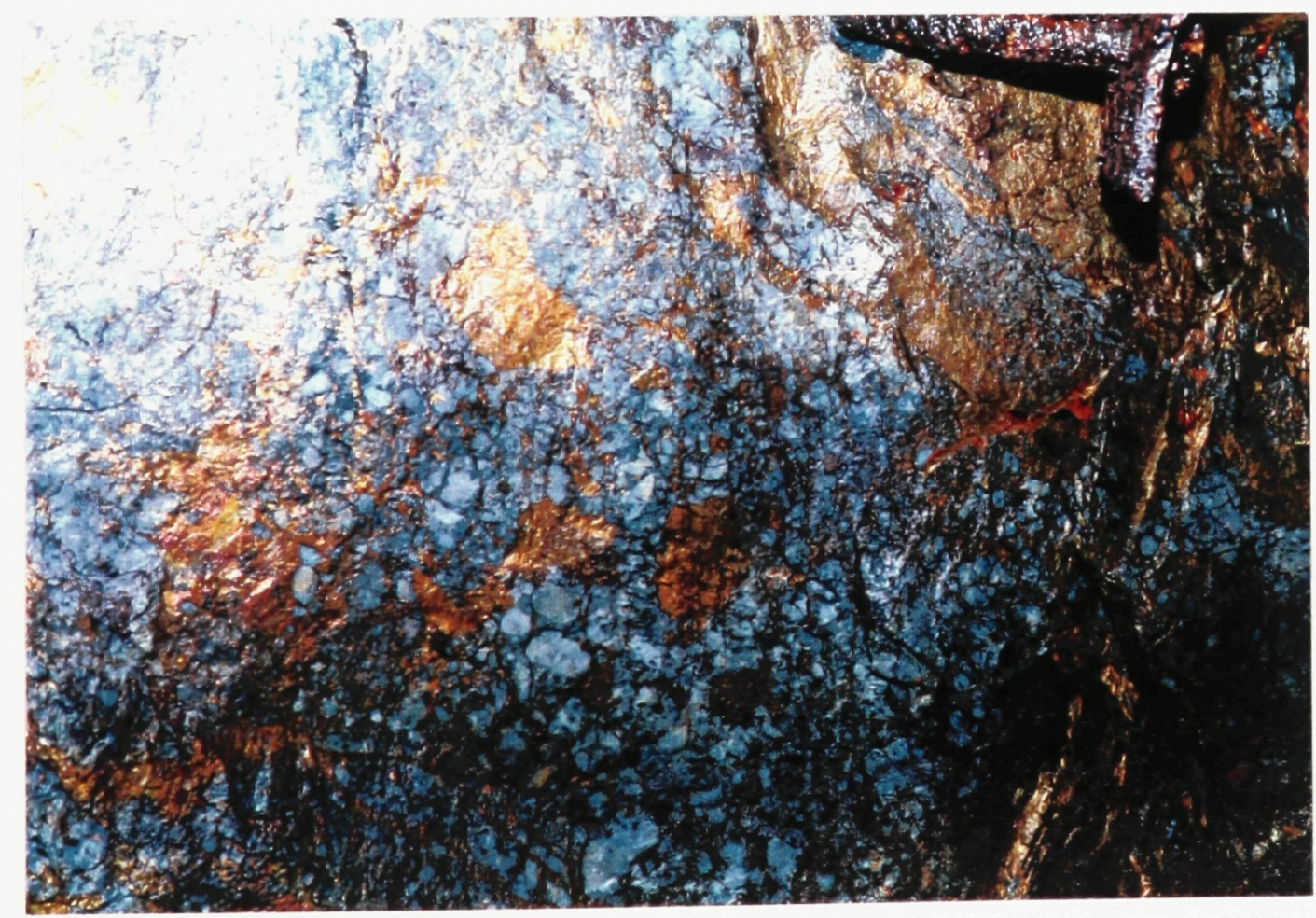

B 
Figure A7.6 (following page)

A. Photograph of back of 60735 Crosscut, 23 m northeast of survey point 8089 . Polymict volcaniclastic pebble conglomerate dominated by rhyolite clasts (Middle member of Kidd Creek formation). Elongate, tan, mafic volcanic clasts up to $2 \mathrm{~cm}$ long are also visible (e.g. clast near centre of photograph). On a metre scale this unit is bedded and weakly graded. Note dark gray-black mudstone layer near right edge of photograph.

B. Photograph of back of 6001 Drive South, $0.5 \mathrm{~m}$ west of survey point 8094 , metal screen has a $10 \mathrm{~cm}$ mesh. Contact between in situ autoclastic rhyolite breccia displaying jig-saw fit texture (left side of photograph) and polymict, volcaniclastic pebble conglomerate (left side of photograph). Broken piece of screen is very near contact. 

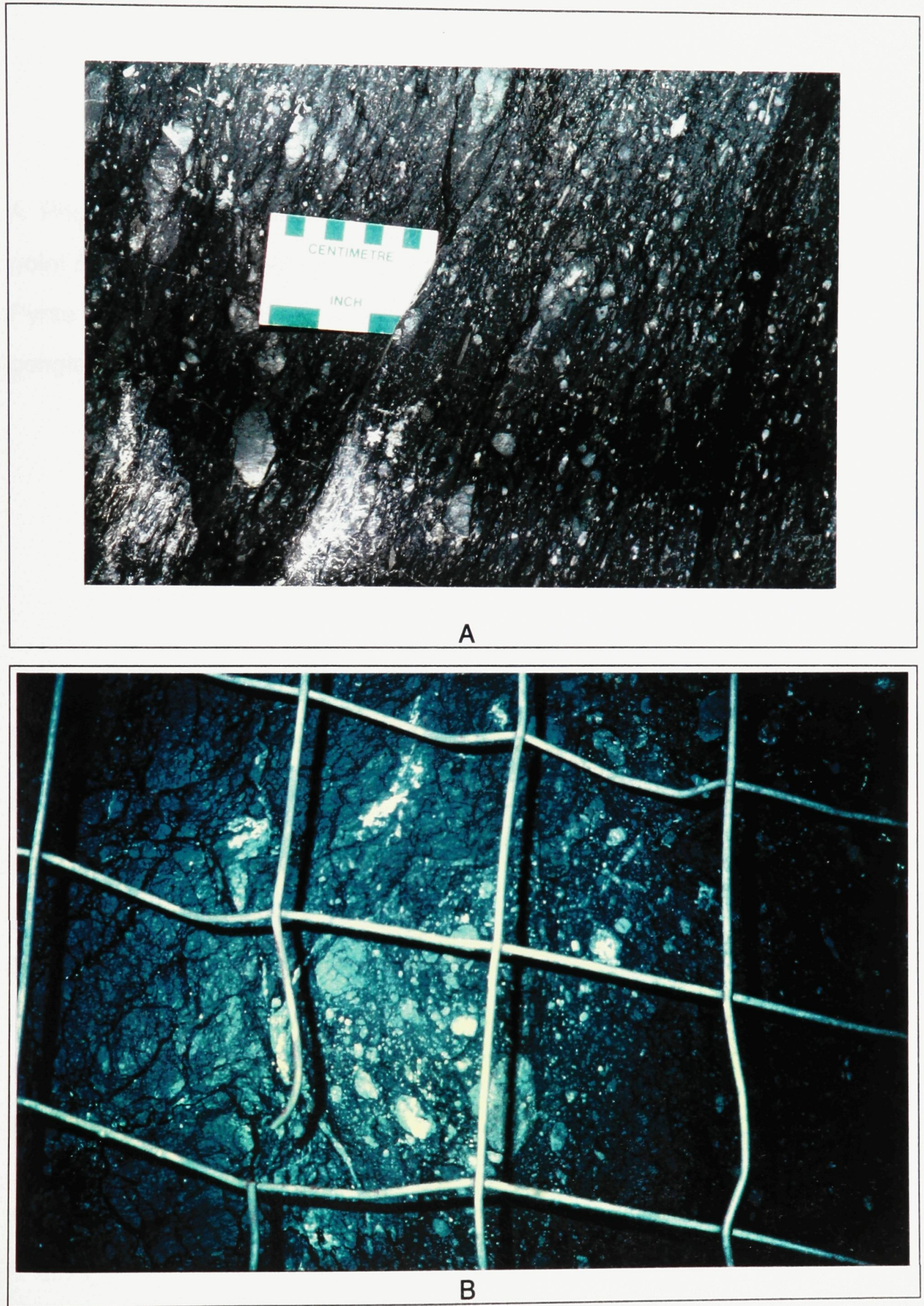
Figure A7.7 (following page)
A. Photograph of southwest wall of 6001 Drive South, $2.5 \mathrm{~m}$ southeast of survey point 8094 , metal screen has a $10 \mathrm{~cm}$ mesh, rock bolt plate is $13 \mathrm{~cm}$ across. Pyrite and sphalerite-pyrite boulders within volcaniclastic boulder conglomerate.

B. Photograph near top of wall immediately west of survey point 7986 in 2421K-Pillar Slot, pen is $11 \mathrm{~cm}$ long. Polymict volcaniclastic conglomerate. Note fracturing in sphalerite stained rhyolite boulder bear centre of photograph. An altered mafic clast (tan, approximately $3 \mathrm{~cm}$ long, irregular outline) is located between the sphalerite-rich clast in the lower left of photograph and the large pyrite clast below pen. 


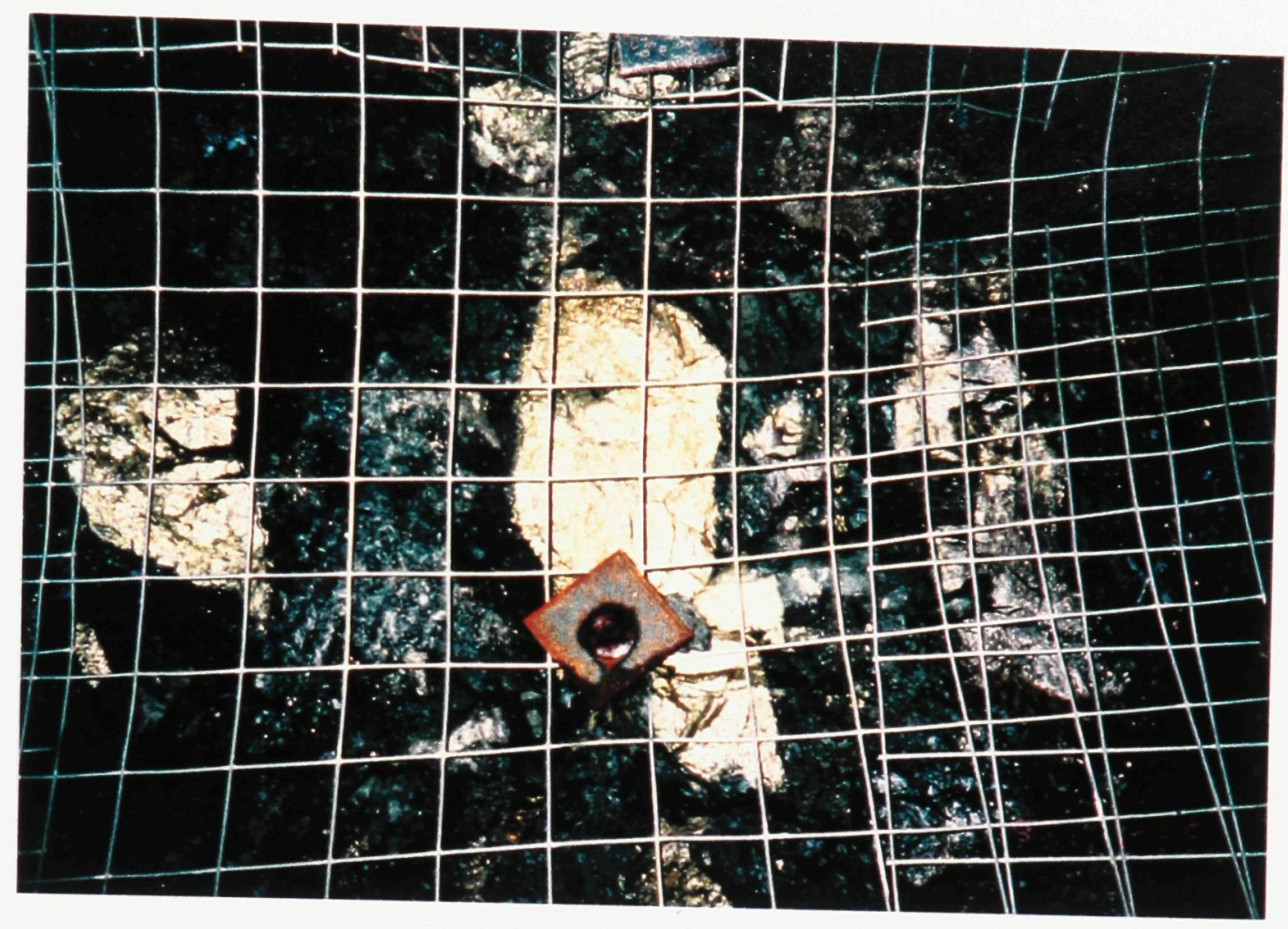

A

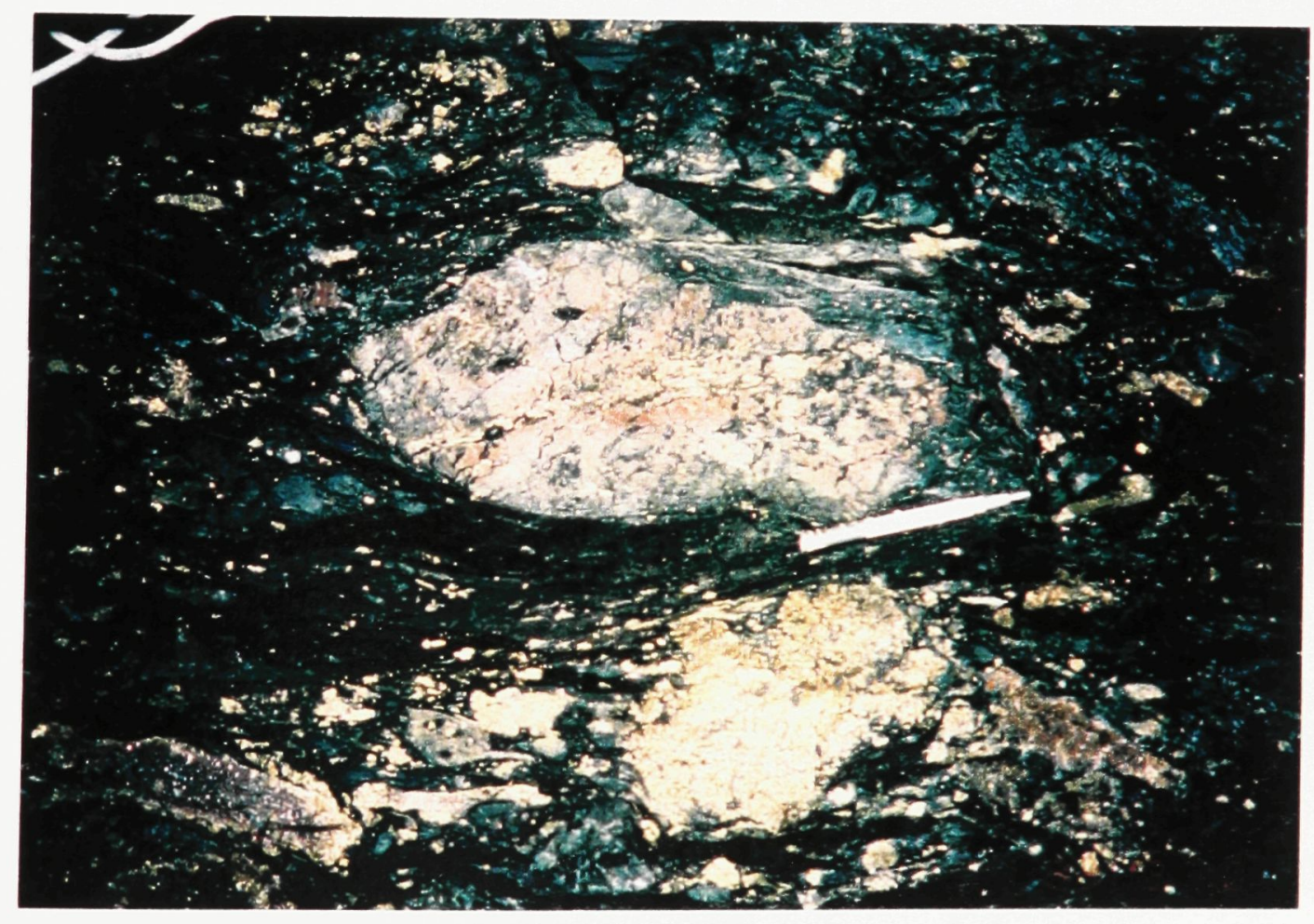


Figure A7.8 (following page)

A. Photograph of back of 2129 Crosscut, approximately $17 \mathrm{~m}$ east of survey point 7448 . Strongly sericitized rhyolite in hanging wall of north orebody.

B. Photograph of southeast wall of 4700 Hanging Wall Drill Drive (structural $\mathrm{HW}$, stratigraphic FW), $31 \mathrm{~m}$ northeast of survey point 7316 , pen is $11 \mathrm{~cm}$ long. Chalcopyrite stringer ( $30 \mathrm{~cm}$ wide) and black chloritie stringers (e.g. behind pen) within silicified autoclastic rhyolite breccia. 


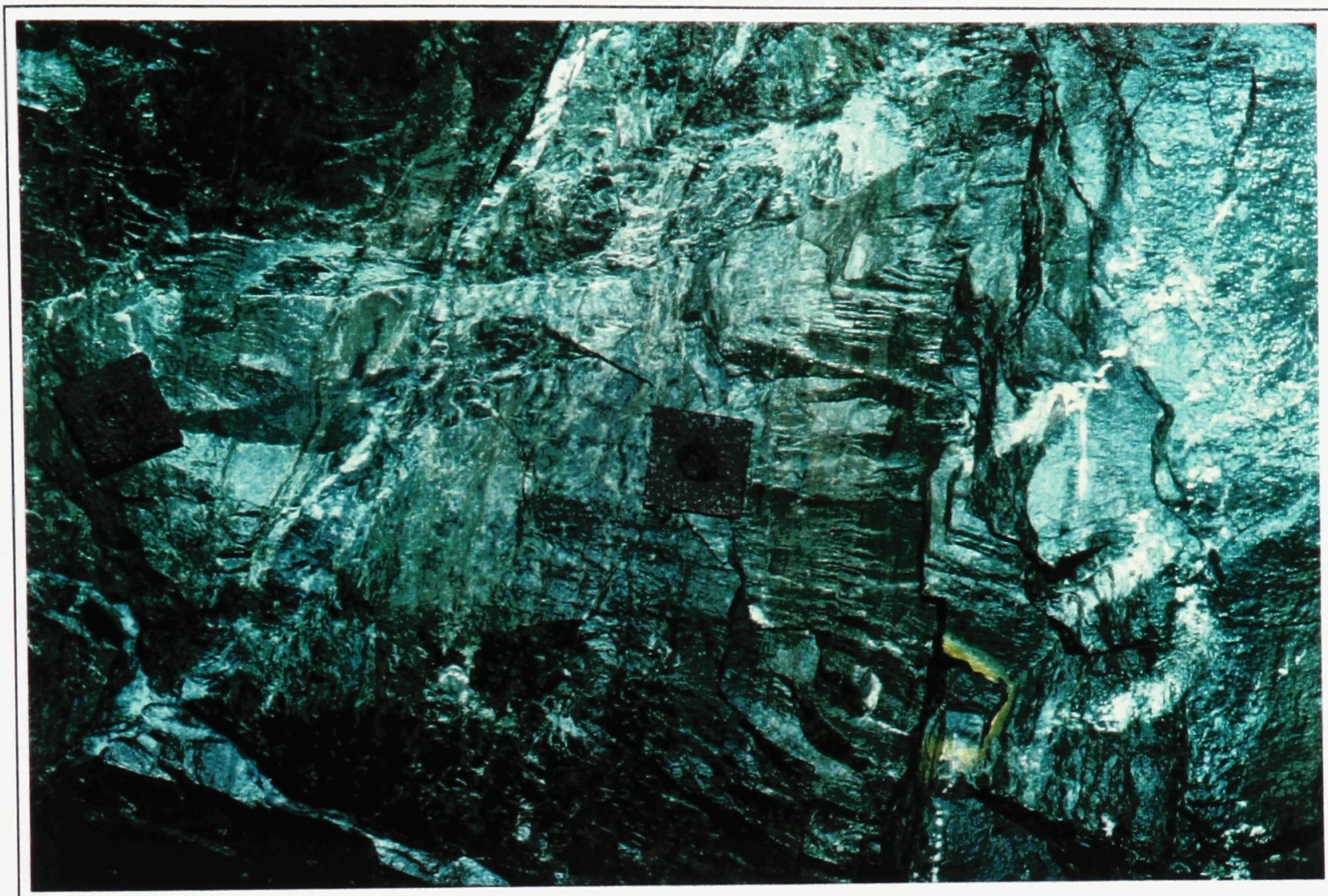

A

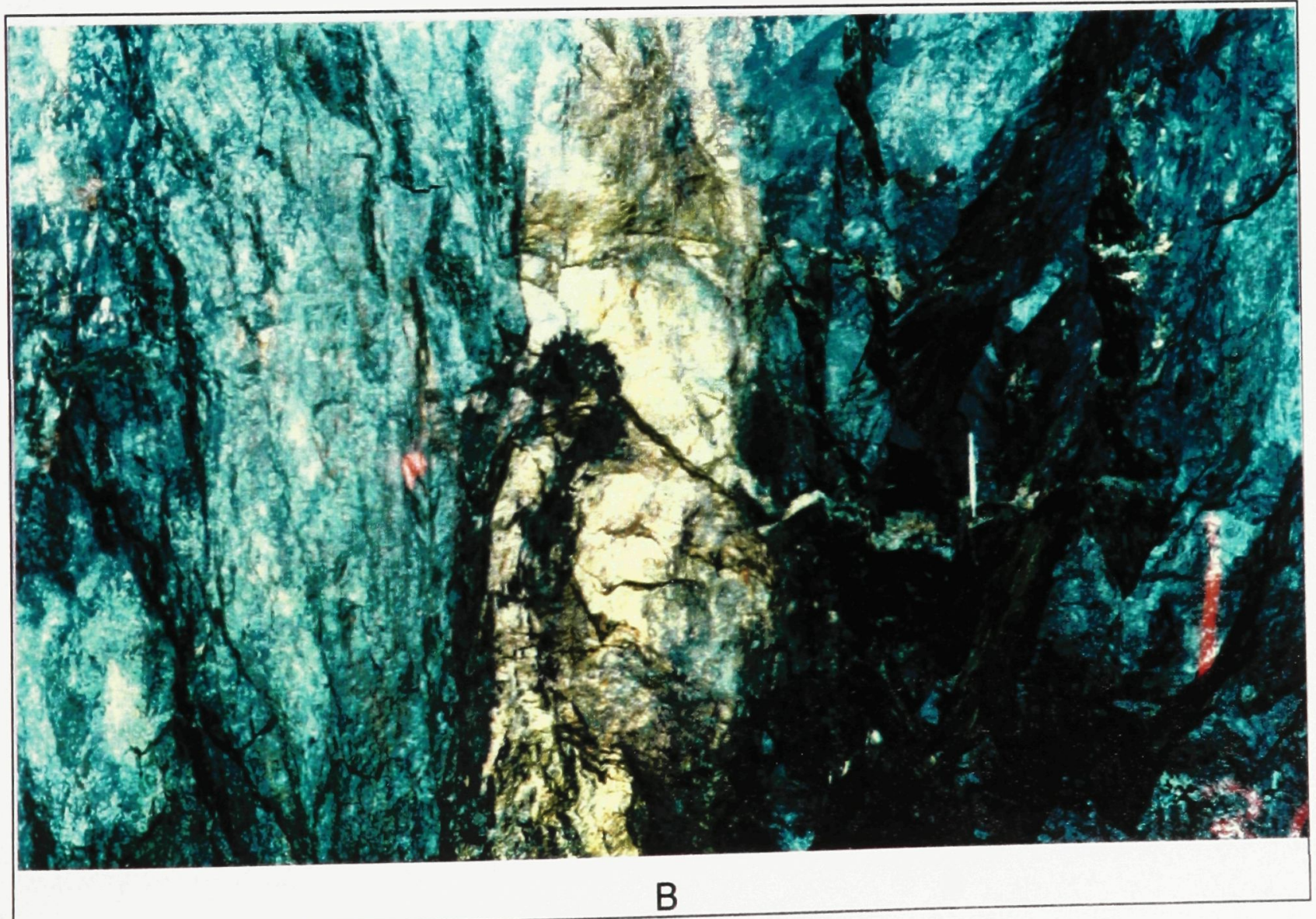


Figure A7.9 (following page)

A. Photograph of polished rock slab 16-14080. Transported, monomict, autoclastic rhyolite breccia-conglomerate (mapped as curdy rhyolite by mine staff). Note flow banded rhyolite fragment near centre of photograph.

Fragments are variably silicified, matrix alteration is primarily sericitization with only weak chloritization despite dark colour. Mineralization consists of $1 \%$ to $3 \%$ disseminated and blebby pyrite. Sample collected from back of 1628-RSlot-Access 6 m west of survey point 7935 (Middle member of Kidd Creek formation).

B. Photograph of polished rock slab 16-14128. Silicified, monomict, in situ rhyolite breccia. Orange-brown colouration is due to very fine grained $(0.01$ $0.05 \mathrm{~mm}$ ) disseminated sphalerite (sphalerite stain). The rock also contains trace - $2 \%$ disseminated pyrite. Dark alteration along fractures is intense sericitization. Sample collected from east wall of 1602 Drive North, $8.5 \mathrm{~m}$ south of survey point 2413 (Lower member of Kidd Creek formation).

C. Photograph of polished rock slab 16-14134. Silicified, monomict, in situ rhyolite breccia with pronounced orange-brown sphalerite stain (5-15\% very fine grained, disseminated sphalerite) and minor pyrite. Fractures are sericitized. Sample collected from east wall of 1602 Drive North, $2 \mathrm{~m}$ north of survey point 2423 (Lower member of Kidd Creek formation). 


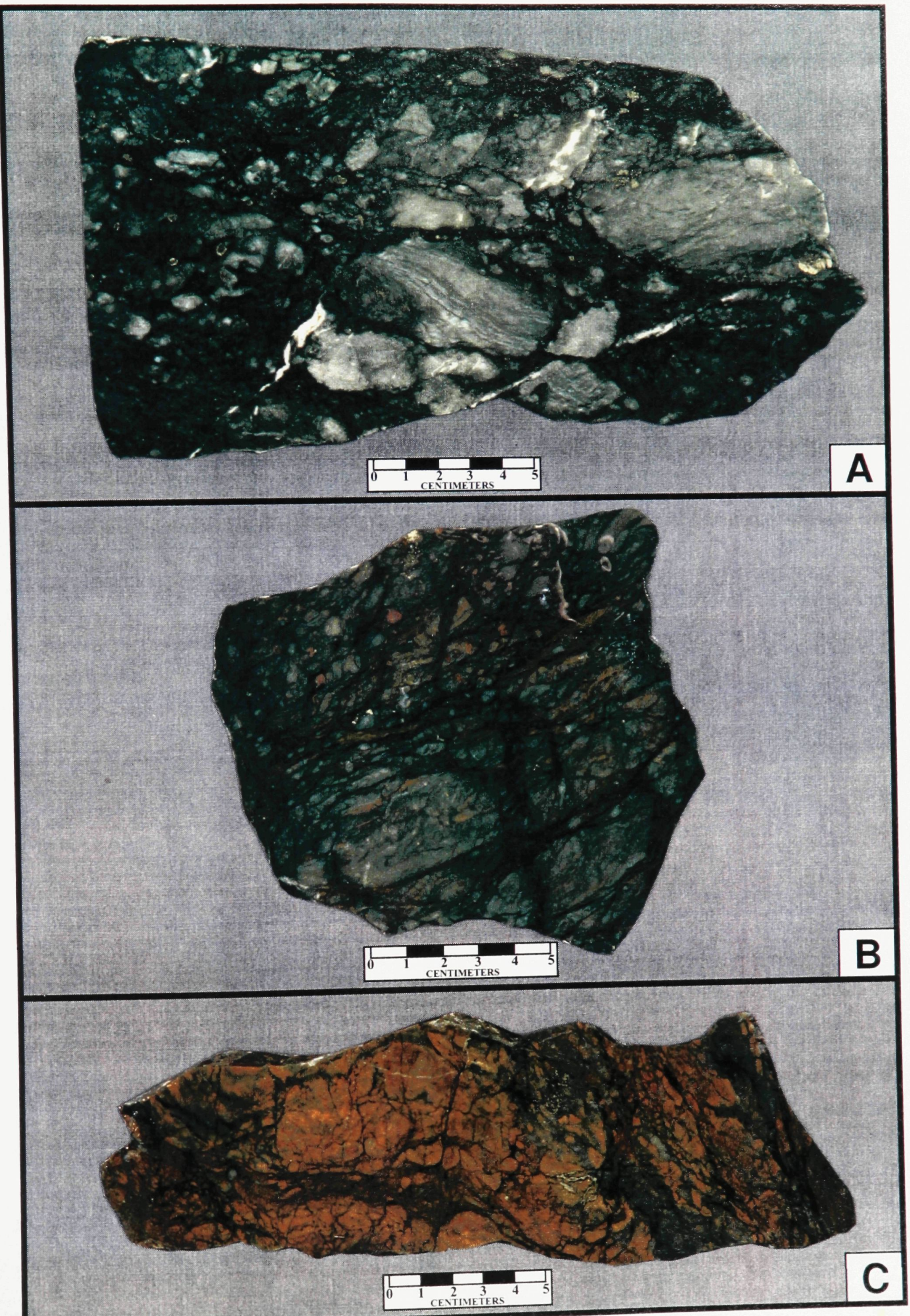


Figure A7.10 (following page)

\begin{abstract}
A. Photograph of polished rock slab 21-14150A. Volcaniclastic, unsorted, polymict pebble conglomerate containing light grey, silicified rhyolite clasts (dominant) and tan mafic clasts. Matrix is chloritic. Mineralization consists of trace-2\% disseminated and blebby pyrite. Sample collected from back of 2129 Crosscut, $1 \mathrm{~m}$ west of survey point 7585 , in footwall of south orebody (Middle member of Kidd Creek formation).
\end{abstract}

B. Photograph of polished rock slab RC-2420-3. Volcaniclastic, unsorted, polymict pebble conglomerate containing rhyolite, mafic, argillite, sphalerite, and pyrite clasts in an argillaceous matrix. Sample collected by Ron Cook in northwest wall of 2420 Crosscut, immediately northwest west of survey point 7980 , in hanging wall of north orebody (Middle member of Kidd Creek formation). 

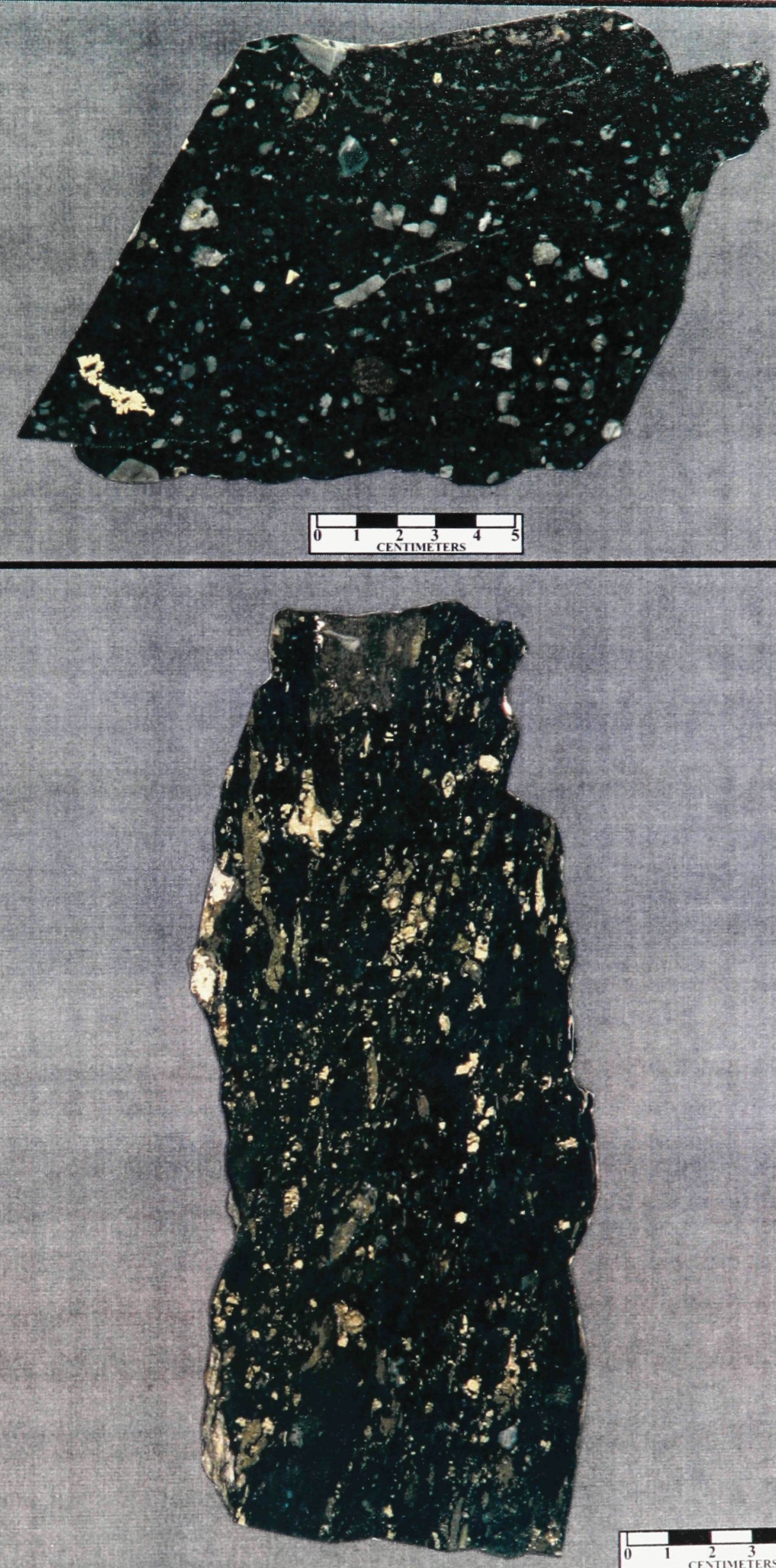
Figure A7.11 (following page)

A. Photograph of polished rock slab 21-14158. Volcaniclastic polymict pebble conglomerate dominated by rhyolite clasts partly replaced by chalcopyrite (10$20 \%$ blebby, disseminated, and veinlet-controlled chalcopyrite). Sample collected from south wall of 2129 Crosscut, 7 m east of survey point 7453 , in zone of semi-massive to heavily disseminated chalcopyrite within south orebody (Middle member of Kidd Creek formation).

B. Photograph of polished rock slab 21-14145. Volcaniclastic polymict pebble conglomerate containing light grey rhyolite clasts (dominant) and tan mafic clasts containing 15-25\% stockwork and replacement chalcopyrite. Sample collected from north wall of 2129 Crosscut, 3 m west of survey point 7453 , in zone of semi-massive to heavily disseminated chalcopyrite within south orebody (Middle member of Kidd Creek formation).

C. Photograph of polished rock slab RC-2420-2. Volcaniclastic polymict pebble conglomerate with argillaceous matrix. Mineralization includes $20-30 \%$ reddish brown, replacement sphalerite, $5-10 \%$ blebby and disseminated pyrrhotite, and $3-5 \%$ blebby and veinlet-controlled pyrite. Sample collected by Ron Cook in northwest wall of 2420 Crosscut, 6 m west of survey point 7980 , in the hanging wall of the north orebody (Middle member of Kidd Creek formation). 


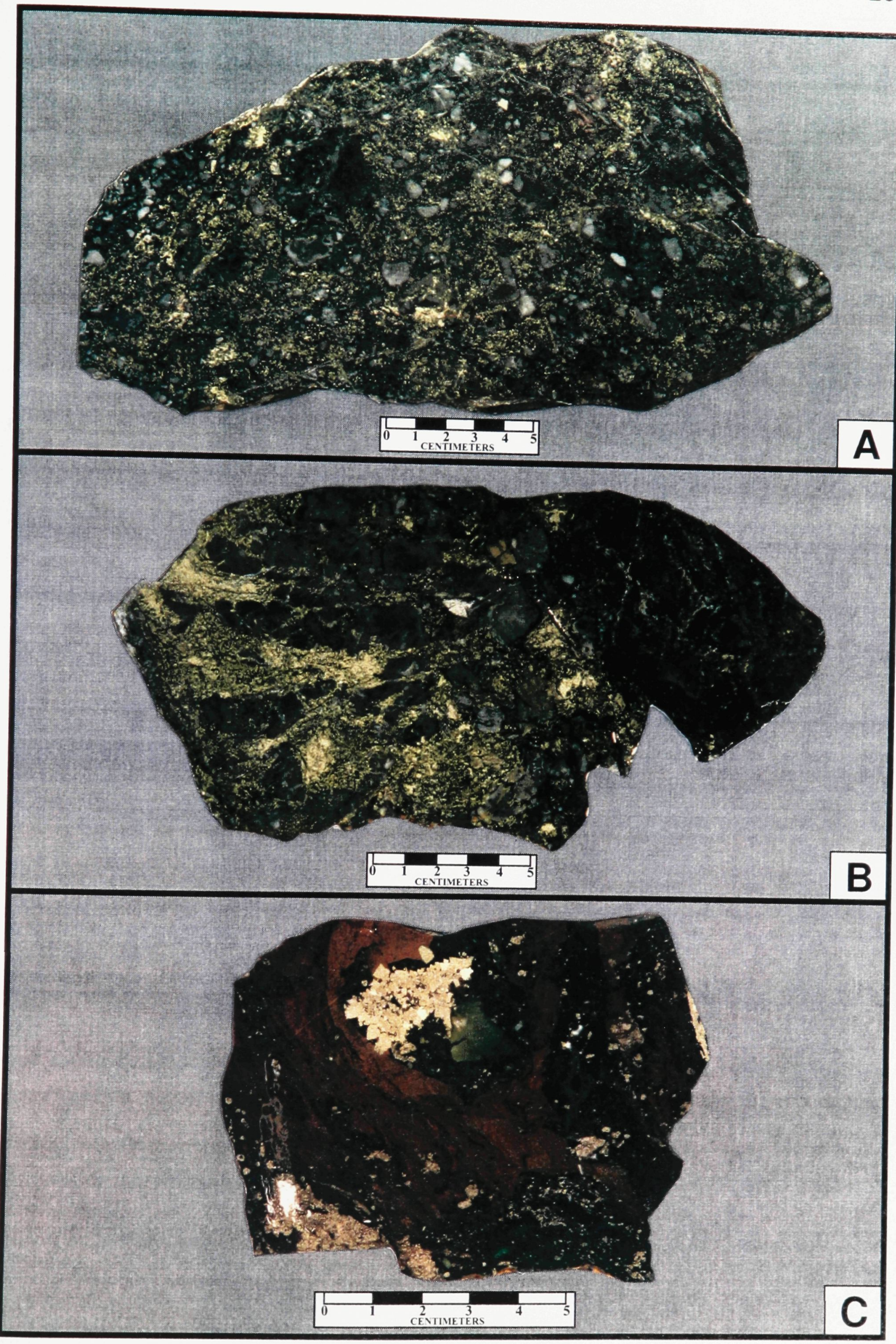


Figure A7.12 (following page)

A. Photograph of polished rock slab 16-14081. Volcaniclastic polymict boulder conglomerate containing rhyolite (including sphalerite-stained rhyolite), mafic, polymict pebble conglomerate, argillite, quartz crystal, sphalerite, and pyrite clasts. Matrix contains pervasive sericite-chlorite alteration. Sample collected from back of 1628-R-Slot Access (1602 Drive South area), $14 \mathrm{~m}$ west of survey point 7935 (Middle member of Kidd Creek formation).

B. Photograph of polished rock slab 16-14086. Volcaniclastic polymict boulder conglomerate similar to 16-14081. Photograph shows strong elongation of sulfide fragments parallel to steep F1 plunge direction (compare to sample 16-14081 which was cut perpendicular to plunge). Sample collected from east wall of 1602 Drive South, 3.6 m south of survey point 2052 (Middle member of Kidd Creek formation). 


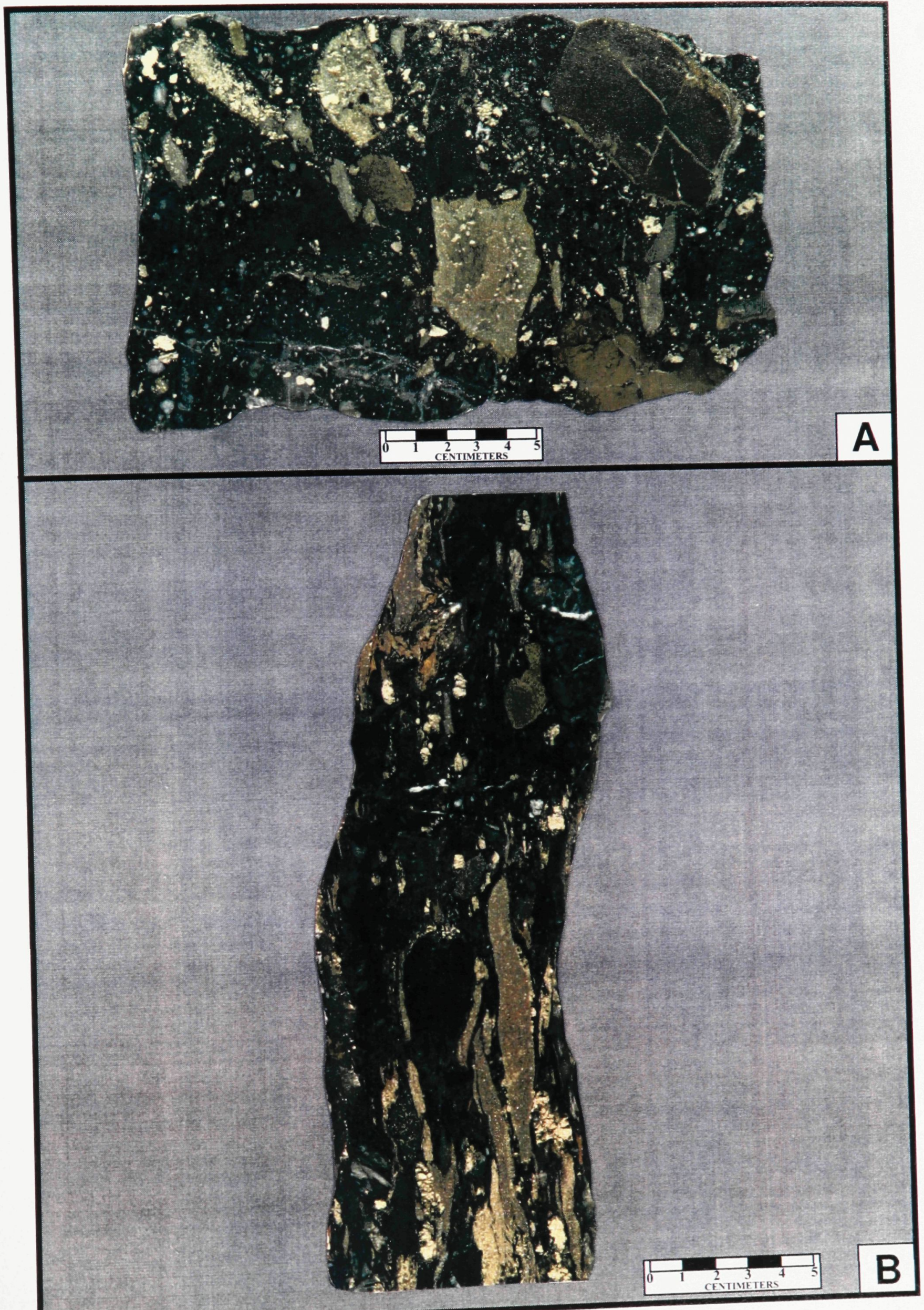


Figure A7.13 (following page)

A. Photograph of polished rock slab 16-14103. Part of clast within volcaniclastic boulder conglomerate of light reddish-brown, sphalerite-rich massive sulfide cut by multidirectional veinlets of pyrite and galena. Sample collected from back of 1628-R-Slot Access (1602 Drive South area) near north wall, $10.7 \mathrm{~m}$ west of survey point 7935 (Middle member of Kidd Creek formation).

B. Photograph of polished rock slab 16-14104. Part of clast within volcaniclastic boulder conglomerate of dark grey, rhyolitic host rock cut by pyrite-sphalerite stockwork. Sphalerite appears to predate pyrite. Sample collected from back of 1628-R-Slot Access (1602 Drive South area), 12 m west of survey point 7935 (Middle member of Kidd Creek formation). 

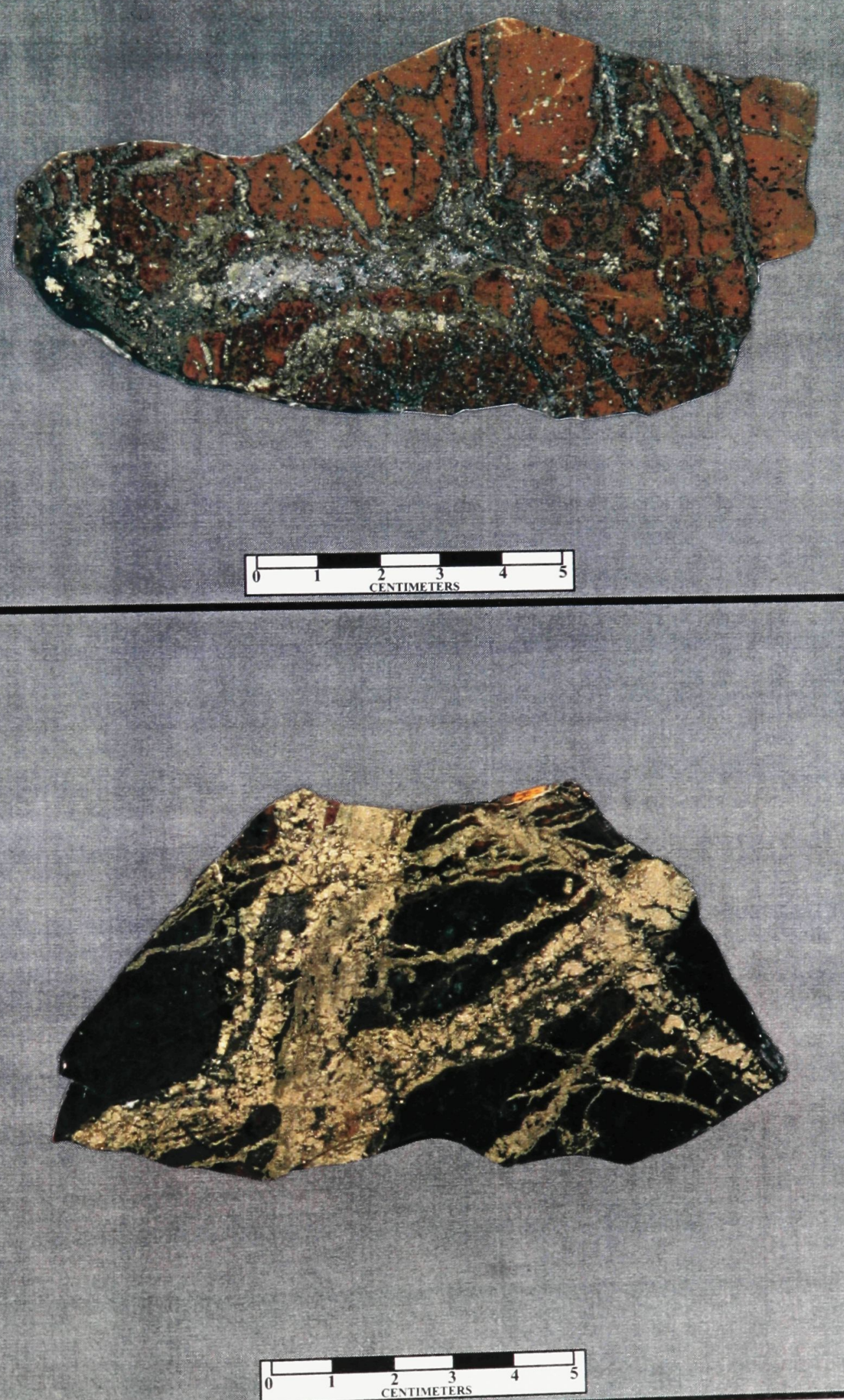
Figure A7.14 (following page)

A. Photograph of polished rock slab 16-14138. Volcaniclastic muddy sandstone dominated by rhyolite and quartz crystal grains bedded on a $\mathrm{mm}$ scale due to grain size variation (many laminae grade from sandstone to mudstone). The rock is sericitized and chloritized, and contains $5-15 \%$ blebby and disseminated pyrite which occurs preferentially along sandy parts of laminae. Sample collected from east wall of 1602 Drive North, $4.6 \mathrm{~m}$ north of survey point 2423 ( $3 \mathrm{~m}$ wide zone of transported volcaniclastic rocks within autoclastic rhyolite breccia, Middle member of Kidd Creek formation).

B. Photograph of polished rock slab 48-14207. Irregular intrusion of altered, tan, subvolcanic mafic rock into felsic volcaniclastic rock (dark grey) at stratigraphic base of wedge gabbro sill. Peperite of mafic volcanic fragments developed locally (e.g. centre of photograph). Peperite development indicates intrusion of mafic rock into unconsolidated felsic volcaniclastic material. Sample collected from back of 48780 Crosscut, near south wall, $0.5 \mathrm{~m}$ east of survey point 8096 (Middle member of Kidd Creek formation). 


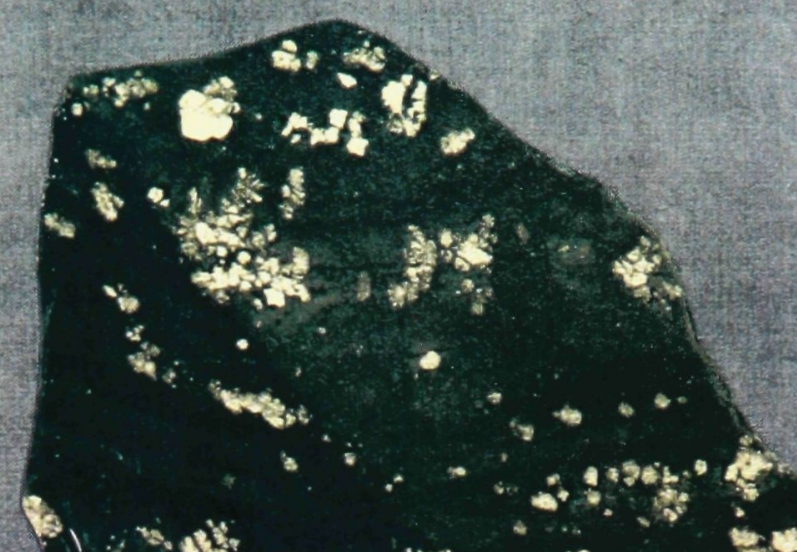

(1) yos

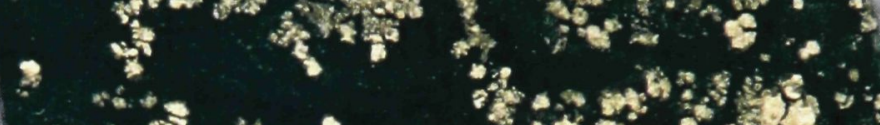

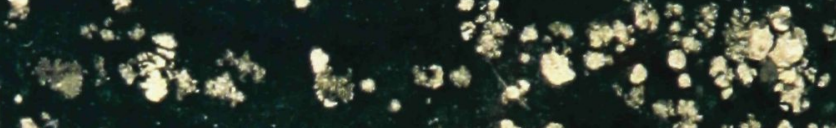

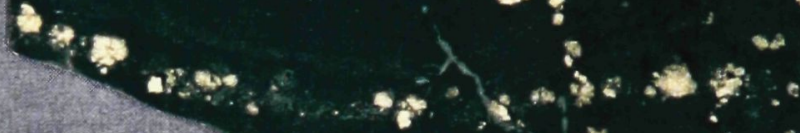

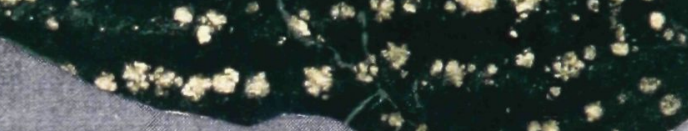

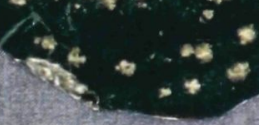

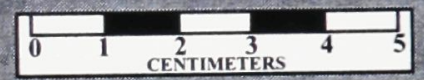

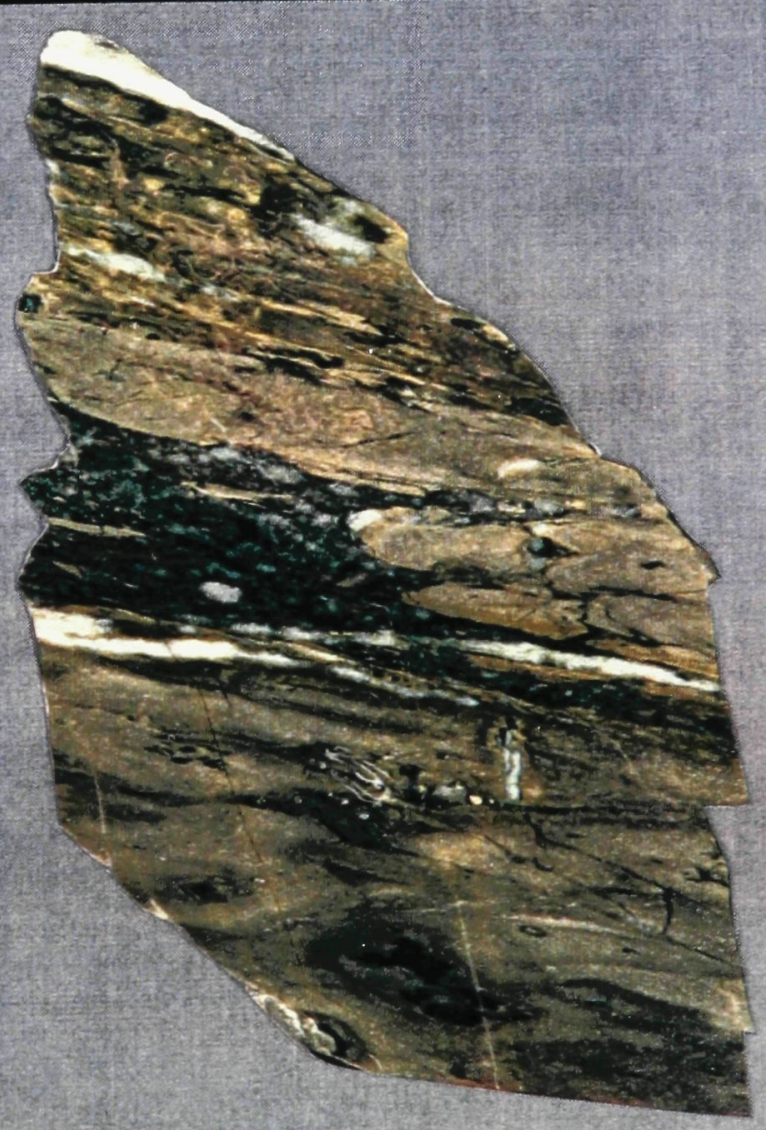

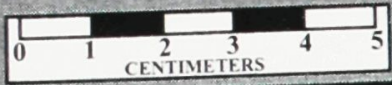


Figure A7.15 (following page)

\begin{abstract}
A. Photomicrograph of thin section 18-14046, crossed nicols, field of view is $10.8 \mathrm{~mm} \times 7.4 \mathrm{~mm}$. Coherent QP rhyolite (Upper member, Kidd Creek formation), phenocryst population dominated by quartz but two small feldspar phenocrysts occur near top of photograph. Sample is from 1829 Crosscut.
\end{abstract}

B. Photomicrograph of thin section 18-14046, crossed nicols, field of view is $5.2 \mathrm{~mm} \times 3.6 \mathrm{~mm}$. Glomeroporphyritic aggregate of feldspar in coherent QP rhyolite (Upper member, Kidd Creek formation). Feldspars are weakly to moderately altered to carbonate, groundmass is moderately sericitized and weakly chloritized. Sample is from 1829 Crosscut. 


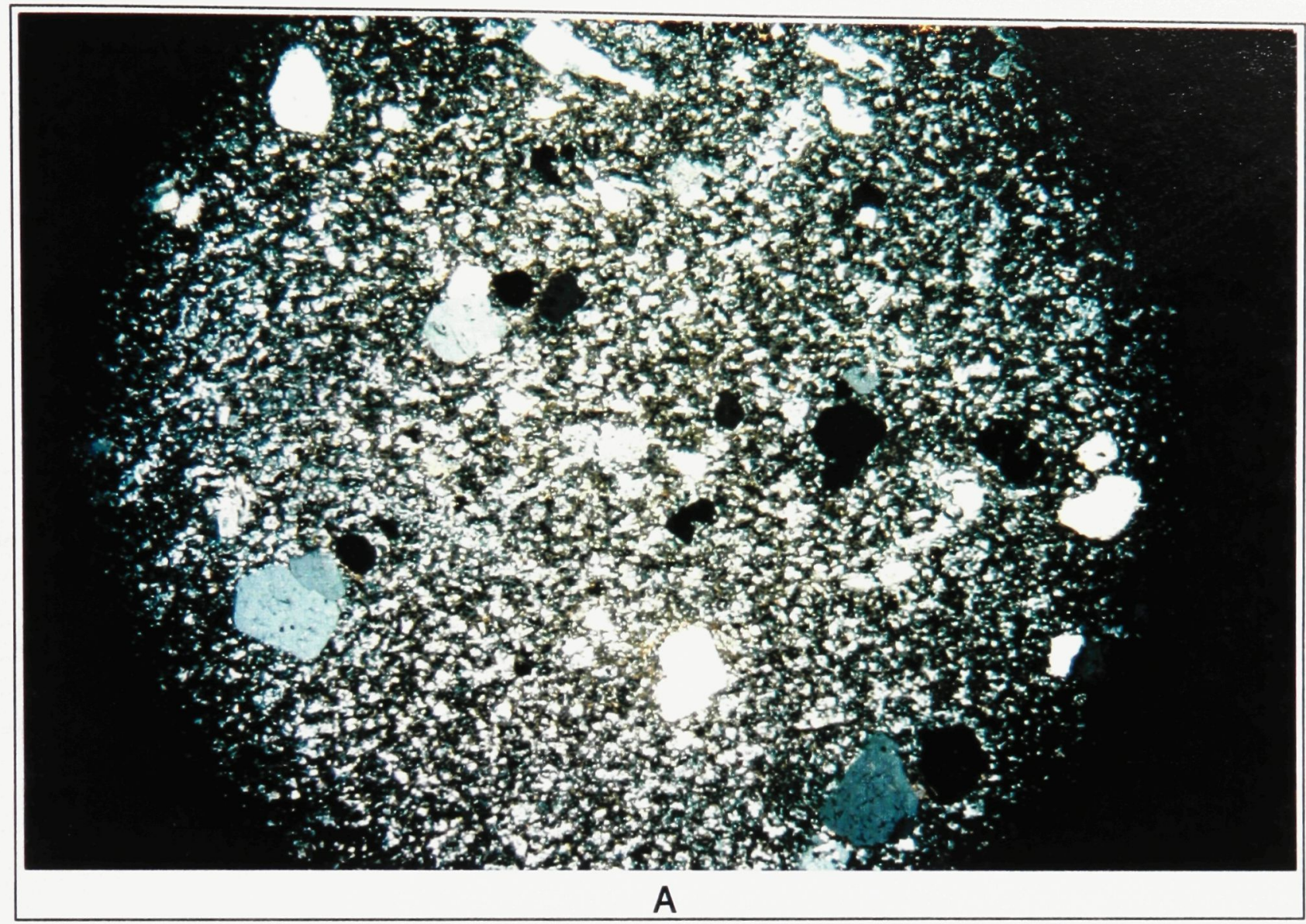

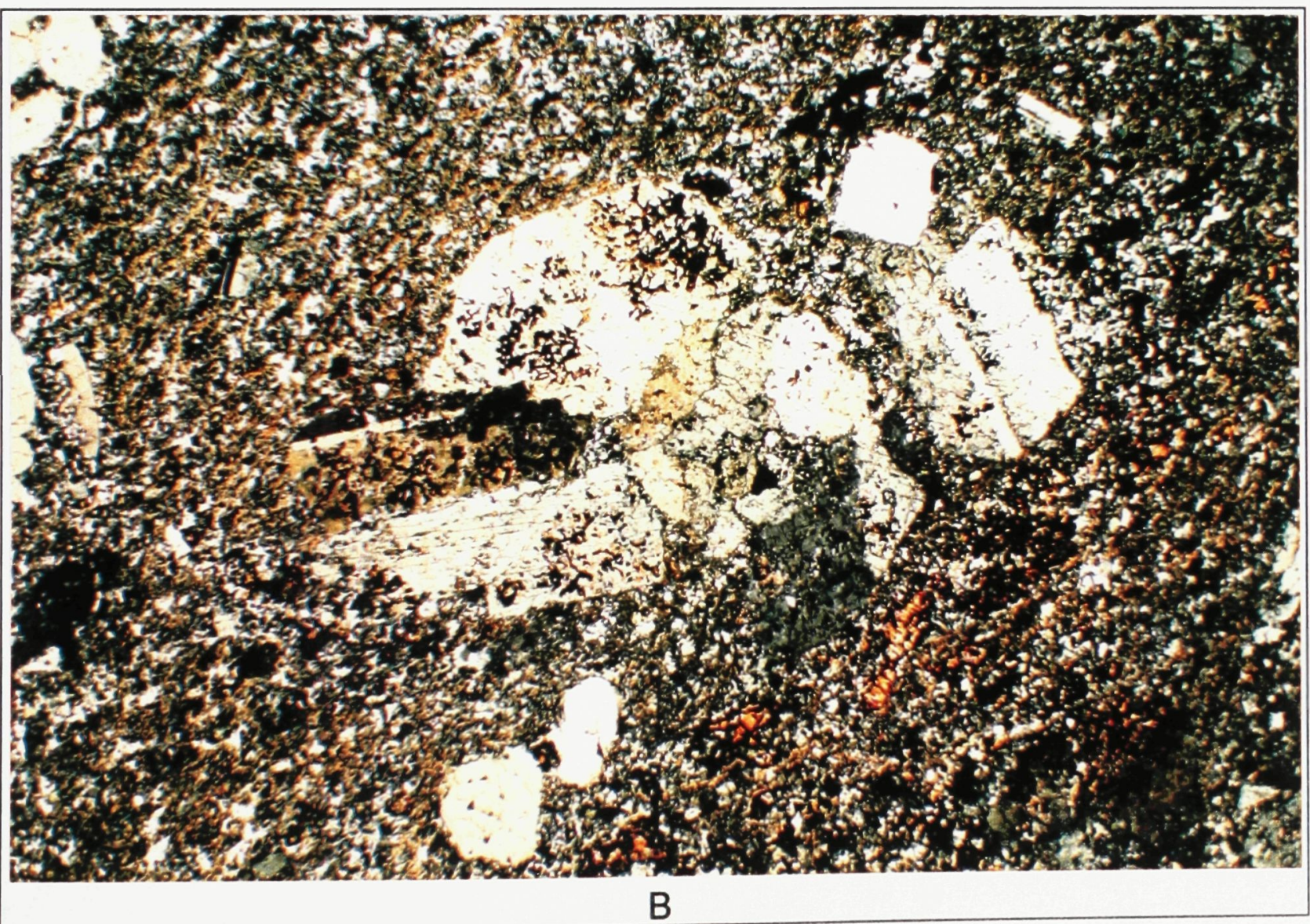


Figure A7.16 (following page)

A. Microphotograph of thin section 18-14050, crossed nicols, field of view is 1.3 $\mathrm{mm} \times 0.9 \mathrm{~mm}$. Quartz phenocryst $(0.40 \mathrm{~mm}$ long) rimmed by spherulitic crystals in coherent QP rhyolite. Veinlet in lower right corner of microphotograph is composed of carbonate and quartz. Sample is from 1829 Crosscut (Upper member, Kidd Creek formation).

B. Microphotograph of thin section 18-14050, crossed nicols, field of view is $0.65 \mathrm{~mm} \times 0.45 \mathrm{~mm}$. Quartz phenocryst $(0.21 \mathrm{~mm}$ across $)$ and spherulite $(0.20$ $\mathrm{mm}$ across) in coherent QP rhyolite. Note spherulitic rim on phenocryst. Sample is from 1829 Crosscut (Upper member, Kidd Creek formation). 

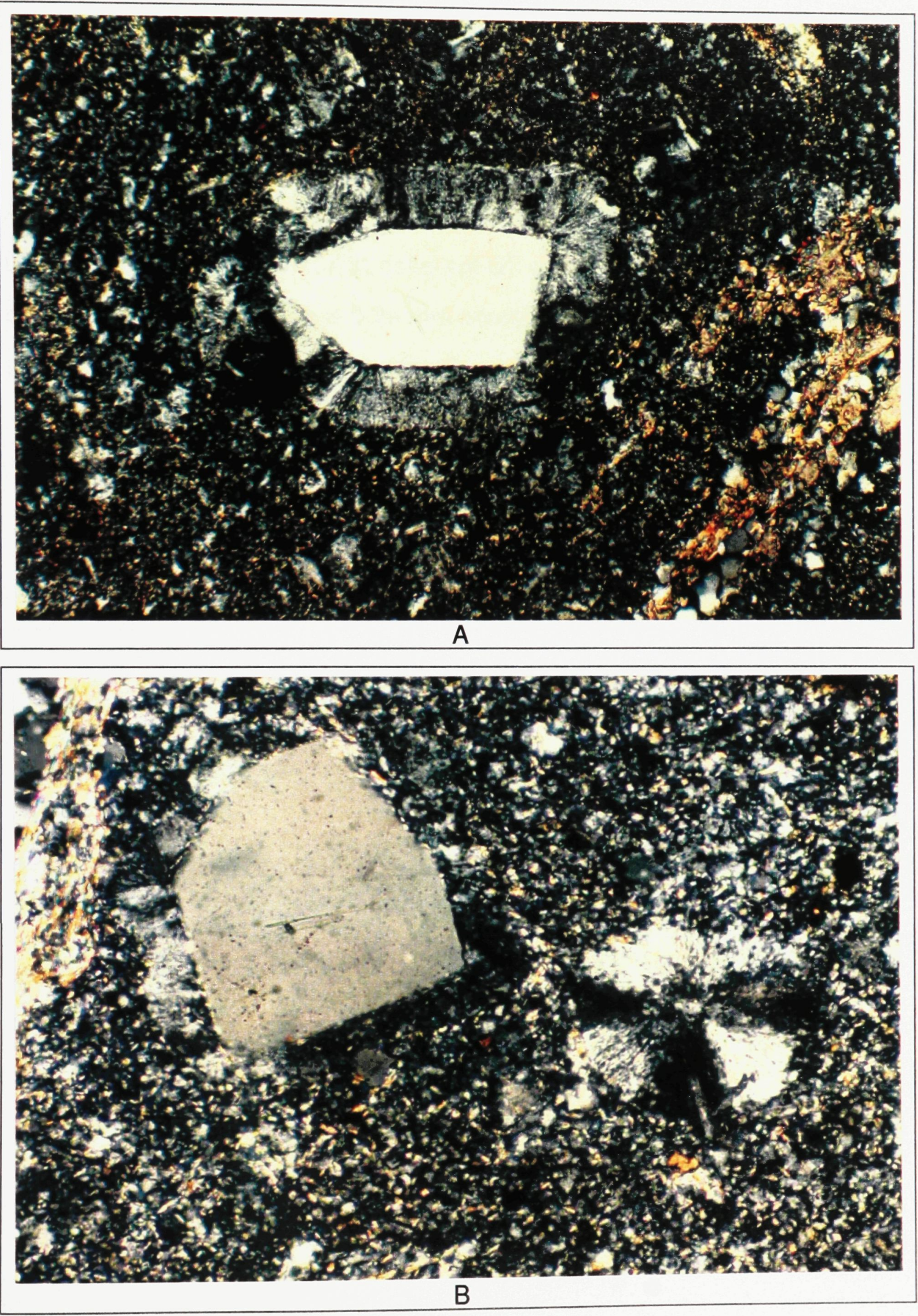
Figure A7.17 (following page)
A. Microphotograph of thin section 18-14050, crossed nicols, field of view is $0.65 \mathrm{~mm} \times 0.45 \mathrm{~mm}$. Spherulitic coherent QP rhyolite. Large spherulite near centre of microphotograph is $0.24 \mathrm{~mm}$ across. Sample is from 1829 Crosscut (Upper member, Kidd Creek formation).

B. Microphotograph of thin section 18-14050, plane light, field of view is $2.6 \mathrm{~mm}$ x $1.8 \mathrm{~mm}$. Spherulitic, coherent QP rhyolite. Small, dark minerals are stilpnomelane. Sample is from 1829 Crosscut (Upper member, Kidd Creek formation). 

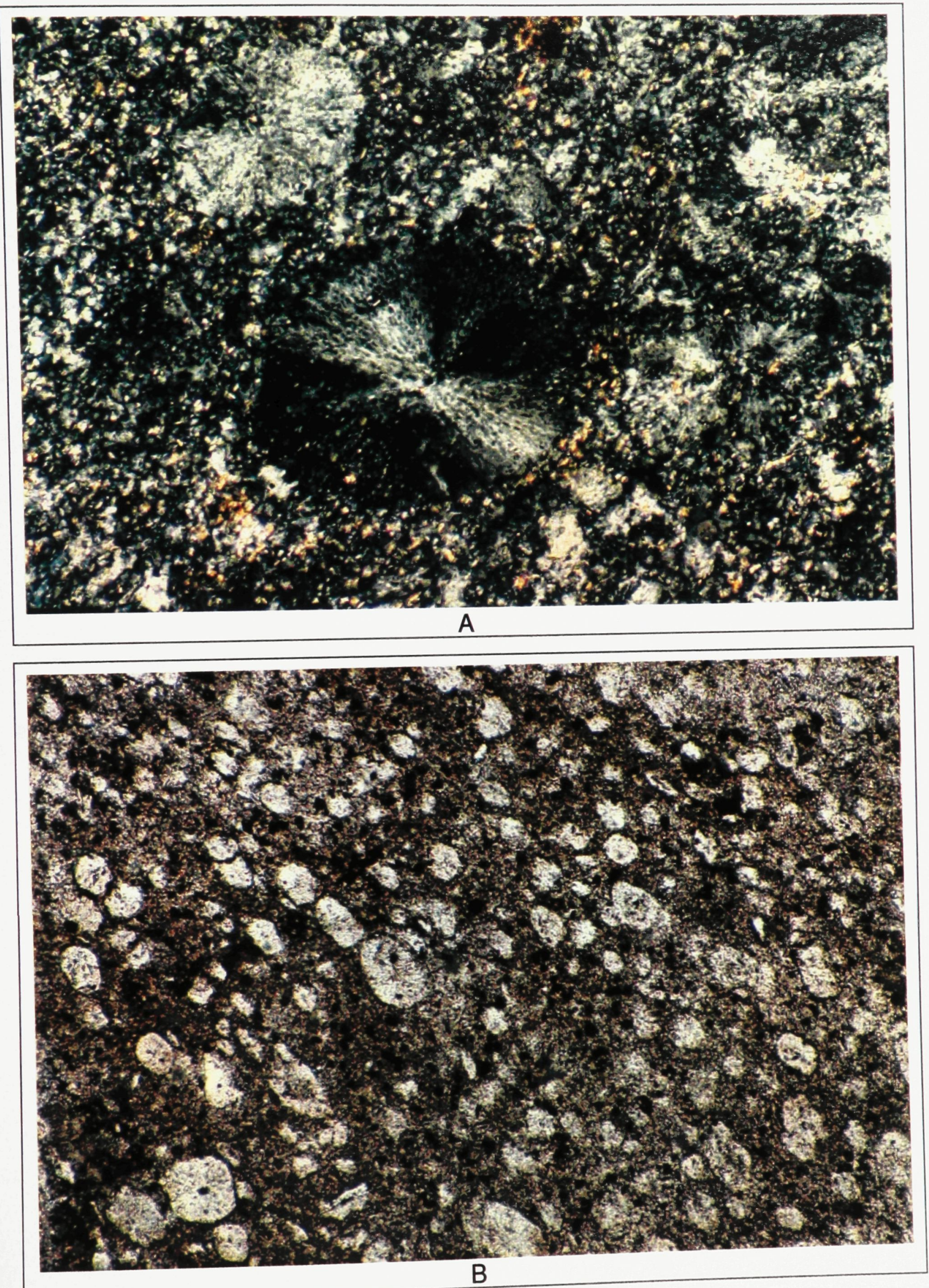
Figure A7.18 (following page)

A. Photomicrograph of thin section HG-2101-22A, plane light, field of view is 5.2 $\mathrm{mm} \times 3.6 \mathrm{~mm}$. Rhyolite-clast and quartz crystal-rich, bedded, volcaniclastic sandstone (probably resedimented QP rhyolite hyaloclastite), Upper member, Kidd Creek formation. Note quartz phenocrysts in some of the rhyolite clasts. Sample is from 2101 Drive South.

B. Photomicrograph of thin section HG-2101-11, plane light, field of view is 10.8 $\mathrm{mm} \times 7.4 \mathrm{~mm}$. Small apophysis of basalt or andesite (dark) intruding QP rhyolite hyaloclastite (Upper member, Kidd Creek formation). Opaque mineral is pyrite. Sample is from 2101 Drive South. 

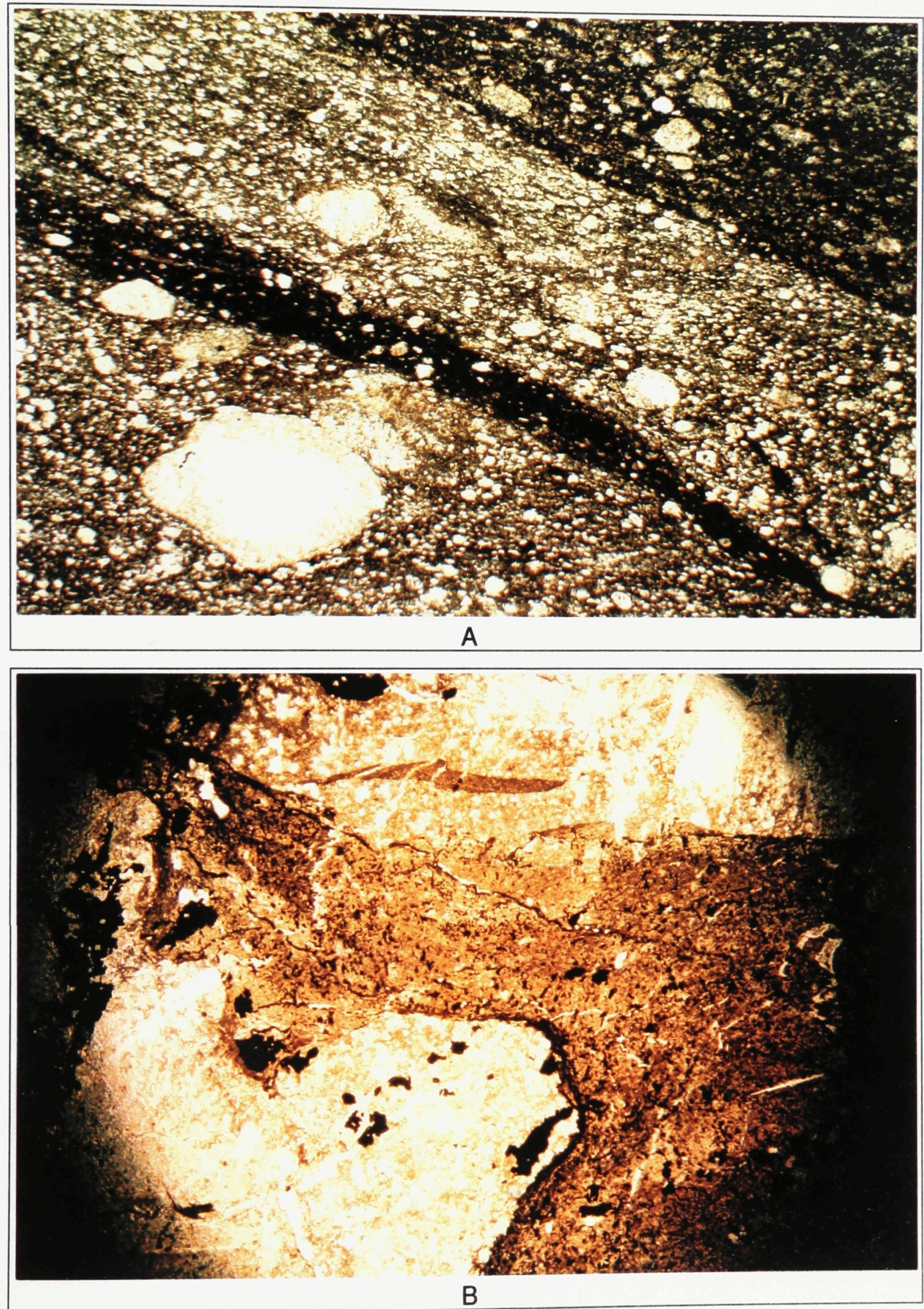
Figure A7.19 (following page)

A. Microphotograph of thin section 2578-1017, plane light, field of view is 10.8 $\mathrm{mm} \times 7.4 \mathrm{~mm}$. QP rhyolite hyaloclastite (Upper member of Kidd Creek formation) locally displaying jigsaw-fit texture. Note flow banding in fragments near centre of microphotograph. Sample collected at $1017 \mathrm{ft}(310 \mathrm{~m})$ from the collar in diamond drill hole 2578 , a relatively flat hole collared on 1600 Level.

A. Microphotograph of thin section 16-14138, plane light, field of view is 10.8 $\mathrm{mm} \times 7.4 \mathrm{~mm}$. Volcaniclastic sandstone with graded bedding, opaque mineral is pyrite. Sample is from 1602 Drive North (small area of transported volcaniclastic rocks within Lower member of Kidd Creek formation). 

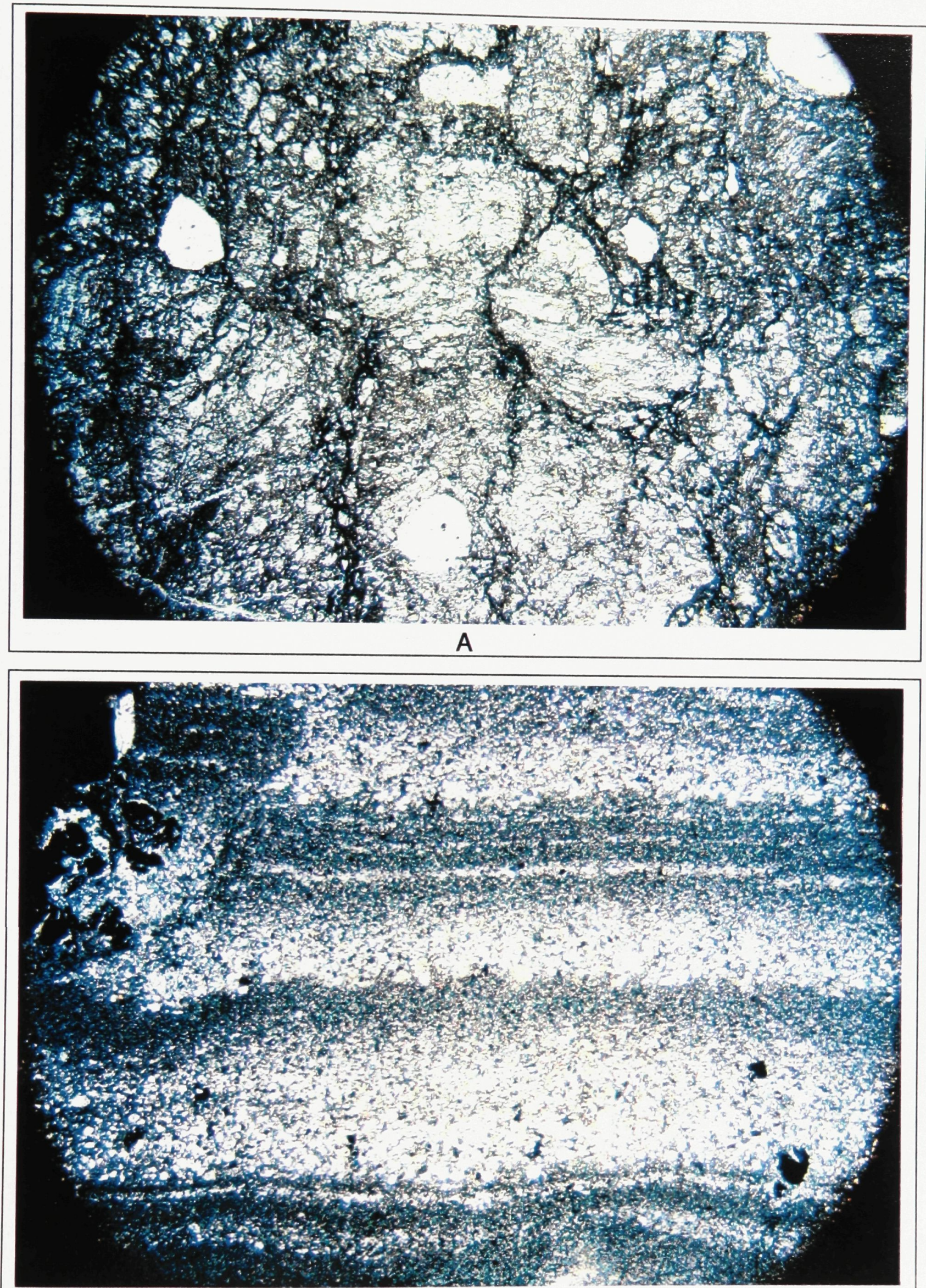
Figure A7.20 (following page)

\begin{abstract}
A. Microphotograph of thin section 21-14236B-E, plane light, field of view is 5.2 $\mathrm{mm} \times 3.6 \mathrm{~mm}$. One large quartz phenocryst (1.1 mm across) and two small quartz phenocrysts in strongly sericitized coherent rhyolite. Dark gray-brown spots are carbonate alteration. Sample is from the immediate hanging wall of the south orebody in 2129 Crosscut (Middle member, Kidd Creek formation).
\end{abstract}

B. Microphotograph of thin section EO-92-1, plane light, field of view is $5.2 \mathrm{~mm}$ $\times 3.6 \mathrm{~mm}$. Perlitic fractures in coherent rhyolite block from East Outcrop rhyolite breccia (Lower member, Kidd Creek formation). 

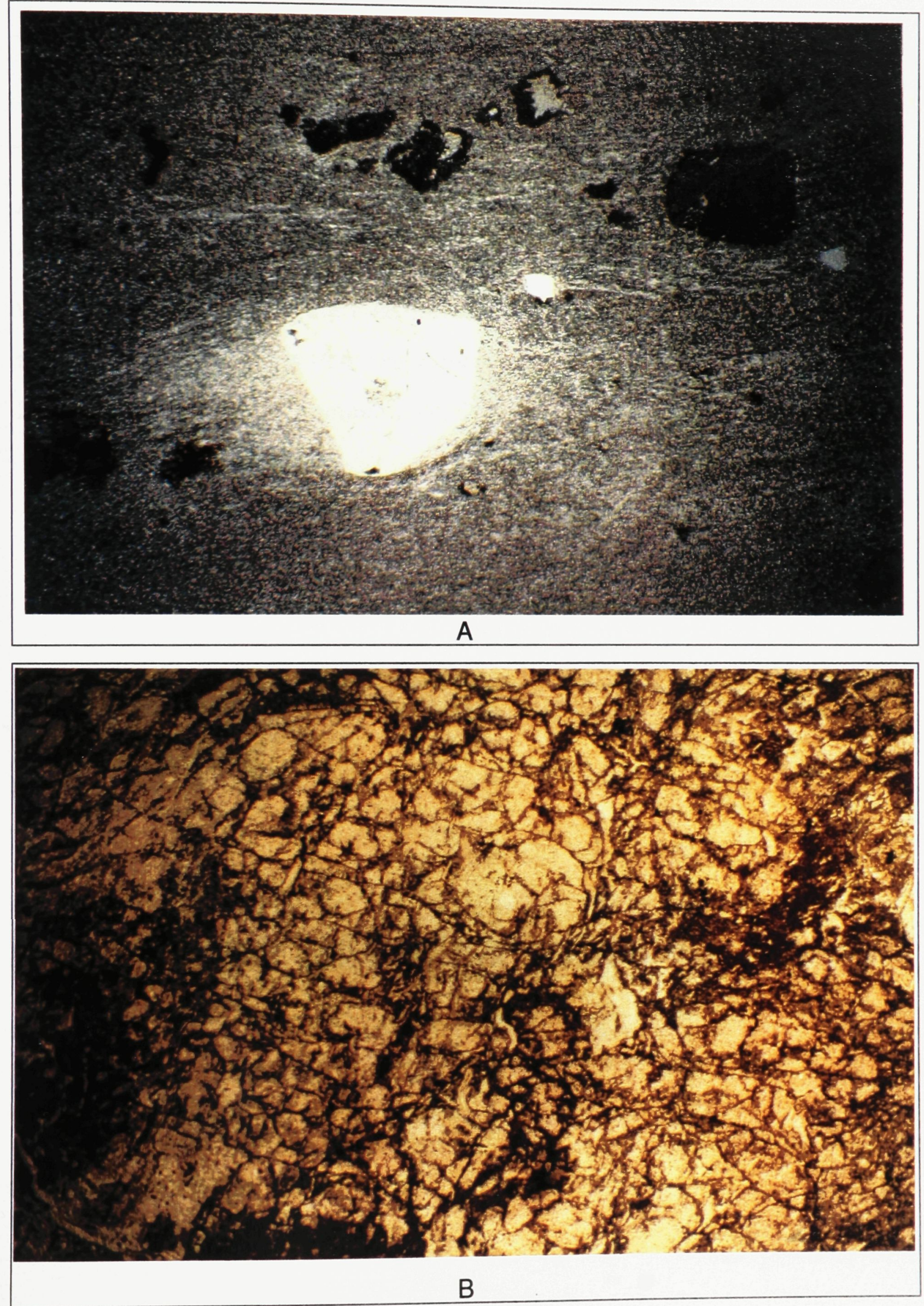
Figure A7.21 (following page)

\begin{abstract}
A. Photomicrograph of thin section 21-14149-2, crossed nicols, field of view is $1.3 \mathrm{~mm} \times 0.9 \mathrm{~mm}$. Spherulitic coherent rhyolite, large spherulite near centre of view is $0.55 \mathrm{~mm}$ across. Material surrounding spherulite is mainly chlorite with some sericite. Sample is from the immediate footwall of the south orebody in 2129 Crosscut (Middle member, Kidd Creek formation).
\end{abstract}

B. Photomicrograph of thin section 21-14149-2, crossed nicols, field of view is $1.3 \mathrm{~mm} \times 0.9 \mathrm{~mm}$. Spherulitic coherent rhyolite, large spherulite near centre of view is $0.5 \mathrm{~mm}$ across. Material surrounding spherulites is mainly chlorite with some sericite. Sample is from the immediate footwall of the south orebody in 2129 Crosscut (Middle member, Kidd Creek formation). 

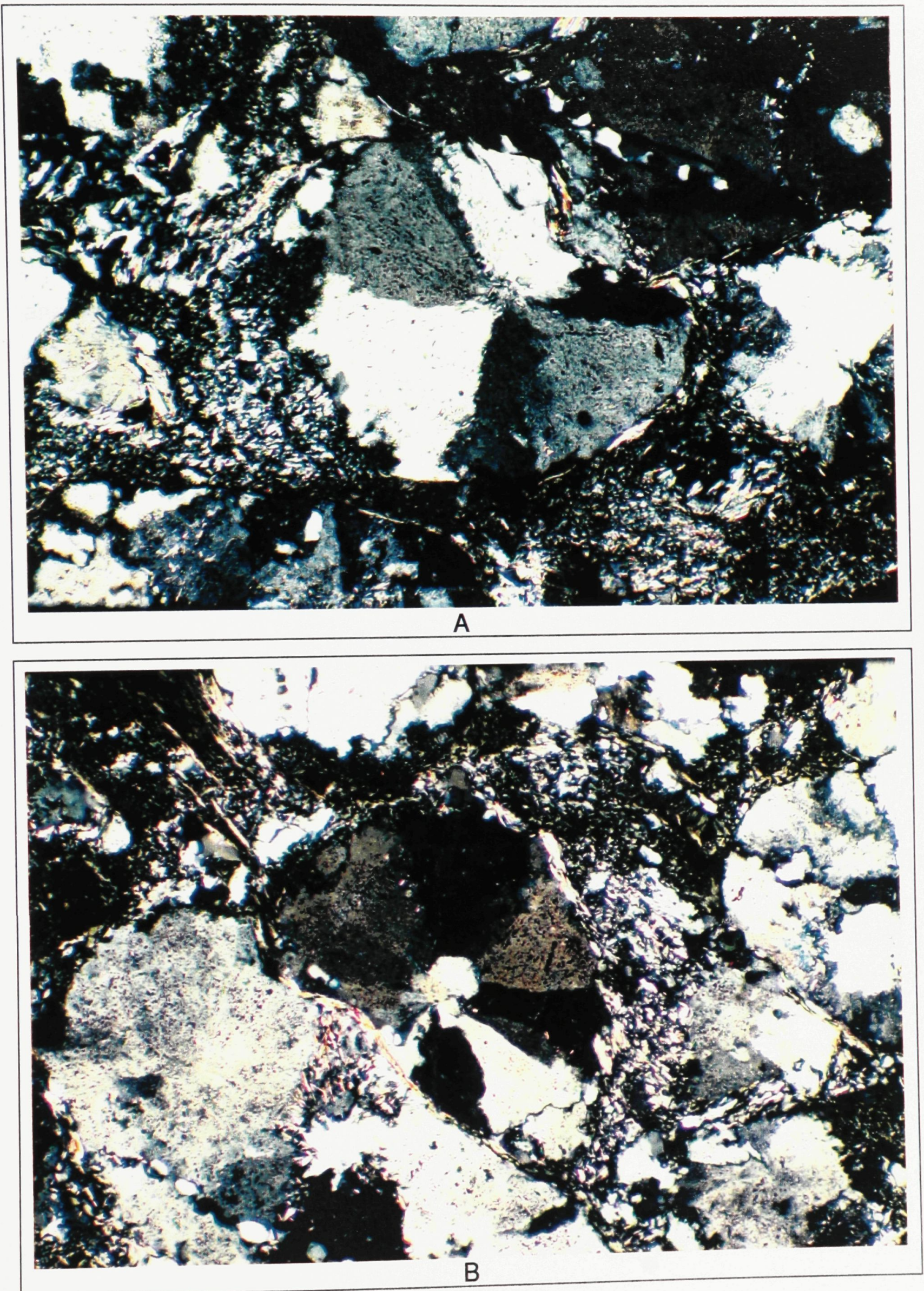
Figure A7.22 (following page)

A. Photomicrograph of thin section 21-14149-2, plane light, field of view is 5.2 $\mathrm{mm} \times 3.6 \mathrm{~mm}$. Zone of spherulites in coherent rhyolite. Note development of anastomosing fractures in areas where spherulites coalesce. Material between spherulites consists chlorite and minor sericite. Sample is from the immediate footwall of the south orebody in 2129 Crosscut (Middle member, Kidd Creek formation).

B. Same as A with crossed nicols. 

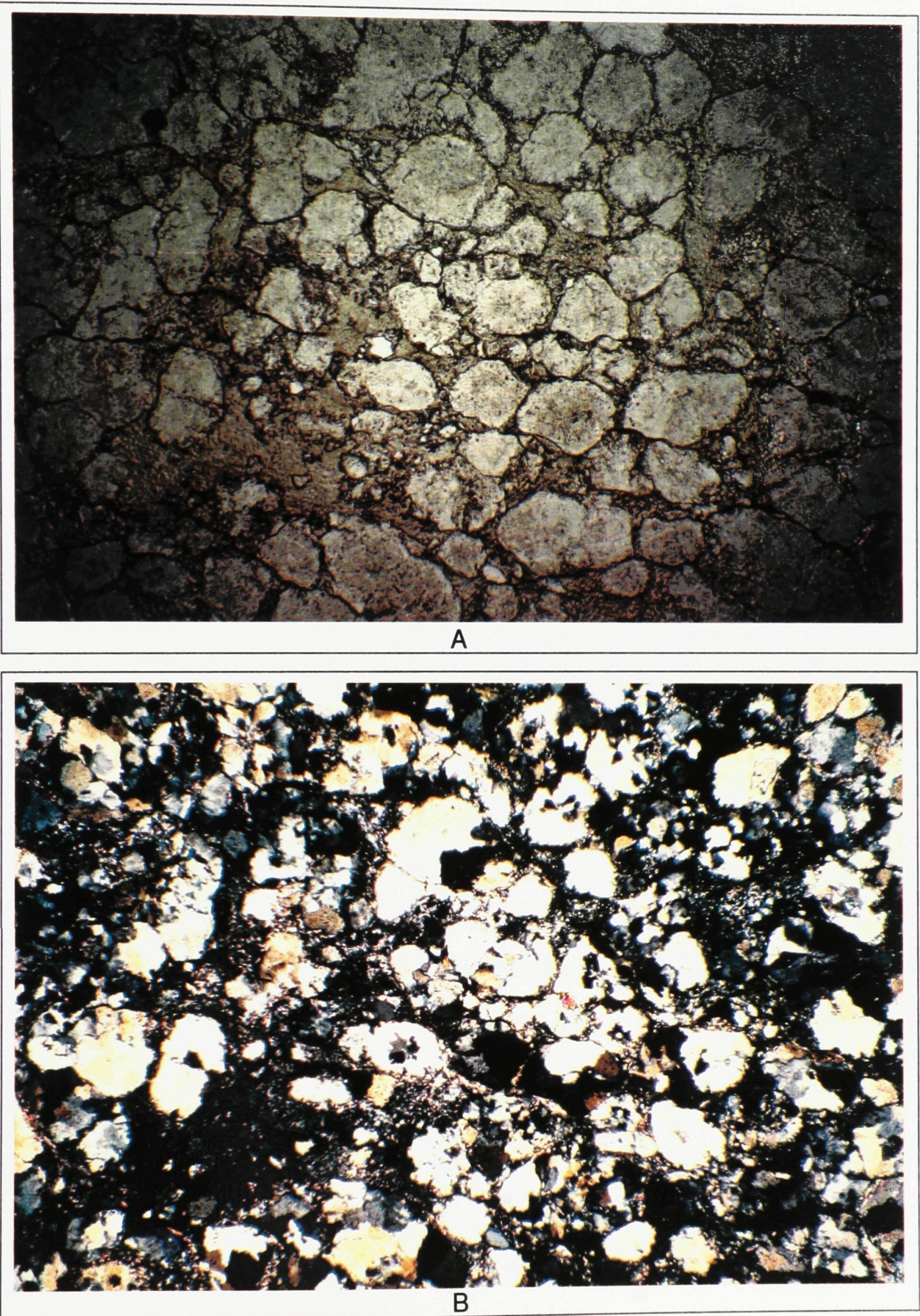
Figure A7.23 (following page)

A. Microphotograph of thin section 16-14061, plane light, field of view is $2.6 \mathrm{~mm}$ $x 1.8 \mathrm{~mm}$. Small spherules (recrystallized spherulites) in coherent rhyolite. Feldspar phenocryst pseudomorph (sericitized) is $0.7 \mathrm{~mm}$ across. Material between spherules is predominantly sericite. Sample is from 1602 Drive South (Lower member, Kidd Creek formation).

B. Microphotograph of thin section 21-14149-2, plane light, field of view is 10.8 $\mathrm{mm} \times 7.4 \mathrm{~mm}$. Spherulitic coherent rhyolite. Material between spherules is predominantly chlorite with minor sericite. Sample is from 2129 Crosscut in the immediate footwall of the south orebody (Middle member, Kidd Creek formation) 

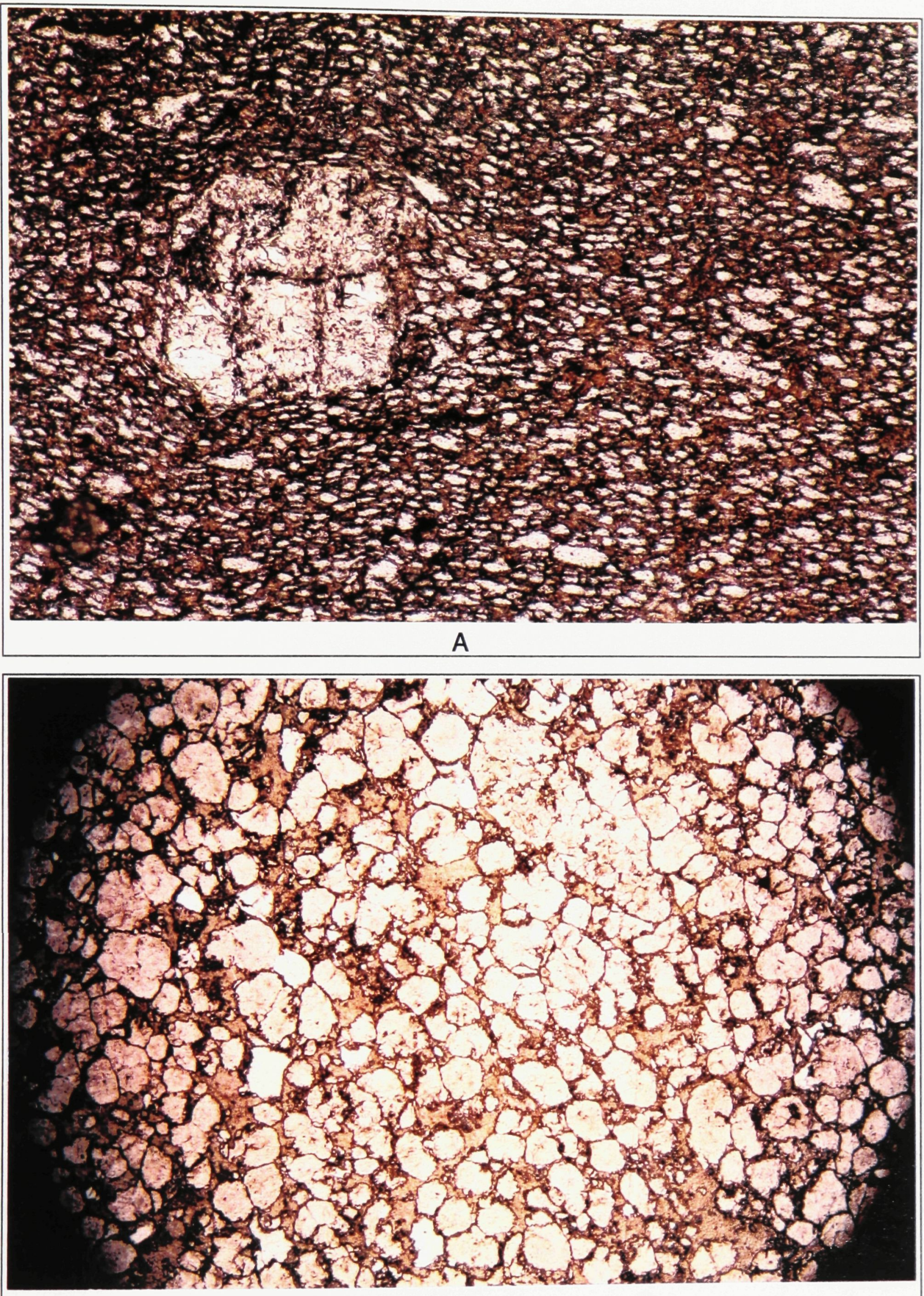
Figure A7.24 (following page)

A. Microphotograph of thin section 16-14061, plane light, field of view is 10.8 $\mathrm{mm} \times 7.4 \mathrm{~mm}$. Contorted flow banding in coherent rhyolite resulting from variable density of spherules (recrystallized spherulites). Spherules are densely packed and coalesced within white bands. Sample is from 1602 Drive South (Middle member, Kidd Creek formation).

B. Microphotograph of thin section 16-14061, plane light, field of view is 10.8 $\mathrm{mm} \times 7.4 \mathrm{~mm}$. Contorted flow banding as in $\mathrm{A}$. 

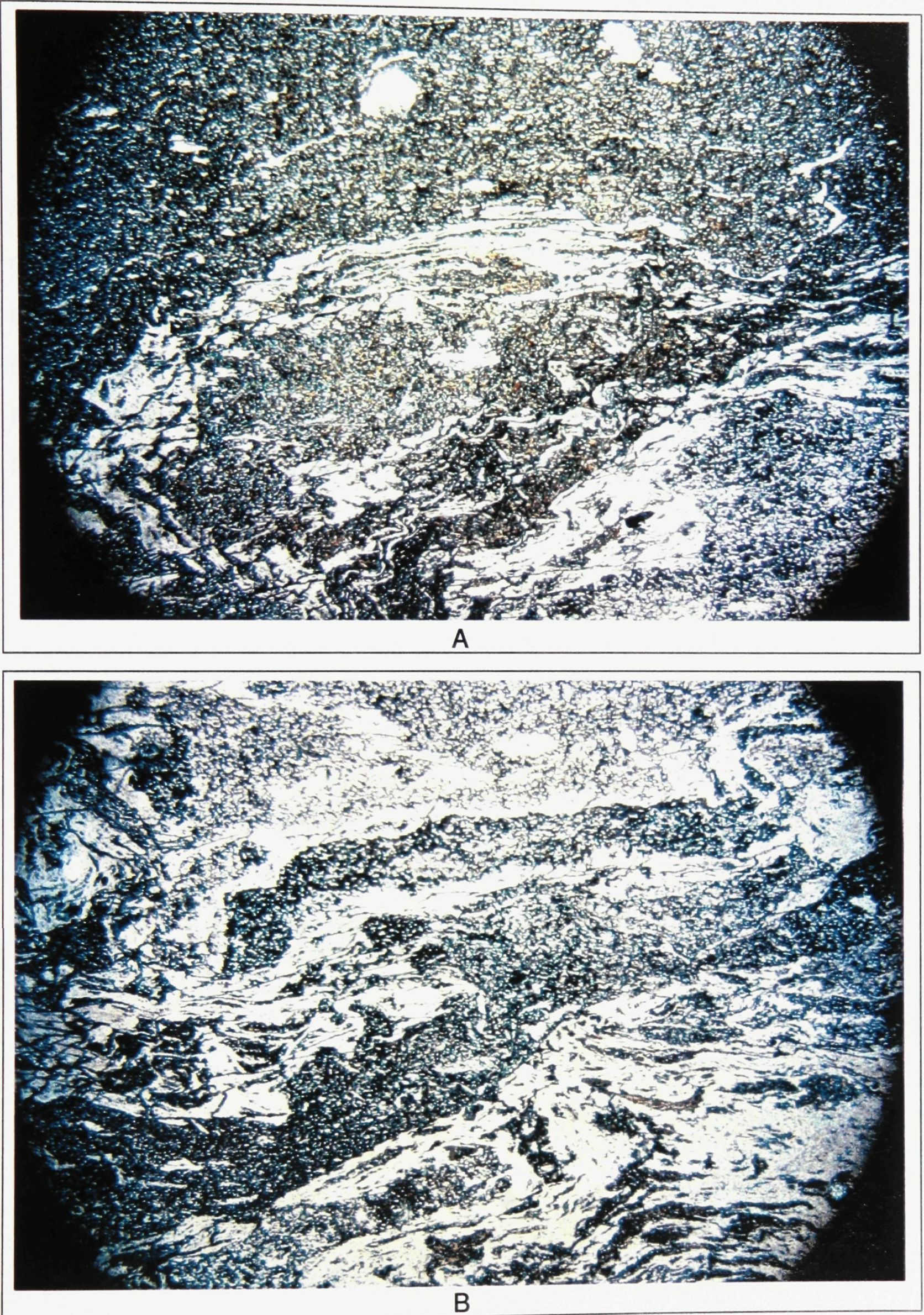
Figure A7.25 (following page)

A. Microphotograph of thin section 21-14150, plane light, field of view is 10.8 $\mathrm{mm} \times 7.4 \mathrm{~mm}$. Polymict volcaniclastic pebble conglomerate composed of rhyolite clasts, quartz crystal clasts (white, unaltered material), and mafic clasts (part of a large mafic clast is visible in the upper right part of microphotograph). Note angularity of some fragments. Sample is from 2129 Crosscut in the footwall of the south orebody (Middle member, Kidd Creek formation).

B. Microphotograph of thin section 16-14106, plane light, field of view is 10.8 $\mathrm{mm} \times 7.4 \mathrm{~mm}$. Contact between in situ rhyolite hyaloclastite (on left) and polymict volcaniclastic pebble conglomerate (on right). Note jigsaw-fit texture in hyaloclastite. Sample is from 2129 Crosscut in the footwall of the south orebody (Middle member, Kidd Creek formation). 

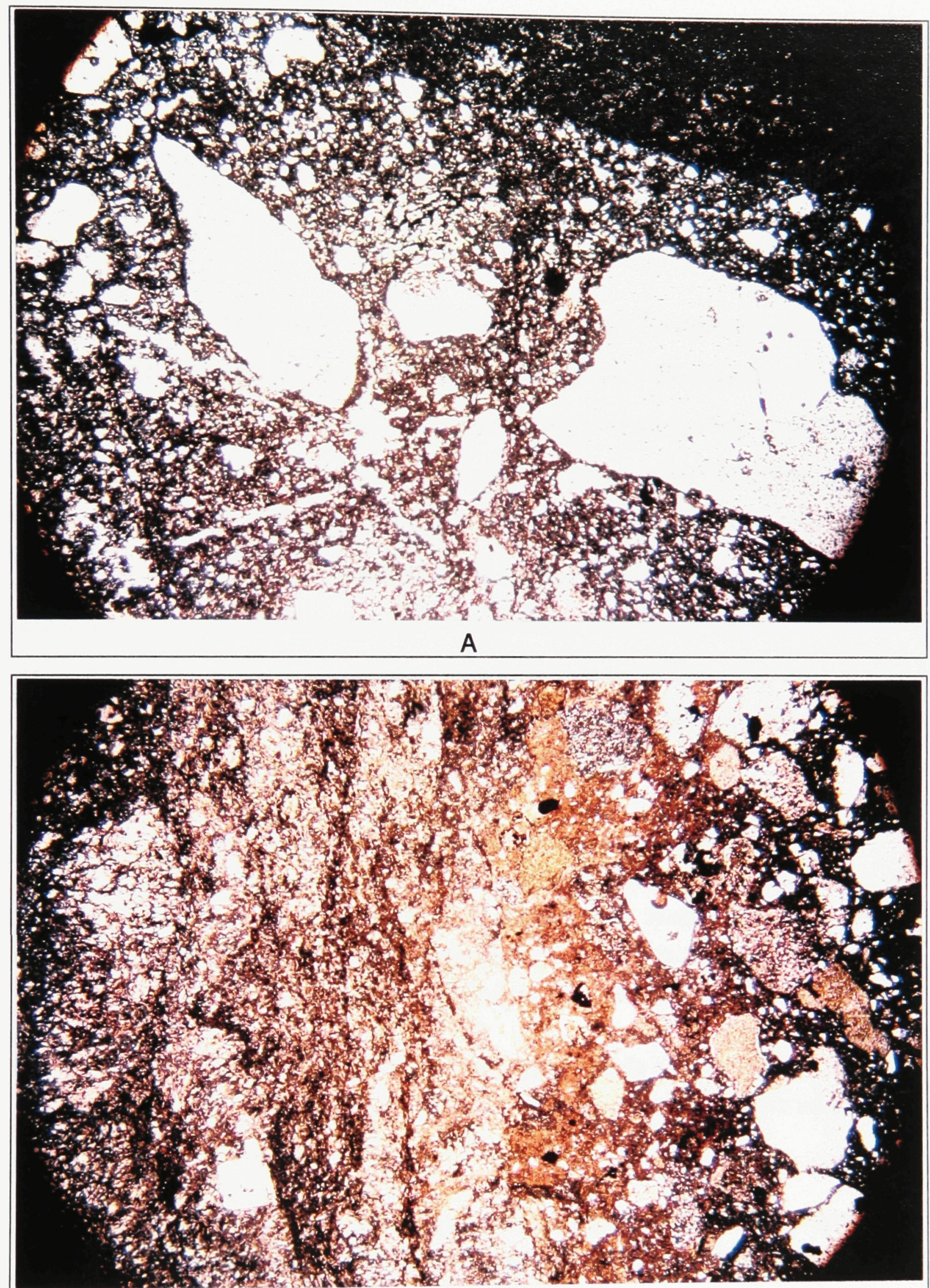

B 


\section{Appendix 8 \\ VOLCANICLASTIC ROCK TERMINOLOGY USED IN THESIS}

"There is, at present, no adequate terminology for autoclastic deposits, nor for resedimented syn-eruptive pyroclastic and autoclastic deposits" (McPhie et al., 1993, p. 8). The rock classification scheme used by company geologists at the Kidd Creek Mine includes several pyroclastic terms, including "tuff", "lapillistone", and "agglomerate", which are used in a non-genetic sense to indicate fragment size in volcaniclastic rocks (Walker and Mannard, 1974). However, when applied rigorously the use of pyroclastic terminology implies formation by pyroclastic processes. This thesis demonstrates that little, if any, of the volume of volcaniclastic rock present in the Kidd Creek formation was formed by pyroclastic processes in the classic sense:

"Pyroclastic - primary volcaniclastic deposits made of particles (pyroclasts) generated by explosive eruptions and deposited by primary volcanic processes (fallout, flow, surge)" (McPhie et al., 1993, p. 94). "Note, in particular that "tuff" is reserved for primary pyroclastic deposits" (McPhie et al., 1993, p. 8).

"pyroclastic (py-ro-clas'-tic) Pertaining to clastic rock material formed by volcanic explosion or aerial expulsion from a volcanic vent" (Bates and Jackson, 1987, p. 540).

"Pyroclastic deposits are those formed by the fragmentation of magma and rock by explosive volcanic activity" (Wright et al., 1980, p. 315). 
Schmid (1981), in recommendations of the IUGS Subcommission on the systematics of igneous rocks, suggested broadening the definition of pyroclastic deposit to include all rocks composed of fragments generated by volcanic action:

"Pyroclastic deposits (="pyroclastics") include both consolidated and unconsolidated assemblages of pyroclasts. They must contain more than $75 \%$ pyroclasts by volume.... Pyroclasts are the individual crystals, crystal fragments, glass fragments, and rock fragments generated by disruption as a direct result of volcanic action" (Schmid, 1981, p. 42).

Using the definitions of Schmid (1981) volcanogenic autoclastic deposits are considered to be pyroclastic and, therefore, pyroclastic terminology can be applied (for example, an autoclastic breccia might be mapped as a rhyolite lapillistone). However, even using Schmid's definition, pyroclastic nomenclature should not be applied to resedimented volcaniclastic rocks.

In this thesis rocks formed by autoclastic processes are not considered to be pyroclastic rocks, consistent with McPhie et al. (1993), Bates and Jackson (1987), and Wright et al. (1980). The classification scheme I have adopted for the volcaniclastic rocks of the Kidd Creek formation is presented in Table A8.1. 


\begin{tabular}{|c|c|c|}
\hline & \multicolumn{2}{|c|}{ Volcaniclastic Rocks } \\
\hline Fragment Size & $\begin{array}{c}\text { Autoclastic Deposits } \\
\text { (in-situ to locally transported) } \\
\text { - generally monomict - }\end{array}$ & $\begin{array}{l}\text { Epiclastic Deposits } \\
\text { - generally polymict - }\end{array}$ \\
\hline $\begin{array}{c}<1 / 16 \mathrm{~mm} \\
(<0.0625 \mathrm{~mm})\end{array}$ & hyaloclastite & volcaniclastic mudstone \\
\hline $1 / 16-2 \mathrm{~mm}$ & hyaloclastite & volcaniclastic sandstone \\
\hline $2-64 \mathrm{~mm}$ & autoclastic breccia* & $\begin{array}{c}\text { volcaniclastic pebble } \\
\text { conglomerate }\end{array}$ \\
\hline$>64 \mathrm{~mm}$ & coarse autoclastic breccia* & $\begin{array}{l}\text { volcaniclastic boulder } \\
\text { conglomerate }\end{array}$ \\
\hline
\end{tabular}

* breccia-conglomerate if fragments have been rounded by abrasion or alteration

Table A8.1. Classification of volcaniclastic rocks formed by autoclastic or epiclastic processes (modified after McPhie et al., 1993). 


\title{
Appendix 9
}

\section{DESCRIPTIONS OF ROCK SAMPLE FROM THE 1600, 1800, 2100, 2300, AND 2400 LEVELS OF THE KIDD CREEK MINE}

\author{
Notes: i. sample number prefix denotes mine level \\ ii. see Maps 2 to 7 for sample locations \\ iii. " $x$ " beneath sample number denotes geochemical analyses
}

\section{Abbreviations Used In Rock Descriptions}

$\underline{\text { General Abbreviations }}$

\begin{tabular}{|c|c|c|c|}
\hline carb & carbonate & $\mathrm{n}$ & nil $(0 \%)$ \\
\hline chl & chlorite & vw & very weak (<2\%) \\
\hline$c p$ & chalcopyrite & w & weak (2-10\%) \\
\hline $\mathrm{cr}$ & coarse & $\mathrm{m}$ & moderate $(10-30 \%)$ \\
\hline diss & disseminated & s & strong $(30-50 \%)$ \\
\hline $\begin{array}{l}\text { fc } \\
\text { fd }\end{array}$ & $\begin{array}{l}\text { Fe-carbonate } \\
\text { feldspar }\end{array}$ & i & intense $(>50 \%)$ \\
\hline fn & fine & \multirow{2}{*}{\multicolumn{2}{|c|}{ Alteration Styles }} \\
\hline FOL & foliation & & \\
\hline gal & galena & $\mathrm{B}$ & blebby \\
\hline$g r$ & grained & D & disseminated \\
\hline HS & hand sample & $\mathrm{F}$ & foliation controlled \\
\hline md & medium & $\mathrm{H}$ & hairline veinlet $(<1 \mathrm{~mm})$ controlled \\
\hline pheno & phenocryst & $\mathrm{L}$ & veinlet $(1-10 \mathrm{~mm})$ controlled \\
\hline plag & plagioclase & $\mathrm{P}$ & pervasive \\
\hline py & pyrite & $\mathrm{R}$ & fracture controlled \\
\hline$q z$ & quartz & $S$ & spotty \\
\hline ser & sericite & $\mathrm{V}$ & vein $(>10 \mathrm{~mm})$ controlled \\
\hline sph & sphalerite & $x$ & crystal replacement \\
\hline sx & sulfide & & \\
\hline $\begin{array}{l}\text { tour } \\
\text { tr }\end{array}$ & $\begin{array}{l}\text { tourmaline } \\
\text { trace }\end{array}$ & & \\
\hline TS & thin section & & \\
\hline v & very & & \\
\hline al & & & \\
\hline
\end{tabular}

Alteration Intensities

n nil $(0 \%)$

very weak $(<2 \%)$

weak $(2-10 \%)$

m moderate $(10-30 \%)$

strong $(30-50 \%)$

intense $(>50 \%)$

\section{Alteration Styles}

B blebby

D disseminated

L veinlet $(1-10 \mathrm{~mm})$ controlled

pervasive

fracture controlled

vein (>10 mm) controlled crystal replacement 
16-14060

1602 DR S

\author{
16-14061 \\ 1602 DR S \\ $\mathrm{x}$
}

\author{
16-14062 \\ 1602 DR S \\ $\mathrm{x}$
}

\section{6-14063 \\ 1602 DR S \\ $\mathrm{x}$}

\section{6-14064 \\ 1602 DR S \\ $\mathrm{x}$}
16-14065
1602 DR S

\author{
16-14066 \\ 1602 DR S \\ $\mathrm{x}$
}

16-14067

1602 DR S

$16-14068$

1602 DR S

\author{
16-14069 \\ 1602 DR S \\ $\mathrm{x}$
}

16-14070

1602 DR S coherent rhyolite, flow banded (sub-mm scale), pronounced

microscopic anastomosing fracture pattern, weak foliation, $1-2 \% \mathrm{qz}$ phenos (random, up to $1.2 \mathrm{~mm}$ across, intact to broken, commonly rimmed by $2^{\circ} \mathrm{qz}$ ), possibly $1-2 \%$ fd pheno pseudomorphs (carb-ser) up to $2 \mathrm{~mm}$ long, m-sPser, wScarb (qz-ser rock), no sulfides

flow banded coherent rhyolite, stong anastomosing fracture pattern, well developed flow banding ( $\mathrm{mm}$ to sub-mm scale), wFOL (locally crenulated), $\mathrm{tr}-1 \%$ qz phenos (subhedral-euhedral, up to $1 \mathrm{~mm}$ across), tr- $1 \%$ fd pheno pseudomorphs (ser-qz \pm chl) up to $2 \mathrm{~mm}$ long, sPser (qz-ser rock), no sulfides

ultramafic rock, sLScarb (some pink carbonate)

ultramafic rock, sVPcarb, vwSfuchsite, no sulfides

volcaniclastic pebble conglomerate, polymict, contains sx clast, matrix alteration: w-mPser-chl, locally wLcarb, wDtour, 30-40\% py-sph, clasts + diss

volcaniclastic pebble conglomerate, polymict, contains sx clasts, flow banded rhyolite clast in TS, minor proportion of sph-chl \pm albite clasts, wPHser, vwDtour, vwHqz, vwScarb, $20-30 \%$ py, 5-10\%sph, $1-2 \%$ gal - clasts $+2^{\circ} \mathrm{BD}$

volcaniclastic sandy mudstone composed predominantly of rhyolite and $\mathrm{qz}$ xtall clasts, largest clast is $0.6 \mathrm{~mm}$ across, $1-2 \%$ sand sized $(>0.06 \mathrm{~mm}$ ) clasts, sPser (qz-ser rock), 1-2\%Dpy

autoclastic rhyolite breccia, local in situ breccia texture (microscopic)

volcaniclastic mudstone in sharp contact with graded volcaniclastic sandstone, sandstone is light grey, lower $2 \mathrm{~cm}$ of sandstone is very $\mathrm{cr}$ $\mathrm{gr}$ with clasts up to $5 \mathrm{~mm}$ of rhy and black argillite, sandstone matrix alteration: sPser-chl; mudstone: sPser, argillite clasts: iPchl, tr-2\%Dpy, mainly in sandstone

volcaniclastic sandy mudstone, composed predominantly of rhyolite clasts and qz xtalls, It grey, grainy in TS, largest clast is $0.26 \mathrm{~mm}$ across (qz xtall), sPser, wScarb, 1-3\%Dpy

contact between coherent rhyolite and in-situ rhyolite hyaloclastite, WFOL, grey alteration zone and increased sericitization along contact, rhyolite: $\operatorname{tr}-1 \%$ qz phenos, hyaloclastite: jig-saw fit common, fragments up to $1.5 \mathrm{~mm}$ across (TS), a few show flow banding(?), $1-2 \%$ qz xtalls up to $1.5 \mathrm{~mm}$ across, $\mathrm{m}$-sPchl-(ser), w-mFser, vwSchl, no sulfides 
16-14071

1602 DR S

16-14072

1602 DR S

16-14073

1602 DR S

16-14074

1602 DR S

$\mathrm{x}$

\section{6-14075}

1602 DR S

16-14076

1602 DR S

16-14077

1602 DR S

16-14078

1602 DR S

16-14079

1602 DR S

$\mathrm{x}$

16-14080

1602 DR S

$\mathrm{x}$

16-14081

1602 DR S

$x$ volcaniclastic boulder conglomerate, polymict, m-sPchl, 10-20\% py-sph clasts + diss

rhyolite hyaloclastite, local jig saw fit texture, anastomosing fracture pattern well developed in $60-80 \%$ of TS, WFOL, sPFser, wSchl vwScarb, $1-3 \%$ Dsph (commonly rimmed by chl), 1-2\%Dpy, trDgal

volcaniclastic boulder conglomerate, polymict, contains sulfide clasts, TS contains $35 \times 15 \mathrm{~mm}$ light grey, aphanitic, strongly altered (qz-ser) rhy clast with incipient fracturing at 1 end

rhyolite autoclastic breccia - rhyolite hyaloclastite, breccia is strongly silicified and sericitized, white to light green (ser),

monomict, largest fragment is $1.5 \times 1 \mathrm{~cm}$, breccia contains a $3 \mathrm{~cm}$ wide zone of dark gray hyaloclastite, $1-2 \%$ qz eyes to $2 \mathrm{~mm}$, breccia: sPqz, sPser, w-mLSfc, 1-3\%Dpy located preferentially in hyaloclastite

ultramafic rock, mVcarb, wVfuchsite (halo on carbonate vein), no sulfides

felsic volcaniclastic rock, collected near ultramafic rocks and $E-W$ shear, s-iPchl, w-mSfc (1-2 mm fc spots); qz-chl-(fc) rock, no sulfides

large clast in volcaniclastic boulder conglomerate, $45 \times 15 \mathrm{~cm}$, felsic volcaniclastic sandstone, $1-2 \%$ qz crystals (some broken)

$c p$ clast in volcaniclastic boulder conglomerate

volcaniclastic sandstone (distal hyaloclastite?), polymict, matrix supported, not foliated, clasts: broken qz xtalls $>$ rhy clasts $>$ chloritized mafic clasts, grain size $=0.02-2 \mathrm{~mm}$, most clasts

subround-subangular, granular hand sample, apx. $1 \%$ tan mafic clasts up to $3 \times 3 \mathrm{~mm}$, sPchl, wHchl, wScarb, 1-3\%DBpy, trDgal

autoclastic rhyolite breccia-conglomerate, transported, monomict, It gray clasts in dark gray matrix, 1 clast flow banded, clasts subround unsorted and variably silicified, largest clast $7.5 \times 4 \mathrm{~cm}$, clasts: $\mathrm{iP}(\mathrm{H})$ si, matrix: sPser, vw-wPchl, wLcarb-(albite); qz-ser rock, $1-3 \%$ DBpy

volcaniclastic boulder conglomerate, $40-60 \%$ subrnd-subang unsorted clasts up to $6 \times 4 \mathrm{~cm}$ (py-sph clasts, rhy clasts, volcaniclastic sandstone clasts, altered (tan) mafic clasts, qz xtall clasts), matrix alteration: mPser-chl, 15-35\% py-sph, clasts+diss, trLcp 
16-14082

1602 DR S

$\mathrm{x}$

16-14083

1602 DR S

$\mathrm{x}$

\section{6-14084 1602 DR S $\mathrm{x}$

\author{
16-14085 \\ 1602 DR S \\ $\mathrm{x}$
}

\section{6-14086 1602 DR S $\mathrm{x}$}

\author{
16-14087 \\ 1602 DR S \\ $\mathrm{x}$
}

\author{
16-14088 \\ 1602 DR S \\ $\mathrm{x}$
}

\section{6-14089 1602 DR S $\mathrm{x}$}

\author{
16-14090 \\ 1602 DR S \\ $\mathrm{x}$
}

\author{
16-14091 \\ 1602 DR S \\ $\mathrm{x}$
}

\section{6-14092 1602 DR S $\mathrm{x}$}

rhyolite hyaloclastite - coherent rhyolite, moderate anastomosing fracture pattern (40-50\% of TS), vwFOL, m-sPser (qz-ser rock), vw-wSchl (commonly rimming sph grains), 1-3\%Dpy, tr-3\%Dsph

mafic intrusive rock, very fn gr, md gray, sLSfc-qz, mDleucoxene, trDpy

volcaniclastic pebble conglomerate, polymict, sx-rich, dk gray gritty matrix, one siliceous clast contains tourmaline, matrix alteration: $\mathrm{m}$-sPchl, $10-30 \%$ py- and sph-rich clasts

rhyolite hyaloclastite, md gray, vf gr, 1-2\% siliceous rhyolite clasts up to $6 \times 4 \mathrm{~mm}$, no sulfides

volcaniclastic boulder conglomerate, polymict, $20-40 \%$ clasts sx(sph-py), volcaniclastic sandstone, rhyolite, and altered (tan) mafic clasts, sph clasts are chl-rich, matrix is dark grey, very fn gr (gritty), matrix alteration: $\mathrm{m}$-sPchl, $10-20 \%$ sph-py, mostly clasts, may also contain some $2^{\circ}$ mineralization

volcaniclastic sandy mudstone, siliceous, dk gray, gritty, mFOL, composed mainly of qz xtalls and rhyolite clasts, most clasts are between 0.02 and $0.2 \mathrm{~mm}$ across, folded py veinlet in TS, SPchl, wPser, nil-2\%LDpy

volcaniclastic sandstone, felsic, medium grey, matrix supported, weakly graded, polymict, major clasts types (>90\%) are recrystallized rhyolite and qz xtalls (subrnd to subang), $30-50 \%$ relatively coarse grains (sand sized, mainly $0.03-1.4 \mathrm{~mm}$ ) in a muddy matrix, sPchl, 3-5\%BDsph, 1-3\%Dpy (cubes to $7 \mathrm{~mm}$ ), tr- $2 \% \mathrm{Bcp}$

rhyolite hyaloclastite, fragment supported, unsorted, monomict TS largest fragment is about $4 \mathrm{~mm}$ across, larger clasts show variable degrees of fragmentation, fragments subround to subangular, HS: medium-dark grey, indistinct clasts up to $1.5 \times 1.0 \mathrm{~cm}$, sPser-chl (qz-ser-chl rock); sPchl zones within large fragments (glass hydration?), no sulfides

volcaniclastic sandy mudstone, felsic, (bedded), polymict, one sandstone laminae in TS $(1.0 \mathrm{~mm}$ thick) average gr size $<0.05 \mathrm{~mm}$, $\mathrm{qz}$ xtall and rhyolite clasts dominant, largest clast $(0.88 \mathrm{~mm}$ across) is composed of chl-sph, sPser-chl, wSfc, vwHqz, no sulfides

volcaniclastic pebble conglomerate with argillaceous matrix, polymict, rhyolite fragments are up to $6 \times 4 \mathrm{~mm}, 2-5 \%$ tan mafic clasts up to $10 \times 4 \mathrm{~mm}$, some very irregular (delicate), $1-2 \%$ qz xtalls, m-sPLchl, w-mPser, nil-trDpy

volcaniclastic pebble conglomerate - graphitic argillite contact, pebble conglomerate has strongly chloritized, argillaceous matrix, argillaceous matrix: S-iPLchl, vw-wPser, no sulfides 
16-14093

1602 DR S

\section{6-14094}

1602 DR S

$\mathrm{x}$

\section{6-14095}

1602 DR S

\author{
16-14099 \\ 1602 DR S \\ $x$
}

\section{6-14100 \\ 1602 DR S}

16-14101

1602 DR S

16-14102

1602 DR S

16-14103

1602 DR S

16-14104

1602 DR S

16-14105

1602 DR S

16-14106

1602 DR S autoclastic rhyolite breccia-hyaloclastite(?) broken qz phenos mPchl, vw-wDtour, 2-3\%Dpo, 1-2\%Dpy (some cubes), trDcp

volcaniclastic sandstone, light grey, felsic, poorly sorted, matrix supported, polymict (rhyolite clasts dominant), wFOL, apx $10 \%$ subround rhyolite clasts to $15 \times 10 \mathrm{~mm}$ (most $<4 \mathrm{~mm}$ ), $1-5 \%$ sericitic wispy clasts, (fiamme-like) up to $18 \times 3 \mathrm{~mm}(\mathrm{TS}$ ), one contains abundant spheriolites, another contains poss flattened vesicles ( $q z$ amygdules), wispy clast alteration: iPser; rhy clasts: iPqz, matrix: sPser, mSfc (some rhombs), trDpy

coherent rhyolite, (similar to 14061), strong anastomosing fracture pattern, in contact with volcaniclastic unit containing $2.5 \mathrm{~cm}$ altered mafic clast, next largest is tan mafic clast of $8 \times 4 \mathrm{~mm}$, large clast has a felty texture of acicular plag pseudos (sericitic) in a chloritic groundmass, mPser (qz-ser rock), trDpy

rhyolite hyaloclastite, medium-dark grey, very fn gr, weakly mottled appearance, $2-3 \%$ oval white blebs to $2 \mathrm{~mm}$ long, contains coherent rhyolite blocks up to $8 \times 3 \mathrm{~cm}$ (very difficult to see in underground exposures), mPchl-ser, trDpy

contact between rhyolite hyaloclastite and volcaniclastic mudstone sPser, mScarb, n-wSchl, 15-20\%LDpy in TS, nearly all in one 0.8 $\mathrm{mm}$ wide veinlet

strongly mineralized ( $p y-s p h$ ) rhyolitic clast in volcaniclastic boulder conglomerate, medium gray to reddish brown (sph stain)

py-sph-(gal)-rich clast in volcaniclastic boulder conglomerate, strongly mineralized part of same clast as sample 14101

massive sulfide clast in volcaniclastic boulder conglomerate, light reddish-brown, sph-rich, massive sph cut by multidirectional veinlets of pyrite and galena

mineralized rhyolitic clast in volcaniclastic boulder conglomerate, dark gray rhyolitic host rock cut by multidirectional (stockwork) py-sph veinlets, $40-60 \%$ Lpy-sph

pyritic zone within autoclastic rhyolite breccia

volcaniclastic boulder conglomerate containing zone of in situ rhyolite hyaloclastite, most clasts in sample are pebble-size, local jig-saw fit in hyaloclastite (TS), hyaloclastite fracturing becomes more intense toward contact (TS), possible injection of rhyolite into volcaniclastic material, matrix: sPser; some clasts: SPchl, VCbdcg: 1-3\%Dpy; RHhy: no sulfides 


\author{
16-14107 \\ 1602 DR S \\ $x$
}

\section{6-14108}

1602 DR S

16-14128

1602 DR N

16-14129

1602 DR N

16-14130

1602 DR N

16-14131

1602 DR N

$\mathrm{x}$

16-14132

1602 DR N

$\mathrm{x}$

16-14133

1602 DR N

$\mathrm{x}$

16-14134

1602 DR N

16-14135

1602 DR N large mafic clast from volcaniclastic polymict boulder

conglomerate, HS: tan (light brown), appears to contain fine gr

acicular xtalls TS: felty texture of very elongate fd pseudomorphs (strongly sericitized), $0.5-1.5 \mathrm{~mm}$ long, rare qz phenos, groundmass alteration: sPchl, no sulfides

volcaniclastic sandy mudstone, It grey, very fine gr, weakly bedded one $1 \mathrm{~cm}$ thick bed is distinctly more sand-rich, $1-2 \%$ randomly distributed anhedral qz crystals up to $2 \mathrm{~mm}$ diameter, possible pyroclastic tuff, sPser, no sulfides

autoclastic rhyolite breccia, sphalerite-stained, monomict, unsorted, light grey, siliceous rhyolite fragments up to $6 \times 3 \mathrm{~cm}$, commonly showing internal fracturing, $1-2 \%$ randomly distributed $q z$ phenos (fractured, intact to weakly fragmented), rhy fragments are recrystallized qz-(ser) rock, interfragmental fractures are dark grey, alteration of rhyolite fragments: s-iPqz, wPser, matrix: iPser, $3-5 \%$ SDHsph (zones of disseminated 0.01-0.05 mm sph grains create "stain), tr-2\%DLpy

autoclastic rhyolite breccia, similar to $16-14128$

coherent rhyolite, md-dk grey

coherent rhyolite, $\operatorname{tr}-1 \%$ anhedral-subhedral qz phenos up to $0.8 \mathrm{~mm}$ across, possible linear zones of recrystallized spheriolites (flow banding?), mFHPser, sPqz (qz-ser rock), vwScarb, vwHqz, no sulfides

coherent rhyolite, spheriolitic (recrystallized), weakly-moderately fractured on microscopic scale, weak foliation $1-2 \%$ anhedral to subhedral, strongly fractured qz phenos up to $1.2 \mathrm{~mm}$ across (some show resorption effects), $\mathrm{tr}-1 \%$ altered subhedral plag phenos up to $1.6 \mathrm{~mm}$ long ( $\mathrm{m}-\mathrm{s}$ altereration to carb $+q z)$, sPqz, mPser, wScarb, wLqz-py-carb, 5-10\%LDpy (veinlets include qz and carb)

coherent rhyolite, weak anastomose fracture pattern (microscopic) $\mathrm{tr}-1 \%$ subhedral - anhedral qz phenos up to $0.8 \mathrm{~mm}$ across (not fractured), sPHqz, sPser, wSHcarb, 3-10\%DBHpy - some diss py consists of microscopic $(0.01-0.03 \mathrm{~mm})$ grains

autoclastic rhyolite breccia, siliceous, strong sphalerite stain, It gray to orange-brown 1-2\% subhedral-anhedral qz phenos up to $1.2 \mathrm{~mm}$ across, weak foliation, sPqz, m-sPFser, 5-15\%HDsph, 2-5\%Hpy (some sph accompanied by chl)

volcaniclastic pebble conglomerate, It grey, rhyolite clast dominated, apx $50 \%$ clasts (in part matrix supported) clasts are unsorted, subround-subangular, up to $3 \times 2 \mathrm{~cm}, \mathrm{~m}-\mathrm{sPqz}$, mFPser, wScarb, wSchl (commonly rims py grains), 5-20\%DBpy, some cubic forms (therefore not clasts) 
16-14136

1602 DR N

16-14137

1602 DR N

16-14138

1602 DR N

$x$

16-14139

1602 DR N

18-14044

$1829 \times C$

18-14045

$1829 \times C$

18-14046

$1829 \times C$

$\times$

18-14047

$1829 \times C$

18-14048

$1829 \times C$

$\mathrm{x}$

18-14049

$1829 \times C$ coherent rhyolite

autoclastic rhyolite breccia

volcaniclastic muddy sandstone, md grey, $v$ fn gr (most grains between $<0.01$ and $0.50 \mathrm{~mm}$ across) delicately bedded on $\mathrm{mm}$ scale due to grain size variation (many laminae grade from sandstone to mudstone) most clasts are round-subround but a few are subangular, nearly all clasts are rhy or qz xtalls, sPser-chl, 5-15\%BDpy, occurs preferentially along sandy parts of laminae

autoclastic rhyolite breccia

coherent QP rhyolite, $10-15 \%$ anhedral to subhedral qz phenos up to $1.5 \mathrm{~mm}$ across, $1-3 \%$ sericite-altered, anhedral to subhedral twinned plag phenos up to $1 \mathrm{~mm}$ long, phenos are randomly distributed, irregular sericitized fractures locally create pseudofragmental texture, $\mathrm{m}$-sPHqz, mRPser, w-iXser (relacing plag), wScarb, vwHqz-carb, vwSstilpnomelane, no sulfides

QP rhyolite, possible hyaloclastite

coherent QP rhyolite, $15-20 \%$ anhedral-subhedral qz phenos up to 2 $\mathrm{mm}$ across, $2-4 \%$ weakly sericitized plag phenos up to $2 \mathrm{~mm}$ long, phenos are randomly distributed, qz veinlet is cut by carbonate veinlet in TS, microscopic, anastamosing, sericitized fractures are common in TS, m-sPqz, mRPser, mSPchl, w-mXser (replacing plag), vwHqz, vwHScarb, no sulfides

coherent QP rhyolite, contains intensely sericitized fd pseudos and 1 possible granophyre grain, S-iPser, wSbio(?)

coherent QP rhyolite, underground exposure is flow banded, 10-15\% anhedral-subhedral qz phenos up to $1 \mathrm{~mm}$ across, no recognizable $\mathrm{fd}$ phenos, zones of high density anastamosing fractures occur in TS m-sPqz, m-sFRPser, w-mScarb, no sulfides

coherent rhyolite, spherulitic (recrystallized), sericitization between spherules imparts a pseudoclatic texture in TS (similar to sandy mudstone), plagioclase phenocrysts present, m-sPser,

wSstilpnomelane, no sulfides 
18-14050 1829 XC

18-14051 $1829 \times C$ $x$

18-14052 $1829 \times C$

18-14053 $1829 \times C$ 18-14054 $1829 \times C$ $\mathrm{x}$

18-14055 $1829 \times C$ $x$

18-14056 $1829 \times C$

18-14057 $1829 \times C$

18-14058 $1829 \times C$ $\times$

18-14059 $1829 \times C$ coherent QP rhyolite, varies from strongly spherulitic (pseudoclastic) to non-spherulitic, some spherules show good radial extinction, spherulites up to $0.3 \mathrm{~mm}$ across (most $<0.2 \mathrm{~mm}$ across), most qz phenos are rimmed by spherulitic crystals (this feature not observed in QP rhyolite samples in which spherulites are absent), mPser, sSstilpnomelane

coherent QP rhyolite, $10-15 \%$ anhedral-subhedral qz phenos up to 3 $\mathrm{mm}$ across, $3-5 \%$ anhedral-subhedral, sericitized plag phenos up to $1 \mathrm{~mm}$ long, some plagioclase occurs in glomerporphyritic aggregates, TS is weakly banded due to variations in intensity of microscopic sericitized, anastamosing fractures, m-sPqz, m-sFPser, m-iXser (replacing plag), vwSstilpnomelane, vwScarb, no sulfides

coherent $Q P$ rhyolite

coherent $Q P$ rhyolite, entire groundmass appears to be spherulitic (looks somewhat like very fn gr sand), no spherules with radial extinction noted

QP rhyolite breccia-conglomerate, clast supported, polymict, dominated by subround to round QP clasts, $1-3 \%$ altered, angular to subangular mafic clasts, some dominated by fd pseudomorphs (sericitized) displaying a felty (pilotaxitic) texture, mafic clasts may represent juvenile, injected magma (pepperite), some Sser probably represents fd pseudos, m-sPqz, m-sPSser, w-mScarb, 1-2\%Dpy

coarse QP rhyolite breccia-conglomerate, unsorted, matrix supported, monomict, unit contains $5-15 \%$ rounded fragments from 5 $\mathrm{mm}$ to $40 \mathrm{~cm}$ long, most fragments (by volume) are $>5 \mathrm{~cm}$ long, nearly all clasts are "bleached" white to light grey (silicified), matrix is dark grey, matrix alteration: sPser, mPqz; QP rhyolite clast alteration: s-iPqz, wHqz, wPser, no sulfides

basalt/andesite from margin of subvolcanic wedge gabbro sill, strong carbonate and chlorite alteration

coherent QP rhyolite, pronounced foliation

coherent $Q P$ rhyolite, $10-15 \%$ anhedral-subhedral qz phenos up to 2 $\mathrm{mm}$ across, $1-3 \%$ possible anhedral to subhedral fd pheno pseudomorphs up to $2 \mathrm{~mm}$ long (large sericite spots), m-sPser, m-sPqz, vwHScarb, vwHqz, vwSchl-stilpnomelane-py, trace py associated with spotty chl-stilpnomelane

coherent QP rhyolite, $15-25 \%$ qz phenos 
$21-14140$

$2129 \times C$

21-14141

$2129 \times C$

$\mathrm{X}$

21-14142

$2129 \times C$

$\mathrm{x}$

21-14143

$2129 \times C$

$\mathrm{x}$

21-14144

$2129 \times C$

$x$

21-14145

$2129 \times C$

21-14146

$2129 \times C$

$\mathrm{x}$

21-14147

$2129 \times C$

21-14148

$2129 \times C$

$x$

21-14149

$2129 \times C$

$\mathrm{x}$ subvolcanic basalt/andesite from margin of wedge gabbro sill, very strongly altered, 10-20\%Dleucoxene (very fn gr, white to light pink), trDpy

coherent rhyolite, light grey, strong anastomosing fracture pattern, $1-2 \%$ qz phenos, subhedral-anhedral, up to $1.5 \mathrm{~mm}$ across, $1-2 \% \mathrm{fd}$ pheno pseudomorphs (carb-chl), phenos concentrated at one side of TS (flow layering?), S-iPser, sPqz, wHScarb (qz-ser rock), no sulfides

coherent rhyolite, light greenish-gray, non-foliated, tr-2\% qz phenos, with intersecting rectilinear fractures filled with qz-carb veinlets (no anastomosing fractures), sPqz, sPser, wHSqz-carb (qz cores, carb margins, dark gray in HS), n-wSchl, no sulfides

clast or pseudoclast of strongly carbonate-altered felsic (qz-ser-carb) rock, boulder-size, sharp contacts, located in coherent rhyolite, sPqz sPser, sSPcarb, no sulfides

felsic (qz-ser-chl) rock, aphanitic, sPqz, mPser, w-mPSchl

volcaniclastic pebble conglomerate, $c p$-rich, polymict, dominantly rhyolite clasts but includes $1-3 \%$ altered (tan) mafic clasts, one end of slab consists of coherent rhyolite (block?) with a minimum width of $8 \mathrm{~cm}$, gangue associated with $\mathrm{cp}$ includes carb, $q \mathrm{z}, \mathrm{chl}$, tour, and albite, $15-25 \%$ LBCp, most occurs along multidirectional veinlets (stockwork), tr-2\%Bpo

felsic, aphanitic rock, exhibits pseudofragmental texture (oval to irregular domains (up to $8 \times 4 \mathrm{~mm}$ in TS) of light grey-white,

aphanitic, recrystallized qz occur seperated from one another by $v$ irregular, dark greenish-gray chloritic fractures), apx. $5 \%$

hydrothermal, very irregular albite porphyroblasts containing $q z$ and chl inclusions, sPqz, sRchl, vwScarb, tr-5\%Dsph (very fn gr)

volcaniclastic pebble conglomerate, matrix supported, $5-10 \%$ pebbles in a dark grey matrix, clast population dominated by rhyolite with subordinate tan (altered) mafic clasts, chl-carb-albite-ser alteration, albite associated with $c p, 4-6 \%$ DLcp, nil-2\%Dsph

coherent rhyolite, light-medium grey, strongly spherulitic (recrystallized), no qz phenos in TS, spherule density varies across TS from tightly packed (coalesced) to zones where spherules are isolated from one another, sample is from unmineralized "island" in semi-masive to massive, cp-rich sulfides, sPVqz, w-mSchl, wLSfc, trDpy

coherent rhyolite, massive, dark grey, aphanitic, trace qz phenos, contains $5 \mathrm{~cm}$ wide zone of well developed spherulites up to $0.3 \mathrm{~mm}$ in diameter, strong anastamose fracture pattern, coarse spherulite $(0.1-0.3 \mathrm{~mm})$ zone has narrow gradational to sharp contact $w$ zone of $<0.1 \mathrm{~mm}$ qz grains which are probably small, recrystallized spherulites, s-iPqz (spherules), mPSchl, w-mLqz-tour-carb-cp-sph, 
$2-4 \%$ Lcp, $1-2 \%$ Lsph (in qz-tour-cp-sph veinlets)

21-14150

$2129 \times C$

$x$

21-14151

$2129 \times C$

$x$

21-14152

$2129 \times C$

21-14153

$2129 \times C$

$x$

21-14154

$2129 \times C$

21-14155

$2129 \times C$

$x$

21-14156

$2129 \times C$

21-14157

$2129 \times C$ volcaniclastic pebble conglomerate, unsorted, $20-30 \%$ angular to round clasts in dark grey, aphanitic matrix, clasts are dominantly light grey to white rhyolite, some with qz phenos, with $1-3 \%$ altered (tan), mafic clasts (chl-ser-qz-opaque phase), largest clasts is $1.8 \times 1.3$ $\mathrm{mm}$, slab B contains a $5 \mathrm{~cm}$ wide, siliceous, mottled white to It brn clast or dike, rhy clasts: s-iPqz, n-wSchl, matrix: sPqz, mPchl, wHqz, tr-2\%DBpy

volcaniclastic pebble conglomerate, matrix supported, $20-40 \%$ round to angular clasts up to $4 \times 2 \times 1.5 \mathrm{~cm}$ in dark grey matrix, white to dark grey rhyolite clasts are dominant, $1-3 \%$ altered (tan) mafic clasts up to $7 \times 5 \mathrm{~mm}, 1-3 \%$ small, black, soft, argillite clasts up to $6 \times 3 \mathrm{~mm}$, sPqz, mPchl-ser, no sulfides

aphanitic felsic rock, massive, medium grey, cut by brown veins of qz-ser up to $2.5 \mathrm{~cm}$ wide with aphanitic qz margins up to $5 \mathrm{~mm}$ wide, locally these qz margins are continuous with qz-(tour?) veins up to 2 $\mathrm{cm}$ wide, mVser, w-mVLqz-tour-(native Ag?-cp), wScarb,

$\operatorname{tr}-0.5 \%$ VLnative $\mathrm{Ag}$ and trVLcp in $q z$-(tour?) veins and veinlets

coherent rhyolite, md grey, massive, spherulitic (recrystallized), random distribution of large spherules up to $0.5 \mathrm{~mm}$ in dia, sericitized and chloritized fractures pass between spherulites creating an anastamosing fracture pattern, fc spots are up to $5 \mathrm{~mm}$ across, spherical, no evidence of elongation (strain), sPHqz, sRPser-chl, wSfc, no sulfides

volcaniclastic pebble conglomerate, unsorted, matrix supported, polymict: angular to round rhy clasts (dominant), $20 \%$ soft, black arg clasts (convoluted contact relationships), 1-5\% altered (tan) mafic clasts (chl-qz-opaque phase), some wispy, up to $18 \times 2 \mathrm{~mm}$, some qz crystal clasts, and a few clasts which appear to be liberated spherulites, matrix: sPqz, sPchl, wSfc; rhy clasts: iPqz, wPchl, no sulfides

rhyolite breccia-conglomerate, resedimented, essentially monomict (angular to round rhy clast dominate, some qz crystal clasts),

unsorted, matrix supported, md-dark grey, most clasts are indistinct in HS, matrix: sPchl-(ser), w-mScarb; rhy clasts: s-iPqz, no sulfides

strongly altered volcaniclastic pebble conglomerate (?), dark grey, 2-3\% anhedral, subangular qz xtalls, some chl spots may represent argillite clasts, sPHqz, sPRSchl, no sulfides

volcaniclastic pebble conglomerate, $\mathrm{cp}$-rich, matrix suported to clast supported, unsorted, dominated by it grey rhyolite clasts, in TS one large rhyolite clast $(22 \times 12 \mathrm{~mm})$ contains recrystallized spherulites, gangue associated with $\mathrm{cp}$ includes $\mathrm{chl}$ and minor albite and carb (albite appears fresh), matrix: sPchl, 10-20\%BLcp, locally semi-massive 
21-14158

$2129 \times C$

21-14159

2129 XC

21-14235

$2129 \times C$

$\mathrm{x}$

21-14236

$2129 \times C$

$\mathrm{x}$

\author{
23-14237 \\ 2323 PIL. ACC \\ $x$
}

\author{
23-14238 \\ 2323 PIL. ACC \\ $x$
}

\section{3-14239 \\ 2323 PIL. ACC $x$}

\section{3-14240}

2323 PIL. ACC

$x$

\author{
23-14241 \\ 2323 PIL. ACC \\ $\mathrm{x}$
}

23-14242

2323 PIL. ACC

$\mathrm{x}$ volcaniclastic pebble conglomerate, $\mathrm{cp}$-rich, clasts dominated by light grey rhyolite, sPSLchl, 10-20\%BDLcp, trace sph associated with $c p$

volcaniclastic pebble conglomerate, $5-20 \%$ clasts, rhyolite clast dominated, largest clast is $4 \times 1.5 \mathrm{~cm}$, minor proportion of altered (tan) mafic clasts (chl-qz-ser-opaque phase), generally it grey rock with abundant black chloritic spots up to $1 \mathrm{~mm}$ across, matrix: sPFser, m-sPqz, w-mSchl, vwScarb, , 1-2\%BDpo

coherent rhyolite, strongly sericitized, similar to $21-14236$

coherent rhyolite containing 1-5\% volcaniclastic pebble conglomerate lenses, It green (sericitized), aphanitic rhyolite containing 5-25\% randomly distributed, carb-rich dk grey alteration blebs up to $2 \times 1 \mathrm{~cm}$ (pseudoclasts), $1-3 \% \mathrm{qz}$ phenos up to $2 \mathrm{~mm}$ across, tr-1\% white fd phenos to $1 \mathrm{~mm}$ long, conglomerate occurs in lenses up to $5 \mathrm{~cm}$ across and contains rhy and altered (tan) mafic clasts, s-iPser, mBcarb, w-mSHfc-qz ( $<1$ to $1 \mathrm{~mm}$ disseminated spots, some form coalesced "beads" along fractures), tr-2\%Dpy

in situ rhyolite breccia, $1-2 \%$ qz phenos to $2 \mathrm{~mm}$, contains seperate sph-rich and py-rich veinlets, gangue in sph veinlets is qz, ser, and tourmaline, gangue in py veinlets is $q z$, ser, tourmaline, and chlorite, sPqz, m-sPser, wHqz, vwLtour (in sph and py veinlets), 3-7\%LDsph, $2-5 \%$ LBDpy, sph and py tend to occur seperately

volcaniclastic pebble conglomerate, polymict, unsorted, local microscopic kink banding (F2) of main foliation (F1), sPqz, sFPser, $1-5 \%$ BDpy, some blebs may represent clasts

volcaniclastic pebble conglomerate, polymict, unsorted, contains sx-rich clasts, s-iPser, m-sPqz, 3-7\% clastic+diss py, trace clastic sph

in situ rhyolite breccia, tr-1\% qz phenos to $2 \mathrm{~mm}$ across, extensive curvilinear (anastamosing) sericitic fractures on 1- $5 \mathrm{~mm}$ scale, contains $1-5 \%$ very irregular, unaltered plagioclase porphyroblasts, some occur in irregular plag-rich and sph-rich veinlets (TS-B), possible perlitic fractures in TS-B, fragment alteration: S-iPqz, $\mathrm{mPHser}$; interfragmental alteration: s-iPser, mPqz: both: vw-wSalb, 3-7\%LDsph, 2-5\%LDpy, both sph and py-sph veinlets occur

coherent rhyolite, $1-2 \%$ anhedral qz phenos up to $1 \mathrm{~mm}$ across, recrystallized microscopic spherulitic texture accompanied by anastamosing microscopic fracture pattern, sPqz, m-sPser, mPcarb, no sulfides

coherent rhyolite, probably fragment within in situ rhyolite breccia, $1-2 \%$ anhedral qz phenos up to $2 \mathrm{~mm}$ across, microscopic recrystallized spherulitic texture and anastomosing fracture pattern, s-iPqz, m-sPFser, no sulfides 
23-14243

2323 PIL. ACC $\mathrm{x}$

23-14244

2323 PIL. ACC $\mathrm{x}$

\section{3-14245}

2323 PIL. ACC $\mathrm{x}$

\section{3-14246 2323 PIL. ACC $\mathrm{x}$}

\section{3-14247 \\ 2323 PIL. ACC}

23-HG-2323-1

2323 PIL. ACC $x$

\author{
23-HG-2323-2 \\ 2323 PIL. ACC \\ $x$
}

23-HG-2323-3

2323 PIL. ACC $\mathrm{x}$

23-HG-2323-4 2323 PIL. ACC. $\mathrm{X}$

24-14228 $2421 \mathrm{~K}$ $\mathrm{x}$

24-14229 $2421 \mathrm{~K}$ coherent rhyolite, $\operatorname{tr}-1 \% \mathrm{qz}$ phenos up to $1 \mathrm{~mm}$ across, sphurlitic (recrystallized), spherule density varies sharply across TS, s-iPqz, m-sPser, wScarb, no sulfides

coherent rhyolite, $1-2 \%$ anhedral qz phenos up to $1 \mathrm{~mm}$ across spherurlitic (recrystallized), strong intersecting curvilinear (anastomosing) fracture pattern observed in TS, SPqz, SFPser, wScarb, no sulfides

in situ rhyolite breccia, $1-2 \%$ anhedral qz phenos up to $1 \mathrm{~mm}$ across, s-iPqz, sPFser, py blebs contain chloritic fractures, 1-5\% Bpy

in situ rhyolite breccia, $c p$-rich, in situ bx texture in TS is best observed with hand lens, gangue associated with $c p-p o$ mineralization includes $q z$, plag and tour but not chl, wallrock adjacent to $c p-p o$ veinlets is sericitic, s-iPqz, sPser, 10-20\%LBcp-po ( $\mathrm{cp}$ is dominant)

in situ rhyolite breccia, $c p$-rich, gangue associated with $c p$ mineralization includes plag, qz, carb, and minor tourmaline (very plag-rich), locally massive cp contains fd "microlites", s-iPqz, sPRser, vwHScarb, 40-60\%LBcp, 3-5\%Bpy, no po

coherent rhyolite, dark grey-brown to black

coherent rhyolite, dark grey-brown to black

coherent rhyolite, light grey

coherent rhyolite, from area of flow banding

volcaniclastic sandy mudstone - volcaniclastic sandstone - argillite, black, non-graphitic, $\mathrm{mm}$ to $\mathrm{cm}$ scale bedding, sand-size clasts (up to $1 \mathrm{~mm}$ dia) are rhy fragments and qz xtalls, contains bedding parallel (primary?) py laminae and indistinct brownish laminae which probably contain diss sph, the unit contains many small scale folds $(1-10 \mathrm{~cm}$ scale), wk-mod foliation, w-sPser, 3-7\% py laminae up to $2 \mathrm{~mm}$ thick, possibly $2-5 \%$ Dsph contained in brownish laminae up to $5 \mathrm{~mm}$ across (seperate from py)

volcaniclastic pebble conglomerate, polymict (rhyolite and altered, tan basalt), rhy clasts up to $1.5 \times 1.0 \mathrm{~cm}$, black aphanitic matrix, m-sFPser, 3-7\%DBpy 
24-14230

$2421 \mathrm{~K}$

$x$

24-14231

$2421 \mathrm{~K}$

24-14232

$2421 \mathrm{~K}$

24-14233

$2421 \mathrm{~K}$

24-14234

$2421 \mathrm{~K}$

\section{4-RC-2420-4}

2421K

$\mathrm{X}$ rhyolite hyaloclastite - volcaniclastic pebble conglomerate monomict to very weakly polymict, rhyolite fragment dominated probable transported rhyolite hyaloclastite (clasts have abundant. internal, irregular, multidirectional fractures), wk-mod foliation, sPser (primarily in matrix), trace- $2 \%$ Dpy

volcaniclastic boulder conglomerate, polymict (py-sph, rhy, and altered tan mafic clasts), black aphanitic matrix with $1-2 \%$ qz eyes up to $2 \mathrm{~mm}$ across, some rhy clasts are strongly stained with sph, wk-mod foliation, sFPser, wBcarbonate (associated with sph clasts or 2nd sph), weak cr gr qz in py pressure shadows, 10-20\%py (clasts+diss), 5-10\%sph (primarily as clasts)

boulder conglomerate, polymict (rhyolite and altered tan mafic clasts), wk-mod foliation, sPFser, vwLcarb, $5-15 \%$ py and $3-7 \%$ sph: clasts, blebs and diss, trace- $2 \%$ Bpo in mafic clasts

volcaniclastic boulder conglomerate, polymict (py, sph, rhy, arg, altered tan mafic clasts), black aphanitic matrix with $1-2 \%$ qz eyes up to $2 \mathrm{~mm}$ across, mFser, wScarb, 5-15\%py, 3-7\%sph: clasts, blebs and diss, trace blebby $c p$

massive sulfide, massive sph-py ore (not a clast) containing 10-20\% qz-rich gangue, sph is medium reddish brown and banded, py is blebby, $30-50 \%$ sph, $30-50 \%$ py, trace galena

graphitic argillite, black, aphanitic, moderately foliated (sample collected by R. Cook at the intersection of $2420 \times C$ and the NE wall of 2421 "K" DD., w-mFgraphite, vw-wHqz-ser, poss vwDtourmaline, $5-15 \%$ LBpy, $1-5 \%$ sph associated with py veinlets 


\section{Appendix 10}

\section{DESCRIPTIONS OF FELSIC VOLCANIC AND VOLCANICLASTIC UNITS BETWEEN THE 1600 AND 2400 LEVELS OF THE KIDD CREEK MINE}

Coherent FW Rhyolite (RHco): Light to dark grey to light green (sericitic), aphanitic rock containing 0.5 to $2 \%$ anhedral to subhedral quartz phenocrysts up to 2 - $3 \mathrm{~mm}$ in diameter (subhedral to euhedral, generally intact, some rimmed by secondary quartz, some embayed due to resorption), and nil to $2 \%$ carbonate-, sericite-, chlorite-, and quartz-altered subhedral plagioclase phenocrysts and pseudomorphs up to $2 \mathrm{~mm}$ long (Figure A7-20). Coherent rhyolite locally contains well developed, moderately to densely packed spherulites up to $0.3 \mathrm{~mm}$ in diameter (Figures A7.21 to A7.23). Some samples display a microscopic anastomosing pattern of curvilinear sericitic fractures which curve through the rock in such a manner as to avoid passing through the spherulites. Strongly recrystallized samples which display an anastomosing fracture pattern are interpreted to have been spherulitic. In addition to the anastomosing fracture pattern described above, microscopic perlitic fracturing was noted in a sample of a coherent rhyolite block within the east outcrop rhyolite breccia (Figure A7.20B). The unit locally displays well developed, mmscale, planar to locally contorted flow-banding which is visible in underground exposures and in blocks in the east outcrop (Figure A7.2). At a microscopic scale some flow-banding appears to reflect linear zones of recrystallized spherulites (Figure A7.24). The best exposures of flow-banding occur in 
coherent rhyolite of the Lower member. However, near the west end of 2129 Crosscut, in the hanging wall of the South orebody (Middle member), variable intensity of sericitization within rhyolite imparts a banded appearance on a 1 to $20 \mathrm{~mm}$ scale to the rock which may reflect original flow-banding (Figure A7.8A). Exposures of coherent FW rhyolite are non-foliated to weakly foliated (microscopic examination shows that the main foliation is locally crenulated).

Alteration includes pervasive and hairline veinlet-controlled silicification, pervasive, foliation-controlled and hairline veinlet-controlled sericitization, pervasive, spotty and fracture-controlled chloritization, and vein-controlled and spotty Fe-carbonate + /- quartz alteration (some exposures contain dark grey blebs of Fe-carbonate up $2 \mathrm{~cm} \times 1 \mathrm{~cm}$ across). Near the west end of 2129 Crosscut subspherical, medium grey, carbonate-altered fragments or pseudofragments up to $30 \mathrm{~cm}$ across occur.

Rocks contains from nil to $10 \%$ pyrite which occurs primarily in multidirectional veinlets but some disseminated and blebby pyrite is also present (Figure A7.2). In the immediate footwall of the South orebody in 2129 Crosscut silicified, spherulitic rhyolite contains 10 to $30 \%$ chalcopyrite and honey-coloured sphalerite in a well developed stockwork.

Autoclastic Rhyolite Breccia (RHbx): This unit is monomict, unsorted, commonly sphalerite stained (2323 Crosscut and 1602 Drive North), and light to medium grey to orange-brown (sphalerite stained areas). The rock is composed primarily of light grey, siliceous, recrystallized rhyolite fragments, 
generally from 1 to $10 \mathrm{~cm}$ across, which contain trace-2\% randomly distributed, subhedral to anhedral quartz phenocrysts up to $2 \mathrm{~mm}$ across. Fragments commonly contain internal polygonal fracturing.

Exposures of In situ facies autoclastic breccia commonly display jigsawfit texture (Figures A7.9A) and grade, with decreasing fracture intensity, into polygonally fractured coherent rhyolite. Interfragmental fractures are dark grey due to phyllosilicate alteration (Figures A7.3 and A7.4). With increasing fracturecontrolled sericitization and/or chloritization alteration selvages on fractures widen, jigsaw-fit texture is lost, and "domains" of siliceous rhyolite between fractures take on a rounded appearance (Figure A7.6B; some of these exposures have been mapped by company geologists as rhyolite lapilli tuff).

Transported autoclastic breccia is monomict, clast supported, and characterized by subangular to subround, light grey, siliceous fragments, a dark grey, sericitic-chloritic, hyaloclastite matrix, and a high fragment to matrix ratio. The name breccia-conglomerate is appropriate for many of these rocks to reflect fragment rounded nature of the fragments. Flow-banded rhyolite fragments occur in some exposures (Figure 7.9A).

Alteration includes (i) pervasive and hairline veinlet-controlled silicification of the rhyolite fragments, (ii) fracture-controlled, foliation-controlled, and pervasive (matrix) sericitization and chloritization, and (iii) very weak to moderate veinlet-controlled and spotty Fe-carbonate alteration. A general progression of mineralization in autoclastic rhyolite breccia outward from the 
chalcopyrite stringer zone is (i) chalcopyrite-pyrrhotite stringers (Figures A7.5, $A 7.8$ ), (ii) disseminated, spotty, and hairline veinlet-controlled sphalerite (sphalerite "stained" zones are created by disseminated 0.01-0.05 mm sphalerite grains), and (iii) disseminated, veinlet-controlled and blebby pyrite (Figure 7.9A).

Rhyolite Hyaloclastite (RHhy): Medium to dark grey, fragment-supported, unsorted, monomict to weakly polymict, mainly aphanitic rock dominated by subround-subangular, sub-mm to $\mathrm{mm}$ rhyolite fragments (Figure A7.25B). The rock locally contains up to $5 \%$ white to light grey to dark grey, round rhyolite fragments up to $1.5 \mathrm{~cm}$ across (dark rhyolitic clasts are difficult to distinguish in walls), and locally contains a minor proportion (up to $3 \%$ ) of altered (tan) mafic clasts up to $15 \times 5 \mathrm{~cm}$. In hand sample the matrix appears granular on 0.1 to 1 $\mathrm{mm}$ scale, contains nil-2\% quartz crystals, and displays nil - moderate foliation (foliation imparts a tuffaceous appearance). In thin section fragments locally display jigsaw-fit texture and some clasts display an anastomosing fracture pattern believed to reflect the presence of (recrystallized) spherulitic texture (see coherent FW rhyolite description) .

Alteration styles include pervasive to foliation-controlled sericitization, pervasive to spotty and veinlet-controlled chloritization, and spotty and hairline veinlet $\mathrm{Fe}$-carbonate alteration. Typical mineralization consists of nil-3\% disseminated to blebby pyrite, nil- $5 \%$ disseminated to blebby sphalerite (commonly mantled by chlorite), nil to $2 \%$ blebby chalcopyrite, and nil to trace disseminated galena. 


\section{Polymict Volcaniclastic Boulder Conglomerate (VCbdcg): Clast-supported to} matrix-supported, polymict, fragmental rock containing up to $60 \%$ subround to subangular, unsorted clasts: light to dark grey rhyolite clasts, volcaniclastic sandstone-mudstone clasts, tan (altered) mafic clasts, pyrite, pyrite-sphalerite, sphalerite, sphalerite-galena (rare), galena (very rare), and chalcopyrite (very rare) clasts (Figures A7.7, A7.12, and A7.13). Silicate and sulfide clasts greater than $1 \mathrm{~m}$ long are not uncommon (the largest mapped clast is a $2.3 \mathrm{~m}$ long volcaniclastic sandy-mudstone clast in 1602 Drive South). Matrix is dark grey (chloritic), very fine-grained, gritty, and contains trace to $2 \%$ quartz eyes up to 3 $\mathrm{mm}$ across. The rock is non-foliated to weakly foliated. Alteration minerals includes pervasive (matrix) chlorite $+/$ - sericite, and hairline veinlet and spotty Fe-carbonate. Mineralization consists of $10-35 \%$ pyrite and sphalerite both as clasts and as secondary mineralization (disseminated and in blebs and lenses), and nil to trace veinlet chalcopyrite. Sphalerite clasts are chlorite-rich.

Polymict Volcaniclastic Pebble Conglomerate (VCpbcg): This is a light to dark grey, unsorted to poorly sorted, matrix-supported to clast-supported, polymict, fragmental rock containing $10-60 \%$ round to angular clasts: rhyolite clasts, sulfide clasts, $\tan$ (carbonate-, sericite-, and chlorite-altered) mafic clasts, volcaniclastic rock clasts, argillite clasts and quartz crystal clasts (Figures A7.6, A7.10, and A7.25). The matrix is very fine-grained (gritty), and light to dark grey. This unit generally displays weak, steeply dipping foliation. Clasts are commonly $2 \mathrm{~mm}$ to $2 \mathrm{~cm}$ across and the largest clasts are $<15 \mathrm{~cm}$ across. Graded bedding occurs locally. Some tan mafic clasts have wispy outlines and 
may represent juvenile material (e.g. peperite; Figure A7.14). In both the pebble and boulder conglomerates rhyolite clasts (light to dark grey) tend to be well rounded and sub-spherical to weakly elongated whereas sulfide and argillite clasts tend to be strongly elongated parallel to foliation (up to $8: 1$ ). Foliation is steep so elongation is much more pronounced in the walls than in the backs of underground workings (Figure. A7.12). The unit varies from having an extensive mixture of clast types to being strongly dominated by rhyolitic clasts. Sample 14094 from 1602 Drive South contains wispy, strongly sericitized fragments, which locally contain spherulites, that may represent altered juvenile clasts.

Alteration includes foliation-controlled, pervasive(matrix), and spotty sericitization and chloritization, pervasive and hairline veinlet-controlled silicification, spotty and hairline fracture-controlled Fe-carbonate, and disseminated tourmaline (associated with sulfide mineralization). The chlorite/sericite ratio increases with proximity to sulfides

Mineralization away from the massive sulfide zone generally consists of nil to $5 \%$ pyrite, disseminated and in blebs up to $4 \mathrm{~cm}$ across. Near the massive sulfides the VCpbcg unit contains 5 to $40 \%$ replacement sulfide mineralization, including sphalerite, pyrite, galena, chalcopyrite, and pyrrhotite (Figure A7.11). The sulfides occur primarily as matrix replacement but also occur as stringers and irregular blebs. This material grades into massive sulfide ore. Gangue associated with chalcopyrite-rich zones includes carbonate, quartz, chlorite, tourmaline, and albite. Locally this unit contains up to $30 \%$ sulfide clasts (pyrite and sphalerite \pm galena). 
Volcaniclastic Sandstone (VCsa): Felsic, medium grey, polymict, matrixsupported, weakly graded rock. Major clast types (>90\%) are subround to subangular recrystallized rhyolite and quartz crystals. Sample 14088 from the margin of the central orebody in 1602 Drive South has undergone strong pervasive chloritization and contains $3-5 \%$ blebby and disseminated sphalerite, $1-3 \%$ disseminated pyrite (some pyrite cubes up to $7 \mathrm{~mm}$ across) and trace$2 \%$ blebby chalcopyrite.

Volcaniclastic Sandy Mudstone (VCsamu): This unit is generally light to medium grey but grades to dark grey, has a homogeneous, slightly gritty, siliceous, aphanitic appearance in hand sample, is non-foliated to moderately foliated and is locally weakly bedded (Figure A7.14). Most of the material is commonly less than $1 / 16 \mathrm{~mm}$ across (mudstone) but some samples contain an appreciable quantify of very fine-grained sand. The sand size material consists primarily of rhyolite clasts (up to $0.6 \mathrm{~mm}$ across) and quartz crystals (up to $3 \mathrm{~mm}$ across, intact and broken). In addition, chloritized mafic clasts up to $1 \mathrm{~mm}$ across and chlorite-sphalerite clasts up to $0.9 \mathrm{~mm}$ across occur locally. The unit contains pervasive sericite and chlorite-sericite alteration, spotty Fe-carbonate alteration, and hairline veinlets of quartz. Mineralization consists of nil to $3 \%$ pyrite - disseminated, blebby, and veinlets. 
Volcaniclastic Muddy Sandstone (VCmusa): Medium grey, very fine-grained rock (most grains between $<0.01$ and $0.5 \mathrm{~mm}$ across) delicately bedded at a $\mathrm{mm}$ scale due to grain size variation (Figure A7-19B; many laminae grade from sandstone to mudstone). Most clasts are round to subround but a few are subangular, and most sand-size material consists almost entirely of rhyolite clasts and quartz crystal clasts. The alteration assemblage is dominated by pervasive sericite-chlorite alteration. Mineralization consists of $5-15 \%$ blebby and disseminated pyrite which occurs preferentially within the sandy parts of laminae.

Coherent QP Rhyolite (QPco): Light-medium grey, to medium brown, to light green (sericitized) rock containing 10-20\% anhedral to subhedral quartz phenocrysts up to $3 \mathrm{~mm}$ in diameter. In addition, up to $5 \%$ sericite-altered, anhedral to subhedral plagioclase phenocrysts up to $2 \mathrm{~mm}$ long occur in some rocks, in some instances in glomeroporphyritic aggregates (Figure A7.15). With increasing alteration a progression exists from (i) sericitized plagioclase phenocrysts, to (ii) sericite-rich feldspar pseudomorphs, to (iii) sericite-rich patches, to (iv) rocks in which there is no petrographic evidence of feldspar phenocrysts. Phenocrysts and phenocryst pseudomorphs are randomly distributed. Exposures are massive to locally flow-banded (near stratigraphic base of unit; Map 4), non-foliated to weakly foliated, and commonly weakly jointed. Fragments of QP rhyolite occur infrequently within the flow-banded zone. Coherent QP rhyolite is locally spherulitic with the density of recrystallized spherulites varying from low to high (Figures A7.16 and A7-17). Spherulites are up to $0.3 \mathrm{~mm}$ in diameter. Spherulitic samples exhibit a microscopic 
anastomosing sericitic fracture pattern (fractures pass around spherulites) which imparts a pseudoclastic texture (reminiscent of very fine-grained sandstone). In some strongly recrystallized samples the presence of a similar anastomosing fracture pattern suggests that recrystallized quartz aggregates (spherules) in these rocks also represent recrystallized spherulites. Alteration includes pervasive and hairline veinlet-controlled silicification, pervasive, fracture-controlled and foliation-controlled sericitization, spotty and pervasive chloritization (significant chloritization occurs in a minority of samples), spotty and hairline veinlet-controlled Fe-carbonate alteration, spotty stilpnomelane alteration, and sericite - carbonate alteration of plagioclase phenocrysts. The unit generally contains from 0 to $2 \%$ disseminated pyrite.

QP Rhyolite Coarse Autoclastic Breccia (QPcrbx): This unit was mapped on 1829 Crosscut where it occurs beneath the QP rhyolite autoclastic breccia and flow-banded QP rhyolite at the stratigraphic base of the QP rhyolite stratigraphy (Map 4). The unit, shown in Figure A7-1, contains 5-15\% angular to subround fragments from $0.5-40 \mathrm{~cm}$ across of which most fragments (by volume) are greater than $5 \mathrm{~cm}$ across (exposures with abundant subround fragments may be identified as coarse breccia-conglomerate). In the walls the fragments are commonly elongate $1: 1$ to $2: 1$ with the axes of elongation having steep easterly plunges subparallel to foliation. All of the fragments appear to be QP rhyolite (monomict) and the vast majority are white to light grey (silicified). The matrix is dark grey and non-foliated to weakly foliated. Matrix alteration includes strong pervasive and fracture-controlled sericitization and moderate pervasive silicification. The QP rhyolite clasts exhibit strong to intense pervasive 
silicification, weak pervasive sericitization, and weak hairline veinlet-controlled quartz alteration. No sulfides were observed in the 1829 Crosscut exposure.

QP Rhyolite Autoclastic Breccia (QPbx): In 1829 Crosscut this unit, up to $2 \mathrm{~m}$ wide, is located stratigraphically above QP rhyolite autoclastic coarse breccia (QPcrbx; gradational contact) and below flow-banded QP rhyolite (QPco; sharp contact). The unit contains $30-60 \%$ fragments, is clast-supported to matrixsupported, and is weakly polymict. Fragment population is dominated by subround QP rhyolite fragments from $0.5-10 \mathrm{~cm}$ across with the majority being majority less than $4 \mathrm{~cm}$ across (these rocks may be referred to as brecciaconglomerates). Most QP rhyolite fragments are light greenish-grey (sericitized) while $5-10 \%$ of the fragments are medium grey QP rhyolite. In the walls the QP rhyolite fragments commonly exhibit down-plunge elongations of 2:1 to $3: 1$ with steep axes of elongation subparallel to foliation. Locally up to $3 \%$ of the fragments are angular to subangular, altered, tan mafic clasts, some of which are dominated by sericitic feldspar pseudomorphs displaying a felty (pilotaxitic) texture. The mafic clasts, which are much more angular than the rhyolite clasts, may represent juvenile, injected magma (peperite) or vent-proximal pyroclasts. The matrix is dark grey and non-foliated to weakly foliated. Alteration includes moderate-strong pervasive silicification, moderate-strong pervasive and spotty sericitization, and weak-moderate spotty carbonate alteration. The exposure in 1829 Crosscut contains $1-2 \%$ disseminated and blebby pyrite. 


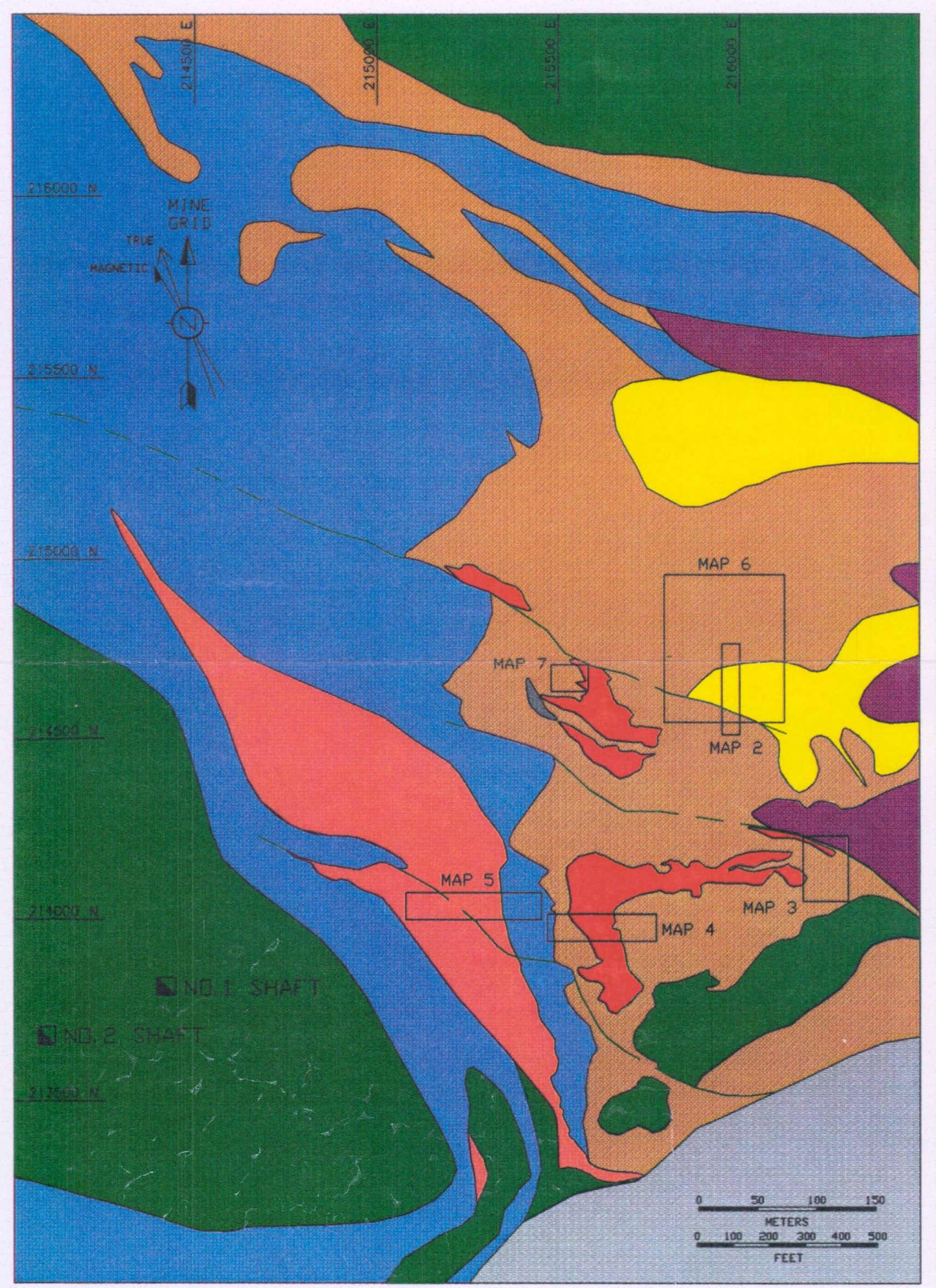

PDRCUPINE GRDUP GREYWACKE

MAFIC EXTRUSIVE ROCKS - MAINLY BASALT, SOME ANDESITE (ME)

MAFIC INTRUSIVE RDCKS - MAINLY GABBRD AND BASALT (MI)

KIDD CREEK FURMATIDN - UPPER MEMBER QP RHYOLITE

$\square$ Massive AND FLow BANDED CDHERENT RHYDLITE (QPCO)

7 autoclastic BRECCIA (QPbx)

$\square$ aUtDCLASTIC CDARSE BRECCIA (QPCrbX)

KIDD CREEK FURMATION - MIDDLE MEMBER

$\square$ VILCANICLASTIC PQLYMICT BOULDER CONGLOMERATE (VCbdCg)

$\square$ Massive SULFIDE (MS)

DEMI-MASSIVE SULFIDE (SMS)

argillite, graphitic argillite (ARG)

VILLCANICLASTIC MUDSTINE, SANDY MUDSTINE (VCMU, VCsamu)

1 VDlCaniclastic SANDStone, muddy SANDstane (VCsa, VCmusa)

$\square$ VQLCANICLASTIC PQLYMict PEBbLe Canglomerate (VCplocg)

KIDD CREEK FIRMATIDN - LDWER MEMBER
FW RHYOLITE
$\square$ HYALOCLASTITE (RHhy)
$\square$ aUtaCLASTIC BRECCIA (RHbx)
MASSIVE AND FLIW BANDED CDHERENT RHYOLITE (RHCO)

ULTRAMAF IC RDCK (UM)

- BEDDING ATTITUDE

- Flow BANDING ATTITUDE

$\longrightarrow$ Foliation ATtitude

//, FLoW Banding

- SHARP CONTACT

- - gradatidnal contact AL TERATION CONTACT

- fault

- quartz i fe carbunate vein

SUlfide stringer

- sulfide boulder

SILICATE BQULDER/BLICK

$x$ INes SAMPLE SITE

- Surver point

PY PYRITE

CP CHALCDPYRITE

SPh SPHALERITE

NOTE: UNDIFFERENTIATED VOLCANICLASTIC NOTE: UNDIFFERENTIATED VILCAN
RDCKS SHOWN IN BROWN ON MAP 1.
MAP 1. LOCATION OF MAPS 2 TO 7 PROJECTED ONTO THE 1600 LEVEL, KIDD CREEK MINE (AFTER FALCONBRIDGE LEVEL PLANS) 


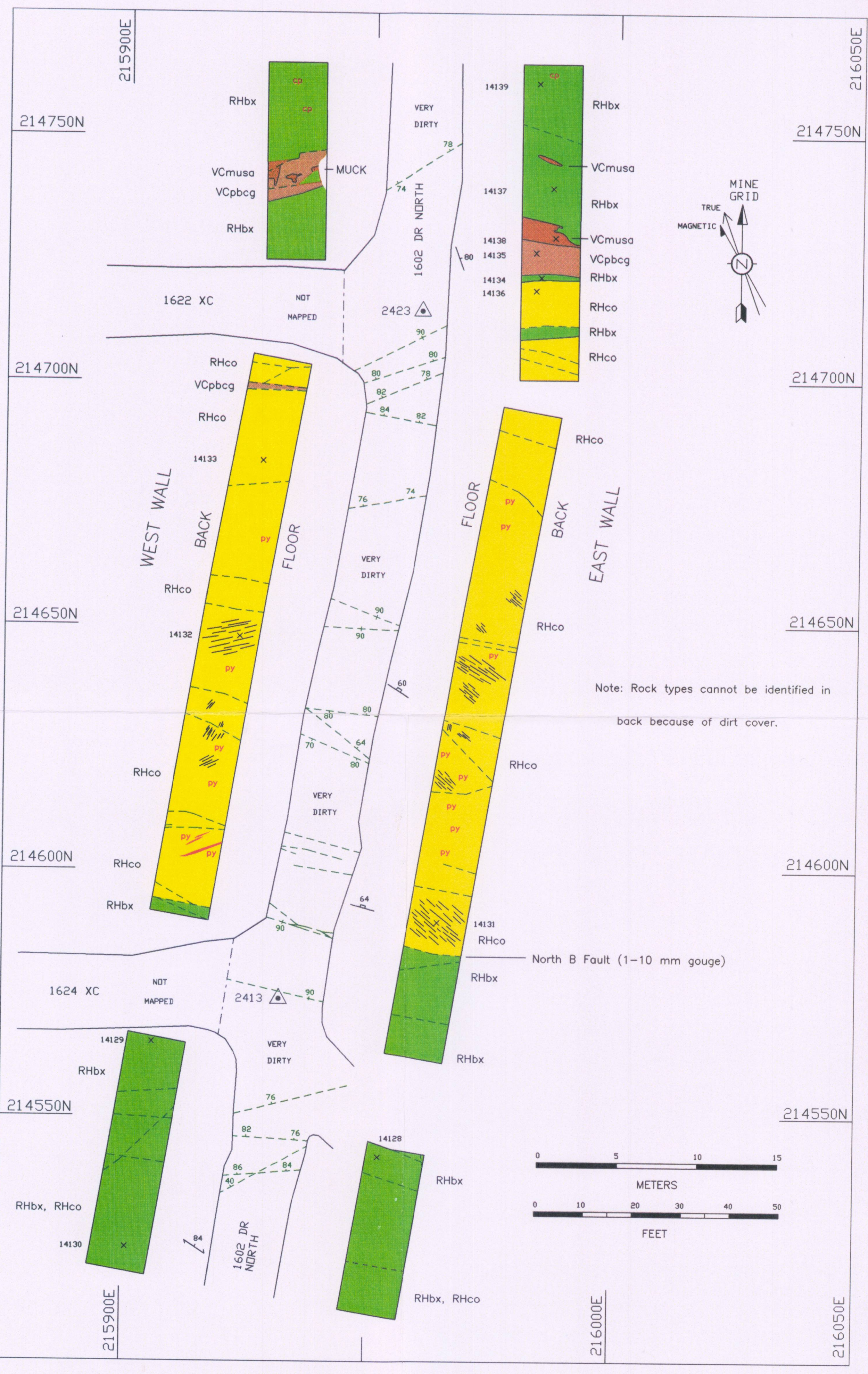

Q.

SHL

Map 2. GEOLOGY OF 1602 DRIVE NORTH, KIDD CREEK MINE 


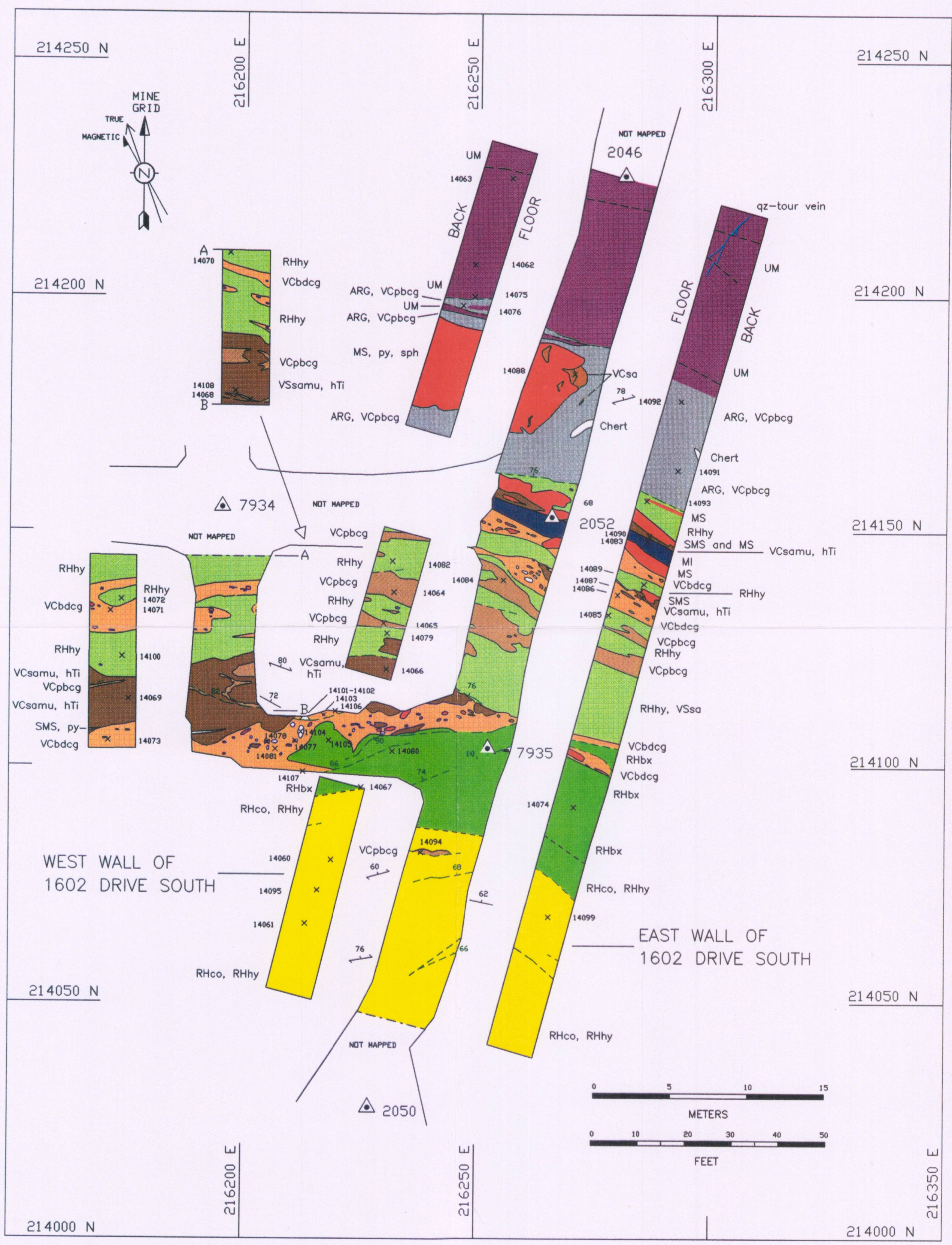

the

MAP 3. GEOLOGY OF 1602 DRIVE SOUTH, KIDD CREEK MINE

std 


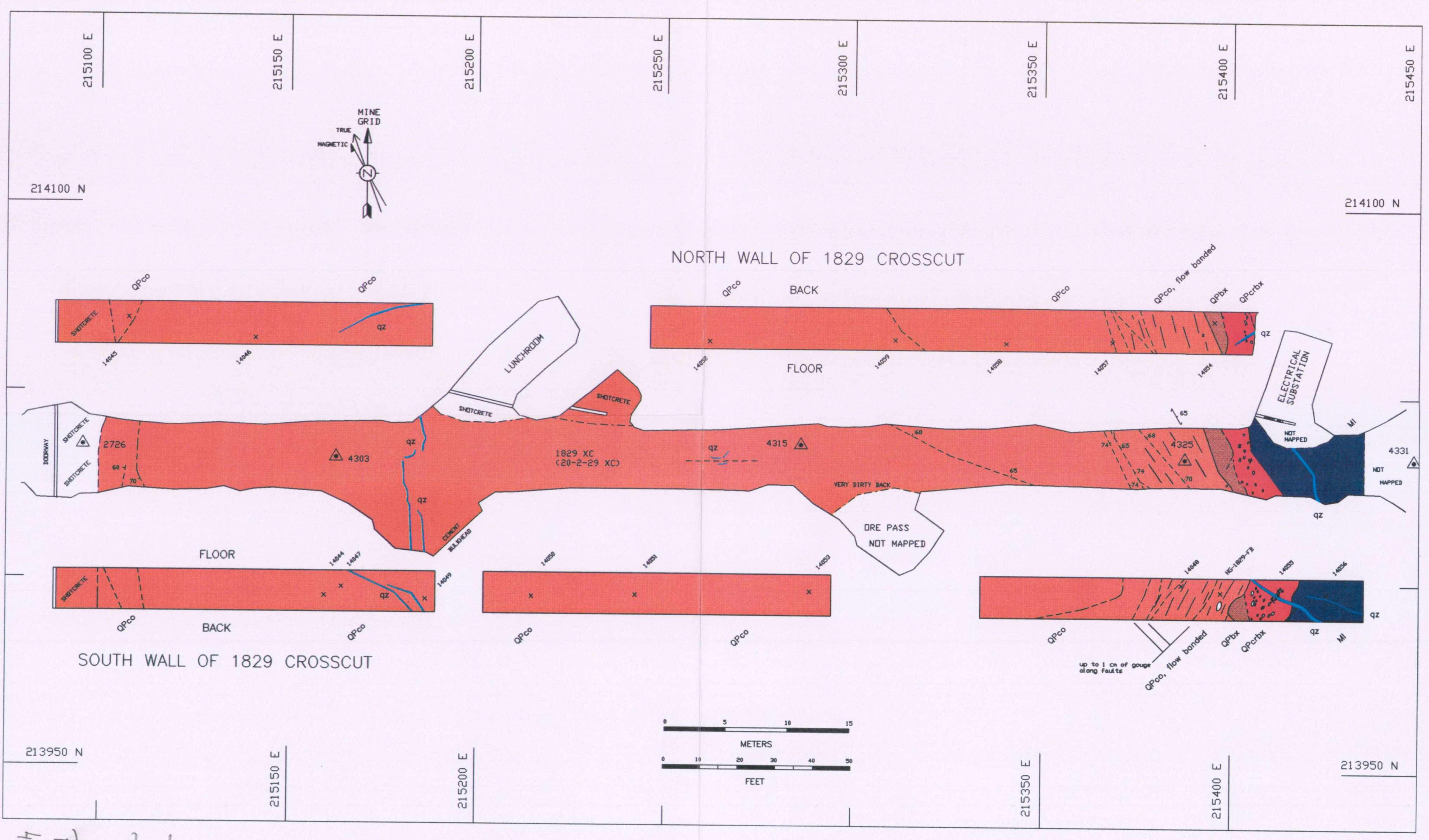

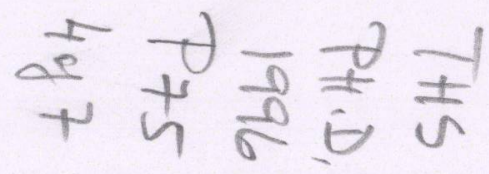

MAP 4. GEOLOGY OF $1829(20-2-29)$ CROSSCUT, KIDD CREEK MINE 


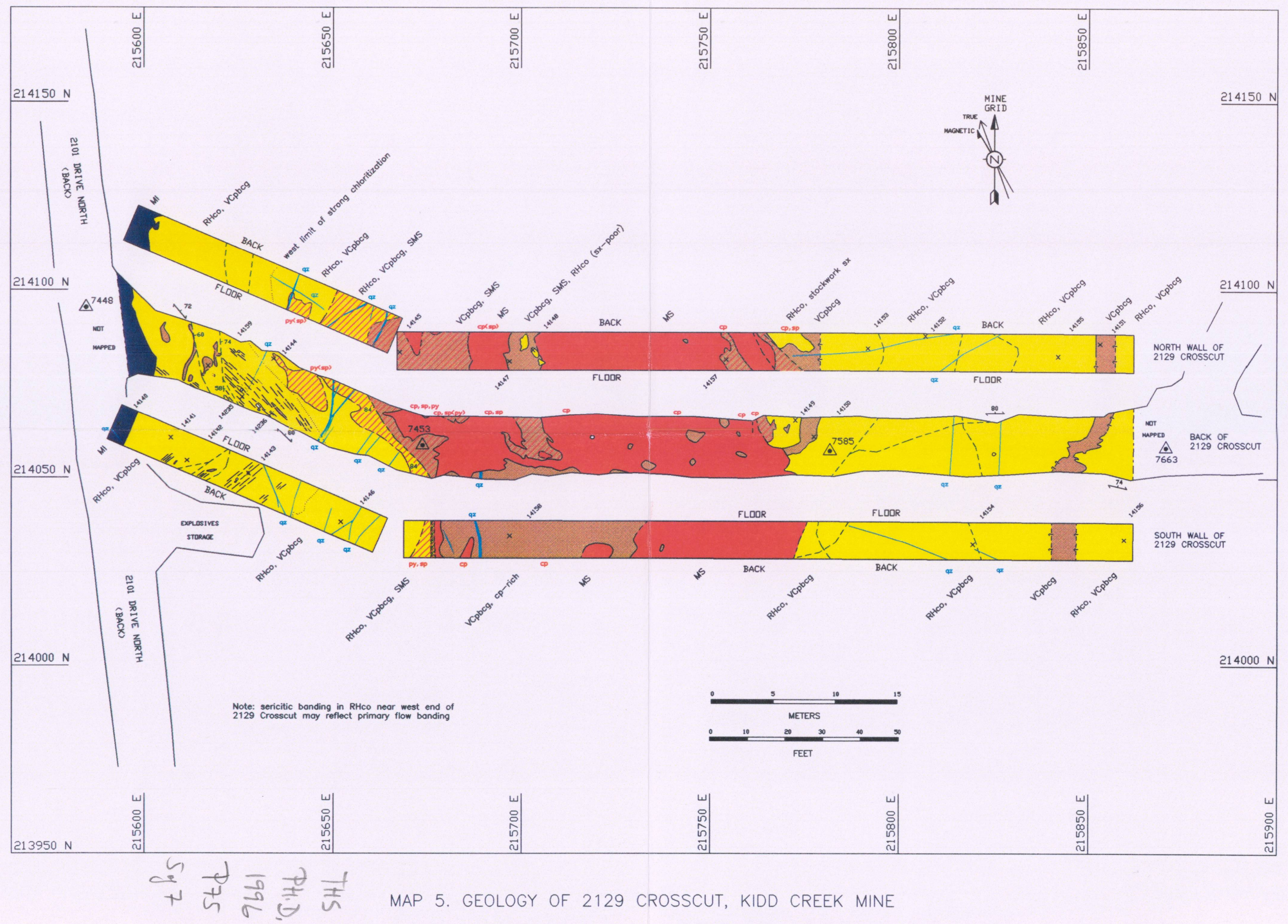




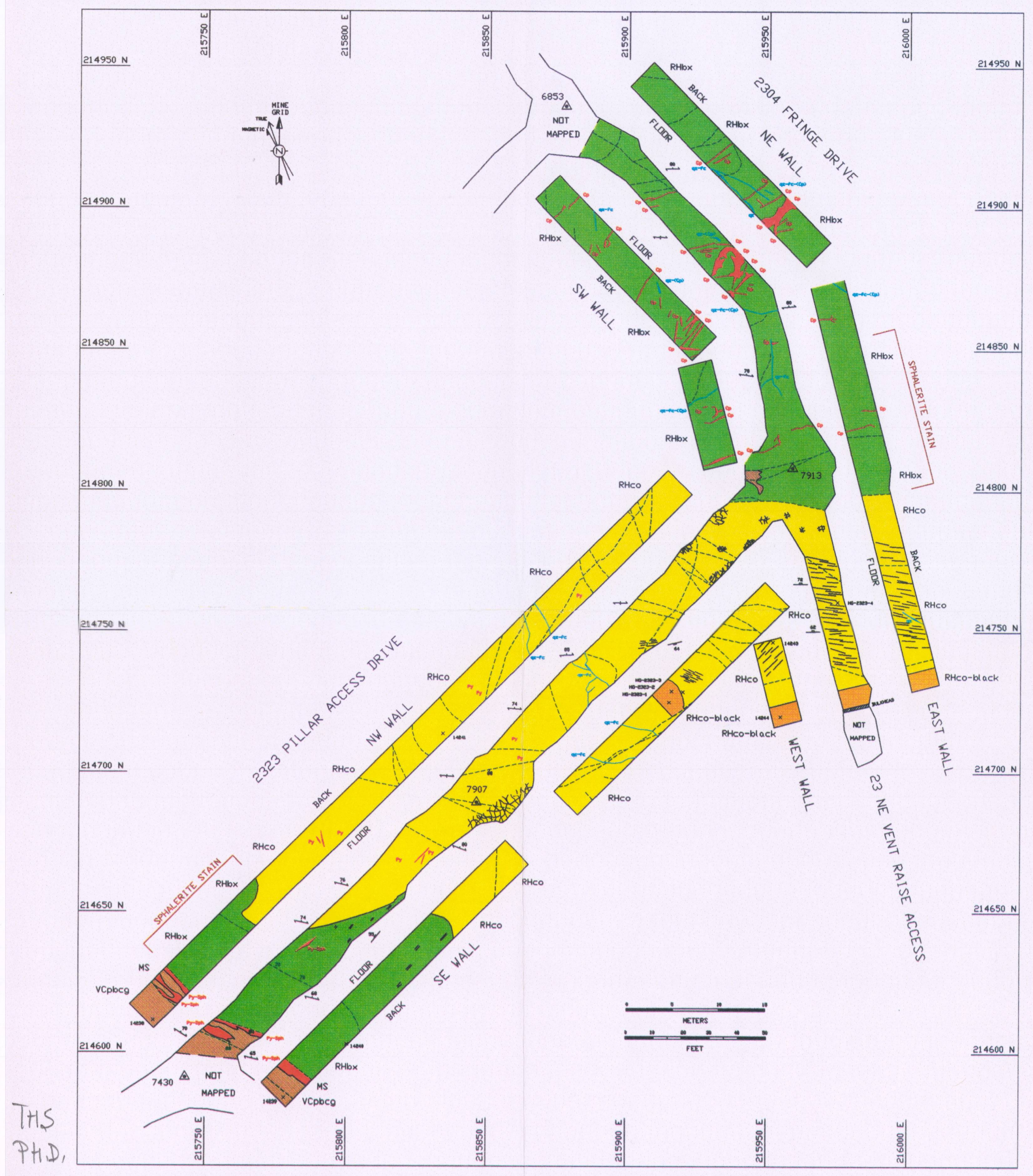

1996

P75

MAP 6. GEQLUGY IF 2323 PILLAR ACCESS DRIVE, KIDD CREEK MINE 6 of 7 
